\title{
ZACHOWANIA MATRYMONIALNE I PROKREACYJNE W POLSCE - UJĘCIE GEOGRAFICZNE
}


$\frac{3}{40}$ 


\author{
Anna Janiszewska
}

\title{
ZACHOWANIA MATRYMONIALNE I PROKREACYJNE W POLSCE \\ - UJĘCIE GEOGRAFICZNE
}

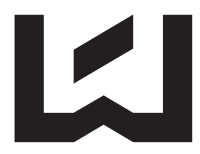

WYDAWNICTWO 
Anna Janiszewska - Uniwersytet Łódzki, Wydział Nauk Geograficznych

Katedra Studiów Ludnościowych i Badań nad Usługami

90-142 Łódź, ul. Kopcińskiego 31

RECENZENT

Tomasz Michalski

SK丈AD KOMPUTEROWY

Karolina Dmochowska-Dudek

PROJEKT OKEADKI

Karolina Dmochowska-Dudek

Na okładce wykorzystano fotografie autorstwa E. Klimy i M. Janiszewskiej

Wydrukowano z gotowych materiałów dostarczonych do Wydawnictwa UŁ przez Wydział Nauk Geograficznych

(C) Copyright by Uniwersytet Łódzki, Łódź 2013

Wydane przez Wydawnictwo Uniwersytetu Łódzkiego

Wydanie I. W.06352.13.0.H

ISBN (wersja drukowana) 978-83-7525-964-3

ISBN (ebook) 978-83-7969-349-8

Wydawnictwo Uniwersytetu Łódzkiego

90-131 Łódź, ul. Lindleya 8

www.wydawnictwo.uni.lodz.pl

e-mail: ksiegarnia@uni.lodz.pl

tel. (42) 66558 63, faks (42) 6655862 
Dla Anny Wincenciak (Mosy) 



\section{Spis treści}

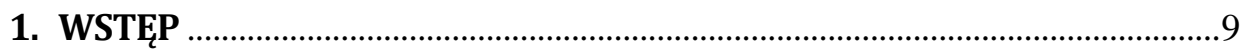

1.1. Problematyka badawcza ..............................................................

1.2. Współczesne zachowania matrymonialne i prokreacyjne w badaniach

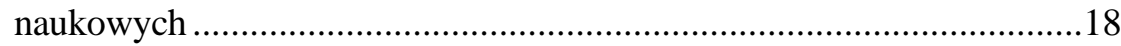

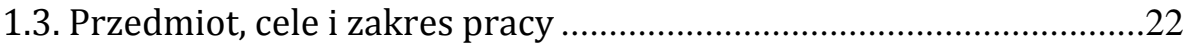

1.3. Materiały źródłowe i metody badawcze …….................................30

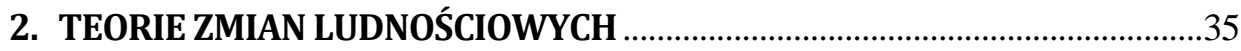

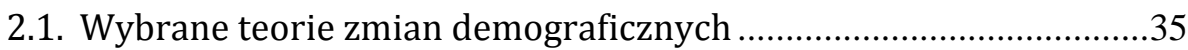

2.1.1. Czasy starożytne i poglądy klasyczne..............................................35

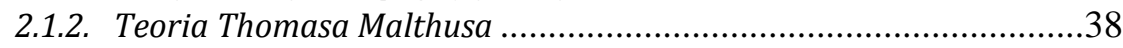

2.1.3. Czasy współczesne - podejścia badawcze ......................................42

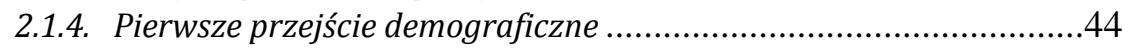

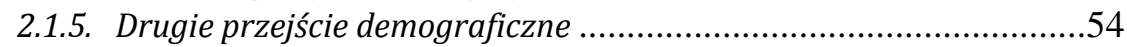

2.1.6. Trzecie przejście demograficzne. Naprawdę przejście?......................64

2.1.7. Wybrane mikroekonomiczne teorie zachowań prokreacyjnych.........71

2.1.8. Syntezy teoretyczne badań nad rozwodami ....................................75

2.2. Wybrane teorie rozwoju społecznego ……………..............................81

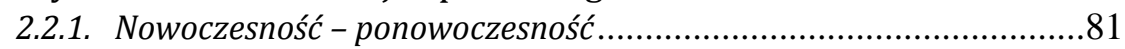

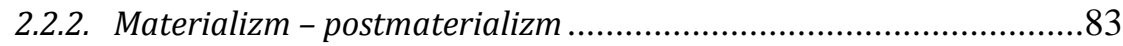

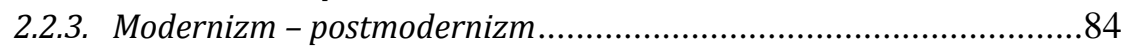

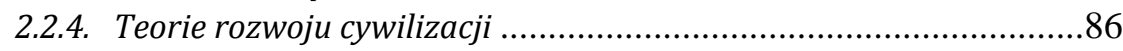

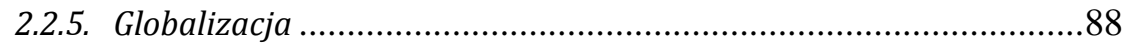

\section{PRZEMIANY ZACHOWAŃ MATRYMONIALNYCH W POLSCE} - OD ZŁOTEGO WIEKU MAŁŻEŃSTWA DO ŚWITU KOHABITACJI .............93

3.1. Zmiany prawne zawierania i rozwiązywania związków małżeńskich w Polsce po II wojnie światowej...................................93

3.2. Formowanie się i rozpad małżeństw od drugiej połowy XX w. .....102

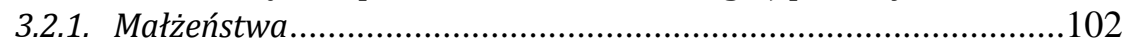

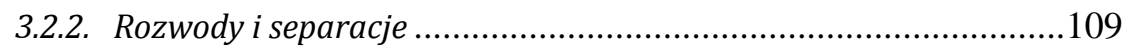

3.2.3. Kohabitacja jako alternatywa małżeństwa? ...............................112

3.3. Przestrzenne zróżnicowanie małżeńskości w Polsce ......................122

3.3.1. Zróżnicowanie przestrzenne zawieranych małżeństw według podregionów................................................................................122

3.3.2. Zróżnicowanie przestrzenne rozwodów i separacji według podregionów....

3.3.3. Zróżnicowanie przestrzenne zjawiska kohabitacji według podregionów.... 


\section{PRZEMIANY ZACHOWAŃ PROKREACYJNYCH W POLSCE - OD ERY KRÓLEWSKIEGO DZIECKA Z RODZICAMI DO ERY PARY KRÓLEWSKIEJ Z DZIECKIEM.}

4.1. Regulacje prawne dotyczące urodzeń ...........................................151

4.2. Kształtowanie się rodności po II wojnie światowej........................154

4.2.1. Zmiany poziomu rozrodczości ..................................................154

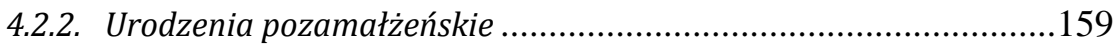

4.2.3. Przemiany płodności kobiet od lat 50. XX w.................................162

4.3. Przestrzenne zróżnicowanie rozrodczości w Polsce .......................170

4.3.1. Zróżnicowanie przestrzenne rozrodczości według podregionów....170

4.3.2. Zróżnicowanie przestrzenne płodności według podregionów .........180

5. UWARUNKOWANIA ZACHOWAŃ DEMOGRAFICZNYCH W POLSCE ..... 187

5.1. Uwarunkowania demograficzne rozwoju podregionów .................187

5.2. Uwarunkowania społeczno-ekonomiczne zmian małżeńskości

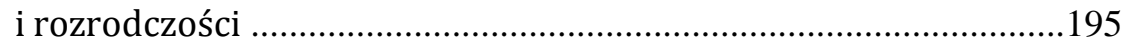

5.2.1. Uwagi wstępne ..........................................................................195

5.2.2. Zróżnicowanie przestrzenne wybranych zjawisk gospodarczych ...198

5.2.3. Zróżnicowanie przestrzenne wybranych zjawisk społecznych.........203

5.2.4. Poziom rozwoju społeczno-gospodarczego podregionów ...............216

5.3. Typy zachowań demograficznych ................................................222

6. PRZEMIANY ZACHOWAŃ DEMOGRAFICZNYCH W OPINIACH

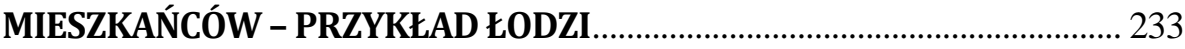

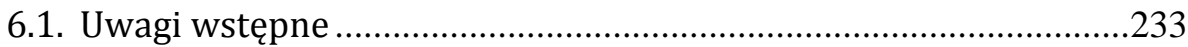

6.2. Charakterystyka respondentów ………………..............................234

6.3. Cele życiowe respondentów oraz ocena zachowań moralnych dotyczących wartości małżeńskich i rodzinnych ............................237

6.4. Opinie mieszkańców dotyczące zachowań matrymonialnych

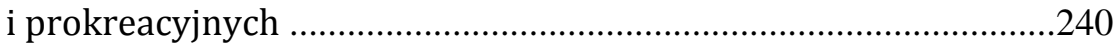

6.4.1. Najlepsza forma życia malżeńsko-rodzinnego wedlug respondentów 240

6.4.2. Kohabitacja wedlug respondentów .................................................244

6.4.3. Rozwody i separacje wedlug respondentów ..................................248

6.4.4. Single według respondentów ........................................................251

6.4.5. Rodziny monoparentalne według respondentów..............................255

6.4.6. Postawy prokreacyjne wedlug respondentów ...................................257

7. WNIOSKI KOŃCOWE.......................................................................................... 259

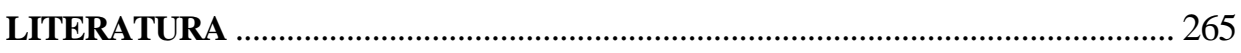

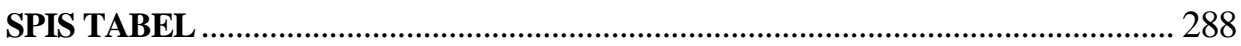

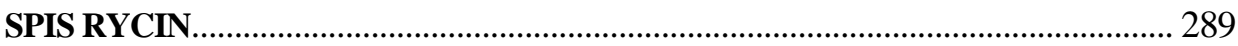

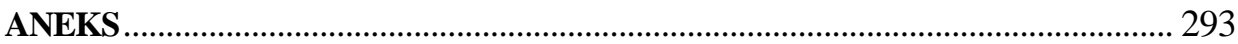




\section{WSTĘP}

\subsection{Problematyka badawcza}

Zmiany modelu formowania się i rozpadu małżeństw oraz idące z nimi $\mathrm{w}$ parze przeobrażenia $\mathrm{w}$ sferze zachowań prokreacyjnych zaczęły się w latach 60. XX w. w wielu rozwiniętych krajach europejskich. Polska dołączyła do tych przemian trzydzieści lat później. Objaśnieniem przyczyn wspomnianych zmian zajmuje się drugie przejście demograficzne. Według jednego z autorów tej koncepcji D. van de Kaa zmiany zachowań demograficznych obszaru małżeńskości i rozrodczości to wynik wpływu wielu czynników o charakterze społeczno-gospodarczym, politycznym, światopoglądowym oraz technologicznym (1994). Do grupy czynników społeczno-gospodarczych należy zaliczyć przemiany strukturalne, które obejmują industrializację, urbanizację, rozwój sektora usług, a także zmiany struktury społeczeństwa i organizacji państwa. Wynikiem tych przemian są m.in. poprawa poziomu życia, zwiększenie poczucia bezpieczeństwa socjalnego, wzrost poziomu wykształcenia ludności i mobilności społecznej oraz przestrzennej, a także zwiększenie się udziału kobiet w życiu ekonomicznym i społecznym. Uwarunkowania polityczne i światopoglądowe wyrażają się poprzez rozwój demokracji i egalitaryzmu społecznego, wzrost autonomii jednostek, sekularyzację, kontestowanie tradycyjnych wartości oraz rozpowszechnianie wartości pluralistycznych i liberalnych, uniwersalizm, indywidualizm, a także prowadzą do przesunięć w hierarchii potrzeb. W trzeciej grupie czynników, tzw. technologicznych, znalazły się zmiany, które w największym stopniu dotyczą postępu w medycynie (druga rewolucja antykoncepcyjna) i rozwoju systemów telekomunikacji. Wymienione wyżej uwarunkowania w zróżnicowany sposób oddziałują na formowanie się i rozpad rodzin w ponowoczesnym lub późnym nowoczesnym świecie, jak nazywa go A. Giddens (2001). Część z nich ma charakter ilościowy, mierzalny i dość łatwo określić zależności między nimi a nowymi postawami w sferze małżeńskości i rozrodczości. Są jednak takie czynniki jakościowe, które nie poddają się tak prostej analizie. 
Współczesne przemiany rodziny, dokonujące się na skutek upadku patriarchatu, są w opinii Francisa Fukuyamy (2000) wyrazem wielkiej zmiany społecznej, którą nazywa on „wielkim wstrząsem”. Według Manuela Castellsa rodzina patriarchalna na przełomie stuleci ,jest podważana przez powiązane ze sobą procesy przekształcania kobiecej pracy i świadomości kobiet" (2009: 180). Wymienia on trzy siły napędowe tych procesów, które pojawiły się od końca lat 60. XX w., tj. powstanie informacyjnej, globalnej gospodarki, zmiany technologiczne $\mathrm{w}$ reprodukcji gatunku ludzkiego oraz potężny ruch feministyczny.

Manuel Castells (2009) twierdzi, że wskaźniki kryzysu rodziny patriarchalnej można znaleźć w większości społeczeństw, zwłaszcza w krajach najbardziej rozwiniętych. Do wskaźników tych zalicza rozwiązywanie gospodarstw domowych par małżeńskich przez rozwód i separację, jako wyraz niezadowolenia z modelu rodziny opartej na długookresowym zaangażowaniu jej członków. Coraz więcej rozpadających się małżeństw prowadzi do formowania się jednoosobowych gospodarstw domowych i/lub gospodarstw $\mathrm{z}$ jednym rodzicem, kończąc $\mathrm{w}$ tym przypadku patriarchalną władzę w rodzinie. Miarą kryzysu patriarchalności jest też narastająca częstotliwość kryzysów małżeńskich i rosnąca trudność pogodzenia małżeństwa i pracy wskutek opóźnionego wstępowania w związki małżeńskie i zakładania związków bez małżeństwa. Występowanie i w tym przypadku braku sankcji prawnych osłabia władzę patriarchalną zarówno w sensie instytucjonalnym, jak i psychologicznym. Na pojawiające się trendy formułowania się i rozpadu rodziny nakładają się także różne procesy demograficzne, np. starzenie się społeczeństwa i różnica we wskaźnikach zgonów między płciami, przyczyniając się do powstawania coraz bardziej zróżnicowanych struktur gospodarstw domowych. Tym samym zmniejsza się udział występowania klasycznego modelu rodziny nuklearnej, a rozpowszechniają się jednoosobowe gospodarstwa domowe i rodziny monoparentalne. Kryzys rodziny patriarchalnej rozszerza się wreszcie na kryzys społecznych wzorców wymiany populacji. Nawet jeśli reprodukcja biologiczna jest zapewniona, to pozostaje ona poza tradycyjną strukturą rodzinną. Mowa tu o urodzeniach pozamałżeńskich, które w dużym odsetku dotyczą samotnych matek, chociaż stanowią one też część urodzeń w związkach kohabitacyjnych. Do tej sfery kryzysu należy również zaliczyć zmianę zachowań reprodukcyjnych kobiet, związaną z opóźnianiem decyzji o narodzinach pierwszego dziecka i ograniczaniem liczby rodzonych dzieci. Innym zjawiskiem, które co prawda jeszcze nie przybiera dużych rozmiarów, jest świadome samotne macierzyństwo lub adopcja dziecka.

Wymienione trendy wzmacniają się nawzajem, tym samym kwestionują strukturę i wartości patriarchalnej rodziny. Nie musi to wcale oznaczać końca rodziny, a tylko powstawanie jej zrekonstruowanych form i, jak pisze 
Stacey (1990), być może lepszych sposobów na to, jak żyjemy ze sobą oraz jak płodzimy i wychowujemy dzieci. A może należałoby mówić, tak jak Giddens (1998), nie o zbliżającym się końcu rodziny, ale uznać współczesne procesy za triumf „emocjonalnego indywidualizmu” jako zasady kierującej życiem osobistym.

Zmiany zachowań demograficznych przyczyniają się do nieuniknionego wzrostu różnych form rodzinnych. Dla tradycyjnej rodziny nuklearnej pojawiają się alternatywy w postaci rodzin nietradycyjnych (tab. 1). Nietradycyjne rodziny, to takie ich odmiany, które pozbawione są takich cech, jak usytuowanie prawne, trwanie przez całe życie, wyłączność seksualna między jedną kobietą i jednym mężczyzną w związku małżeńskim, posiadanie dzieci, wysoka pozycja mężczyzny.

Tabela 1

Cechy rodzin tradycyjnych i ich alternatyw

\begin{tabular}{|l|l|}
\hline \multicolumn{1}{|c|}{ Cechy tradycyjnej rodziny } & \multicolumn{1}{c|}{ Nietradycyjne alternatywy } \\
\hline Prawnie zawarte małżeństwo & $\begin{array}{l}\text { Niezamężna kohabitacja, nigdy niezamęż- } \\
\text { ne osoby żyjące samotnie }\end{array}$ \\
\hline Posiadanie dzieci & Dobrowolna bezdzietność \\
\hline Dwoje rodziców & $\begin{array}{l}\text { Samotne rodzicielstwo (bez małżeństwa } \\
\text { w ogóle, poprzedzone małżeństwem) }\end{array}$ \\
\hline Trwałość & $\begin{array}{l}\text { Powtórny związek (w tym sytuacja opieki } \\
\text { prawnej nad dzieckiem obojga rozwie- } \\
\text { dzionych rodziców, binuklearne rodziny, } \\
\text { rodziny rekonstruowane) }\end{array}$ \\
\hline $\begin{array}{l}\text { Mężczyzna utrzymuje rodzinę, posiada } \\
\text { autorytet }\end{array}$ & $\begin{array}{l}\text { Praca zawodowa obojga małżonków, } \\
\text { małżeństwa „otwarte”, małżeństwa } \\
\text { rozdzielone z powodu pracy (commuter } \\
\text { marriage) }\end{array}$ \\
\hline Wyłączność seksualna & $\begin{array}{l}\text { Pozamałżeńskie związki (w tym małżeń- } \\
\text { stwa seksualnie otwarte, modele „waha- } \\
\text { dłowe”) }\end{array}$ \\
\hline Heteroseksualność & \begin{tabular}{l} 
Związi osób tej samej płci \\
\hline Gospodarstwo dwóch dorosłych osób
\end{tabular} \\
$\begin{array}{l}\text { Gospodarstwo wielu dorosłych (w tym } \\
\text { komuny, wspólnoty, rozszerzona rodzina, } \\
\text { rodzina z dołączonymi członkami niespo- } \\
\text { krewnionymi, „niby” rodziny) }\end{array}$ \\
\hline
\end{tabular}

Źródło: Kwak 2005.

Nie ma wątpliwości, że w wyniku przeobrażeń społecznych nastąpiła zmiana pozycji kobiet $\mathrm{w}$ strukturze świata społecznego. Doszło do tego poprzez masową aktywizację kobiet i zmianę ich świadomości. Masowe wchodzenie kobiet na rynki pracy było spowodowane z jednej strony in- 
formacjonizacją ${ }^{1}$, usieciowieniem i globalizacją gospodarki, a drugiej strony genderową sytuacją rynku pracy, wykorzystującego specyficzne warunki społeczne kobiet do podniesienia produktywności, kontroli menedżerskiej, a w rezultacie także zysków. Eksplozja zatrudnienia kobiet była wynikiem kilku czynników. Jeden z nich był związany z podnoszeniem przez nie kwalifikacji i umiejętności. W ten sposób kobiety zaczęły tworzyć zasób kwalifikacji, które były natychmiast wykorzystywane przez pracodawców płacących im mniej za podobną pracę. Należy jednak podkreślić, że w większości przypadków kobiety nie są zatrudniane na stanowiskach poniżej ich kwalifikacji. Drugim istotnym powodem zwiększonego zapotrzebowania na pracę kobiet są ich umiejętności relacyjne coraz bardziej niezbędne w gospodarce informacjonizmu, w której administrowanie rzeczami przesuwa się na dalsze miejsce za zarządzaniem ludźmi. $W$ tym sensie jest to rozszerzenie charakterystycznego dla patriarchalizmu genderowego podziału pracy na tradycyjnie męska produkcję i tradycyjnie kobiece zajmowanie się domem i sprawami społecznymi. Tak się dzieje, ponieważ nowa gospodarka wymaga stosowania w coraz większym stopniu umiejętności, które były wcześniej ograniczane do prywatnej sfery podtrzymywania związków, a teraz są wykorzystywane do zarządzania i obróbki informacji, a także kierowania ludźmi. I wreszcie trzeci czynnik pobudzający wzrost zatrudnienia kobiet, związany z ich elastycznością jako pracowników. Kobiety stanowią większą część zatrudnionych $\mathrm{w}$ niepełnym wymiarze czasu pracy i zatrudnionych tymczasowo, a ich udział $\mathrm{w}$ samozatrudnieniu zwiększa się, co $\mathrm{w}$ pełni pokrywa się z potrzebami nowej gospodarki, z uelastycznieniem $w$ niej pracy jako jednej z głównych cech. Ten rodzaj zależności ma również swoje uwarunkowania genderowe, gdyż kobiety są w dalszym ciągu odpowiedzialne za prowadzenie gospodarstwa domowego i wychowanie dzieci dlatego podejmowanie pracy elastycznej daje im możliwość pogodzenia ról życiowych (Castells 2009).

Zwiększenie aktywizacji zawodowej kobiet, które nastąpiło w latach 60., przyczyniło się do zaistnienia na rynku pracy silnej konkurencji kobiet wobec mężczyzn. Jednocześnie doprowadziło do dramatycznego wzrostu obciążenia kobiet (praca zawodowa, praca w gospodarstwie domowym, wychowanie dzieci, rola żony). Wpływ nastawienia kobiet do pracy zawodowej, działalności ruchów feministycznych był w tych zmianach oczywisty, ale nie jedyny. Zwraca się też uwagę, że wyjście kobiet z orbis interior „na zewnątrz" to wpływ epoki informacyjnej z jej indywidualizmem i samorea-

1 Ang. informationalism - atrybut określonej formy organizacji społecznej, w której tworzenie, przetwarzanie i przekazywanie informacji stają się podstawowymi zasobami decydującymi o produktywności i władzy (tłumaczenie Tomasz Hornowski za: Castells 2003: 52). 
lizacją. Kobietom przestało wystarczać pełnienie funkcji żony i matki (Friedan 1963). W kształtującym się społeczeństwie postindustrialnym powstawały miejsca pracy w sektorze usług odpowiadające predyspozycjom psychofizycznym kobiet. Podjęcie pracy zawodowej przez kobiety umożliwiło im osiągnięcie niezależności ekonomicznej.

Wcześniej dla kobiet jednym z najważniejszych celów życiowych było znalezienie właściwego partnera życiowego. Wraz z rozpoczęciem epoki postindustrialnej cel ten dotyczył znalezienia pracy, samorealizacji i, co najważniejsze, podnoszenia poziomu wykształcenia. Zmiany pozycji społecznej i ekonomicznej kobiet, jakie obserwujemy w społeczeństwie postindustrialnym, nie oznaczają równouprawnienia płci we wszystkich jego obszarach. W większości krajów kobiety są pracownikami gorzej zarabiającymi, mniejszy jest ich udział na stanowiskach kierowniczych, jak również są słabiej reprezentowane na stanowiskach władzy politycznej. Jest to zjawisko „podwójnej dyskryminacji”, gdyż większość kobiet aktywnych zawodowo ponosi również w głównej mierze odpowiedzialność za prowadzenie gospodarstwa domowego i opiekę nad dziećmi (Giddens 1998).

Analizując zmiany w ramach rodziny pod wpływem zwiększania się niezależności kobiet nie sposób nie odnieść się do współczesnego ruchu feministycznego. Początki jego powstania to lata 60. w Stanach Zjednoczonych i lata 70. XX w. na kontynencie europejskim. Feminizm, najkrócej rzecz ujmując, jest „zaangażowaniem się w zakończenie męskiej dominacji” (Mansbridge 1995: 29). Jako ruch społeczny jest on bardzo zróżnicowany, ale $\mathrm{w}$ każdym $\mathrm{z}$ wymienionych przez Castellsa typów zasadniczym jego celem jest obrona praw kobiet (tab. 2). Ta różnorodność, jak twierdzi Castells, nie jest jego słabością, lecz źródłem „siły w społeczeństwie cechującym się elastycznymi sieciami i zmiennymi sojuszami w dynamice konfliktów społecznych i walk o władzę" (2009: 239). W rozmaitych postaciach i różnymi drogami feminizm osłabia patriarchalną dychotomię mężczyzna/kobieta, która manifestuje się w instytucjach społecznych i społecznej praktyce.

Feminizm drugiej fali (współczesny), nie lekceważąc formalnoprawnych przejawów dyskryminacji kobiet i nie rezygnując z walki o ich likwidację, koncentruje uwagę na kulturze, w której widzi źródło dyskryminacji. Sprawą kluczową są dla niego społeczno-kulturowe treści ról „kobiety" i „mężczyzny" oraz pojęć „kobiecości” i „męskości”. Kwestionując ich dotychczasową postać, dąży do nowego ich zdefiniowania w sposób prowadzący do zrównania obu płci nie tylko $\mathrm{w}$ wymiarze formalnoprawnym, ale i obycza- 
jów o kulturowym podłożu. Nowa problematyka wprowadziła nowe terminy: gender i seksizm².

Tabela 2

Analityczna typologia ruchów feministycznych

\begin{tabular}{|l|l|l|l|}
\hline \multicolumn{1}{|c|}{ Typ } & \multicolumn{1}{|c|}{ Tożsamość } & \multicolumn{1}{c|}{ Przeciwnik } & \multicolumn{1}{c|}{ Cel } \\
\hline $\begin{array}{l}\text { Ruch na rzecz praw } \\
\text { kobiet (liberalny, } \\
\text { socjalistyczny) }\end{array}$ & $\begin{array}{l}\text { Kobiety jako ludzie } \\
\text { /istoty }\end{array}$ & $\begin{array}{l}\text { Państwo patriarchal- } \\
\text { ne i/lub patriarchal- } \\
\text { ny kapitalizm }\end{array}$ & $\begin{array}{l}\text { Równe prawa } \\
\text { (włącznie z prawem } \\
\text { reprodukcyjnym) }\end{array}$ \\
\hline Feminizm kulturowy & $\begin{array}{l}\text { Wspólnotowość } \\
\text { kobiet }\end{array}$ & $\begin{array}{l}\text { Patriarchalne insty- } \\
\text { tucje i wartości }\end{array}$ & $\begin{array}{l}\text { Kulturowa autono- } \\
\text { mia }\end{array}$ \\
\hline $\begin{array}{l}\text { Esencjalny feminizm } \\
\text { (spirytualizm, } \\
\text { ekofeminizm) }\end{array}$ & Kobiecy sposób życia & Męski sposób życia & $\begin{array}{l}\text { Matriarchalna } \\
\text { wolność }\end{array}$ \\
\hline Feminizm lesbijski & $\begin{array}{l}\text { Płciowe/kulturowe } \\
\text { siostrzeństwo }\end{array}$ & $\begin{array}{l}\text { Patriarchalna hete- } \\
\text { roseksualność }\end{array}$ & $\begin{array}{l}\text { Zniesienie płci } \\
\text { społecznej przez } \\
\text { separatyzm }\end{array}$ \\
\hline $\begin{array}{l}\text { Specyficzne tożsa- } \\
\text { mości kobiet (etnicz- } \\
\text { ne, narodowościowe, } \\
\text { samookreślane, np. } \\
\text { czarny feminizm } \\
\text { lesbijski) }\end{array}$ & $\begin{array}{l}\text { Samodzielnie kon- } \\
\text { struowana tożsamo- } \\
\text { ści }\end{array}$ & Kulturowa dominacja & $\begin{array}{l}\text { Oddzielony od płci } \\
\text { społecznej multikul- } \\
\text { turalizm }\end{array}$ \\
\hline $\begin{array}{l}\text { Feminizm praktycz- } \\
\text { ny (robotnice, } \\
\text { samoobrona spo- } \\
\text { łeczności, macie- } \\
\text { rzyństwo itd.) }\end{array}$ & $\begin{array}{l}\text { Eksploatowa- } \\
\text { ne/wykorzystywane } \\
\text { kobiety/gospodynie } \\
\text { domowe }\end{array}$ & $\begin{array}{l}\text { Patriarchalny kapita- } \\
\text { lizm }\end{array}$ & $\begin{array}{l}\text { Przetrwa- } \\
\text { nie/godność }\end{array}$ \\
\hline
\end{tabular}

Źródło: Castells 2009: 236.

Występują trzy podstawowe odmiany feminizmu: liberalny, socjalistyczny i radykalny. Różnią się one diagnozą przyczyn upośledzenia kobiet w społeczeństwie oraz wyborem dróg prowadzących do jego likwidacji (Szacka 2003). Feminizm liberalny cieszy się największą popularnością, a jego główna teza głosi, że poza podstawowymi różnicami biologicznymi nic nie różni obu płci. Wszelkie odmienności mężczyzn i kobiet w reakcjach psychologicznych,

2 Gender słownikowo oznacza rodzaj, męski lub żeński, w gramatyce. Poza gramatyką dotyczy rozróżnienia między kobietami i mężczyznami, które jest oparte na cechach społecznych i kulturowych, przyswojonych w trakcie socjalizacji i ukształtowanych odmiennie w różnych kulturach. W literaturze polskiej często występuje w brzmieniu oryginalnym lub jest tłumaczony jako „płeć kulturowa” bądź „płeć społeczno-kulturowa". Seksizm z kolei jest terminem utworzonym przez analogię do rasizmu. Tak jak rasizm dzieli ludzi na należących do lepszej i gorszej rasy, tak seksizm dzieli ludzi na należących do lepszej i gorszej płci (Równość praw... 2000: 10). 
kierunkach zainteresowań, sprawnościach intelektualnych i manualnych są rezultatem wyłącznie pierwotnej i wtórnej socjalizacji. To właśnie podczas procesu socjalizacji każda z płci kształtowana jest odmiennie, w wyniku czego jedne predyspozycje i sposoby zachowania stają się kobiece, a inne męskie. Feminizm liberalny domaga się, aby kobiety i mężczyźni, mając jednakowe możliwości, mieli równy dostęp do wszystkich pozycji zawodowych i ról społecznych. W sztywnym podziale ról na kobiece i męskie upatruje krzywdy dla obu płci. Kobiety, mając ograniczony obyczajem dostęp do wielu ról zawodowych, nie mogą w pełni rozwijać swoich talentów; mężczyźni z kolei są wykluczani ze sfery prywatnej i pozbawiani wielu radości, jakie daje np. kontakt $\mathrm{z}$ własnymi dziećmi. Ta odmiana feminizmu zmierza do zmiany dotychczasowych praktyk kulturowych oraz sprzeciwia się wszelkim przejawom odmiennego traktowania kobiet i mężczyzn, uważając je za dyskryminację. To podejście wyraża także sprzeciw wobec przekazywania $\mathrm{w}$ toku socjalizacji (w tym w edukacji szkolnej) tradycyjnych stereotypów "kobiety” i "mężczyzny”. Feminizm socjalistyczny zwany bywa także marksistowskim bądź lewicowym. Przyczyn ucisku kobiet upatruje w kapitalizmie i opisuje je w języku marksistowskim, nazywając kobiety klasą wyzyskiwaną. Dostrzega ich wyzysk nie tylko na rynku pracy, ale także w domu rodzinnym, w którym pracują „nieodpłatnie” jako żony i matki. Z ich pracy jako gospodyń domowych korzystają wszyscy mężczyźni, chociaż największy zysk czerpią kapitaliści, ponieważ reprodukcja nowych pokoleń robotników nic ich nie kosztuje. Feminizm socjalistyczny widzi wspólnotę interesów kobiet i klasy robotniczej. Uważa, że jednym i drugim wolność może przynieść jedynie obalenie kapitalizmu. Podczas kiedy feminizm socjalistyczny za upośledzenie kobiet wini kapitalizm i kapitalistów, feminizm radykalny obarcza za to winą patriarchalizm i mężczyzn. Przyczynę ucisku kobiet widzi we wrodzonych skłonnościach mężczyzn do dominacji i agresji. Uważa, że nierówność płci istnieje dzięki stałym wspólnym wysiłkom mężczyzn, skierowanym na umacnianie swojego panowania nad kobietami i ich wyzyskiwanie. Głosi, że panowanie mężczyzn nad kobietami wspierają wszystkie instytucje społeczne, a zwłaszcza rodzina. Feminizm radykalny widzi w niej źródło wszelkiego zła. Dla feminizmu tej odmiany mężczyźni są klasą rządząca, kobiety - podporządkowaną. Nawołuje on do walki z patriarchalizmem i domaga się całkowitej przebudowy społecznej. W tym względzie wyraża podobne poglądy jak feminizm socjalistyczny. Te trzy nurty, zresztą wewnętrznie niejednolite, nie wyczerpują wszystkich odmian feminizmu. Odmian tych jest wiele i bywają wyróżniane na podstawie rozmaitych kryteriów. Można więc spotkać się z wyodrębnianiem feminizmu postmodernistycznego, psychoanalitycznego, lesbijskiego, a także ekofeminizmu, postfeminizmu itd. (Johnson 2000; Evans 1995; Whelehan 1995). 
Poszukując przyczyn zmian społecznych, w tym dokonujących się w ramach współczesnej rodziny, wymienia się modernizację jako prowadzącą do indywidualizacji i autonomizacji jednostki. Modernizacja jako proces obejmujący nowe wydarzenia o charakterze strukturalnym, kulturowym i psychologicznym, zmieniła tradycyjny porządek. Trudno ocenić, które procesy były pierwsze, strukturalne czy kulturowo-psychologiczne. W przypadku kulturowej i psychologicznej modernizacji doszło do zmiany sposobu myślenia i doświadczania naszego życia w stosunku do wcześniejszych okresów. Wśród najistotniejszych zmian znalazły się indywidualizacja, racjonalizacja, gwałtowny przepływ informacji i rozwój kultury konsumenckiej.

Indywidualizm nie jest ani statyczny, ani jednoznacznie rozumiany, podlega stałej rewizji w zależności od kontekstu strukturalnego, ekonomicznego i politycznego, w którym występuje. R. Leastheaghe (1983) stwierdza, że w latach 60. indywidualizm niósł ze sobą nacisk na rozwój samego siebie, osiąganie indywidualnych celów i równość możliwości (zwłaszcza dla kobiet). Dla J. Simonsa (1995) indywidualizm to kontinuum, na którego jednym końcu znajduje się nacisk na prawa i wolność jednostek w połączeniu z odpowiedzialnością i tolerancją wobec innych (indywidualizm moralny), na drugim zaś akcent na niezależność osobistą, zdecydowane nastawienie na samego siebie, realizację własnych praw, które znajdują się ponad prawami i potrzebami innych osób (indywidualizm pragmatyczny).

Indywidualizacja ma, według U. Becka, trzy wymiary:

1) uwolnienia od tradycyjnej struktury władzy i ochrony bytu, czyli historycznie danych form społecznych i więzi (tzw. wymiar uwolnienia),

2) utraty stabilności w wyniku odrzucenia tradycyjnych przekonań dotyczących działania, wiary i norm (tzw. wymiar odczarowania),

3) ponownej integracji, czyli nowego rodzaju więzi społecznych (tzw. wymiar kontrolny lub reintegracyjny).

Te trzy wymiary tworzą „ahistoryczny wymiar indywidualizacji”. Jednym z przejawów indywidualizacji jest rozpad istniejących wcześniej form społecznych, co ujawnia się poprzez coraz większą kruchość takich kategorii, jak status społeczny, role płci i sąsiedztwo. Do innych jej przejawów należą wymagania, kontrola i przymus stawiane przed jednostkami w nowoczesnych społeczeństwach przez rynek pracy, instytucje i system ubezpieczeń społecznych (Beck, Beck-Gernsheim 2002).

Indywidualizację należy traktować jako proces długofalowy, nieplanowany, niosący wzrost możliwości skierowanych do jednostki. Stało się to możliwe w wyniku kulturowych zmian postaw wobec jednostek oraz zmian psychologicznych dokonujących się wewnątrz samych jednostek. Dokonało się też uwolnienie od tradycyjnych więzi społecznych i zobowiązań. W społeczeństwie nowoczesnym jednostce przedstawia się oferty, zachęca do działania i pokazuje jej możliwości, ale to jednostka dokonuje wyboru. 
W wyniku indywidualizacji wzrosła liczba dopuszczalnych moralnie i praktycznie wyborów, gdy chodzi o formę życia. Jednostka może i musi podejmować decyzje dotyczące jej samej. Jej pozycja społeczna nie jest wyznaczana przez sam fakt urodzenia się w takiej, a nie innej klasie społecznej czy religijnej, ale zdobywa się ją samemu przez wykształcenie i rodzaj zatrudnienia. Proces ten można opisać jako przejście od regulacji wzajemnych stosunków opartych na autorytaryzmie i podporządkowaniu do relacji opartych na negocjacjach. Takie przejście jest najbardziej wyraźne w relacjach intymnych miedzy kochankami, małżonkami, rodzicami i dziećmi (Kwak 2005).

Modernizacja jest zwykle łączona z rodziną nuklearną, postuluje indywidualizm, samorealizację i autonomię lub przynajmniej pewną formę wolności od autokratycznej kontroli wewnątrz rodziny. Wzrost autonomii przekłada się na wzrost ruchliwości, mniejsze rozmiary rodziny, zwiększa liczbę relacji z osobami spoza kręgu rodzinnego. Przyczynia się do poprawy warunków życia, równości między płciami, wzrostu dostępu do edukacji, różnych form usług dla ludzi starych, młodocianych czy niepełnosprawnych. Procesy modernizacji dotyczą zmian rodziny w wymiarze strukturalnym, jak i relacji między jej członkami. Istotna jest zmiana relacji wewnętrznych w rodzinie, zwłaszcza stosunków między rodzicami i dziećmi. Należy zwrócić uwagę na fakt, że decyzja o posiadaniu lub nieposiadaniu dziecka może być podejmowana przez jednostki i nie jest przesądzona koniecznością tego zadania społecznego. Obecnie jest ona uwarunkowana oczekiwaniami wzajemnych gratyfikacji emocjonalnych, jakie mogą dać rodzice dziecku, a dziecko rodzicom.

Indywidualizacja jednostek wpływa na życie rodzinne, w wyniku tego współczesne życie rodzinne nie zawęża się tylko do tradycyjnej rodziny nuklearnej, zwiększył się bowiem zakres wyboru jej form alternatywnych. Jednoznacznie do niedawna rozumiane pojęcia rodzina, małżeństwo, rodzicielstwo przestały być tak oczywiste. Istotne jest również to, że obecnie kobieta i mężczyzna stają się widoczni jako odrębne jednostki, powiązane z rodziną różnymi relacjami i oczekiwaniami. Nie oznacza to wcale anarchii w ramach rodziny i zaniku więzi. Pomimo znacznej skali rozwodów przeważają jednak związki, nawet jeśli są to związki nieformalne. Postępujący proces indywidualizacji zmienia jednak powszechnie obowiązujące formy współżycia. Rozluźnia się bowiem związek miedzy rodziną, a - jak to nazywa Beck - biografią indywidualną. Jednostka coraz bardziej żyje własnym życiem, następuje zmiana z priorytetu rodziny na biografię indywidualną. Dokonujemy nie tylko wyboru pomiędzy życiem w rodzinie czy nierodzinnych formach życia, ale pojawia się możliwość wyboru tzw. pluralistycznej nieciągłej trajektorii biografii, czyli „biograficzny pluralizm form życia" (Beck 2002). 


\subsection{Wspólczesne zachowania matrymonialne i prokreacyjne w badaniach naukowych}

Literatura przedmiotu badań rozumianego jako współczesne zmiany zachowań demograficznych w sferze małżeńskości i rozrodczości obejmuje opracowania przedstawicieli wielu dyscyplin naukowych - obok geografii są to m.in. demografia, socjologia czy antropologia kultury. Prowadzone analizy obejmują różne skale przestrzenne, od ujęć regionalnych, najczęściej dotyczących krajów europejskich, po mniejsze jednostki w obrębie poszczególnych państw. Tematyką tych opracowań są, w przeważającej części, poszczególne zachowania matrymonialne i prokreacyjne analizowane w świetle drugiego przejścia demograficznego (tab. 3).

Tabela 3

Opracowania naukowe podejmujące problematykę współczesnych zachowań matrymonialnych i prokreacyjnych

\begin{tabular}{|l|l|l|l|l|l|}
\hline \multirow{2}{*}{$\begin{array}{c}\text { Zakres } \\
\text { przestrzenny }\end{array}$} & $\begin{array}{c}\text { Przemiany } \\
\text { demogra- } \\
\text { ficzne }\end{array}$ & $\begin{array}{c}\text { Drugie } \\
\text { przejście } \\
\text { demogra- } \\
\text { ficzne }\end{array}$ & $\begin{array}{c}\text { Zachowa- } \\
\text { nia pro- } \\
\text { kreacyjne }\end{array}$ & $\begin{array}{c}\text { Zachowania } \\
\text { matrymo- } \\
\text { nialne }\end{array}$ & $\begin{array}{c}\text { Wybrane } \\
\text { zachowania } \\
\text { matrymo- } \\
\text { nialne lub } \\
\text { prokreacyjne }\end{array}$ \\
\hline $\begin{array}{l}\text { Grupy krajów/ } \\
\text { regiony }\end{array}$ & & & & & \\
\hline Kraje & & & & & \\
\hline $\begin{array}{l}\text { Jednostki admini- } \\
\text { stracyjne średniego } \\
\text { szczebla }\end{array}$ & & & & & \\
\hline Miasta & & & & & \\
\hline $\begin{array}{l}\text { Małe jednostki } \\
\text { administracyjne }\end{array}$ & & & & & \\
\hline
\end{tabular}

Uwaga: natężenie szarości informuje o natężeniu częstości podejmowania problematyki badawczej w literaturze.

Źródło: oprac. własne na podstawie literatury.

Andrzej Gawryszewski w Historii polskiej geografii z 2008 r. pisze, że „badania nad ruchem naturalnym ludności są liczebnie najsłabiej reprezentowanym tematem w publikacjach z zakresu geografii ludności" po 1945 r. Podkreśla fakt, że od połowy lat 70. tematyka dotycząca reprodukcji ludności i płodności kobiet była głównie podejmowana przez demografów (np. E. Frątczak, K. Iglicka, L. Nowak, M. Okólski, Z. Strzelecki,), a opracowania geograficzne były nieliczne (Iwanicka-Lyrowa 1991; Korcelli 1991; Kupiszewski 1991; Iwanicka-Lyrowa, Witkowski 1991; Potrykowska 1991). Wzrost zainteresowania problematyką ruchu naturalnego ludności wśród 
geografów daje się zauważyć od lat 90. ubiegłego wieku (np. Eberhardt 2002; Eberhardt 2007; Eberhardt 2011; Flaga 2000; Dzieciuchowicz 1992; 1998; 2001;2002; 2009/2010a; 2009/2010b).

Problematyka zachowań demograficznych pojawia się w wielu opracowaniach mających charakter analiz sytuacji demograficznej, w których zagadnienia te omawiane są obok wielu innych, stanowiąc tylko część całkowitego obrazu sytuacji ludnościowej. Prace owe często mają charakter raportów, diagnoz, które są opracowywane na zlecenie różnych jednostek rządowych czy instytucji (np. Sytuacja Demograficzna Polski. Raport 2011-2012, Rządowa Rada Ludnościowa; Demography Report 2010. Older, More Numerous and Diverse Europeans, Eurostat, European Commission). Analizy przemian sfery małżeńskości i rozrodczości spotykamy także w innych opracowaniach opisujących zmiany ludnościowe w różnych przekrojach przestrzennych, np. kraje rozwinięte gospodarczo (np. Reher 2007; Ogden 1998).

Odrębną grupę stanowią opracowania monograficzne i podręczniki z geografii ludności. Wśród monografii na uwagę zasługują prace w całości poświęcone zagadnieniom ludnościowym i poruszające problematykę współczesnych zmian demograficznych (np. Ludność Polski w XX wieku oraz Ludność Warszawy $w$ XX wieku autorstwa Andrzeja Gawryszewskiego). W grupie podręczników mieszczą się najnowsze prace z geografii ludności (np. J. R. Weeks, 2008, Population. An Introduction to Concepts and Issues; D. Jędrzejczyk, 2001, Podstawy geografii ludności), a także demografii (np. M. Okólski, 2005, Demografia. Podstawowe pojęcia, procesy i teorie w encyklopedycznym zarysie; J. Z. Holzer, 1999; 2003, Demografia).

Od lat 80. ubiegłego wieku, kiedy to po raz pierwszy zidentyfikowano przemiany w sferze małżeńskości i nazwano je drugim przejściem demograficznym, powstało wiele opracowań odnoszących się do tej koncepcji. Pierwszymi były oczywiście prace autorów tej teorii, tj. D. van de Kaa i R. Lestheage, w których na podstawie zaobserwowanych przemian wysunęli założenia nowej koncepcji (van de Kaa 1978; Lesthaeghe 1983; Lesthaeghe, van de Kaa 1986; van de Kaa 1987). W następnych latach ukazały się opracowania, w których doprecyzowaniu i rozwinięciu uległa teoria drugiego przejścia demograficznego (van de Kaa 1994; 1997; 1999; 2001a; 2001b; 2001c; 2008; Lesthaeghe 1995; Lesthaeghe, Surkyn 2002). W polskiej literaturze przedmiotu problematyka drugiego przejścia demograficznego została przedstawiona w pracy zbiorowej pod red. M. Okólskiego (1990). W opracowaniu tym autor omawia założenia teoretyczne oraz próby ilościowego opisu procesów występujących w ramach tego przejścia. Na polskie warunki zaadaptowała koncepcję drugiego przejścia demograficznego I. Kotowska (1998; 1999).

W pierwszym okresie, prowadzenia analiz obejmujących współczesne przemiany zachowań matrymonialno-prokreacyjnych, powstały opracowa- 
nia omawiające te zagadnienia w krajach Europy Północnej i Zachodniej. Było to oczywiste, skoro wspomniane przemiany rozpoczęły się właśnie w tej części Europy. Następne lata przyniosły wiele opracowań omawiających tę problematykę w pozostałych regionach europejskich, zwłaszcza w krajach Europy Środkowowschodniej oraz Stanach Zjednoczonych (Lesthaeghe, Surkyn 2002; Rychtarikova 2000; Sobotka, Zeman, Kantorova 2003; Sobotka 2002; Zakharov, Ivanova 1996; Frejka 2008; Zakharov 1997; 2008; Lesthaeghe, Neidert, Surkyn 2006; Kotowska 1998; Kurkiewicz 1998; Eberhardt 2002). Zwracano $w$ nich uwagę na nieco odmienny przebieg i tempo procesów zmian oraz inne ich uwarunkowania.

W następnym etapie rozwoju badań nad współczesnymi zachowaniami analizie poddawano odrębnie zarówno zachowania prokreacyjne, jak i matrymonialne oraz poszczególne ich rodzaje. W tym przypadku skala przestrzenna opracowań zaczęła być bardziej zróżnicowana, coraz większa liczba prac dotyczyła mezoskali (kraj), a także mikroskali - miast i mniejszych jednostek administracyjnych.

W obszarze badań nad zachowaniami matrymonialnymi często podejmowane są łącznie problemy formowania związków małżeńskich i ich rozpadu (Styrc 2011; Kowalska 1999; Barański, Kaczmarek 2007; Frątczak 2012; Wilson, Smallwood 2008) lub zależności pomiędzy małżeńskością a płodnością (Gołata 1995). Analizie demograficznej podlegają też procesy zawierania małżeństw powtórnych (wcześniejsze uwagi dotyczyły w większości małżeństw pierwszych), tj. takich, z których co najmniej jeden z współmałżonków był już kiedyś w związku (Kluzowa, Slany 1990; 1993; Rydzewski 1993; Guraj-Kaczmarek 1995).

Interesującym zagadnieniem badanym przez demografów i socjologów są postawy i preferencje młodzieży w wieku matrymonialnym (Ignatczyk 1990; 1993; 2000; Zagórny 1991; Włostowska 1996; Pielka 1996; 1997; 1998; Michalczyk 1991; Slany 2001). Wyniki tych badań są wykorzystywane do konstrukcji wzorca postaw małżeńskich i prokreacyjnych oraz prognozowania rozmiarów ruchu naturalnego.

W literaturze, zwłaszcza socjologicznej, procesy przemian demograficznych są $w$ dużej mierze łączone z przeobrażeniami w ramach rodziny (Slany 2002b, Warzywoda-Kruszyńska 2004; Kwak 2005; Tyszka 2003). W tym kontekście analiza obejmuje rozpowszechniające się nowe formy życia małżeńsko-rodzinnego, takie jak kohabitacja, single live, monoparentalność. Są to zjawiska, które są coraz bardziej „popularne”, szczególnie w środowisku wielkomiejskim. Związki nieformalne są poddawane badaniom ze względu na skłonność do ich zawierania, dobór partnerski, postawy prokreacyjne, trwałość rozwiązań legislacyjnych. Przeważajaca część opracowań dotyczy różnych aspektów związków kohabitacyjnych w poszczególnych krajach europejskich, np. Polski (Matysiak 2009; Mynarska, Matysiak 
2010; Mynarska, Bernardi 2007; Szukalski 2004; Warzywoda-Kruszyńska 2004; Slany, Baszarkiewicz 2004); Hiszpanii (Baizán, Aassve, Billari 2003); Wielkiej Brytanii (Haskey 2001); Bułgarii (Hoem, Kostova 2008); Niemiec Zachodnich (Nazio, Blossfeld 2003); Wegier (Nazio, Blossfeld 2003); Francji (Marti, Thery 2001) lub Europy (Prinz 1995; Manting 1996; Kiernan 2000; 2002). Obok związków kohabitacyjnych zainteresowanie badawcze wywołują także inne alternatywne formy życia małżeńsko-rodzinnego jak rodziny monoparentalne i życie w pojedynkę (Paprzycka 2009; Czernecka 2009; Tymicki 2001). W badaniach demograficznych, które odnoszą się do „nowych" zachowań matrymonialnych i prokreacyjnych często analizy dotyczą współzależności procesów demograficznych i ekonomicznych, a zwłaszcza przeobrażeń rodziny i struktur ludności w powiązaniu ze zmianami na rynku pracy oraz zagadnień polityki ludnościowej i społecznej (Kotowska 2005, 2009a, 2009b; 2010; Kotowska i in. 2007; Kotowska, Giza-Poleszczuk 2010; Kotowska, Jóźwiak 2012).

Do niedawna dorobek geografów w badaniach małżeńskości w porównaniu z innymi dyscyplinami (socjologia, demografia) nie był znaczący (przynajmniej ilościowo). Jak pisze B. Miszewska (1994), dla geografów „małżeństwa nie są elementem różnicującym wyraźnie populacje, dlatego w literaturze omawiane są najczęściej z innymi elementami ruchu naturalnego". Według D. Jędrzejczyka (2001) małżeństwa (oraz wiek nowożeńców) z reguły rozpatrywane są z punktu widzenia potrzeb analizy urodzeń.

Przeobrażenia w sferze małżeńskości związane z drugim przejściem demograficznym przyczyniły się do ponownego zainteresowania geografów problematyką zachowań matrymonialnych. Najnowsze opracowania w dużej mierze dotyczą wybranych problemów, np. procesu zawierania małżeństw i ich przestrzennego zróżnicowania (Podogrodzka 2011; 2012b; 2013; Gałka 2009).

W przypadku zachowań prokreacyjnych wiele uwagi poświęcają badacze dzietności i jej zmianom w ostatnich latach. Rozpatrują przy tym przyczyny jej spadku, wskazując proces transformacji ustrojowo-gospodarczej (Kotowska 1999; Sobotka, Zeman, Kantorova 2003; Sobotka 2002; Frątczak 2004) lub zjawisko wzmożonego odkładania urodzeń (Billari, Kohler 2004; Sobotka 2004; Sanchez-Barricarte, Fernandez-Carro 2007; Frejka, Sobotka 2008). Wymieniane są także inne powody spadku dzietności, w tym dyfuzja nowych wartości, różnorodności stylów życia, światopoglądów czy innowacji technologicznych, które według niektórych autorów mają większe znaczenie niż uwarunkowania ekonomiczne (Bryant 2007; Wilson, Airey 1999; Cleland 2001; Bongaarts, Watkins 1997).

Zachowania prokreacyjne podobnie jak matrymonialne mają niewątpliwie mniejszy związek z przestrzenią geograficzną i zapewne jest to wynik mniej licznego podejmowania analizy tych zagadnień w ujęciu przestrzen- 
nym. Nie oznacza to jednak, że zjawiska te nie są zróżnicowane przestrzennie, na co wpływają złożone cechy w zakresie sytuacji społecznoekonomicznej obszaru. Badania zachowań prokreacyjnych w tym dzietności koncentrują się nie tylko na analizie przestrzennej tych zjawisk, ale także na wyjaśnianiu przyczyn tego zróżnicowania. Wśród czynników warunkujących niejednorodność przestrzenną zachowań prokreacyjnych wymienia się bardzo wiele elementów. Zaliczyć do nich należy, np. czynniki indywidualne (poziom wykształcenia, aktywność ekonomiczną, religijność, narodowość), a także czynniki regionalne (Duchêne i in. 2004; de Beer, Deerenberg 2007; Hoem 2000).

W Polsce badania dotyczące zachowań prokreacyjnych skupiają się na terytorialnym zróżnicowania płodności oraz urodzeniach pozamałżeńskich. Wskazują na pojawienie się nowych wzorców płodności oraz wzroście odsetka urodzeń pozamałżeńskich, podkreślając m.in. wpływ czynników społeczno-ekonomicznych na "nowe” zachowania demograficzne (Podogrodzka 2012a; Brzozowska 2011; Szukalski 2001; 2004b; 2010; Budnik i in. 2007; Gołata 1990; 1995; Frątczak 2000; Florczak 2008; Młynarska 2009; Toński 1999).

Jednak w literaturze brak jest opracowań, które w sposób kompleksowy ujmowałyby zagadnienie zmian zachowań demograficznych w Polsce w aspekcie przestrzennym. Lukę tę niejako wypełnia praca S. Kurka i M. Lange - Zmiany zachowań prokreacyjnych $w$ Polsce $w$ ujęciu przestrzennym z 2012 r. Autorka niniejszego opracowania wyraża nadzieję, że jej książka może być także wzbogaceniem wiedzy z geografii ludności dotyczącej zachowań matrymonialnych i prokreacyjnych w Polsce.

\subsection{Przedmiot, cele i zakres pracy}

Przedmiotem opracowania są zachowania matrymonialne i prokreacyjne w Polsce i ich zmiany obserwowane od lat 90 . ubiegłego wieku. W ramach małżeńskości poddano badaniu spadek skłonności zawierania związków małżeńskich, opóźnienie typowego wieku zawarcia małżeństwa, upowszechnienie alternatywnych form związków kohabitacyjnych oraz postępujące nasilenie rozwodów i tendencje dotyczące separacji. Wśród zmian drugiego wzmiankowanego obszaru przemian demograficznych analizowano spadek dzietności, opóźnienie typowego wieku prokreacji, zmniejszenie średniej liczebności rodziny oraz zwiększanie się rozmiarów rodności pozamałżeńskiej. Wymienione zachowania demograficzne są niewątpliwie nowymi jakościowo zjawiskami w naszym kraju, związanymi z procesami przemian wyjaśnianymi przez teorię drugiego przejścia demograficznego. Nowe wzory w zakresie życia małżeńskiego i rodzinnego upowszechniają się w Polsce niezwykle szybko, wzrasta także poziom przyzwolenia spo- 
łecznego na nowe formy zachowań matrymonialnych i prokreacyjnych. W opracowaniu poddano także analizie opinie ludzi na temat nowych zjawisk w ramach małżeńskości i rozrodczości. Jako studium przypadku wzięto pod uwagę poglądy mieszkańców Łodzi, miasta, w którym przemiany zachowań matrymonialnych i prokreacyjnych następują już od wielu lat i są pod względem ilościowym jednymi z najwyższych w kraju.

Podjęty temat badawczy mieści się w nurcie badań z geografii ludności. Jest to jedna z siedmiu subdyscyplin geografii, którą zalicza się do geografii ekonomicznej według schematu zaproponowanego przez S. Leszczyckiego (1962) w I tomie Geografii powszechnej. L. Kosiński autor Geografii ludności, która ukazała się w 1967 r. pisze, że:

Geografia ludności jest odrębną dyscypliną ekonomiczno-geograficzną, która analizuje i interpretuje zmieniające się w czasie i przestrzeni zjawiska i procesy ludnościowe na powierzchni Ziemi [...] Zadaniem geografii ludności jest wykrycie ogólnych prawidłowości rządzących zróżnicowaniem przestrzennym stosunków ludnościowych oraz krytyczna ocena istniejącej sytuacji z punktu widzenia potrzeb społecznych.

Przedstawił także najważniejsze problemy badawcze tej subdyscypliny, jako:

- problemy ogólnoteoretyczne (metodologia, techniki i metody badań, historia geograficznych badań ludności);

- rozmieszczenie ludności (rozmieszczenie i gęstość w ekumenie, w układzie osadniczym, miary syntetyczne rozmieszczenia);

- dynamika ludności (ruch naturalny, ruch migracyjny);

- struktura ludności (demograficzna, społeczno-ekonomiczna).

Pole badawcze geografii ludności wyznaczone przez L. Kosińskiego pozostaje w zasadniczym kształcie aktualne współcześnie, choć problemów badawczych przybyło $\mathrm{w}$ związku ze zmieniającą się sytuacją społeczno-gospodarczą i pojawieniem się nowych zjawisk oraz procesów ludnościowych w ponowoczesnym świecie.

W podobny sposób wyznacza przedmiot badań geografii ludności A. Jagielski (1978: 38), pisząc, że jest to „ludność jako zjawisko przestrzenne, a do głównych zadań badawczych należą opis, analiza i wyjaśnianie struktur i zachowań przestrzennych zbiorowości ludzkich jakiegokolwiek rodzaju wielkości”. A. Jagielski wyróżnia cztery kierunki zainteresowań badawczych geografii ludności, są to:

- kierunek chorologiczny (inaczej ujęcie regionalne), w którym przedmiotem badań są właściwości różnego rodzaju jednostek terytorialnych, wydzielonych przeważnie na podstawie kryteriów fizycznogeograficznych albo administracyjnych, 
- kierunek środowiskowy (ujęcie ekologiczne), za główny cel badań uznaje relacje pomiędzy środowiskiem geograficznym a społeczeństwem i ich wzajemne przystosowywanie się,

- kierunek analityczno-przestrzenny, który kładzie nacisk na badanie przestrzennych właściwości zbiorów ludzi i różnych zjawisk,

- kierunek eklektyczny, w którym badacze nie zajmują określonego stanowiska metodologicznego i wykorzystują wszystkie elementy wymienionych poprzednio ujęć.

D. Jędrzejczyk, autor trzeciego podręcznika z geografii ludności w Polsce, podkreśla, że geografia ludności, jako dyscyplina geograficzna analizuje oraz interpretuje zmieniające się w czasie i przestrzeni zjawiska tudzież procesy ludnościowe na powierzchni Ziemi, a „przedmiotem jej badań jest ludność traktowana jako zjawisko przestrzenne" (Jędrzejczyk 2001: 16). Podkreślając specyfikę tej dyscypliny naukowej wynikającą ze skupiania uwagi na przestrzennych właściwościach zbiorowości ludzkich, zwraca uwagę na fakt, że posługuje się ona głównie wielkościami mierzalnymi lub dającymi się porządkować, używając do tego w głównej mierze języków sformalizowanych oraz metod i technik badawczych. Nie jest to jednak równoznaczne $\mathrm{z}$ przekształcaniem się geografii ludności $\mathrm{w}$ dyscyplinę matematyczną, zachowuje ona bowiem swój społeczny i humanistyczny charakter.

W ramach geografii ludności wyróżniany jest dział określany jako demogeografia, „który zajmuje się geograficznymi aspektami zjawisk demograficznych, a więc przede wszystkim problemami przestrzennymi procesów wzrostu lub spadku liczby mieszkańców i związanych z nimi zmian we właściwościach strukturalnych ludności" (Jagielski 1978: 27-28).

W badaniach społecznych życie człowieka od momentu urodzenia do śmierci może być traktowane jako ciąg zdarzeń. Wśród zdarzeń występują też te o charakterze demograficznym, jak chociażby urodzenia, zgony, zawieranie czy rozwiązywanie małżeństw. Są one ewidencjonowane i przypisane konkretnym jednostkom. W przypadku zjawisk/zachowań demograficznych odnosimy się do pojęć abstrakcyjnych zachodzących w populacjach (tab. 4). Terminologia stosowana do zdarzeń i zachowań demograficznych pozwala odróżnić jedne od drugich tylko w przypadku dwóch, tj. rozrodczości i umieralności.

Zdarzenia demograficzne mają charakter powtarzalnych lub niepowtarzalnych. Powtarzalne to takie, które mogą występować wielokrotnie w życiu danej jednostki, np. zawieranie małżeństw, urodzenia dzieci czy migracje. Do niepowtarzalnych możemy zaliczyć zawarcie czy też rozpad pierwszego małżeństwa, urodzenie trzeciego dziecka itd. Do tej grupy bez wątpienia zaliczyć należy także zgon. Inną cechą zdarzeń, bardzo istotną w analizach demograficznych, jest zależność lub niezależność od woli. 
Jedynym niezależnym od woli człowieka zdarzeniem jest zgon (musi kiedyś nastąpić), w przypadku pozostałych ich realizacja jest w mniejszym lub większym stopniu zależna od woli człowieka

Zachowanie demograficzne jest definiowane jako „ogół reakcji wywołanych czynnikami zewnętrznymi (sytuacją) bądź wewnętrznymi (potrzebami, zamiarami, aspiracjami), odnoszących się do wyboru partnera, miejsca zamieszkania oraz strategii reprodukcyjnej i zdrowotnej. Są to zatem występujące rzeczywiście reakcje, przy założeniu, że są one świadome" (Szukalski 2012). Jednak nie o wszystkich rzeczywistych zachowaniach mamy wiedzę, wiemy tylko o tych zachowaniach demograficznych, które zostały zgłoszone $\mathrm{w}$ odpowiednich organach administracji publicznej bądź o których informacje zaczerpnęliśmy z innych źródeł. Przechodząc do badania grup, dokonywana jest agregacja zdarzeń demograficznych w konstrukt mówiący o liczbie i natężeniu tychże zdarzeń, który nazywany jest zjawiskiem demograficznym. W sytuacji, gdy owo zjawisko analizowane jest w jakimś okresie, mamy do czynienia z procesem demograficznym.

Tabela 4

Rodzaje zjawisk i zdarzeń demograficznych

\begin{tabular}{|l|l|}
\hline \multicolumn{1}{|c|}{ Zjawisko/zachowanie } & \multicolumn{1}{c|}{ Zdarzenie } \\
\hline Zawieranie małżeństw & Małżeństwo bez rozróżnienia kolejności \\
& Małżeństwo $k$-tej kolejności \\
\hline Rozwiązywanie małżeństw & $\begin{array}{l}\text { Owdowienie bez rozróżnienia kolejności } \\
\text { Owdowienie } k \text {-tej kolejności } \\
\text { Rozwód bez rozróżnienia kolejności } \\
\text { Rozwód k-tej kolejności }\end{array}$ \\
\hline Rozrodczość, rodność, płodność & Urodzenia bez rozróżnienia kolejności \\
& Urodzenia $k$-tej kolejności \\
\hline Umieralnośćc & Zgon \\
\hline Migracje wewnętrzne & Przyjazd bez rozróżnienia kolejności \\
- napływ & Przyjazd $k$-tej kolejności \\
- odpływ & Wyjazd bez rozróżnienia kolejności \\
& Wyjazd $k$-tej kolejności \\
\hline Migracje zewnętrzne (zagraniczne) & Imigracja bez rozróżnienia kolejności \\
- imigracja & Imigracja $k$-tej kolejności \\
- emigracja & Emigracja bez rozróżnienia kolejności \\
& Emigracja $k$-tej kolejności \\
\hline
\end{tabular}

Źródło: Kurkiewicz 2010.

W opracowaniu, poddając analizie zachowania demograficzne, zmierzano przede wszystkim do ustalenia:

1. Jakie są tendencje ogólnokrajowe i regionalne w procesie formowania i rozpadu związków małżeńskich oraz zachowań prokreacyjnych?

2. Jakie są uwarunkowania zmian w zachowaniach demograficznych? 
3. Jaki jest rozkład przestrzenny analizowanych zachowań demograficznych?

4. Czy występuje tendencja do koncentracji obszarów pod względem podobieństwa w zachowaniach demograficznych ludności?

5. Jak kształtują się opinie społeczeństwa polskiego na temat zmieniających się zachowań matrymonialnych i prokreacyjnych w Polsce? - studium przypadku - Łódź.

Postawienie pytań badawczych umożliwiło wyznaczenie celów badawczych. Ogólnie przyjętym celem w opracowaniu jest określenie tendencji zmian w zachowaniach matrymonialnych i prokreacyjnych w Polsce, uwarunkowań tych przemian oraz wyjaśnienie ich przestrzennego zróżnicowania. Cele szczegółowe obejmowały zadania, które wymagały rozwiązania problemów głównie w warstwie empirycznej i metodycznej. Pierwszym celem było określenie tendencji i kierunku zmian w zachowaniach obszaru małżeńskości i rozrodczości w Polsce w dłuższej perspektywie czasowej, tj. od lat 50. ubiegłego wieku do roku 2011. Było to zadanie, które miało nakreślić ogólną sytuację przeobrażeń związanych z zachowaniami matrymonialnymi i prokreacyjnymi w Polsce. Umożliwiło także porównanie sytuacji w Polsce $\mathrm{z}$ sytuacją $\mathrm{w}$ innych krajach europejskich, znajdujących się na różnych etapach przemian drugiego przejścia i dało możliwość określenia poziomu zmian, na którym znalazł się nasz kraj. Następnym celem, który starano się osiągnąć w pracy, była analiza przestrzennego zróżnicowania zachowań demograficznych w Polsce według podregionów (ryc. 1).

Wybór jednostki odniesienia był podyktowany specyfiką badanych zjawisk. Chcąc uniknąć przypadkowości rejestrowanych zjawisk w populacjach mało licznych, zdecydowano się na przeprowadzenie analizy przestrzennej dla podregionów. Dodatkowym argumentem przemawiającym na korzyść podregionów była zbliżona liczebność populacji tych jednostek (z wyjątkiem największych miast Polski, które są także podregionami). Autorka miała świadomość również negatywnych aspektów związanych $\mathrm{z}$ doborem jednostek odniesienia. Jednym z nich był sposób wyznaczenia granic podregionów, dość „sztuczny” i kontrowersyjny w przypadku kilku z nich. Co prawda składają się one z powiatów, ale utworzono je głównie na potrzeby statystyki regionalnej Eurostatu i GUS-u. W przypadku analizy przestrzennego zróżnicowania zakres czasowy obejmował znacznie krótszą perspektywę, tj. lata 2002-2011. Należy mieć też na uwadze fakt, że dla wybranych zjawisk demograficznych informacje pochodzą tylko ze spisów powszechnych, co było także powodem wyznaczenia takiego zakresu czasowego. Brak dostępności danych uniemożliwił autorce opracowania zbadanie zmian struktury gospodarstw domowych i rodzin, ponieważ Główny Urząd Statystyczny nie opublikował jeszcze owych informacji (według 


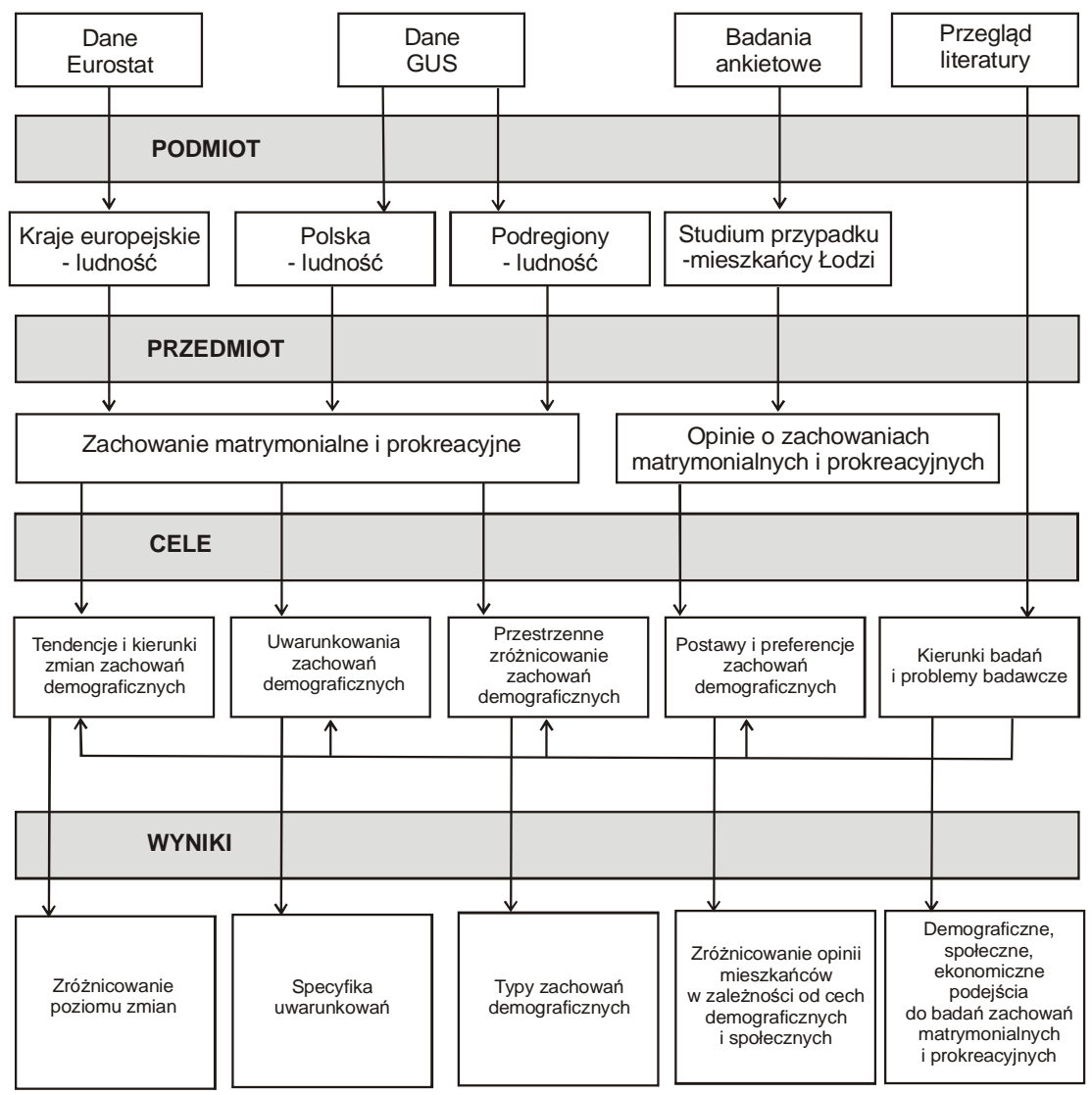

Ryc. 1. Schemat badań Źródło: oprac. własne

harmonogramu publikacji wyników NSP 2011 dojdzie do tego pod koniec 2013 r.). Analiza zróżnicowania przestrzennego zachowań małżeńskości i rozrodczości umożliwiła wyznaczenie ogólnych tendencji w zróżnicowaniu przestrzennym zachowań matrymonialnych i prokreacyjnych. Kolejnym celem było wyznaczenie typów zachowań demograficznych w Polsce według podregionów, co umożliwiło identyfikację jednostek podobnych pod względem zachowań w sferze małżeńskości i rozrodczości. Jednym z celów opracowania było też określenie uwarunkowań zmian zachowań demograficznych. Analizie poddano dwie grupy czynników - demograficzne oraz społeczno-ekonomiczne. Przeprowadzono także typologię i grupowanie liniowe tych cech dla podregionów, aby sprawdzić jak wpływają na zjawiska małżeńskości i rozrodczości. Istotnym celem z poznawczego punktu widzenia było także poznanie opinii mieszkańców jednego z podregionów (Łodzi) na temat zachowań demograficznych obserwowanych w Polsce. $\mathrm{W}$ tym przypadku analiza objęła materiały pozyskane $\mathrm{w}$ trakcie badań 
surveyowych. Innym z celów pracy było określenie kierunków badań i problemów badawczych dotyczących zjawisk sfery matrymonialnej i prokreacyjnej. Teoretyczne podstawy badań tych zagadnień są w zasadniczej części wynikiem dorobku dwóch dyscyplin naukowych, tj. demografii i socjologii.

Podejście naukowe jest zróżnicowane z punktu widzenia poziomu analizy. Niniejsze opracowanie dotyczące zachowań matrymonialnych i prokreacyjnych w zdecydowanej części ma charakter badań makroskalowych i mezoskalowych mających na celu przedstawienie zmian tych zachowań w kraju i podregionach. Część pracy odnosi się do megaskali i dotyczy zbiorowości krajów europejskich.

Przestrzennym zakresem pracy jest obszar Polski w jej granicach administracyjnych, w podziale na podregiony (NUTS 3). Podregiony zostały ustanowione jako jeden z poziomów klasyfikacji NUTS w 2003 r. zgodnie z Rozporządzeniem (WE) nr 1059/2003 Parlamentu Europejskiego i Rady z dnia 26 maja 2003 r. ${ }^{3}$ Wspólna klasyfikacja została ustanowiona w celu zbierania, opracowania i rozpowszechniania na obszarze UE porównywalnych danych dla określonych statystyk regionalnych (np. z zakresu rachunków regionalnych, demografii, rynku pracy i społeczeństwa informacyjnego). Klasyfikacja NUTS służy również kształtowaniu regionalnych polityk krajów UE i jest niezbędna do przeprowadzania analiz stopnia rozwoju społeczno-gospodarczego regionów. Wcześniej, bo w 2000 r. w naszym kraju wprowadzono Nomenklaturę Jednostek Terytorialnych do Celów Statystycznych (NTS) ${ }^{4}$. Klasyfikacja dzieli Polskę na terytorialne, hierarchicznie powiązane jednostki na pięciu poziomach, z czego trzy określono, jako poziomy regionalne, dwa jako poziomy lokalne. Poziom regionalny obejmuje swym zasięgiem:

- poziom 1 - obszar całego państwa,

- poziom 2 - województwa,

- poziom 3 - podregiony.

Poziom lokalny obejmuje swoim zasięgiem:

- poziom 4 - powiaty,

- poziom 5 - gminy.

W latach 2000-2007 były wydzielone 44 podregiony. Od 1 stycznia $2008 \mathrm{r}$. weszło w życie Rozporządzenie Rady Ministrów z dnia 14 listopada 2007 r. ${ }^{5}$ wprowadzające podział kraju na 66 podregionów (ryc. 2; A I). Główny

3 DzUrz, UE L, 154 z 21 czerwca 2003 r., z późn. zm.

${ }^{4}$ Rozporzadzenie Rady Ministrów z dnia 13 lipca w sprawie wprowadzenia Nomenklatury Jednostek Terytorialnych do Celów Statystycznych (DzU, 2000, nr 58, poz. 685).

${ }^{5}$ DzU, 2007, nr 214, poz. 1572 i 1573. 
Urząd Statystyczny dokonuje agregacji danych i informacje o podregionach w Polsce dla wybranych zjawisk są dostępne już dla roku 1999 (w niektórych przypadkach nawet 1995).

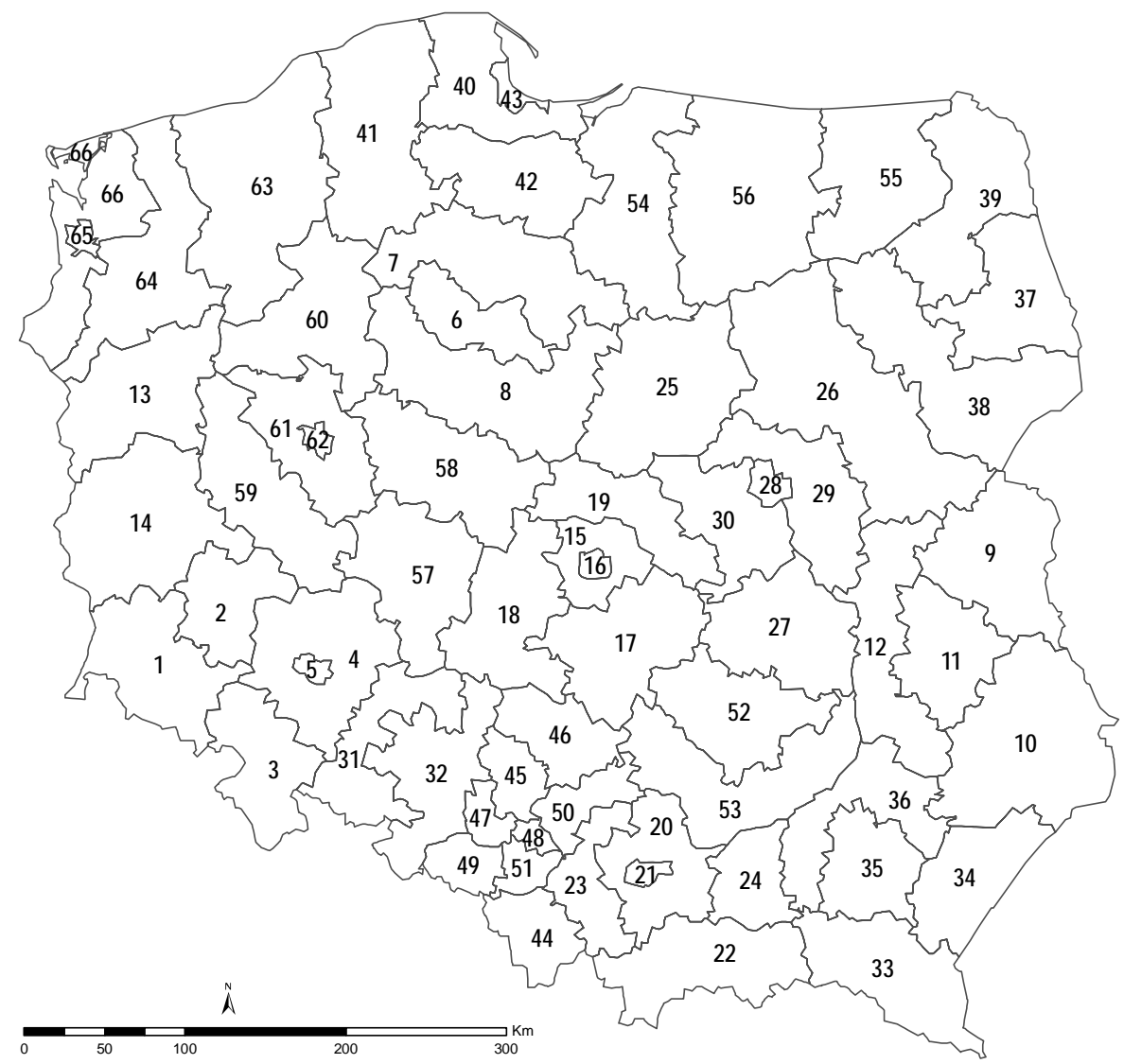

Ryc. 2. Podział Polski na podregiony od $2008 \mathrm{r}$.

1 - jeleniogórski; 2 - legnicko-głogowski; 3 - wałbrzyski; 4 - wrocławski; 5 - m. Wrocław; 6 - bydgosko-toruński; 7 - grudziądzki; 8 - włocławski; 9 - bialski; 10 - chełmsko-zamojski; 11 - lubelski; 12 - puławski; 13 - gorzowski; 14 - zielonogórski; 15 - łódzki; 16 - m. Łódź;

17 - piotrkowski; 18 - sieradzki; 19 - skierniewicki; 20 - krakowski; 21 - m. Kraków; 22 - nowosądecki; 23 - oświęcimski; 24 - tarnowski; 25 - ciechanowsko-płocki; 26 - ostrołęcko-siedlecki; 27 - radomski; 28 - m. Warszawa; 29 - warszawski wschodni; 30 - warszawski

zachodni; 31 - nyski; 32 - opolski; 33 - krośnieński; 34 - przemyski; 35 - rzeszowski;

36 - tarnobrzeski; 37 - białostocki; 38 - łomżyński; 39 - suwalski; 40 - gdański; 41 -słupski;

42 - starogardzki; 43 - trójmiejski; 44 - bielski; 45 - bytomski; 46 - częstochowski;

47 - gliwicki; 48 - katowicki; 49 - rybnicki; 50 - sosnowiecki; 51 - tyski; 52 - kielecki;

53 - sandomiersko-jędrzejowski; 54 - elbląski; 55 - ełcki; 56 - olsztyński; 57 - kaliski;

58 - koniński; 59 - leszczyński; 60 - pilski; 61 - poznański; 62 - m. Poznań; 63 - koszaliński; 64 - stargardzki; 65 - m. Szczecin; 66 - szczeciński Źródło: Bank Danych Lokalnych, GUS, Warszawa 
W Polsce prowadzone są badania dotyczące zróżnicowania przestrzennego wybranych zachowań demograficznych (np. małżeństw, rozwodów, płodności, urodzeń pozamałżeńskich) w układzie województw lub powiatów dla wybranego regionu kraju. Brakuje opracowań, które w sposób pełny omawiałyby zróżnicowanie przestrzenne większości zachowań matrymonialnych i prokreacyjnych. Celem opracowania jest poszerzenie wiedzy na ten temat. Postawiono następujące hipotezy badawcze:

1. Zachowania matrymonialne i prokreacyjne w Polsce odznaczają się specyficznymi cechami odróżniającymi je od pozostałych krajów Europy Środkowowschodniej. Jest to przede wszystkim łagodniejszy przebieg zmian demograficznych obszaru małżeńskości i rozrodczości.

2. Zachowania w zakresie małżeńskości i rozrodczości wykazują zróżnicowanie przestrzenne, utrwala się linia podziału w wybranych zachowaniach pomiędzy regionami o wyższym konserwatyzmie obyczajowym i wyższym poziomie religijności a pozostałymi.

3. Można mówić o wyodrębnianiu się obszarów w Polsce, które ze względu na szybsze i głębsze zmiany małżeńskości i rozrodczości stają się pionierami zachowań demograficznych.

4. Poziom akceptacji i przyzwolenia społecznego dotyczący zachowań matrymonialnych i prokreacyjnych jest zróżnicowany i zależy od cech demograficzno-społecznych respondentów.

\subsection{Materiały źródłowe i metody badawcze}

Podstawowy materiał źródłowy wykorzystany w opracowaniu został pozyskany dwiema drogami. Istotne $\mathrm{z}$ punktu widzenia celu pracy były dane statystyczne pochodzące z GUS-u (Bank Danych Lokalnych, Baza Demografia, roczniki statystyczne branżowe i wojewódzkie) oraz Eurostatu. W tym miejscu należy zwrócić uwagę na niedostateczny zasób informacji o zachowaniach matrymonialnych i prokreacyjnych dla podregionów, jakie udostępniają Główny Urząd Statystyczny i urzędy wojewódzkie. W wielu przypadkach materiał pierwotny pozyskany przez GUS jest agregowany do poziomu regionów lub województw i tylko w takiej formie udostępniany. W innych przypadkach są to dane dla jednostek niższego rzędu, daje to jednak możliwość przetworzenia ich do poziomu podregionów, o ile są przedstawione w wartościach bezwzględnych. Materiał statystyczny wykorzystany w pracy pochodził także z Państwowej Komisji Wyborczej, Centralnej Komisji Egzaminacyjnej oraz raportów Ministerstwa Rozwoju Regionalnego, Ministerstwa Pracy i Polityki Społecznej. Bardzo cenny materiał źródłowy stanowiły opracowania naukowe zarówno polskich, jak i zagranicznych autorów, które dostarczyły informacji w warstwie teoretycznej a także empirycznej. 
Następne źródło informacji pochodziło z badań terenowych. Były to badania ankietowe przeprowadzone $\mathrm{z}$ mieszkańcami Łodzi $\mathrm{w}$ celu poznania ich opinii na temat dokonujących się przemian w zachowaniach demograficznych. Pierwszy kwestionariusz był skierowany do mieszkańców Łodzi powyżej 18. roku życia i zawierał pytania odnośnie do nowych zjawisk demograficznych (blisko 800 respondentów). W drugim bloku badań ankietowych poznano opinie młodych łodzian (18-35 lat), których preferencje matrymonialne i prokreacyjne wpływają na ich zachowania demograficzne (ponad 900 respondentów).

Technika ankietowa jako narzędzie badań surveyowych należy do grupy typowych badań społecznych i polega na pozyskaniu informacji na podstawie wypełnianego przez respondenta kwestionariusza. Niewątpliwie zaletą tej techniki jest możliwość pozyskania nieskrępowanych wypowiedzi respondentów poprzez wyeliminowanie udziału osoby ankietera w procesie udzielania odpowiedzi. Nieobecność ankietera (tu osoby prowadzącej badania) może jednak wpływać niekorzystnie na wyniki badań z powodu udzielania niepełnych czy też nieistotnych dla badania odpowiedzi. Aby uniknąć takiej sytuacji, kwestionariusz był wręczany przez autorkę opracowania (bądź przez studentów grupy prowadzącej badania w ramach ćwiczeń terenowych z geografii społeczno-ekonomicznej w lipcu 2010, 2011 r.) i przez nią odbierany, co umożliwiło wyjaśnienie nieścisłości lub pokonanie trudności. Biorąc pod uwagę formę dostarczenia kwestionariusza do respondenta i sposób zwrócenia go badaczowi, dokonano badań techniką ankiety rozdawanej (Lutyński 2000). Konstrukcja ankiety skierowanej do mieszkańców Łodzi była zgodna z zaleceniami budowy tego narzędzia badawczego sformułowanymi przez J. Lutyńskiego (1977), K. Lutyńską (1984) i L. A. Gruszczyńskiego (1991). W celu sprawdzenia poprawności konstrukcji ankiety przeprowadzono badania pilotażowe.

Przeprowadzone badania miały charakter próby dostępnościowej i celowej (w przypadku drugiego kwestionariusza skierowanego tylko do młodych łodzian). Ponieważ próba oparta na dostępności badanych odznacza się niższym stopniem reprezentatywności niż próba losowa, uwzględniono także kwotowy dobór próby (Babbie 2004). Reprezentatywność zbadanej próby respondentów określono poprzez porównanie ich struktury ze strukturą mieszkańców Łodzi ze względu na płeć i wiek. Wyniki porównania tych struktur wykazały, że reprezentatywność dobranej w ten sposób próby była relatywnie wysoka.

Mając na uwadze niedoskonałość omawianej techniki zbierania danych (ankiety) należało dokonać oceny wartości uzyskanych wyników. Jak pisze J. Lutyński (2000) „Niezależnie bowiem od tego, że w socjologii - i nie tylko zresztą socjologii - nie opracowano dotychczas efektywnych metod ścisłej oceny wartości tych wyników, wielu badaczy i metodologów stara się pod- 
dać analizie i na tej podstawie dojść do jakichś oceniających wniosków". Analizę oceny wiarygodności wyników liczbowych, traktowaną jako ich weryfikację, przeprowadzono na podstawie wewnętrznej zgodności logicznej odpowiedzi - porównując odpowiedzi uzyskane na poszczególne pytania. Innym problemem dotyczącym oceny wyników badań ankietowych jest kwestia nieudzielania odpowiedzi na wszystkie pytania. Ogółem 58 ankiet zostało odrzuconych, ponieważ "braki” występujące w odpowiedziach dotyczyły zagadnień zasadniczych. $\mathrm{W}$ rezultacie do dalszej analizy zakwalifikowano odpowiedzi ponad 1700 respondentów.

$\mathrm{Na}$ potrzeby analizy wykorzystano różnorodne metody statystyczne i kartograficzne. Najważniejszym jednak kryterium doboru metod badawczych powinien być zawsze problem badawczy. W tym przypadku szukano odpowiedzi na pytanie o tendencje w procesie formowania się i rozpadu małżeństw oraz zachowań prokreacyjnych, a także ich zróżnicowań przestrzennych. Starano się także poznać uwarunkowania ich przebiegu. Istotne również z poznawczego punktu widzenia było, co myślą ludzie na temat nowych procesów demograficznych, szczególnie ludzie młodzi, którzy w niedługim czasie będą podejmować decyzje matrymonialne i prokreacyjne. Dlatego też podjęto próbę ujęcia tego problemu w sposób ilościowy i jakościowy. Autorka uważa, że połączenie tych podejść może przyczynić się do lepszego rozpoznania zmian, jakie dokonują się w procesach demograficznych w naszym kraju. Najistotniejsze z punktu widzenia celu pracy było zidentyfikowanie zróżnicowania przestrzennego zjawisk demograficznych w ujęciu dynamicznym, dlatego też w opracowaniu prezentowane jest podejście scjentystyczne. Jednocześnie szukając odpowiedzi na pytanie, co sądzą mieszkańcy Łodzi na temat przeobrażeń modelu rodziny w Polsce, uwzględniono podejście humanistyczne. To opinie bowiem, szczególnie ludzi młodych, wpływają na ich przyszłe zachowania matrymonialne i prokreacyjne, identyfikacja tego , co sądzą na ten temat młodzi jest istotna dla procesów demograficznych w przyszłości.

Specyfika przedmiotu badań przyczyniła się do zastosowania odpowiednich do celów pracy metod badawczych. W analizach tych źródeł zastosowano różne procedury statystyczne (wbudowane w programy SPSS i Excel) oraz narzędzia kartograficzne (przy wykorzystaniu narzędzi GIS-owych pakietów MapInfo 8.5 i ArcGIS 10). Wśród wykorzystanych procedur statystycznych wymienić można jedną z metod analizy skupień, a mianowicie metodę aglomeracji Warda, która posłużyła do określenia zróżnicowania przestrzennego zachowań demograficznych. Wykorzystywano również metodę miernika rozwoju Z. Hellwiga do wyznaczenia grup podregionów ze względu na poziom rozwoju społeczno-gospodarczego. W przypadku określenia znaczenia i wpływu cech demograficznych i społeczno-ekonomicznych posłużono się regresją wieloraką. 
Znaczenie pracy rozpatrywać można w dwóch aspektach - poznawczym i aplikacyjnym. W przypadku aspektu aplikacyjnego wskazać można jego znaczenie w:

- polityce społecznej i ludnościowej - realizowanie długofalowych działań na rzecz zaspokajania potrzeb i rozwiązywania problemów społecznych, stosowanie właściwych instrumentów z punktu widzenia potrzeb społecznych nie jest możliwe bez rzetelnych informacji o procesach, tendencjach i kierunkach zmian zachowań matrymonialnych i prokreacyjnych,

- gospodarce przestrzennej i planowaniu przestrzennym - planowanie rozwoju społeczno-ekonomicznego kraju wymaga informacji na temat potencjału demograficznego i jego możliwości rozwoju, informacji o stanie ludności, jej strukturze, procesach demograficznych oraz zróżnicowaniu przestrzennym.

W aspekcie poznawczym proponowany projekt możne stanowić rozwinięcie badań, które były dotychczas podejmowane w ramach geografii w Polsce. Większość publikowanych do tej pory prac odnosi się do wybranych zagadnień i obszarów. Podjęcie rozważań nad większością zachowań matrymonialnych i prokreacyjnych $\mathrm{w}$ Polsce $\mathrm{w}$ ujęciu przestrzennym oraz ich uwarunkowań może stanowić wzbogacenie dorobku geografii ludności. 



\section{TEORIE ZMIAN LUDNOŚCIOWYCH}

\subsection{Wybrane teorie zmian demograficznych}

Rozwój myśli demograficznej sięga początków rozwoju cywilizacji oraz kultury, nadal trwa i zapewne nadal będzie trwał, ponieważ dyskusja na temat prawidłowości i uwarunkowań rozwoju ludności jest podstawą rozwoju społeczno-gospodarczego. Zainteresowanie stanem liczebnym ludności, jej strukturą, było zawsze obecne wśród różnych społeczności, czego wynikiem była tradycja i praktyka spisów powszechnych. Intencje władz inicjujących i przeprowadzających spisy ludności zmierzały w kierunku sprawnego administrowania, ale ich decyzje odnośnie do powszechności i systematyczności pozyskiwania informacji o ludności umożliwiły prowadzenie badań i analiz empirycznych w ujęciu dynamicznym.

Każda epoka miała swoich przedstawicieli, którzy zajmowali się wyjaśnianiem prawidłowości rozwoju ludnościowego i podejmowali próby konstruowania „praw demograficznych”. Były to ujęcia uwzględniające różne aspekty zmian ludnościowych: kulturowe, ekonomiczne, społeczne, psychologiczne, ekologiczne, a także przyrodnicze.

W przypadku teorii ludnościowych od samego początku zainteresowań ludnością występuje w pracach badaczy niezawoalowane wartościowanie, zalecanie czy nawet moralizatorstwo. Mamy więc do czynienia z występowaniem w koncepcjach ludnościowych silnych akcentów normatywnych i aksjologicznych, które utrzymywały się do współczesności.

Przedstawiony subiektywny wybór dorobku myśli demograficznej został podyktowany celami opracowania, w którym analizowane są zmiany w obszarze małżeńskości i rozrodczości. Dlatego też oprócz ogólnych teorii ludnościowych zaprezentowano teorie mikroekonomiczne i socjologiczno-psychologiczne.

\subsubsection{Czasy starożytne i poglądy klasyczne}

Poszukiwanie mechanizmów rządzących przemianami ludnościowymi nie jest cechą czasów nowożytnych. Zainteresowanie ludnością i jej cechami 
oraz zaludnieniem terenu pojawiło się już w czasach historycznych. Towarzyszyło temu konstruowanie koncepcji optymalnej liczby ludności na danym obszarze na podstawie liczby mieszkańców, przyczyn zgonów, posiadania dużej lub małej liczby dzieci, tendencji do pozostawania bądź przeprowadzania się w inne miejsce.

Starożytność to czasy, kiedy w polityce ludnościowej dominowało podejście pronatalistyczne, podyktowane zwiększeniem możliwości obronnych terytorium. Wezwanie do „wzrastania i rozmnażania” się możemy odnaleźć nie tylko w Starym Testamencie, ale prawie we wszystkich świętych księgach starożytnych religii. W starożytnej Grecji idea „osiągnięcia optymalnego stanu ludności" była przedmiotem rozważań filozofów w kontekście idealnych miast-państw. Spartanie, ze względu na wysoki poziom umieralności wskutek prowadzonych wojen, zmuszali swoich obywateli do zawierania małżeństw, a ojców posiadających trzech lub czterech synów nagradzali. Polityka proludnościowa była prowadzona także w Atenach, choć tu nie zabiegano tak bardzo o przyrost ludności, niemniej jednak istniały przepisy prawne przeciwko celibatowi i zwyczaje propagujące płodność małżeńską. Jednakże w okresie, gdy nie prowadzono wojen, skłaniano się ku ograniczaniu urodzeń, propagowano zawieranie małżeństw w późniejszym wieku, a „nadwyżki” ludności wysyłano do kolonii (Stangeland 1966).

Wizja Platona, dotycząca idei optimum ludności, zakładała daleko idącą ingerencję władzy odnośnie do zachowań prokreacyjnych mieszkańców, uważał on bowiem, że:

A gdyby niektórym brakło osobistego wdzięku albo się komuś urodzi za dużo dziewcząt, albo jakoś za dużo chłopców byłoby u każdego, albo i na odwrót, gdyby ich było za mało, bo przyszedłby nieurodzaj na dzieci, nad tym wszystkim zastanowi się władza najwyższa i najczcigodniejsza, która byśmy ustanowili i pomyśleli, co robić z nadmiarem lub niedoborem dzieci, i obmyślili sposób na to, żeby koniecznie zawsze było tylko pięć tysięcy i czterdzieści gospodarstw. A sposobów jest dużo. Są ograniczenia liczby urodzeń u tych, którym się dzieci sypią i na odwrót, można się starać i poważnie dbać o to, żeby ilość urodzeń zwiększyć z pomocą zaszczytnych nagród i hańbiących kar i upomnień ze strony starszych pod adresem młodych; starsi powinni na ten temat do młodych przemawiać; to wszystko może sprowadzić skutek, o którym mówimy. No, a w końcu, jeżeli będzie kłopot nie do zniesienia z utrzymaniem tych równo pięciu tysięcy i czterdziestu i zacznie nas zalewać nadmiar obywateli, bo tak się będą ludzie kochali, że nie będziemy wiedzieli, co począć, to zostaje przecież stary wypróbowany środek, o którym mówiliśmy nieraz: wysłanie do kolonii (Platon 1997: 436).

Idei miasta-państwa w stylu Platona nie podzielał inny starożytny filozof Arystoteles. Ale w sprawach zaludnienia głosił podobne poglądy zmierzające do określenia optymalnej liczby ludności, tak aby „zapewniła dobre życie społeczności". Wskazywał na zależność pomiędzy zarządzaniem miasta 
a gęstością jego zaludnienia, twierdząc, że tam gdzie gęstość ludności jest zbyt wysoka nie można dobrze nim zarządzać (Arystoteles 2006).

Imperium Rzymskie z powodu prowadzenia ekspansji terytorialnej propagowało wysoki poziom dzietności. Cesarz Oktawian August, panujący w latach 27 p.n.e. - 14 n.e. wydał prawo wspierające zawieranie małżeństw i rodzenie dzieci. Wcześni pisarze chrześcijańscy zwracali uwagę na potrzebę wzrostu liczby ludności i możliwość wyludnienia spowodowanego zgonami w wyniku chorób lub klęsk żywiołowych. Pojawienie się religii chrześcijańskiej zmieniło zapatrywania na celibat, dowartościowując go, podobnie jak dziewictwo i wstrzemięźliwość płciową. Nie inaczej było z małżeństwem i rodzinami wielodzietnymi (Nam, Philliber 1984).

Czasy nowożytne, w których nastąpił szybki rozwój miast i krajów, ekspansja handlu i postęp intelektualny, to dalszy rozwój sposobów wyjaśniania zmian ludnościowych. Jednym z nich było podejście arabskiego filozofa z XIV w. Ibn-Khalduna, który zajmował się wzajemnymi relacjami między liczbą ludności a bogactwem narodowym, a także wpływem zanieczyszczenia na wzrost współczynnika zgonów. Wraz z powstawaniem podwalin pod gospodarkę kapitalistyczną na kontynencie europejskim zaczęto zwracać uwagę na temat roli czynników wpływających na gospodarkę i politykę państw. Zauważalny rozwój handlu zagranicznego i produkcja w manufakturach były głównymi instrumentami oddziaływania na wzrost gospodarczy, a zwiększenie potencjału ludnościowego stymulowało powstawanie nowych rynków zbytu i wzrost znaczenia militarnego państwa (Balicki i in. 2007).

Przedstawiciele merkantylizmu jako propagatorzy utożsamiania zamożności kraju z osiąganiem dodatniego bilansu handlowego byli zwolennikami wzrostowej dynamiki potencjału demograficznego. Głosili poglądy o stosowaniu polityki ukierunkowanej na przyrost populacji, promowanie małżeństw, wielodzietne rodziny, poprawę zdrowia publicznego, nadzór nad emigracją do innych państw oraz otwarcie na imigrantów, szczególnie na utalentowanych rzemieślników.

Przedstawione wyżej, w dużym skrócie, stanowiska i poglądy dotyczące wyjaśniania zmian ludnościowych nie stanowią usystematyzowanej wiedzy, chociaż autorzy tych podejść określali różne czynniki mające wpływ na wzrost ludności. Były to epidemie, wojny, klimat, nieurodzaj, nałogi, aborcja, późne małżeństwa, umieralność, emigracja, imigracja. Żadne z tych stanowisk nie mogą być jednak określone jako teorie ogólne wyjaśniające mechanizmy zmian ludnościowych. 


\subsubsection{Teoria Thomasa Malthusa}

Teorie mogą odnosić się do ogólnego rozwoju populacji ludzkich, ale mogą to być także teorie cząstkowe opisujące i objaśniające prawidłowości wybranych procesów demograficznych. Do ogólnych teorii objaśniających zaliczyć należy teorię Malthusa, teorię przejścia demograficznego i teorię drugiego przejścia demograficznego.

Autorem, który silnie wpłynął swoimi poglądami na rozwój rozważań demograficznych i jednocześnie na wiele lat wyznaczył kierunek dyskusji odnoszącej się do zmian ludnościowych był Thomas Malthus, anglikański duchowny, a jednocześnie przedstawiciel ekonomii klasycznej. Oczywiste wydaje się więc powiązanie jego poglądów w zakresie zmian ludnościowych z rozwojem ekonomicznym.

T. R. Malthus (1766-1834) w swoim dziele opublikowanym w 1798 r. pt. Rozprawa o prawie ludności autor odniósł się do tezy W. Godwina, według której zmiana systemu własności będzie jednym z warunków doskonalenia się gatunku ludzkiego i ratunkiem przed przeludnieniem i ubóstwem. Założył, że wzrost liczby ludności jest zależny i ograniczany przez zasoby żywności, z czego wynika, że liczba ludności wzrasta tam, gdzie jest wystarczająco dużo żywności i brak przeszkód hamujących siłę rozrodczą przez czynniki pozytywne i prewencyjne. Przeszkodami tymi są:

opóźnione zawieranie małżeństw i życie w czystości do czasu małżeństwa, ale również prostytucja, nienaturalne namiętności, pogwałcenie łoża małżeńskiego, nieczyste praktyki w celu zniszczenia skutków nielegalnych związków, podyktowane przewidywaniem odległych konsekwencji. Przeszkody pozytywne obejmują czynniki, które w jakimś stopniu przyczyniają się do skrócenia naturalnej długości życia. Należą do nich wszystkie szkodliwe zawody, praca w trudnych warunkach, także klimatycznych, skrajne ubóstwo, niedostateczna opieka nad dziećmi, życie w wielkich miastach, różnorodne choroby społeczne, epidemie, wojny, głód i inne plagi (Cieślak 1992: 28).

Według Malthusa wysoki poziom rozrodczości to efekt „namiętnej skłonności jednej płci do drugiej", który w rezultacie prowadzi do ubóstwa, głodu, wojen i epidemii. To z kolei przyczynia się do wzrostu śmiertelności i zrównoważenia przyrostu ludności z przyrostem środków utrzymania. Wymienione czynniki ograniczające rozrodczość to hamulce pozytywne. Do prewencyjnych czynników, wpływających hamująco na przyrost ludności, Malthus zalicza rozum, z którego płyną ograniczenia, np. moralne, jak powściągliwość w zaspokajaniu popędów. To dzięki rozumowi człowiek uświadamia sobie zagrożenia, jakie mogą dla niego wyniknąć chociażby z zawarcia małżeństwa. Decydując się na ten krok człowiek powinien „oszacować”, jak zmieni się jego sytuacja w zakresie statusu materialnego, społecznego czy przyzwyczajeń. Podobne rozważania powinny odnosić się do 
przyszłej, ewentualnej rodziny, szczególnie do potomstwa w kwestii edukacji i niezależności w utrzymaniu rodziny. To wszystko, zdaniem autora teorii, powinno skłonić człowieka do podjęcia decyzji o zawarciu małżeństwa dopiero w chwili, gdy osiągnie on taki status materialny, który pozwala na założenie rodziny. Dla Malthusa mężczyzna, który zamierza zawrzeć małżeństwo, powinien podjąć decyzję w chwili, gdy będzie mógł utrzymać żonę i pięcioro, sześcioro dzieci. Jednak decyzja ta powinna być wynikiem dobrowolnego wyboru, ponieważ człowiek jest odpowiedzialny tylko przed Bogiem.

W teorii Malthusa znajdujemy także relację ilościową pomiędzy przyrostem ludności a przyrostem pożywienia. Według niego ludność przyrasta w postępie geometrycznym, a pożywienia w postępie arytmetycznym (ryc. 3). Oznacza to, że wzrost liczby ludności powinien być utrzymany w granicach narzucanych przez zasoby żywności. Autor teorii podkreślał znaczenie danych ilościowych, według niego informacje pozwalają prześledzić związki pomiędzy liczbą osób dorosłych i liczbą zawartych małżeństw, rozpowszechnianie się zachowań zaliczanych do nieobyczajnych, jakie może spowodować powstrzymywanie się od wczesnego zawierania małżeństw. Dlatego też zwracał uwagę na konieczność ciągłej rejestracji takich zdarzeń jak małżeństwa, urodzenia i zgony. Wizja Malthusa odnośnie do przyszłości demograficznej była pesymistyczna, a sposoby prowadzenia polityki ludnościowej, z naszego współczesnego punku widzenia, dość szokujące i niehumanitarne:

Jest bezsporną prawdą, że bez względu na stopę wzrostu zasobów żywności musi ona ograniczyć przyrost ludności, przynajmniej od tego momentu, gdy żywność zostanie podzielona na mniejsze racje, zaledwie wystarczające do utrzymania ludności przy życiu. Wszystkie nowo narodzone dzieci, których liczba przekroczyłaby wyznaczoną $\mathrm{w}$ ten sposób granicę, musiałyby z konieczności zginąć, chyba że śmierć dorosłych osób zwolniłaby dla nich miejsce. Aby więc działać konsekwentnie, powinniśmy ułatwiać zadanie naturze sprowadzającej tę śmiertelność, zamiast głupio i bezskutecznie starać się jej przeszkodzić; a jeśli obawiamy się zbyt częstych nawrotów straszliwego głodu, to powinniśmy uciekać się do pomocy natury i pilnie ułatwić działanie innych form zniszczenia. Zamiast zalecać biednym wstrzemięźliwość, powinniśmy zachęcać ich wręcz do odmiennego postępowania. W naszych miastach powinniśmy zwężać ulice, wtłaczać do mieszkań coraz więcej ludzi i ułatwić w ten sposób nawrót zarazy. Na wsi powinniśmy zakładać nasze osiedla blisko wód stojących, w szczególności zaś zachęcać do osiedlania się na wszelkiego rodzaju bagnistych i niezdrowych gruntach. Przede wszystkim jednak powinniśmy potępić wszystkie środki zapobiegające niszczycielskiemu działaniu chorób oraz potępiać tych poczciwych, lecz pozostających w wielkim błędzie ludzi, którzy sądzili, że oddadzą ludzkości przysługę, wysuwając projekty mające na celu całkowitą likwidację poszczególnych przeszkód w rozmnażaniu. Jeżeli za pomocą tych i tym podobnych środków osiągniemy zwiększenie liczby zgonów [...], to prawdopodobnie każdy 
z nas będzie mógł wstąpić w związek małżeński po dojściu do dojrzałości, a poza tym niewielu będzie takich, którzy będą stale głodni (Cieślak 1992: 28-29).

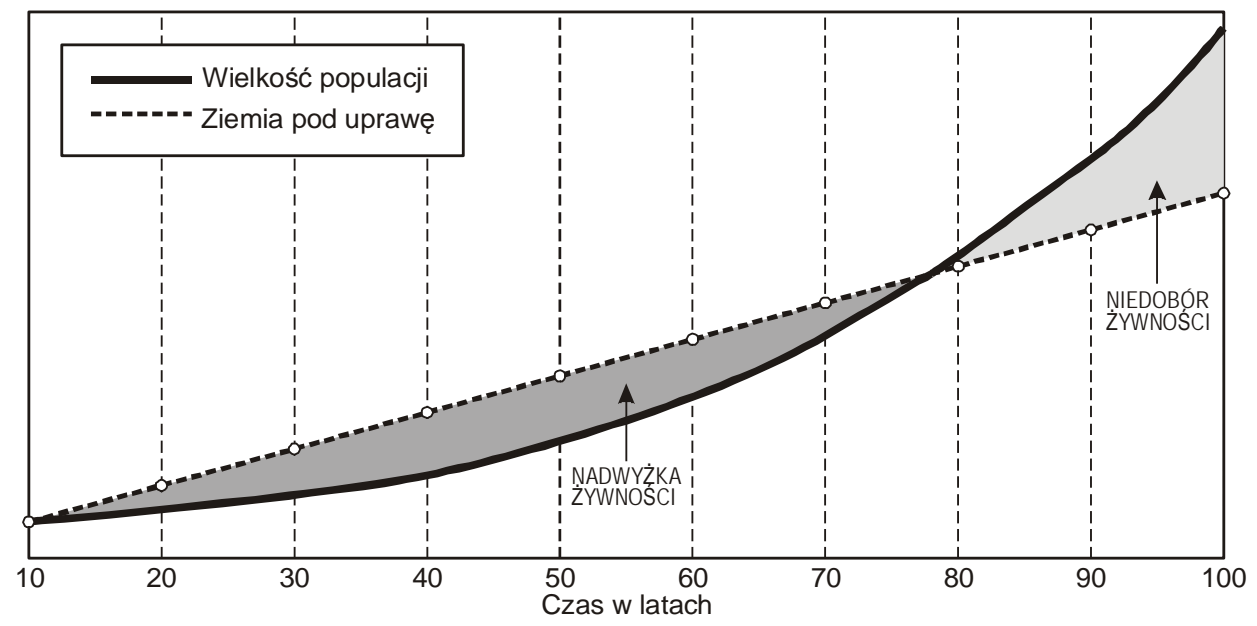

Ryc. 3. Wzrost liczby ludności i produkcja żywności Źródło: Belmont 1999 za: Balicki i in. 2007

Koncepcja Malthusa wywołała żywą dyskusję już w czasach, kiedy powstała, ale także w XX w. podejmowano analizy jej założeń i wyników. Krytyka tej teorii dotyczy kilku kwestii. Jedną z nich jest fakt, że nie potwierdziła się ona w rzeczywistości, jest w niej niedostatek „naukowości”, co jest efektem pomieszania ideologii $\mathrm{z}$ analizą naukową. Powołanie Malthusa jako pastora anglikańskiego nie pozwalało mu na uznawanie antykoncepcji za sposób regulacji urodzeń. Mimo to, zdaniem Davisa (1955), jego zasługi dla rozwoju myśli demograficznej i ekonomicznej są znaczne. Inny krytyk podejmuje problem niewłaściwych założeń, według których Malthus rozpatrywał zależności między liczbą ludności i gospodarką. Te założenia to wyłącznie płodność i obserwowana jej fluktuacja, która w czasach Malthusa była zależna wprost proporcjonalnie od liczby zawieranych małżeństw (Wrigley 1983). Analiza koncepcji Malthusa była też prowadzona w rozważaniach, jak autor oceniłby swoje dzieło, gdyby powrócił do życia w czasach współczesnych. Jak twierdzi van de Walle (1983) istnieją co najmniej trzy powody, które podważają tę teorię:

- populacja świata jest obecnie znacznie liczniejsza niż wyobrażano to sobie w przeszłości; przeszkody pozytywne nie ograniczyły wzrostu ludności,

- popęd płciowy wprawdzie nie osłabł, ale antykoncepcja stosowana jest dość powszechnie,

- standard życia wzrósł niewyobrażalnie w porównaniu z sytuacją w XIX w.

Malthus nie przewidział wielu zmian cywilizacyjnych o charakterze społecznym i gospodarczym, w tym rewolucji przemysłowej i technologicznej, 
urbanizacji, modernizacji społeczeństwa, które w sposób zasadniczy zdecydowały o obniżeniu śmiertelności, ale także ograniczeniu dzietności. Niemniej jednak jako pierwszy opisał i usystematyzował podstawowe komponenty dynamiki demograficznej (urodzenia i zgony), tworząc podwaliny pod teorię demografii. Jego koncepcja wywarła wpływ na współczesne teorie, $w$ tym teorię przejścia demograficznego i teorię Beckera.

Jednym z głównych opozycjonistów Malthusa w środowisku ekonomicznym był Karol Marks. Opracował on, wraz ze swoim współpracownikiem Fryderykiem Engelsem, historię gospodarczą społeczeństw, której wersja znacznie się różniła od podejścia Malthusa. Marks często odwoływał się do wcześniejszej teorii, wykorzystując opracowania Malthusa, jako cel polemik. Najważniejsze zarzuty, jakie stawiał Malthusowi dotyczyły stwierdzenia, że wzrost liczby ludności obniża poziom życia. Razem z Engelsem byli zdania, że wzrost liczby ludności wywoływał większe trudności w sferze środków zatrudnienia niż środków utrzymania. W przeciwieństwie do Malthusa reprezentował postawę optymistyczną co do przyszłości rozwoju ludności, ale także bardzo przesyconą ideologicznie. Tezy Marksa i Engelsa odnośnie do kierowania procesami demograficznymi w taki sam sposób, jak zjawiskami ekonomicznymi, znalazły praktyczne zastosowanie $\mathrm{w}$ pracy chińskiego komunisty, który opisując metody polityki rodzinnej w swoim kraju powołuje się na słowa Engelsa:

Jeśli społeczeństwo komunistyczne będzie pewnego dnia zmuszone do uregulowania produkcji istot ludzkich, tak jak reguluje się produkcję dóbr, wówczas będzie w stanie dokonać tego bez większych trudności (Zheng Yi 1981, za: Balicki i in. 2007: 42).

W wieku XIX i w pierwszych latach XX w. większość badaczy zajmujących się zmianami ludnościowymi odwoływała się do wspomnianych koncepcji Malthusa i Marksa. Byli jednak tacy, którzy podejmowali własne próby wyjaśnień, odrębne od założeń ww. autorów. Jednym z nich był H. Spencer, twórca teorii ewolucji biologicznej, która wprowadzała zasadę samoregulacji wzrostu ludności. Wyznaczone przez niego dwie siły: podtrzymywania życia i rozmnażania uznał za wzajemnie sprzeczne. W sytuacji, kiedy siła podtrzymująca życie jest słaba, po to, by przetrwać potrzebna jest wysoka płodność. Wzrost płodności prowadzi do różnego rodzaju problemów społecznych, które stymulują możliwości podtrzymywania życia. W konsekwencji siła reprodukcji słabnie, a rosną możliwości podtrzymywania życia. Inną koncepcją, która powstała pod koniec XIX w., była teoria optymalnego zaludnienia Henry'ego Sidgwicka. Zaobserwował on bowiem, że po osiągnięciu pewnego stopnia gęstości zaludnienia, wraz ze wzrostem liczby pracowników rolnych na danym obszarze wydajność pracy wykazywała tendencję spadkową. Optimum ludnościowe było wyznaczone jako 
punkt maksymalnej wydajności pracownika. Proponowano różne kryteria determinujące optimum - były to dochód na osobę, wydajność, dobrobyt gospodarczy, poziom życia, dochód realny oraz stopa zatrudnienia, jednak nigdy nie ustalono tego kryterium. Inne podejście w wyjaśnianiu zmian ludnościowych reprezentował Louis Dumont, który jest autorem socjologicznej teorii nazwanej koncepcją zasady społecznego przenikania. Jako punkt wyjścia swoich rozważań bierze rodzinę i jej wielkość, wpływającą na poprawę pozycji społecznej. Autor przyrównuje wznoszenie się rodziny na drabinie społecznej do podnoszenia się słupka cieczy w naczyniach włosowatych. Twierdzi, że by rodzina odniosła awans społeczny, musi być nieliczna, tak jak wąski jest słup cieczy, aby mógł podnieść się pod wpływem woskowatości (Balicki i in. 2007). Nowsze teorie, które wymieniono, nie wzbudziły jednak takiego odzewu jak teoria Malthusa.

\subsubsection{Czasy współczesne - podejścia badawcze}

Współczesne poglądy dotyczące przemian ludnościowych można podzielić na analizy opisowe, typologie oraz modele wyjaśniające (w perspektywie makro i mikro). Perspektywa makro, wyjaśniająca zachodzące procesy demograficzne na poziomie ogólnym, obejmuje podejście ekologiczne, orientację socjokulturową, modernizację oraz podejście instytucjonalne. Podejście ekologiczne skupia się na analizie relacji występujących pomiędzy takimi kategoriami, jak technologia, organizacja społeczna, środowisko naturalne. Przedstawiciele tego kierunku podkreślają ich względną równowagę, a przemiany ludnościowe tłumaczą dążeniem do jej osiągnięcia. Drugim przykładem podejścia makro jest orientacja socjokulturowa. U jej podstaw leży założenie, że system społeczno-kulturowy, występujący na danym obszarze, kształtuje procesy demograficzne. Trzecie podejście makro wyznacza modernizacja. Poprzez proces modernizacji społeczeństwa dostosowują się do zmieniających się warunków życia. Dostosowaniu temu towarzyszy zmiana poglądów odnoszących się do rozmiarów populacji i jej struktury. Ostatnie podejście makroinstytucjonalne, kładzie nacisk na transformację instytucji społecznych (ekonomicznych, edukacyjnych, religijnych i politycznych) i jej wpływ na przemiany ludnościowe. Perspektywa mikro skupia natomiast uwagę na jednostce, małżeństwie i rodzinie. Przedmiotem szczególnego zainteresowania jest tu proces podejmowania decyzji prokreacyjnych oraz czynniki z nim związane.

Najbardziej popularna wśród demografów analiza opisowa opiera się na uogólnieniach i z tego względu jest niedoskonała. Celem opracowania modeli wyjaśniających jest przedstawienie teoretycznej podstawy określającej najbardziej krytyczne czynniki procesów demograficznych oraz rozpoznanie ich wzajemnych relacji. Pamiętać jednak należy o fakcie, że struktura 
teoretyczna modelu, oparta na logice i dotychczasowych badaniach, nie zawsze jest w pełni weryfikowalna empirycznie. Przykładem typologii są etapy przejścia demograficznego przyjęte $\mathrm{w}$ badaniach nad ludnością. Klasyfikacja procesu przejścia demograficznego odnosi się do typologii opartej na kombinacjach trendów umieralności i dzietności oraz związanych z nimi przemian społecznych.

Niezależnie od tego, jaki sposób (metodę) stosowano do wyjaśniania przemian ludnościowych, zawsze istotne były uwarunkowania filozoficzne i ideologiczne. Już od drugiej połowy XVIII w. przedstawicieli badających zjawiska ludnościowe podzielić można na optymistów i pesymistów. Grupa tych pierwszych zakładała, że rosnąca populacja jest źródłem siły narodu, bezpieczeństwa i bogactwa oraz że wpływa na wysoką wydajność produkcji i stymuluje postęp gospodarczy. Byli oni także przekonani o nieograniczoności zasobów naturalnych naszej planety i możliwości korzystania z nich. Drugi biegun poglądów to orientacja pesymistyczna, której zwolennicy uważali, że zbyt duża liczba ludności w stosunku do środków utrzymania prowadzi „do poważnych szkód”. Szczególnego niebezpieczeństwa upatrywali w wysokim poziomie reprodukcji wśród najuboższej części społeczeństwa i jej niechęci do ograniczania urodzeń, co w rezultacie prowadziło do pogorszenia kondycji gospodarki.

Stanowiska dotyczące przemian ludnościowych, mające charakter optymistyczny lub pesymistyczny, nigdy nie były wolne od orientacji filozoficznych i ideologicznych ich propagatorów. Współcześnie mamy do czynienia $\mathrm{z}$ podobnym dualnym podejściem do tych zagadnień. Niewątpliwie do obozu pesymistycznego należy zaliczyć wiele ruchów ekologicznych, które czasami w sposób alarmujący przedstawiają zagrożenia dla środowiska naturalnego ze strony nieograniczonego wzrostu liczby ludności. Czasami też od sposobu podejścia zależy interpretacja danych ilościowych. Z taką sytuacją mieliśmy do czynienia w przypadku prognozy ludności ONZ i wyboru jej wariantów do dalszej analizy przez dwie różne organizacje. Mowa tu o Funduszu Środowiskowym (The Environmental Found) i Agencji Stanów Zjednoczonych do spraw Rozwoju Międzynarodowego (U.S. State Depatrment's Agency for International Development), które na bazie tego samego opracowania prognostycznego opracowały dwie różne wizje zaludnienia na świecie i w poszczególnych krajach. Ten przypadek pokazuje, jak w różny sposób mogą być interpretowane te same dane wyjściowe, w zależności od podejścia ideologicznego. Fundusz Środowiskowy wybrał bowiem najwyższy wariant prognozy (jako propagator idei przeludnienia świata), AID zaś, która angażuje się w działania zmierzające do kontroli urodzeń, przyjęła do analizy wskaźniki niższe (Nam, Philliber 1984). 
Opisany przykład wskazuje także na wpływ prowadzonej polityki na wizje dotyczące zaludnienia i życia społecznego. Zresztą przykładów odzwierciedlających te zależności doszukać się można w wielu krajach i prowadzonych przez nie politykach pro- lub antynatalistycznych. Często też politycy różnych orientacji ideologicznych w sposób nieuzasadniony powołują się na wyniki badań naukowych. Dlatego należałoby zastanowić się nad tym, o czym pisze Simon (1981: 344):

Sama nauka nie stwierdza i nie może stwierdzić, czy dana liczba ludności jest zbyt wysoka lub zbyt niska, albo czy tempo wzrostu populacji jest zbyt szybkie lub zbyt wolne. Nauka może jedynie zaoferować obywatelom i politykom lepsze zrozumienie konsekwencji takiej lub innej decyzji w sprawach ludnościowych; niestety nazbyt często prace naukowe dezinformują i powodują, że tracą oni (politycy i obywatele) orientację. Na społeczne i osobiste decyzje odnośnie do urodzenia dziecka lub migracji należy patrzeć zarówno w kontekście wartości, jak i prawdopodobnych konsekwencji. Decyzje te mają wymiar moralny niezależny od tego, co proponuje nauka.

\subsubsection{Pierwsze przejście demograficzne ${ }^{6}$}

Teoria przejścia demograficznego została sformułowana $\mathrm{w}$ połowie ubiegłego stulecia. Koncepcji tej trudno przypisać jednego autora, za jej prekursorów uważani są A. Landry (1909; 1934; 1945), F. M. Notenstein (1945), K. Davis (1945), W. S. Thompson $(1929 ; 1946)$ - por. np. Chesnais 1986; Okólski 1990. Teoria opisuje długookresowe przemiany zachodzące w populacjach ludzkich, które polegają na przejściu od reprodukcji prymitywnej (tradycyjnej) do reprodukcji nowoczesnej (oszczędnej). Przemiany, które dokonują się podczas przejścia demograficznego, odbywają się w formie następujących po sobie etapów, określanych jako fazy. Są one wyróżniane na podstawie zmian w zakresie natężenia urodzeń, zgonów i przyrostu naturalnego. Klasyczny model przejścia demograficznego obejmuje naturalny system demograficzny, właściwe przejście i fazę stabilizacji (ryc. 4).

Spośród autorów tej koncepcji propozycja W. S. Thompsona (1929) jest najbardziej ogólna. Zaproponowany przez niego model zmian jest trójfazowy (ryc. 5). Wyróżnił on:

1) fazę równowagi prymitywnej, charakteryzującą się wysokim natężeniem zgonów i urodzeń,

${ }^{6}$ Wraz z pojawieniem się teorii drugiego przejścia demograficznego, dla uporządkowania terminologicznego niektórzy badacze zaczęli nazywać teorię przejścia demograficznego pierwszym przejściem. 
2) fazę przejścia demograficznego, w której następuje zachwianie równowagi wywołane spadkiem umieralności przy wciąż wysokiej płodności,

3) fazę równowagi nowoczesnej, z niskim natężeniem urodzeń i zgonów.
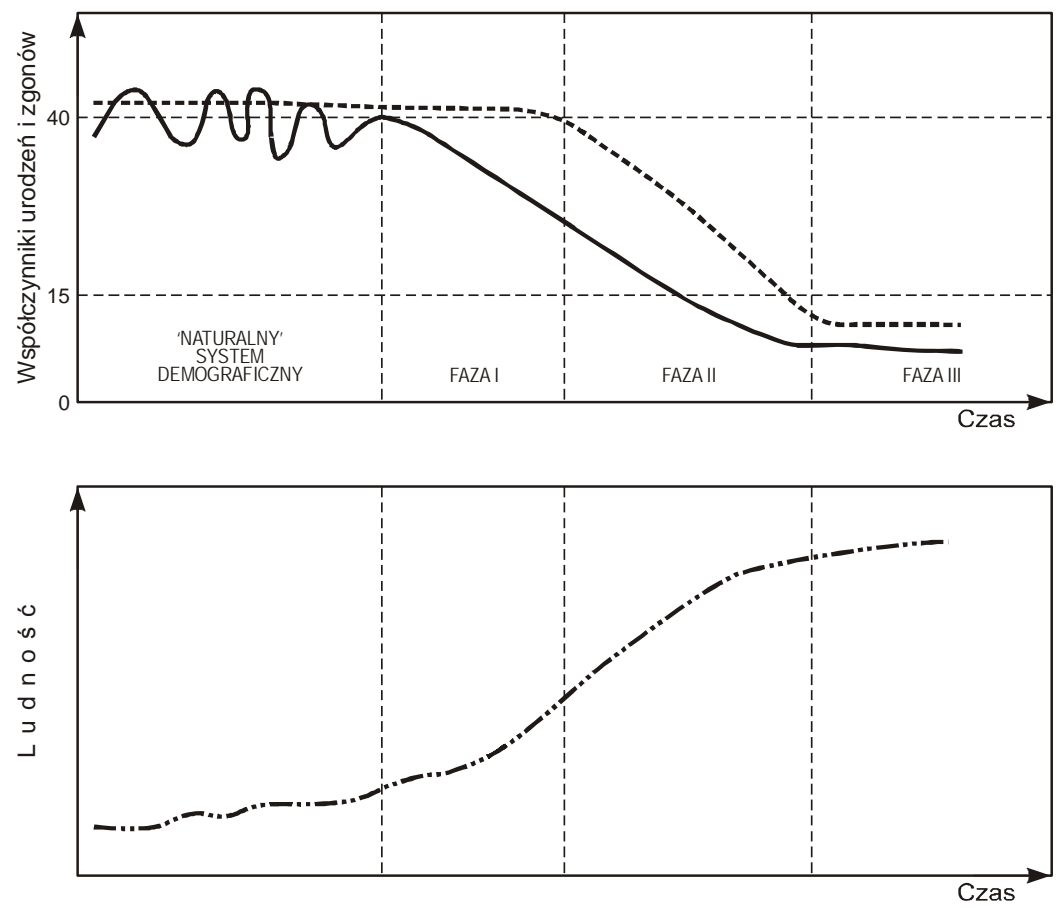

Ryc. 4. Klasyczny model przejścia demograficznego

Źródło: Ph. Mochez 1964, za: J. M. Poursin 1976

Uwzględniając stopień zaawansowania przemian $\mathrm{w}$ procesie przejścia demograficznego W. S. Thompson przeprowadził podział krajów na trzy grupy: A, B i C. W grupie A znalazły się kraje zachodnioeuropejskie oraz leżące za oceanem obszary zaludnione przez imigrantów z kontynentu europejskiego. Ten typ odznaczał się obniżającym się tempem wzrostu liczby ludności i spadkiem potencjału ludnościowego. Według przewidywań autora silny spadek płodności przy niskiej już umieralności doprowadzi do stanu stacjonarnego, co $\mathrm{w}$ konsekwencji przyczyni się do zmniejszenia się liczby ludności. Drugi typ - B, do którego zaliczył kraje Europy Południowej i Wschodniej charakteryzował się równoczesnym spadkiem umieralności i płodności, przy wcześniejszym i silniejszym spadku umieralności. Taki przebieg podstawowych procesów demograficznych w tych krajach w początkowym etapie prowadził do gwałtownego wzrostu liczby ludności, dopóki tendencje spadkowe płodności nie dorównały obniżaniu się umieralności. Kraje $\mathrm{z}$ tej grupy znajdują się na etapie przemian, jaki trwał 
w krajach z grupy A ok. 35-40 lat wcześniej. Dlatego też dojście do stanu stacjonarnego będzie w typie B opóźnione o ten właśnie okres. Ostatni typ wymieniony przez W. S. Thompsona wyróżniał się brakiem kontroli zarówno nad płodnością, jak i umieralnością. Oszacował on, że jest to najludniejsza grupa krajów, skupiająca ok. 70-75\% ludności świata. Ze względu na różny poziom zaawansowania zmian, tylko część z nich po 30-40 latach przejdzie do typu B.

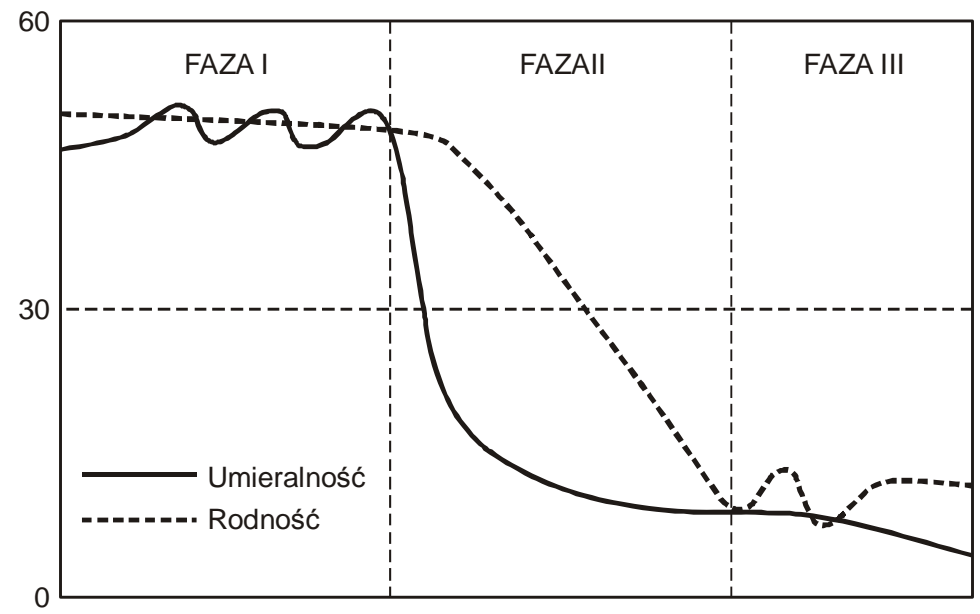

Ryc. 5. Trójfazowy model przejścia demograficznego Źródło: Nam, Philliber 1984

W podobny sposób dokonali periodyzacji A. Landry i F. M. Notestein, wydzielając po trzy fazy - pierwszy z wymienionych nazywał je reżimami. Były to reżim prymitywny, pośredni i współczesny. A. Landry poczynił pewne przewidywania co do reżimu współczesnego, który występował wówczas w Europie Zachodniej i w krajach zamorskich będących obszarem imigracji europejskiej, zakładając jego rozpowszechnienie się na całym świecie oraz przyspieszenie przemian na tych obszarach, które były słabiej pod tym względem zaawansowane.

Podejście F. M. Notesteina do opisywanych zmian wydaje się najbardziej klasyczne. Podobnie jak u innych autorów jego periodyzacja składa się z trzech faz. Analizując przemiany zwrócił on uwagę na zmiany struktury wieku i ich wpływ na liczebność populacji. Pierwszej fazie przyporządkował wysoki potencjał wzrostu liczebności populacji, następna faza to przejście, a trzeci etap jest okresem możliwego spadku. Jego prognozowana liczba ludności w 2000 r. wynosiła 3,3 mld7.

${ }^{7}$ Liczba ludności w 2000 r. przekroczyła 6 mld, w 2012 r. na świecie mieszkało 7,08 mld ludzi. Prognozy demograficzne zakładają jej wzrost do ponad 9 mld w 2050 r. (http://unstats.un.org/unsd/demographic/products/dyb/dyb2.htm). 
Fazy przejścia demograficznego można scharakteryzować poprzez ich właściwości, którymi są następujące parametry: przeciętne dalsze trwanie życia, współczynnik dzietności i typ struktury wieku (ryc. 6). W poszczególnych fazach osiągają one następujące wartości:

- naturalny system demograficzny:

- przeciętne dalsze trwanie życia jest bardzo krótkie $\left(\mathrm{e}_{0}<45\right)$,

- na skutek wysokiej umieralności, zastępowalność pokoleń ma charakter prosty lub tylko lekko rozszerzony, mimo wysokiej dzietności $\left(W_{\mathrm{dz}}>6\right)$,

- struktura wieku ludności jest potencjalnie progresywna, ponieważ tylko nieliczna część córek dożywa wieku prokreacyjnego, a w ogóle nieliczna część dzieci dożywa wieku starszego,

- przyrost naturalny jest niewielki,

- faza pierwsza (pierwszy etap przejścia demograficznego):

- przeciętne dalsze trwanie życia szybko wydłuża się i osiąga 45-55 lat,

- zastępowalność pokoleń ulega silnemu rozszerzeniu na skutek szybkiego obniżania się umieralności przy wciąż wysokiej dzietności $\left(4,5<W_{d z}<6\right)$,

- struktura wieku ludności ma charakter progresywny,

- przyrost naturalny, szczególnie w końcowym okresie tej fazy, jest bardzo duży (eksplozja demograficzna),

- faza druga (drugi etap przejścia demograficznego):

- przeciętne dalsze trwanie życia nadal wydłuża się, ale tempo przyrostu jest coraz niższe $\left(55<\mathrm{e}_{0}<65\right)$,

- zastępowalność pokoleń stopniowo maleje wskutek obniżania się dzietności w tempie szybszym niż obniżanie się umieralności, chociaż dzietność utrzymuje się jeszcze na wysokim poziomie $\left(3<\mathrm{W}_{\mathrm{dz}}<4,5\right)$,

- struktura ludności zmienia się stopniowo z progresywnej w stacjonarną,

- przyrost naturalny stopniowo maleje, ale jest wciąż duży,

- faza trzecia (etap stabilizacji przyrostu naturalnego):

- przeciętne dalsze trwanie życia osiąga wysoki poziom, chociaż istnieje jeszcze możliwość jego wydłużenia, np. poprzez wyeliminowanie chorób cywilizacyjnych, zwłaszcza chorób układu krążenia i nowotworowych $\left(\mathrm{e}_{0}>65\right)$,

- zastępowalność pokoleń przyjmuje poziom lekko rozszerzony lub prosty $\left(\mathrm{W}_{\mathrm{dz}}<3\right)$,

- struktura ludności jest stacjonarna, 
- przyrost naturalny kształtuje się na niskim poziomie bądź oscyluje wokół zera (Holzer 1999).
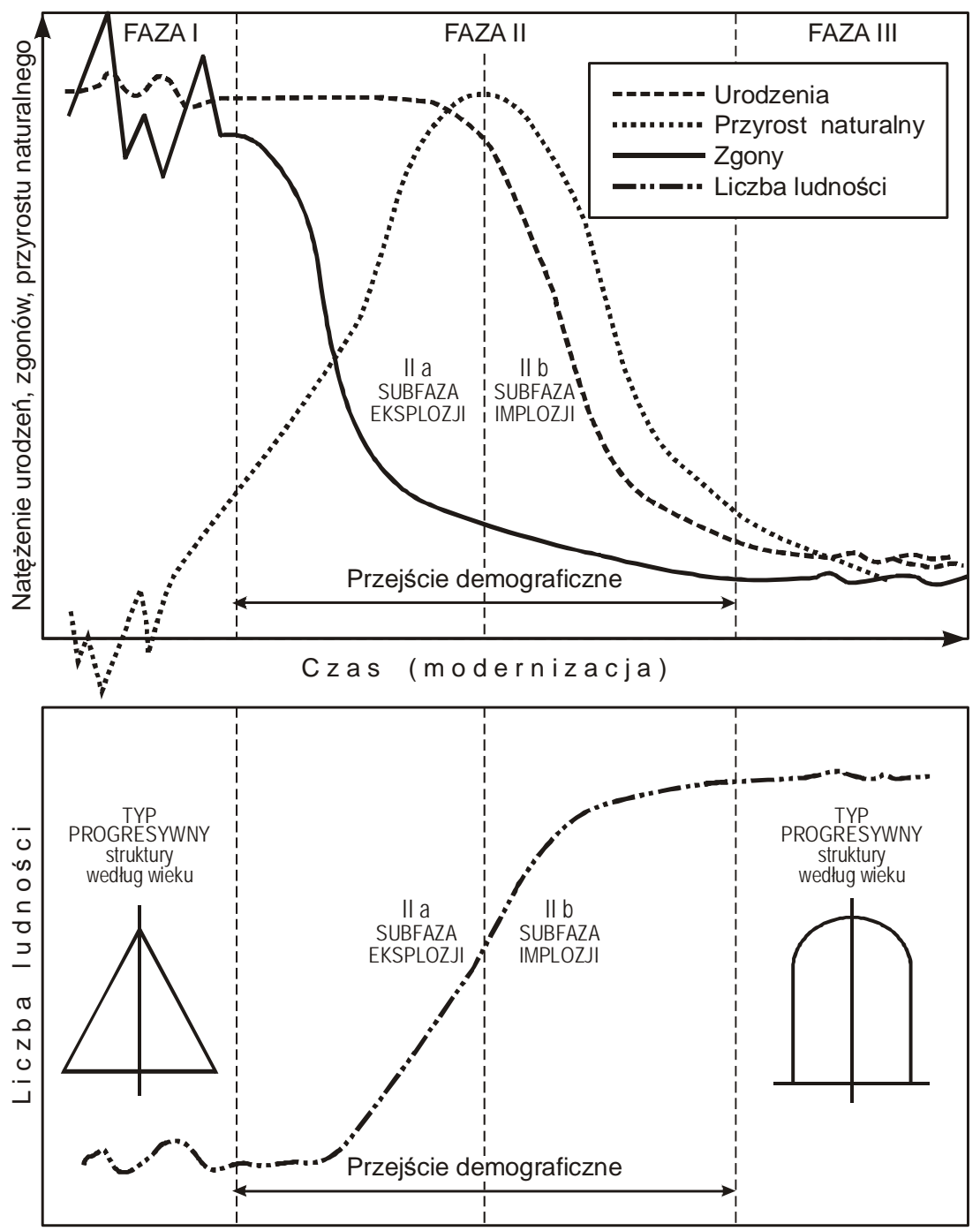

Czas (modernizacja)

Ryc. 6. Trójfazowy model przejścia demograficznego a struktura wieku Źródło: Okólski 2005

Obecnie w literaturze bardzo popularny jest czterofazowy model przejścia demograficznego (ryc. 7). W fazie pierwszej występuje naturalny proces reprodukcji, stopy urodzeń i zgonów utrzymują się na bardzo wysokim poziomie, w wyniku czego przyrost naturalny jest niewielki. Możliwe są też sytuacje, gdzie występuje ubytek naturalny, spowodowany np. działaniami 
wojennymi lub klęskami żywiołowymi. Jest to faza przejścia charakterystyczna dla społeczeństw o niskim poziomie rozwoju gospodarczego. Dzietność jest bardzo wysoka, powyżej sześciu dzieci na kobietę, a przeciętne dalsze trwanie życia nie przekracza 45 lat. Wysoka umieralność charakterystyczna dla pierwszego okresu przejścia jest początkowo powoli, a potem bardzo dynamicznie zastępowana przez niskie jej wartości. Dzieje się tak wskutek rozwoju medycyny i zwiększenia dostępu do placówek służby zdrowia. Ponieważ rodność pozostaje na wysokim poziomie $(4,5$ do 6 dzieci na kobietę), to przyrost naturalny w tej fazie (szczególnie pod jej koniec) jest bardzo wysoki. Początek fazy trzeciej to wciąż wysoka rodność i niska śmiertelność (bardzo wysoki przyrost naturalny). 0 ile w przypadku stopy zgonów mamy do czynienie z niewielkim jej spadkiem, o tyle stopa urodzeń obniża się w tej fazie gwałtownie. Fazę trzecią charakteryzuje dzietność na poziomie 3-4,5 dziecka i trwanie życia w granicach 55-65 lat. Ostatnia faza to okres, gdzie stopy zgonów i urodzeń pozostają na zbliżonym poziomie. Natężenie zgonów bliskie jest minimalnych wartości, co wynika z obecnego stanu wiedzy medycznej, zasięgu oddziaływania służby zdrowia i struktury ludności według wieku. W tej fazie dzietność jest niższa niż troje dzieci na kobietę, a przeciętne dalsze trwanie życia przekracza 65 lat. Przyrost naturalny jest niewielki, ale dodatni, może też jednak dojść do sytuacji, gdy np. pogorszy się sytuacja gospodarcza (kryzys, recesja), co może wpłynąć na obniżenie rodności i wtedy może pojawić się ubytek naturalny. Jest to już według niektórych badaczy faza piąta (Holzer 2003).

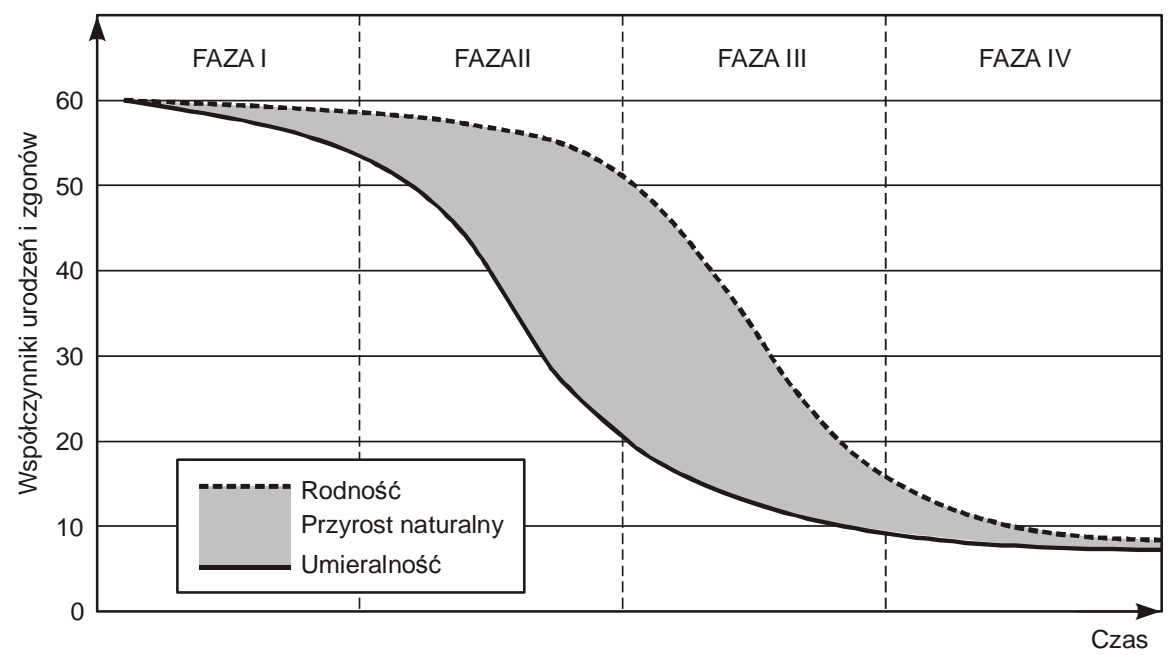

Ryc. 7. Czterofazowy model przejścia demograficznego Źródło: Holzer 1999

Teoria przejścia demograficznego, a szczególnie jej wczesne ujęcie, była poddawana różnym modyfikacjom. Propozycje C. P. Blackera, jak i K. Davisa 
dotyczyły liczby faz wyróżnianych w tym modelu. Obydwaj wyodrębnili po pięć okresów rozwojowych (ryc. 8). Różnice pomiędzy autorami dotyczyły wizji przyszłości demograficznej. Davis nie przewidywał depopulacji, zakładając, że niska płodność będzie przewyższała umieralność. C. P. Blacker wydzielił:

- fazę poprzedzającą przejście,

- fazę niekontrolowanej płodności, przy równoczesnym spadku umieralności,

- fazę spadku płodności w tempie przewyższającym tempo spadku umieralności,

- fazę równowagi umieralności i płodności,

- fazę przewagi natężenia zgonów nad natężeniem urodzeń.

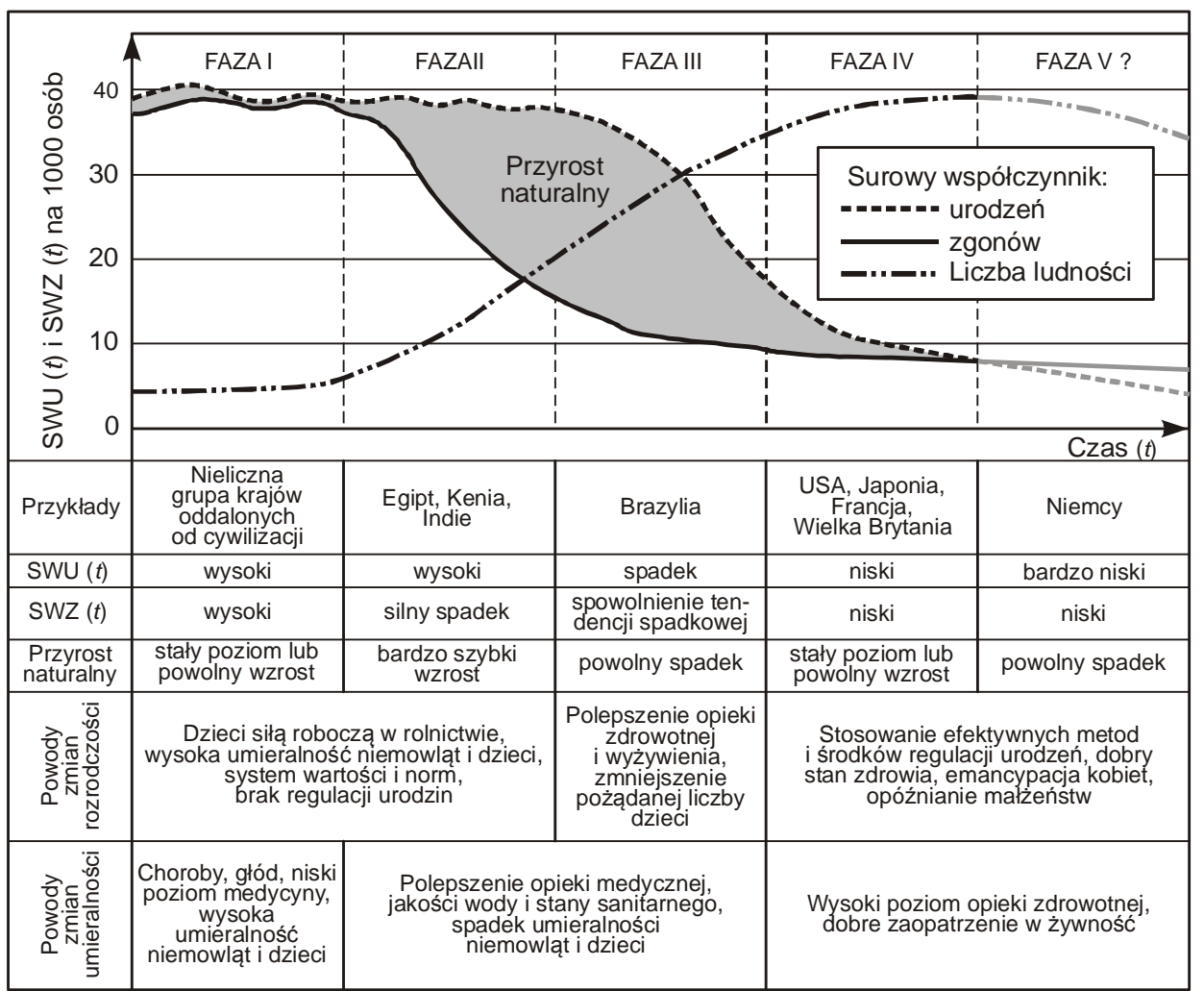

Ryc. 8. Powiązanie przemian modernizacyjnych i postmodernizacyjnych z przekształceniami ludnościowymi w poszczególnych fazach przejścia demograficznego

Źródło: Vogeler, http://www.uwec.edu/geography/ivogeler/w111/demmodel.htm za: Kurkiewicz 2010

Teoria przejścia demograficznego w swojej warstwie wyjaśniającej opisuje mechanizmy, które przyczyniły się do zmian śmiertelności i rodności 
społeczeństw. Ukazywanie uwarunkowań zachodzących procesów stanowi sposób wyjaśniania tego modelu przemian i jest jednocześnie jej podstawą naukową. Jako istotne uwarunkowania przejścia demograficznego F. M. Notestein wskazywał przede wszystkim czynniki społeczno-ekonomiczne, łącząc te przemiany z modernizacją, która wywarła wpływ na zmianę zachowań zarówno jednostki, jak i społeczeństwa. Przejście demograficzne jest praktycznie zbiorem powiązanych przejść (ryc. 9).

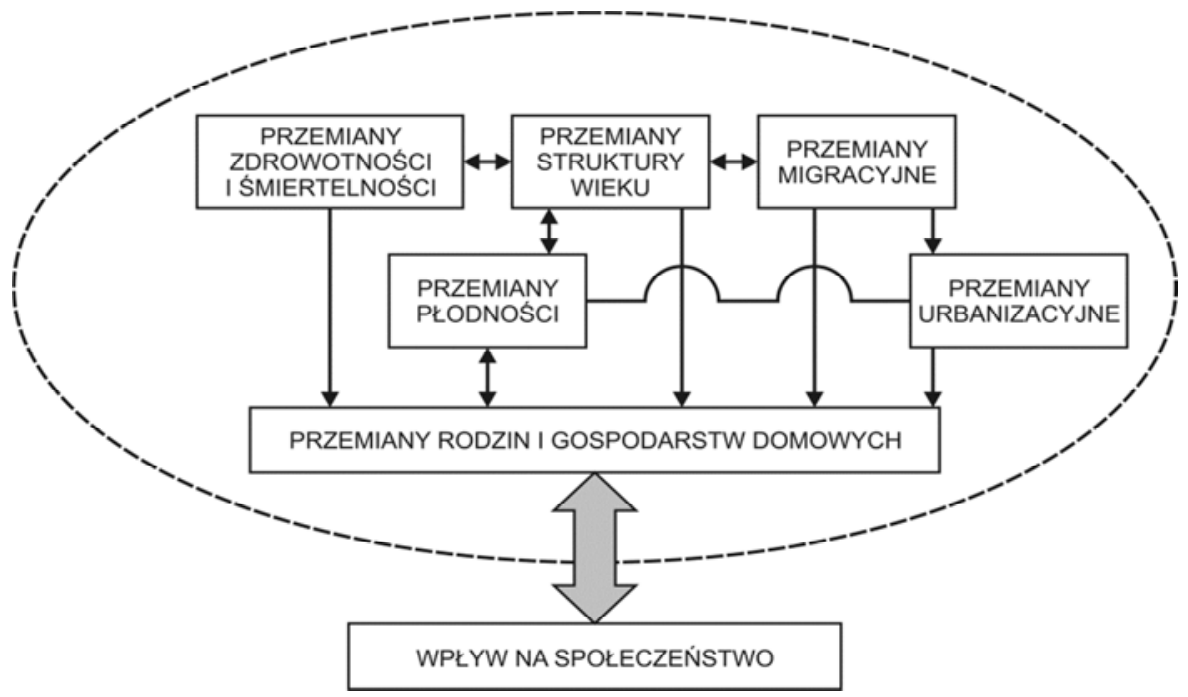

Ryc. 9. Przemiany w ramach przejścia demograficznego

Źródło: Weeks 2008

Mechanizmem przejścia jest spadek umieralności, który w poszczególnych regionach świata wystąpił w różnych okresach. W Europie pojawił się on najwcześniej, bo już w XVIII i na początku XIX w. zaobserwowano go we Francji, w Czechach i w Skandynawii (z wyjątkiem Finlandii). Dopiero po 75 latach objął Europę Północną, Zachodnią, Środkową, na wschodzie Polskę i Rosję europejską, a później Włochy i Jugosławię. Musiało upłynąć kolejnych 20 lat, aby śmiertelność zaczęła się obniżać w Hiszpanii, Portugalii, Bułgarii i Rumunii. Przemiany obszaru śmiertelności były spowodowane ogólnym postępem społeczno-gospodarczym, w tym przede wszystkim w zakresie medycyny ${ }^{8}$.

${ }^{8} \mathrm{~W}$ dziedzinie medycyny rewolucyjną rolę odegrały: wynaleziona przez E. Jennera w 1796 r. szczepionka przeciw ospie, osiągnięcia R. Kocha, wśród których szczególne znaczenie miało odkrycie w 1882 r. prątków gruźlicy, oraz prace L. Pasteura, którego pierwsza szczepionka przeciw wściekliźnie został zastosowana u człowieka w 1885 r. Dzięki tym osiągnięciom udało się znacznie obniżyć umieralność z powodu chorób zakaźnych. I wojna światowa i lata po jej zakończeniu to 
Nieco więcej trudności nastręcza znalezienie mechanizmów spadku płodności w okresie przejścia demograficznego. Wcześnie formułowane koncepcje, np. A. Landry'ego (1909), poszukują przyczyn ograniczania urodzeń $\mathrm{w}$ racjonalnych zachowaniach i zmianie norm moralnych. Autor wymienia czynniki ekonomiczne, społeczne i kulturowe oraz ich współdziałanie zmierzające do obniżenia płodności. Jego podejście jest, jak na początek XX w., wyjątkowo nowoczesne, chociażby przez fakt wskazywania środków kontroli urodzeń jako przyczyny spadku natężenia urodzeń. Postawy indywidualne członków społeczeństw przejawiające skłonności do kontroli urodzeń, nazwał egoistycznymi. Był zdania, że decyzje przyszłych rodziców są zależne od kosztów utrzymania dziecka, konieczności ograniczenia aktywności zawodowej i czasu wolnego kobiety. Swoimi poglądami wyprzedził dyskusje nad indywidualizmem i samorealizacją, jaka pojawiła się dopiero od lat 60. wieku XX.

Analiza uwarunkowań obniżania się płodności dotyczy dwóch skal, makro- i mikrospołecznej. Skala makro modernizacji dokonuje się poprzez industrializację i urbanizację, w wyniku czego następują zmiany popytu na pracę. Utrzymujący się wysoki poziom płodności na początku okresu przemian był uwarunkowany zapotrzebowaniem na pracę o niskich kwalifikacjach pracowników, czyli taką, którą mogły wykonywać również dzieci. Stwarzało to możliwości ich zatrudnienia i uzyskania dodatkowych dochodów gospodarstw domowych. Drugim czynnikiem wpływającym na obniżenie płodności jest urbanizacja. Poprzez zmiany struktury produkcji nastąpiło ograniczenie roli rodziny jako jednostki wytwarzającej dobra i świadczącej usługi. Dla niektórych produktów i usług, powstających dotychczas w gospodarstwie domowym, konkurencję stanowił rynek. Jeżeli koszty produkcji gospodarstwa domowego były wyższe niż ceny, to rezygnowano z pracy dzieci. Dodatkowo edukacja dzieci i ich nieobecność w domu spowodowały, że w miejskim środowisku duża rodzina stała się zbyt kosztowna. W wyjaśnianiu przyczyn spadku płodności zwraca się też uwagę na uczestnictwo kobiet na rynku pracy i konieczność ich kształcenia się. Dodatkowym czynnikiem był rozwój technologii, a przede wszystkim rozpowszechnianie się środków kontroli urodzeń.

Powstały także wyjaśnienia bazujące na zmianie kierunku transferu (przepływu) bogactwa (pieniądza, dóbr i innych zasobów) między generacjami. Autor tej teorii, J. C. Caldwell, zakładał, że w tradycyjnym społeczeń-

okres, w którym rozpowszechniano nowe techniki medyczne i prowadzono masową edukację w dziedzinie higieny i ochrony zdrowia. W czasie II wojny światowej rozpowszechniło się zastosowanie antybiotyków. W 1943 r. zaczęto na masową skalę produkować penicylinę odkrytą przez A. Flaminga w 1929 r. (Chesnais 1986, za: Kurkiewicz 2010). 
stwie przepływ bogactwa netto odbywa się od generacji młodszych do starszych, tzn. od dzieci do rodziców. Był to czynnik motywujący do posiadania licznego potomstwa. W sytuacji, gdy rodzice zaczynają dbać o lepsze wychowanie potomstwa oraz podnoszą poziom jego edukacji, dzieci z zasobu przekształcają się w koszt. W takiej sytuacji najbardziej ekonomicznie opłacalne byłoby pozostanie bezdzietnym.

Zmiany związane z przejściem demograficznym są zróżnicowane w zależności od specyficznych cech społeczeństwa, którego dotyczą. $\mathrm{W}$ chwili rozpoczęcia przejścia, tj. w XVIII w., prawie wszystkie kraje były w podobnej sytuacji demograficznej. Dopiero z czasem zachodzące przeobrażenia doprowadziły do zróżnicowania pomiędzy społeczeństwami znajdującymi się na różnym poziomie rozwoju. Pojawienie się przejścia na kontynencie europejskim, o specyficznych uwarunkowaniach społecznych, gospodarczych i kulturowych, było powodem podważania uniwersalności tej teorii dla innych społeczeństw. Dowodów na potwierdzenie, że jest to teoria uniwersalna dostarczył J. C. Chesnais przeprowadzając analizę bardzo bogatego materiału empirycznego dotyczącego większości populacji i wykorzystującego długie serie czasowe. Udowodnił on, że podstawowe twierdzenia teorii są zasadne nie tylko w odniesieniu do Europy Północnej i Zachodniej, ale również do niemal wszystkich innych populacji. Skutkiem badań Chesnaisa była typologia przejścia demograficznego, oparta na koncepcji „wysokości przejścia” i „długości przejścia” (ryc. 10). Pozwoliła ona na wyjaśnienie mechanizmów przejścia i różnic w przebiegu tego procesu pomiędzy populacjami pionierskimi i rozpoczynającymi przejście później, oraz skali całkowitego wzrostowego efektu przejścia, czyli jego mnożnika. Wysokość przejścia to najwyższa $\mathrm{w}$ trakcie przejścia $\mathrm{w}$ danej populacji wartość współczynnika przyrostu naturalnego, długość przejścia to liczba lat między początkiem trwałego spadku umieralności i końcem trwałego spadku rozrodczości, a mnożnik przejścia to wielokrotność liczebności populacji na końcu tego procesu względem jego początku. Według Chesnaisa populacje pionierskie doświadczyły przejścia niskiego, lecz długiego, a populacje najbardziej opóźnione - przejścia wysokiego, ale krótkiego (Okólski 2005).

Demografowie polscy mieli także udział w rozwoju teorii. Autorem monografii poświęconej teorii przejścia demograficznego jest Marek Okólski, którego opracowanie ukazało się w $1990 \mathrm{r}$.

Można przyjąć, że w krajach obecnie wysoko rozwiniętych proces przejścia demograficznego zakończył się w trzeciej dekadzie XX w. (Europa Zachodnia i Północna, Ameryka Północna, Australia i Nowa Zelandia). Kraje Europy Środkowej i Wschodniej oraz Japonia zakończyły ten proces w szóstej dekadzie XX w., a Chiny w dziewiątej dekadzie. Kraje rozwijające się dołączyły do społeczeństw, w których następują przemiany przejścia 
demograficznego, dopiero $\mathrm{w}$ drugiej połowie XX w. W prognozach ONZ zakłada się zakończenie procesu przejścia demograficznego: w Ameryce Łacińskiej - w pierwszej dekadzie XXI w., w Afryce do końca trzeciej dekady XXI w., w pozostałych krajach Azji także do końca trzeciej dekady XXI w. Zaobserwowano jednocześnie, że przejście demograficzne trwa tym krócej, im później się rozpoczyna i im kraje są mniejsze. Przykładem takiej sytuacji były kraje Centralnej i Wschodniej Europy (Kotowska, Jóźwiak 2003).

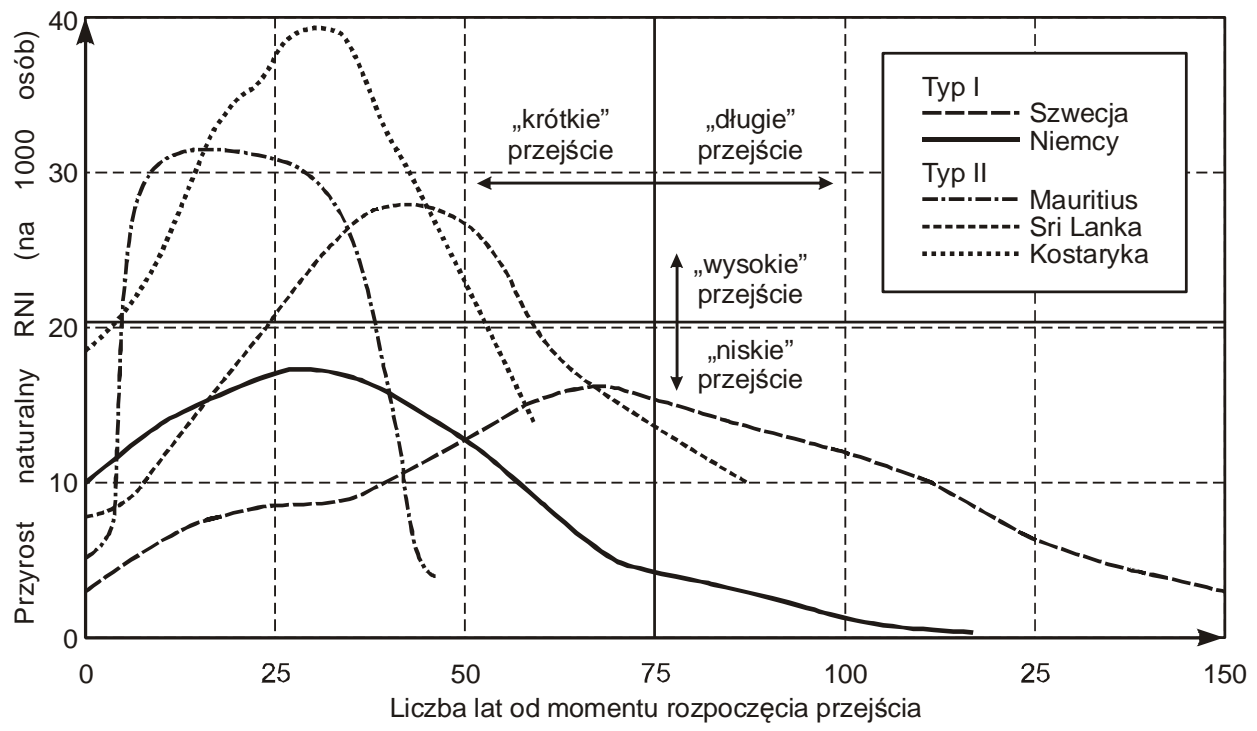

Ryc. 10. Podstawowe typy przejścia demograficznego (według J. C. Chesnaisa) Źródło: Chesnais 1986, za: Okólski 2005

\subsubsection{Drugie przejście demograficzne}

Przewidywane $\mathrm{w}$ ramach pierwszego przejścia demograficznego osiągnięcie nowoczesnej równowagi przy niskiej umieralności i płodności okazało się nietrafne. W krajach uprzemysłowionych, wysoko gospodarczo rozwiniętych, zaczęto odnotowywać już w połowie lat 60 . XX w. nowe zmiany demograficzne. Cechą charakterystyczną tych przemian jest pełna kontrola urodzeń, która osiągnęła poziom znacznie odbiegający od gwarantującego prostą zastępowalność pokoleń. Zmiany dotyczące odchylenia od stanu równowagi, wyznaczonego przez stabilizację przyrostu ludności przy niskiej płodności i umieralności, okazały się trwałe, choć początkowo uznawano je za okresowe zakłócenia prawidłowości przewidywanych zgodnie $\mathrm{z}$ teorią przejścia demograficznego. Ten nowy etap przemian demograficznych w Europie Północnej i Zachodniej, który rozpoczął się na przełomie lat 50. i 60. ubiegłego wieku, został nazwany drugim przejściem demograficznym, a za twórców tej teorii uznaje się D. van de Kaa i R. Lesthaeghe'a. 
Zarysy powstawania teorii drugiego przejścia demograficznego pojawiły się na przełomie lat 70. i 80. ubiegłego wieku (van de Kaa 1978; Lesthaeghe 1983). Według jednego z autorów tej koncepcji D. J. van de Kaa, nazwa jej po raz pierwszy pojawiła się podczas rozmowy w Brukseli w 1985 r., którą przeprowadził z R. Lesthaeghe’em. Rok później pojawiło się ich wspólne opracowanie pt. Two demographic transitions? i od tego czasu określenie drugie przejście demograficzne weszło do powszechnego użycia w opracowaniach, nie tylko naukowych, jako koncepcja określająca przemiany zachowań demograficznych związane z transformacją modelu rodziny. Doprecyzowanie założeń i uwarunkowań znalazło się w ich późniejszych pracach (Lesthaeghe, van de Kaa 1986; van de Kaa 1987; 1994; 1997; 1999; 2001a; 2001b; 2001c; 2008; Lesthaeghe 1995; Lesthaeghe, Surkyn 2002).

Cechą inicjująca przemiany drugiego przejścia był spadek płodności, który wynikał ze zmniejszenia się pożądanej liczby dzieci w rodzinie w kolejnych generacjach. Diametralna zmiana postaw i motywacji prokreacyjnych stała się przyczyną zerwania ciągłości reprodukcji ludności. W trakcie pierwszego przejścia rodzice ograniczali liczbę dzieci w rodzinie, by móc inwestować w kapitał ludzki swojego potomstwa, a w celu zapewnienia mu odpowiedniej opieki do czasu osiągnięcia dojrzałości trwali we wzajemnym związku nawet wtedy, jeśli stało to $\mathrm{w}$ sprzeczności $\mathrm{z}$ osobistym interesem każdego z nich lub gdy nie występowała pomiędzy nimi więź emocjonalna. Motywacja posiadania potomstwa i ograniczania jego liczby są inne w drugim przejściu demograficznym i odgrywają rolę głównie (a może jedynie) wspomagania ich samorealizacji. Zmiana postaw prokreacyjnych dotyczy pokolenia urodzonego wkrótce po zakończeniu II wojny światowej i późniejszych. Nowe zachowania i postawy niewątpliwie były konsekwencją doświadczeń i przeżyć związanych z II wojną światową i utratą wiary w misję cywilizacyjną Europy. Nie bez znaczenia dla przekształceń społeczno-kulturowych były także okrucieństwa związane z totalitarnymi ideologiami oraz niepowodzenia $w$ konstruowaniu lepszego porządku światowego. Przyczyniło się to do zwrotu w kierunku myślenia indywidualistycznego, które wskazywało na to, że mamy tylko jedno życie i warto przeżyć je zgodnie $\mathrm{z}$ własnym wyborem. Ten zwrot $\mathrm{w}$ myśleniu obejmował coraz szersze kręgi (Okólski 2004).

Zjawiska demograficzne, charakterystyczne dla drugiego przejścia demograficznego, należą do dwóch obszarów - małżeńskości i rozrodczości. W ramach pola małżeńskości najważniejsze są:

- upowszechnienie przedmałżeńskich (a nawet „przedpartnerskich”) stosunków erotycznych,

- opóźnienie typowego wieku zawarcia małżeństwa,

- zmniejszenie proporcji osób pozostających w związkach małżeńskich (zwłaszcza w tzw. związkach dozgonnych), 
- dywersyfikacja i upowszechnienie alternatywnych form związków partnerskich,

- zwiększenie trwałego celibatu (pozostawanie poza związkami partnerskimi),

- wzrost nasilenia rozwodów,

- powszechność rodzin niepełnych,

- rozszerzenie się zjawiska wielości i różnorodności związków partnerskich w przebiegu życia jednostki.

Do nowych zjawisk obszaru rozrodczości należą:

- zmniejszenie średniej liczebności potomstwa w rodzinie,

- zanik wielodzietności i wzrost dobrowolnej bezdzietności,

- upowszechnienie "nowoczesnych”, niezawodnych, tanich i łatwych w stosowaniu środków przeciwciążowych (nazwane drugą rewolucją antykoncepcyjną),

- opóźnienie typowego wieku prokreacji (co przy przyspieszeniu inicjacji erotycznej wydłużyło okres aktywności erotycznej z wykluczeniem rodzicielstwa) - por. Okólski 2005.

Procesy drugiego przejścia nie przebiegały jednakowo w poszczególnych krajach europejskich, a ich natężenie było zróżnicowane w czasie. Rozpoczęły się one w krajach skandynawskich w latach 50., rozprzestrzeniały się, poprzez kraje Europy Zachodniej w latach 60., aż po kraje Europy Południowej w latach 70 . Obserwacje tych tendencji pozwoliły na wydzielenie trzech podokresów przemian demograficznych:

- lata 1955-1970, w których nastąpiło przyspieszenie wzrostu liczby rozwodów, dalszy spadek płodności oraz zahamowanie zmniejszania się wieku zawierania pierwszych związków małżeńskich,

- lata 1970-1985 to okres rozpowszechniania się związków konsensualnych i związków typu LAT (Living-Apart-Together) ${ }^{9}$, zwiększania się liczby urodzeń pozamałżeńskich, wzrostu średniego wieku matki w momencie urodzenia pierwszego dziecka, wzrostu średniego wieku małżonków, spadku częstości zawierania małżeństw,

- od roku 1985 obserwuje się stabilizację natężenia rozwodów, spadek częstości powtórnie zawieranych małżeństw oraz zwiększenia się natężenia kohabitacji i związków typu LAT wśród osób rozwiedzionych lub owdowia-

9 Różnica pomiędzy tymi dwoma typami związków nieformalnych polega na tym, iż w przypadku kohabitacji partnerzy zamieszkują wspólnie, z kolei w przypadku związków typu LAT utrzymywaniu intymnej, niekiedy długookresowej więzi nie towarzyszy wspólne zamieszkiwanie. Z reguły kryterium pozwalającym na rozdzielenie tych dwóch typów związków jest spędzanie wspólne przynajmniej czterech nocy tygodniowo przez okres nie krótszy niż trzy kolejne miesiące (Janicka 2006). 
łych, dalszy spadek płodności w najmłodszych grupach wieku (15-24 lata) i wzrost płodności wśród kobiet w wieku 30-39 lat (Lesthaeghe 1991).

Drugie przejście demograficzne obejmuje następujące przemiany dotyczące modelu rodziny oraz zasad jej tworzenia i rozwiązywania:

1) zmniejszenie się znaczenia małżeństwa jako formy współżycia ludzi na rzecz kohabitacji,

2) przejście od modelu rodziny „dziecko z rodzicami” (the king-child with parents) do modelu „rodzice $\mathrm{z}$ dzieckiem” (the king-pair with a child),

3) przejście od zapobiegawczej antykoncepcji do świadomej prokreacji,

4) przejście od homogenicznych typów rodzin i gospodarstw domowych do form różnorodności (van de Kaa 1987).

W ramach tych zmian van de Kaa wymienia sekwencję zmian demograficznych, które nastąpiły w latach 1965-1995 w krajach Europy Północnej i Zachodniej. Obejmują one następujące fakty:

- spadek współczynnika dzietności ogólnej, wynikający ze zmniejszenia się płodności w starszych grupach wieku, spadek współczynnika urodzeń wyższej kolejności,

- spadek liczby ciąż przedmałżeńskich i małżeństw wymuszonych ciążą,

- opóźnienie urodzenia dziecka w małżeństwie, spadek płodności młodych kobiet, obniżenie się współczynników urodzeń niższej kolejności,

- wzrost liczby separacji i rozwodów,

- opóźnianie związku małżeńskiego współwystępuje z coraz częstszą kohabitacją przedmałżeńską, wzrost średniego wieku zawarcia pierwszego małżeństwa,

- rozpowszechnianie się kohabitacji przedmałżeńskiej, powstrzymywanie się z decyzją zawarcia związku do czasu zajścia partnerki w ciążę, wzrost liczby urodzeń pozamałżeńskich,

- wzrost średniego wieku rodzenia pierwszego dziecka,

- dalszy spadek niepożądanych urodzeń w wyniku zalegalizowania sterylizacji i aborcji, kontynuacja spadku płodności w skrajnych grupach wieku,

- wzrost społecznej akceptacji kohabitacji, która coraz częściej dotyczy osób rozwiedzionych i owdowiałych,

- postrzeganie kohabitacji jako alternatywy dla małżeństwa, dalszy wzrost płodności pozamałżeńskiej,

- stabilizacja współczynnika dzietności ogólnej na niskim poziomie,

- nieznaczny wzrost współczynnika dzietności ogólnej wskutek pojawienia się odraczanych urodzeń, zwiększenie się współczynników urodzeń niższej kolejności wśród starszych kobiet,

- nie wszystkie odroczone urodzenia mogą być zrealizowane przez kobiety w starszych grupach wieku rozrodczego,

- zwiększanie się zakresu dobrowolnej bezdzietności, 
- stabilizacja dzietności kohortowej poniżej prostej zastępowalności pokoleń (van de Kaa 1987).

Podłożem tym zmian są głębokie przemiany w sferze wartości, norm, postaw i zachowań społeczeństw postindustrialnych krajów Europy Zachodniej i Północnej. Czynniki, które przyczyniły się do szeroko pojętych przemian społeczno-ekonomicznych, van de Kaa rozważa w trzech grupach (tab. 5). Pierwsza z nich dotyczy społeczno-gospodarczych przemian strukturalnych i obejmuje industrializację, urbanizację, rozwój sektora usług, a także zmiany struktury społeczeństwa i organizacji państwa. Wynikiem tych przemian są m.in. poprawa poziomu życia, zwiększenie poczucia bezpieczeństwa socjalnego, wzrost poziomu wykształcenia ludności i mobilności społecznej oraz przestrzennej, a także zwiększenie się udziału kobiet w życiu ekonomicznym i społecznym. Następna grupa czynników jest związana ze zmianami politycznymi i światopoglądowymi, które Ronald Inglehart określa jako „cicha rewolucja” (silent revolution). To w ich wyniku doszło do rozwoju demokracji i egalitaryzmu społecznego, wzrostu autonomii jednostek, sekularyzacji, kontestowania tradycyjnych wartości oraz rozpowszechniania wartości pluralistycznych i liberalnych, uniwersalizmu, indywidualizmu, a także do przesunięć w hierarchii potrzeb. Ostatnia grupa uwarunkowań to zmiany technologiczne, które w największym stopniu dotyczą rozwoju medycyny (druga rewolucja antykoncepcyjna) i rozwoju systemów telekomunikacji. Wyodrębnione przemiany można rozpatrywać w skali makro, tzn. na poziomie społeczeństwa, bądź na poziomie grup społecznych podstawowych - rodziny, pary i wtórnych - grup politycznych, religijnych itd. oraz jednostek (van de Kaa 1994; 2001c) - por ryc. 11. 
Tabela 5

Koncepcja wyjaśniania przemian drugiego przejścia demograficznego

\begin{tabular}{|c|c|c|c|}
\hline \multirow{3}{*}{$\begin{array}{l}\text { Poziomy oddzia- } \\
\text { ływania }\end{array}$} & \multicolumn{3}{|c|}{ Jednostki społeczne } \\
\hline & \multirow{2}{*}{ grupy społeczne } & grupy podstawowe & \multirow{2}{*}{ jednostki } \\
\hline & & rodzina, para & \\
\hline 1 & 2 & 3 & 4 \\
\hline \multicolumn{4}{|c|}{ PROCESY STRUKTURALNE } \\
\hline $\begin{array}{l}\text { 1. Modernizacja, } \\
\text { rozwój społeczeń- } \\
\text { stwa postindu- } \\
\text { strialnego i pań- } \\
\text { stwa dobrobytu } \\
\text { 2. Wzrost: } \\
\text { - poziomu życia } \\
\text { - bezpieczeństwa } \\
\text { socjalnego } \\
\text { - zróżnicowania } \\
\text { funkcjonalnego } \\
\text { państwa } \\
\text { - strukturalnej } \\
\text { złożoności systemu } \\
\text { - mobilności } \\
\text { społecznej i prze- } \\
\text { strzennej } \\
\text { - poziomu wy- } \\
\text { kształcenia - } \\
\text { uczestnictwa kobiet } \\
\text { w życiu społecznym }\end{array}$ & $\begin{array}{l}\text { - rozwój klasy } \\
\text { średniej } \\
\text { - ograniczenie } \\
\text { funkcji zabezpiecza- } \\
\text { jących klasy społecz- } \\
\text { ne } \\
\text { - spadek znaczenia } \\
\text { grup ideologicznych } \\
\text { (politycznych, } \\
\text { religijnych itp.) } \\
\text { - pojawienie się } \\
\text { zachowań grupo- } \\
\text { wych }\end{array}$ & $\begin{array}{l}\text { - wzrost kosztów } \\
\text { alternatywnych } \\
\text { małżeństwa } \\
\text { i macierzyństwa } \\
\text { - większa niezależ- } \\
\text { ność współmałżon- } \\
\text { ków (partnerów), } \\
\text { większa swoboda ich } \\
\text { wyboru } \\
\text { - rosnące trudności } \\
\text { łączenia ról partnera } \\
\text { i rodzica }\end{array}$ & $\begin{array}{l}\text { - indywidualne umie- } \\
\text { jętności, ambicje i } \\
\text { kwalifikacje określają } \\
\text { pozycję społeczną } \\
\text { jednostki i jej dochód } \\
\text { - jednostki są stawiane } \\
\text { wobec rosnących } \\
\text { różnorodnych wyma- } \\
\text { gań, które trudno jest } \\
\text { spełnić jednocześnie } \\
\text { - konieczność pozosta- } \\
\text { wania mobilnym } \\
\text { (elastycznym) } \\
\text { - częściowa integracja } \\
\text { - wczesna niezależność } \\
\text { - wzrost poczucia } \\
\text { indywidualnego bezpie- } \\
\text { czeństwa }\end{array}$ \\
\hline \multicolumn{4}{|c|}{ KULTURA } \\
\hline $\begin{array}{l}\text { 1. Cicha rewolucja } \\
\text { 2. Wzrost: } \\
\text { - demokracji } \\
\text { - równości } \\
\text { - autonomii } \\
\text { - pluralizmu } \\
\text { - uniwersalizmu } \\
\text { - sekularyzacji } \\
\text { - indywidualizmu } \\
\text { - orientacji na } \\
\text { potrzeby wyższego } \\
\text { rzędu }\end{array}$ & $\begin{array}{l}\text { - spadek znaczenia } \\
\text { grup tworzących } \\
\text { normy i je propagu- } \\
\text { jących } \\
\text { - ograniczenia } \\
\text { stopnia spoistości } \\
\text { tych grup i możliwo- } \\
\text { ści kontroli prze- } \\
\text { strzegania norm } \\
\text { - wzrost mobilności } \\
\text { między grupami } \\
\text { społecznymi } \\
\text { - wzrost rywalizacji } \\
\text { (konfliktu) płci } \\
\text { - wzrost konfliktu } \\
\text { między różnymi } \\
\text { generacjami itp. }\end{array}$ & $\begin{array}{l}\text { - zmiany w układzie } \\
\text { sił (ról) między } \\
\text { kobietą i mężczyzną } \\
\text { - brak silnych zasad i } \\
\text { norm } \\
\text { - potrzeba określa- } \\
\text { nia własnych norm i } \\
\text { zasad } \\
\text { - pogląd, że dzie- } \\
\text { ci/partner ogranicza- } \\
\text { ją swobodę wyboru } \\
\text { - trudności pogodze- } \\
\text { nia różnych karier } \\
\text { życiowych }\end{array}$ & $\begin{array}{l}\text { - niechęć do tworzenia } \\
\text { związków/zobowiązań } \\
\text { długookresowych } \\
\text { - wzrost znaczenia } \\
\text { samorealizacji } \\
\text { - trudności określenia } \\
\text { indywidualnej tożsamo- } \\
\text { ści } \\
\text { - poszukiwanie indywi- } \\
\text { dualnego stylu życia } \\
\text { - wzrost niezależności } \\
\text { kobiet w wyborze } \\
\text { karier życiowych } \\
\text { - konflikt różnych ról } \\
\text { społecznych }\end{array}$ \\
\hline
\end{tabular}


Tabela 5 c. d.

\begin{tabular}{|c|c|c|c|}
\hline 1 & 2 & 3 & 4 \\
\hline \multicolumn{4}{|c|}{ TECHNOLOGIA } \\
\hline $\begin{array}{l}\text { 1. Druga rewolucja } \\
\text { antykoncepcyjna } \\
\text { 2. Rozwój: } \\
\text { - transportu } \\
\text { - łączności i } \\
\text { komunikacji } \\
\text { - ochrony zdrowia } \\
\text { - technologii } \\
\text { medycznych } \\
\text { - metod i środków } \\
\text { kontroli urodzeń }\end{array}$ & $\begin{array}{l}\text { - gwałtowny rozwój } \\
\text { technik informacyj- } \\
\text { nych } \\
\text { - zmniejszenie } \\
\text { kosztów przekazy- } \\
\text { wania informacji } \\
\text { - wzrost uprawnień } \\
\text { do usług medycznych } \\
\text { wynikły z rozwoju } \\
\text { systemu ubezpieczeń } \\
\text { zdrowotnych } \\
\text { - równość dostępu } \\
\text { do usług medycznych } \\
\text { i edukacyjnych dla } \\
\text { wszystkich grup } \\
\text { społecznych }\end{array}$ & $\begin{array}{l}\text { - dostępność infor- } \\
\text { macji o sytuacji na } \\
\text { rynku pracy (miejsca } \\
\text { pracy, zarobki itp.) } \\
\text { - szybkie rozprze- } \\
\text { strzenianie się } \\
\text { wiedzy } \\
\text { - możliwość zapo- } \\
\text { biegania niepożąda- } \\
\text { nej ciąży } \\
\text { - rezygnacja } \\
\text { z antykoncepcji jako } \\
\text { wynik świadomej } \\
\text { decyzji } \\
\text { - społeczna akcepta- } \\
\text { cja bezdzietności }\end{array}$ & $\begin{array}{l}\text { - antykoncepcja może } \\
\text { być wynikiem indywi- } \\
\text { dualnej decyzji } \\
\text { - wzrost swobody } \\
\text { seksualnej } \\
\text { - dopuszczalność } \\
\text { usunięcia niepożądanej } \\
\text { ciąży } \\
\text { - wzrost świadomości } \\
\text { i odpowiedzialności } \\
\text { indywidualnej }\end{array}$ \\
\hline
\end{tabular}

Źródło: van de Kaa 1994, za: Kotowska 1998.

Procesy modernizacji społeczeństwa można więc traktować jako uwarunkowania drugiego przejścia demograficznego, podkreślając znaczenie czynników socjologicznych, psychologicznych czy ekonomicznych dla zaistniałych przeobrażeń demograficznych. W literaturze można spotkać wiele koncepcji i teorii, które eksponują znaczenie tych czynników w procesach przeobrażeń społeczno-ekonomicznych. Zmiany modelu rodziny są np. przypisywane rewolucjom seksualnym. Pierwsza z nich zmieniła kryteria wyboru partnera, stawiając na pierwszym miejscu jego atrakcyjność i uczucia, druga przyczyniła się do wzrostu znaczenia erotyki w kontaktach międzyludzkich. Modernizację rodziny można też rozpatrywać pod kątem zmian, jakie przyniosły rewolucje w zakresie regulacji urodzeń. 0 ile pierwsza rewolucja antykoncepcyjna dostarczyła środków o stosunkowo niskiej efektywności, o tyle druga zapewniła metody nowoczesne, wysoce efektywne. Przeobrażenia $w$ ramach rodziny, związane ze zmianami zachowań prokreacyjnych, są według P. Ariesa (1980) wynikiem zmian motywacji, jest to przejście od modelu rodziny z priorytetem inwestycji w dzieci (the kingchild with parents) do modelu rodziny zachowującej partnerskie relacje między rodzicami oraz rodzicami i dziećmi (the king-pair with a child). Istotnym elementem, który podkreślają Lesthaeghe i Meekers, wśród czynników modernizacyjnych jest autonomia jednostki traktowana jako prawo do swobodnego wyboru norm i wartości oraz sposobu zachowania. Autonomia jednostki była także istotnym elementem zmian pierwszego przejścia (szczególnie jej wzrost), w drugim przejściu ważne wydaje się publiczne wyrażenie tej potrzeby i dążenie do jej zaspokojenia. Wiązało się to ze stopniowym wzrostem znaczenia postaw liberalnych i poglądów antyauto- 
rytarnych, które zaobserwowano po II wojnie światowej, a ich szybkie rozpowszechnienie nastąpiło po $1955 \mathrm{r}$. L. Roussel (1994) nazywa ten proces przełamywaniem barier, czyli zmian wartości takich, jak indywidualizm, autonomia jednostek czy poszukiwanie satysfakcji i przyjemności. Uważa także, że podstawą analizowanych przemian demograficznych była erozja instytucji małżeństwa. Przystosowanie tej instytucji do nowych aspiracji jednostek spowodowało stopniową rezygnację z małżeństwa jako sposobu formowania związku partnerskiego. W początkowym etapie przyczyniło się to do zmian decyzji prokreacyjnych, ale później traktowanie małżeństwa jako czystej formalności spowodowało, że związek między decyzją o rodzicielstwie i małżeństwem uległ dalszemu rozluźnieniu.

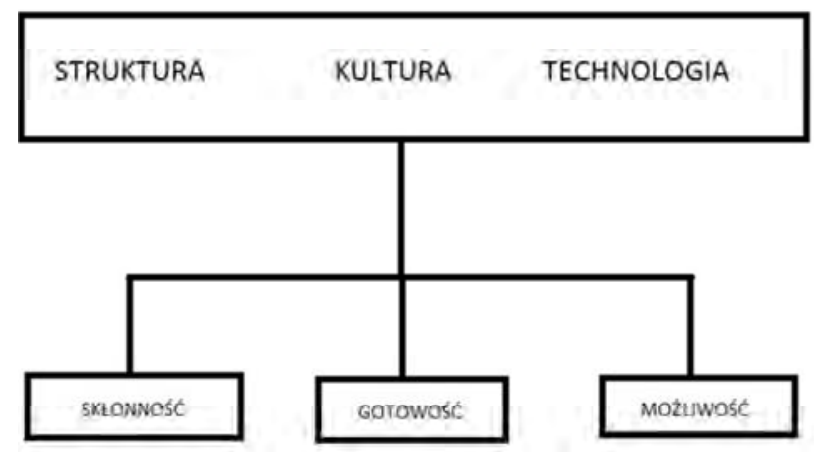

Ryc. 11. Społeczne zmiany relacji międzyludzkich na poziomie makro i mikro Źródło: van de Kaa 2001c

Współczesne przemiany demograficzne doprowadziły do powstania różnorodnych typów rodzin i gospodarstw domowych. Według Weeksa (2008) „sterownikami różnorodności” są trzy grupy przyczyn. Pierwsza z nich dotyczy wydłużenia życia człowieka i wpływa na liczbę i różnorodność związków w przebiegu życia jednostki (wzrost prawdopodobieństwa znalezienia się w stanie wdowim czy rozwiedzionym). Do drugiej grupy zalicza zmniejszenie presji społecznej by w młodym wieku zawierać związki małżeńskie i rozpoczynać macierzyństwo. Do przyczyn z trzeciej grupy zalicza przemiany urbanizacyjne, w wyniku których nie tylko w miastach ale i na terenach wiejskich upowszechnia się miejski styl życia dopuszczający różnorodność opcji stylu życia małżeńskiego i rodzinnego (ryc.12).

Bardzo istotne dla procesów prokreacyjnych są przemiany płodności, które są całkowicie pod kontrolą kobiet (albo bardziej ogólnie par). Jak piszą Lloyd i Ivanov (1988) jest to zmiana od „rodziny budowanej przez przypadek” do „rodziny budowanej przez zaprojektowanie”.

Procesy modernizacyjne społeczeństwa są także wynikiem wpływu różnych czynników ekonomicznych. Szukając wyjaśnień w postaci determinant drugiego przejścia demograficznego należy również rozpatrzyć stanowiska 
i poglądy ekonomistów. Wśród nich znany jest model rodziny G. S. Beckera $^{10}$ (1981; 1990), który wyjaśnia zmiany płodności i ich determinanty. Hipoteza o dochodach względnych E. A. Easterlina ${ }^{11}$ (1976) przedstawia wpływ aspiracji - ukształtowanych w dzieciństwie i możliwości ich zaspokojenia, określonych przez sytuację na rynku pracy - na kształtowanie się płodności i zachowań matrymonialnych.

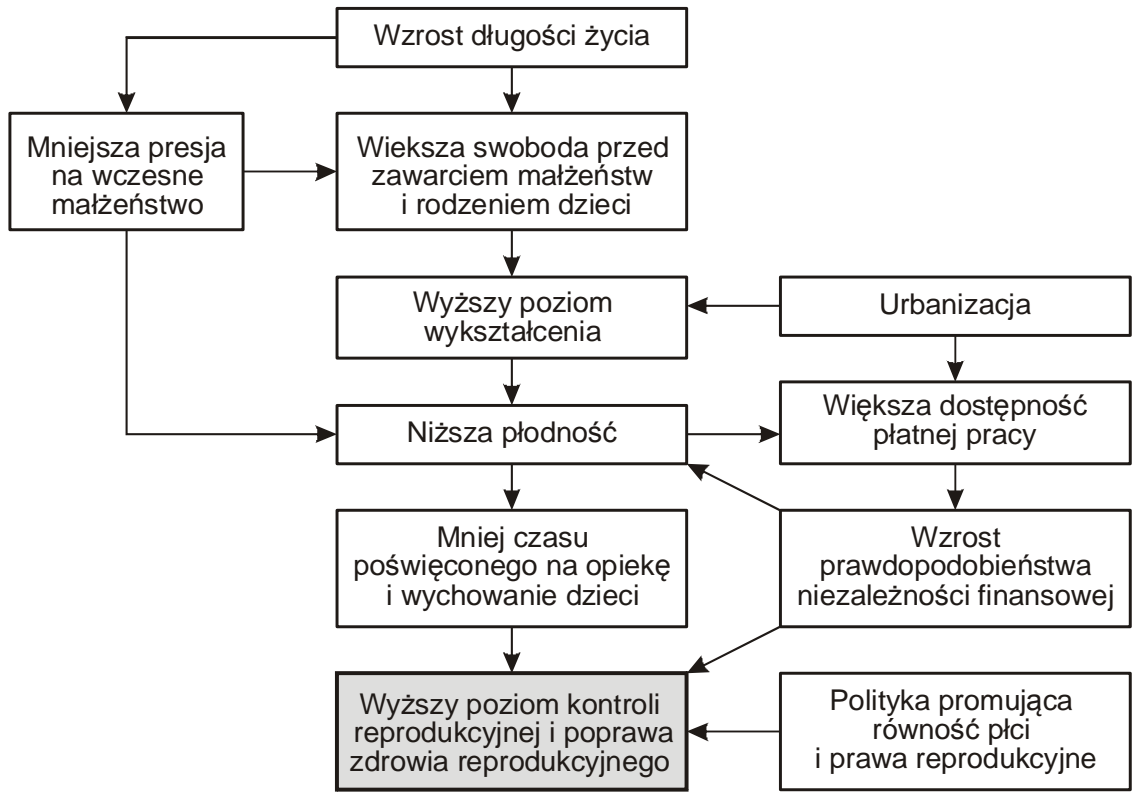

Ryc. 12. Czynnik wpływające na przemiany w sferze płodności Źródło: Weeks 2008

Koncepcja drugiego przejścia demograficznego od momentu jej pojawienia się była utożsamiana ze zmianami na polu rozrodczości oraz małżeńskości i traktowana jako niezależna od zmian dotyczących umieralności i procesów migracyjnych. Van de Kaa w 2002 r. wprowadził modyfikację do swojej koncepcji i zaproponował interpretację długofalowej tendencji reprodukcji ludności w populacji w trakcie drugiego przejścia. Proponuje w niej komplementarność przemian rozrodczości, umieralności i migracji zagranicznej (ryc. 13). Zgodnie z założeniami drugiego przejścia, populacja, w której pojawiły się przemiany rozrodczości, osiąga stabilizację płodności na poziomie, przy jakim współczynnik urodzeń jest niższy aniżeli współczynnik zgonów, co oznacza trwale ujemny współczynnik przyrostu naturalnego. $\mathrm{W}$ takiej społeczności obniżeniu ulega nasilenie emigracji, nato-

${ }^{10}$ Więcej o teorii G. S. Beckera zob. podrozdział 2.1.7.

${ }^{11}$ Więcej o teorii E. A. Easterlina zob. podrozdział 2.1.7. 
miast rośnie imigracja, co powoduje trwale dodatnie saldo migracji zagranicznych. Oznacza to zerowy wzrost ludności i zrównoważoną jej reprodukcję, którą w tej sytuacji zapewniają zjawiska migracyjne (Okólski 2005).

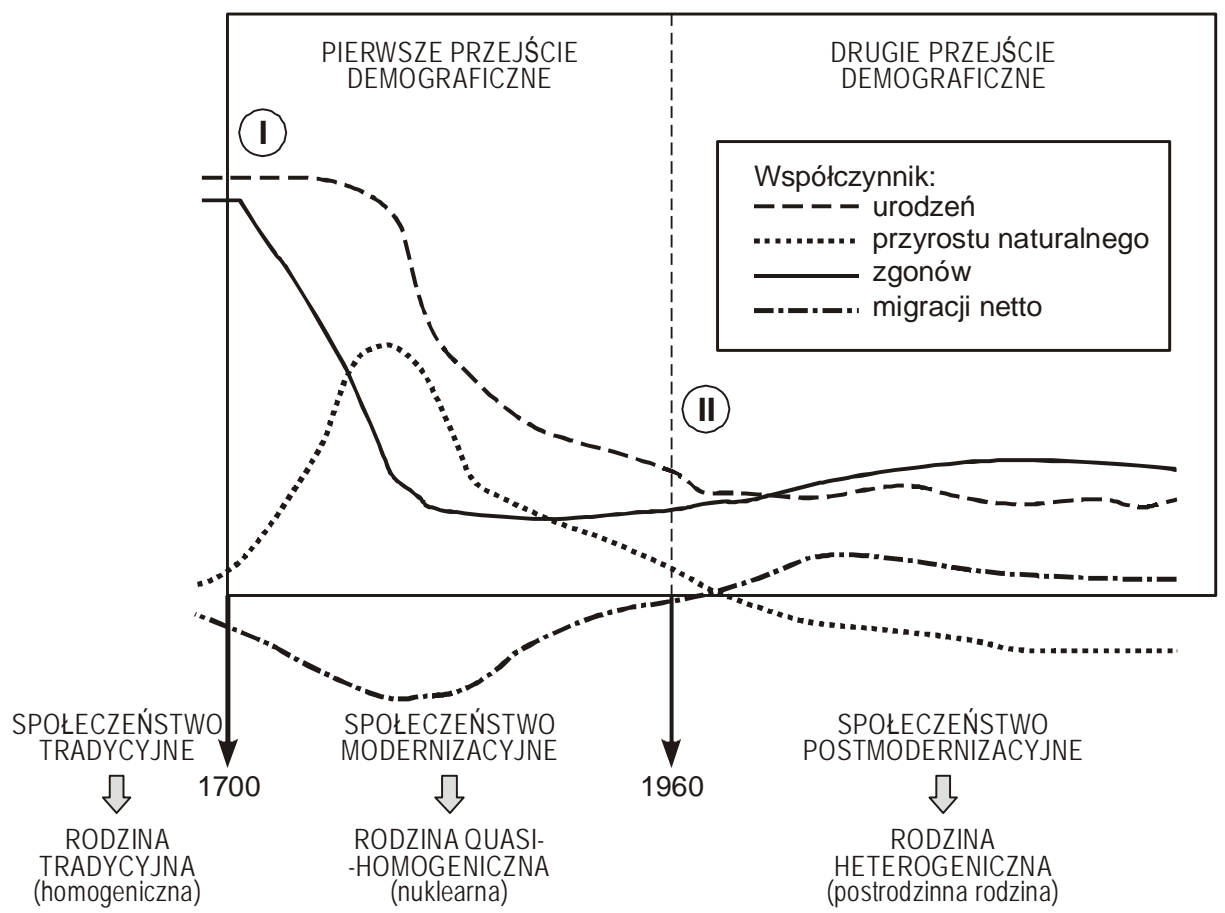

Ryc. 13. Powiązanie przemian modernizacyjnych i postmodernizacyjnych z przekształceniami ludnościowymi w poszczególnych fazach przejścia demograficznego Źródło: Van de Kaa 1994, za: Slany 2003

Od początku pojawienia się teorii drugiego przejścia demograficznego trwa ożywiona dyskusja na temat jej walorów i niedostatków. Przeciwko koncepcji drugiego przejścia demograficznego z fazą depopulacji zdecydowanie wypowiadał się E. Rosset, chociaż nie wykluczał możliwości jej przejściowego występowania. W jego ocenie ludność świata rozwija się prawdopodobnie według praw cyklicznych i po okresach wzrostu należy spodziewać się okresów zmniejszania się liczby ludności, aby ponownie mógł nastąpić jej wzrost (Rosset 1987).

Podczas obrad Europejskiej Konferencji Ludnościowej w Warszawie w 2003 r. odbyła się ożywiona dyskusja na temat koncepcji drugiego przejścia demograficznego z udziałem wybitnych demografów, w której uczestniczył także D. J. van de Kaa. Podkreślano wówczas, że drugie przejście demograficzne nie ma walorów uniwersalności przede wszystkim ze względu na:

- ograniczony zasięg zawężonej zastępowalności pokoleń w świecie, 
- krótki okres trwania obecnej depresji demograficznej w krajach wysoko rozwiniętych,

- brak walorów predykcyjnych (jaka przyszłość?).

D. Coleman (2001) stawia pytanie: czy kraje o podobnym poziomie gospodarczym, rozwiniętej opiece nad dzieckiem, zbliżonym dobrobycie mogą doświadczać takiej samej płodności? Jaka będzie przyszłość demograficzna Europy? W konkluzji stwierdza: „czas pokaże”, ponieważ aktualny przebieg zastępowalności pokoleń, zmierzający do ubytku naturalnego ludności nawet w wielu już krajach, trwa zbyt krótko - krócej niż pół wieku. Po kilku latach od swojej wypowiedzi Coleman podjął próbę odpowiedzi na temat dalszych zmian demograficznych w krajach gospodarczo rozwiniętych.

\subsubsection{Trzecie przejście demograficzne. Naprawdę przejście?}

Niedawno w anglojęzycznej literaturze pojawiła się teza, że niektóre kraje - z powodu specyficznych procesów demograficznych w nich występujących - są aktualnie pod wpływem trzeciego przejścia demograficznego. Kraje te to Stany Zjednoczone i zachodnie kraje europejskie. Tezę tę sformułował David Coleman i przedstawił ją m.in. w opracowaniu Immigration and Ethnic Change in Low-Fertility Countries: A Third Demographic Transition zamieszczonym w „Population and Development Review” w 2006 r. Wnioski z przeprowadzonych badań empirycznych pozwoliły mu na sformułowanie założeń swojej koncepcji. Jego teza składa się z dwóch twierdzeń. Pierwsze z nich zawiera dwa elementy:

- w niektórych krajach uprzemysłowionych wyraźna jest gwałtowna zmiana struktury ludności według pochodzenia narodowościowego lub etnicznego, wynikająca bezpośrednio bądź pośrednio z imigracji na przestrzeni ostatnich kilku dekad,

- prognozy oparte na prawdopodobnych założeniach sugerują, w ramach konwencjonalnej skali czasu prognoz, że nastąpi znacząca zmiana struktury ludności, która - w przypadku jej kontynuacji w dalszej perspektywiemoże doprowadzić do przesunięcia ludności pierwotnej na pozycję mniejszości. Pierwsze twierdzenie jest stosunkowo łatwe do przedstawienia w sposób empiryczny przy zastosowaniu bezpośrednich i udowadnialnych założeń. Drugie zakłada, iż gdyby taki proces miał trwać, wykazując wpływ demograficzny w tak krótkim czasie, wymagałby określenia „przejścia”. Ostateczne przyjęcie takiego określenia zależałoby od tego, czy przekształcenie okazało się trwałe i ogólne, a co za tym idzie, byłoby porównywalne z pierwszym i drugim przejściem.

Coleman (2007) twierdzi, że jeżeli pierwsze przejście demograficzne dotyczyło zmian przyrostu naturalnego, rodności i śmiertelności, a drugie 
zmian zachowań seksualnych, organizacji życia rodziny i jej form, to trzecie przejście demograficzne zajmuje się ostatnim składnikiem charakteryzującym ludność, a mianowicie jej strukturą.

Jak sądzi Coleman, żadne pojęcie przejścia nie podejmuje jednoznacznie problemu migracji lub chociażby jakichkolwiek zmian z niej wynikających w strukturze ludności, chociaż van de Kaa uznaje wzrost imigracji za naturalny, jako pośredni skutek niskiego przyrostu w krajach docelowych. Z drugiej strony emigracja jest najwyższa w szczycie wzrostu ludności w połowie przejścia, jak to działo się w dziewiętnastowiecznej Europie i jak to wygląda dziś w krajach rozwijających się. Coleman zauważa, że marginalny status migracji może się zmienić12. Obserwowane ostatnio nowe potoki migracyjne, szczególnie z krajów trzeciego świata, przyczyniają się do wzrostu liczby ludności Europy, Ameryki Północnej, Australii i Nowej Zelandii. Do początku XXI w. przyrost migracyjny stał się głównym składnikiem utrzymującego się wzrostu ludności w większości krajów europejskich. Tam zaś, gdzie śmiertelność przekracza wysokość współczynnika urodzeń (np. w Niemczech albo we Włoszech), migracyjny przyrost nieco łagodzi ubytek ludności.

Opisywane i przewidywane procesy, wynikające z niskiej płodności $\mathrm{w}$ połączeniu z wysokim stopniem imigracji, są znaczące, ponieważ zmieniają strukturę populacji krajowych, a co za tym idzie i kulturę, wygląd fizyczny, doświadczenia społeczne oraz własne postrzeganie swojej tożsamości przez mieszkańców krajów europejskich. Jeśli aktualne tendencje utrzymają się, przeważająca część wielu, jeśli nie większości lokalnych społeczności krajów europejskich ulegnie zrównaniu liczbowemu lub nawet stanie się liczbowo podrzędna względem ludności niedawnej imigracji bądź o mieszanym pochodzeniu. Stanowiłoby to krańcowy przykład „wymiany migracyjnej”, nigdy wcześniej niezaobserwowanej na taką skalę z przyczyn innych niż w wyniku inwazji lub wojny.

Według Colemana do niedawna przykładano niewielką wagę do wpływu migracji na strukturę ludności. W centrum zainteresowań znajdowały się skutki imigracji oddziałującej przede wszystkim na wielkość populacji. Twierdzono na przykład, że dowolna stała wielkość migracji do krajów z dzietnością na poziomie niezapewniającym zastępowalności pokoleń oraz ze stałą śmiertelnością zawsze prowadzi do tworzenia się ludności zastojowej (tj. takiej, której liczba nie rośnie ani nie maleje), o ile płodność imigrantów pozostaje na podobnym poziomie jak populacji pierwotnej. Płynie z tego wniosek, że dowolna populacja o współczynnikach demograficznych niezapewniających zastępowalności pokoleń, której wielkość pozostaje

${ }^{12}$ Jak mówi Coleman (2007), przestanie być traktowana przez współczesną demografię jak biedna krewna. 
stała lub rośnie dzięki imigracji, stanie się grupą o przeważająco, a z czasem całkowicie, imigracyjnym pochodzeniu (z wyłączeniem pokrewieństwa w związkach mieszanych). W dowolnej populacji ze średnim przyrostem naturalnym niezapewniającym zastępowalności pokoleń, dowolna grupa mniejszościowa z większym przyrostem naturalnym musi zaś w dłuższej perspektywie osiągnąć liczbową przewagę. Ludność pierwotna ulega zmianie niezależnie od tego, czy rosnąca nowa populacja zachowuje ścisłe rozgraniczenie tożsamościowe, czy staje się mieszana. Ostateczny efekt wymiany pozostaje niezmieniony niezależnie od tego, czy ludność imigracyjna przejmuje lokalny niski współczynnik przyrostu szybko, powoli lub w ogóle go nie przejmuje. Dalej Coleman zauważa, że można oponować twierdząc, że takie tezy są bezzasadne, gdyż wnioski z nich płynące są „długoterminowe”, a jego badania omawiają krótszą perspektywę czasową, jednakże taki zarzut nie ma wpływu na prognozowany skutek. Prognozy wskazują bowiem na znaczący wpływ znacznej imigracji na strukturę ludności pierwotnej 12 krajów UE oraz wybranych miast europejskich i Holandii do 2050 r.

Organizacja Narodów Zjednoczonych w 2000 r. zaprezentowała obszerny zestaw przykładów wpływu migracji w kilku krajach wyliczonych przy użyciu tej samej metodologii. Wskazują one na możliwość bardzo dużego wzrostu ludności pochodzenia imigracyjnego od 2000 do 2050 r. przy założeniu różnych poziomów imigracji (np. zapewniających utrzymanie ogólnej wielkości ludności, ludności w wieku produkcyjnym oraz struktury wieku populacji o niskiej płodności). Przykładowo średnie saldo migracji na poziomie 1,4 mln osób rocznie do Unii Europejskiej (UE-15) pozwoliłoby zachować liczbę ludności w wieku produkcyjnym na poziomie z 1995 r. aż do 2050 r. Wartość 1,4 mln osób jest bliska faktycznemu saldu imigracji od 2000 r. Gdyby taki potok migrantów przybywał do Europy rocznie, od 1995 aż do 2050 r., dałoby to ludność w liczbie 108 mln imigrantów i ich dzieci, tj. $26 \%$ prognozowanej ludności UE w tym roku.

Jako warunki wstępne zaistnienia procesów, które prowadzą do przemian trzeciego przejścia Coleman wymienia niską płodność oraz wysoki poziom imigracji. Sytuacja demograficzna większości krajów uprzemysłowionych spełnia dziś podstawowe wymogi do zaistnienia przemian trzeciego przejścia. Współczynniki dzietności we wszystkich krajach, z wyjątkiem USA, nie zapewniają zastępowalności pokoleń i taka sytuacja występuje od kilku dziesięcioleci w Zachodniej Europie, a od niedawna także w Południowej i Wschodniej Europie oraz na Dalekim Wschodzie i w innych krajach o korzeniach europejskich. Zmiana zachowań prokreacyjnych, zmierzająca do zaistnienia zastępowalności pokoleń spośród dzisiejszych młodszych kohort wymagałaby nieprawdopodobnego zwiększenia płodności w starszym wieku. Oficjalne prognozy jednogłośnie zakładają, że średnia dzietność w przyszłości nie będzie przekraczać 1,85 lub 1,9 osoby (ONZ 
2004; Eurostat 2005). Większość demografów (do których Coleman się nie zalicza) uważa zatem, że stan niezapewniający zastępowalności pokoleń „zadomowił" się u nas na dobre.

Jako drugi warunek wymienia Coleman imigrację do Europy Zachodniej oraz Stanów Zjednoczonych, która znacznie wzrosła od lat 50. ubiegłego wieku i wciąż utrzymuje się na wysokim poziomie (patrz ryc. 14). Pomimo wahań roczne saldo imigracji do krajów UE-15 w ostatnich latach przekraczało $1 \mathrm{mln}$, podobne wartości osiągał napływ brutto do USA. W związku z tym około roku 2000 ponad 10\% ludności niektórych krajów Europy Zachodniej urodziło się poza granicami tych krajów, w przypadku Austrii, Niemiec, Luksemburga i Szwajcarii odsetek ten był zaś wyższy niż w Stanach Zjednoczonych (12,3\% w 2000 r.). Spośród krajów rozwiniętych, jedynie niektóre kraje Europy Wschodniej, Japonia i Korea Południowa odnotowują skromny napływ migracyjny.

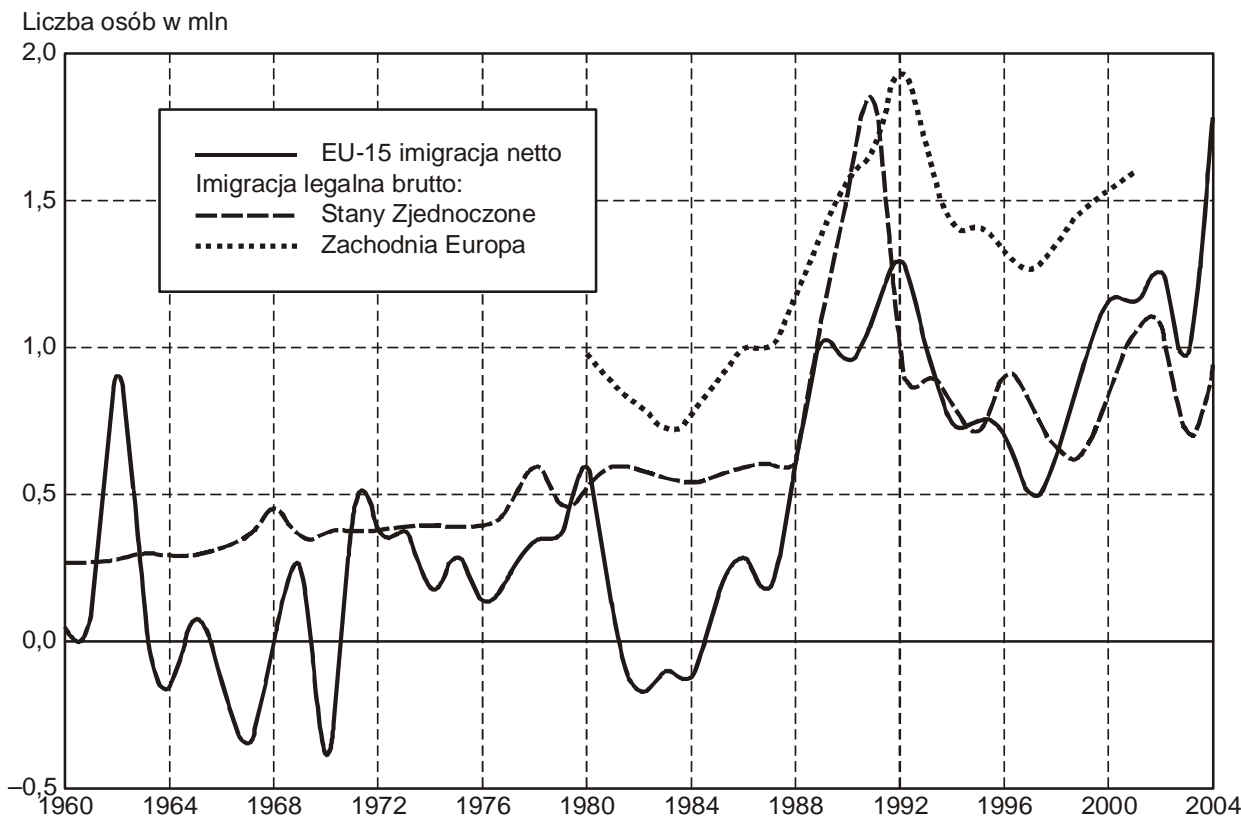

Ryc. 14. Roczna imigracja legalna, EU-15 (netto), 12 zachodnioeuropejskich krajów (brutto), i Stany Zjednoczone (brutto)

Źródło: Coleman 2006

Zgodnie z tym migracja stała się siłą napędową zmian demograficznych w wielu krajach Europy zarówno bezpośrednio, jak i pośrednio, poprzez przyrost naturalny ludności o pochodzeniu imigracyjnym (Coleman 2003; Héran 2004; OECD 2004; Salt 2005). W niektórych przypadkach (Niemcy, Włochy) imigracja uniemożliwia lub ogranicza spadek liczby ludności. 
W innych wznowiła rozwój ludności (Belgia, Holandia, Norwegia, Szwecja oraz Wielka Brytania).

W pewnych krajach europejskich około roku 2000 niemal dwie trzecie imigrantów pochodziło spoza Europy (66\% w Wielkiej Brytanii, 62\% w Holandii, 59\% we Francji). W innych, jak chociażby w Belgii i Szwecji, proporcje te są odwrócone. W Europie i Stanach Zjednoczonych przyrost naturalny ludności nieeuropejskiej obcego pochodzenia jest często wyższy od wzrostu ludności rodzimej, co jest spowodowane młodszą strukturą wiekową, wyższymi współczynnikami płodności dla poszczególnych grup wiekowych oraz chwilowymi zaburzeniami budowania rodziny, wynikającymi z samego procesu migracji (ryc. 15). Na początku XXI w. 18\% urodzeń w Anglii i Walii oraz we Francji, a aż $23 \%$ w Stanach Zjednoczonych przypadało na imigrantki. Jednak niektóre grupy imigrantów wykazują niższe współczynniki płodności dla poszczególnych grup wiekowych w porównaniu z krajowymi średnimi.

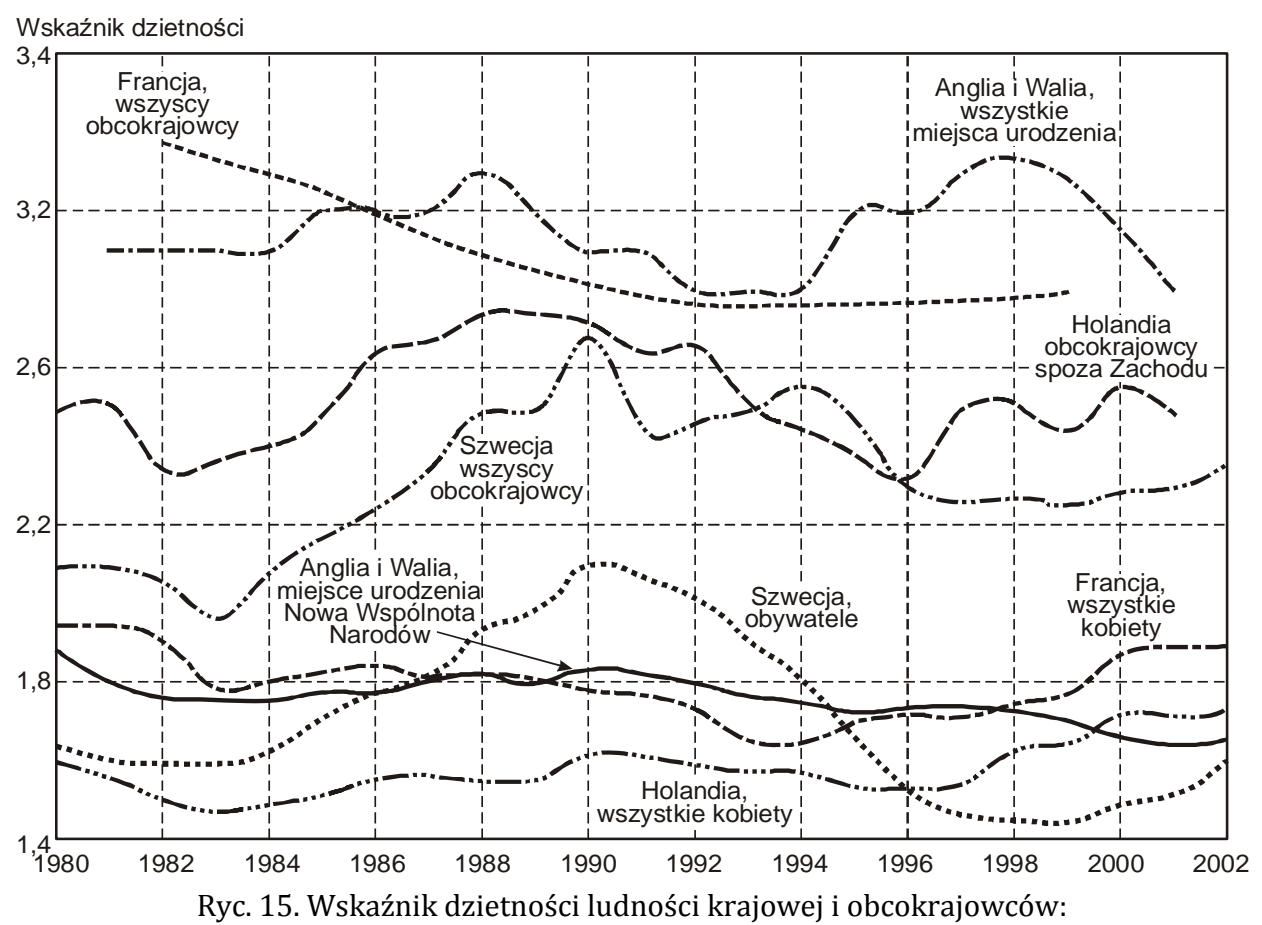
wybrane kraje europejskie 1980-2002 Źródło: Coleman 2006

Od siedemnastego wieku aż do okresu powojennego większość krajów europejskich oprócz Francji było krajami emigracji. Dla odmiany od lat 50. $\mathrm{XX}$ w. większość z nich doświadczała znacznego napływu, w tym - po raz pierwszy na dużą skalę - napływu z krajów nieeuropejskich. Podczas gdy 
wewnątrzeuropejskie migracje osłabły, trend przechylił się $\mathrm{w}$ kierunku napływu nieeuropejczyków, którego dynamiczny wzrost był wyraźny ze względu na nowe, znaczące zmiany w wyglądzie, kulturze, języku i religii. Dla przykładu w Wielkiej Brytanii w 1951 r. liczebność ludności kolorowej o dowolnej narodowości lub miejscu urodzenia szacowano na około 50 tys. Podczas spisu w roku 1971 ich liczba wynosiła 1,3 mln osób, w roku 1991 3,0 mln, a 4,5 mln w 2001 r. (średni roczny wzrost o 4,1\%). Przyrost niektórych grup ludności był nawet jeszcze szybszy, np. ludność o pochodzeniu afrykańskim podwajała się co dziesięć lat, począwszy od 108 tys. osób w 1981 r. do 480 tys. w roku 2001 - roczny wzrost o 7,5\%. W Holandii ludność obcego pochodzenia wzrastała średnio o 2,7\% rocznie w latach 1995-2003. Wzrost ten znacznie przyczynił się do ogólnego rozwoju populacji i rozszerzył etniczną i rasową różnorodność społeczeństwa, które wcześniej uważało się za stosunkowo jednolite (co prawda podzielone odwiecznymi różnicami regionalnymi).

Dokładna analiza struktury ludności obcego pochodzenia w krajach europejskich jest utrudniona, jak stwierdza Coleman, ze względu na stosowane kryteria klasyfikacji i nazewnictwo. Większość krajów europejskich zwyczajowo określa ludność obcego pochodzenia na podstawie kryterium obywatelstwa (narodowości) i definiuje urodzenia obcego pochodzenia na podstawie obywatelstwa matki. Takich danych dostarczają Eurostat, OECD oraz Rada Europy. W niektórych krajach dzieci obywateli zagranicznych nie stają się automatycznie obywatelami kraju, w którym się urodziły. W wielu krajach wysoki poziom naturalizacji sprawia, że dane oparte na obywatelstwie stały się bezużyteczne jako wskaźniki ludności obcego pochodzenia w każdym, oprócz prawnego, znaczeniu. Naturalizacje w danym roku często przekraczają roczny napływ imigrantów. Zjawisko to znacznie zredukowało statystyczną, choć nie rzeczywistą, liczbę osób obcego pochodzenia w Belgii, we Francji, w Holandii, Szwecji itp. W krajach tych dane oparte na obywatelstwie pomniejszają wielkość ludności obcego pochodzenia oraz tempo jej wzrostu o połowę lub nawet w większym stopniu. Dla uzyskania bardziej reprezentatywnego obrazu niektóre kraje europejskie przyjmują definicje statystyczne ludności obcego pochodzenia obejmujące zarówno imigrantów, jak i drugie pokolenie imigrantów („potomkowie”, „osoby o zagranicznym pochodzeniu"). Na przykład w Holandii każda osoba, której choć jeden z rodziców urodził się za granicą, określana jest jako „osoba zagranicznego pochodzenia". Pozostałych, w tym należących do trzeciego pokolenia imigracji, uznaje się za Holendrów. To wyłączenie większości trzeciego i kolejnych pokoleń prowadzi do postępującego niedoszacowania i zaniżania prognoz udziału ludności obcego pochodzenia w porównaniu z trwalszymi kryteriami etnicznymi lub rasowymi. Na tej podstawie ludność obcego pochodzenia w Holandii w 2003 r. oszacowano na poziomie 3,04 mln osób 
na 16 mln całkowitej liczby ludności (19\%), dla porównania liczba osób o obcym obywatelstwie wynosiła 700 tys. (4\%). Pierwsza grupa gwałtownie wzrosła, wielkość drugiej maleje zaś od 1995 r. (patrz ryc. 16).

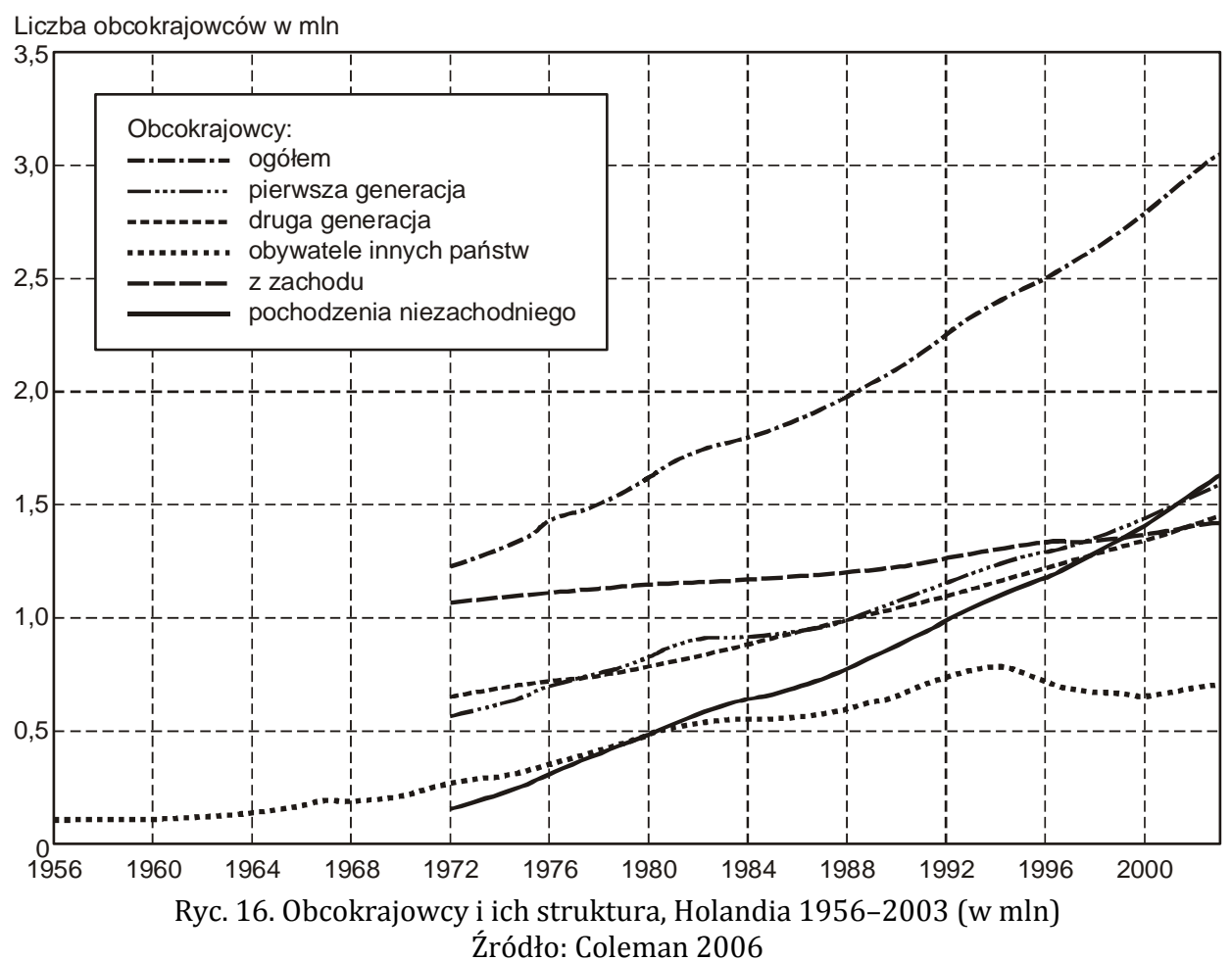

W sytuacji, gdy cechy kulturowe imigrantów oraz ich tożsamość utrzymują się na przestrzeni pokoleń, klasyfikacja etniczna może ukazać prawdziwszy obraz struktury ludności oraz skutków procesu migracyjnego, o ile tożsamość i oficjalne kategorie są trwałe, a wewnątrzetniczne związki nie są zbyt popularne. Takie klasyfikacje są szeroko stosowane w krajach angielskojęzycznych zarówno w odniesieniu do nowo przybyłych imigrantów spoza Europy, jak i dawniejszych oraz miejscowych mniejszości. Klasyfikacje te opierają się na samoidentyfikacji $\mathrm{z}$ daną grupą etniczną. Żaden z krajów Europy kontynentalnej nie używa kategorii etnicznych. We Francji pojęcie to uważa się za zasadniczo sprzeczne z zasadą równości pod względem obywatelstwa. Francja nie gromadzi danych statystycznych opartych na kryteriach etnicznych lub religijnych.

Końcowym etapem opisanych przemian mogą być radykalne zmiany struktury ludności, polegające na zmianach etnicznych. W konsekwencji w populacjach może dominować ludność napływowa i jej potomkowie albo ludność mieszana. I jeżeli obecne tendencje utrzymają się do końca stulecia, 
to głównym czynnikiem, wpływającym na charakterystyki ludności, będzie imigracja, a nie różnice we współczynniku urodzeń rdzennej i napływowej ludności.

Czy opisane przemiany można uznać za nowe, trzecie przejście demograficzne? Sam autor zwraca uwagę na fakt, że cześć jego założeń opiera się na długoterminowych prognozach demograficznych obejmujących ruchy migracyjne. Migracja jest zjawiskiem demograficznym bardzo decyzyjnym i zależnym od wielu czynników o charakterze obiektywnym, ale także od uwarunkowań osobowościowych, indywidualnych. Do tej pory nie udało się znaleźć jednoznacznej, wyczerpującej odpowiedzi, dlaczego ludzie podejmują decyzje migracyjne (poza oczywistymi powodami ekonomicznymi, politycznymi, społecznymi). Człowiek nie zawsze bowiem zachowuje się w swoim życiu jak homo economicus.

\subsubsection{Wybrane mikroekonomiczne teorie zachowań prokreacyjnych}

Teoria H. Leibensteina

Ekonomiczna teoria płodności H. Leibensteina została sformułowana w 1957 r. i opierała się na następujących założeniach:

- wszelkie wybory dokonywane w gospodarstwie domowym, dotyczące również posiadania dzieci, są racjonalnie uzasadnione,

- podejmując decyzję o powiększeniu rodziny o kolejne dziecko, rodzice porównują użyteczność, jaka wynika z jego posiadania, oraz związane z tym koszty z innymi alternatywnymi wyborami.

Autor koncepcji stwierdza, że dziecko jest użyteczne, ponieważ - podobnie jak inne dobra konsumpcyjne - zaspokaja potrzeby rodziców. Wprowadził trzy typy użyteczności i dwa typy kosztów związane z dodatkowym dzieckiem.

Typy użyteczności według H. Leibensteina:

1) użyteczność dziecka rozważanego jako „dobro konsumpcyjne” - źródło radości dla rodziców,

2) użyteczność dziecka rozważanego jako dziecko-producent - po pewnym czasie dziecko przystąpi do pracy zarobkowej i przyczyni się do wzrostu dochodów rodziny,

3) użyteczność przyszłego dziecka jako potencjalnego źródła zabezpieczenia, np. na starość.

Koszty posiadania dodatkowego dziecka dzieli natomiast H. Leibenstein na:

1) bezpośrednie, tj. bieżące wydatki na utrzymanie dziecka aż do chwili, kiedy samo zacznie zarabiać (mieszkanie, wyżywienie, odzież),

2) pośrednie, tj. utracone możliwości w następstwie urodzenia kolejnego dziecka (niemożliwość pracy matki, utracone zarobki w okresie ciąży, mniejsza mobilność rodziców itp.). 
Do swoich rozważań wprowadził analizy zależności pomiędzy zachowaniami prokreacyjnymi a poziomem dochodów. Na tej podstawie wyróżnił cztery fazy przemian demograficznych:

- stadium pierwsze, w którym niskim dochodom towarzyszy wysoka umieralność oraz wysoka płodność, użyteczność potomstwa jest wówczas wysoka, niskie są bowiem koszty utrzymania i wysokie ryzyko zgonu w młodym wieku,

- stadium drugie, w którym obniża się stopa zgonów i wzrastają dochody; obniżające się bezpośrednio koszty utrzymania dzieci skłaniają do zwiększenia liczebności potomstwa,

- stadium trzecie, w którym występują warunki skłaniające do obniżenia liczebności potomstwa, wzrastają bowiem dochody i uczestnictwo kobiet na rynku pracy,

- stadium czwarte, któremu autor nie przypisuje prawidłowości przemian demograficznych, jest fazą trwałego rozwoju gospodarczego.

H. Leibenstein prowadził analizy przemian zachowań prokreacyjnych współwystępujących z mobilnością społeczną, a więc dążeniem do zajmowania coraz wyższego miejsca $\mathrm{w}$ hierarchii grup społecznych. Wynika $\mathrm{z}$ nich, że chęć awansu społecznego prowadzi do ograniczenia wielkości rodziny (Leibenstein 1963).

\section{Teoria dzietności G. S. Beckera ${ }^{13}$}

Teoria G. S. Beckera jest określana mianem nowej ekonomicznej teorii gospodarstw domowych (new home economics theory). Według autora decyzje o posiadaniu dzieci należy rozpatrywać na równi z innymi decyzjami ekonomicznym, takimi jak praca czy czas wolny i włączyć je do funkcji produkcji gospodarstw domowych. Płodność jest więc wynikiem świadomej decyzji oraz przemyślanego, celowego działania. Kluczowe znaczenie w ekonomicznej teorii dzietności ma teza, że w gospodarstwie domowym zachodzą interakcje między liczbą dzieci i ich składnikiem jakościowym, co zarazem oznacza, że pożądana liczba dzieci jest silnie uwarunkowana pełnymi kosztami ich utrzymania i pełnymi dochodami gospodarstw domowych. Główne ustalenia opierają się na analizie funkcji użyteczności i funkcji produkcji gospodarstwa domowego. Założenie tej teorii mówi, że dziecko jest wytworzonym w gospodarstwie domowym dobrem o określonej wartości, która jest determinowana jego jakością: stanem zdrowia, wykształceniem, uzdolnieniami, przyswojonym systemem wartości, poziomem kultury, umiejętnościami. Za pomocą obydwu funkcji rozważane są zachodzące

${ }^{13}$ G. S. Becker za rozszerzenie dziedziny analizy mikroekonomicznej na szerokie spektrum spraw związanych z ludzkimi zachowaniami i interakcjami został wyróżniony Nagrodą Banku Szwecji im. Alfreda Nobla w 1992 r. 
w gospodarstwie domowym relacje między dochodem, cenami, funduszem czasu, liczbą i jakością dzieci, które to relacje wpływają na zachowania prokreacyjne małżonków. Jeżeli przedmiotem maksymalizacji jest użyteczność dzieci w rodzinie, to wówczas optymalne wybory liczby i jakości dzieci wyznaczają krzywe obojętności wyboru użyteczności dzieci i krzywe ograniczeń budżetowych gospodarstwa domowego (ryc. 17).

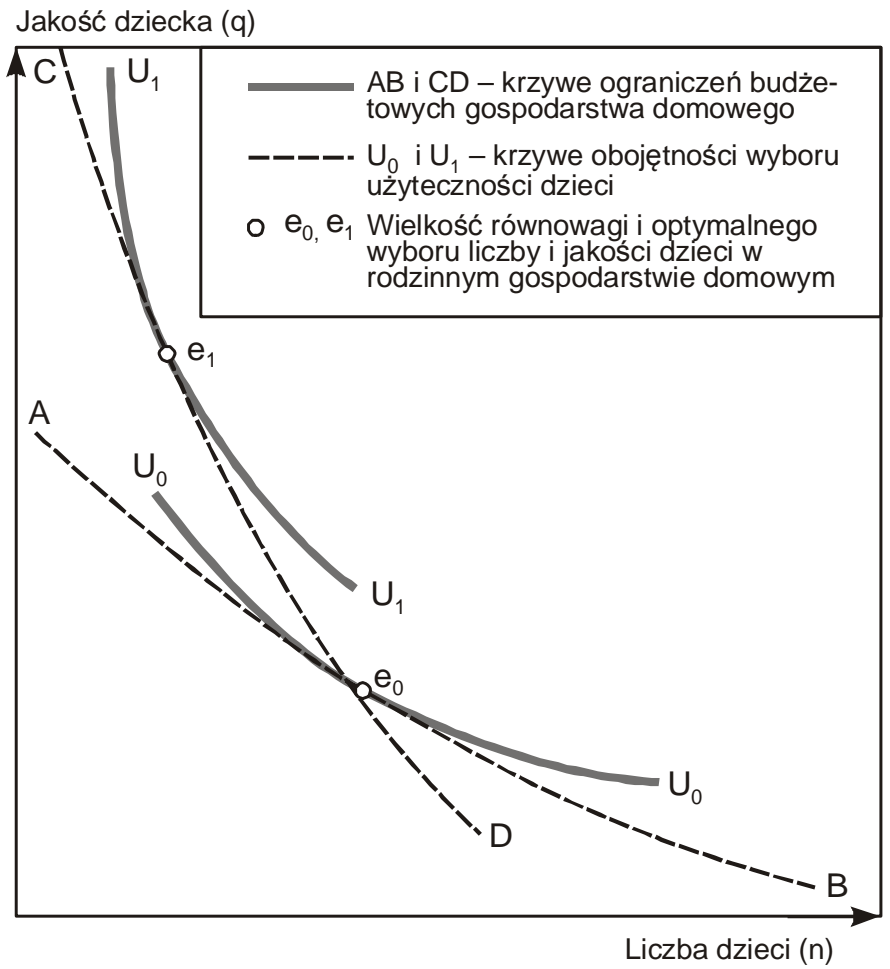

Ryc. 17. Interakcje między liczbą i jakością dzieci w rodzinie: krzywe obojętności wyboru dzieci oraz krzywe ograniczeń budżetowych gospodarstwa domowego Źródło: Becker 1981

Zaproponowany model był sukcesywnie rozwijany. Jako przykłady należy wymienić wzbogacenie źródła użyteczności poprzez uwzględnienie altruizmu oraz wprowadzenie funkcji dynastycznej (dynastic function) jako elementu optymalnej alokacji zasobów. Altruizm beckerowski polega na połączeniu funkcji użyteczności wszystkich członków gospodarstwa domowego (Becker 1981).

Teoria G. S. Beckera jest jedną z propozycji wyjaśniania spadku płodności w okresie przejścia demograficznego oraz powojennego wyżu w Europie Zachodniej i USA. Teoria ta ma wielu zwolenników, ale jest także przedmiotem krytyki za pominięcie w analizie warunków społecznych, kulturowych 
i politycznych, w jakich podejmowane są decyzje w gospodarstwach domowych.

\section{Teoria i hipoteza R. A. Easterlina}

W koncepcjach R. A. Easterlina można wyróżnić dwa zasadnicze nurty, które tworzą:

1) teorię będącą propozycją uznania spadku płodności w okresie przejścia demograficznego, a więc w społeczeństwach rozwijających się,

2) hipotezę odnoszącą się do cykliczności zjawisk demograficznych przede wszystkim w USA i w innych krajach zamorskich zaludnionych przez emigrantów z państw anglosaskich.

R. A. Easterlin przedstawił nowe podejście w ocenie czynników kształtujących płodność. Zdaniem autora wszystkie determinanty płodności oddziałują przez jeden lub więcej z następujących czynników:

1) popyt na dzieci, wyrażony liczbą dzieci dożywających wieku dorosłego, jaką rodzice chcieliby mieć, gdyby kontrola urodzeń nie pociągała żadnych kosztów,

2) potencjalna liczba rodzonych dzieci, wyrażona liczbą dzieci dożywających wieku dorosłego, jaką rodzice mieliby, gdyby świadomie nie kontrolowali płodności,

3) koszty kontroli urodzeń.

Bezpośrednimi determinantami popytu na dzieci są: dochody, koszt dziecka w porównaniu z kosztem dóbr (trwałego użytku) i subiektywne preferencje posiadania dzieci w porównaniu z innymi dobrami (trwałego użytku). Potencjalna liczba urodzonych dzieci zależy od płodności naturalnej i prawdopodobieństwa dożycia dziecka do wieku dorosłego. Koszty regulacji urodzeń obejmują postawy wobec stosowania środków i metod kontroli urodzeń, ich dostępność oraz czas i pieniądze niezbędne do dotarcia do tych środków. Motywacja do ograniczenia urodzeń wystąpi wtedy, gdy podaż dzieci przewyższa popyt na nie.

Ograniczenia płodności wynikają z:

- budżetu - poprzez ceny dóbr i usług rynkowych, płac i niezarobkowych dochodów członków gospodarstwa domowego, a także poprzez czas, jaki mają oni do dyspozycji,

- technologii gospodarstwa domowego, która pozwala przekształcić dobra rynkowe i czas, jakim dysponuje rodzina, w podstawowe środki utrzymania będące argumentami funkcji użyteczności,

- funkcji urodzeń, w których liczbę urodzeń żywych objaśnia: częstość stosunków seksualnych, okres reprodukcji, metody i środki antykoncepcyjne, niepłodne okresy w życiu kobiety,

- umieralności niemowląt i dzieci, którą określa zdrowie i wyżywienie. 
Dla objaśnienia przemian zachowań prokreacyjnych zachodzących w krajach o niskiej płodności konieczne było rozwinięcie proponowanych modeli zarówno popytowych, jak i popytowo-podażowych. W ten zakres rozważań wpisuje się hipoteza R. A. Easterlina. Zakłada ona, że cykliczność w procesie rodności jest oparta na danym mechanizmie socjoekonomicznym, którego działanie prowadzi do kształtowania się określonych postaw i zachowań prokreacyjnych. Cykliczne zmiany płodności (o cyklu 20-25 lat) wyrażają się tym, że liczna kohorta rodzicielska decyduje się na małą liczbę dzieci, ponieważ dostrzega niedogodności społeczne i ekonomiczne w dużej liczebności rówieśników. Z kolei mało liczna generacja decyduje się na posiadanie licznego potomstwa, widząc społeczne i ekonomiczne niedogodności w małej liczbie rówieśników. Zdaniem R. A. Easterlina zmiany te, z opóźnieniem czasowym, powodują falowanie procesów demograficznych (Easterlin 1976).

\subsubsection{Syntezy teoretyczne badań nad rozwodami}

Rozwód jest zjawiskiem wielowymiarowym, wieloaspektowym i ta jego specyfika wymusza stosowanie w badaniach podejść wielodyscyplinowych. Rozwód, będąc przedmiotem zainteresowania różnych dyscyplin naukowych, jest przez każdą z nich spostrzegany w odmienny sposób. Obszar kompetencji poszczególnych dziedzin zawiera aspekt specyficzny, charakterystyczny dla danej dyscypliny oraz aspekt niespecyficzny, wspólny dla różnych nauk, stąd niekiedy wynika trudność w precyzyjnym rozgraniczeniu pola zainteresowań poszczególnych dyscyplin.

Z demograficznego punktu widzenia rozwód uznaje się za czynnik wstrzymujący reprodukcję, wpływający na ograniczenie liczby urodzeń, ponieważ do rozwodów często dochodzi w okresie prokreacyjnym. Syntezy teoretyczne w demografii rodziny skupiają się przede wszystkim na wypracowaniu modeli opisujących zależności między płodnością i rozpadem małżeństwa (Rydzewski 1994). Można mówić o trzech takich modelach:

- model zależności jednokierunkowej - posiadanie i liczba dzieci wpływają na prawdopodobieństwo rozpadu małżeństwa (Cherlin 1977; Mott, Moore 1979),

- model zależności dwukierunkowej - posiadanie i liczba dzieci wpływają na prawdopodobieństwo rozpadu małżeństwa i odwrotnie, rozkład pożycia małżeńskiego wpływa na płodność małżeńską w okresie poprzedzającym rozwód (Becker i in.1977; Thornton 1977),

- symultaniczny model logiczny - dochodzi tu nowy czynnik - czas, jaki upłynął od urodzenia ostatniego dziecka do momentu rozkładu pożycia małżeńskiego. W modelu tym przyjmuje się, że prawdopodobieństwo rozpadu małżeństwa zależy od obecności i liczby dzieci, jak również od tego, 
czy urodzenia nastapiły we wczesnym okresie trwania małżeństwa, czy też kilka lat przed rozpadem (Koo, Janovitz 1983).

W dorobku socjologii notowane są udane próby mające na celu wyjaśnienie mechanizmu rozwodów. Można do takich zaliczyć teorię G. S. Beckera oraz koncepcję G. Levingera, następnie rozwiniętą przez R. A. Lewisa i G. P. Spaniera. Teorie te mają wiele cech wspólnych, opierają się bowiem na założeniach teorii wymiany społecznej.

Teoria wymiany społecznej - obecnie jedna z najbardziej wpływowych ogólnych teorii socjologicznych na gruncie socjologii rodziny - jest szczególnie przydatna w analizie zjawisk patologii i cieszy się w ostatnich latach wzrastającym zainteresowaniem badaczy zajmujących się socjologią małych grup. Generalnym jej założeniem jest teza, że jednostki wchodzące ze sobą w interakcje usiłują maksymalizować zyski i minimalizować poniesione koszty w celu otrzymania najbardziej korzystnych wyników. Interakcja jest kontynuowana, jeżeli zyski przewyższają koszty. Jedną z najciekawszych prób wyjaśnienia procesu rozpadu związku małżeńskiego jest teoria Levingera (Rydzewski 1990). Levinger jest twórcą modelu, który można uznać za podstawowy w przypadku rozważań nad procesami integracji i dezintegracji rodziny. Jest to koncepcja podstawowa, gdyż wyprzedza inne podobne próby, jak również dlatego, że jest teoretyczną bazą, punktem odniesienia późniejszych modyfikacji i rozwinięć. Pierwszą wersję modelu opracowano w 1965 r., wersja druga - stanowiąca pewne uzupełnienie, a przede wszystkim jakby przypomnienie wcześniejszej - powstała w roku 1976. Istotna zmiana, to silniejsze zaakcentowanie opcji psychologiczno-społecznej, choć również w wersji pierwotnej punktem wyjścia było zagadnienie spójności małżeństwa podejmowane $\mathrm{w}$ aspekcie psychospołecznym (Levinger powołuje się na pojęcia zaczerpnięte od Kurta Levina).

Inną interesująca próbą zastosowania teorii wymiany na gruncie socjologii rodziny jest teoria jakości i stabilności związku małżeńskiego sformułowana przez Lewisa i Spaniera (Lewis, Spanier 1979). Wydaje się, że jest to - jak dotychczas - najbardziej pełna i dojrzała koncepcja usiłująca wyjaśnić zjawisko rozwodu. Jej zaletami są: mocne oparcie na danych empirycznych, łączenie $\mathrm{w}$ jeden model czynników związanych z jakością i stabilnością małżeństwa, udane zaadaptowanie schematu Levingera. Model Lewisa i Spaniera jest bowiem poszerzeniem schematu Levingera. Rozbudowano tu zwłaszcza partie dotyczące czynników składających się na atrakcyjność związku małżeńskiego, wzbogacające jakość małżeństwa. Istotne miejsce w tym nurcie rozważań nad rodziną mają propozycje teoretyczne psychologów społecznych Thibout i Kelleya (Thibout, Kelley 1959). Używane przez nich pojęcie poziomu porównania umożliwia wprowadzenie do analizy elementu subiektywnej oceny oraz podkreśla rolę szerszego społecznego kontekstu, w którym funkcjonuje małżeństwo. 
Punktem wyjścia teorii jest stwierdzenie, że tym większe jest prawdopodobieństwo rozwodu, im niższa jakość małżeństwa. Jakość małżeństwa jest tym większa, im większe są społeczne i osobowe środki sprzyjające właściwemu funkcjonowaniu ról małżeńskich, im większa jest satysfakcja małżonków z ich stylu życia, im większe są zyski z małżeńskich interakcji. W koncepcji Levingera odpowiednikiem pojęcia jakości małżeńskiej jest pojęcie atrakcyjności związku małżeńskiego. Na atrakcyjność małżeństwa składają się zyski symboliczne, takie jak wykształcenie, status zawodowy, podobieństwo między małżonkami w zakresie wykształcenia, przynależności do grupy religijnej, wieku oraz zyski materialne, takie jak dochód rodziny czy własny dom. Zyski mogą mieć też charakter emocjonalny (koleżeństwo, szacunek, satysfakcja seksualna) - Levinger 1976. Zależność między jakością a stabilnością małżeństwa nie jest prosta ani jednokierunkowa. Jednym z istotnych czynników wpływających na tę relację są bariery chroniące przed rozwodem, niejednokrotnie utrzymujące trwałość małżeństwa mimo jego niskiej jakości lub nawet mimo dramatycznych napięć. Levinger uważa, że o losie małżeństwa decyduje nie tylko to, ile satysfakcji (lub bolesnych przeżyć) doświadczają partnerzy w małżeństwie, ale również to, jak bardzo silne są więzy krępujące małżonków, którzy chcieliby się rozwieść (Levinger 1965). Bariery funkcjonują więc jako koszty. Jeżeli bariery okażą się wystarczająco silne, możemy mieć do czynienia z nierzadkim przypadkiem trwałych, aczkolwiek nieszczęśliwych małżeństw. Ale bywa też tak, że dochodzi do rozwodu mimo wysokiej jakości małżeństwa. Należy przypuszczać, że współistniały w tych sytuacjach słabe bariery przed rozwodem i silne atrakcje alternatywne. Levinger wymienia następujące tego rodzaju bariery: poczucie zobowiązania wobec niesamodzielnych dzieci, presja ze strony grup podstawowych (rodzina, przyjaciele) oraz otoczenia społecznego, przekonania religijne, poczucie zobowiązania do zachowania przysięgi małżeńskiej, a także przewidywane koszty związane z rozwodem (Levinger 1965).

Koncepcjom wyrosłym z teorii wymiany społecznej zarzuca się często przesadną „ekonomizację” zachowań ludzkich, pozbawienie ich cechy bezinteresowności oraz daleko idące uproszczenia. Zarzuty te, jak twierdzi Rydzewski (1994), są w pewnym stopniu uzasadnione, gdyby jednak pozostać na gruncie analizy stosunków rodzinnych zaproponowane modele wydają się przydatne jako narzędzia analizy i porządkowania wiedzy o rozwodach.

W psychologii podjęto próby usystematyzowania rozwodu jako zjawiska o charakterze procesualnym. Dążono do skonstruowania modeli procesu rozwodowego, odtworzenia sekwencji etapów tego procesu oraz stworze- 
nia uniwersalnych modeli rozpadu i przystosowania porozwodowego w perspektywie czasowej ${ }^{14}$.

Modele sekwencyjne budowane są na podstawie założenia, że przebiegi procesów rozwodowych można sprowadzić do względnie stałego schematu. Modele te nie wyjaśniają ani nie opisują całej różnorodności form procesu rozwodowego, ale poszukują tego, co stanowi uniwersalny rdzeń różnych wersji tego procesu. Wysiłki idą w kierunku stworzenia schematu procesu rozwodowego odzwierciedlającego czasowe uporządkowanie (sekwencję) stadiów czy też etapów tego procesu. Sekwencja faz procesu ma charakter „względnie” stały. Ta „elastyczność" modeli sekwencyjnych jest wymuszona przede wszystkim niemożliwością jednoznacznego określenia miejsca fazy separacji. Takie, a nie inne umiejscowienie tej fazy w sekwencji jest bardziej kwestią konwencji niż wyraźnej prawidłowości. Modele sekwencyjne są najczęściej budowane na podstawie doświadczeń poradnictwa rozwodowego.

Ponieważ istnieje wiele podobieństw między różnymi modelami procesu rozwodowego, można podjąć próbę uogólnienia i sformułowania modelu syntetycznego (Rydzewski 1991a). Model ten obejmuje następujące fazy: fazę dyssatysfakcji, fazę konfliktów, fazę separacji, fazę decyzyjną, fazę stresu porozwodowego oraz fazę przystosowania i odbudowy.

\section{Faza dyssatysfakcji}

Narastanie napięcia spowodowanego nierozwiązanymi problemami wywołuje uczucia dyssatysfakcji i frustracji. Uświadomienie sobie przez jedno lub oboje małżonków tego stanu rzeczy jest właściwym początkiem procesu rozpadu, przy czym zwykle bywa tak, że jedno z małżonków odczuwa napięcie silniej niż drugie (Kressel 1985). Etap uświadomienia sobie sytuacji jest zwykle poprzedzany przez fazę, w której dochodzi do prób rozwiązywania pojawiających się problemów. W tej fazie małżonkowie jeszcze nie zdają sobie sprawy z tego, że podstawowym źródłem napięć między nimi jest samo małżeństwo i usiłują znaleźć drogę wyjścia z kryzysu poprzez działania zastępcze, np. zmianę mieszkania, pracy itp. Dopiero po okresie rozpoznania faktycznego stanu rzeczy i realnego zagrożenia rozpadem związku szukanie dróg wyjścia nabiera cech racjonalnych. Do takich prób można zaliczyć „ucieczkę” w aktywność pozarodzinną, zmianę stylu życia, zmianę orientacji z prorodzinnej na bardziej indywidualną. Mimo to często utrzymuje się gra pozorów, fasada trwałości (Ahrons 1980). Fak-

14 Rozwód jako proces obejmuje zarówno okres poprzedzający rozwód (okres rozpadu małżeństwa), jak i okres porozwodowy, aż do odzyskania przez jednostkę równowagi psychicznej i społecznej, a przez rozbitą rodzinę zdolności do wypełniania niektórych funkcji (głównie rodzicielskiej) - Rydzewski 1994. 
tycznie jednak można już mówić wówczas o zaawansowanym rozwodzie emocjonalnym.

\section{Faza konfliktów}

Uświadomienie sobie, że dane małżeństwo samo w sobie jest przyczyną napięć i zrozumienie ryzyka czy wręcz nieuniknioności separacji zwiększa intensywność emocji. Charakterystyczna jest ich silna ambiwalencja - od miłości do nienawiści (Ahrons 1980). Ponownie pojawiają się próby pojednania, ale też wzmagają się konflikty będące wyrazem pogłębiającego się rozpadu więzi. Następuje wyraźny zanik intymności życia małżeńskiego, co wyraża się m.in. w poszukiwaniu alternatywnego partnera jako formy psychologicznego „zabezpieczenia” na wypadek separacji. Rysuje się rozłam w fasadzie małżeńskiej solidarności, związek wkracza w fazę otwartej, często publicznej walki, również z udziałem prawników (Kressel 1985). Przejście fazy konfliktów z płaszczyzny wewnątrzrodzinnej na forum dyskusji publicznej znamionuje nowy jakościowo etap procesu rozwodowego. Jak już wspomniano, kwestią konwencji pozostaje takie, a nie inne usytuowanie fazy separacji w schemacie procesu rozwodowego. Separacja może pojawić się $\mathrm{w}$ którymkolwiek $\mathrm{z}$ etapów tego procesu, jak również może w ogóle nie wystąpić. W niektórych specyficznych przypadkach separacja nie pojawia się nawet po rozwodzie (Kressel 1985). Separacja jest z wielu względów fazą krytyczną, zwiększa się intensywność uczuć - lęku, bezradności, depresji, wrogości, odrzucenia, opuszczenia oraz poczucia niższej wartości (Kolevzon, Gottlieb 1984). Kryzys jest jeszcze bardziej destrukcyjny, gdy małżeństwo nie przeszło przez wcześniejsze etapy lub nie zostały one zakończone, czyli gdy separacja wyprzedziła fazę dyssatysfakcji i/lub fazę konfliktów. W fazie separacji w dalszym ciągu utrzymuje się wysoki poziom ambiwalencji uczuć (Ahrons 1980).

\section{Faza decyzyjna}

Najpełniejszą charakterystykę okresu decyzyjnego podali Kressel i Deutsch (Kressel 1985). Na plan pierwszy wysuwa się ambiwalencja wobec decyzji rozwodowej - małżonkowie często zmieniają zdanie. Okresy pojednania przeplatane są ponownymi wybuchami konfliktów. Podjęta decyzja rozwodowa z jednej strony budzi uczucie wyzwolenia, z drugiej zaś pojawia się lęk, a nawet panika w obliczu rozwodu. W tej fazie może wzmocnić się intymność związku. Podejmowanie i odwoływanie decyzji rozwodowej czemu towarzyszą silne emocje - trwa tak długo, aż nie zostanie ostatecznie zaakceptowana nieuniknioność rozwodu. Podjęcie ostatecznej decyzji ponownie wyzwala falę ostrych konfliktów. 
Faza stresu porozwodowego

Cały proces rozwodowy jest nasycony silnymi emocjami. W okresie następującym bezpośrednio po rozwodzie stres jest jeszcze silniejszy niż $\mathrm{w}$ fazie rozpadu. Wraz z upływem czasu wzrasta depresja odzwierciedlająca kłopoty natury emocjonalnej i materialnej. Depresja pojawia się jako konsekwencja przełomowych zmian w życiu, pomimo że uzyskanie rozwodu wydawałoby się formą wyjścia z bardzo trudnej i stresującej sytuacji rozbitego małżeństwa. $\mathrm{W}$ okresie porozwodowym stres nabiera także innego kolorytu: dominuje uczucie winy, współodpowiedzialności, porażki. Bywa i tak, że żal wywołany utratą współmałżonka jest silniejszy niż byłby po jego śmierci (Kressel 1985). Reakcje emocjonalne małżonków mogą się istotnie różnić w zależności od tego, jaką rolę przyjęli (inicjator - nieinicjator rozwodu) zarówno w perspektywie rozwodu prawnego, jak i całego procesu rozwodowego.

\section{Faza przystosowania i odbudowy}

W okresie tym można dostrzec dwa aspekty, psychologiczny i społeczny. W tym pierwszym proces rozwodowy kończy się ukształtowaniem się nowego stylu życia, przywróceniem poczucia wartości i ponownym zdefiniowaniem celów życiowych. Jednocześnie słabną negatywne uczucia i pojawia się gotowość do nawiązywania nowych, satysfakcjonujących związków z pełnym zaangażowaniem emocjonalnym (Kolevzon, Gottlieb 1984).

Pomyślne zakończenie procesu rozwodowego oznacza reorganizację i redefinicję rodziny. Każdy z byłych małżonków musi ustalić swoje kontakty z dziećmi (jeżeli są). Jest to o tyle trudne, że nie ma modeli ról ani zasad społecznych regulujących zachowania osoby rozwiedzionej w stosunku do społeczności lokalnej (przyjaciół, sąsiadów) i rodziny pochodzenia. Warunkiem dobrego przystosowania jest zakończenie procesu rozwodu psychicznego i osiągnięcie porozumienia. Kressel i Deutsch stwierdzają: „Dobry rozwód, podobnie jak dobre małżeństwo, jest wspólnym przedsięwzięciem. Oboje małżonkowie muszą chcieć zakończyć swój związek, tak jak kiedyś chcieli go zainicjować" (Kressel 1985: 76). 


\subsection{Wybrane teorie rozwoju społecznego}

Rozpatrywanie zmian w sferze matrymonialno-reprodukcyjnej nie jest możliwe bez odniesienia się do współczesnych przeobrażeń społecznych. Dynamika zmian społecznych, od końca lat 60. ubiegłego wieku, kiedy to skończyła się era industrialna, jest bardzo duża. Epoka, która po niej nastała jest zasadniczo odmienna pod względem szeroko rozumianego porządku społecznego. Badacze społeczni dokonują prób objaśniania nowych zjawisk i procesów społecznych, opisując przeobrażenia przynajmniej na czterech płaszczyznach:

1) technologiczno-informacyjnej, związanej z wiedzą i nauką,

2) ekonomicznej - nowe sektory gospodarki (sektor usług, w tym nauki i informacji), aktywizacja zawodowa kobiet,

3) społecznej - nowe ruchy społeczne, rewolucja seksualna i feministyczna, przeobrażenia w małżeństwie i rodzinie, osłabienie więzi społecznej, społecznego zaufania, przejście od kolektywizmu do indywidualizmu,

4) kulturowej - nowe wartości, normy, prądy i ideologie, tożsamość ponowoczesna.

Autorka, podobnie jak w przypadku teorii demograficznych, dokonała subiektywnego wyboru teorii z bogatego dorobku myśli socjologicznej. W sposób syntetyczny przedstawione zostały te koncepcje, które opisują nowy świat i zmieniający się porządek społeczny

\subsubsection{Nowoczesność - ponowoczesność}

Koncepcje ponowoczesności wyrosły na podłożu doświadczeń i konsekwencji nowoczesności - zarówno jedne, jak i drugie bywały pozytywne bądź negatywne. Jedna z wizji dotycząca przyszłości społeczeństwa ludzkiego jest zakorzeniona $\mathrm{w}$ optymistycznym klimacie klasycznej socjologii i głosi, że występujące obecnie tendencje, przeważnie pozytywne, będą kontynuowane w przyszłości. Nowoczesność będzie po prostu ewoluować w tym samym kierunku, osiągając coraz bardziej dojrzałą, doskonałą formę. Zalążki tej przyszłości można znaleźć w teraźniejszości, w bardziej zaawansowanych typach społeczeństw (Europa Zachodnia, Japonia i Ameryka Północna). Obecne tendencje rozwojowe społeczeństw posłużą do opracowania wizji przyszłości. Są to podstawy teorii społeczeństwa postindustrialnego. Najważniejszymi megatrendami wyznaczonymi przez J. Naisbitta dla społeczeństwa postindustrialnego są:

1) zmiana dominujących sektorów gospodarki, w miejsce przemysłu, jako dominujące, „wchodzą" usługi,

2) wzrost znaczenia ludności zatrudnionej w usługach, szczególnie w nauce, badaniach i rozwoju, opiece społecznej, edukacji, ochronie zdrowia, kulturze, ubezpieczeniach społecznych, rekreacji, 
3) rozkwit nowych „technologii intelektualnych”,

4) rozwój technologiczny,

5) zdobywanie wiedzy za pomocą różnych form edukacji szkolnej.

Druga wizja powstała wraz ze wzrostem świadomości negatywnych aspektów nowoczesności. Biorąc pod uwagę antyludzkie konsekwencje nowoczesności, pojawiła się idea mówiąca o tym, że społeczeństwo nie może dalej podążać tą samą drogą. Notowane są nostalgiczne wezwania do nawrotu społeczeństwa tradycyjnego, do odbudowy wspólnot czy też nawoływania do większego zainteresowania ochroną zdegradowanego środowiska naturalnego. Jednak część badaczy dostrzega nieuchronność zmian i proponuje nową jakościowo zmianę w kierunku ponowoczesności. Jest to trzecia wizja zmian społecznych, chociaż nie wiadomo do końca, w jakim kierunku będą one zmierzać. Dokonywano prób nazwania nowego typu społeczeństwa, np. posthistoria, postcywilizacja czy ponowoczesność. Ostatnia, czwarta wizja jest bardziej powściągliwa w przewidywaniach przyszłości i ogranicza się do szczegółowej analizy nowoczesności, jej autorem jest Anthony Giddens (Sztompka 1993). Jego koncepcja nazywana jest teorią „szczytową” lub nową „nowoczesnością”. Autor twierdzi, że za wcześnie jest jeszcze, aby mówić o ponowoczesności. Wyróżnia cztery cechy „późnej nowoczesności”: zaufanie, ryzyko, nieprzejrzystość i globalizację.

Tak pisze o naturze nowoczesności:

Wykorzystując dla ilustracji konkretne badanie, proponuję charakterystykę kluczowych aspektów rozwoju nowoczesności. Obok refleksyjności instytucjonalnej nowoczesne życie społeczne cechują procesy dogłębnej reorganizacji czasu i przestrzeni, powiązane z ekspansją mechanizmów wykorzeniających, na których drodze relacje społeczne zostają wyrwane z bezpośrednich uwarunkowań i ponownie uporządkowane w skali wielkich dystansów przestrzenno-czasowych. Skutkiem takiej reorganizacji czasu i przestrzeni, wraz z towarzyszącymi jej mechanizmami wykorzeniającymi, jest wzmocnienie i globalizacja zaznaczających się już wcześniej przejawów nowoczesności oraz zmiana treści i natury życia codziennego.

\section{$[\cdots]$}

W posttradycyjnym porządku nowoczesności, w kontekście nowych form zapośredniczania doświadczenia, tożsamość jednostki staje się przedsięwzięciem refleksyjnym. Refleksyjny projekt „ja”, który polega na utrzymywaniu spójnych, chociaż wciąż na bieżąco weryfikowanych, narracji biograficznych, rozgrywa się w kontekście wielokrotnego wyboru zapośredniczonego przez systemy abstrakcyjne. Pojęcie stylu życia nabiera w warunkach nowoczesności szczególnego znaczenia. Wraz ze słabnącym oddziaływaniem tradycji i rosnącym udziałem dialektycznego współoddziaływania globalności i lokalności w rekonstytuowaniu życia codziennego, jednostki są zmuszone dokonywać wyborów tożsamościowych spośród różnorakich opcji. Oczywiście występują też przeciwstawne, standaryzujące tendencje. Ich najwyraźniejszym chyba przejawem jest urynkowienie, ponieważ kapitalistyczna pro- 
dukcja i dystrybucja stanowią rdzeń instytucji nowoczesności. Jednakże z uwagi na „otwarty” charakter życia społecznego, zwielokrotnienie kontekstów działania i różnorodność ośrodków „władzy” rośnie znaczenie wyboru stylu życia w konstruowaniu własnej tożsamości i organizowaniu codziennej aktywności. Głównym czynnikiem strukturacji tożsamości jednostki staje się refleksyjne planowanie życia, które ze swej natury zakłada ocenę ryzyka zapośredniczoną przez kontakt z systemami eksperckimi (Giddens 2001: 7).

A. Giddens widzi w nowoczesności łączny rezultat czterech procesów: rozwoju kapitalizmu, uprzemysłowienia, poszerzenia zakresu administracyjnego nadzoru nad ludźmi i kształtowania się państwa narodowego. Giddensowska koncepcja nowoczesności jest wielowymiarowa, obok procesów ekonomicznych i społecznych obejmuje bowiem procesy polityczne, obok przemian makrospołecznych - przemiany mentalności, osobowości i najbardziej intymnych stosunków między ludźmi; obok zjawisk globalnych - mikrozjawiska życia codziennego; obok ideologii - np. postawy wobec czasu i przestrzeni (Szacki 2010).

\subsubsection{Materializm - postmaterializm}

Punktem wyjścia koncepcji Ronalda Ingleharta jest teoria Abrahama Maslowa o hierarchizacji potrzeb i ich zaspokajania - od potrzeb fizjologicznych, przez potrzeby bezpieczeństwa, przynależności, uznania, estetycznointelektualne, aż do potrzeb samorealizacji. Na tej podstawie sformułował on dwie bazowe dla swojej koncepcji hipotezy: hipotezę niedostatku (scarcity hypothesis) i hipotezę socjalizacji (socialization hypothesis). Hipoteza niedostatku głosi, że porządek wartości jednostki stanowi odbicie środowiska socjoekonomicznego: największą subiektywną wartość przypisuje się rzeczom, które są względnie trudno dostępne. Według hipotezy socjalizacji hierarchia wartości nie dostosowuje się do środowiska socjoekonomicznego natychmiast, występuje tu znaczące opóźnienie, ponieważ podstawowe wartości danej osoby w dużej mierze stanowią odbicie warunków panujących przed jej wejściem w dorosłe życie. Inglehart zwraca uwagę na znaczenie socjalizacji pierwotnej i socjalizacji wtórnej w okresie adolescencji (nastoletniości). W tym właśnie czasie kształtują się podstawowe zręby jednostkowego systemu wartości, nieulegające $w$ zasadzie zmianie przez resztę życia. Powyższe hipotezy mają według Ingleharta niebagatelne znaczenie podczas wyjaśniania przyczyn zmian zachodzących w rozwiniętych społeczeństwach (i w zasadzie tylko w nich). Gdy dorośnie pokolenie wychowane $\mathrm{w}$ dobrobycie, to zmienia się hierarchia wartości tegoż społeczeństwa. Potrzeby materialne zostały zaspokojone, więc - zgodnie z teorią Maslowa - uwaga jednostek kieruje się w stronę zaspokajania potrzeb wyższego rzędu, takich jak poczucie przynależności, szacunek, satysfakcja 
intelektualna. Zmiana nie dotyczy jednak pokolenia rodziców - bo ono nie zaznało w młodości dobrobytu i w całym swoim życiu będzie wciąż postępować tak, jakby niedostatek trwał. Zmiana odnosić się będzie do pokolenia dzieci, które dorastając nie zaznały biedy. Dlatego doświadczenie długotrwałego dobrobytu przekłada się - w skali całego społeczeństwa - na spadek znaczenia wartości materialistycznych, a wzrost znaczenia wartości postmaterialistycznych, z kilkunastoletnim opóźnieniem. W sferze polityki zmiana jest jeszcze bardziej opóźniona - wszakże musi upłynąć trochę czasu nim dzieci postmaterializmu dorosną, zasilą szeregi elektoratów, a potem same przejmą najważniejsze stanowiska w państwie. Oczywiście należy pamiętać o tym, że okresy dobrobytu będą wzmacniać postmaterializm, ale wystąpienie czasu niedoboru przyniesie powrót do materializmu. Analizując zmiany zachodzące w społeczeństwach kapitalistycznych Inglehart wyróżnił dwie grupy wartości - materialistyczne i postmaterialistyczne. Te pierwsze związane są z zapewnieniem poczucia fizycznego, a także ekonomicznego bezpieczeństwa. Wartości postmaterialistyczne to zaś te, które stają się ważne po osiągnięciu przez ludzi bezpieczeństwa ekonomicznego i dlatego właśnie stają się ważne, bo owo bezpieczeństwo zostało osiągnięte. Do 1971 r. Inglehart używał innej terminologii dla określenia wyróżnionych przez siebie typów wartości politycznych: acquisitive i postbourgeois values. Zmiana miała na celu podkreślenie, że wartości materialistyczne to bezpieczeństwo nie tylko ekonomiczne, ale i fizyczne.

W późniejszej, rozszerzonej interpretacji przejście od wartości materialistycznych do wartości postmaterialistycznych traktowane jest przez Ingleharta jako jeden z elementów przejścia od nowoczesności do ponowoczesności. Oprócz wspomnianej zmiany hierarchii wartości dokonuje się także zmiana uznawanych przez społeczeństwo autorytetów. Miejsce tradycji, rodziny, religii zajmuje panowanie racjonalno-legalne sprawowane przez państwo i jego biurokrację. Zmiana ta interpretowana jest przez Ingleharta jako wskaźnik modernizacji. Natomiast przejście od wartości materialistycznych do postmaterialistycznych traktowane jest jako wskaźnik postmodernizacji (Inglehart 2006).

\subsubsection{Modernizm - postmodernizm}

Myśl postmodernistyczna przyjmuje w nurcie teorii społecznych opozycyjną postawę do nowoczesności. Punktem wyjścia postmodernistów jest z reguły krytyka zespołu wyobrażeń charakterystycznych dla nowoczesnego świata i nowoczesnego światopoglądu. Nowoczesność jest przez nich traktowana jako racjonalny fundamentalizm, uniwersalizm, absolutyzm uznawanej prawdy, optymizm i naiwna wiara w postęp, ubóstwianie nauki i techniki, ostre odgraniczenie podmiotu i przedmiotu poznania, wyobraże- 
nie autonomicznego podmiotu i pogarda dla cywilizacji „niższości”. Co ciekawe, niektórym postmodernistom nowoczesność kojarzy się z ograniczeniami, nietolerancją i swego rodzaju umysłowym zniewoleniem.

Inaczej mówiąc postmodernizm jest krytyką modernizmu jako światopoglądu i gruntownym „przewartościowaniem jego wartości”. Postmodernizm jest swego rodzaju „klimatem opinii”, do którego powstania przyczyniły się różne idee. Środowisko postmodernistów jest dość zróżnicowane, niemniej można wyróżnić pewne poglądy dla nich wspólne. Jednym z nich jest radykalny relatywizm oznaczający w tym wypadku negację "modernistycznej" idei uniwersalnego rozumu odkrywającego obiektywną, jednakową i obowiązkową dla wszystkich prawdę. W postmodernistycznym świecie nic nie jest do niczego ostatecznie przypisane, nic i nikt nie ma nigdy swojego stałego miejsca. Zmianie ulegają wyobrażenia czasu i przestrzeni. Pojęcia ładu, prawidłowości, przewidywalności i kierunku zostają wyklęte, podobnie jak słowo „prawda obiektywna” czy „autorytet”.

Spór z postmodernizmem nie dotyczy tego, jaka jest domniemana ponowoczesność, ale tego, czy należy się na nią zgodzić, jak zalecają postmoderniści. Chodzi też o diagnozę świata postmodernistów i o fakt, czy uprawnione jest stosowanie jej do naszej współczesności oraz o możliwość ekstrapolacji wyników obserwacji poczynionych na stosunkowo niewielu społeczeństwach zachodnich na całą resztę świata.

W wizji świata postmodernistycznego na plan pierwszy wysuwają się następujące zjawiska:

- ośrodkiem ludzi ponowoczesnych staje się konsumpcja,

- sprawą o znaczeniu kluczowym dla wszystkich dziedzin życia jest obieg informacji i dostęp do nich,

- jednostki są w coraz mniejszym stopniu przywiązane do jednego zawodu i jednego miejsca życia, stają się współczesnymi koczownikami,

- niebywale wzrasta rola środków masowego przekazu, które bezustannie wytwarzają obrazy zastępujące ich odbiorcom bezpośredni ogląd rzeczywistości,

- zmienia się charakter władzy, która coraz mniej nakazując i nadzorując, w coraz większym stopniu „uwodzi” obywateli za pomocą nowoczesnych środków komunikowania się masowego,

- ze współczesnego społeczeństwa znikają dawne metanarracje wyznaczające dla wszystkich wielkie cele ogólne i pozwalające jednostce połączyć w sensowną całość oddzielne epizody swej egzystencji społecznej,

- nie ma w tym społeczeństwie jednolitego kanonu kultury,

- trwa kryzys tożsamości, rozkładowi ulegają bowiem wszystkie tradycyjne grupy odniesienia: klasa, społeczność lokalna, państwo narodowe, Kościół itd., 
- do społeczeństwa ponowoczesnego przestaje mieć zastosowanie pojęcie całości.

Wszystkie te procesy miałyby być tak bardzo zaawansowane, że niektórzy postmoderniści uważają za możliwe mówienie o zaniku sfery społecznej, tym co pozostaje jest według nich kultura, której poświęcają uwagę.

\subsubsection{Teorie rozwoju cywilizacji}

Cywilizacja to jeden $\mathrm{z}$ wielkich tematów myśli europejskiej ostatnich dwóch stuleci, tematów, które są „konceptualizowane i przeżywane wciąż na nowo, w coraz to innych, choć nierzadko i powracających kształtach" (Jedlicki 1988: 7). Pojęcie cywilizacji pojawiło się w drugiej połowie wieku XVIII i od tej pory było i jest stale obecne zarówno w naukach społecznych, jak i w publicystyce czy myśleniu potocznym.

Termin „cywilizacja” wiązał się z ideą postępu, która ukształtowała się mniej więcej w tym samym czasie. Mówiąc o cywilizacji, miano na myśli pozytywnie oceniany rezultat długiego procesu (opisanego przez Fergusona czy Morgana), w którego następstwie ludzkość oddala się najpierw od stanu dzikości, później zaś wyzbywa się stopniowo znamion barbarzyństwa. Proces ten traktowali oni jako doskonalenie się ludzi oraz ich stosunków wzajemnych, a także powiększanie przez nich władzy nad przyrodą. Niekiedy zwracano większą uwagę na doskonalenie umysłowe i moralne, czasem na poprawę ustroju politycznego, czasem na wzrost dobrobytu, zawsze jednak chodziło o zmiany na lepsze, traktowane jako „przeznaczenie rodzaju ludzkiego” (np. F. Guizot). Za „cywilizowane” uważano przede wszystkim społeczeństwa zachodniej Europy, zakładając, że ich śladem pójdą wcześniej lub później wszystkie ludy świata.

W wieku XX pojawiło się zupełnie inne pojęcie cywilizacji, które ujęcie pierwotne przypominało jedynie tym, że tak samo zakładało wzajemny związek różnych sfer życia społecznego. Wiązało się z nim jednak odrzucenie idei ogólnoludzkiego postępu oraz, na ogół, przekonanie o wielości cywilizacji, które nie dają się charakteryzować, jako „wyższe” lub „niższe”, nade wszystko bowiem są różne. Oznaczało to rezygnację z pozytywnego wartościowania cywilizacji jako takiej na rzecz opisowego i porównawczego traktowania różnych cywilizacji.

Według Oswalda Spenglera „cywilizacja” to tylko schyłkowa faza w rozwoju każdej wielkiej kultury, nie zaś inna nazwa tego samego fenomenu, jak to ujmuje wielu wcześniejszych autorów. W całej historii ludzkości Spengler wyróżnił zaledwie osiem takich kultur, postępując zupełnie inaczej aniżeli antropologowie, skłonni - jak widzieliśmy - zakładać, iż kultur było i jest nieskończenie wiele. Te osiem kultur to kultury: babilońska, egipska, chińska, hinduska, meksykańska, antyczna, zachodnioeuropejska i rosyjska. 
Jego zdaniem cywilizacja to kultura, która utraciła „duszę” - kultura w dobie swojego zmierzchu i obumierania, zewnętrzności i sztuczności, przychodzących z „nieubłaganą koniecznością” na mocy „ścisłej i koniecznej kolejności organicznej”. Miejsce duszy zajmuje teraz intelekt; miejsce ludu masa; miejsce ojczyzny - kosmopolityzm; miejsce serca - pieniądz; miejsce pracy nad sobą - ekspansja; miejsce państwa - zatomizowane społeczeństwo; miejsce służby państwowej - wola mocy itd. Społecznym podłożem tych zmian jest przemieszczenie się ludności ze wsi do miasta, co przeobraża całkowicie sposób życia i mentalność, tworząc nowy rodzaj człowieka. Cywilizacja to kultura wielkich nowoczesnych metropolii, które doprowadzają do „uwiądu prowincję i zabijają jej cnoty”. W tę fazę swego rozwoju Europa wkroczyła w wieku XIX, tak jak Grecy wkroczyli w nią w wieku IV przed naszą erą. Wizje dotyczące cywilizacji europejskiej są więc wyjątkowo złowróżbne (Spengler 2001).

Historia cywilizacji i ich cykli życiowych w ujęciu Arnolda Toynbee zakłada z kolei, że cywilizacje powstają za sprawą dwóch połączonych czynników - obecności twórczej elity i odpowiednich warunków środowiskowych - ani zbyt niesprzyjających, ani zbyt korzystnych. By powstała cywilizacja musi ona sprostać wyzwaniom środowiskowym (przyrodniczym i społecznym) dzięki twórczej elicie. Według Toynbee odrębność cywilizacji zależy głównie od czynników natury duchowej lub może nawet po prostu religijnych, wierzył on bowiem, że człowiek nie jest po prostu zwierzęciem społecznym, lecz również osobowością szukającą bezpośredniego związku z najwyższą rzeczywistością duchową. Toynbee wyróżnił 21 cywilizacji. Cywilizacje upadają ze względu na niemożność sprostania nowym wyzwaniom, takim jak wyczerpanie się sił twórczych elity oraz bunt „zewnętrznego proletariatu", czyli barbarzyńców. Autor tej koncepcji twierdzi, że spośród wielkich cywilizacji co najmniej 16 jest już „martwych i pochowanych” (Szacki 2010; Sztompka 1993).

Inna socjologiczna teoria cykli ma bardziej współczesne pochodzenie. Mowa tu o teorii cyklicznej Pitirima Sorokina. Proponuje on rozróżnienie dwóch przeciwstawnych, niemożliwych do pogodzenia ze sobą typów kultury. Określa je mianem typu Ideacyjnego i Zmysłowego. Są one rozumiane jako typy idealne, nieistniejące $\mathrm{w}$ czystej postaci $\mathrm{w}$ żadnej epoce, natomiast realne kultury przyjmują różne mieszane pośrednie formy, z których jedna zasługuje na oddzielne miano Idealistycznej. W kulturze Ideacyjnej rzeczywistość ma naturę duchową, niematerialną, jest wieczna i niezmienna. Najważniejsze cele i potrzeby mają charakter duchowy (zbawienie duszy, służba Bogu, obowiązki moralne), zaspokojenie ich dokonuje się poprzez samodoskonalenie umysłu i ciała. Kultura Zmysłowa charakteryzuje się jedynie rzeczywistością materialną dostępną zmysłom, a potrzeby i cele są wyłącznie cielesne i zmysłowe (głód, pragnienie, seks, schronie- 
nie) i żeby je zaspokoić należy modyfikować oraz eksploatować środowisko zewnętrzne. Pośrednia kultura Idealistyczna przedstawia zrównoważoną mieszankę elementów Ideacyjnych i Zmysłowych. Rzeczywistość w niej jest wielowymiarowa - zarówno materialna, jak i duchowa, a potrzeby mają charakter cielesny i duchowy. W kulturze Idealistycznej dopóki to co Ideacyjne pozostaje $\mathrm{w}$ harmonii z tym co Zmysłowe, i na odwrót, posiada wartość pozytywną. Najważniejszą zasadą typologii do biegu okresu dziejowego jest periodyzacja, wyróżniająca powtarzające się sekwencje kultur Ideacyjnych, Idalistycznych i Zmysłowych (tab. 6).

Tabela 6

Periodyzacja historii według Sorokina

\begin{tabular}{|l|l|}
\hline \multicolumn{1}{|c|}{ Okres } & \multicolumn{1}{c|}{ Typy kultury } \\
\hline Grecja VIII-VI w p.n.e. & Ideacyjny \\
\hline Grecja V w p.n.e. & Idealistyczny \\
\hline Rzym IV w p.n.e-IV w n.e. & Zmysłowy \\
\hline Europa IV-VI w n.e. & Idealistyczny \\
\hline Europa VI-XII w n.e. & Ideacyjny \\
\hline Europa XII-XIV w n.e. & Idealistyczny \\
\hline Europa XIV - czasy współczesne & Zmysłowy \\
\hline
\end{tabular}

Źródło: Sztompka 1993.

Współczesna zachodnia cywilizacja jest przez Sorokina oceniana bardzo krytycznie. Trwająca od kilku stuleci „fala Zmysłowa” wytwarza wiele patologicznych, negatywnych zjawisk i powoduje ogólny upadek kultury. Jego prognozy na nadchodzące czasy są pesymistyczne i zakładają:

- zapanowanie większej moralnej i estetycznej anarchii,

- „urzeczowienie” ludzi, którzy będą traktowani jak maszyny,

- zatracenie konsensu moralnego i intelektualnego, zapanowanie chaosu opinii i przekonań,

- utrzymywanie porządku społecznego jedynie za pomocą przymusu,

- zdegenerowanie wolności do poziomu pustego sloganu, mającego zwodzić i zniewalać,

- postępujący paraliż rodziny,

- dominację kultury masowej nad kulturą wyższego rzędu,

- obniżenie się jakości życia,

- dominację w życiu politycznym apatii, wąskiego egoizmu i ucieczki do sfery prywatnej (Sztomka 1993).

\subsubsection{Globalizacja}

Zachodzące obecnie zmiany stanowią równocześnie największe, od czasu pojawienia się marksizmu na Zachodzie w latach sześćdziesiątych, wyzwanie dla obowiązujących paradygmatów nauk społecznych [...]. Od czasu wyczerpania się eks- 
planacyjnej roli marksizmu, globalizacja jest najistotniejszą zmianą i motywem przewodnim współczesnego życia i teorii społecznej (Albrow 2005: 689-691).

Odnosząc się do słów Martina Albrowa teorię globalizacji można traktować jako interdyscyplinarną teorię zmiany społecznej oraz struktury społecznej i odróżnić ją należy od zachodzących od dawna procesów unifikacji w sferze gospodarki, kultury, polityki itd. W tym drugim wymiarze termin "globalizacja” definiować można w rozmaitych kontekstach. Najogólniej o zjawisku tym można mówić wówczas jako o „internacjonalizacji”, gdzie mamy do czynienia z intensyfikacją relacji między suwerennymi państwami, bądź też jako o „liberalizacji” - znoszeniu restrykcji stosowanych przez rządy wobec przepływu czynników produkcji przez granice i wprowadzaniu tzw. otwartej gospodarki światowej. W wymiarze społeczno-kulturowym globalizację utożsamia się często z „uniwersalizacją”, tzn. rozszerzaniem zasięgu oddziaływania poprzez rozprzestrzenianie się towarów, idei, wynalazków i doświadczeń do innych krajów; w wymiarze stricte kulturowym o globalizacji zaś mówi się często jako o „amerykanizacji/westernizacji" - rozprzestrzenianiu się zachodnich wartości i wzorów kulturowych kosztem kultur rodzimych (albowiem o kierunku przepływu kulturowego decyduje siła ekonomiczna - w tym wypadku głównie Stanów Zjednoczonych) - por. Czaputowicz 2004. Nieco inaczej systematyzuje procesy globalizacji Edward Wnuk-Lipiński wymieniając następujące kategorie znaczeń:

- globalizacja jako rynek światowy; globalizację utożsamia się tu przede wszystkim z przemianami ekonomicznymi zachodzącymi we współczesnym świecie i wskazuje się, że proces ten nie byłby możliwy bez światowej ekspansji systemu kapitalistycznego i postępu w deregulacji stosunków gospodarczych w wymiarze światowym;

- globalizacja jako relatywizacja; masowa wymiana informacji, dóbr i usług, a także „kapitału ludzkiego” - zwłaszcza po upadku bloku wschodniego - prowadzi do oswajania obcości innych krajów i ludzi z nich pochodzących. W rozumieniu bardziej „ekonomicznym”, relatywizacja definiowana jest jako proces, gdzie systemy niższego rzędu (ekonomiczne, kulturowe, społeczne itd.), jeżeli chcą być częścią globalizującego się świata, muszą tworzyć się i rozwijać w odniesieniu do owej abstrakcyjnej, wszechogarniającej „całości” (np. gospodarki narodowe w relacji do rynku światowego);

- globalizacja jako modernizacja i „detradycjonalizacja”; wspomniana deregulacja rynków wymusza modernizację zapóźnionych w rozwoju, lokalnych systemów ekonomicznych i struktur społecznych, który to proces - niejako na zasadzie sprzężenia zwrotnego - przyczynia się w efekcie do podtrzymywania tempa bądź wręcz przyspieszania globalizacyjnych procesów. Związany z tym proces „detradycjonalizacji” sprowadza się do rezy- 
gnacji z lokalnych sposobów życia na rzecz tych funkcjonujących w światowym obiegu dóbr i usług, a także idei i wartości;

- globalizacja jako homogenizacja lub hybrydyzacja; dyfuzja identycznych produktów, usług i wzorów zachowań prowadzi w efekcie do stanu unifikacji - narastania elementów wspólnych i zmniejszania się elementów różnicujących w poszczególnych społeczeństwach. Z drugiej strony występuje także proces przyswajania (i przetwarzania) jedynie niektórych elementów globalnego obiegu dóbr, usług czy idei, gdzie nie występuje jakiś jeden dominujący, „imperialny” wzorzec, skazujący kultury lokalne na wymarcie (Wnuk-Lipiński 2004: 22-29).

Uwzględniając szczególne powiązanie procesów z zakresu polityki, ekonomii i kultury należy zwrócić uwagę, że teoria globalizacji dobrze opisuje odmienność dominujących obecnie wzorów zmiany społecznej od stanu rzeczy, który analizie poddawano w teoriach modernizacji. Stąd koncepcja globalizacji ujmowana bywa jako „nowa” teoria konwergencji lub wręcz teoria dywergencji, gdzie procesom homogenizacji, zbliżania się form organizacji (społecznej, kulturowej, przemysłowej, rynkowej), towarzyszy jednocześnie proces różnicowania się poszczególnych rejonów świata, związany tak z procesami opisywanymi przez teorię systemu światowego, jak i z głoszoną tezą o ogólnym wzroście indywidualizacji, pragmatyzacji postaw i stosunków społecznych oraz o załamywaniu się życia publicznego i wspólnotowego (Starosta 2000). Warto przy tym wspomnieć o nurtach teorii społecznej, które mogą być potraktowane jako prekursorskie w stosunku do współczesnych ujęć teorii globalizacji. Sztompka wskazuje na trzy, z których każdy ma wyraźne korzenie marksistowskie, zajmuje się głównie sferą ekonomiczną i jest nastawiony na wyjaśnienie mechanizmów eksploatacji i niesprawiedliwości. Są to:

- teoria imperializmu, której zręby opracował J. A. Hobson, lecz jej najbardziej znaną wersją jest ta autorstwa Włodzimierza Lenina i Mikołaja Bucharina;

- teoria zależności - niejako kontynuacja teorii imperializmu - dotycząca okresu postkolonialnego, kiedy to bezpośrednia podległość polityczna krajów zacofanych została co prawda zniesiona, niemniej w jej miejsce powstało silne neokolonialne uzależnienie ekonomiczne; tym samym cechy społeczne i ekonomiczne regionów nierozwiniętych nie wynikają z ich „tradycyjności”, lecz stanowią rezultat oddziaływania i eksploatacji ze strony krajów rozwiniętych;

- teoria systemu światowego, autorstwa Immanuela Wallersteina, formułowana z pozycji ewidentnie lewicowych i wieszcząca upadek systemu kapitalistycznego, niejako mieszcząca w sobie dwie wyżej wspomniane teorie, która - jak się wskazuje - jako pierwsza wyszła poza państwo naro- 
dowe jako podstawową jednostkę analizy i już choćby z tego powodu uznawana jest za pierwszą teorię globalizacji (Sztompka 2005).

Jak się wydaje, to właśnie propozycja Wallersteina uznawana jest powszechnie za najbardziej odpowiednią intelektualną „bazę” teorii globalizacji; propozycje poszczególnych autorów odnośnie do myślowych inspiracji dla teorii globalizacji mogą różnić się między sobą, niemniej koncepcja Wallersteina zwykle jest $\mathrm{w}$ nich wspomniana na jednym $\mathrm{z}$ pierwszych miejsc i to zarówno w odniesieniu do samej teorii globalizacji (Starosta 2000), jak i do problematyki zmiany społecznej (Matuszek 2004). Wspomniane zerwanie przez teorię systemu światowego z kategorią państwa narodowego, jako kluczową jednostką analizy, stanowi w analizach wielu autorów istotny rys globalizacji. Według Albrowa (2005), unifikacja (ergo globalizacja) paradoksalnie podważyła główny element (państwo), który doprowadził do jej powstania. „Promowane” przez państwo narodowe pieniądz i handel, uwolniły się spod jego kontroli, a owo oddzielenie się sfery finansów od państwa stanowić ma kluczową cechę tej nowej „formacji”, w której obecnie przyszło nam żyć (Abramowicz 2008). 



\section{PRZEMIANY ZACHOWAŃ MATRYMONIALNYCH W POLSCE - OD ZLOTEGO WIEKU MAEŻEŃSTWA DO ŚWITU KOHABITACJI}

\subsection{Zmiany prawne zawierania i rozwiązywania związków małżeń- skich w Polsce po II wojnie światowej}

Obecna sytuacja „w obszarze małżeńskości” w Polsce jest wynikiem bardzo wielu czynników, w tym istotnych także uwarunkowań historycznych. Po II wojnie światowej zmieniły się nie tylko granice i obszar państwa polskiego, ale przeobrażenia dotyczyły też potencjału ludnościowego i jego struktury. Pierwsze lata okresu powojennego odznaczały się wzmożoną mobilnością ludności, wynikającą z różnych przyczyn (przesiedlenia, repatriacje), co dodatkowo oddziaływało na formowanie się związków małżeńskich. Powstanie państwa w nowym kształcie, w nowym układzie sił politycznych oraz znalezienie się $\mathrm{w}$ zasięgu wpływu Związku Radzieckiego wymuszało zmianę ustawodawstwa w różnych dziedzinach życia politycznego, gospodarczego i społecznego, w tym oczywiście także rozwiązań prawnych dotyczących zwierania związków małżeńskich.

Z chwilą zakończenia II wojny światowej na terenie kraju funkcjonowało kilka systemów prawnych regulujących zawieranie i rozwiązywanie małżeństw. Była to spuścizna jeszcze $\mathrm{z}$ okresu zaborów ${ }^{15}$. Ponieważ $\mathrm{z}$ chwilą odzyskania niepodległości na obszarze państwa polskiego obowiązywało sześć systemów prawnych: prawo niemieckie i pruskie, prawo austriackie, prawo węgierskie (Spisz i Orawa), prawo francuskie (Kodeks Napoleona) i prawo rosyjskie (na ziemiach wschodnich w całości, a ze znacznymi odrębnościami na obszarze b. Królestwa Kongresowego) i nie powiodły się

15 W zaborze pruskim obowiązywała (od 1874 r.) świecka rejestracja związków małżeńskich w urzędach stanu cywilnego. W zaborze austriackim stosowano system mieszany, świecko-wyznaniowy. W Królestwie Polskim od 1836 r. sprawy małżeńskie podlegały wyłącznie kompetencji sądów duchownych czterech oficjalnie uznawanych wyznań, tj. rzymskokatolickiego, greckokatolickiego, prawosławnego i protestanckiego. Przez cały okres II Rzeczypospolitej w zakresie prawa rodzinnego moc obowiązującą nadal miały przepisy byłych państw zaborczych. 
próby wprowadzenia jednolitego systemu prawnego ${ }^{16}$, to stan ten utrzymał się do $1945 \mathrm{r}$.

Już we wrześniu 1945 r. dekretem poddano regulacji prawnej, obowiązującej na terenie całego kraju, prawo małżeńskie (DzU, 1945, nr 48, poz. 270) wprowadzając instytucję rozwodów ${ }^{17}$, równocześnie dekretem z dnia 25 września 1945 r. (DzU, 1945, nr 48, poz. 272), wprowadzono jednolite prawo o aktach stanu cywilnego i powołano z dniem 1 stycznia 1946 r. na obszarze całego kraju świeckie „urzędy stanu cywilnego, których obowiązkiem jest prowadzenie ksiąg stanu cywilnego i wykonywanie innych czynności w zakresie rejestracji stanu cywilnego". Tego samego dnia wydano też dekret (DzU, 1945, nr 48, poz. 273) uchylający szereg dotychczas obowiązujących przepisów dotyczących prawa małżeńskiego i akt stanu cywilnego, poczynając od dekretu króla saskiego z 23 lutego 1809 r. dla Księstwa Warszawskiego.

Wprowadzone rozwiązania prawne zmieniały zasady rejestracji związków małżeńskich. Nowo zawierane związki miały moc prawną tylko wówczas, gdy zostały zawarte w urzędzie stanu cywilnego. Przez kilka powojennych lat część związków była zawierana jedynie w Kościele i statystyka oficjalna ich nie obejmowała, a związki te z opóźnieniem były prawnie zawierane w urzędzie. Dlatego utworzone świeckie urzędy stanu cywilnego przejęły od parafii wyznaniowych funkcje rejestracji ruchu naturalnego. Nowe prawo obniżało również dolną granicę wieku zawierania małżeństw z 21 do 18 lat (DzU, 1945, nr 48, poz. 270, art. 6). Oczekiwano w efekcie na wzrost liczby urodzeń i szybsze zniwelowanie wojennych strat ludnościo-

16 Powołana w czerwcu 1919 r. Komisja Kodyfikacyjna RP podjęła prace nad uporządkowaniem, unifikacją i unowocześnieniem polskiego prawa. Przygotowany przez podkomisję pod przewodnictwem Karola Lutostańskiego (1880-1939), profesora prawa Uniwersytetu Warszawskiego, projekt prawa małżeńskiego z 1929 r. opublikowany w 1931 r. pt. Zasady projektu prawa małżéskiego przewidywał fakultatywne śluby cywilne i wyznaniowe, rozwody, równość praw i obowiązków małżonków oraz przekazanie orzecznictwa w sprawie małżeństw sądom państwowym. Projekt był popierany przez pewne środowiska inteligenckie, których głównym rzecznikiem był Tadeusz Boy-Żeleński. Jednak nagonka kół klerykalnych oraz protest prymasa Polski kardynała Augusta Hlonda (20 XI 1931), określający projekt jako „zuchwałą próbę [...] wydania rodziny polskiej na bezeceństwa bolszewickie” (Hlond 1931) spowodowały, że rząd obawiając się konfliktu z Kościołem katolickim nie zdecydował się na ogłoszenie projektu w formie rozporządzenia prezydenta, ani też na przedłożenie go do uchwalenia izbom ustawodawczym. Prace podkomisji zostały w znacznej mierze wykorzystane po latach przy unifikacji prawa małżeńskiego w 1945 r.

17 Episkopat Polski wydał 7 grudnia 1945 r. orędzie W sprawie małżeńskiej stwierdzające, że nowe prawo nie uwzględnia uprawnień i prawodawstwa Kościoła i jest niezgodne z chrześcijaństwem i katolickimi tradycjami kraju (Gawryszewski 2005). 
wych. Pierwsze powojenne prawo o aktach stanu cywilnego, regulujące sprawy rejestracji małżeństw, urodzeń i zgonów, przetrwało dziesięć lat. Do kolejnych zmian doszło w dniu 8 czerwca 1955 r. (DzU, 1955, nr 55, poz. 151), kiedy to dekretem wprowadzono Prawo o aktach stanu cywilnego, zmieniające obowiązujące przepisy, ale nie podstawowe zasady rejestracji w urzędach stanu cywilnego. Nowelizacja z 2 grudnia 1958 r. (DzU, 1958, nr 72, poz. 358) zabroniła zawierania ślubu kościelnego przed zarejestrowaniem związku małżeńskiego w urzędzie stanu cywilnego. Prawo o aktach stanu cywilnego wprowadzono ustawą z 29 września 1986 r. (DzU, 1986, nr 36, poz. 180) i nowelizowane obowiązuje do dnia dzisiejszego.

Prawo rodzinne skodyfikowane w kodeksie rodzinnym ustawą z dnia 27 kwietnia 1950 r. (DzU, 1950, nr 34, poz. 308) zastąpiło prawo małżeńskie z 1945 r. Z dniem 1 stycznia 1965 r. wszedł w życie, uchwalony 25 lutego 1964 r., Kodeks rodzinny i opiekuńczy (DzU, 1964, nr 9, poz. 59 z późniejszymi zmianami) obowiązujący do dzisiaj. W obu ustawach, z 1950 i 1965 r., utrzymano zasadę dopuszczalności rozwiązania małżeństwa przez rozwód. Rozwód jest rozwiązaniem ważnego związku małżeńskiego przez sąd na żądanie jednego lub obojga małżonków. W prawie polskim podstawową przesłanką rozwodu jest istnienie trwałego i zupełnego rozkładu pożycia małżeńskiego. Informacje statystyczne o prawomocnie orzeczonych rozwodach zbierane są przez Ministerstwo Sprawiedliwości od 1 stycznia 1949 r. W Kodeksie rodzinnym i opiekuńczym z 1 stycznia 1965 r. podniesiono dolną granicę wieku mężczyzn, uprawniającego do zawarcia małżeństwa z 18 do 21 lat, co przejściowo ograniczyło liczbę przedwczesnych związków (Gawryszewski 2005).

Dalsze zmiany legislacyjne zawierania małżeństw nastąpiły w wyniku podpisania konkordatu między Stolicą Apostolską i RP (w dniu 28 lipca 1993 r. i ratyfikowaniu go przez rząd polski 3 kwietnia 1998 r.). Porozumienie umożliwiło zawieranie związku wyznaniowego $w$ obecności duchownego, podlegające prawu polskiemu i pociągające za sobą takie same skutki cywilnoprawne, jak małżeństwo zawarte przed kierownikiem urzędu stanu cywilnego. Małżeństwa wyznaniowe mogą być zawierane jedynie w określonych Kościołach i Związku Wyznaniowym ${ }^{18}$, a zaświadczenie stanowiące podstawę sporządzenia aktu małżeńskiego mogą wystawiać wymienione poniżej osoby ${ }^{19}$ :

${ }^{18}$ Rocznik Demograficzny, 2012, GUS, Warszawa.

19 Załacznik do obwieszczenia Ministra Spraw Wewnętrznych i Administracji $z$ dnia 4 listopada 1998 r. (poz. 554) - Wykaz stanowisk, których zajmowanie upoważnia do sporządzenia zaświadczenia stanowiq̨cego podstawę sporzq̨dzenia aktu małżeńskiego zawartego w sposób określony w art. 1 \$2 i 3 „Kodeksu rodzinnego i opiekuńczego". 
1. Kościół katolicki - ordynariusz miejsca, proboszcz, administrator parafii, wikariusz w zastępstwie proboszcza, duchowny w zastępstwie proboszcza,

2. Polski Autokefaliczny Kościół Prawosławny - biskup, proboszcz, wikariusz z upoważnienia proboszcza,

3. Kościół Ewangelicko-Augsburski - biskup, proboszcz, administrator, wikariusz,

4. Kościół Ewangelicko-Reformowany - wszyscy ordynowani duchowni,

5. Kościół Ewangelicko-Metodystyczny - pastor parafii,

6. Kościół Chrześcijan Baptystów - prezbiter, kaznodzieja,

7. Kościół Adwentystów Dnia Siódmego - duchowni starsi,

8. Kościół Polskokatolicki - proboszcz, administrator parafii,

9. Związek Gmin Wyznaniowych Żydowskich - rabin, podrabin,

10. Kościół Starokatolicki Mariawitów - biskup naczelny, ordynariusz, biskup, proboszcz, administrator parafii,

11. Kościół Zielonoświątkowy - prezbiter.

Jednakże w polskim systemie prawa, podobnie jak w innych krajach europejskich, obowiązuje świecki model małżeństwa. Wyraża się on m.in. tym, że małżeństwo może zostać rozwiązane przez rozwód. Najważniejszym jednak rysem świeckości jest kontrola państwa nad zawieraniem i rozwiązywaniem małżeństw. Dzieje się tak nawet w przypadku tzw. małżeństw konkordatowych, a więc zawieranych przed duchownym. Kierownik USC jest zobowiązany do wystawienia zaświadczenia stwierdzającego brak okoliczności wyłączających zawarcie małżeństwa według prawa polskiego. Bez tego zaświadczenia duchowny nie może przyjąć oświadczenia woli o wstąpieniu w związek małżeński. Małżeństwo konkordatowe zostaje zawarte, jeśli mężczyzna i kobieta podlegający prawu wewnętrznemu Kościoła albo innego związku wyznaniowego w obecności duchownego oświadczą wolę jednocześnie zawarcia małżeństwa w zgodzie z prawem polskim, a kierownik USC sporządzi następnie akt małżeństwa.

Zachowanie świeckości małżeństw w polskim prawie nie oznacza odmowy Kościołom i innym związkom wyznaniowym jakichkolwiek praw do udzielania małżeństw, poza faktem złożenia oświadczenia o woli wstąpienia w związek małżeński. Ustawodawca nie ingeruje w wewnętrzne przepisy poszczególnych Kościołów i innych związków wyznaniowych, pozostawiając im swobodę nie tylko w zakresie formy złożenia oświadczenia, ale i własnych wymagań stawianych osobom zamierzającym wstąpić w związek małżeński. Ta sytuacja z kolei zakłada nawet prawo odmowy przyjęcia przez duchownego oświadczenia woli, pomimo spełnienia cywilnoprawnych przesłanek ważności takiego oświadczenia, jeżeli osoby zamierzające zawrzeć związek małżeński nie spełniają wymogów stawianych przez prawo wewnętrzne danego Kościoła. Nie ma też możliwości odwołania się 
do sądu cywilnego $\mathrm{w}$ razie zaistnienia sprzeciwu, a zatem takim osobom pozostaje oświadczenie woli w USC (Sitek 2002).

Relacje państwa i Kościoła, wraz z ich prawodawczą aktywnością dotyczącą małżeństwa, na przestrzeni wieków kształtowały się różnie. Szczególne miejsce $w$ sferze prawnego uregulowania wzajemnych relacji między prawem kościelnym a prawem państwowym dotyczącym małżeństw mają umowy międzynarodowe (konkordaty), zawierane między Stolicą Apostolską i poszczególnymi państwami.

W praktyce można obecnie mówić o trzech systemach państwowych regulujących zawieranie małżeństwa. Pierwszym z nich jest system obligatoryjnego małżeństwa cywilnego. Obowiązuje on w wielu krajach, np. we Francji, w Belgii i w Holandii. Występuje wówczas, gdy przepisy prawa pozytywnego zobowiązują obywateli danego państwa do zawierania małżeństwa według formy określonej przez prawo cywilne i konsekwentnie na forum prawa państwowego tylko te małżeństwa mogą wywołać skutki prawne. Drugim systemem jest system fakultatywny, dopuszczający zawarcie małżeństwa bądź w formie cywilnej, bądź w formie religijnej. System ten stosuje wiele państw i to nie tylko tych, które podpisały umowy konkordatowe ze Stolicą Apostolską (np. USA). Dla pełnego obrazu należy jeszcze dodać trzeci system, a mianowicie obligatoryjne zawieranie małżeństwa $\mathrm{w}$ formie religijnej, z tym że w dzisiejszych czasach występuje on wyłącznie $\mathrm{w}$ tradycyjnych państwach wyznaniowych i jest niejako naturalną konsekwencją tego faktu ustrojowego (Adamczewski 1999; Góralski 1994; Gręźlikowski 2000).

Regulacje dotyczące małżeństw zawarte $\mathrm{w}$ polskim konkordacie $\mathrm{z}$ roku 1993, nie mają swoich odpowiedników w poprzednio obowiązującej umowie ze stolicą Apostolską z 1925 r. Ta dziedzina prawa konkordatowego nie miała więc $\mathrm{w}$ Polsce dłuższej tradycji. System prawa małżeńskiego był w Polsce przed II wojną światową bardzo niejednolity. Dopiero po jej zakończeniu wprowadzono nowe regulacje prawne odnoszące się do małżeństwa, z pominięciem wszakże jakichkolwiek odniesień do religijnej sfery.

Przepisy konkordatu zostały wprowadzone w obieg prawa polskiego nowelizacją Kodeksu rodzinnego i opiekuńczego oraz Prawa o aktach stanu cywilnego z dnia 24 lipca $1998 r^{20}$. Natomiast partykularne prawo kanoniczne zostało znowelizowane $\mathrm{w}$ tym względzie poprzez wydanie odpowiedniej instrukcji Konferencji Episkopatu Polski w dniu 22 października 1998 r. ${ }^{21}$ Oba te akty prawne weszły w życie z dniem 15 listopada $1998 \mathrm{r}$. Konferencja Episkopatu Polski, na zebraniu plenarnym w dniu 4 czerwca

20 DzU z 1998 r., nr 117, poz. 757.

${ }^{21}$ Instrukcja dla duszpasterzy, dotycząca małżeństwa konkordatowego, 1998, „Akta Konferencji Episkopatu Polski”, t. 1, nr 2, s. 55. 
1998 r., podjęła następującą uchwałę: „Wierni Kościoła katolickiego w Polsce zawierający małżeństwo kanoniczne mają obowiązek uzyskania dla niego skutków cywilnych, zapewnionych w Konkordacie (art. 10). Bez zgody Ordynariusza miejsca nie wolno zatem asystować przy małżeństwach nupturientów, którzy nie chcą, by ich małżeństwo wywierało skutki w prawie polskim. Ordynariusz miejsca może zezwolić na zawarcie małżeństwa bez skutków cywilnych tylko w wyjątkowych przypadkach z ważnych powodów pastoralnych" (por. kan. $1071 \S 1$, nr 2, KPK). Powyższa uchwała uzyskała recognitio Stolicy Apostolskiej pismem nr 8426/98 RS, z dnia 29 października 1998 r. i niniejszym zostaje promulgowana, jako obowiązująca od dnia 15 listopada 1998 r. (Instrukcja... 1998).

Kolejną zmianą w Kodeksie rodzinnym i opiekuńczym była ustawa z 21 maja 1999 r. (DzU, 1999, nr 52, poz. 532) wprowadzająca z dniem 16 grudnia 1999 r. instytucję separacji, istniejącą w kościelnym prawie kanonicznym. Separacja uchyla wspólnotę małżeńską (majątkową) bez prawa wstępowania współmałżonków w nowe związki małżeńskie. Artykuł 61, § 2 tejże ustawy brzmi „Jednakże mimo zupełnego rozkładu pożycia orzeczenie separacji nie jest dopuszczalne, jeżeli wskutek niej miałoby ucierpieć dobro wspólnych małoletnich dzieci małżonków albo jeżeli z innych względów orzeczenie separacji byłoby sprzeczne z zasadami współżycia społecznego". Jak twierdzi Gawryszewski (2005) wprowadzenie instytucji separacji świadczy nie tyle o dbałości o ograniczenie liczby - zakazanych przez prawo kanoniczne - rozwodów ${ }^{22}$, ile o rosnącym wpływie Kościoła na kształtowa-

${ }^{22}$ W Kościele katolickim, zgodnie z prawem kanonicznym, małżeństwo może być rozwiązane przez unieważnienie przez sąd konsystorski lub zgon jednego z małżonków. Nie istnieje instytucja rozwodu, możliwa natomiast jest separacja „od łoża i stołu", ale nie stanowi ona rozwiązania małżeństwa. Często ze względu na pozorne podobieństwo do rozwodu cywilnego stwierdzenie nieważności małżeństwa określane jest jako rozwód kościelny. Jednakże jest to mylne wyobrażenie, gdyż w kanonicznym procesie małżeńskim strony starają się dowieść, że małżeństwo było nieważne od samego początku. W procesie cywilnym, co do zasady dowodzi się zaś, że nastąpił zupełny i trwały rozkład pożycia małżeńskiego. Prawnokanoniczne tytuły nieważności małżeństwa można podzielić na trzy grupy. W pierwszej kolejności należy wymienić tzw. przeszkody małżeńskie, od których nie uzyskano przewidzianej prawem dyspensy. Gdy zaistnieje taka przeszkoda, osoba, której ona dotyczy, nie jest zdolna do zawarcia małżeństwa (np. jest za młoda lub pozostaje już w sakramentalnym związku małżeńskim). W procesie nieważności możemy dowodzić także na podstawie wystąpienia tzw. wad zgody małżeńskiej. Składając przysięgę małżeńską musimy w sposób dobrowolny wyrazić wolę, że chcemy wstąpić w związek małżeński. Czasem jednak zdarzają się sytuacje, że małżonek nie wyraża zgody na zawarcie małżeństwa bądź też wyraża ją w sposób wadliwy. Wtedy także można starać się o stwierdzenie nieważności małżeństwa. Małżeństwo może zostać zawarte nieważnie także w przypadku 
nie prawa rodzinnego w Polsce. Ponadto od 1991 r. sprawy rozwodowe prowadzą wyłącznie sądy wojewódzkie, poprzednio były to sądy rejonowe. Zmiana ta ogromnie wydłużyła samą procedurę i spowodowała istotną niedogodność dla zainteresowanych ze względu na konieczne dojazdy do siedziby sądu.

Rozwiązania legislacyjne mogą wpływać na liczebność zawieranych związków małżeńskich, ale mają charakter krótkotrwały. W Polsce w 1964 r. nastąpił niewielki, ale zarazem nieoczekiwany wzrost stopy małżeństw. W następnym roku liczba zawartych małżeństw obniżyła się natomiast w o wiele większym stopniu niż można było tego oczekiwać. Przyczyną tych zmian były nowe regulacje prawne, tj. podniesienie wieku małżeńskiego dla mężczyzn (do 21 lat) od 1965 r., co skłoniło wielu młodych ludzi do wcześniejszego zawarcia małżeństwa. Zmniejszyła się z tego powodu liczba małżeństw zawartych w następnym roku. Natomiast zmiany prawne, które nastąpiły w Polsce w 1998 r. (w ich wyniku m.in. obniżono wiek małżeński mężczyzn) nie wywołały zmian w liczebności zawieranych małżeństw ${ }^{23}$.

Od opisanych zmian w prawodawstwie nie weszły w życie żadne nowe rozwiązanie prawne dotyczące zawierania i rozwiązywania małżeństw. $\mathrm{W}$ ostatnich latach $\mathrm{w}$ Polsce toczy się jednak bardzo burzliwa dyskusja wokół zmian w prawodawstwie polskim odnośnie do legalizacji związków partnerskich. Biorą w niej udział zarówno autorytety świeckie, jak i osoby duchowne, a sama dyskusja w dużej liczbie przypadków ma bardziej wydźwięk emocjonalny niż merytoryczny. Stanowiska i poglądy uczestników

niezachowania kanonicznej formy jego zawarcia. To, w jaki sposób powinna przebiegać ceremonia zaślubin określone jest przepisami prawa. Jeżeli $w$ tzw. formie kanonicznej zawierania małżeństwa wystąpiłyby określone braki, wtedy także można starać się o stwierdzenie nieważności małżeństwa. Co roku do kościelnych trybunałów w Polsce wpływa przeszło 10 tysięcy wniosków o unieważnienie sakramentu ślubu. Dodać należy, że orzeczenie o nieważności małżeństwa następuje w przeszło 95\% spraw (http://prawokanoniczne.org/stwierdzenieniewaznoscimalzenstwa-854/).

${ }^{23}$ Do zawarcia związku małżeńskiego potrzeba nie tylko dojrzałości fizycznej, ale także emocjonalnej i społecznej. Dlatego ustawodawcy poszczególnych państw prawnie wyznaczają minimalny wiek legalizacji związków małżeńskich. W krajach europejskich dolna granica wieku zawierania związków jest podobna, jest to 18 lat, ale zdarzają się pewne wyjątki dotyczące wieku wstępowania w związki za zgodą rodziców. W większości krajów europejskich, które przewidują taką możliwość, jest to wiek 16 lat, tylko w Danii, Estonii, Słowenii, na Ukrainie i na Litwie można za zgodą rodziców zalegalizować małżeństwo w wieku lat 15, a w Hiszpanii nawet 14. W kilku krajach europejskich obniżenie wieku zawarcia małżeństwa może nastąpić także za zgodą sadu (np. w Austrii) lub ministra sprawiedliwości (np. w Finlandii) - Yearbook Demographic 2011. 
dyskursu społecznego różnią się wyraźnie pomiędzy grupą zwolenników liberalizacji życia małżeńsko-rodzinnego i ich przeciwnikami - konserwatystami. Tam gdzie takich debat nie ma, jak zauważa A. Giddens (1999), winne są temu rządy autorytarne i zachowawcze ugrupowania.

Chociaż proponowane zmiany nie dotyczą instytucji małżeństwa jako takiej, to $\mathrm{z}$ racji podejmowanego tematu autorka postanowiła przedstawić chronologię wydarzeń z ostatnich lat i losy projektów ustaw o związkach partnerskich, które jak do tej pory w naszym kraju nie znalazły rozwiązania w postaci ustawy.

Od wielu lat toczą się $\mathrm{w}$ różnych państwach ożywione dyskusje nad zmieniającymi się formami życia małżeńskiego, modelem rodziny - jej tworzeniem i rozpadem. Przeobrażenia, jakie dokonują się w ramach rodziny jako instytucji, są wyzwaniem dla społeczeństw i ich polityki społecznej. Tym przemianom towarzyszą bowiem nowe podmioty, nowe sfery życia rodzinnego, których wcześniej nie było, więc nie były objęte programem tejże polityki. Pojawienie się ich niejako wymusza także zmiany w prawodawstwie kraju. W Europie i na świecie spotykamy przykłady wielu państw, które mają już za sobą rozwiązanie „problemu” prawnego dotyczącego legalizacji związków partnerskich.

Prace nad projektem ustawy o związkach partnerskich mają już w naszym kraju kilkuletnią historię. Pierwszy projekt, autorstwa Marii Szyszkowskiej, został w 2004 r. przyjęty przez Senat, jednak nie odbyło się ani jedno jego czytanie w Sejmie. Drugi projekt - ustawy o umowach dotyczących związków partnerskich, przygotowany przez Grupę Inicjatywną ds. Związków Partnerskich, został złożony w Sejmie w 2011 r. Nad tym projektem odbyły się dwie dyskusje - na plenum połączonych komisji sejmowych i w specjalnie stworzonej podkomisji. Prace nad projektem nie były kontynuowane z racji rozpoczęcia kampanii wyborczej.

W trakcie trwania Sejmu VII kadencji podjęte zostały ponownie prace nad projektem ustawy o związkach partnerskich. 13 stycznia 2012 r. na konferencji przedstawiciele Ruchu Palikota, Sojuszu Lewicy Demokratycznej, Trans-Fuzji, Grupy Inicjatywnej ds. Związków Partnerskich oraz Miłość Nie Wyklucza poinformowali, że w najbliższym czasie do Sejmu złożone zostaną dwa projekty ustaw - o umowach związków partnerskich oraz o instytucji związku partnerskiego. Projekt ustawy zgłosiła także Platforma Obywatelska. Jednakże Sejm odrzucił 25 stycznia 2013 r. wszystkie projekty ustaw dotyczące związków partnerskich. Przepadły propozycje PO, SLD i Ruchu Palikota. Najbliżej sukcesu był wniosek zgłoszony przez posła Artura Dunina (PO). Propozycja posła zawierała m.in. możliwość zarejestrowania związków partnerskich w urzędach stanu cywilnego, wprowadzenie ustawowego dziedziczenia oraz obowiązku wzajemnej opieki, zagwarantowanie szansy na zdobycie informacji o stanie zdrowia partnera, 
kiedy ten przebywa $\mathrm{w}$ szpitalu oraz prawo odmowy zeznań przeciwko partnerowi. SLD i RP poszły o krok dalej, proponując możliwość wspólnego rozliczania się z podatków. Wszystkie projekty dotyczyły nie tylko par homoseksualnych, o których prawach z pewnością mówiło się najwięcej, ale i par heteroseksualnych. Żaden z nich nie przewidywał możliwości adopcji dziecka przez związek partnerski. Za odrzuceniem wniosku zagłosowało 228 posłów, natomiast 211 było za wprowadzeniem zmian. W tym momencie warto też zaznaczyć, że głosowanie w Sejmie nie było równoznaczne z ewentualnym przyjęciem nowej ustawy, ale z jej skierowaniem do dalszych prac parlamentarnych oraz do dyskusji w komisjach. Projekt wprowadzany był z dużą ostrożnością. Jego autor, poseł Dunin mówił, że w żadnym wypadku nie zmierza on do zrównania związku partnerskiego z instytucją małżeństwa i dotyczy jedynie podstawowych spraw codziennych, które mogą ułatwić życie Polakom, którzy nie chcą albo nie mogą zawrzeć związku małżeńskiego.

Społeczeństwo polskie w swoich opiniach na temat legalizacji związków partnerskich jest bardziej liberalne niż nasza władza. Dwie trzecie Polaków (67\%) popiera wprowadzenie przepisów regulujących prawa osób żyjących w związkach partnerskich heteroseksualnych. Zdecydowanie mniej (47\%) jest za takimi prawami dla par homoseksualnych - wynika z sondażu TNS Polska. Sondaż przeprowadzony na początku marca 2013 r. pokazał, że ok. 34\% Polaków nie aprobuje wprowadzania przepisów, które regulowałyby prawa (np. dziedziczenie, prawo do informacji medycznej) ludzi żyjących w związkach partnerskich w przypadku osób różnej płci. Jednak większość, czyli ok. $67 \%$ badanych, opowiada się za tym. Nieco więcej zwolenników takiego rozwiązania jest wśród kobiet (68\%) niż wśród mężczyzn (65\%). Jeżeli chodzi o wiek badanych, to największą grupę popierających wspomniane rozwiązanie stanowią osoby pomiędzy 20 . a 29 . rokiem życia (74\%), najmniej jest ich zaś w grupach powyżej 40. roku życia (40-49 lat 62\%, 50-59 lat - 63\%, 60 lat i więcej - 62\%). Preferencje partyjne badanych mają znaczny wpływ na zróżnicowanie opinii. Najwięcej osób opowiadających się za uregulowaniem praw osób z partnerskich związków heteroseksualnych (84\%) jest wśród zwolenników Ruchu Palikota, najmniej zaś wśród popierających Prawo i Sprawiedliwość (57\%). Także zwolennicy Platformy Obywatelskiej oraz Sojuszu Lewicy Demokratycznej są w większości $(74 \%)$ za wprowadzeniem regulacji w tym zakresie. Wśród osób identyfikujących się z poglądami Polskiego Stronnictwa Ludowego takie rozwiązanie popiera $68 \%$ badanych. $\mathrm{Z}$ kolei biorąc pod uwagę praktyki religijne, najwięcej zwolenników jest wśród osób niepraktykujących (77\%), nieco mniej wśród nieregularnie praktykujących (69\%), a najmniej wśród wierzących i regularnie praktykujących (59\%). Na podział preferencji wpływ ma również wykształcenie badanych. Więcej osób opowiadających 
się „za” jest w grupie z wykształceniem wyższym (72\%) oraz średnim i pomaturalnym (70\%). Poparcie jest natomiast mniejsze niż średnia w grupie ankietowanych z wykształceniem podstawowym i gimnazjalnym (54\%) oraz zasadniczym zawodowym (65\%). Wprowadzenie uregulowania praw osób żyjących w związkach partnerskich homoseksualnych ma z kolei wśród ogółu społeczeństwa więcej przeciwników (53\%) niż zwolenników $(47 \%)^{24}$.

\subsection{Formowanie się i rozpad małżeństw od drugiej połowy $\mathrm{XX}$ w.}

\subsubsection{Małżeństwa}

Pierwsze powojenne lata to okres, w którym można zaobserwować tendencje wzrostowe natężenia liczby zawieranych małżeństw. Część z nich stanowiły małżeństwa odraczane ze względu na działania wojenne czy też politykę okupanta w tym względzie (na terenach włączonych do Rzeszy Niemieckiej władze okupacyjne wprowadziły zakaz zawierania małżeństw przed ukończeniem 28 lat dla mężczyzn i 24 lat przez kobiety). Był to też efekt opóźnionej rejestracji wcześniej już zawartych związków wyznaniowych. Koniec lat 40. był rekordowym okresem pod względem liczby zawieranych małżeństw w całej powojennej historii Polski zarówno w wartościach bezwzględnych, jak i wartości współczynnika zawierania małżeństw ${ }^{25}$.

W 1946 r. częstość zawierania małżeństw w Polsce była o 45\% wyższa niż w roku 1938 i wynosiła 11,9 małżeństw na 1000 ludności. Rok później współczynnik wzrósł do 13,0, a w 1948 r. do 13,3 i był najwyższy, jaki odnotowano dla całego kraju w XX w. ${ }^{26}$ - por. ryc. 18 . W 1950 r. natężenie

${ }^{24}$ Badanie zostało zrealizowane na zlecenie PAP $\mathrm{w}$ pierwszych dniach marca 2013 r., na ogólnopolskiej reprezentatywnej próbie 1000 osób.

${ }^{25}$ Miarą natężenia zawierania związków małżeńskich, najczęściej wykorzystywaną, jest ogólny współczynnik zawierania małżeństw, który oblicza się jako stosunek liczby małżeństw zawartych w badanym okresie do ogólnej liczby ludności w tymże okresie, w przeliczeniu na 1000 (100 lub 10 000) osób. Współczynnik ten nie uwzględnia wpływu zmian struktury wieku zbiorowości, dlatego jego wartość poznawcza i porównawcza jest ograniczona. Bardziej poprawny metodycznie jest współczynnik zawierania małżeństw obliczany jako stosunek liczby małżeństw do liczby ludności w wieku uprawniającym do zawierania związków małżeńskich (np. 15 lat i więcej).

${ }^{26}$ Zaobserwowaną prawidłowością jest niska częstość zawierania małżeństw w czasie wojny i wysoka ich częstość w pierwszych latach powojennych, na co zwrócił uwagę polski demograf Edward Rosset. Ten osobliwy cykl demograficzny według Rosseta składa się z wojennej fazy destrukcyjnej - z wysoką liczbą zgonów, niską liczbą małżeństw, urodzeń i kurczącym się przyrostem naturalnym, oraz powojennej fazy kompensacyjnej - z charakterystycznym wzrostem liczby małżeństw 
zawierania małżeństw zmniejszyło się do 10,8\%o i było bardzo zróżnicowane regionalnie. Wyjątkowo wysokie współczynniki zawierania małżeństw występowały $\mathrm{w}$ powiatach tzw. ziem odzyskanych, przede wszystkim na Dolnym Śląsku (rzędu 22\%o w powiatach wałbrzyskim i dzierżoniowskim czy ok. 21\%o w miastach Świdnica i Wrocław), najniższe zaś w Małopolsce (od 6 do 7\%o w powiatach Limanowa, Nowy Sącz, Brzozów, Dąbrowa Tarnowska). Zróżnicowanie stopy małżeństw między tzw. ziemiami odzyskanymi i dawnymi było konsekwencją odpływu ludzi młodych z ziem dawnych na tereny zachodnie i północne, z którymi wiązali swoje plany życiowe i tam też zakładali rodziny (Gawryszewski 2005). Wysoka stopa małżeństw $\mathrm{w}$ pierwszej połowie lat 50. pozostawała jeszcze pod wpływem gasnącej tendencji kompensacyjnej i dopiero w 1954 r. współczynnik małżeństw spadł poniżej 10\%o. Na początku lat 60 . wystąpił gwałtowny spadek liczby zawieranych małżeństw, w wiek matrymonialny wkraczały bowiem mniej liczne roczniki urodzone w czasie II wojny światowej. Poza tym, z początkiem stycznia 1965 r. wszedł w życie nowy kodeks rodzinny i opiekuńczy, podnoszący granicę wieku zawierania małżeństw dla mężczyzn do 21. roku życia. W drugiej połowie lat 60 . w związki małżeńskie zaczynają wstępować coraz liczniejsze roczniki powojenne i malejąca uprzednio stopa małżeństw zaczyna się zwiększać - od 7,2\%o w roku 1963 do 8,5\%o w 1970 r. Nadal występowało zróżnicowanie częstości zawierania małżeństw między obszarami zachodnimi i północnymi a dawnymi. W znacznej mierze wynikało to z przeszłości, najwięcej małżeństw zawierano bowiem tam, gdzie 25 lat wcześniej notowano maksimum urodzeń. Częstość zawierania małżeństw, głównie przez pokolenia wyżu powojennego, rosła do 1975 r. (9,7\%o), po czym przez następne ćwierćwiecze, gdy w wiek matrymonialny wkraczało pokolenie niżu demograficznego, systematycznie malała do 5,5\%o w 2000 r. Odnotować też należy zacieranie się różnic pomiędzy ziemiami dawnymi i odzyskanymi, które były wynikiem procesów migracyjnych. Początek lat 90. to okres, w którym wchodziły $\mathrm{w}$ wiek matrymonialny roczniki $\mathrm{z}$ echa wyżu powojennego, oczekiwano więc i zakładano $\mathrm{w}$ prognozach wzrost tendencji zawierania małżeństw. Tak się jednak nie stało, przyczyniły się do tego nie tylko zmiany społecznogospodarcze rozpoczynającej się w naszym kraju transformacji, ale i przemiany demograficzne związane $\mathrm{z}$ drugim przejściem demograficznym. Wynika z tego, że rola czynnika demograficznego, tak ważna w okresie powojennym, od lat 90. wyraźnie traci na znaczeniu (Slany 2000).

Początek XXI w. zaowocował dalszym obniżeniem się tendencji wchodzenia w związki małżeńskie, szczególnie dotyczy to pierwszych jego lat, po

(a potem i urodzeń) i podnoszącym się przyrostem naturalnym; w fazie kompensacyjnej zawierane są małżeństwa odraczane wskutek wojny (Rosset 1975). 
2006 r. tendencja ta nieco osłabła, ale ostatnie lata świadczą o powrocie obniżki częstości zawierania małżeństw. Co ciekawe, odwrócił się rozkład przestrzenny częstości zawieranych małżeństw, tereny bowiem północne i zachodnie, które przez wiele lat wykazywały najwyższe wartości współczynnika małżeństw, obecnie mają wartości zbliżone lub niższe od średniej krajowej (więcej na ten temat w podrozdziale 3.3).

Charakterystyczny jest też rozkład współczynnika zawierania małżeństw w układzie miasto-wieś. Aż do końca lat 80. ubiegłego wieku częstość zawierania małżeństw w miastach była wyższa niż na terenach wiejskich (były co prawda lata, gdy tendencja ta była odwrócona - 1959, 1967, 1973, 1975, 1977 r.), a różnice w wartościach, sięgające na początku okresu 3\%o, zmniejszały się sukcesywnie do 0,5-1\%o. Od 1989 r. tendencje odwróciły się i częstość legalizowania związków jest teraz wyższa na wsi, choć różnice wartości wskaźnika są niewielkie (por. ryc. 18).

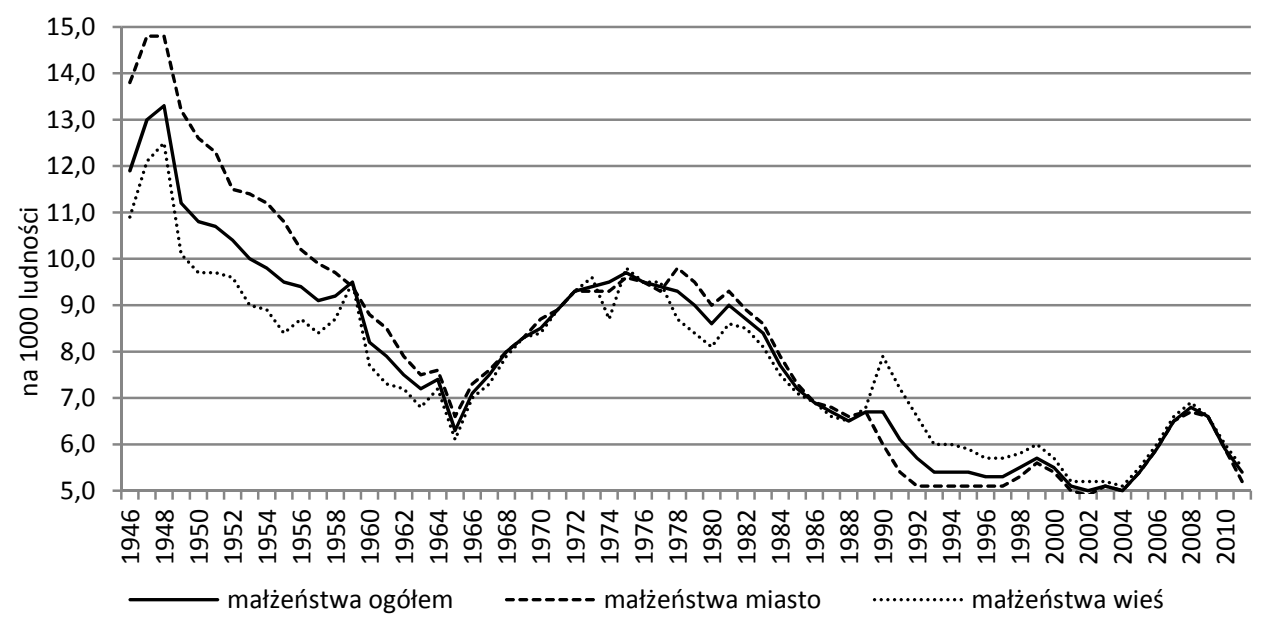

Ryc. 18. Małżeństwa na 1000 mieszkańców w Polsce w latach 1946-2011 Źródło: oprac. własne na podstawie Rocznik Demograficzny, 2012, GUS, Warszawa

Procesy przemian demograficznych rozpoczęte na północy i zachodzie Europy od lat 90. ubiegłego stulecia obejmują kraje Europy Wschodniej i Środkowej. Zacierają się różnice pomiędzy Zachodem a Wschodem Europy wyznaczone linią Hajnala, w zamian można mówić o nowym zróżnicowaniu przestrzennym krajów europejskich w ramach zachowań demograficznych. Wyznaczona w latach 60. przez Hajnala granica dzieliła Europę wzdłuż linii Sankt Petersburg - Triest, dzieląc kontynent na część europejską (model europejski) i część wschodnio-europejską (model wschodnio-europejski). Podział ten dotyczył modelu zawierania małżeństw, który był obserwowany od początku XVIII aż do połowy XX w. W Europie Wschodniej dominowa- 
ły małżeństwa zawierane wcześnie, w modelu europejskim decyzje o zawarciu małżeństwa odkładano zaś na późniejszy okres życia lub rezygnowano z jego zawarcia (tab. 7).

Tabela 7

Udział kawalerów i panien w wybranych grupach wieku w $1900 \mathrm{r}$.

(na 100 osób danej grupy wieku i płci)

\begin{tabular}{|l|c|c|c|c|c|c|}
\hline \multirow{2}{*}{ Kraje } & \multicolumn{7}{c|}{ Mężczyźni } & \multicolumn{3}{c|}{ Kobiety } \\
\cline { 2 - 7 } & $20-24$ & $25-29$ & $45-49$ & $20-24$ & $25-29$ & $45-49$ \\
\hline \multicolumn{7}{|c|}{ Model europejski } \\
\hline Belgia & 85 & 50 & 16 & 71 & 41 & 17 \\
\hline Francja & 90 & 48 & 11 & 58 & 30 & 12 \\
\hline Szwecja & 92 & 61 & 13 & 80 & 52 & 19 \\
\hline \multicolumn{7}{|c|}{ Model wschodnio-europejski } \\
\hline $\begin{array}{l}\text { Grecja (model pośred- } \\
\text { ni) }\end{array}$ & 82 & 47 & 9 & 44 & 13 & 4 \\
\hline Bułgaria & 58 & 9 & 3 & 24 & 3 & 1 \\
\hline Serbia & 50 & 23 & 3 & 16 & 2 & 1 \\
\hline
\end{tabular}

Źródło: Hajnal 1965, za: Kurkiewicz 1998.

Badania, które podjęła Kurkiewicz (1998) wskazują, że jeszcze na początku lat 70. kraje Europy Środkowej i Wschodniej nie wyróżniały się pod względem zawierania pierwszych małżeństw z grupy krajów wziętych do analizy (wybrane kraje Europy Północnej, Zachodniej, Południowej i Środkowowschodniej). Po dziesięciu latach grupa krajów Europy Środkowej i Wschodniej wyróżniała się jako obszar o wysokiej intensywności zawierania pierwszych małżeństw. W ciągu dziesięciu kolejnych lat pogłębiały się różnice między krajami Europy Środkowowschodniej i Europy Zachodniej. W chwili rozpadu kraje demokracji ludowej charakteryzowały się dość podobnymi zachowaniami matrymonialnymi. Już w połowie lat 90 . wartości charakterystyk małżeńskości tych krajów zaczęły zbliżać się do Europy Zachodniej i Północnej. Jak twierdzi większość badaczy zajmujących się przemianami demograficznymi drugiego przejścia demograficznego, rozpoczęcie procesów przemian z opóźnieniem skutkuje ich większą dynamiką, tak jest właśnie w przypadku krajów Europy Środkowej i Wschodniej. Według jednego z twórców tej koncepcji, van de Kaa, dodatkowym elementem wpływającym na przebieg procesów w tych krajach są czynniki społeczno-ekonimczne jako główne przyczyny powodujące głębokie i dynamiczne zmiany (van de Kaa 1994; 1996; 2001a; Lesthaeghe 1995; Lesthaeghe, Surkyn 2002; Frejka 2008; Kotowska i in. 2008).

Instytut na rzecz Polityki Rodzinnej UE w Raporcie Ewolucja rodziny w Europie 2009 stwierdził, że w krajach europejskich (analiza 27 krajów UE) mamy od 1980 r. do czynienia z drastycznym spadkiem liczby zawieranych małżeństw pomimo wzrostu liczby ludności o ponad $42 \mathrm{mln}$ osób. 
W latach 1980-2007 liczba zawieranych małżeństw spadła o 750 tys. (23,4\%), a współczynnik małżeństw z 6,75\%o (1980 r.) do 4,87\%o (2007 r.). Tylko dwa kraje, Dania i Szwecja, odnotowały wzrost liczby zawieranych związków (w wartościach bezwzględnych, a współczynnik małżeństw wykazywał tendencję zmienną i pod koniec okresu zmniejszył się). Sytuacja najgorzej przedstawiała się natomiast w Bułgarii, Słowenii i Estonii, gdzie spadek oscylował wokół 50\%. Rozpatrując jeszcze dłuższą perspektywę czasową, tj. lata 1960-2011, należy zauważyć systematyczne utrzymywanie się tendencji spadkowej współczynnika zawierania małżeństw w krajach europejskich (UE i pozostałych), chociaż można zaobserwować krótkie okresy wzrostu w krajach Europy Środkowowschodniej, np. 2003-2007. Najniższe wartości współczynnika małżeństw dotyczyły w 2011 r. Bułgarii $(2,9 \% 0)$, Andory $(3,1 \% 0)$, Słowenii $(3,2 \%)$ i Luksemburga $(3,3 \% 0)$, a najwyższe były w Macedonii (7,3\%o) i na Cyprze (7,2\%o). Polska, z wartością współczynnika małżeństw 5,4\%o, mieści się w grupie państw europejskich o wartościach średnich - por. ryc. 19. Uwzględnienie spadku częstości zawieranych małżeństw w krótkiej perspektywie czasowej, tj. w latach 2003-2011 wskazuje także na jego zróżnicowanie. Najwyższe jego wartości wystąpiły np. w Portugalii (33,3\%), Hiszpanii (32\%), Bułgarii (25,6\%), na Węgrzech (25\%). Polska znalazła się w grupie, gdzie wystąpił nieznaczny wzrost wartości współczynnika, ale jest to wynik przyjętego okresu analizy, jak wcześniej zaznaczono, od roku 2003 do 2007, w Polsce nawet do 2008, mieliśmy do czynienia z niewielkim, krótkookresowym wzrostem częstości wstępowania w związki małżeńskie, a po tym okresie znów nastąpiła tendencja spadkowa.

Wśród innych charakterystyk dotyczących zawieranych małżeństw istotną cechą jest wiek nowożeńców. W okresie międzywojennym (1931 r.) związki małżeńskie najczęściej zawierali mężczyźni w wieku 20-24 lata $(37,2 \%)$ oraz z grupy $25-29$ lat $(36,4 \%)$, w przypadku kobiet dominował przedział wiekowy $20-24$ lata $(44,3 \%)$. Wysoki był w tym czasie udział kobiet bardzo młodych (19 lat i mniej), które wchodziły w związki małżeńskie (siegał ponad 20\% wszystkich kobiet zawierających małżeństwa). W pierwszych latach po II wojnie światowej struktura wieku nowożeńców uległa niewielkim zmianom. Wyraźne przemiany w strukturze tego wieku nastąpiły od lat 60 . i polegały na zwiększeniu częstości związków zawieranych w młodszych grupach wiekowych (ryc. 20). Od lat 90., w wyniku zmian systemu społeczno-ekonomicznego, zmieniły się aspiracje i preferencje młodzieży wkraczającej w dorosłe życie. Wyrazem tych przemian jest m. in. zawieranie związków małżeńskich w późniejszym wieku, w $2011 \mathrm{r}$. blisko 45\% mężczyzn i ponad 39\% kobiet wstąpiło w związek małżeński mając 25-29 lat. Mediana wieku nowożeńców wyniosła 28,5 roku dla mężczyzn i 26,7 roku dla kobiet. W nieco późniejszym wieku zawierali małżeń- 
stwa mieszkańcy miast $(29,1$ roku mężczyźni i 27,4 roku kobiety) niż wsi (27,7 roku mężczyźni i 26,5 roku kobiety).

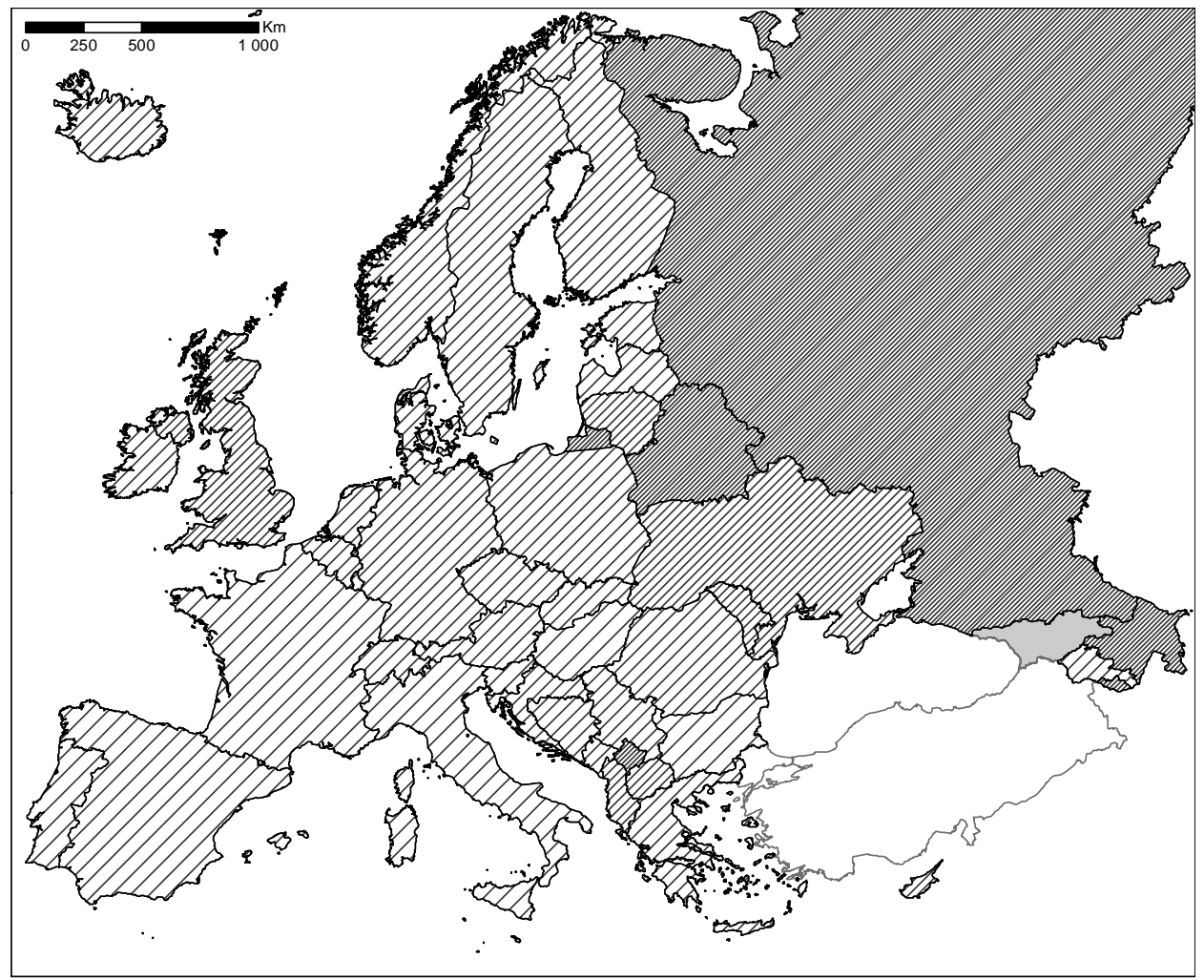

Współczynnik zawierania małżeństw [\%]

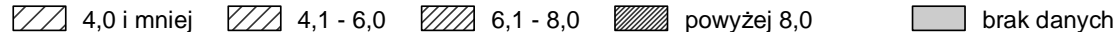

Ryc. 19. Współczynnik zawierania małżeństw w krajach europejskich w $2011 \mathrm{r}$.

Źródło: oprac. własne na podstawie Eurostat,

http://epp.eurostat.ec.europa.eu/portal/page/portal/population/data/database

W Polsce od 15 listopada 1998 r. wprowadzono możliwość zawierania, obok związków cywilnych, małżeństw wyznaniowych ze skutkami w prawie cywilnym, które potocznie są określane jako małżeństwa konkordatowe. W roku 2011 takich małżeństw zawarto 64,9\%, pozostałe zawarte małżeństwa stanowiły związki cywilne, $\mathrm{w}$ miastach odsetek ten wynosił niespełna $60 \%$, bardziej „popularne” były związki wyznaniowe na terenach wiejskich, gdzie stanowiły ponad $72 \%$ z ogółu wszystkich zalegalizowanych związków. Proporcje pomiędzy liczbą zawieranych związków wyznaniowych i cywilnych od 1999 r. zmieniały się na korzyść związków kościelnych, np. w roku 2002 stanowiły ponad 73\% zawartych związków. Sukcesywnie ich udział jednak malał i obecnie utrzymuje się na poziomie zbliżonym do $1999 \mathrm{r}$. 

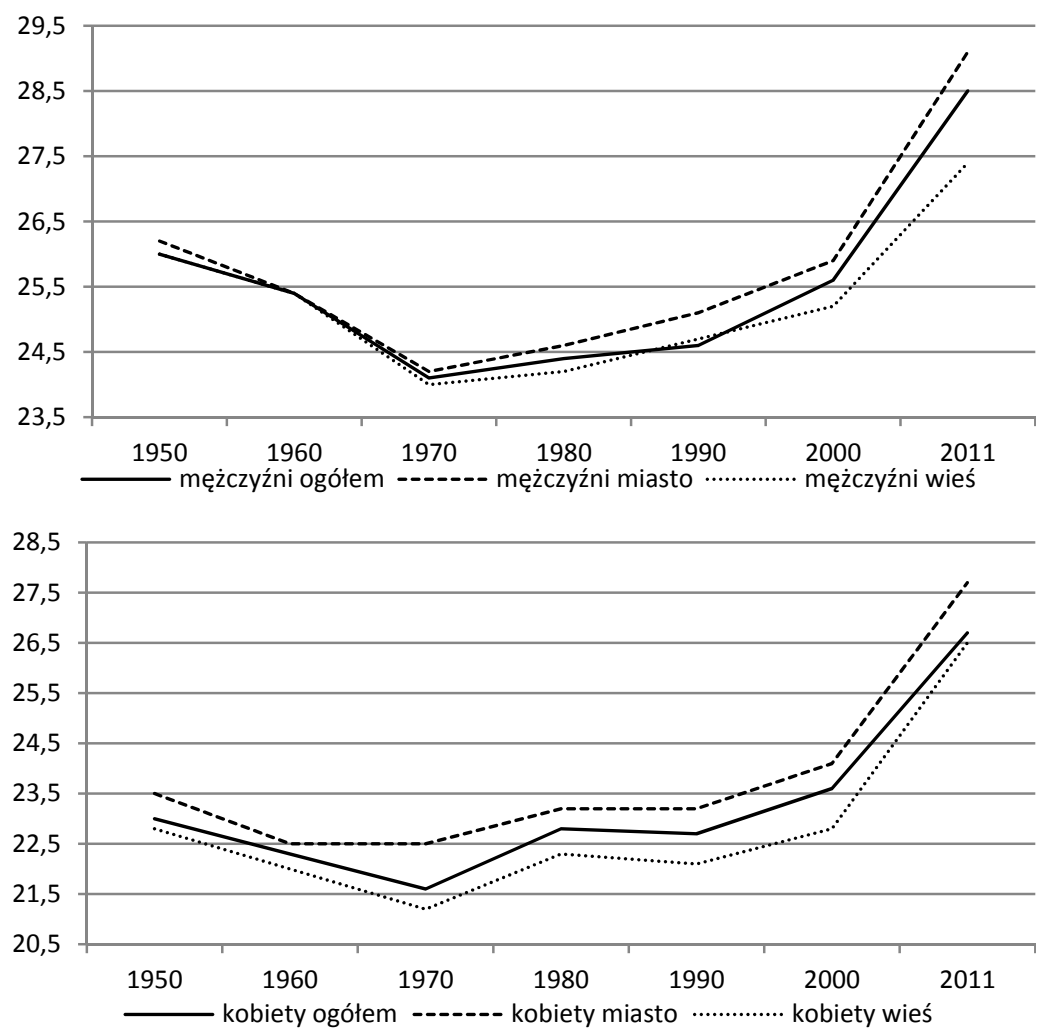

Ryc. 20. Mediana wieku nowożeńców w Polsce w latach 1950-2011

Źródło: oprac. własne na podstawie: Holzer 2003, Rocznik Demograficzny 2012, 2013, GUS, Warszawa

Wśród małżeństw zawieranych $\mathrm{w}$ Polsce zdecydowanie dominują małżeństwa pierwsze, tj. związki, w które wstępują panny i kawalerowie. Od lat na niemal niezmienionym poziomie utrzymuje się udział małżeństw pierwszych wśród ogółu zawieranych związków. W 2001 r. na 100 zawieranych małżeństw przypadało średnio 87 związków pierwszych; w kolejnych latach proporcja ta nieco uległa zmianie. W 2011 r. pary zawierające związek pierwszy raz stanowiły tylko 83,9\% ogółu. Odsetek małżeństw powtórnych, zawieranych przez obie osoby owdowiałe lub rozwiedzione, przez cały okres pozostawał na niemal niezmienionym poziomie i wynosił: $4,5 \%$ w 2001 r., 4,3\% w roku 2005 i 5,2\% w 2011 r. W miastach odsetki te były znacząco wyższe w zestawieniu z poziomem na wsi. Niskie wartości udziałów małżeństw powtórnych mogą wskazywać na malejącą skłonność do zawierania kolejnych związków. Jednak wysoce prawdopodobne jest, że zastępują je nieformalne związki (Sytuacja demograficzna... 2011). 
Kształtowanie się liczby i struktury małżeństw zawieranych w Polsce Ludowej było wypadkową zmian czynników demograficznych, a także uwarunkowań społeczno-ekonomicznych. Formowanie się małżeństw w okresie transformacji społeczno-ustrojowej w Polsce wskazuje na większą rolę czynników ekonomicznych i zmian świadomości społeczeństwa. Na modernizację społeczeństwa wpłynęła nie tylko transformacja ustrojowogospodarcza dokonująca się w naszym kraju, ale i przekształcenia w sferze osobowościowej wyrażające się w procesie autonomizacji jednostek, któremu towarzyszy rozwój idei wolności jednostki i jej samorealizacji także poza pracą (Tyszka 2002). Obrazem modernizacji społeczeństwa są m.in. zachowania demograficzne, a wśród nich zachowania matrymonialne.

\subsubsection{Rozwody i separacje}

Instytucja rozwodów została wprowadzona w Polsce 1 stycznia $1946 \mathrm{r}$. We wczesnym okresie powojennym, do 1955 r., częstość rozwodów była bardzo niska i utrzymywała się na poziomie 4,4-5,0 na 10 tys. ludności, dopiero w 1963 r. przekroczyła 6, a w 1969 - 10 (ryc. 21). Przez następne trzydzieści lat liczba rozwodów oscylowała wokół 11 na 10 tys. osób. W pierwszych latach wieku XXI liczba orzekanych rozwodów zwiększyła się z 45,3 (2001 r.) do 71,9 tys. (2006 r.), a następnie zmniejszyła się do 64,6 tys. w 2011 r. Stopa rozwodów dla kraju w 2011 r. wyniosła 1,7 na 1000 ludności ogółem (dla miast 2,1, a dla wsi 1,0). Według skali Edwarda Rosseta (opracowanej w latach 70.) jest to wysoki poziom współczynnika rozwodów, mieszczący się w przedziale $15-20$ rozwodów na 10 tys. ludności ${ }^{27}$. Od samego początku po wprowadzeniu możliwości rozwiązania małżeństwa poprzez rozwód, częściej korzystali z niej mieszkańcy miast niż wsi. Współczynnik rozwodów w drugiej połowie XX w. był w miastach kilkakrotnie wyższy niż na wsi, ale należy też zwrócić uwagę na sukcesywny wzrost rozpadu związków na terenach wiejskich. Co prawda nie są to duże wartości względne, ale w $2011 \mathrm{r}$. stopa rozwodów na terenach wiejskich była już tylko dwukrotnie mniejsza niż w miastach, a jeszcze $w$ latach 90 . była to wartość trzykrotna. Ponieważ różnice współczynnika rozwodów pomiędzy miastem a wsią były jeszcze do niedawna bardzo duże, to rozwody traktowano jako „problem miejski”. Od początku, biorąc pod uwagę wartości bezwzględne tego zjawiska, większość rozwodów była udzielana mieszkańcom miast, w 1946 r. spośród wszystkich rozwodów blisko 79\% dotyczyło

27 Edward Rosset zaproponował pięciostopniową skalę współczynników rozwodów: bardzo niskie (poniżej 5 rozwodów na 10 tys. ludności), niskie (5-10), średnie (10-15), wysokie (15-20) i bardzo wysokie (20 i więcej) - por. Rosset $1975 ; 1986$. 
ludności miejskiej. Odsetek ten już pod koniec lat 50. zwiększył się do ponad $85 \%$ i przez długi czas pozostawał na podobnym poziomie. W pierwszej dekadzie XXI w. udział rozwodów w miastach w ogólnej liczbie rozwodów zmniejszył się do niespełna 77\%, co świadczy o nasileniu się tego zjawiska na terenach wiejskich.

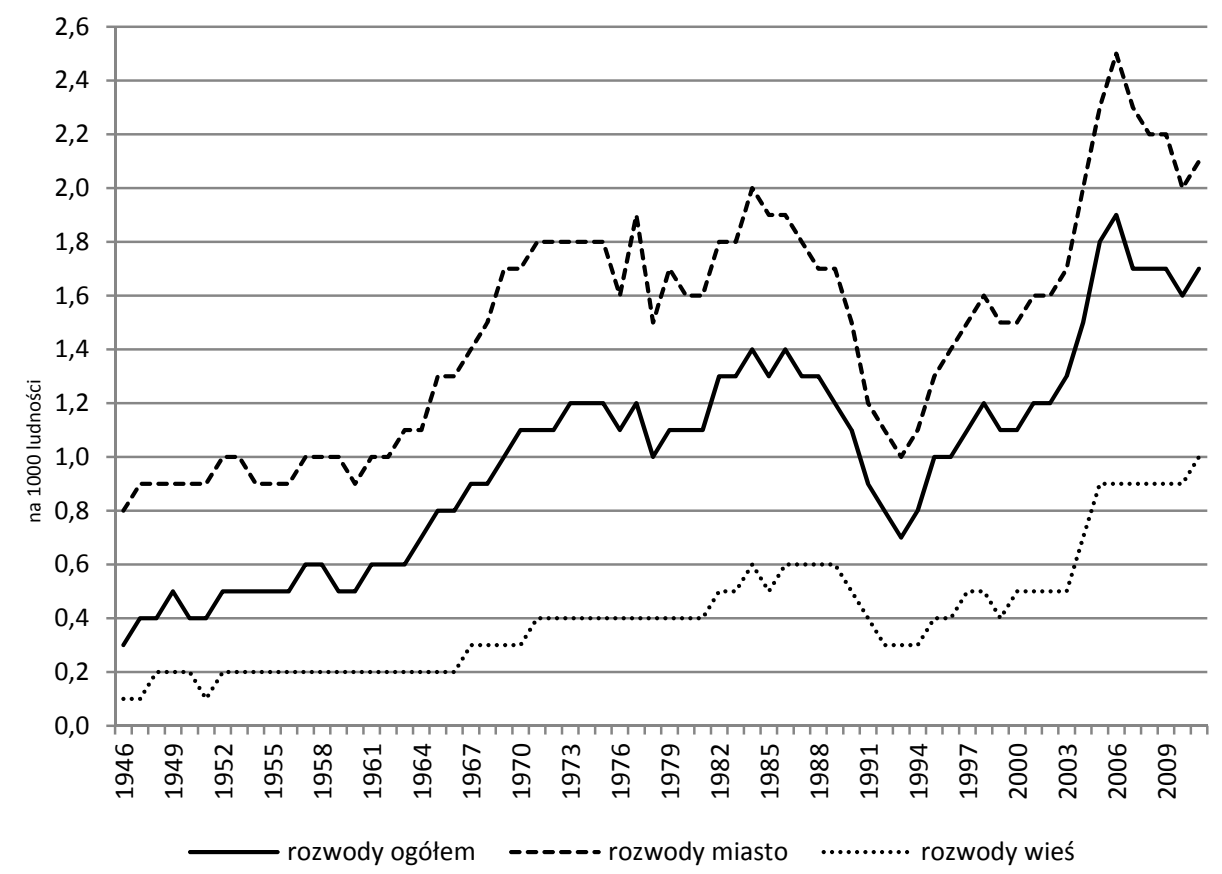

Ryc. 21. Rozwody na 1000 ludności w Polsce w latach 1946-2011

Źródło: oprac. własne na podstawie Rocznik Demograficzny 2012, 2013, GUS, Warszawa

Przedstawiony obraz rozpadu polskiej rodziny w wyniku rozwodów, przeprowadzony na postawie prostego miernika rozwodów, nie wskazuje na wyjątkowo złą sytuację w tym obszarze. Ale już poszerzenie analizy tego zjawiska o miarę obrazującą relacje liczby udzielonych rozwodów do nowo zawartych małżeństw prowadzi do zgoła innych wniosków (ryc. 22). Miernik ten wykazuje ogromną dynamikę $w$ analizowanym okresie, od wartości 28 rozwodów na 1000 zawartych związków małżeńskich w 1946 r. do 313 w 2011 r. Współczynnik rozwodów w przeliczeniu na 1000 małżeństw nowo zawartych zarówno w skali ogólnopolskiej, jak i w przekroju miastowieś zwiększył się znacząco. W 2011 r. na każde 1000 nowo zawartych małżeństw w mieście rozpadło się wskutek rozwodu 401 związków, na wsi była to wartość 178 . 


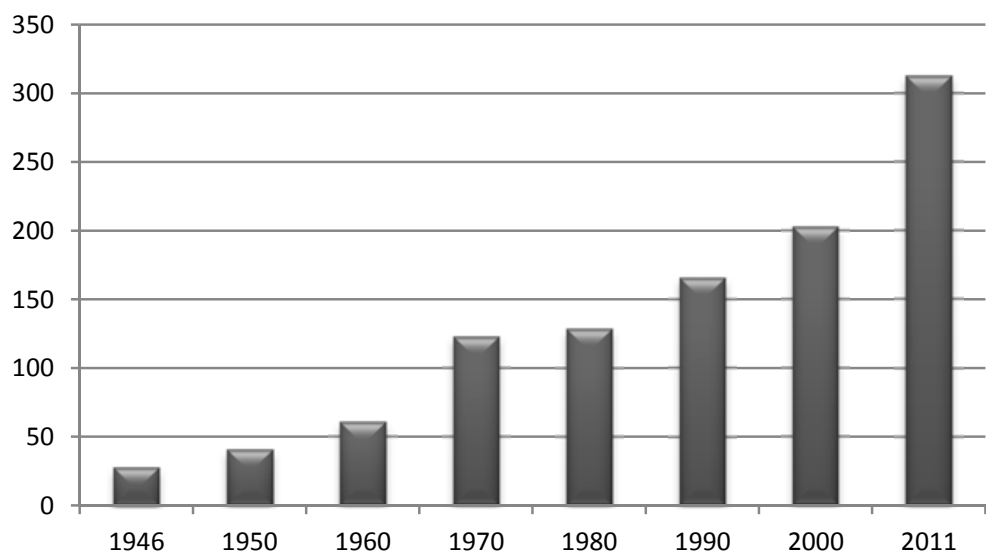

Ryc. 22. Rozwody na 1000 zawartych małżeństw w Polsce w latach 1946-2011 Źródło: oprac. własne na podstawie Rocznik Demograficzny 2012, 2013, GUS, Warszawa

Tendencja wzrostowa liczby udzielanych rozwodów występuje w wielu krajach europejskich, zróżnicowane jest jednak jej tempo. Na fakt wzrostu liczby rozwodów przy jednoczesnej spadkowej tendencji zawierania małżeństw w państwach europejskich wskazują Sobotka i Toulemon (2008). Wspomniany wyżej Raport Ewolucja rodziny w Europie 2009 podaje, że w 1980 r. w UE udzielono blisko 673 tys. rozwodów, a w 2007 już 1030 tys. W latach 1997-2007 na skutek rozwodu rozpadło się 10,3 mln małżeństw, które wychowywały ponad $17 \mathrm{mln}$ dzieci. Na początku lat 60. współczynniki rozwodów w Europie oscylowały od 0,3\%o w Grecji do 2,4\%o na Łotwie, a pięćdziesiąt lat później - od 0,1\%o na Malcie do 4\%o na Łotwie (ryc. 23). W większości krajów europejskich współczynnik rozwodów w tym czasie zwiększył się kilkukrotnie (np. w Belgii z 0,5 do 2,9\%; na Litwie z 0,9 do 3,4\%o, w Polsce z 0,5 do 1,7\%o). Wśród krajów Europy Środkowej i Wschodniej Polska ma jeden z niższych wskaźników rozwodów.

W polskim prawie funkcjonuje (od 1999 r.) obok rozwodów instytucja separacji uchylająca wspólnotę małżeńską (majątkową) bez prawa wstępowania współmałżonków w nowe związki małżeńskie. Liczba separacji prawomocnie orzeczonych w Polsce dynamicznie rosła, w 2000 r. orzeczono ich 1340, a w 2005 r. już 11600 (wzrost ponadośmiokrotny). Od 2006 r. rejestruje się spadek liczby orzeczonych separacji, w 2011 r. były to tylko 2843 przypadki. Współczynnik separacji (liczba orzeczonych separacji na 100 tys. mieszkańców) wyniósł w 2011 r. 7,4 i podobnie jak w przypadku rozwodów ich natężenie jest większe w miastach niż na wsiach (8,8 miasta, 5,1 wieś). Pomimo spadku bezwzględnej liczby orzeczonych separacji współczynnik separacji na 1000 nowo zawartych małżeństw zwiększył się do 13,8 w stosunku do roku poprzedniego (2010), w miastach wyniósł 16,8, a na wsi 9,3. 


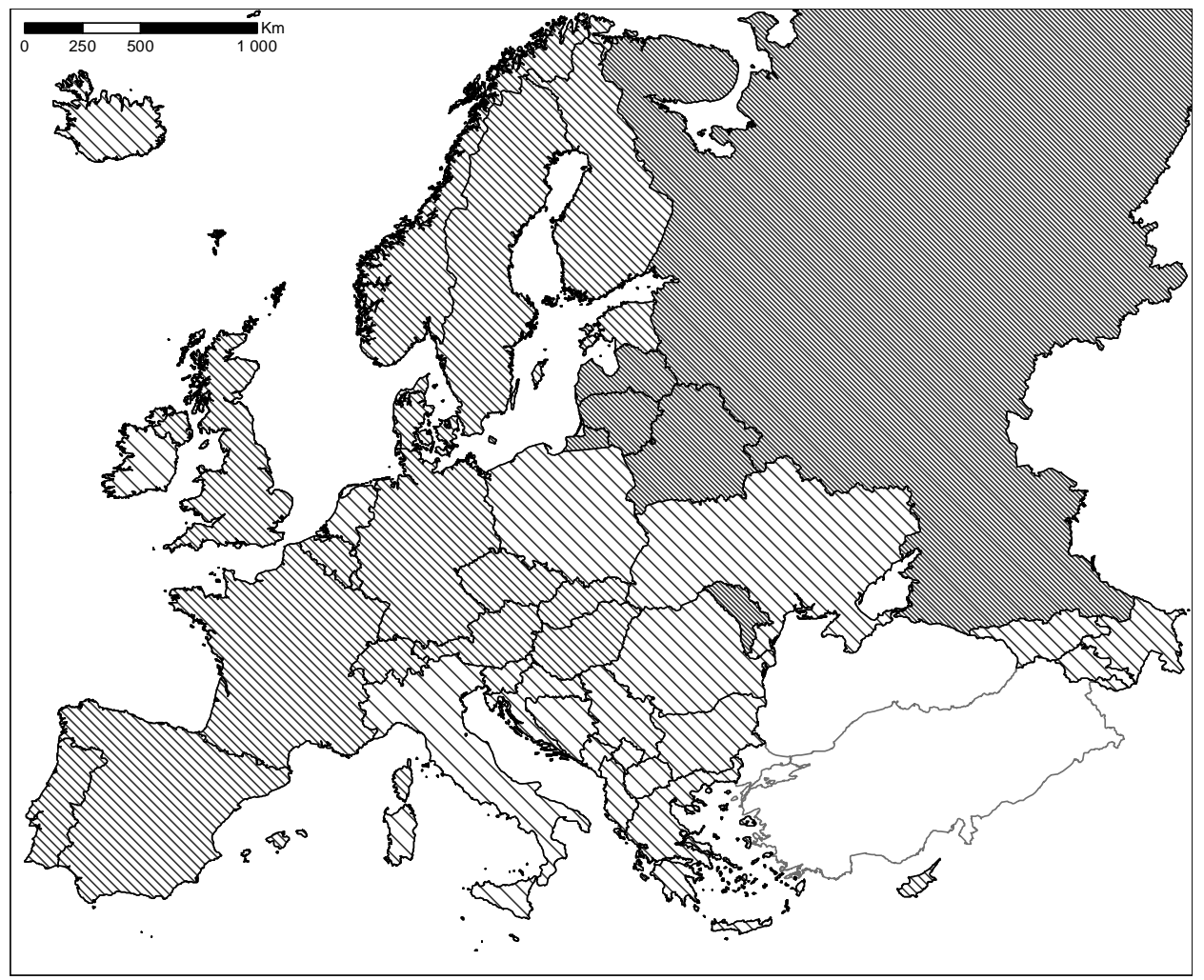

Współczynnik rozwodów

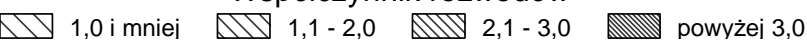

Ryc. 23. Rozwody w krajach europejskich w 2011 r.

Źródło: oprac. własne na podstawie Eurostat,

http://epp.eurostat.ec.europa.eu/portal/page/portal/population/data/database

\subsubsection{Kohabitacja jako alternatywa małżeństwa?}

Anthony Giddens, jeden z bardziej wnikliwych obserwatorów i analityków współczesności, twierdzi, że nie ma dzisiaj zmian poważniejszych i bardziej spektakularnych od tych, jakie zachodzą w obrębie małżeństwa, rodziny, życia osobistego i relacji emocjonalnych. Jego zdaniem rozgrywa się na naszych oczach globalna rewolucja stylu życia, z epicentrum w obszarze prywatności i intymności, a jej globalny charakter oznacza, że nie ma możliwości nieuczestniczenia w zmianach, jakie niesie nowoczesność. Są one jak huragan, który wcześniej czy później dociera wszędzie, a dotykając lokalnych układów nie pozostawia ich już takimi, jakie były wcześniej. Charakterystyczne jest to, że im później zmiany te gdzieś docierają, tym bardziej intensywny i burzliwy jest ich przebieg (Giddens 2006). 
Jednym z zjawisk związanych z nowym etapem życia małżeńskorodzinnego w ponowoczesnym świecie jest kohabitacja. Jest to forma, która staje się stopniowo uniwersalną formą życia rodzinnego oraz instytucją, ponieważ rodzą się w niej i wychowują dzieci. Kohabitacja nie jest nowym zjawiskiem (w sensie formalnym, ale nowym pod względem jakościowym), które pojawiło się wraz z innymi przemianami drugiego przejścia demograficznego. W niektórych krajach tradycja związków kohabitacyjnych jest długa, w innych pojawiła się na większą skalę w latach 60. XX w.

Krystyna Slany twierdzi, że generalnie można wyróżnić trzy typy związków małżeńskich: formalne (religijne lub świeckie), kohabitacyjne oraz zwyczajowe (Slany 2002a). Związek zwyczajowy nie wymaga formalizacji, zostaje bowiem zawarty poprzez złożenie wzajemnej deklaracji intencji poślubienia się. Taki typ małżeństwa obowiązuje często w małych, zamkniętych społecznościach. Dotychczas związki zwyczajowe uznawane są np. w krajach Ameryki Łacińskiej, a nawet w niektórych stanach USA - m.in. w Idaho, gdzie kohabitacja jest zakazana, i są ekwiwalentem małżeństwa formalnego. Jednak wraz z postępującą modernizacją nowoczesne społeczeństwa coraz częściej opierają się na związkach formalnych, określanych przez prawo. Państwo wkracza na „teren małżeństwa” z wieloma regulacjami prawnymi, chroniącymi małżonków i dzieci.

Zainteresowania badawcze kohabitacją nie są skoncentrowane tylko na analizach popularności tych związków wśród różnych grup ludzi oraz na ich definiowaniu, ale także na porównywaniu kohabitacji z małżeństwem bądź życiem w samotności. Analizom poddaje się wpływ związków kohabitacyjnych na trwałość i jakość małżeństwa, dobór partnerski oraz poziom dzietności takich związków i sytuację ekonomiczną dzieci ze związków nieformalnych (Raley 2000).

Próbując zdefiniować, czym jest kohabitacja, w sposób najprostszy można określić, że jest to „życie razem”, lecz bez dopełnienia formalności. Margaret Matlin (1996: 308) tak określa ten rodzaj związku: „kohabitacja oznacza, że dwie osoby płci przeciwnej żyją razem jak mąż i żona, nie będąc jednak małżeństwem”. Podkreślanie, że jest to związek bez formalizacji i instytucjonalizacji występuje także w podejściu Jana Trosta (1979). Kohabitacja, według tego autora, występuje wtedy, gdy osoby płci przeciwnej wspólnie zamieszkują ze sobą przez dłuższy czas, prowadzą gospodarstwo domowe i utrzymują związek seksualny. Takie zdefiniowanie kohabitacji jednoznacznie wyklucza utożsamianie jej z common-law marriage, czyli małżeństwem według prawa zwyczajowego. W niektórych stanach USA parę uważa się za małżeństwo jeśli spełnia ona pewne warunki, np. wspólnie mieszka jak żona i mąż przez pewien okres. Para taka ma prawa i obowiązki jak małżeństwa zawarte w sposób formalny (Megasłownik [b.d.]). Inaczej mówiąc, są to występujące we wszystkich kulturach stałe 
związki pozbawione właściwej im ceremonialnej oprawy, jasnych reguł dotyczących ich początku i zakończenia, cieszące się różnym stopniem akceptacji społecznej. Tym, co zbliża takie związki do małżeństwa, jest kooperacja w zajmowaniu się potomstwem i względna stabilność.

W tradycji zachodniej istnieją dla tych związków dwa terminy - konkubinat i kohabitacja. Pierwszy ma długą tradycję, istnieje od czasów starożytnego Rzymu. Rozumienie jego znaczenia podlegało wielu zmianom. Konkubinat jest $\mathrm{w}$ miarę stabilnym związkiem między partnerami bez spólnego zamieszkiwania (z łac. con cubare, czyli spać ze sobą - Kopaliński 1989). Drugi termin jest nowszy, choć też wzięty z łaciny. Kohabitacja jest związkiem, któremu koniecznie towarzyszy współzamieszkiwanie partnerów (z łac. habitare - mieszkać i com - wespół, z - por. Kopaliński 1989), bez zawarcia formalnego związku zgodnie z tym, jak jest on definiowany przez daną społeczność. Przy braku dzieci kohabitacja pozostaje formą związku partnerskiego, po pojawieniu się ich staje się rodziną. W polskim prawie brak jest definicji konkubinatu. Jego zdefiniowanie spadło na wymiar sprawiedliwości. W wyroku z 31 marca 1988 r. Sąd Najwyższy stwierdził, że „przez konkubinat należy rozumieć współżycie analogiczne do małżeństwa, tyle że pozbawione legalnego węzła. Oznacza to istnienie ogniska domowego charakteryzującego się duchową, fizyczną i ekonomiczną więzią łączącą mężczyznę i kobietę" (Brzezińska, Ćwiek, Pietkiewicz 2003). Krystyna Slany (2003) apeluje, aby upowszechniać stosowanie terminu kohabitacja, który co prawda nie ma wydźwięku romantycznego, ale też nie ma zabarwienia pejoratywnego, jak konkubinat. Jest według niej określeniem neutralnym i powinien funkcjonować w publikacjach naukowych czy publicystyce obok takich pojęć, jak związki nieformalne czy konsensualne.

Antropolodzy w stosunku do kohabitacji i konkubinatu sformułowali pewne prawidłowości. Kohabitacja i konkubinat wydają się strukturami, które poprzedzają zawarcie małżeństwa. Stymulują nakierowanie na nie, jeśli inaczej związek miałby być nieakceptowany, bądź stanowią przejściową formę między kolejnymi małżeństwami. Następną prawidłowością jest opozycyjność wobec formalnych struktur małżeńskich. Polega ona na wybieraniu kohabitacji lub konkubinatu jako kompromisowej formy związku, gdy nie chce się lub nie może z jakichś względów zawrzeć małżeństwa, a jednocześnie nie chce się poprzestawać wyłącznie na krótkotrwałych i rwanych relacjach (Jabłoński, Ostasz 2001).

Podobne stanowisko w kwestii klasyfikacji form kohabitacji zajmuje Anna Kwak, która jako jedna z pierwszych podjęła się w Polsce badań nad tym zjawiskiem. Według niej kohabitacja może:

- poprzedzać małżeństwo i stanowić okres przedłużonego „chodzenia ze sobą", 
- poprzedzać małżeństwo i stanowić przygotowanie do niego,

- stanowić alternatywną formę małżeństwa, zwłaszcza dla osób, które nie zamierzają się pobrać,

- stanowić formę niezamężnego życia, wyrastającą z ideologii niezależności (Kwak 1995a; b).

Istotnym czynnikiem pozwalającym rozpoznać związek kohabitacyjny jest czas pozostawania w nim; winien on wynosić przynajmniej kilka miesięcy. Badania Brow i Booth (1996) pokazują, że okres dwóch lat funkcjonowania w związku nieformalnym jest krytyczny. Oznacza to, że po tym czasie związek albo przestaje istnieć, albo partnerzy podejmują decyzję o jego legalizacji. Tak dzieje się w przypadku ok. 50\% kohabitantów. Tylko co dziesiąta para podejmowała zobowiązania długoterminowe, nie kończące się małżeństwem (Bumpass, Sweet 1989). Według badań prowadzonych w wielu krajach zjawisko kohabitacji upowszechnia się, rozciąga na różny wiek, stan cywilny, rasy czy klasy społeczne. Staje się bardzo szybko częścią kultury normatywnej danego społeczeństwa. Fenomenowi temu towarzyszy wzrost społecznej akceptacji, która jest wynikiem nowego, liberalnego podejścia do życia seksualnego niezamężnych osób. Dlatego badacze uważają, że kohabitacja może pojawić się w każdej fazie cyklu życia człowieka. Jest ważnym wydarzeniem w życiu ludzi młodych, osób w średnim wieku, a także ludzi starszych, będących po śmierci partnera/partnerki czy po rozwodzie. Wydawać by się mogło, że zainteresowanie kohabitacją jest największe ze strony ludzi młodych. Biorąc jednak pod uwagę fakt, że wydłuża się trwanie życia ludzkiego, to grupa osób, która utraciła partnera, może chcieć wejścia w nowy związek i nie musi to oznaczać małżeństwa. Istnieją geograficzne zróżnicowania $\mathrm{w}$ nasileniu się tego fenomenu. Jak pokazują badania socjologiczne i demograficzne, związki te są najbardziej popularne w krajach skandynawskich (chociaż w Norwegii znacznie mniej), szczególnie w Szwecji, gdzie mają długą tradycję (Kwak 1995b).

Dobór partnera w związku nieformalnym zależy od określenia znaczenia kohabitacji dla danego partnera. Jeśli jest ona substytutem formalnego małżeństwa, to dobór partnera nie powinien się różnić od doboru małżeńskiego. Wielu autorów podkreśla (Sanchez, Mannig, Smock 1998), że pomimo zachodzących zmian odnoszących się do sfery wolności osobistej, intymnej, aktywności zawodowej (przede wszystkim kobiet), jednostki dążą do wyboru partnera zgodnie z tradycyjnymi wzorami.

Wraz z pojawieniem się nowych zachowań i postaw demograficznych na polu małżeńskości, dokonują się także zmiany w prawodawstwie wielu krajów. Można pokusić się o stwierdzenie, że mamy do czynienia z ogólnoświatowym trendem ujmowania $w$ ramy prawne funkcjonowania związków pozamałżeńskich, $w$ tym także jednopłciowych. W tym ostatnim kontekście należy podkreślić, że od 1989 r. wiele państw wprowadziło do swoich 
porządków prawnych możliwości formalizacji związków tworzonych przez pary jednopłciowe. Państwa europejskie, które zdecydowały się na wprowadzenie nowych rozwiązań prawnych albo w drodze krajowego orzecznictwa sądowego usankcjonowały prawnie istnienie takich związków, to Andora, Austria, Belgia, Chorwacja, Czechy, Dania, Finlandia, Francja, Hiszpania, Holandia, Irlandia, Islandia, Liechtenstein, Luksemburg, Niemcy, Norwegia, Portugalia, Słowenia, Szwajcaria, Szwecja, Węgry, Wielka Brytania. Pierwszym krajem, który zdecydował się na wprowadzenie związków partnerskich była - w 1989 r. - Dania. Trzeba zauważyć, że w chwili obecnej w większości państw członkowskich Unii Europejskiej (w tym także w niektórych państwach, które przystąpiły do UE wraz z Polską w 2004 r.) wprowadzono regulacje pozwalające na formalizację wspólnego pożycia par osób tej samej płci. Instytucjonalizacja związków jednopłciowych w wymienionych powyżej państwach przybiera różne formy, zależne od woli ustawodawców krajowych. Należy wyróżnić cztery podstawowe formy regulowania funkcjonowania takich par:

1) małżeństwo,

2) związek partnerski,

3) konkubinat rejestrowany,

4) konkubinat nierejestrowany.

Małżeństwo - w zakresie, w jakim jest dostępne dla par różnopłciowych - zostało udostępnione (otwarte) jako instytucja prawna dla par jednopłciowych w dziesięciu państwach europejskich: Belgii, Danii, Hiszpanii, Holandii, Islandii, Norwegii, Portugalii, Szwecji oraz ostatnio we Francji i w Wielkiej Brytanii. Wprowadzenie możliwości zawierania małżeństw przez pary jednopłciowe odbyło się, w zależności od państwa, albo na zasadzie rozszerzenia w odpowiednich ustawach (np. kodeksy cywilne, kodeksy rodzinne) zakresu podmiotów uprawnionych do takiej formy instytucjonalizacji związku, albo poprzez przyjęcie specjalnych, odrębnych aktów prawnych regulujących funkcjonowanie takich małżeństw. Warto podkreślić, że niezależnie od przyjętej ścieżki wprowadzenia opisanej instytucji w wymienionych państwach - nie powstała w nich odrębna instytucja „małżeństw jednopłciowych” ani, tym bardziej, „małżeństw homoseksualnych”. Zmienił się jedynie krąg podmiotów uprawnionych do korzystania z niego.

Kolejną formą instytucjonalizacji związków par jednopłciowych, która została przyjęta przez wielu ustawodawców zagranicznych, jest związek partnerski, zwany też rejestrowanym partnerstwem. Rozwiązanie to funkcjonuje m.in. w Czechach, Irlandii, Niemczech, na Węgrzech i w Wielkiej Brytanii. Rejestrowane partnerstwo powstaje poprzez oficjalny akt rejestracji i przewiduje określony pakiet praw i obowiązków, ustalonych przez ustawodawcę, zazwyczaj z wyłączeniem praw rodzicielskich. Rozwiązanie takie wydaje się kompromisem pomiędzy poszanowaniem praw osób żyją- 
cych w związkach jednopłciowych a takimi względami, jak np. konstytucyjna definicja małżeństwa wykluczająca małżeństwo osób tej samej płci. Instytucja związku partnerskiego najczęściej reguluje podstawowe kwestie organizacyjne, takie jak rozliczenia podatkowe, sprawy emerytalne, ubezpieczeniowe, rentowe i spadkowe, problematykę najmu, pobytu w danym państwie oraz możliwość ustanowienia wspólnoty majątkowej. Jest jednocześnie - wśród państw, które zdecydowały się na regulację związków jednopłciowych - dużo popularniejsza niż małżeństwa. Obok związków partnerskich pojawiła się instytucja rejestrowanego konkubinatu, przewidująca węższy zakres uprawnień i obowiązków niż ww. formy instytucjonalizacji. Cechą charakterystyczną tej formy związku jest brak zmiany stanu cywilnego tworzących go osób. Pomimo to ten rodzaj konkubinatu nie tylko niesie ze sobą pewne uprawnienia i obowiązki, często uregulowane w jednym akcie prawnym, ale także - dla zaistnienia - wymaga ujawnienia i rejestracji przez państwo. Szczególnym przypadkiem - na pograniczu rejestrowanego partnerstwa i rejestrowanego konkubinatu - było francuskie rozwiązanie Pacte civil de solidarité (PACS). PACS jest cywilnoprawną umową, której zawarcie jest możliwe zarówno dla par jednopłciowych, jak i par różnopłciowych; większość uprawnień wynikających z PACS ma charakter majątkowy oraz socjalny. Co charakterystyczne, inaczej niż w przypadku małżeństwa czy związku partnerskiego, w przypadku PACS wzajemne obowiązki i prawa partnerów są określane przez nich samych, a nie przez ustawodawcę, który ustalił jedynie katalog praw i obowiązków służących im wobec osób trzecich. Od innych rejestrowanych konkubinatów PACS odróżnia przede wszystkim to, że wzajemne prawa i obowiązki partnerów zostają spisane, są zatem dookreślone, a nie płynne i niejasne. Ustawa o PACS składa się z 15 artykułów i - w odróżnieniu od ustaw wprowadzających związki partnerskie, kompleksowo regulujących tę instytucję $\mathrm{w}$ jednym akcie prawnym - stanowi nowelizację kilku innych aktów prawnych, w tym francuskiego kodeksu cywilnego, kodeksu podatkowego, kodeksu zabezpieczenia społecznego, przepisów dotyczących działalności urzędów publicznych rządowych i samorządowych, najmu lokali mieszkalnych, przepisów prawa pracy oraz regulacji dotyczących pobytu na terenie Francji.

Konkubinat nierejestrowany to najprostsza forma prawnego ujęcia związku dwóch osób. Jest to określony przez ustawodawcę lub orzecznictwo i piśmiennictwo stan faktyczny, z którym przepisy prawa, zwykle rozproszone w wielu aktach prawnych, wiążą pewne konsekwencje prawne obowiązki, uprawnienia, ale często też ograniczenia. Dla par jednopłciowych rozwiązanie takie ma zastosowanie albo z woli ustawodawcy (tak jest m.in. w przypadku Węgier czy Chorwacji), albo w przypadku konsekwentnej i spójnej wykładni przepisów. W Polsce konkubinat, występujący pod 
nazwą wspólnego pożycia (w niektórych ustawach - „faktycznego wspólnego pożycia"), obejmuje tylko i wyłącznie pary różnopłciowe. W naszym kraju, o czym była już mowa w podrozdziale 3.1., od lat 90. prowadzona jest dyskusja publiczna i na forum parlamentu o możliwościach legalizacji związków partnerskich w naszym kraju.

Analiza zjawiska kohabitacji nie jest możliwa bez wiedzy o jej rozmiarach. Pierwsze informacje o rozmiarach tej formy związków w Polsce można znaleźć w pracach W. Chechlińskiego (1978; 1982). Opierając się na danych z mikrospisu z 1974 r. oszacował on, że wśród ogółu par małżeńskich związki kohabitacyjne stanowiły 1\%, czyli liczą ok. 90 tys. par. S. Golinowska (1995) oceniła na postawie wyników spisu powszechnego z 1988 r., że forma konkubinatu występowała w Polsce rzadko, w porównaniu $\mathrm{z}$ innymi krajami, i oszacowała, że tego typu związków było ok. 200 tys., co stanowiło ok. 2\% wszystkich związków rodzinnych.

Przeprowadzone w pierwszej połowie lat 90 . XX w. badania obejmujące kraje europejskie przyniosły wiele cennych informacji, pokazując rozmiary kohabitacji w Polsce na tle innych państw europejskich. Badaniami objęto cztery grupy państw:

1) północnej Europy - Norwegia, Finladia, Szwecja,

2) zachodniej Europy - Austria, Szwajcaria, Francja, Niemcy (podzielone na zachodnie i wschodnie),

3) południowej Europy - Hiszpania, Włochy,

4) wschodniej Europy - Łotwa, Litwa, Polska, Węgry.

Analizie poddano m.in. sposób formowania się pierwszych związków, wyróżniając trzy sytuacje: bezpośrednie zawarcie małżeństwa bez kohabitacji, kohabitacja poprzedzająca małżeństwo, kohabitacja (tab. 8). Wyniki tych badań jednoznacznie wskazały na zróżnicowanie procesu formowania się pierwszych związków w zależności od wieku kobiet i przynależności kraju do danej grupy. Zarówno młodsze (25-29), jak i starsze kobiety (3539) z krajów wschodniej Europy najczęściej wchodziły w związki małżeńskie. Szczególnie wysokie wskaźniki miały tu Polska, Węgry i Litwa. Natomiast w krajach północnej i zachodniej Europy kobiety, dla których małżeństwo stanowi pierwszy związek, należą do mniejszości. Polska w pierwszej połowie lat 90. ubiegłego wieku na tle wyników badań jawi się jako kraj najbardziej stabilny w utrzymywaniu pierwszego związku.

Dane statystyczne z roku 1995 (z mikrospisu) mówią, że w Polsce 310545 osób żyło w związkach nieformalnych, ale dane te ocenia się jako niepełne i zaniżone (Slany 2002a). Związki takie występowały przede wszystkim w miastach - 75,2\%. Większość kohabitantów (70\%) w Polsce to osoby o niższych poziomach wykształcenia - zasadniczym zawodowym, podstawowym i niepełnym podstawowym. Spis powszechny z 2002 r. dostarczył informacji o stanie cywilnym zarówno prawnym, jak i faktycz- 
nym mieszkańców naszego kraju. Wynika z nich, że w związkach partnerskich żyły w Polsce 396054 osoby, co stanowiło 1,3\% wszystkich mieszkańców powyżej 15. roku życia (1,5\% mieszkańców miast i 0,9\% mieszkańców wsi). Związki nieformalne były bardziej rozpowszechnione w miastach, 75\% wszystkich związków tworzyli bowiem mieszkańcy miast, a tylko 25\% żyjący na wsi. Na podstawie wyników NSP 2002 po raz pierwszy można porównać liczbę ludności według stanu cywilnego prawnego i faktycznego. Z danych wynika, że ponad 140 tys. żonatych mężczyzn i blisko 174 tys. zamężnych kobiet zrezygnowało $\mathrm{z}$ życia $\mathrm{w}$ prawnie zawartym związku małżeńskim (stan cywilny żonaci/zamężne - niepozostający w małżeństwie), przy czym - spośród nich - ok. 17 tys. mężczyzn (12\%) i 13 tys. kobiet (2\%) stworzyło związki partnerskie, a pozostali żyli w separacji faktycznej (tab. 9). Dla pozostałych kategorii stanu cywilnego różnica między liczbą osób o stanie cywilnym prawnym i faktycznym wskazuje, ile osób o danym stanie cywilnym prawnym stworzyło związki partnerskie. Największą grupę partnerów tworzą kawalerowie (102,5 tys.) i panny (97,0 tys.) oraz osoby rozwiedzione (67 tys. mężczyzn i 59,4 tys. kobiet), a stosunkowo rzadko osoby owdowiałe (odpowiednio 9,8 tys. i 26,9 tys. osób). W przypadku 86,1\% związków partnerskich pozostawanie w związku nieformalnym jest kwestią wyboru, ponieważ zgodnie z obowiązującym prawem stan cywilny obojga partnerów umożliwia im zawarcie związku małżeńskiego. Największą grupę związków partnerskich (34,7\%) tworzą kawalerowie i panny, a 15,9\% - osoby rozwiedzione. Ponad połowa (54,1\%) wśród partnerów-mężczyzn jest w wieku 40 lat i więcej; kobiety w tym samym wieku stanowią 46,2\% partnerek.

Tabela 8

Rodzaje pierwszych związków wśród kobiet według wieku w czasie badania

(European Fertility and Family Survey)

\begin{tabular}{|c|c|c|c|c|c|c|}
\hline \multirow[b]{2}{*}{ Państwo } & \multicolumn{3}{|c|}{ Wiek kobiet 25-29 lat } & \multicolumn{3}{|c|}{ Wiek kobiet 35-39 lat } \\
\hline & $\begin{array}{c}\text { małżeństwo } \\
\text { bezpośred- } \\
\text { nio }\end{array}$ & $\begin{array}{c}\text { kohabita- } \\
\text { cja } \\
\text { i małżeń- } \\
\text { stwo }\end{array}$ & $\begin{array}{c}\text { kohabita- } \\
\text { cja }\end{array}$ & $\begin{array}{c}\text { małżeństwo } \\
\text { bezpośred- } \\
\text { nio }\end{array}$ & $\begin{array}{c}\text { kohabita- } \\
\text { cja } \\
\text { i małżeń- } \\
\text { stwo }\end{array}$ & $\begin{array}{c}\text { kohabita- } \\
\text { cja }\end{array}$ \\
\hline 1 & 2 & 3 & 4 & 5 & 6 & 7 \\
\hline Szwecja & 7 & 41 & 52 & 8 & 62 & 30 \\
\hline $\begin{array}{l}\text { Norwe- } \\
\text { gia }\end{array}$ & 24 & 40 & 35 & 62 & 40 & 7 \\
\hline Finlandia & 17 & 43 & 40 & 31 & 36 & 23 \\
\hline Francja & 12 & 30 & 58 & 48 & 34 & 19 \\
\hline Austria & 19 & 41 & 40 & 30 & 42 & 28 \\
\hline
\end{tabular}


Tabela 8 c. d.

\begin{tabular}{|l|c|r|r|r|r|r|}
\hline \multicolumn{1}{|c|}{1} & 2 & 3 & 4 & 5 & 6 & 7 \\
\hline $\begin{array}{l}\text { Szwajca- } \\
\text { ria }\end{array}$ & 19 & 44 & 37 & 30 & 52 & 18 \\
\hline RFN & 16 & 38 & 46 & 38 & 33 & 29 \\
\hline NRD & 15 & 35 & 50 & 21 & 26 & 53 \\
\hline Włochy & 86 & 8 & 6 & 91 & 5 & 4 \\
\hline $\begin{array}{l}\text { Hiszpa- } \\
\text { nia }\end{array}$ & 80 & 8 & 12 & 91 & 4 & 5 \\
\hline Łotwa & 50 & 34 & 17 & 67 & 26 & 8 \\
\hline Litwa & 75 & 9 & 16 & 78 & 10 & 12 \\
\hline Węgry & 76 & 14 & 10 & 84 & 9 & 7 \\
\hline Polska & 95 & 3 & 2 & 96 & 3 & 1 \\
\hline
\end{tabular}

Źródło: Kiernan 2000, za: Kwak 2005.

Tabela 9

Ludność w wieku 15 lat i więcej według stanu cywilnego prawnego i faktycznego oraz płci w $2002 \mathrm{r}$.

\begin{tabular}{|l|r|r|r|r|r|r|}
\hline \multirow{4}{*}{ Stan cywilny } & \multicolumn{3}{|c|}{ Mężczyźni } & \multicolumn{3}{c|}{ Kobiety } \\
& \multicolumn{2}{|c|}{$\begin{array}{c}\text { według stanu cywilnego (w tys.) } \\
\text { prawne- } \\
\text { go }\end{array}$} & $\begin{array}{c}\text { faktycz- } \\
\text { nego }\end{array}$ & różnica & \multicolumn{2}{c|}{ prawhug stanu cywilnego (w tys.) } \\
\hline Ogółem & 14962,1 & 14962,1 & $\mathrm{x}$ & 16326,3 & \multicolumn{1}{c|}{$\begin{array}{c}\text { faktycz- } \\
\text { nego }\end{array}$} & różnica \\
\hline Panna/kawaler & 4965,5 & 4863,0 & $-102,5$ & 3966,1 & 3869,1 & $-97,0$ \\
\hline $\begin{array}{l}\text { Żona- } \\
\text { ty/zamężna }\end{array}$ & 8963,7 & 8823,4 & $-140,3$ & 9054,1 & 8880,4 & $-173,7$ \\
\hline $\begin{array}{l}\text { Part- } \\
\text { ner/partnerka }\end{array}$ & $\mathrm{x}$ & 198,0 & $\mathrm{x}$ & $\mathrm{x}$ & 198,0 & $\mathrm{x}$ \\
\hline $\begin{array}{l}\text { Wdo- } \\
\text { wiec/wdowa }\end{array}$ & 434,5 & 424,7 & $-9,8$ & 2473,2 & 2446,3 & $-26,9$ \\
\hline Rozwiedzeni & 461,2 & 394,2 & $-67,0$ & 695,2 & 635,8 & $-59,4$ \\
\hline Separowani & 10,7 & 134,0 & $+123,3$ & 14,5 & 175,2 & $+160,7$ \\
\hline Nieustalony & 126,5 & 124,8 & $-1,7$ & 123,2 & 121,5 & $-1,7$ \\
\hline
\end{tabular}

Źródło: Ludność. Stan i struktura demograficzno-społeczna, 2003, GUS, Warszawa.

W spisie ludności z roku 2011 stan cywilny faktyczny był ustalany na podstawie charakteru związku, w jakim faktycznie żyje dana osoba. Osoby żyjące w związkach nieformalnych (kohabitanci), niezależnie od ich stanu cywilnego prawnego, zostały ujęte jako pary tworzące związki partnerskie. Zatem stan cywilny faktyczny - oprócz kategorii prawnych: kawaler/panna, osoby pozostające w prawnym związku małżeńskim, osoby owdowiałe i rozwiedzione wyodrębnia także dwie dodatkowe kategorie, tj. osoby żyjące w związkach kohabitacyjnych oraz małżonkowie pozostający $\mathrm{w}$ separacji (w separacji orzeczonej prawnie lub deklarowanej). Tym samym populacje ludności w wieku 15 lat i więcej według stanu cywilnego prawnego i faktycznego różnią się istotnie (por. tab. 10). Wyniki spisu 2011 r. w zakresie stanu cywilnego 
faktycznego ukazały strukturę populacji bardzo zbliżoną do uzyskanej w spisie 2002 r. Dodatkowo, zaobserwowane zmiany były analogiczne do stanu cywilnoprawnego, tj. - w stosunku do 2002 r. - proporcje kawalerów/panien pozostały praktycznie na tym samym poziomie (nieznacznie obniżył się udział dla kobiet), odsetek osób deklarujących pozostawanie w związku małżeńskim obniżył się o 1,5\%, w przypadku zaś osób owdowiałych odnotowano nieznaczny wzrost, zwiększył się też (o 1,1\%) udział osób rozwiedzionych. Znacząco większe zmiany nastąpiły w przypadku osób pozostających w związkach kohabitacyjnych. Liczba partnerek/partnerów wzrosła o prawie 2/3 (z niespełna 400 tys. w 2002 r. do prawie 650 tys. w 2011 r.) - co oznacza wzrost liczby związków kohabitacyjnych z prawie 200 tys. w 2002 r. do ok. 320 tys. w 2011 r. Inna sprawa, że udział tej grupy osób w całej populacji nadal nie jest znaczący - w 2002 r. kohabitanci stanowili 1,3\%, w 2011 r. zaś 2,0\% ogółu ludności w wieku 15 lat i więcej. Zdecydowana większość partnerów mieszka w mieście (80\%). Jak wynika z analizy porównawczej stanu cywilnego prawnego i faktycznego największe grupy wśród osób będących w związkach nieformalnych stanowią kawalerowie (203,6 tys.) oraz panny (192,7 tys.).

Tabela 10

Ludność w wieku 15 lat i więcej według stanu cywilnego prawnego i faktycznego oraz płci w 2011 r.

\begin{tabular}{|l|r|r|r|r|r|r|}
\hline \multirow{2}{*}{ Stan cywilny } & \multicolumn{4}{|c|}{$\begin{array}{c}\text { Mężczyźni według stanu } \\
\text { cywilnego (w tys. }\end{array}$} & \multicolumn{3}{c|}{$\begin{array}{c}\text { Kobiety według stanu } \\
\text { cywilnego (w tys.) }\end{array}$} \\
\cline { 2 - 8 } & $\begin{array}{c}\text { prawne- } \\
\text { go }\end{array}$ & $\begin{array}{c}\text { faktyczne- } \\
\text { go }\end{array}$ & $\begin{array}{c}\text { różni- } \\
\text { ca }\end{array}$ & $\begin{array}{c}\text { prawne- } \\
\text { go }\end{array}$ & $\begin{array}{c}\text { faktycz- } \\
\text { nego }\end{array}$ & $\begin{array}{c}\text { różni- } \\
\text { ca }\end{array}$ \\
\hline Ogółem & 15652,2 & 15652,2 & $\mathrm{x}$ & 17027,4 & 17027,4 & $\mathrm{x}$ \\
\hline Panna/kawaler & 5289,4 & 5085,8 & $-203,6$ & 4130,6 & 3937,9 & $\begin{array}{r}- \\
192,7\end{array}$ \\
\hline Żonaty/zamężna & 9095,1 & 8999,0 & $-96,1$ & 9141,4 & 9020,3 & - \\
\hline $\begin{array}{l}\text { Part- } \\
\text { ner/partnerka }\end{array}$ & $\mathrm{x}$ & 326,2 & $\mathrm{x}$ & $\mathrm{x}$ & 317,6 & $\mathrm{x}$ \\
\hline Wdowiec/wdowa & 481,8 & 472,6 & $-9,2$ & 2645,0 & 2621,3 & $-23,7$ \\
\hline Rozwiedzeni & 656,2 & 561,5 & $-94,7$ & 973,3 & 886,9 & $-86,4$ \\
\hline Separowani & $\mathrm{x}$ & 78,6 & $\mathrm{x}$ & $\mathrm{x}$ & 106,5 & $\mathrm{x}$ \\
\hline Nieustalony & 129,7 & 129,6 & $-0,1$ & 137,1 & 137,0 & $-0,1$ \\
\hline
\end{tabular}

Uwaga: a - w 2011 r. kategoria osób separowanych w klasyfikacji stanu cywilnego prawnego była zaliczana do osób żonatych/zamężnych.

Źródło: Ludność. Stan i struktura demograficzno-społeczna, 2013, GUS, Warszawa.

Wśród par nieformalnych istnieje w Polsce dość duże zróżnicowanie, jeśli chodzi o wiek, płeć czy też motywy przebywania w związku. Pary nieformalne tworzą bowiem nie tylko partnerzy $\mathrm{z}$ „przeszłością matrymonialną", a więc mający doświadczenie z poprzednich formalnych związków 
małżeńskich, ale głównie młodzi ludzie nielegalizujący związku z różnych powodów, m.in. są to przeszkody ekonomiczne, mieszkaniowe czy obawa przed utratą wolności (Brzezińska, Ćwiek, Pietkiewicz 2003). Występują także trwałe nieformalne związki par homoseksualnych.

\subsection{Przestrzenne zróżnicowanie małżeńskości w Polsce}

\subsubsection{Zróżnicowanie przestrzenne zawieranych małżeństw według pod- regionów}

Zawieranie związków małżeńskich ma podstawowe znaczenie dla śledzenia zmian w zakresie stosunków ludnościowych. Ma ono określone skutki dla kształtowania się procesów ludnościowych, gdyż głównie w małżeństwie jako podstawowej komórce społeczeństwa dokonuje się w dalszym ciągu w Polsce proces reprodukcji. Poszukiwaniem tendencji w sposobie zawierania związków małżeńskich, czyli formowania się małżeństw, interesowano się od dawna. Do czynników mających wpływ na kształtowanie się stopy małżeństw zalicza się: aktualną sytuację demograficzną, która jest wynikiem wydarzeń lat minionych, zmiany gospodarcze, regulacje prawne oraz przekształcenia świadomościowo-mentalne społeczeństwa. Wymienione czynniki często działają razem, a w pewnych okresach, dłuższych bądź krótszych, zarysowuje się przewaga jednego z nich. Potwierdzają to badania prowadzone $\mathrm{w}$ wielu krajach. W Polsce na zachowania demograficzne, $\mathrm{w}$ tym matrymonialne, od lat 60 . XX w. poczynając, silniej oddziałują czynniki ekonomiczno-społeczne i świadomościowe aniżeli uwarunkowania w zakresie procesów i struktur ludnościowych (Slany 2000). Proces spadku małżeńskości trwa w Polsce od lat 80. ubiegłego wieku. Trudno ocenić, na ile spowodowany jest on przemianami gospodarczymi, a w jakim stopniu wynika ze związanych z nim przeobrażeń świadomościowych, z przenoszenia wzorców zachowań z wysoko rozwiniętych krajów zachodnich. Część badaczy jest zdania, że o ile w Europie Północnej i Zachodniej zmiany zachowań rodzinnych powinny być interpretowane jako stanowiące głównie konsekwencje zmian systemu wartości i norm zgodnie z teorią drugiego przejścia demograficznego, o tyle w krajach Europy Środkowowschodniej w pierwszej kolejności znaczenie mają czynniki ekonomiczne (Frejka 2008; Kotowska i in. 2008).

W Polsce rozważania na temat przestrzennych przemian małżeńskości prowadzone są według województw (Gawryszewski 2005; Barański, Karczmarek 2007) czy powiatów dla wybranego regionu kraju (Gałka 2009). Wszystkie one wskazują na istotne przestrzenne różnice skłonności do zawierania małżeństw, niezależnie od stopnia agregacji danych i ich zmienności w czasie. Jednocześnie powstało relatywnie mało prac ujmujących zjawisko 
odrębnie dla obszarów miejskich i wiejskich, wskazują one jednak na odmienność zachowań mieszkańców (Podogrodzka 2012b; 2013).

Analiza przestrzennego zróżnicowania zachowań demograficznych w obszarze małżeńskości została przeprowadzona w ujęciu podregionów. Dysproporcje regionalne są tu wyraźne, ale charakter zróżnicowania dla poszczególnych elementów małżeńskości nie jest jednakowy, podobnie jak tempo ich zmian. Dynamikę większej części przemian w zachowaniach demograficznych określono dla lat 2002-2011.

Przez kilkadziesiąt lat od zakończenia II wojny światowej dynamika zmian w zachowaniach matrymonialnych w Polsce była imponująca. Dotyczyła przede wszystkim spadku częstości zawierania małżeństw, ale także zmian zróżnicowania przestrzennego. Analizy zróżnicowania regionalnego prowadzone przez Gawryszewskiego (2005) wykazały, że układ przestrzenny częstości zawierania małżeństw w roku 2000 jest odwróceniem rozkładu, jaki występował pół wieku wcześniej, tylko na o połowę niższym poziomie wartości współczynników. Ziemie zachodnie, gdzie w 1950 r. występowała wysoka stopa małżeństw, obecnie wyróżniają się niską częstością ich zawierania, natomiast ziemie dawne odwrotnie, obecnie mają wyższe współczynniki zawieranych małżeństw. Poza tym zróżnicowania stopy małżeństw są niewielkie: w 1950 r. współczynnik zmienności stopy małżeństw według powiatów wynosił 26\% średniej krajowej, w 1970 r. 11\%, w 2000 zaś tylko 9\% średniej krajowej stopy małżeństw i podobnie w roku $2011(9,5 \%)$.

W 2011 r. współczynnik zawierania małżeństw na 1000 ludności w wieku 15 lat i więcej wyniósł dla Polski 6,3\%o, najwyższe zaś wartości (powyżej 7\%o) osiągnął w podregionach: bialskim, nowosądeckim, ostrołęckosiedleckim, krośnieńskim, przemyskim, tyskim i leszczyńskim. Wartości tego współczynnika są wyższe dla obszarów wiejskich $(6,7 \% 0)$ niż dla miast $(6,1 \% 0)$, ale różnica jest niewielka, co świadczy o podobieństwie zachowań matrymonialnych mierzonych częstością zawierania małżeństw. Podregiony o podobnych wartościach wskaźnika tworzą skupiska stosunkowo zwartych przestrzennie obszarów rozmieszczonych w różnych częściach kraju (ryc. 24). Nieco wyraźniejsze jest ich grupowanie w przypadku terenów wiejskich niż miast, można tutaj wyróżnić cztery takie zgrupowania: trzy z nich (podregiony południowo-wschodnie, środkowo-wschodnie i północno-środkowe) o największej częstości zawierania małżeństw i jedno zgrupowanie, które tworzą podregiony zachodnie, gdzie skłonności do wstępowania w związki małżeńskie są najniższe. Natomiast dla miast wyraźne jest jedno zgrupowanie przestrzenne, tworzą je podregiony zachodnie (koszaliński, stargardzki, szczeciński, Szczecin, gorzowski i zielonogórski), w których wartość współczynnika zawierania małżeństw na 1000 ludności w wieku 15 lat i więcej zawiera się w przedziale 5,5-6,0. 
Ostatnie dwanaście lat (1999-2011) to okres dalszych zmian w formowaniu się małżeństw w Polsce, gdzie obserwujemy w przeważającej liczbie podregionów sukcesywny spadek skłonności do zawierania związków małżeńskich. Pokazują to różnice wartości współczynnika zawierania małżeństw na 1000 ludności w wieku 15 lat i więcej pomiędzy 2011 i 1999 r., które tylko dla trzech podregionów były dodatnie (gliwicki, katowicki i tyski).

Od 2004 r. w Polsce mieliśmy do czynienia z krótkookresowym wzrostem częstości zawierania małżeństw. Jest to widoczne przy analizie porównawczej dla 2002 i 2011 r.28 (ryc. 25). W tym czasie większość podregionów (42) odnotowała bardzo niewielki wzrost współczynnika zawierania małżeństw, tylko $\mathrm{w}$ podregionie tyskim i gliwickim był to przyrost powyżej 1\%o. Zmiany te nie wpłynęły, jak widać, na ogólny obraz zróżnicowania przestrzennego częstości zawierania małżeństw w Polsce (ryc. 26).

${ }^{28}$ Autorka uzasadniała we wstępie powody wyboru okresu analizy zróżnicowania przestrzennego zachowań w Polsce (2002-2011), niemniej jednak tam, gdzie jest to możliwe dokonuje porównań w dłuższym czasie, by wnioski dotyczyły tendencji, a nie krótkookresowych zmian. 


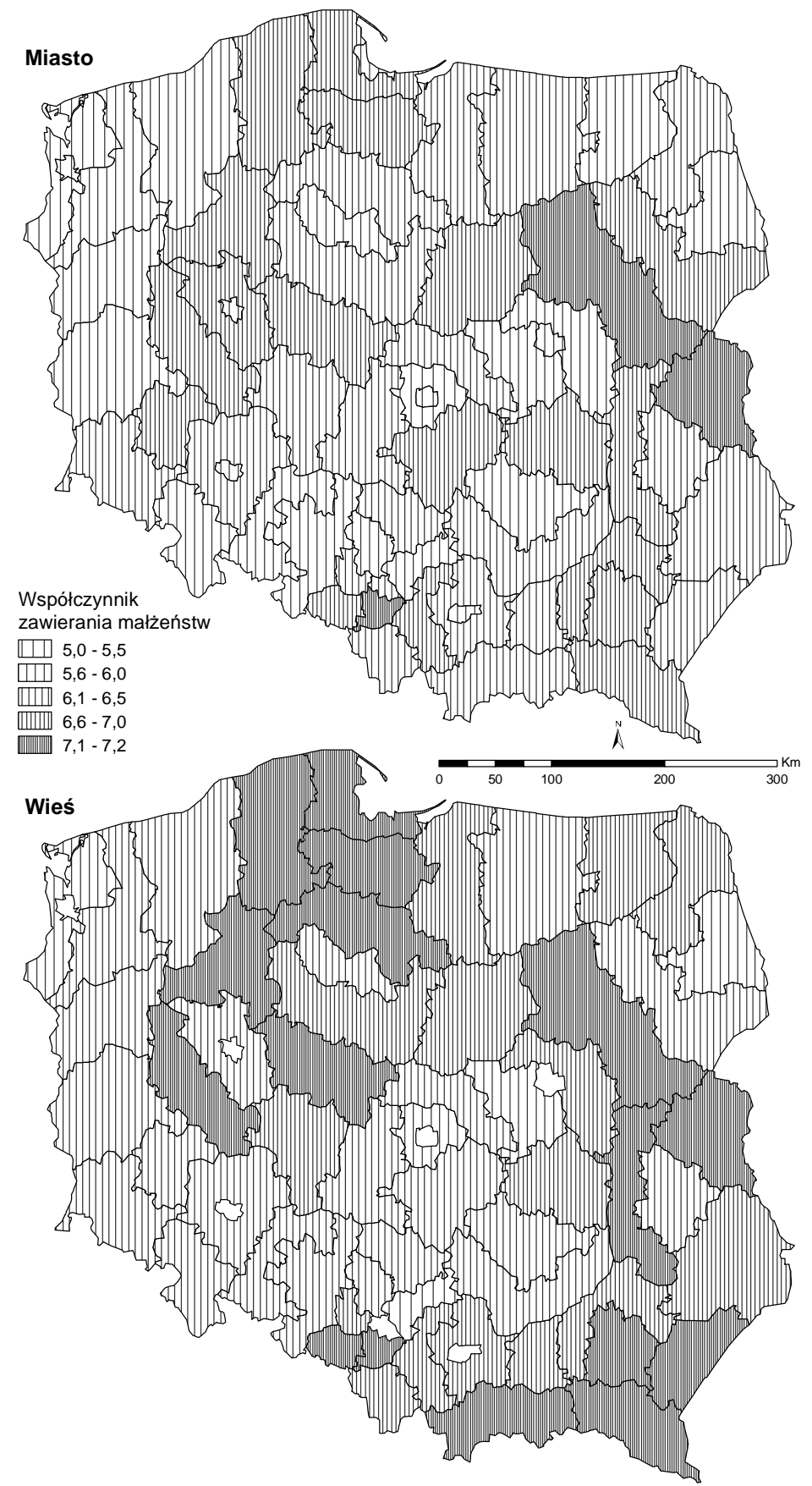

Ryc. 24. Współczynnik zawierania małżeństw na 1000 ludności w wieku 15 lat i więcej w 2011 r. według podregionów - miasto-wieś

Źródło: oprac. własne na podstawie Bazy Demografia, GUS, Warszawa 


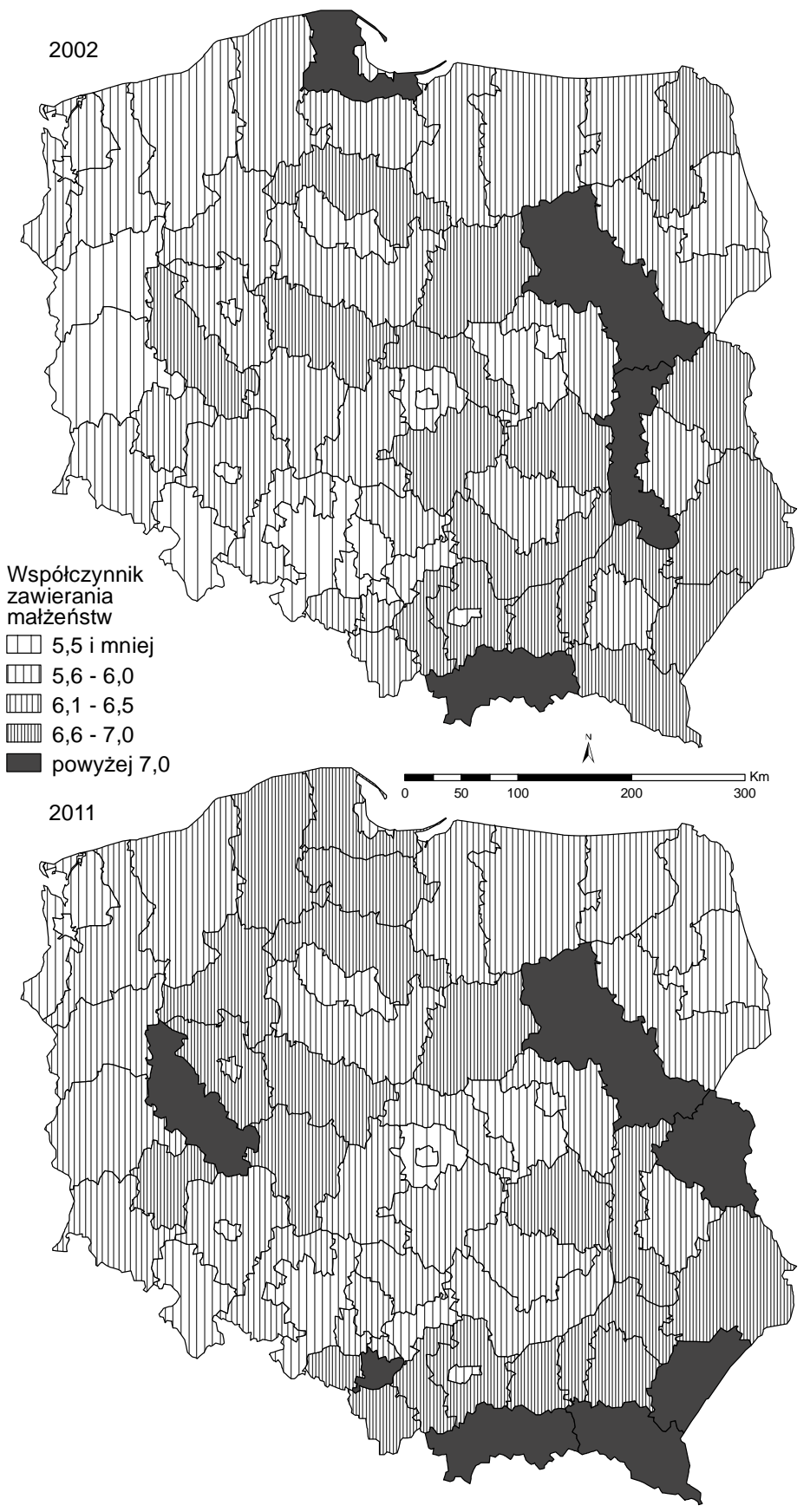

Ryc. 25. Współczynnik zawierania małżeństw na 1000 ludności w wieku 15 lat i więcej w 2002 i 2011 r. według podregionów

Źródło: oprac. własne na podstawie Bazy Demografia, GUS, Warszawa 


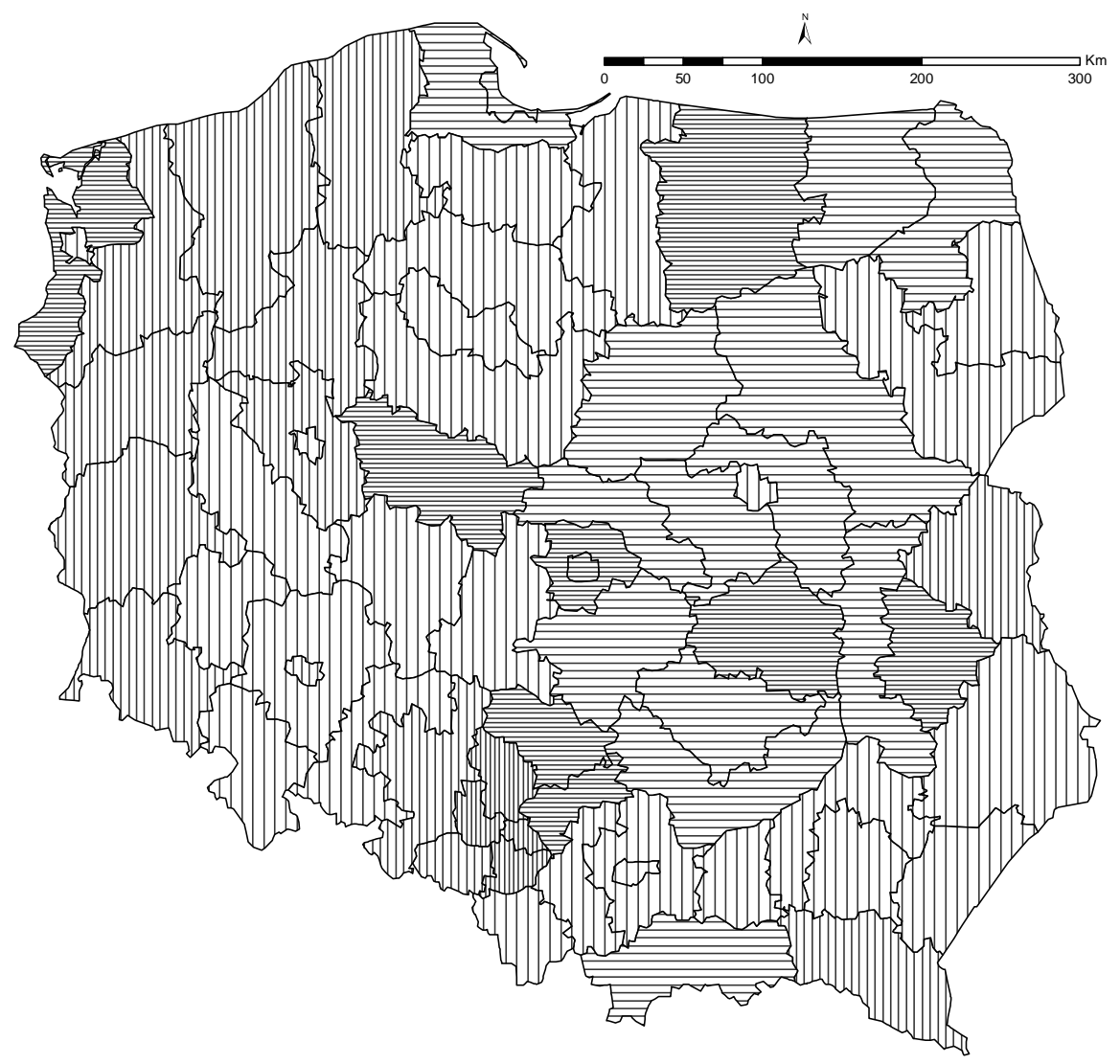

Przyrost/ubytek współczynnika zawierania małżeństw

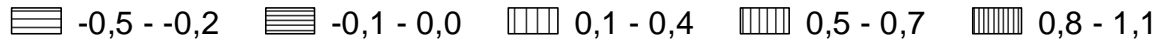

Ryc. 26. Zmiany wartości współczynnika zawierania małżeństw na 1000 ludności w wieku 15 lat i więcej pomiędzy 2011 i 2002 r. według podregionów Źródło: oprac. własne na podstawie Bazy Demografia, GUS, Warszawa

Zawieranie małżeństw wyznaniowych bądź cywilnych jest bardzo ściśle skorelowane $\mathrm{z}$ uznawanym systemem wartości, $\mathrm{w}$ tym religijnych. $\mathrm{W}$ badaniu religijności kluczowym pytaniem jest pytanie o ocenę własnego stosunku do wiary, według Piwowarskiego (1977) jest to globalny stosunek do wiary. Dużym badaniem społecznym, w którym uwzględnia się pytania dotyczące religii, jest Polski Generalny Sondaż Społeczny (PGSS). 0 różne aspekty religijności pytano $\mathrm{w}$ pomiarach $\mathrm{w}$ latach 1992-2008. Interesowano się m.in.: wyznaniem i częstością praktyk religijnych, siłą wiary, wiarą w życie po śmierci, zaufaniem do Kościoła katolickiego, oceną wpływu Kościoła i organizacji wyznaniowych na życie publiczne w Polsce oraz tolerancji wobec ateistów. Wyniki PGSS świadczą o relatywnej stabilności deklarowanego związku z religią i stosunku do wiary, co potwierdza rów- 
nież analiza przestrzennego zróżnicowania zjawiska (ryc. 27). Wynika z niej, że zaangażowanie religijne mieszkańców wschodnich i południowych obszarów Polski jest dużo większe niż w zachodniej części kraju. Oczywiście istniał związek między deklaracją dotyczącą przynależności do wyznania i stopniem religijności. W ciągu szesnastu lat spadła liczba głęboko wierzących, jednocześnie jednak w 2008 r. w stosunku do 1992 r. mniej było niewierzących (Klima 2011). Według Zaręby (2006) religijność jest wyraźnie zróżnicowana regionalnie (diecezjalnie), a linia demarkacyjna zdaje się oddzielać tereny południowo-wschodnie od reszty kraju, gdzie religijność jest dużo słabsza we wszystkich swych parametrach.

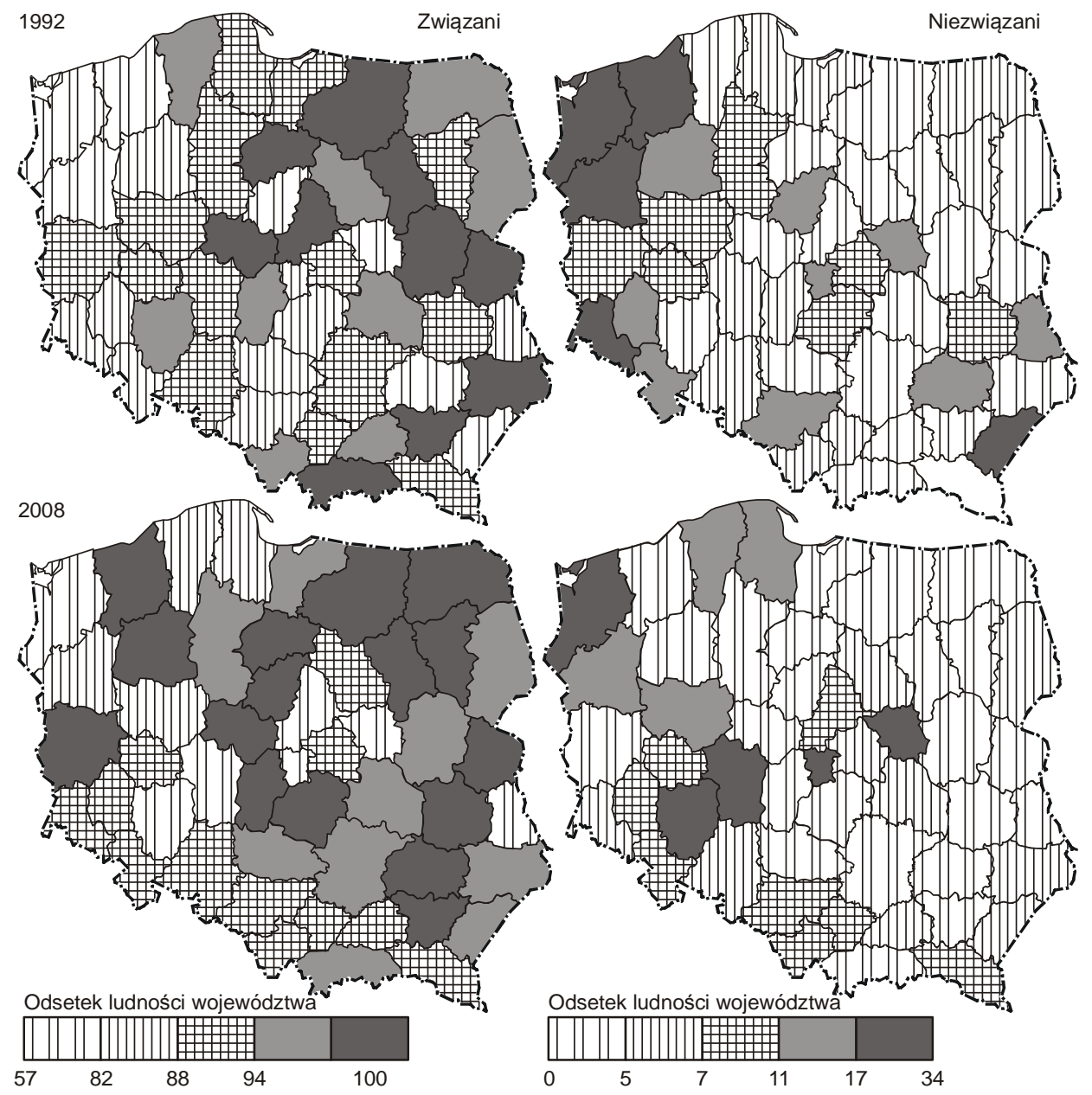

Ryc. 27. Związek z religią według województw w latach 1992 i 2008 (w podziale administracyjnym obowiązującym w latach 1975-1998)

Źródło: Klima 2011 
Zróżnicowanie regionalne poziomu religijności w dość oczywisty sposób przekłada się na rozkład przestrzenny zawierania małżeństw wyznaniowych. Potwierdza to rozkład przestrzenny odsetka małżeństw wyznaniowych zawieranych zarówno w 2002, jak i 2011 r. (ryc. 28). Najwięcej związków konkordatowych w 2011 r. (powyżej 70\%) zawierano w podregionach południowych, wschodnich i centralnych (z wyjątkiem dużych miast, takich jak Warszawa, Łódź, Kraków). Analogicznie do deklarowanego niskiego poziomu religijności największą popularnością związki cywilne cieszyły się w zachodnich i północnych podregionach, a w podregionie jeleniogórskim było ich nawet więcej niż wyznaniowych (50,5\%). Biorąc pod uwagę współczynnik zawierania małżeństw wyznaniowych, najwyższe jego wartości (powyżej 4,6 związków wyznaniowych na 1000 ludności w wieku 15 lat i więcej) wystąpiły w podregionach przemyskim, rzeszowskim, chełmskozamojskim, krakowskim, radomskim, ostrołęcko-siedleckim. Rekordowo niską wartość odnotowano w Łodzi - tylko 2,5\%o. Tak jak pisano już w podrozdziale 3.2.1 skłonność do zawierania związków wyznaniowych spadła w stosunku do początkowego okresu, w którym wskutek zmian prawa taka możliwość zaistniała, np. w podregionie nowosądeckim spadek wyniósł ponad 24\% (ryc. 29). Z wyjątkiem nowosądeckiego zmniejszenie się częstości zawierania związków konkordatowych dotyczyło w głównej mierze podregionów leżących w zachodniej i północnej części kraju. 


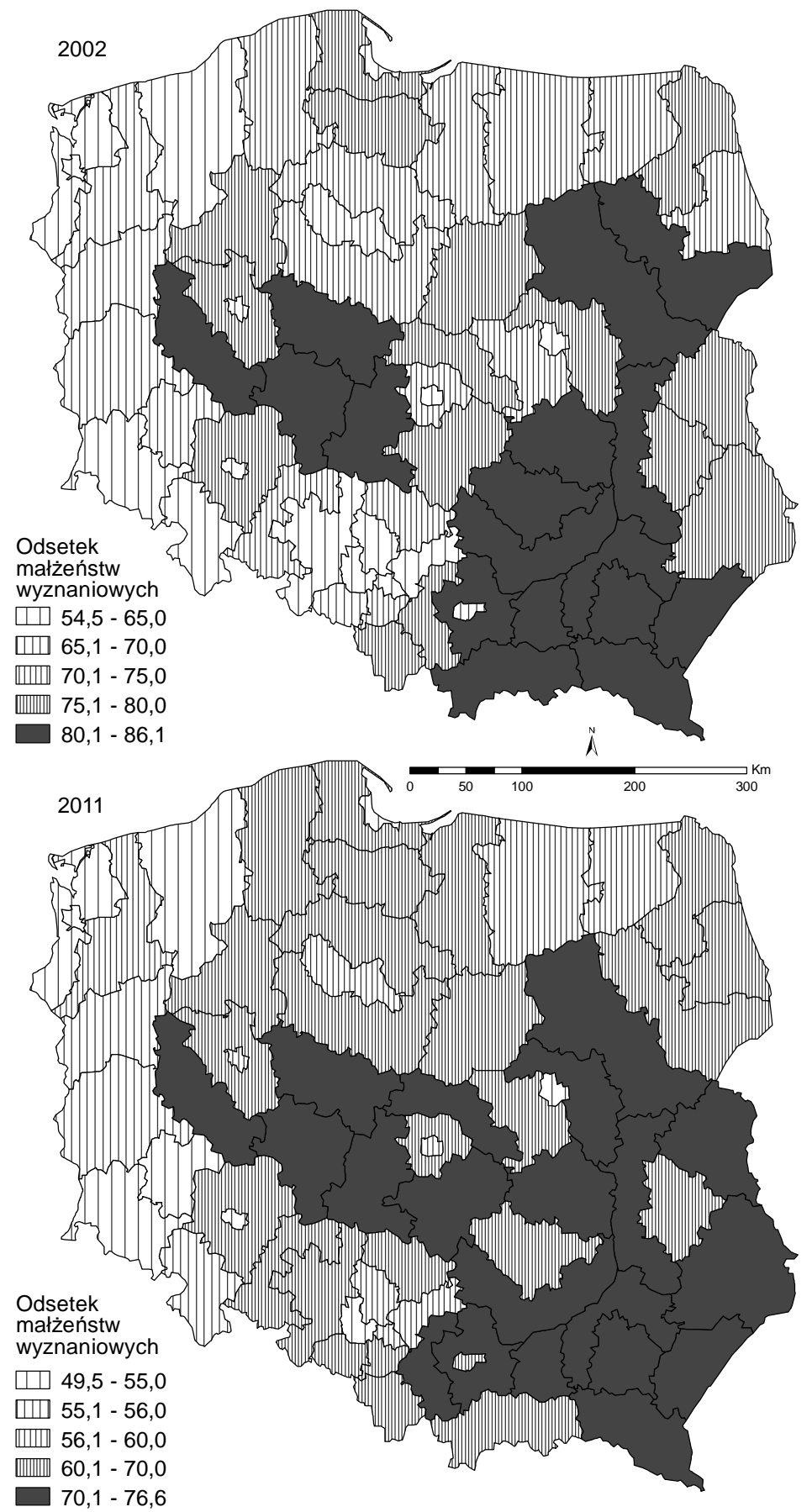

Ryc. 28. Odsetek małżeństw wyznaniowych w 2002 i 2011 r. według podregionów Źródło: oprac. własne na podstawie Bazy Demografia, GUS, Warszawa 


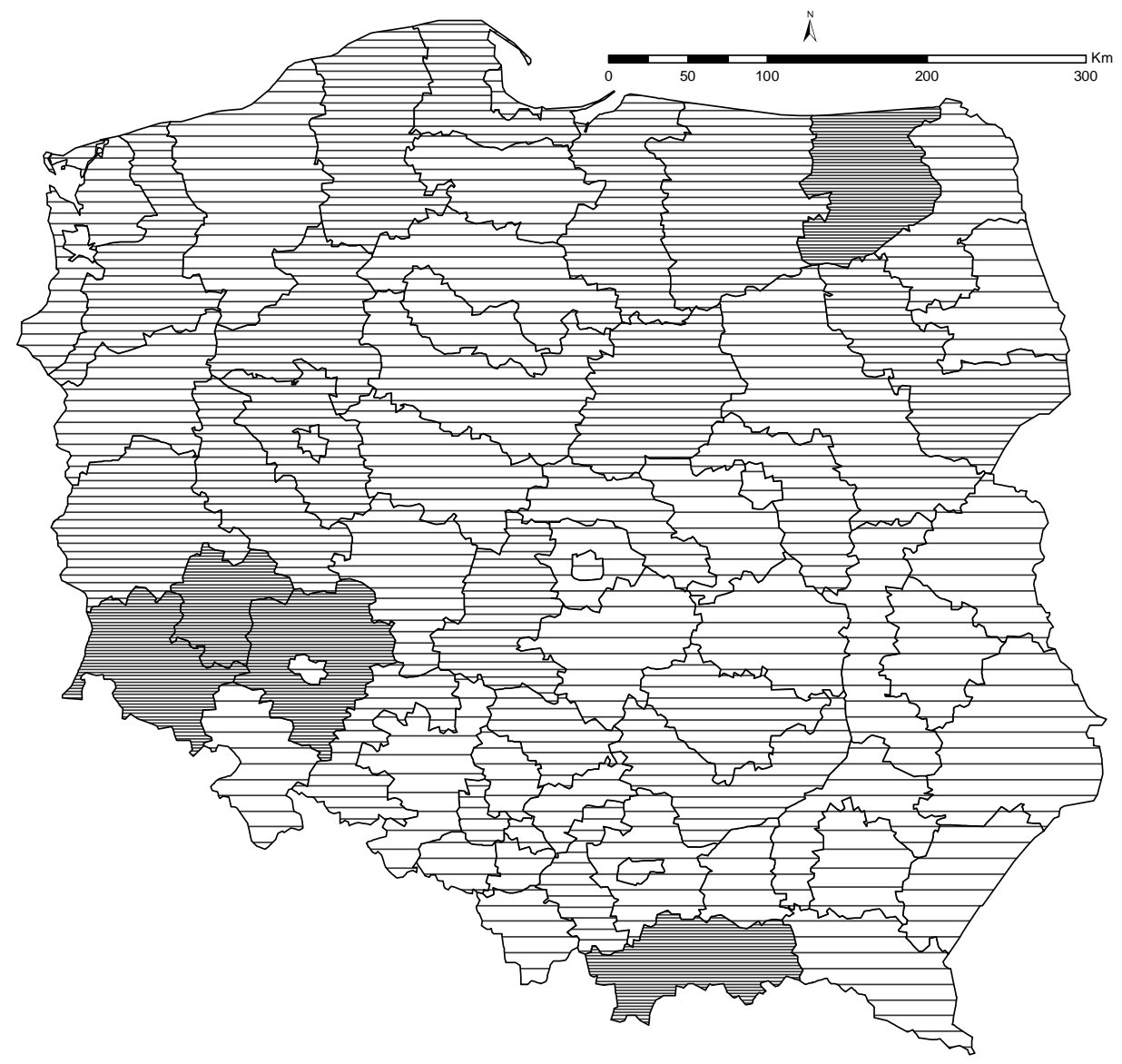

Spadek odsetka małżeństw wyznaniowych

$-24,4--13,0 \boxminus-12,9--11,0 \boxminus-10,9--8,0 \square-7,9--5,0 \square-4,9--2,4$

Ryc. 29. Spadek odsetka małżeństw wyznaniowych pomiędzy 2011 i 2002 r. według podregionów

Źródło: oprac. własne na podstawie Banku Danych Lokalnych, GUS, Warszawa

O sytuacji w „obszarze” małżeńskości świadczą też udział osób będących w stanie małżeńskim i zmiany dokonujące się w strukturze stanu cywilnego. Zmniejszające się skłonności do zawierania związków, rozpad małżeństw w wyniku rozwodów i separacji to powody, które przyczyniły się do ubytku osób w stanie małżeńskim pomiędzy 2002 a 2011 r. w większości podregionów. Tylko nieliczne podregiony odnotowały przyrost osób pozostających w małżeństwach (zresztą bardzo niewielki bo od 0,1 do 0,3\%). Były to podregiony warszawski wschodni, krakowski i tyski. Najmniej małżonków ubyło $\mathrm{w}$ podregionach południowo-wschodnich i na terenach silnie zurbanizowanych, szczególnie wokół dużych miast, co jest wynikiem odpływu ludności na tereny metropolitalne tych miast (ryc. 30). 


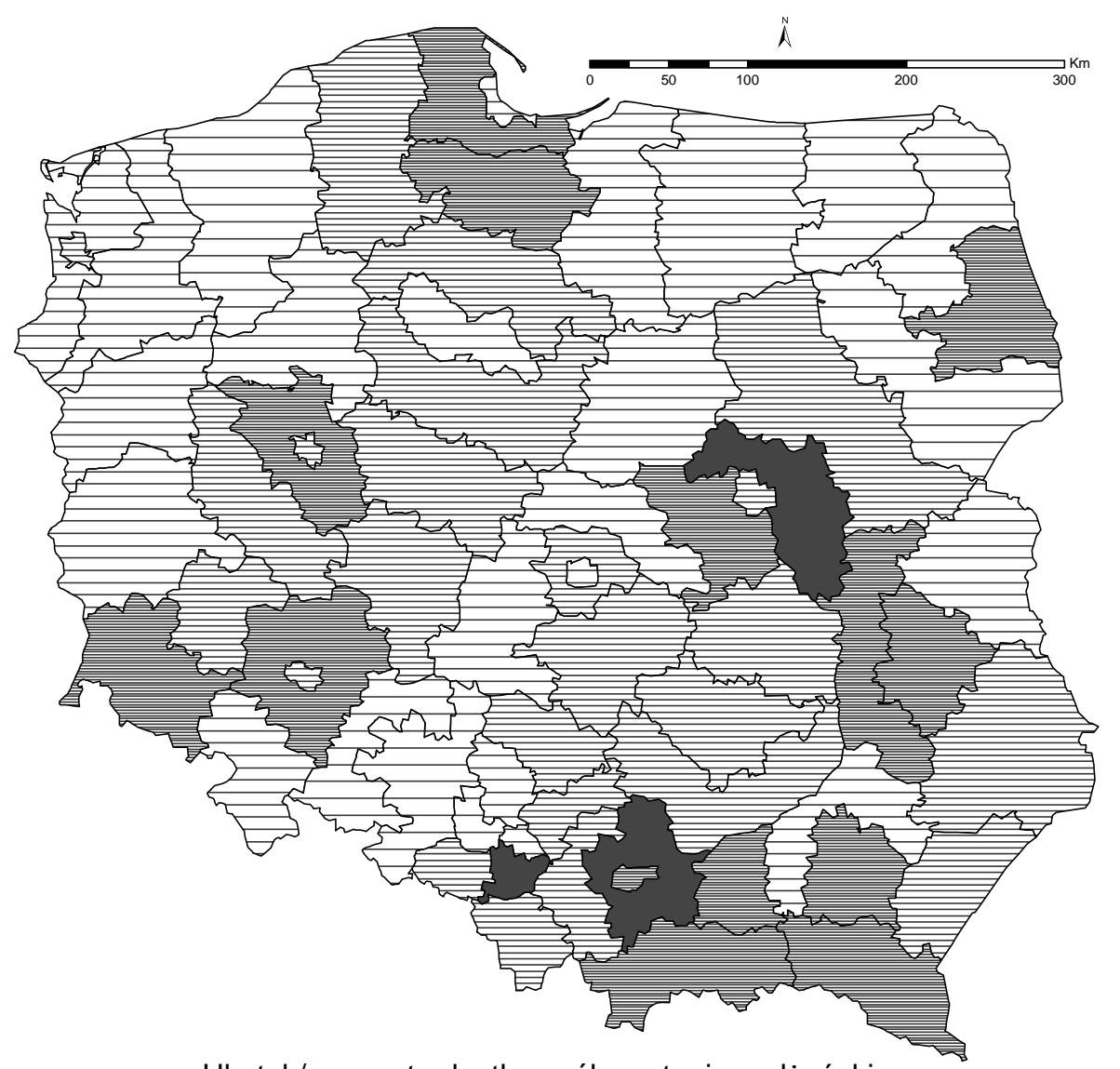

Ubytek/przyrost odsetka osób w stanie małżeńskim

$$
\square-3,6--2,6 \sqsubseteq-2,5--1,5 \sqsubseteq-1,4--1,0 \sqsubseteq-0,9-0,0 \square 0,1-0,3
$$

Ryc. 30. Udział osób w stanie małżeńskim w ogólnej liczbie osób w wieku 15 lat i więcej różnice pomiędzy 2011 i 2002 r.

Źródło: oprac. własne na podstawie Banku Danych Lokalnych, GUS, Warszawa

Analizując zróżnicowanie regionalne zachowań związanych z małżeńskością zwrócono także uwagę na cechy demograficzne nowożeńców, tj. wiek i stan cywilny w chwili zawierania związku. Jak wiemy, jedną z cech znamionujących przemiany drugiego przejścia demograficznego jest opóźnianie zawierania związków. Tym, co różnicuje podregiony w Polsce biorąc pod uwagę wiek nowożeńców jest udział osób najmłodszych i najstarszych wśród legalizujących związki. Najwięcej najmłodszych nowożeńców mężczyzn (19 lat i mniej) w 2002 r. legalizowało swoje związki w podregionach piotrkowskim, rybnickim, chełmsko-zamojskim, puławskim, tarnobrzeskim i ełckim, ale wartości te były bardzo niskie - zaledwie po 2,9\% ogółu nowożeńców (ryc. 31, 32). W tych podregionach (a także w sieradzkim, ostrołęcko-siedleckim, sandomiersko-jędrzejowskim) wysokie były również udziały 
nowożeńców z następnej grupy wiekowej, tj. 20-24 lata (ok. 40\%). W przypadku młodych kobiet nowożeńców rozkład przestrzenny jest podobny, z tym że udziały ich są kilkakrotnie wyższe w najmłodszej grupie wiekowej (wynoszą ok. 12-14\%) i o kilkanaście procent większe w grupie wiekowej 20-24 lata. Zarówno młodzi mężczyźni, jak i młode kobiety w największych miastach zawierają małżeństwa zdecydowanie później, świadczą o tym ich niskie udziały w ogólnej liczbie nowożeńców (w przypadku mężczyzn nawet dwukrotnie niższe, np. w Warszawie nowożeńców w wieku 20-24 lata było $20,8 \%$, a w podregionie sieradzkim 41,4\%). Zjawisko przesuwania się „w górę” wieku zawarcia małżeństwa bardzo widoczne jest w miastach i podregionach zurbanizowanych, wśród nowożeńców (zarówno kobiet, jak i mężczyzn) w grupie wiekowej 30-34 lata, jak i starszych, im starsi nowożeńcy, tym dysproporcje ich udziału pomiędzy największymi miastami a pozostałymi podregionami są większe. Mediana wieku nowożeńców kobiet z wyjątkiem największych miast (Warszawa - 26,41; Łódź - 25,96; Wrocław - 25,90; Poznań - 26,00; Kraków - 25,66; Szczecin - 26,18), nie przekraczała 24 lat. Mężczyźni nowożeńcy byli starsi o ok. 2-3 lata i podobnie jak w przypadku młodych panien najwyższe wartości mediany wystąpiły w podregionach: Warszawa - 27,88; Łódź - 27,37; Wrocław - 27,57; Poznań - 27,23; Kraków - 27,11; Szczecin - 27,76 (A II). Opisane tendencje zróżnicowania przestrzennego, dotyczące struktury wiekowej nowożeńców w 2002 r., odnoszą się również do roku 2011. Jedyne różnice, jakie zaobserwowano, dotyczą zmian ilościowych. Jedną z nich jest spadek udziału wśród nowożeńców osób najmłodszych. Jest to korzystne zjawisko, do sukcesu małżeńskiego bowiem, tzn. do sprawienia, żeby było ono szczęśliwe i trwałe, potrzeba nie tylko dojrzałości biologicznej, ale także emocjonalnej i społecznej. Badania wskazują, że im młodszy był wiek zawarcia związku małżeńskiego, tym szybciej ulegał on rozpadowi (Zawadzki 1995). Mediana wieku nowożeńców z 2011 r. dość wyraźnie różnicuje polskie podregiony w układzie południowy wschód i wschód oraz zachód i południowy zachód, najniższa wartość zarówno dla mężczyzn (26,9 roku), jak i kobiet $(24,9$ roku) występuje w podregionie nowosądeckim. Wartości najwyższe mediany zaobserwowano, poza największymi miastami Polski (Warszawa - najwyższe wartości, mężczyźni 29, kobiety 28,3 roku), w podregionach zachodnich: gorzowskim, szczecińskim, jeleniogórskim, wałbrzyskim (A II). 


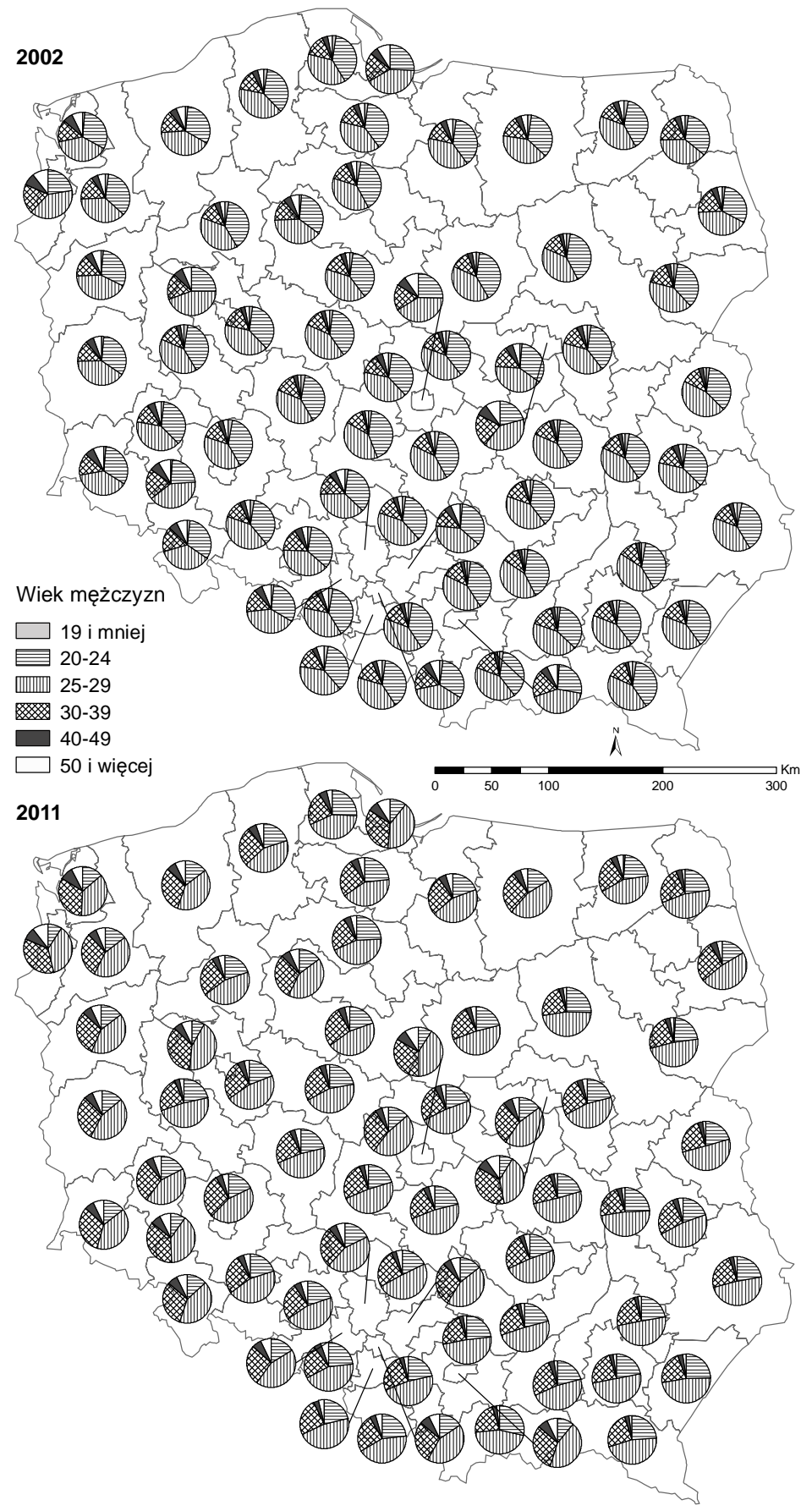

Ryc. 31. Struktura wieku nowożeńców - mężczyzn w 2002 i 2011 r. według podregionów Źródło: oprac. własne na podstawie Bazy Demografia, GUS, Warszawa 

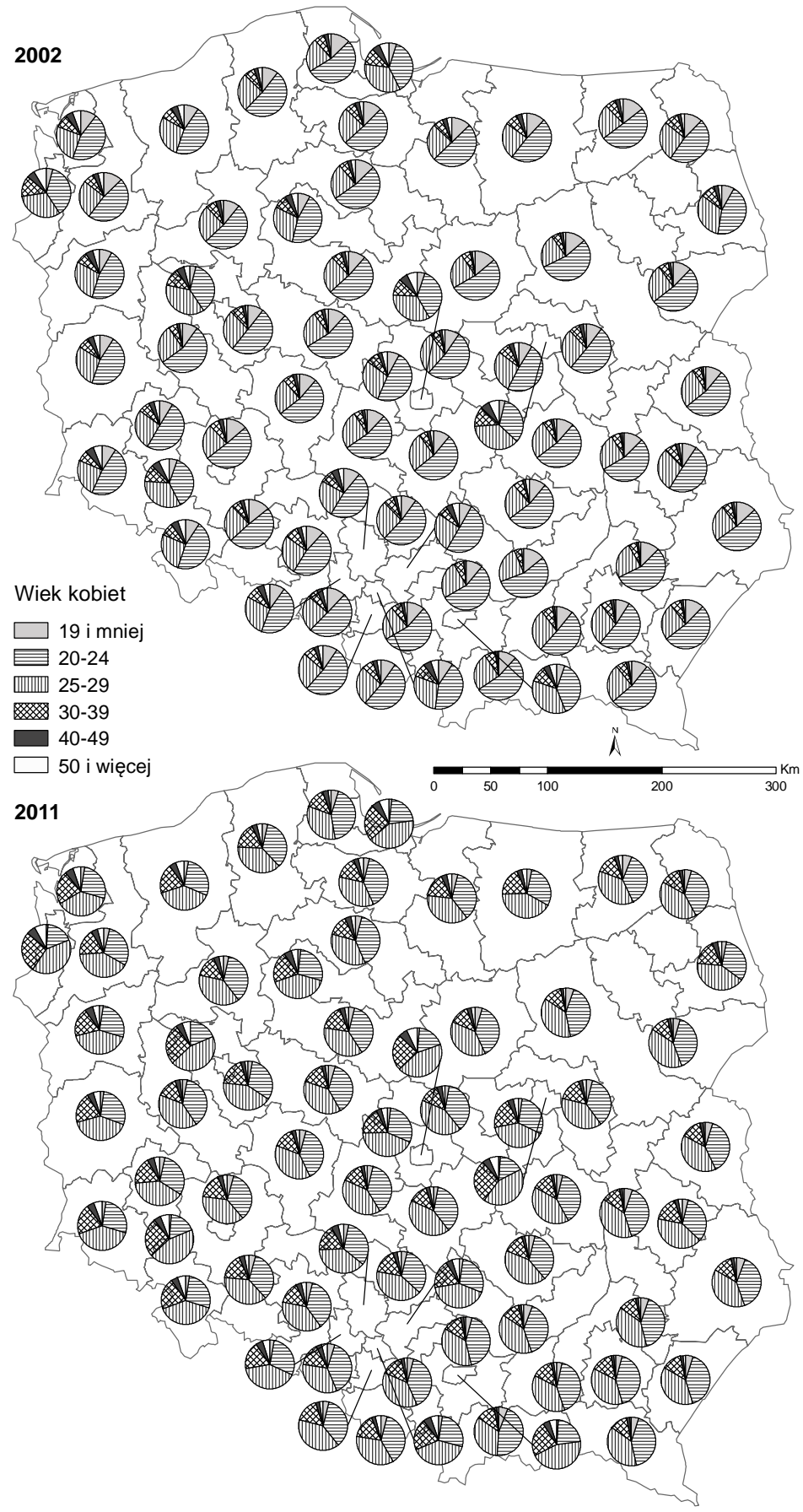

Ryc. 32. Struktura wieku nowożeńców - kobiet w 2002 i 2011 r. według podregionów Źródło: oprac. własne na podstawie Bazy Demografia, GUS, Warszawa 
Przestrzenne zróżnicowanie regionalne według struktury stanu cywilnego nowożeńców jest zbliżone do obrazu, jaki tworzą podregiony pod względem wieku nowożeńców (ryc. 33, 34). Obraz ten jest jednak bardziej jednorodny, różnice nie są duże i w rzeczywistości dotyczą zwiększania się udziału osób rozwiedzionych, które zawierają ponowne związki małżeńskie. W roku 2002 osoby rozwiedzione stanowiły od kilku $(2,1 \%$ kobiety; 2,4\% mężczyźni - podregion nowosądecki) do kilkunastu procent wszystkich nowożeńców (14,2\% kobiety; 17,4\% mężczyźni - podregion Warszawa). Linia demarkacyjna przebiegała dosyć podobnie jak w przypadku struktury wieku nowożeńców, w bardziej religijnych, tradycyjnych podregionach południowych i wschodnich udział rozwiedzionych był zdecydowanie mniejszy niż w dużych miastach oraz na zachodzie i północy kraju. Taki rozkład zachował się i zdecydowanie uległ dalszemu umocnieniu w 2011 r. - nadal mamy, co prawda, do czynienia z dominacją zawierania małżeństw pierwszych przez panny i kawalerów, ale małżeństwa powtórne zyskują na ilościowym znaczeniu. W strukturze stanu cywilnego udział osób rozwiedzionych, które decydują się na zawarcie małżeństwa, rośnie, w rankingu tym nadal najniżej plasuje się podregion nowosądecki (po 3,6\% kobiet i mężczyzn nowożeńców o stanie cywilnym „rozwiedzeni”), natomiast „liderami” w przypadku kobiet nowożeńców stają się Szczecin $(17,4 \%)$ i Warszawa $(17,3 \%)$, gdzie udział nowożeńców będących rozwiedzionymi był największy. 


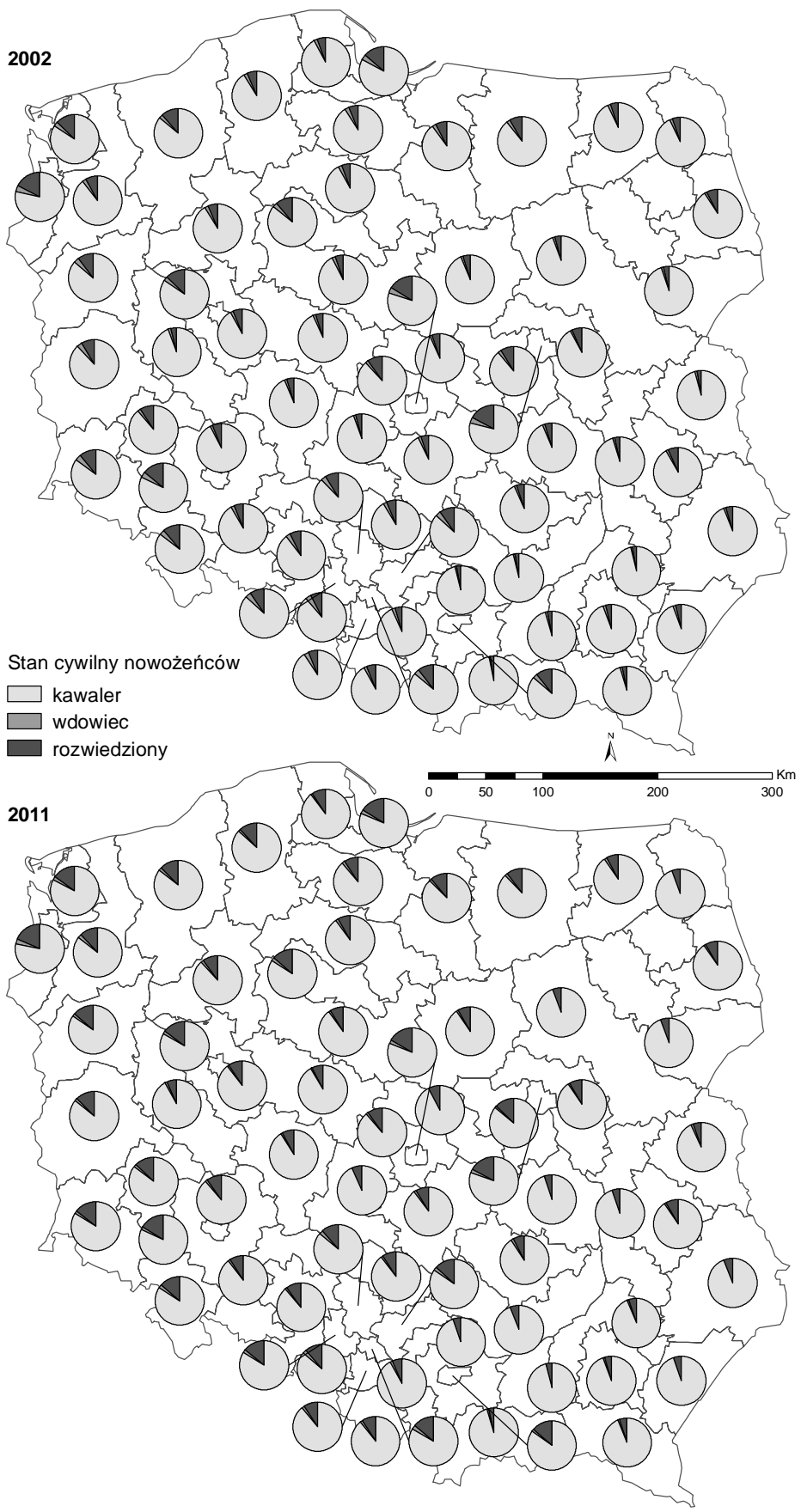

Ryc. 33. Struktura stanu cywilnego nowożeńców - mężczyzn w 2002 i 2011 r. według podregionów

Źródło: oprac. własne na podstawie Bazy Demografia, GUS, Warszawa 


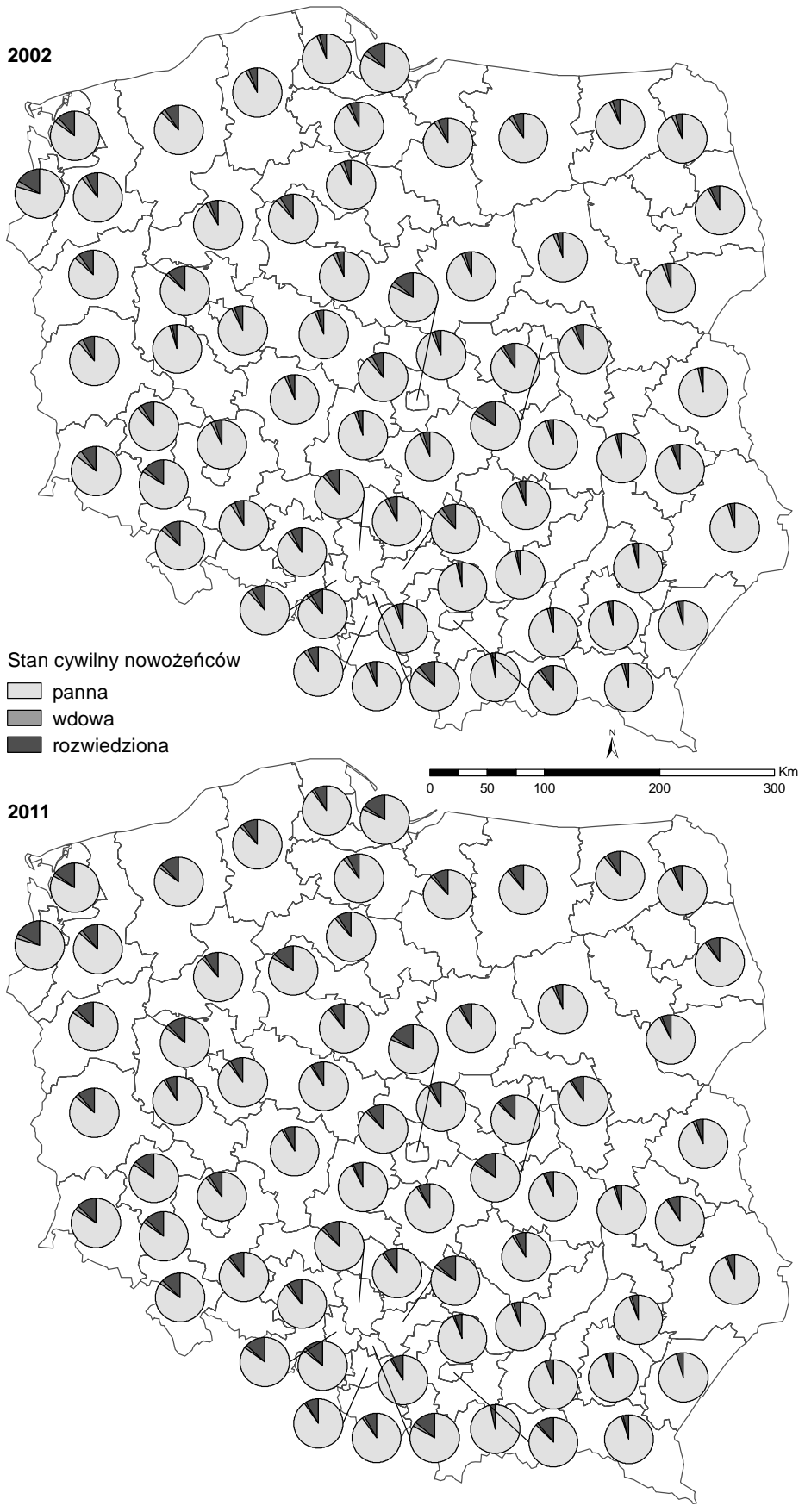

Ryc. 34. Struktura stanu cywilnego nowożeńców - kobiet w 2002 i 2011 r. według podregionów Źródło: oprac. własne na podstawie Bazy Demografia, GUS, Warszawa 


\subsubsection{Zróżnicowanie przestrzenne rozwodów i separacji według podre- gionów}

Rozwód traktowany jako zjawisko demograficzne jest czynnikiem wstrzymującym reprodukcję, wpływającym na ograniczenie liczby urodzeń, ponieważ do rozwodów często dochodzi w okresie prokreacyjnym. Rozpad związku przyczynia się więc do zmniejszenia przyrostu naturalnego i zwiększenia liczby rodzin małodzietnych. Konsekwencją tych decyzji, oprócz wstrzymanej prokreacji, jest konstruowanie się rodzin niepełnych. Co prawda osoby rozwiedzione, przynajmniej ich część, decydują się na małżeństwa powtórne, ale $\mathrm{w}$ ich wyniku następuje przesunięcie prokreacji w czasie. Na zahamowanie prokreacji wpływa też poprzedzający rozwód okres dezintegracji, sytuacja niepewności i braku poczucia bezpieczeństwa (Rydzewski 1994). Rozwód można także traktować jako złożoną kwestię społeczno-pedagogiczną z powodu jego wpływu na funkcjonowanie rodziny oraz konsekwencje dla dzieci. Jak pisze Maria Beisert „Rozwód należy do klasycznych sytuacji znaczących emocjonalnie ze względu na wysokie ryzyko utraty istotnych wartości; na przykład - obniżenie samooceny, utrata miłości, spadek dochodów, zaburzenie potrzeby bezpieczeństwa" (1994: 42).

Określenie zróżnicowania rozkładu w przestrzeni rozwodów jest istotne nie tylko z poznawczego punktu widzenia, ale powinno być cenną wskazówką dla władz zajmujących się polityką ludnościową i społeczną w regionach i na poziomie krajowym. Jak wcześniej pisano, Polska znajduje się w grupie państw o niskim wskaźniku rozwodów. Zjawisko to jednak wyraźnie różnicuje się w przestrzeni kraju (ryc. 35), o wiele wyraźniej niż małżeństwa. Obraz ten wskazuje na zauważalną odrębność ziem północnych i zachodnich, pokazuje to zarówno ogólna wartość współczynnika rozwodów, jak również wskaźniki w rozbiciu na miasto i wieś. Różnice natężenia rozwodów w mieście i na wsi są w dalszym ciągu dostrzegalne, ale już dziś nie możemy mówić, że jest to tylko problem miejski. Współczynnik rozwodów na 1000 ludności w wieku 20 lat i więcej ogółem w 2011 r. kształtował się na poziomie od 0,9 w podregionie nowosądeckim do 2,93 w Szczecinie. Podregiony o najwyższych wartościach tego współczynnika (nieco powyżej $3 \%$ ) dla miast to szczeciński, jeleniogórski, legnicko-głogowski, wrocławski, bydgosko-toruński, elbląski, ełcki i olsztyński, najniższe wartości dotyczyły zaś podregionów Polski południowej i wschodniej (powyżej 1,5\%o). Podobny układ przestrzenny występuje na trenach wiejskich, a absolutne minimum spotykamy w podregionie nowosądeckim, gdzie wartość współczynnika wyniosła w 2011 r. zaledwie 0,58\%o. Bardzo podobny rozkład przestrzenny (niemal identyczny) współczynnika rozwodów odnotowano w 2002 r. 


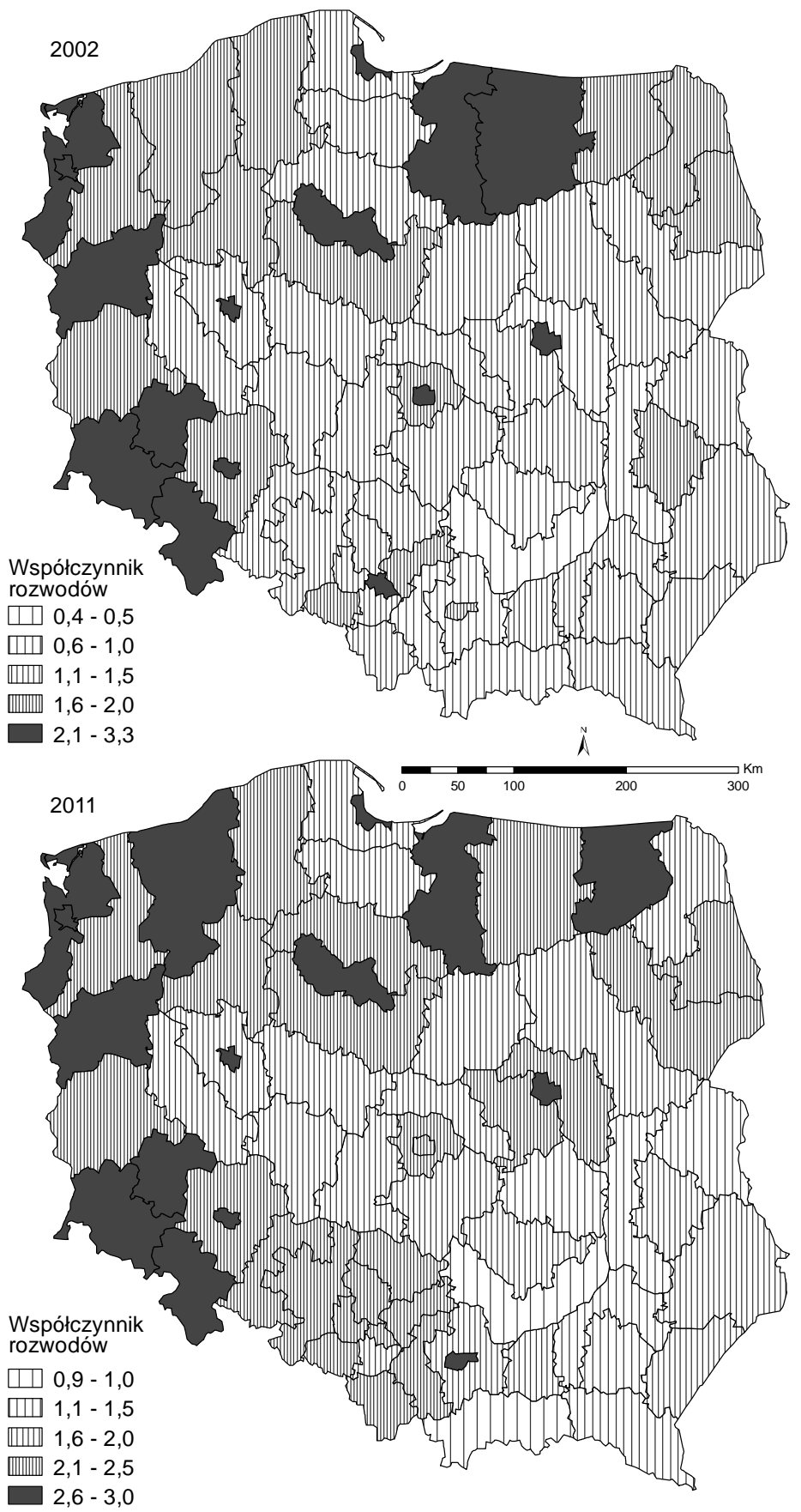

Ryc. 35. Współczynnik rozwodów na 1000 ludności w wieku 20 lat i więcej w 2002 i 2011 r. według podregionów Źródło: oprac. własne na podstawie Bazy Demografia, GUS, Warszawa 
Współczesny układ przestrzenny współczynnika rozwodów utrzymuje się w ogólnym kształcie niezmiennie od lat 50. ubiegłego wieku, co znaczy, że największa częstość rozwodów występowała w regionach północnej i zachodniej Polski. Większe rozpowszechnienie rozwodów na tzw. ziemiach odzyskanych po wojnie tłumaczy się migracyjną genezą ludności zamieszkującej te obszary oraz wyższą częstością zawieranych tam wtedy małżeństw, której statystycznie towarzyszy większa liczba rozwodów. Na ziemiach dawnych, szczególnie w ówczesnych województwach poznańskim i rzeszowskim zarówno w pierwszym okresie powojennym, jak i w latach późniejszych stopa rozwodów należała do najniższych w kraju.

Aktualnie przyczyn zróżnicowania przestrzennego rozwodów należy upatrywać m.in. w wyższym poziomie religijności i w przywiązaniu do tradycyjnych wartości, charakterystycznym dla podregionów Polski południowej i wschodniej. Analiza dynamiki zmian natężenia rozwodów w analizowanym okresie 2002-2011 według podregionów wykazała dwie tendencje o przeciwnych kierunkach. Jedna z nich dotyczyła obniżenia się skłonności do rozwodów, wyrażonej poprzez ubytek wartości współczynnika rozwodów, jednak dotyczyło to tylko dwóch podregionów (Łodzi i Szczecina). W pozostałych podregionach mieliśmy do czynienia ze wzrostem współczynnika rozwodów, przyrost ten osiągnął wartości mniejsze niż $1 \%$, z wyjątkiem podregionu warszawskiego wschodniego, warszawskiego zachodniego, krakowskiego, oświęcimskiego, łomżyńskiego, koszalińskiego i Krakowa, gdzie były to wartości wyższe od 1,0\%o - por. ryc. 36 .

Zwiększanie się liczby udzielanych rozwodów skutkuje przyrostem osób rozwiedzionych w strukturze stanu cywilnego. Oczywista jest tutaj zależność pomiędzy współczynnikiem rozwodów a strukturą stanu cywilnego. Okres pomiędzy 2002 a 2011 r. to czas, kiedy zaobserwowano przyrost liczby rozwodów (udzielono ich $\mathrm{w}$ tym czasie 613,1 tys.). Dlatego we wszystkich podregionach z wyjątkiem bydgosko-toruńskiego odnotowano przyrost odsetka osób rozwiedzionych. Najwięcej takich osób przybyło w podregionach zachodnich, północnych i na Górnym Śląsku. Niskie wartości przyrostu odsetka osób rozwiedzionych na południowym wschodzie to przyczyna niskiego współczynnika rozwodów (ryc. 37). 


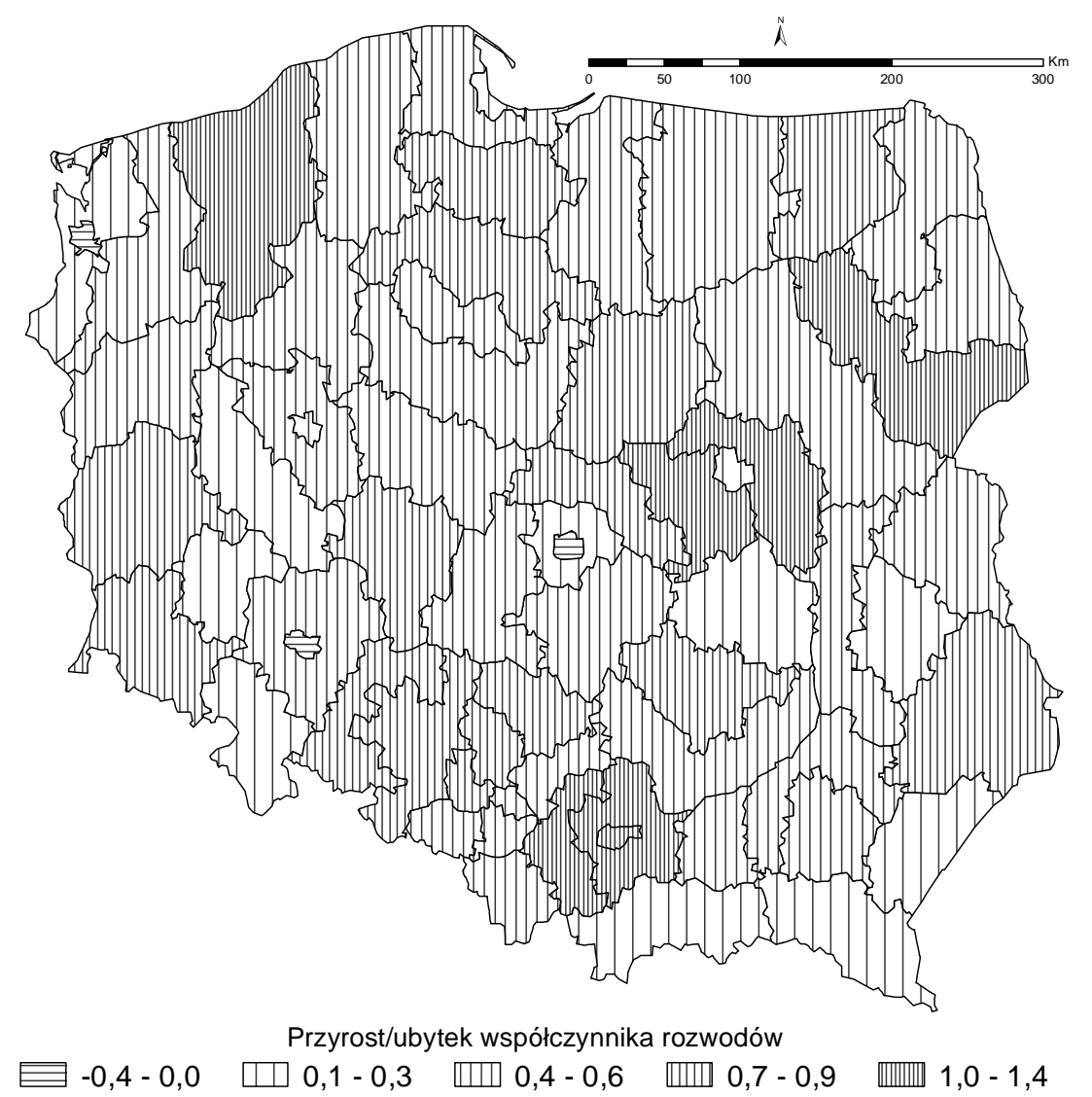

Ryc. 36. Różnice wartości współczynnika rozwodów na 1000 ludności w wieku 20 lat i więcej pomiędzy 2011 i 2002 r. według podregionów

Źródło: oprac. własne na podstawie Bazy Demografia, GUS, Warszawa

Separacje są stosunkowo nowym zjawiskiem, możliwość wystąpienia do sądu o orzeczenie separacji pojawiła się dopiero w końcu 1999 r., a rejestruje się je od $2000 \mathrm{r}$. Nie jest to zachowanie demograficzne, przynajmniej w sensie statystyczno-ilościowym, masowe, jego rozmiary są niewielkie (zaledwie kilka tysięcy rocznie), najwyższą liczbę separacji odnotowano w 2005 r. i wynosiła ona 11600 . Umożliwienie separacji prawnej teoretycznie może zwiększać intensywność rozpadów małżeństw o te osoby, które nie zdecydowały się na rozwód. Istnieje także możliwość, że wprowadzenie separacji odbędzie się kosztem liczby rozwodów, tzn. część osób, które zdecydowałyby się na rozwód, mając do wyboru rozwód i separację wybierze tę ostatnią. W dłuższym okresie separacja może nawet zwiększać odsetek rozwodów, ponieważ po pewnym czasie jej trwania łatwiej jest udowodnić, że rozpad małżeństwa jest ostateczny. Biorąc jednak pod uwagę wpływ separacji na poziom rozwodów, trzeba pamiętać, że liczba separacji 
w Polsce jest stosunkowo niska. W 2011 r. orzeczono ponad 2,8 tys. separacji w stosunku do 64,6 tys. rozwodów, co sprawia, że „wkład” separacji do ogólnej liczby rozpadających się małżeństw jest stosunkowo niewielki.

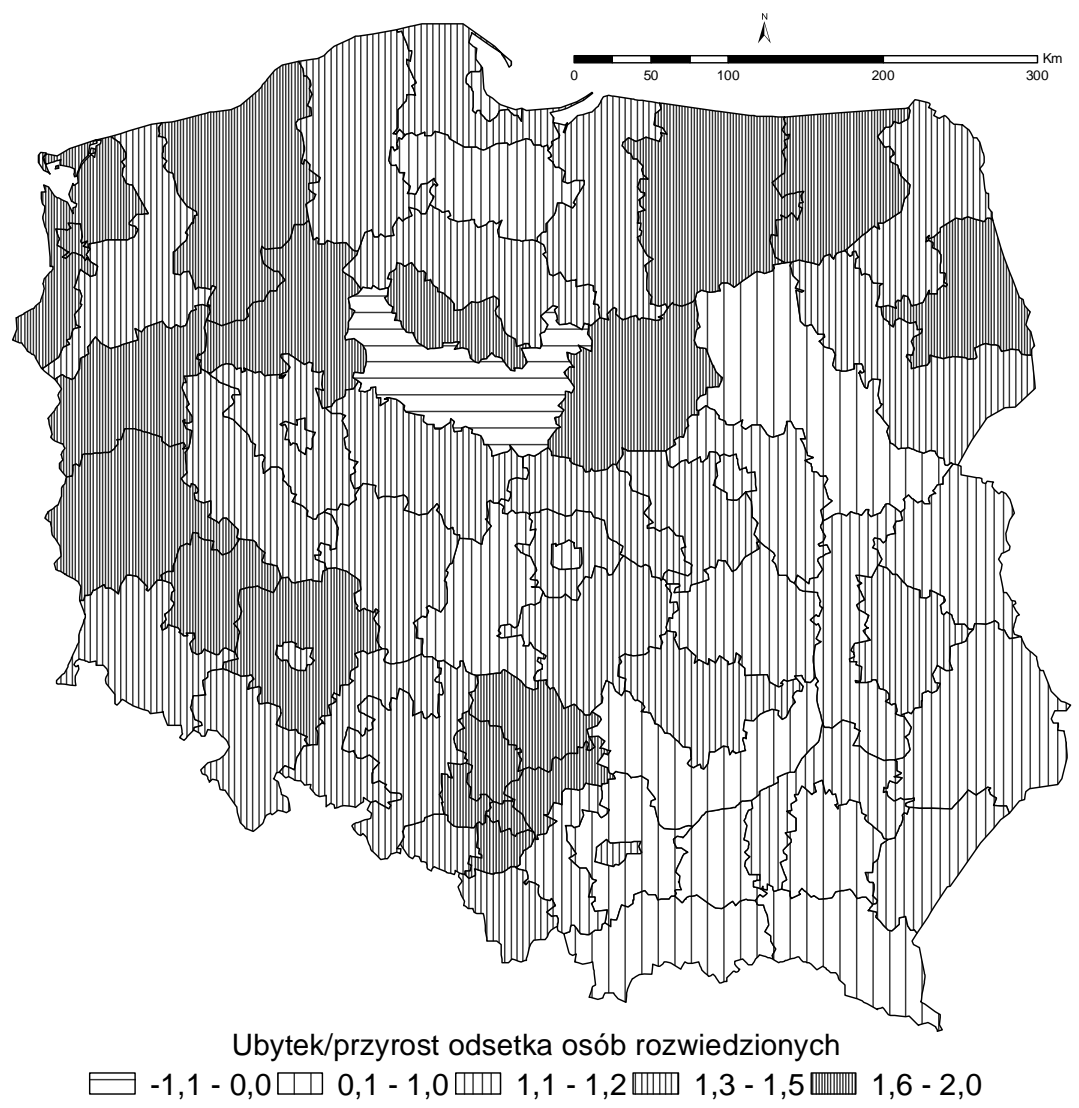

Ryc. 37. Udział osób rozwiedzionych w ogólnej liczbie osób w wieku 15 lat i więcej - różnice pomiędzy 2011 i $2002 \mathrm{r}$.

Źródło: oprac. własne na podstawie Banku Danych Lokalnych, GUS, Warszawa

Zróżnicowanie przestrzenne współczynnika separacji zarówno w 2002, jak i 2011 r. przypomina układ mozaikowy, wymieszany (ryc. 38). Wyjątkiem jest jeden obszar o podobnej wartości tego współczynnika. Mowa tu o 2011 r. i podregionach położonych w południowo-wschodniej Polsce (lubelski, chełmsko-zamojski, tarnobrzeski, rzeszowski, przemyski, krośnieński, nowosądecki, tarnowski, krakowski, Kraków), w których poziom separacji osiąga wartości od 6 do 10 zdarzeń na 100 tys. ludności. Nie są to wartości najwyższe (powyżej 10), bo te występują w podregionach białostockim, elbląskim, kaliski, sieradzkim, częstochowskim, bielskim, rybnickim, katowickim i w Łodzi. Najniższe wartości wspomnianego współczynnika występują w podregionach położonych w różnych częściach kraju. 


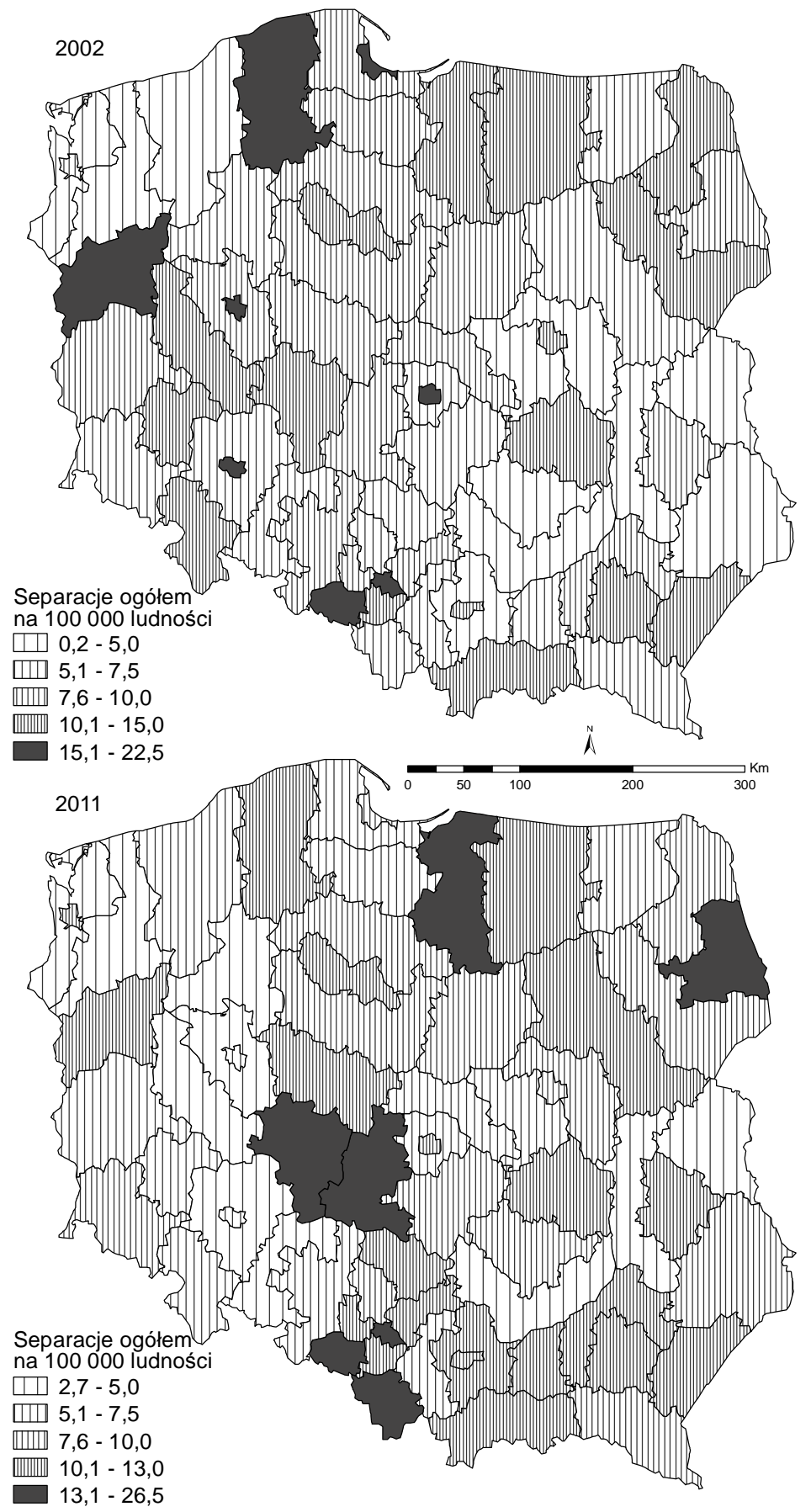

Ryc. 38. Separacje ogółem na 100000 ludności w 2002 i 2011 r. według podregionów Źródło: oprac. własne na podstawie Bazy Demografia, GUS, Warszawa 
Zmiany liczby orzekanych separacji nie wykazują trwałych tendencji, ale jest to dość nowa forma stanu cywilnego, rejestrowana dopiero od kilkunastu lat. W przestrzeni kraju (w latach 2002-2011) wyodrębniają się dwa dość zwarte obszary, w którym nastąpił przyrost współczynnika separacji (ryc. 39). Jeden z nich rozciąga się od południowego wschodu w kierunku północno-zachodnim i swym zasięgiem obejmuje podregiony centralne, większość jednostek leżących w tym obszarze charakteryzuje się najwyższymi wartościami wzrostu współczynnika separacji. Drugi obszar rozciąga się wzdłuż wschodnich granic łącząc się z podregionami Polski północnej o podobnych wartościach tego współczynnika.

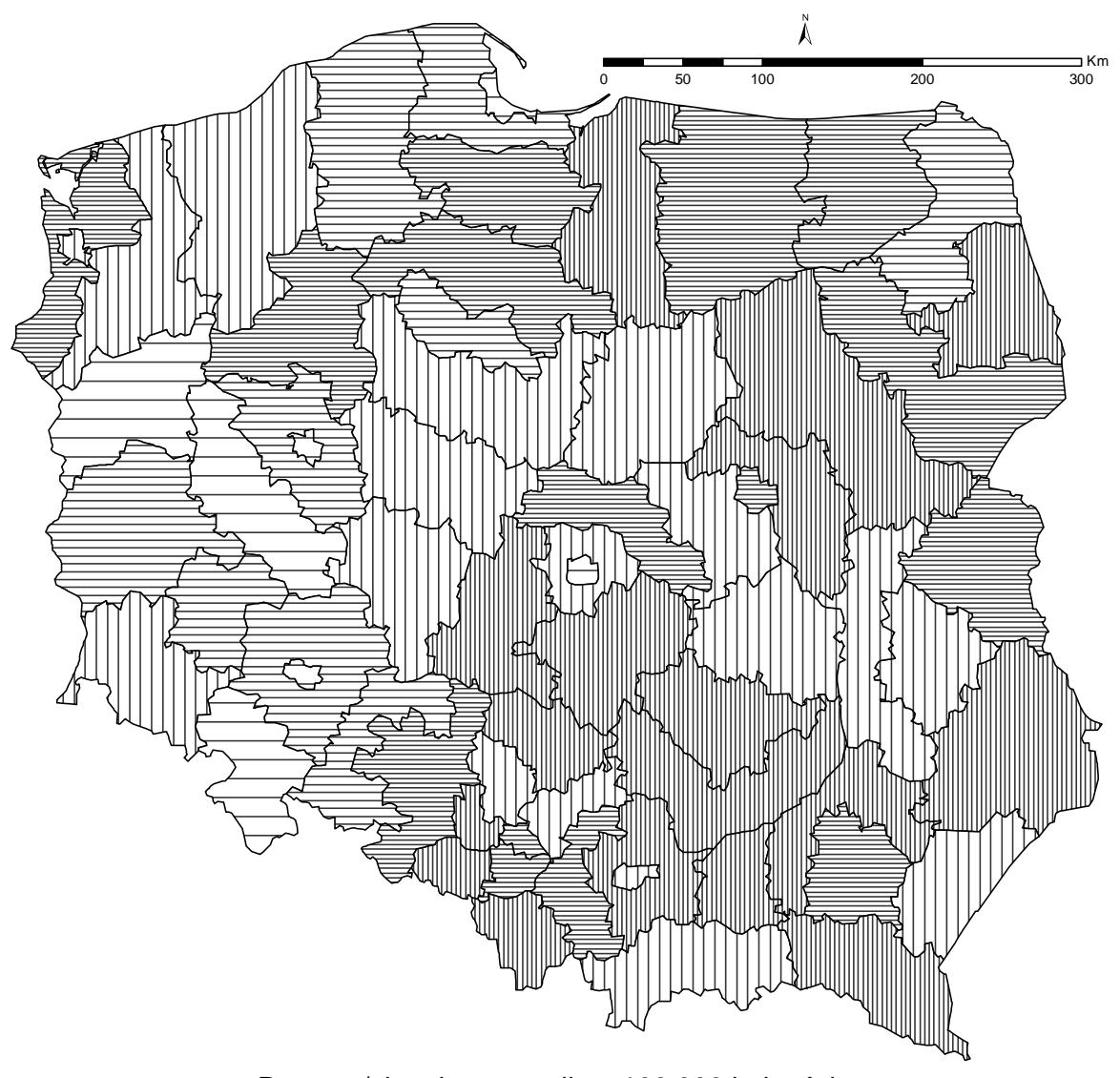

Przyrost/ubytek separacji na 100000 ludności

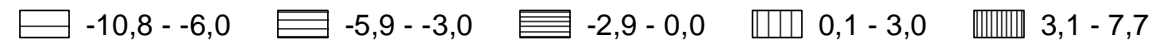

Ryc. 39. Różnice wartości współczynnika separacji na 100 tys. ludności w wieku 20 lat i więcej pomiędzy 2011 i 2002 r. według podregionów Źródło: oprac. własne na podstawie Bazy Demografia, GUS, Warszawa 


\subsubsection{Zróżnicowanie przestrzenne zjawiska kohabitacji według podre- gionów}

Badacze zgodnie podkreślają, że kohabitacja jest zjawiskiem złożonym, występuje przed małżeństwem, po małżeństwie, między małżeństwami, może być wstępem do małżeństwa bądź zastępować małżeństwo. M. Murphy (2000) uważa, że kohabitacja promuje małżeństwo odkąd praktyka poprzedzania zawarcia małżeństwa życiem w nieformalnym związku stała się powszechna.

Prowadzone od kilkudziesięciu lat badania nad zjawiskiem kohabitacji pozwoliły na obserwację podobieństw i różnic między związkami nieformalnymi a małżeństwami. Najczęściej wymieniane są takie podobieństwa między tymi dwoma typami związków, jak:

- heteroseksualność partnerów,

- utrzymywanie stosunków seksualnych,

- posiadanie przynajmniej pewnego poziomu ekonomicznej konsolidacji,

- stwarzanie środowiska, w którym dzieci są rodzone i wychowywane,

- występowanie obu typów związków w różnych okresach dorosłego życia, czyli możliwość pojawienia się ich w ciągu całej dorosłości.

Z. Wu i M. S. Pollard (2000) wskazują natomiast następujące aspekty różnic:

- kohabitacja może być podobna do małżeństwa w swoich funkcjach i rolach, ale z prawnego punktu widzenia niekoniecznie są one takie same,

- istotnie mniej środków ekonomicznych łączonych jest w związkach kohabitacyjnych niż w małżeńskich; kohabitanci maja tendencję do trzymania swoich środków oddzielnie,

- prawne zobowiązania małżonków i kohabitantów są różne, co powoduje, że wchodzenie i wychodzenie ze związków nieformalnych jest prostsze,

- mimo społecznego poparcia dla związków kohabitacyjnych, nie jest ono tak silne, jak w stosunku do małżeństw; w pewnym sensie wpływa to na rozpadanie się związków nieformalnych w warunkach, w których od par małżeńskich oczekuje się pozostawania razem i zachęca się je do tego,

- kohabitanci rzadziej mają dzieci i rzadziej chcą je mieć,

- kobiety w związkach kohabitacyjnych mniej czasu poświęcają pracy w gospodarstwie domowym, a więcej pracy zawodowej.

Z przytoczonych różnic i podobieństw pomiędzy małżeństwami i związkami konsensualnymi wynikają m.in. konsekwencje dla rozwoju demograficznego i społecznego kraju i regionów. Co prawda rozmiary zjawiska kohabitacji (według danych spisowych) są w Polsce w dalszym ciągu niewielkie, należy jednak pamiętać o tendencji wzrostowej liczby związków nieformalnych. W takim kontekście istotne wydaje się rozpoznanie zróżni- 
cowania przestrzennego osób, które deklarują przebywanie w związkach kohabitacyjnych.

Informacje statystyczne o stanie cywilnym są pozyskiwane podczas spisów powszechnych. Ostatnie dwa spisy, które odbyły się w 2002 i 2011 r., odnosiły się zarówno do stanu cywilnego faktycznego, jak i formalnoprawnego mieszkańców. W spisie z 2002 r. dane o faktycznym stanie cywilnym były uzyskane wtórnie (było to pytanie o stopień pokrewieństwa/ powinowactwa lub innego związku z głową gospodarstwa domowego, gdzie wymieniono, jako jedną $\mathrm{z}$ wielu możliwości, relacje: partner/partnerka [konkubent/konkubina]), w ostatnim badaniu spisowym były to zaś dwa pytania o stan cywilny prawny i faktyczny.

Rozkład przestrzenny osób kohabitujących w Polsce w 2002 r. był wyraźnie zróżnicowany. Najwięcej osób (powyżej średniej krajowej - 1,26\%), które żyły w związkach nieformalnych zamieszkiwało tereny Polski północnej i zachodniej oraz Warszawę - por. ryc. 40. Zjawisko kohabitowania najmniej było popularne $\mathrm{w}$ podregionach nowosądeckim, rzeszowskotarnobrzeskim i krośnieńsko-przemyskim. Wskazuje to na odmienność zachowań i postaw demograficznych mieszkańców południowo-wschodniej oraz północnej i zachodniej Polski, wynikającą z uznawanego systemu wartości i poziomu religijności. Jeszcze wyraźniej zarysowuje się ta regionalna odmienność zachowań demograficznych w przypadku odsetka osób kohabitujących na terenach wiejskich.

W spisie powszechnym z 2002 r. pozyskując informację o strukturze stanu cywilnego prawnego dano osobom będącym w małżeństwie możliwość określenia ich faktycznego stanu cywilnego. Stąd uzyskano dane o mieszkańcach naszego kraju, którzy mimo że formalnie są w związku małżeńskim to faktycznie $\mathrm{w}$ nim nie pozostają. Część $\mathrm{z}$ tych osób tworzy nowe związki, są to oczywiście związki nieformalne z powodu nieuregulowanego stanu prawnego ich sytuacji matrymonialnej29. Respondenci deklarujący ten stan nie stanowili dużego odsetka małżonków (314 tys. osób, co stanowiło 1,8\% ogółu osób żonatych/zamężnych), niemniej jednak fakt ten świadczy o rozpadzie pożycia owej części małżeństw. Mogą oni zasilić w przyszłości grupę osób rozwiedzionych, separowanych lub kohabitujących.

Obraz zróżnicowania regionalnego w przypadku tego zjawiska jest dość wyraźnie rozproszony, podregiony o najwyższym udziale osób nie pozostających faktycznie w małżeństwie występują bowiem zarówno na zachodzie kraju (podregion szczeciński, Szczecin), jak i w centrum (Łódź) oraz na południu (podregion sosnowiecki, katowicki). Obok skupiska podregionów o wysokim udziale tych osób na zachodzie kraju, na Górnym Śląsku oraz $\mathrm{w}$ centrum, mamy do czynienia $\mathrm{z}$ wysokimi odsetkami $\mathrm{w}$ podregionach

${ }^{29}$ Pisano o tym w podrozdziale 3.2.3. 
wschodnich (bialski, lubelski, chełmsko-zamojski) - por. ryc. 41. Być może świadczy to o wyższym poczuciu prawnego zobowiązania małżonków w stosunku do związku małżeńskiego pomimo faktycznego rozpadu związku.

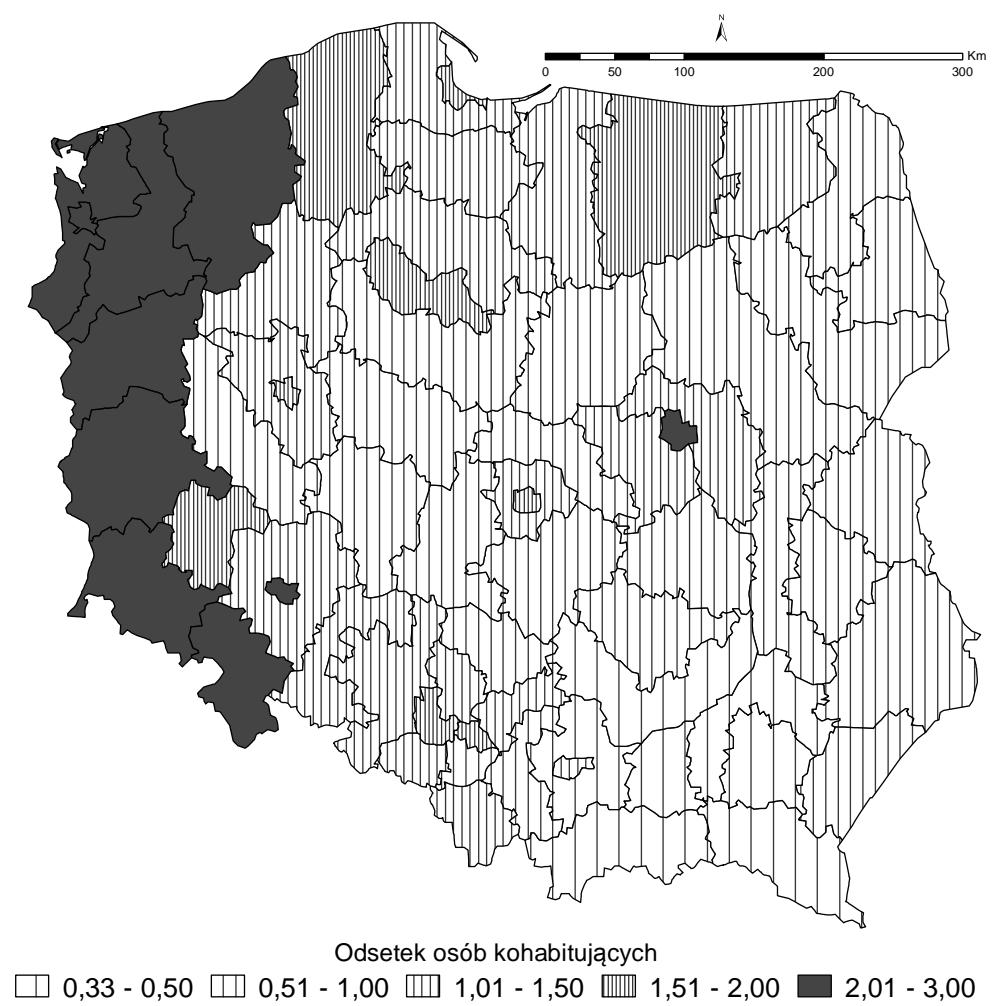

Ryc. 40. Odsetek osób kohabitujących w 2002 r. według podregionów

Źródło: oprac. własne na podstawie danych udostępnionych przez GUS, Warszawa

Osoby żyjące w związkach konsensualnych w Polsce w 2011 r. to przede wszystkim mieszkańcy podregionów zachodnich, północnych, największych miast polskich i podregionów silnie zurbanizowanych (ryc. 42). Wynika z tego, że zjawisko kohabitacji w Polsce, w świetle statystyki, nie jest związane tylko z dużymi miastami czy terenami silnie zurbanizowanymi. Okazuje się, że obszary Polski zachodniej i północnej odznaczają się specyficznymi cechami zachowań demograficznych, upodabniającymi je do krajów bardziej zaawansowanych w procesach drugiego przejścia demograficznego. Wnioski te jednak należy wysuwać z dużą ostrożnością, ponieważ rozmiary kohabitacji rejestrowanej w naszym kraju są bardzo niewielkie z porównaniu z krajami Europy Północnej czy Zachodniej. Jeden fakt jest jednak niezaprzeczalny, liczba osób żyjących w Polsce w związkach nieformalnych stale się powiększa. 


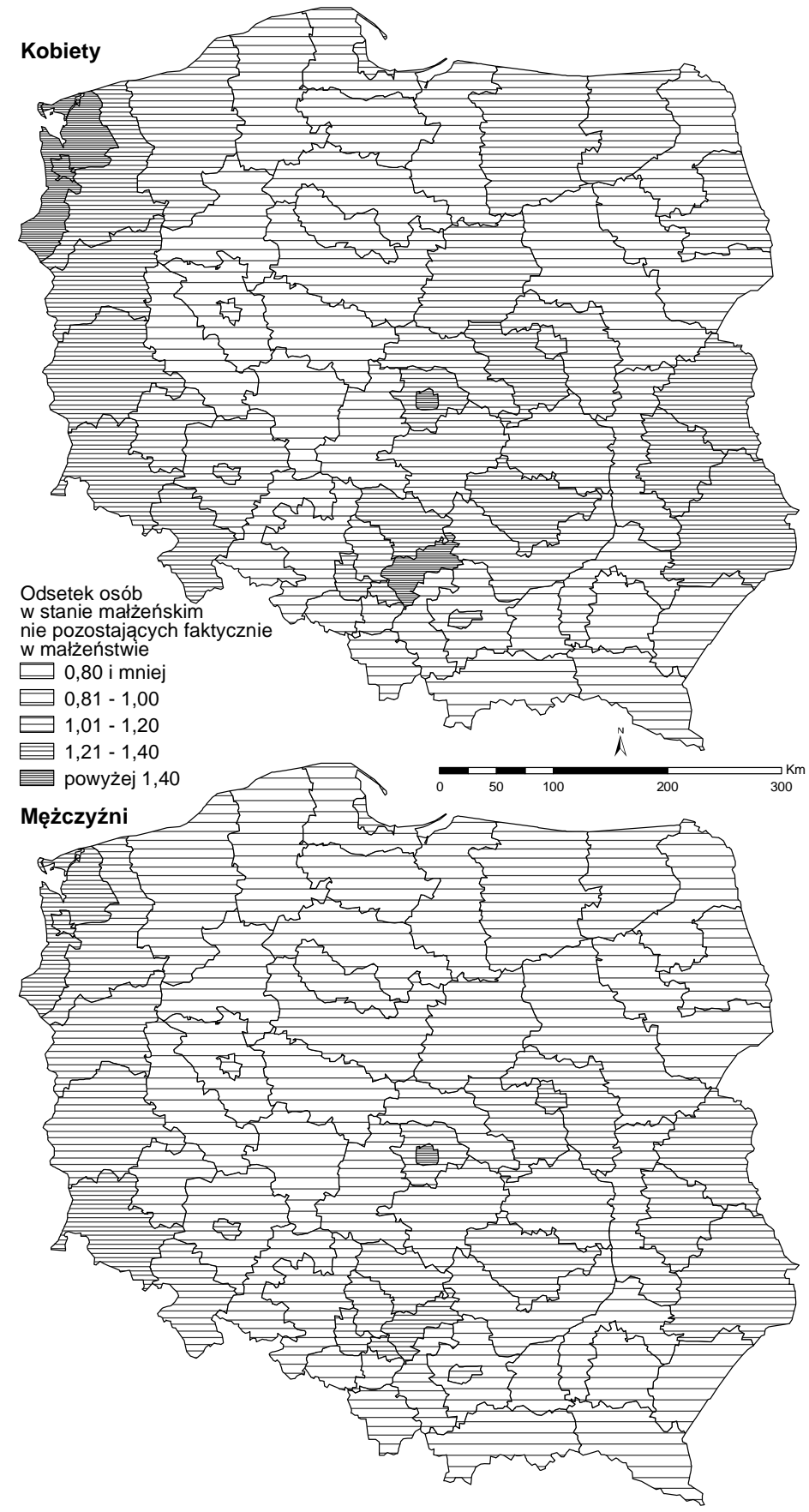

Ryc. 41. Odsetek osób w stanie małżeńskim nie pozostających w małżeństwie w 2002 r. według podregionów

Źródło: oprac. własne na podstawie Bazy Demografia, GUS, Warszawa 


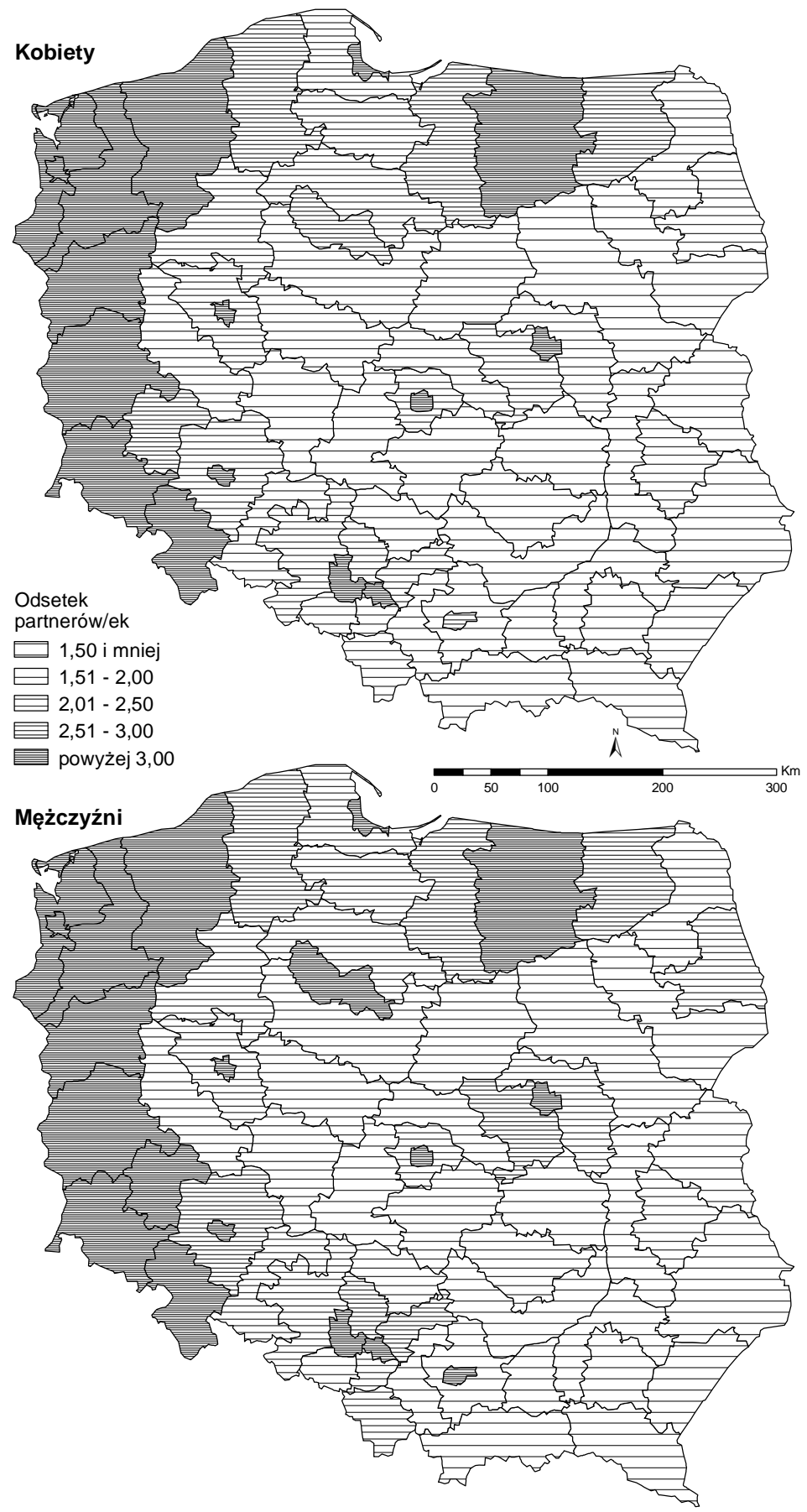

Ryc. 42. Odsetek osób kohabitujących w 2011 r. według podregionów Źródło: oprac. własne na podstawie Roczników statystycznych województw, GUS 


\section{PRZEMIANY ZACHOWAŃ PROKREACYJNYCH W POLSCE - OD ERY KRÓLEWSKIEGO DZIECKA Z RODZICAMI DO ERY PARY KRÓLEWSKIEJ Z DZIECKIEM}

\subsection{Regulacje prawne dotyczące urodzeń}

Podobnie jak na inne zjawiska demograficzne, na poziom urodzeń wpływa polityka ludnościowa, oczywiście jeśli jej instrumenty są skuteczne. Jednym z jej elementów jest prawo pracy i zakres uprawnień przysługujących pracującym kobietom w okresie ciąży, połogu i wychowania małego dziecka. Choć pierwsze akty prawne dotyczące ochrony macierzyństwa wydano w Polsce w 1919 r. i po II wojnie światowej zwiększano zakres ochrony macierzyństwa $\mathrm{w}$ kolejnych aktach prawnych, to dopiero $\mathrm{w}$ roku 1974 skodyfikowano prawo i uchwalono kodeks pracy (DzU, 1974, nr 24, poz. 141), wprowadzający jednolite zasady uprawnień przysługujących kobietom pracującym. Zapewnił on kobietom m.in. trwałość stosunku pracy w okresie ciąży i płatne urlopy macierzyńskie, związane z porodem, w wymiarze 16 tygodni przy pierwszym porodzie, 18 tygodni przy każdym następnym porodzie i 26 tygodni przy urodzeniu więcej niż jednego dziecka podczas jednego porodu. Natomiast dopiero od 1 lipca 1981 r. kobiety mogą korzystać z trzyletniego urlopu wychowawczego do ukończenia przez dziecko czterech lat, zachowując ciągłość pracy, oraz z zasiłku wychowawczego przez dwa lata w czasie urlopu wychowawczego (DzU, 1981, nr 19, poz. 97).

W roku $2013 \mathrm{w}$ odpowiedzi na potrzeby społeczne dokonano zmian dotyczących urlopów rodzicielskich (macierzyńskich i tzw. tacierzyńskich). Zgodnie z przepisami nowelizacji kodeksu pracy oraz niektórych innych ustaw, od 17 czerwca 2013 r. łączny wymiar płatnego urlopu po urodzeniu jednego dziecka zwiększy się z sześciu miesięcy do roku (52 tygodnie), a w przypadku porodu mnogiego nawet do 71 tygodni w zależności od liczby dzieci. Z płatnego rocznego urlopu będą mogli skorzystać rodzice wszystkich dzieci urodzonych w 2013 r. Będzie on obejmował 20 tygodni urlopu macierzyńskiego oraz do 6 tygodni dodatkowego urlopu macierzyń- 
skiego przy urodzeniu jednego dziecka. Rodzice bliźniąt, trojaczków i większej liczby dzieci urodzonych w trakcie jednego porodu otrzymają urlop macierzyński w wymiarze od 31 do 37 tygodni w zależności od liczby dzieci oraz do 8 tygodni dodatkowego urlopu macierzyńskiego. Do czasu nowelizacji ustawy dodatkowy urlop macierzyński wynosił do 4 tygodni przy jednym dziecku lub do 6 tygodni przy porodzie mnogim. Ponadto ustawa wprowadza dodatkowo nowy, 26-tygodniowy urlop rodzicielski. Jego długość jest stała, bez względu na liczbę dzieci urodzonych podczas jednego porodu. Zmiany w przepisach dotyczą także m.in. wysokości wynagrodzeń wypłacanych rodzicom w przypadku korzystania z urlopów. Rodzic, który zdecyduje się tylko na półroczny pobyt z dzieckiem otrzyma $100 \%$ pensji. Jeśli będzie chciał przedłużyć urlop o kolejne pół roku, jego pensja przez ten okres wyniesie 60\%. Rodzic, który od razu zdecyduje o skorzystaniu z rocznego urlopu otrzyma $80 \%$ wynagrodzenia. Nowe przepisy umożliwią elastyczne korzystanie z urlopów przez rodziców dziecka oraz godzenie ról zawodowych i rodzinnych. Przewidziano np. możliwość podzielenia tych urlopów między matkę i ojca. Nowe regulacje mają sprzyjać częstszemu wykorzystywaniu urlopów przez ojców. Nowelizacja powinna również poprawić sytuację kobiet na rynku pracy. Można będzie łączyć pracę maksymalnie na pół etatu $\mathrm{z}$ dodatkowym urlopem macierzyńskim i urlopem rodzicielskim. Wtedy pracownik otrzyma połowę zasiłku macierzyńskiego. Pracodawca nie będzie musiał godzić się na łączenie zatrudnienia i urlopu, bo nie na każdym stanowisku możliwa jest praca w niepełnym wymiarze. W takiej sytuacji będzie musiał poinformować pracownika o przyczynach odmowy. Nowelizacja zmienia również przepisy dotyczące urlopu wychowawczego. Trzyletni urlop wychowawczy będzie można wykorzystać do ukończenia przez dziecko 5. roku życia, a nie jak obecnie do końca 4. roku jego życia. Sejm uchwalił ustawę 28 maja 2013 r., a 10 czerwca 2013 r. podpisał ją prezydent. Ustawa weszła w życie 17 czerwca 2013 r. http://orka.sejm. gov.pl/proc7.nsf/ustawy/1105_u.htm).

Instrumentem prawnym wpływającym na regulacje urodzeń jest ustawodawstwo dotyczące aborcji. W Polsce $\mathrm{w}$ odniesieniu do przerywania ciąży do 1956 r. obowiązywał kodeks karny z 1932 r. W dniu 27 kwietnia 1956 r. Sejm przyjął ustawę o warunkach dopuszczalności przerywania ciąży (DzU, 1956, nr 12, poz. 61). Ustawa przewidywała możliwość wykonania zabiegu $w$ trzech przypadkach:

1) ze wskazań lekarskich,

2) w trudnych warunkach życiowych kobiety ciężarnej,

3) w razie uzasadnionego podejrzenia, że ciąża powstała w wyniku przestępstwa (gwałtu).

Przepisy ustawy z 27 kwietnia 1956 r., z późniejszymi rozporządzeniami wykonawczymi (DzU, 1960, nr 2, poz. 15; 1962, nr 7, poz. 35; 1980, nr 26, 
poz. 110), nie precyzowały pojęcia trudnych warunków życiowych, pozostawiając ich ocenę kobiecie stwierdzającej ustnie swoją wolę. Rozporządzenie z 1980 r. stawiało jedynie wymóg dokonywania zabiegu „przez lekarza będącego specjalistą pierwszego lub drugiego stopnia w dziedzinie ginekologii i położnictwa". Do początku lat 90. zabiegi przerywania ciąży ze względów medycznych i społecznych były ogólnie dostępne i dokonywane nieodpłatnie na oddziałach położniczych w szpitalach rejonowych oraz odpłatnie w prywatnych gabinetach lekarskich. Lekarze prywatni byli zobowiązani do prowadzenia sprawozdawczości statystycznej z wykonanych zabiegów. Z końcem lat 80. środowiska związane z Kościołem katolickim rozpoczęły kampanię propagandową przeciwko legalnej aborcji. Na początku marca 1989 r., z inicjatywy grupy posłów z Polskiego Związku Katolicko-Społecznego, złożono w sejmie projekt ustawy o prawnej ochronie dziecka poczętego. Projekt proponował wprowadzenie karalności aborcji, wzbudził falę protestów i w ówczesnym składzie sejmu nie został skierowany pod obrady plenarne. Pierwszym prawnym efektem dyskusji było rozporządzenie ministra zdrowia i opieki społecznej z dnia 30 kwietnia 1990 r. (DzU, 1990, nr 29, poz. 178) wprowadzające tryb orzekania o dopuszczalności przerwania ciąży ze względu na trudne warunki życiowe (pisemne oświadczenie kobiety, zasięgnięcie opinii drugiego lekarza specjalisty, lekarza ogólnego, rozmowa kobiety z psychologiem). Zarządzenie zezwalało lekarzowi na uchylenie się „od wydania orzeczenia o dopuszczalności przerwania ciąży oraz wykonania zabiegu przerwania ciąży, z wyjątkiem przypadku, gdy niewykonanie zabiegu przerwania ciąży zagraża bezpośrednio życiu kobiety". Kobieta, w przypadku wydania orzeczenia o niedopuszczalności przerywania ciąży, mogła się zwrócić z wnioskiem o rozpatrzenie sprawy przez komisję lekarską. W 1991 r. samorząd lekarski na Krajowym Zjeździe Lekarzy uchwalił Kodeks Etyki Lekarskiej, w którym przerwanie ciąży z przyczyn społecznych i powstałej wskutek gwałtu uznano za niedopuszczalne, natomiast przerywanie ciąży ze względów medycznych zostało poważnie ograniczone. Sejm uchwalił 7 stycznia 1993 r. Ustawę o planowaniu rodziny, ochronie płodu ludzkiego i warunkach dopuszczalności przerywania ciąży (DzU, 1993, nr 17, poz. 78), zwaną powszechnie „ustawą antyaborcyjną". Sejm w sierpniu 1996 r. złagodził jej brzmienie (DzU, 1996, nr 139, poz. 646) zezwalając na przerwanie ciąży, gdy „kobieta ciężarna znajduje się w ciężkich warunkach życiowych lub trudnej sytuacji osobistej". W grudniu 1996 r. grupa senatorów złożyła wniosek do Trybunału Konstytucyjnego o zbadanie zgodności znowelizowanej ustawy z obowiązującą konstytucją. W dniu 27 maja 1997 r. Trybunał orzekł, że przepisy ustawy dopuszczające przerywanie ciąży naruszają gwarancje konstytucyjne dla życia ludzkiego (Orzeczenie K.26/96 z dnia 27 maja, ogłoszone 28 maja). W grudniu 1997 r. (DzU, 1997, nr 157, poz. 1040) sejm zatwierdził 
orzeczenie Trybunału Konstytucyjnego. Obecnie ustawa antyaborcyjna zezwala na przerwanie ciąży w trzech przypadkach. Może do tego dojść, gdy:

1) ciąża stanowi zagrożenie dla życia lub zdrowia kobiety ciężarnej,

2) badania prenatalne lub inne przesłanki medyczne wskazują na duże prawdopodobieństwo ciężkiego i nieodwracalnego upośledzenia płodu albo nieuleczalnej choroby zagrażającej jego życiu,

3) zachodzi uzasadnione podejrzenie, że ciąża powstała w wyniku czynu zabronionego.

Jedynym krajem europejskim, w którym obowiązuje zakaz przerywania ciąży jest Irlandia, gdzie aborcja jest dopuszczalna tylko dla ratowania życia kobiety. W większości państw europejskich aborcja jest dopuszczalna na życzenie kobiety podczas trzech pierwszych miesięcy ciąży. W przypadku bardziej zaawansowanej ciąży aborcja jest możliwa z przyczyn społecznych, ze względu na zagrożenie zdrowia i życia, jeśli ciąża jest następstwem gwałtu bądź $\mathrm{w}$ przypadku uszkodzenia płodu. W Hiszpanii, Portugalii i Szwajcarii zabieg można przeprowadzić tylko wówczas, gdy zagrożone jest życie i zdrowie kobiety, a w Finlandii i Wielkiej Brytanii przyczyną przerwania ciąży może być zła sytuacja społeczno-ekonomiczna oraz uszkodzenie płodu. W ostatniej dekadzie wieku XX kolejne rządy polskie obok aktywnej polityki antyaborcyjnej właściwie nie prowadziły żadnej polityki w dziedzinie oświaty seksualnej i świadomego macierzyństwa, nie dopuściły także do wprowadzenia przedmiotu edukacja seksualna do programu szkolnego (Gawryszewski 2005).

\subsection{Kształtowanie się rodności po II wojnie światowej}

\subsubsection{Zmiany poziomu rozrodczości}

Pierwsze lata po zakończeniu wojny to okres odznaczający się niezwykle wysoką częstością urodzeń, rosnącą od 26,2 w 1946 r. do 31 na 1000 ludności w 1951 r. i stopniowo malejącą w następnych latach, aż do roku 1955 (ryc. 43). W okresie 1951-1955 liczba urodzeń przekraczała rocznie 750 tys., osiągając maksimum (w wartościach bezwzględnych) w 1955 r. - było to 793,8 tys. urodzeń żywych (współczynnik urodzeń osiągnął wartość 29,1). Pokolenie urodzone w końcu lat 40. i pierwszej połowie lat 50. jest określane jako pokolenie powojennego „wyżu demograficznego" 30 . W rozkładzie

$30 \mathrm{Na}$ konferencji zorganizowanej przez Instytut Gospodarstwa Społecznego w 1967 r. proponowano zaliczyć do wyżu demograficznego „osoby urodzone w tych latach po drugiej wojnie światowej, dla których współczynniki urodzeń i współczynniki dzietności były wyższe od analogicznych współczynników poprzedzających wybuch drugiej wojny światowej". Do zbiorowości tej zaliczono 15 roczników osób urodzonych w latach 1946-1960, które w dniu spisu z 6 grudnia 1960 r. liczyły 9,9 mln osób, czyli 1⁄33 ogółu ludności Polski (Romaniuk 1967: 31). 
przestrzennym rodności według powiatów w 1950 r. występuje zdecydowana różnica między poziomem urodzeń na ziemiach dawnych i tzw. ziemiach odzyskanych. Ziemie zachodnie i północne charakteryzowała bardzo wysoka stopa urodzeń, wynosząca 39,1\%0, przy ogólnokrajowym poziomie urodzeń 30,7\%o i zbliżonym poziomie urodzeń na ziemiach dawnych $27,8 \%$. W liczbach bezwzględnych sytuacja wyglądała podobnie, gdyż z ogólnej liczby 763,1 tys. urodzeń 31\% przypadało na ziemie zachodnie i północne - gdy ludność tych ziem stanowiła tylko 25\% ludności kraju (Gawryszewski 2005).

Od końca lat 50. powojenna tendencja kompensacyjna urodzeń wygasała, liczba urodzeń stopniowo zmniejszała się do 1967 r., w którym zarejestrowano 521,8 tys. urodzeń żywych (16,3\%o). Ponowny wzrost urodzeń nastąpił z końcem lat 60., kiedy to $\mathrm{w}$ wiek prokreacyjny zaczęło stopniowo wkraczać pokolenie wyżu demograficznego, nastąpił wzrost liczby zawieranych małżeństw i ponowny wzrost liczby urodzeń w postaci echa pierwszego powojennego wyżu demograficznego. Proces ten trwał z niewielkimi wahaniami w latach 1967-1983. Maksymalna liczba urodzeń w tej oktawie wyżu demograficznego wystąpiła w 1983 r. i wyniosła 723,6 tys. (19,7\%o).

Pomimo zmian wprowadzonych w prawie pracy, od $1983 \mathrm{r}$. występował systematyczny spadek liczby urodzeń do 351,1 tys. (9,2\%o) w 2003 r., mimo że pod koniec lat 90. wstępowało $\mathrm{w}$ wiek prokreacyjny pokolenie wyżu demograficznego z lat 1976-198331. Spadek liczby urodzeń rejestrowano w miastach do 2002 r., na wsi zaś do 2004 r. W wyniku przekształceń społeczno-politycznych z początku lat 90 . nastąpiła zmiana wzorców płodności, której efektem było wygaszenie efektu drugiego echa powojennego wyżu demograficznego, i w miejsce spodziewanego wzrostu liczby urodzeń w latach 1996-2003, rodność nadal malała (Gawryszewski 2005). Natomiast w latach 2004-2009 w całym kraju liczba urodzeń rosła średnio o 2\% rocznie, aby osiągnąc poziom 417,6 tys. w roku 2009. W ostatnich latach ponownie odnotowano spadek liczby urodzeń, w 2011 r. było ich 388,4 tys. $(10,1 \%)$.

${ }^{31}$ Kierunku zmian demograficznych w Polsce w latach 90. nie udało się poprawnie określić w prognozach GUS-u. Zakładano, że rozwój demograficzny ulegnie dalszemu wyhamowaniu, ale nie przewidziano tak gwałtownej obniżki stopy urodzeń, która doprowadziła do ubytku naturalnego. Dodatkowym czynnikiem, który wpłynął na przyrost rzeczywisty był wzrost emigracji (Eberhardt 2012). 


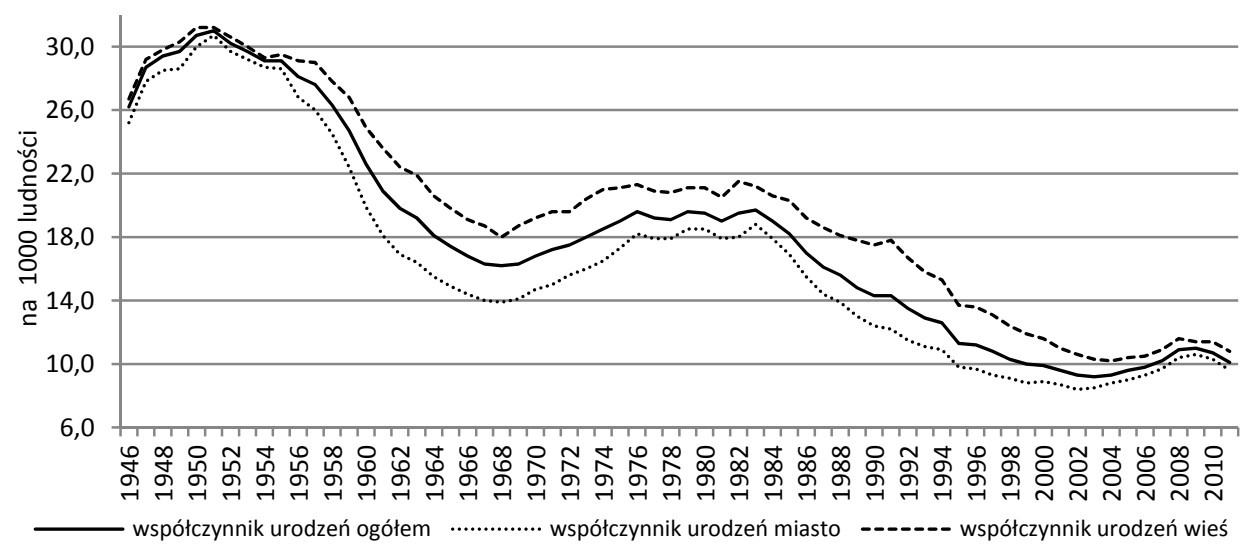

Ryc. 43. Urodzenia w Polsce w latach 1946-2011

Źródło: oprac. własne na podstawie Rocznik Demograficzny 2012, 2013, GUS, Warszawa

Przedstawione powyżej przemiany rodności w naszym kraju wykazywały zróżnicowanie przestrzenne już od lat 50. ubiegłego wieku. Wcześniej już wspomniano o wysokiej dynamice rodności na ziemiach północnych i zachodnich. Dynamika ta utrzymywała się przez kilkadziesiąt lat po wojnie (tab. 11). 0 wysokim poziomie rodności na tych terenach decydowała ich specyficzna sytuacja demograficzna, wynikająca z procesu masowego zasiedlania tych ziem przez młodą ludność oraz działania powojennej tendencji kompensacyjnej, tzn. odrabiania wojennych „zaległości” matrymonialnych i prokreacyjnych.

Tabela 11

Urodzenia żywe na ziemiach dawnych oraz zachodnich i północnych w latach 1948-2011

\begin{tabular}{|l|l|l|l|l|l|l|l|l|}
\hline \multirow{2}{*}{ Ziemie } & \multicolumn{7}{|c|}{ Urodzenia żywe na 1000 ludności w latach } \\
\cline { 2 - 10 } & 1948 & 1950 & 1960 & 1965 & 1968 & 1972 & 2000 & 2011 \\
\hline Polska ogółem & 29,1 & 30,7 & 22,6 & 17,3 & 16,2 & 17,5 & 9,8 & 10,1 \\
\hline Miasta & 27,8 & 30,0 & 19,8 & 14,9 & 13,9 & 15,6 & 8,8 & 9,6 \\
\hline Wieś & 29,8 & 31,2 & 25,3 & 19,7 & 18,0 & 19,6 & 11,4 & 10,8 \\
\hline Ziemie dawne & 26,7 & 27,8 & 21,3 & 16,8 & 15,9 & 17,0 & 9,9 & 10,2 \\
\hline Miasta & 24,5 & 25,0 & 18,4 & 14,2 & 13,4 & 15,0 & 8,8 & 9,8 \\
\hline Wieś & 27,8 & 29,3 & 23,8 & 19,1 & 18,3 & 19,1 & 11,6 & 10,7 \\
\hline $\begin{array}{l}\text { Ziemie północne } \\
\text { i zachodnie }\end{array}$ & 37,3 & 39,1 & 25,7 & 18,6 & 16,8 & 18,5 & 9,4 & 9,8 \\
\hline Miasta & 36,7 & 36,3 & 22,8 & 16,2 & 14,6 & 16,8 & 8,5 & 9,2 \\
\hline Wieś & 37,7 & 41,6 & 29,3 & 21,9 & 20,1 & 20,9 & 11,2 & 10,9 \\
\hline
\end{tabular}

Źródło: Gawryszewski 2005; Rocznik Demograficzny 2012, 2013, GUS, Warszawa.

Udział kobiet w wieku 15-49 lat w ogólnej liczbie kobiet wynosił na ziemiach zachodnich i północnych 55,7\%, na ziemiach dawnych zaś 52,8\%, a ogółem w kraju 53,4\%. Jeszcze wyższe zróżnicowanie wykazywał udział 
kobiet w wieku 20-29 lat, tj. w wieku, na który przypadało blisko $2 / 3$ urodzeń: na ziemiach zachodnich i północnych udział ten wynosił 39,0\%, podczas gdy na ziemiach dawnych 31,8\%. Na wysoką rodność wpływały również wzorce kulturowe ludności napływowej, głównie wiejskiej, przybyłej w blisko połowie $(48,8 \%)$ z ziem dawnych i w ponad $27 \%$ z dawnych kresów wschodnich, włączonych po wojnie do Związku Radzieckiego. W powiatach ziem zachodnich i północnych z wysokim udziałem ludności rodzimej (autochtonicznej) poziom urodzeń był niższy niż $\mathrm{w}$ powiatach $\mathrm{z}$ wysokim udziałem ludności napływowej (Gawryszewski 2005).

Sukcesywny spadek natężenia rodności, jaki następował w Polsce dotyczył zarówno ziem dawnych, jak i północnych oraz zachodnich. Przewaga wielkości poziomu rodności na tych ostatnich zakończyła się w $2000 \mathrm{r}$. Współczynniki urodzeń zarówno ogólny, jak i dla miast i wsi były niższe w północnej i zachodniej Polsce niż na ziemiach dawnych. Odwrócona tendencja natężenia rodności w przestrzeni „ziemie dawne-ziemie północne i zachodnie" utrzymuje się nadal.

Zmiany rodności w Polsce po wojnie dotyczyły także kolejności urodzenia dziecka przez daną matkę. Przy rozpatrywaniu urodzeń według kolejności mamy do czynienia z urodzeniami pochodzącymi co roku z innej zbiorowości kobiet. Zbiorowość ta składa się wyłącznie z kobiet rodzących w danym roku. W 1950 r. urodzenia pierwsze i drugie stanowiły w kraju blisko $62 \%$ wszystkich urodzeń, a obecnie (2011 r.) już ponad $85 \%$. Na ten wzrost miały znaczący wpływ urodzenia pierwsze, których przybywało zarówno w miastach, jak i na wsiach (tab. 12). Jednocześnie zmniejszały się udziały urodzeń kolejnych, zwłaszcza wyższych. We wszystkich rozpatrywanych latach udziały urodzeń trzecich i kolejnych były większe wśród mieszkanek wsi niż miast.

Jak piszą M. Okólski i A. Fihel (2008) zmiany liczby urodzeń nie są i nie mogą być jednokierunkowe a zarazem liniowe. W okresach wieloletnich cechuje je trend, który jednak po pewnym czasie sam ulega zmianie. Trendowi temu towarzyszą zwykle wahania o charakterze systematycznym, tworzące często swoisty cykl. Biorąc pod uwagę skutki społeczne wynikające z procesów demograficznych, szczególnie ważne są cykle złożone ze względnie długotrwałych, przeplatających się faz wzrostu i spadku. Jedną z teorii ekonomicznych wyjaśniających to zjawisko opisał Richard Easterlin. Cykl urodzeń złożony z długotrwałych przemiennych wzrostów i spadków może, jak to dzieje się we współczesnej Polsce, wynikać ze zdarzenia o charakterze nadzwyczajnym, na przykład z zakłóceń w reprodukcji populacji spowodowanych przez wojnę lub okupację kraju. W okresie II wojny światowej w Polsce na dużą skalę odraczano zakładanie rodziny, a w istniejących rodzinach na dużą skalę odraczano prokreację. Wynikiem tych decyzji była znacznie niższa liczba urodzeń $\mathrm{w}$ stosunku do obserwowanego 
(malejącego) trendu. Dało to początek cyklowi o bardzo silnych wahaniach liczby urodzeń, potęgowanych przez mechanizm typowy dla cyklu Easterlina. Wspomniany cykl urodzeń w Polsce współwystępował z malejącym trendem, który stanowił komponent przejścia demograficznego, czyli względnie uniwersalnego długookresowego procesu modernizacyjnego, polegającego na zastąpieniu reprodukcji ludności z typową wysoką dzietnością rodziny (kobiety) przez reprodukcję charakteryzującą się m.in. niską dzietnością.

Tabela 12

Urodzenia żywe według kolejności urodzenia w Polsce w latach 1950-2011

\begin{tabular}{|c|c|c|c|c|c|c|c|c|c|}
\hline \multirow{3}{*}{ Rok } & \multicolumn{8}{|c|}{ Kolejność urodzenia dziecka } & \multirow{3}{*}{$\begin{array}{l}\text { Przecięt- } \\
\text { na kolej- } \\
\text { ność } \\
\text { urodzenia }\end{array}$} \\
\hline & 1 & 2 & 3 & 4 & 5 & 6 & 7 & $\begin{array}{c}8 \\
\text { i więcej }\end{array}$ & \\
\hline & \multicolumn{8}{|c|}{ w odsetkach } & \\
\hline \multicolumn{10}{|c|}{ Ogółem } \\
\hline 1950 & 33,0 & 28,8 & 18,0 & 9,3 & 4,8 & 2,6 & 1,5 & 1,9 & 2,49 \\
\hline 1970 & 42,6 & 28,4 & 13,6 & 6,9 & 3,7 & 2,1 & 1,2 & 1,5 & 2,23 \\
\hline 1980 & 41,2 & 35,0 & 14,1 & 5,3 & 2,2 & 1,1 & 0,5 & 0,6 & 2,03 \\
\hline 1990 & 39,5 & 32,1 & 16,4 & 6,7 & 2,8 & 1,2 & 0,6 & 0,7 & 2,11 \\
\hline 2000 & 47,8 & 30,4 & 12,3 & 5,0 & 2,2 & 1,1 & 0,5 & 0,6 & 1,93 \\
\hline 2005 & 51,2 & 32,1 & 10,2 & 3,5 & 1,5 & 0,7 & 0,4 & 0,4 & 1,78 \\
\hline 2011 & 49,2 & 35,9 & 10,2 & 2,9 & 1,0 & 0,4 & 0,2 & 0,2 & 1,74 \\
\hline \multicolumn{10}{|c|}{ Miasta } \\
\hline 1950 & 37,8 & 31,7 & 16,8 & 7,2 & 3,2 & 1,6 & 0,8 & 0,9 & 2,20 \\
\hline 1970 & 50,6 & 30,5 & 10,7 & 4,1 & 1,9 & 1,0 & 0,5 & 0,7 & 1,86 \\
\hline 1980 & 45,1 & 37,9 & 11,8 & 3,3 & 1,1 & 0,4 & 0,2 & 0,2 & 1,81 \\
\hline 1990 & 42,6 & 34,3 & 15,0 & 5,0 & 1,8 & 0,7 & 0,3 & 0,3 & 1,94 \\
\hline 2000 & 52,4 & 30,7 & 10,5 & 3,6 & 0,5 & 0,7 & 0,3 & 0,3 & 1,66 \\
\hline 2005 & 54,9 & 32,3 & 8,5 & 2,5 & 1,0 & 0,4 & 0,2 & 0,2 & 1,76 \\
\hline 2011 & 51,3 & 36,4 & 8,8 & 2,3 & 0,8 & 0,3 & 0,1 & 0,1 & 1,67 \\
\hline \multicolumn{10}{|l|}{ Wieś } \\
\hline 1950 & 30,3 & 27,2 & 18,7 & 10,4 & 5,7 & 3,2 & 1,9 & 2,4 & 2,66 \\
\hline 1970 & 36,0 & 26,5 & 15,9 & 9,2 & 5,2 & 3,1 & 1,8 & 2,3 & 2,54 \\
\hline 1980 & 36,3 & 31,3 & 17,1 & 7,8 & 3,6 & 1,8 & 0,9 & 1,2 & 2,29 \\
\hline 1990 & 36,0 & 29,4 & 18,1 & 8,6 & 4,0 & 1,9 & 0,9 & 1,1 & 2,31 \\
\hline 2000 & 42,2 & 29,9 & 14,5 & 6,7 & 3,2 & 1,7 & 0,9 & 1 & 1,95 \\
\hline 2005 & 46,1 & 31,9 & 12,6 & 4,9 & 2,2 & 1,1 & 0,6 & 0,7 & 2,13 \\
\hline 2011 & 46,3 & 35,2 & 12 & 3,9 & 1,4 & 0,6 & 0,3 & 0,3 & 1,83 \\
\hline
\end{tabular}

Źródło: Roczniki Demograficzne z różnych lat, GUS, Warszawa.

W okresie powojennym przejawem trendu, w ramach którego cykl obejmował do tej pory dwie fazy wzrostu i dwie fazy spadku, było to, że szczyty kolejnych faz wzrostowych, jak również szczyty kolejnych faz spadkowych były coraz niższe; świadczyło to o trendzie malejącym. Pierwsza faza wzrostu trwała do połowy lat 50., a pierwsza faza spadku do końca lat 
60., podczas gdy druga faza wzrostu zakończyła się w roku 1983, natomiast druga faza spadku w roku 2003. Jest prawdopodobne, że ludność Polski znajduje się obecnie na progu kolejnej fazy wzrostu.

\subsubsection{Urodzenia pozamałżeńskie}

Jeszcze do niedawna zachowania prokreacyjne bardzo ściśle wiązały się $\mathrm{z}$ zachowaniami na rynku matrymonialnym. Zależności pomiędzy liczbą zawieranych małżeństw a liczbą urodzeń zarówno potencjalnych, jak i faktycznych były wysokie. Przemiany wpisujące się $\mathrm{w}$ drugie przejście demograficzne objęły także zachowania prokreacyjne, przyczyniając się do wzrostu odsetka urodzeń pozamałżeńskich, w tym w związkach partnerskich i przez samotne matki.

Urodzeniem pozamałżeńskim jest, zgodnie z przepisami polskiego prawa wydanie na świat dziecka przez matkę nie będącą w aktualnym związku małżeńskim. Dzieje się tak w następujących przypadkach:

1) przed zawarciem małżeństwa, o ile jego zawarcie nie nastąpi przed sporządzeniem aktu urodzenia (Prawo o aktach stanu cywilnego, art. 46),

2) po upływie 300 dni od chwili ustania lub unieważnienia małżeństwa (Kodeks rodzinny i opiekuńczy, art. $62 \S 1$ ).

W sytuacji, gdy małżeństwo trwa, domniemywa się, że ojcem dziecka jest małżonek jego matki, niezależnie od stanu faktycznego. Powyższy sposób rozumienia urodzenia pozamałżeńskiego zmniejsza liczbę takich urodzeń o porody dokonywane przez zamężne kobiety żyjące w faktycznej separacji, jak i o urodzenia, w przypadku których ojcem biologicznym nie jest małżonek zamężnej kobiety32.

Okres Polski Ludowej odznaczał się stabilizacją odsetka urodzeń dzieci nieślubnych na niskim poziomie (4-6\%) ${ }^{33}$. Dopiero lata 90. i początek wieku XXI przyniosły szybki wzrost tego udziału (tab. 13). Wzrost ten jest tym bardziej widoczny, że w sytuacji szybkiego spadku płodności i ogólnej liczby urodzeń po roku 1989, znacząco wzrosła liczba przychodzących na

32 Prowadzone w niektórych krajach rozwiniętych badania wskazują, że ok. 10\% dzieci jest potomkiem innego ojca niż domniemany (którym jest najczęściej małżonek matki). Odpowiednie odsetki wynoszą od 1\% w przypadku mężczyzn o wysokim statusie w Szwecji i USA, 5-6\% dla mężczyzn z klasy średniej w USA i Wielkiej Brytanii, do 10-30\% dla osobników o niskim statusie w USA, Wielkiej Brytanii i Francji (Baker 2000: 155).

33 Wyjątkiem w tym względzie były pierwsze powojenne lata, okres niestabilności społecznej i obyczajowej. Jednakże po wprowadzeniu w 1955 r. prawa dopuszczającego aborcję, poziom płodności pozamałżeńskiej szybko się obniżał - $\mathrm{z}$ tej formy „antykoncepcji” korzystały przede wszystkim kobiety, które nie miały szansy na legalizację związku bądź krótkotrwałej znajomości z biologicznym ojcem dziecka (Szukalski 2010). 
świat dzieci urodzonych przez matki nie pozostające w ważnym z punktu widzenia prawa związku. Choć już druga połowa lat 80. przyniosła nasilenie częstości urodzeń pozamałżeńskich, dopiero w okresie po przełomie politycznym roku 1989 następuje stały, regularny i prawie liniowy wzrost odsetka, zazwyczaj o $0,5-0,6 \%$ z roku na rok. W rezultacie, począwszy od roku 1993, corocznie "bity jest nowy rekord” dla okresu powojennego (Szukalski 2001). Obecnie praktycznie co piąty noworodek przychodzi na świat poza małżeństwem.

Tabela 13

Urodzenia pozamałżeńskie w Polsce w latach 1960-2011

\begin{tabular}{|l|c|c|r|}
\hline \multirow{2}{*}{ Rok } & \multicolumn{3}{|c|}{ Urodzenia pozamałżeńskie } \\
\cline { 2 - 4 } & ogółem & miasto & wieś \\
\hline 1960 & 4,5 & 5,2 & 3,9 \\
\hline 1970 & 5,0 & 5,7 & 4,4 \\
\hline 1980 & 4,8 & 5,2 & 4,2 \\
\hline 1990 & 6,2 & 5,8 & 4,4 \\
\hline 1998 & 11,6 & 14,3 & 8,3 \\
\hline 2000 & 12,1 & 14,8 & 8,8 \\
\hline 2004 & 17,1 & 20,2 & 13,0 \\
\hline 2007 & 19,5 & 22,4 & 15,4 \\
\hline 2010 & 20,6 & 23,1 & 17,0 \\
\hline 2011 & 21,2 & 23,6 & 17,9 \\
\hline
\end{tabular}

Źródło: Roczniki Demograficzne z różnych lat, GUS, Warszawa.

Bardzo ważną kwestią, związaną z urodzeniami pozamałżeńskimi, jest występująca $\mathrm{w}$ całym powojennym okresie różnica $\mathrm{w}$ poziomie częstości urodzeń pozamałżeńskich pomiędzy obszarami miejskimi i wiejskimi. W miastach udział urodzeń pozamałżeńskich jest stale o blisko połowę wyższy niż wśród ludności wiejskiej. Przyczyn należy upatrywać zapewne w większym konserwatyzmie obyczajowym mieszkańców wsi, większym ich rygoryzmie moralnym, wyższej religijności, wyższej wartości przypisywanej instytucji małżeństwa, a także silniejszej społecznej kontroli prowadzącej do zawierania małżeństw „naprawczych” w przypadku wystąpienia ciąży (Kałuża 2008). Również w ramach populacji zamieszkującej miasta widoczne jest zróżnicowanie - generalnie, im większe skupisko ludzkie, tym mamy do czynienia z wyższą skłonnością do wydawania na świat potomstwa pozamałżeńskiego. Wynika to zapewne $\mathrm{z}$ faktu, że wszystkie wymienione powyżej cechy charakteryzujące mieszkańców wsi w największym stopniu znajdują swe przeciwieństwa $\mathrm{w}$ zbiorowości mieszkańców miast największych, $\mathrm{z}$ reguły najbardziej zatomizowanych, skupiających jednostki najlepiej wykształcone i samodzielne mentalnie (w tym także pod względem religii) - por. Szukalski 2010 . 
Dynamiczny przyrost odsetka urodzeń pozamałżeńskich jest charakterystyczny nie tylko dla Polski, ale także dla wielu innych krajów europejskich. Na początku okresu przemian demograficznych związanych z drugim przejściem demograficznym (lata 60.) urodzenia pozamałżeńskie stanowiły od kilku do kilkunastu procent ogółu urodzeń (wyjątek stanowiła Islandia 25,3\%). Kraje Europy Środkowej i Wschodniej aż do czasu rozpoczęcia transformacji nie wykazywały zróżnicowania pod względem wartości odsetka urodzeń pozamałżeńskich (Kurkiewicz 1998). Obecnie w wielu krajach europejskich więcej niż połowa dzieci rodzi się poza małżeństwami, wśród nich są kraje wschodnio- i środkowoeuropejskie, pod tym względem dość wyraźnie zróżnicowane (Estonia - 59,7\%; Słowenia - 56,8\%; Bułgaria - 56,1\%; Chorwacja - 14\%; Polska - 21,2\%), ale liderem jest w dalszym ciągu Islandia (65\%). Tylko w krajach, gdzie wartości religijne wciąż odgrywają istotna rolę, a poziom laicyzacji społeczeństwa jest niski, obserwuje się niskie odsetki urodzeń pozamałżeńskich, np. w Grecji czy Polsce (ryc. 44).

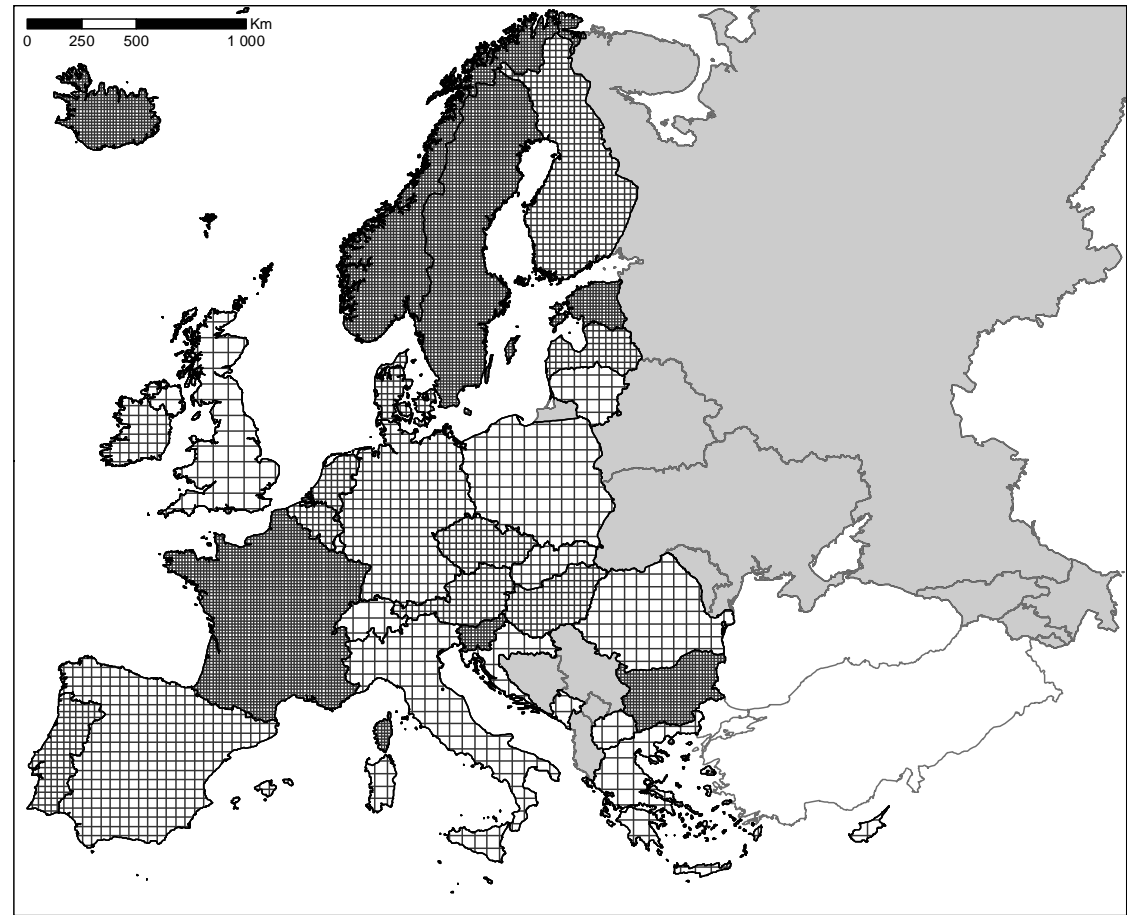

Odsetek urodzeń pozamałżeńskich

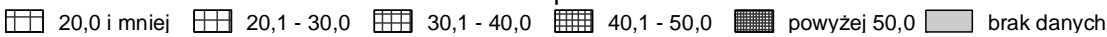

Ryc. 44. Urodzenia pozamałżeńskie w wybranych krajach europejskich w $2011 \mathrm{r}$.

Źródło: oprac. własne na podstawie: Eurostat, http://epp.eurostat.ec.europa.eu/portal/page/ population/data/database 


\subsubsection{Przemiany płodności kobiet od lat 50. $X X$ w.}

Natężenie urodzeń w Polsce, liczone na 1000 kobiet w wieku rozrodczym, systematycznie malało od połowy lat 50. Kilka lat po wojnie matką zostawała co dziesiąta kobieta w wieku rozrodczym, a w $2011 \mathrm{r}$. już tylko co trzydziesta (tab. 14). Zaraz po wojnie współczynniki płodności były najwyższe wśród kobiet w wieku 25-29 lat, a i następna grupa wiekowa (30-34 lata) odznaczała się wysoką rodnością, był to wynik odraczanych decyzji prokreacyjnych z okresy wojny. Prawie do końca XX w. najwyższa płodność występowała wśród młodych kobiet pomiędzy 20. i 24. rokiem życia. Przez cały ten okres częściej matkami zostawały mieszkanki wsi niż miast. W pierwszej dekadzie XXI w. odnotowano symptomy odraczania decyzji prokreacyjnych na późniejszy wiek, co skutkowało zwiększeniem wartości współczynnika płodności w następnych grupach pięcioletnich kobiet zarówno w mieście, jak i na wsi.

Największy wpływ na liczbę urodzeń miał spadek płodności wśród najmłodszych kobiet, które nie przekroczyły 25. roku życia. W okresie 19902011 współczynnik urodzeń na 1000 kobiet spadł o 69\% w grupie 20-24 lata i była to tendencja powszechna i w miastach, i na terenach wiejskich. Natomiast w przypadku starszych grup wiekowych obserwowano odmienne tendencje $w$ miastach i na wsi, przy czym płodność mieszkanek miast malała w mniejszym tempie niż płodność mieszkanek wsi. I tak, dla kobiet w wieku 25-29 lat współczynnik urodzeń na 1000 kobiet zmalał o 22,6\% w miastach i 30,8\% na wsiach, dla kobiet w wieku 30-34 lat i 35-39 lat wzrósł w miastach o odpowiednio 44 i 55\%, na terenach wiejskich spadł zaś o 8 i $14,7 \%$.

Opisane wyżej tendencje przemian płodności kobiet w Polsce wskazują na zmiany wzorca płodności. Uwzględniając wartości cząstkowych współczynników płodności dla trzech grup wiekowych, w których płodność jest największa, tj. 20-24, 25-29 oraz 30-34 lata można wyznaczyć sześć wzorców płodności według wieku ${ }^{34}$ :

Wzorzec I - najwyższe wartości współczynnika płodności występują w wieku 20-24 lata i są wyraźnie wyższe (różnice między wartościami przewyższają 10\%) niż zaobserwowane w wieku 25-29 lat,

Wzorzec II - współczynniki płodności kobiet w wieku 20-24 i 25-29 lat kształtują się na zbliżonym poziomie (różnice między wartościami nie są wyższe niż 10\%),

Wzorzec III - wartości współczynnika płodności w wieku 20-24 lata są wyraźnie niższe aniżeli w wieku 25-29 lat,

34 Podobny sposób analizy zmian płodności przeprowadziła M. Podogrodzka (2012a), w jej opracowaniu wyróżniono pięć wzorców płodności. 
Płodność kobiet w latach 1950-2011

\begin{tabular}{|c|c|c|c|c|c|c|c|c|}
\hline \multirow{2}{*}{ Rok } & \multicolumn{8}{|c|}{ Płodność - urodzenia żywe na 1000 kobiet w wieku } \\
\hline & $15-49$ & $15-19$ & $20-24$ & $25-29$ & $30-34$ & $35-39$ & $40-45$ & $45-49$ \\
\hline \multicolumn{9}{|c|}{ Ogółem } \\
\hline 1950 & 109 & 39 & 194 & 209 & 157 & 100 & 38 & 4 \\
\hline 1955 & 110 & 42 & 208 & 203 & 144 & 89 & 32 & 3 \\
\hline 1960 & 93 & 45 & 199 & 165 & 103 & 60 & 22 & 2 \\
\hline 1965 & 72 & 32 & 184 & 144 & 84 & 43 & 15 & 2 \\
\hline 1970 & 64 & 30 & 165 & 126 & 71 & 36 & 11 & 1 \\
\hline 1975 & 71 & 31 & 170 & 137 & 71 & 34 & 10 & 1 \\
\hline 1980 & 76 & 33 & 180 & 136 & 69 & 29 & 8 & 1 \\
\hline 1985 & 74 & 35 & 183 & 141 & 70 & 30 & 7 & 1 \\
\hline 1990 & 58 & 32 & 165 & 121 & 59 & 25 & 6 & 0 \\
\hline 1995 & 43 & 22 & 113 & 105 & 54 & 23 & 6 & 0 \\
\hline 2000 & 37 & 17 & 81 & 92 & 51 & 21 & 5 & 0 \\
\hline 2011 & 41 & 14 & 51 & 89 & 71 & 30 & 6 & 0 \\
\hline \multicolumn{9}{|c|}{ Miasta } \\
\hline 1950 & 99 & 41 & 189 & 187 & 129 & 75 & 24 & 2 \\
\hline 1955 & 101 & 46 & 198 & 183 & 117 & 67 & 22 & 2 \\
\hline 1960 & 77 & 45 & 182 & 133 & 73 & 39 & 13 & 1 \\
\hline 1965 & 57 & 29 & 148 & 112 & 59 & 26 & 8 & 1 \\
\hline 1970 & 51 & 26 & 134 & 102 & 52 & 22 & 6 & 0 \\
\hline 1975 & 59 & 28 & 130 & 111 & 56 & 23 & 6 & 0 \\
\hline 1980 & 66 & 28 & 151 & 121 & 59 & 22 & 5 & 0 \\
\hline 1985 & 64 & 33 & 159 & 125 & 61 & 25 & 5 & 0 \\
\hline 1990 & 48 & 29 & 143 & 106 & 50 & 20 & 5 & 0 \\
\hline 1995 & 36 & 20 & 96 & 93 & 47 & 19 & 5 & 0 \\
\hline 2000 & 32 & 15 & 68 & 85 & 48 & 18 & 4 & 0 \\
\hline 2011 & 39 & 13 & 41 & 82 & 72 & 31 & 6 & 0 \\
\hline \multicolumn{9}{|c|}{ Wieś } \\
\hline 1950 & 116 & 38 & 197 & 226 & 177 & 116 & 47 & 5 \\
\hline 1955 & 118 & 39 & 218 & 222 & 169 & 109 & 42 & 5 \\
\hline 1960 & 109 & 45 & 217 & 202 & 137 & 82 & 32 & 3 \\
\hline 1965 & 88 & 34 & 231 & 186 & 115 & 64 & 22 & 3 \\
\hline 1970 & 79 & 34 & 208 & 161 & 99 & 55 & 18 & 2 \\
\hline 1975 & 90 & 35 & 248 & 186 & 99 & 51 & 16 & 1 \\
\hline 1980 & 94 & 40 & 229 & 167 & 90 & 42 & 12 & 1 \\
\hline 1985 & 92 & 38 & 215 & 169 & 89 & 42 & 11 & 1 \\
\hline 1990 & 77 & 35 & 196 & 146 & 75 & 34 & 9 & 1 \\
\hline 1995 & 58 & 26 & 138 & 123 & 66 & 31 & 8 & 0 \\
\hline 2000 & 47 & 19 & 104 & 104 & 58 & 26 & 7 & 0 \\
\hline 2011 & 44 & 15 & 66 & 101 & 69 & 29 & 6 & 0 \\
\hline
\end{tabular}

Źródło: Roczniki Demograficzne z różnych lat, GUS, Warszawa. 
Wzorzec IV - natężenie płodności jest najwyższe w wieku 25-29 lat, ale równocześnie w sąsiednich grupach wieku kształtuje się na nieznacznie niższym poziomie,

Wzorzec V - natężenie płodności jest najwyższe w wieku 25-29 lat, a w wieku 20-24 lata jest niższe w porównaniu z wiekiem 30-34 lata,

Wzorzec VI ${ }^{35}$ - najwyższe wartości współczynnika płodności występują w wieku 30-34 lata.

Zmiany ludnościowe w Polsce powojennej były w przeważającej części konsekwencją działań wojennych. Odraczane na później decyzje matrymonialne z czasów wojny oraz związane z nimi zamierzenia prokreacyjne były realizowane po zakończeniu wojny. Zaraz po wojnie i jeszcze do połowy lat 50. utrzymywał się drugi wzorzec płodności, w którym najwyższe wartości współczynnika płodności występowały w grupach kobiet 20-24 i 25-29 lat i były do siebie zbliżone (tab. 15). Co prawda zmieniała się kolejność niewielkiej dominacji płodności $w$ tych grupach, początkowo nieco wyższe były one wśród starszych kobiet (25-29), a potem w grupie 20-24 lata, ale różnice były bardzo małe. Nieco inaczej sytuacja przedstawiała się na terenach wiejskich, gdzie dominowały urodzenia w grupie 25-29 lat, a więc mieliśmy do czynienia $\mathrm{z}$ trzecim wzorcem płodności, który przeszedł w drugi i przetrwał do lat 60 . Aż do połowy lat 90 . zarówno w miastach, jak i na wsiach utrzymywał się w Polsce pierwszy wzorzec płodności. Zmiany transformacyjne dokonujące się wówczas w kraju wpłynęły niewątpliwie na zjawisko płodności kobiet nie tylko w wymiarze ilościowym, ale także na podejmowanie zachowań prokreacyjnych w późniejszym wieku. Skutkowało to wzrostem płodności w starszych grupach wiekowych i zbliżeniem się wartości współczynnika płodności pomiędzy kobietami z grup 20-24 i 2529 lat, co było jednoznaczne z zachowaniami opisanymi w trzecim wzorcu. Takie postawy prokreacyjne są charakterystyczne dla kraju i ludności miejskiej do 1995 r., natomiast na wsi polskiej drugi wzorzec płodności utrzymywał się do końca XX w. W pierwszej dekadzie XX w. doszło do dalszych zmian w ramach płodności, związanych z wiekiem kobiet, obecnie najwyższą płodność notujemy u kobiet mających 25-29 lat i jest to piąty wzorzec płodności.

Miarą syntetyczną służącą do analizy rodności jest współczynnik dzietności Total Fertility Rate (TFR), który jest miernikiem aktywności w procesie reprodukcji i określa liczbę dzieci (chłopców i dziewcząt) wydanych na świat przez jedną kobietę w ciągu pełnego okresu rozrodczego. Aby była zapewniona zastępowalność pokoleń, wartość tego współczynnika musi być większa od 2,1 dziecka na jedną kobietę.

${ }^{35}$ Wzorzec VI wystepuje w kilku podregionach - por. podrozdział 4.3.2. 
Tabela 15

Wzorce płodności w Polsce w latach 1950-2011

\begin{tabular}{|l|c|c|c|}
\hline \multirow{2}{*}{ Rok } & \multicolumn{3}{|c|}{ Wzorzec płodności } \\
\cline { 2 - 4 } & ogółem & miasto & wieś \\
\hline 1950 & II & II & III \\
\hline 1955 & II & II & II \\
\hline 1960 & I & I & I \\
\hline 1965 & I & I & I \\
\hline 1970 & I & I & I \\
\hline 1975 & I & I & I \\
\hline 1980 & I & I & I \\
\hline 1985 & I & I & I \\
\hline 1990 & I & I & I \\
\hline 1995 & I & I & I \\
\hline 2000 & III & III & II \\
\hline 2011 & V & V & V \\
\hline
\end{tabular}

Źródło: oprac. własne na podstawie Roczników Demograficznych z różnych lat, GUS, Warszawa.

Okres powojenny odznaczał się bardzo wysoką dzietnością, wynoszącą powyżej trojga, na wsi nawet powyżej czworga dzieci (ryc. 45). Skłonności do posiadania licznego potomstwa sukcesywnie malały przez 40 lat po wojnie, a na przełomie wieków doszło do obniżenia wartości współczynnika poniżej prostej zastępowalności pokoleń. Należy dodać, że tendencje spadkowe współczynnika dzietności rejestruje się zarówno na terenach miejskich, jak i wiejskich. W rezultacie w okresie 1990-2011 współczynnik dzietności spadł w miastach średnio o 31,5\%, natomiast na wsiach średnio o 42,5\%. To, iż spadek TFR był wyższy na wsi niż w miastach, wynikało z wyższego poziomu początkowego płodności na terenach wiejskich, a także $\mathrm{z}$ tendencji do stopniowego zbliżania się poziomu początkowego płodności na terenach wiejskich i miejskich.

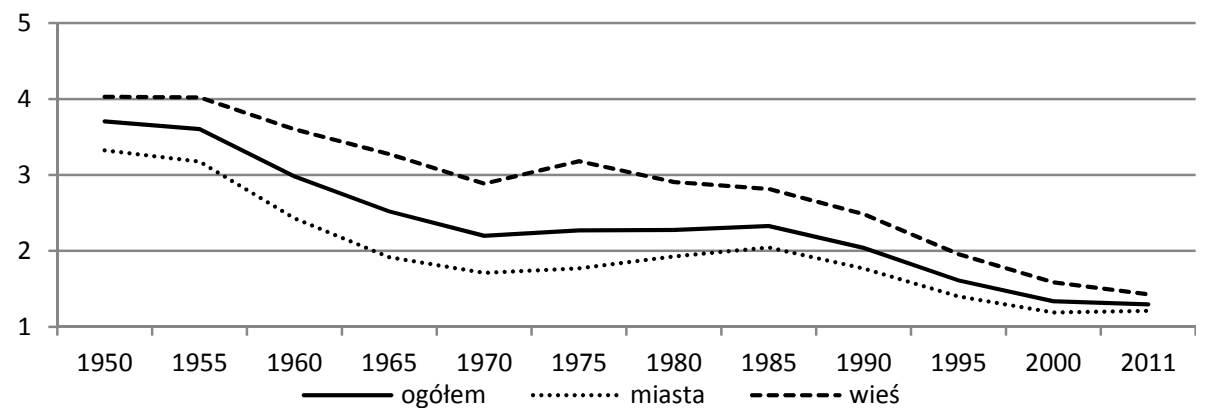

Ryc. 45. Współczynnik dzietności w latach 1950-2011

Źródło: oprac. własne na podstawie: Gawryszewski 2005; Rocznik Demograficzny 2012, 2013, GUS, Warszawa 
Podobnie jak w Polsce, tak i w innych krajach europejskich istotnym elementem zmiany wzorca zachowań reprodukcyjnych jest obniżająca się dzietność kobiet (Kurczewska 2011). O ile w roku 1990 w kilku krajach (m.in. w Polsce, Szwecji czy Irlandii) rejestrowano wartości powyżej 2, bliskie poziomowi prostej zastępowalności pokoleń, to w 2011 r., według Eurostatu, nie było w Europie kraju, gdzie wskaźnik dzietności przekraczałby wartość 2,1 dziecka na kobietę. Najbliżej tych wartości były Irlandia i Islandia (odpowiednio 2,05; 2,04). Najniższe wartości wskaźników notowały kraje postkomunistyczne, w tym Polska (ryc. 46). W krajach Europy Północnej i Zachodniej, które zainicjowały procesy drugiego przejścia demograficznego, można zaobserwować względną stabilizację dzietności (na poziomie 1,8-1,9) lub niewielki jej wzrost, w krajach środkowoeuropejskich zaś od 2002 r. tendencje te są zmienne. Są kraje, w których w latach 2002-2011 zwiększyła się dzietność (np. Bułgaria, Czechy, Estonia), kraje gdzie wartości współczynnika praktycznie nie uległy zmianie (np. Polska, Chorwacja) i wreszcie przykład Węgier i Macedonii, w których odnotowany został dalszy spadek dzietności. Oprócz zmniejszającej się dzietności obserwuje się $w$ ramach drugiego przejścia wzrost średniego wieku matek rodzących. Analiza porównawcza obejmująca nawet krótką perspektywę czasową, tj. lata 2002-2011, wskazuje na opóźnianie decyzji prokreacyjnych o dwa lub blisko dwa lata (Estonia, Litwa, Słowacja, Bułgaria, Czechy). Najstarszymi matkami rodzącymi dzieci w Europie, biorąc pod uwagę średni wiek, są mieszkanki Irlandii, Hiszpanii i Włoch (ryc. 47).

Z poznawczego punktu widzenia, obok zachowań prokreacyjnych, interesujące są również postawy (intencje) prokreacyjne. $\mathrm{Z}$ prowadzonych badań wynika, że również same pragnienia i zamierzenia prokreacyjne ulegają zmianom. Chociaż nadal istnieje rozbieżność pomiędzy tym, jaka jest pożądana lub idealna liczba dzieci w rodzinie a tym, ile dzieci się faktycznie rodzi - to kolejne pokolenia chcą mieć coraz mniejsze rodziny (Goldstein i in. 2003; Lutz i in. 2005). 


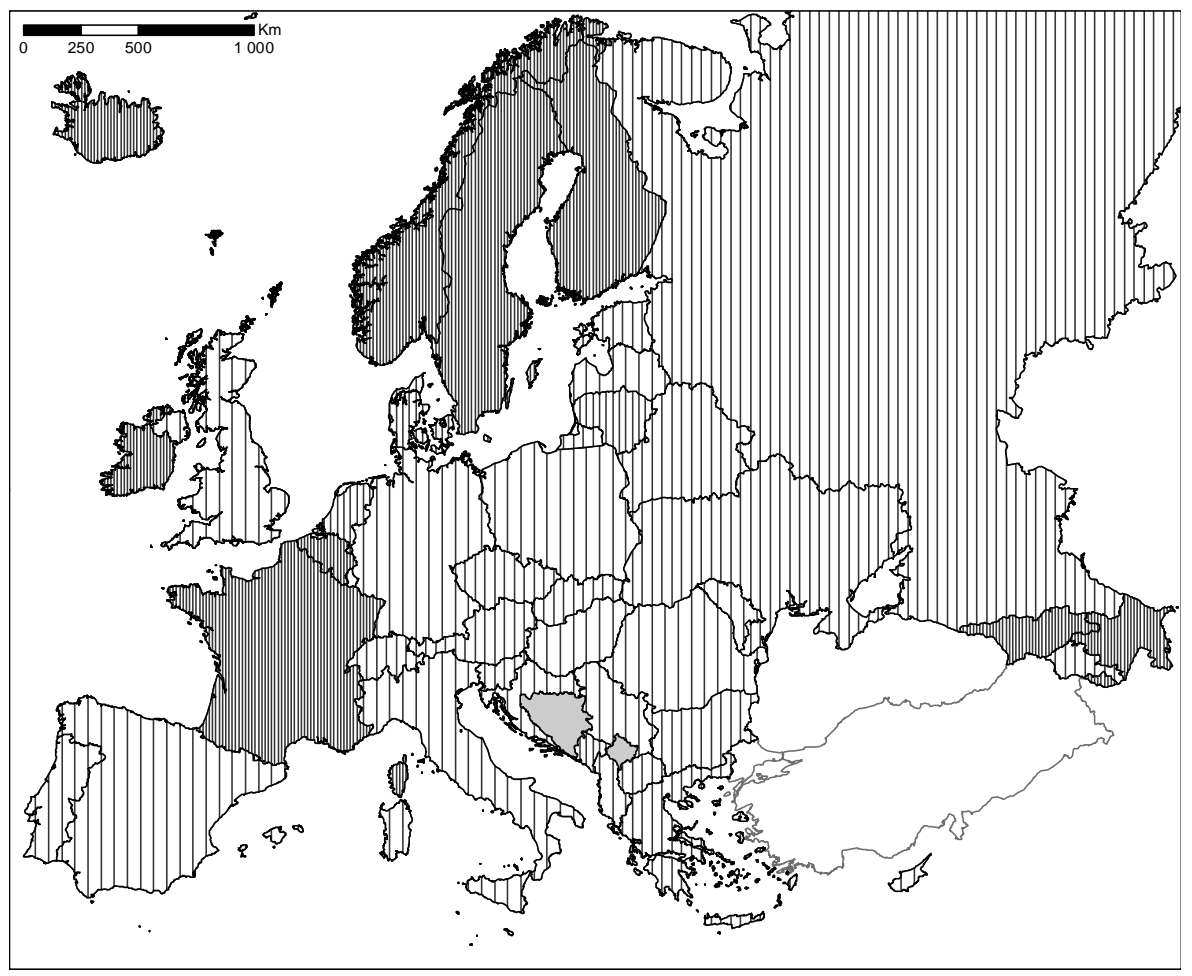

Współczynnik dzietności

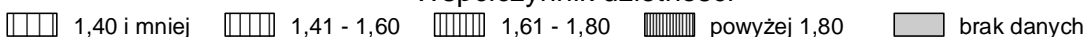

Ryc. 46. Współczynnik dzietności w krajach europejskich w $2011 \mathrm{r}$.

Źródło: oprac. własne na podstawie: Eurostat,

http://epp.eurostat.ec.europa.eu/portal/page/portal/population/data/ database

Określenie tego, jakie intencje dominują w społeczeństwie, stanowi również cenną informację z punktu widzenia przewidywania trendów urodzeń w kolejnych latach. Nawet, jeżeli weźmiemy pod uwagę, że nie wszystkie plany prokreacyjne są realizowane oraz nie wszystkie ciąże są planowane, pomiar intencji dostarcza nam informacji odnośnie do ogólnego nastawienia ludzi do planowania rodzicielstwa. Ponieważ postawy prokreacyjne osób w wieku 18-44 lata i ich realizacja są decydujące dla kształtowania się liczby urodzeń $\mathrm{w}$ Polsce, zatem ta populacja powinna być przedmiotem szczególnej uwagi w działaniach wspierających rodzicielstwo. To ta grupa osób musi być najlepiej rozpoznana ze względu na ich cechy i potrzeby, by dostosować do nich wprowadzane rozwiązania.

W Polsce badania intencji i zamierzeń dotyczących posiadania potomstwa prowadzono w ramach międzynarodowego projektu Generacje i Płeć Kulturowa (Generations and Gender Programme - GGP), który obejmuje realizację trzech rund badania panelowego (Generations and Gender Survey 
- GGS) - por. Kotowska i Jóźwiak 2011. Dane pozyskane w pierwszej rundzie badania, zrealizowanego w Polsce na przełomie lat 2010 i 2011 (GGSPL) ${ }^{36}$, pozwalają na dokonanie charakterystyki zamierzeń prokreacyjnych w populacji, a także na analizę leżących u ich podłoża czynników. Informacje pochodzące z drugiej rundy badania umożliwią w przyszłości analizę stopnia realizacji tych intencji oraz czynników, które mogły w ich realizacji przeszkodzić lub im sprzyjać.

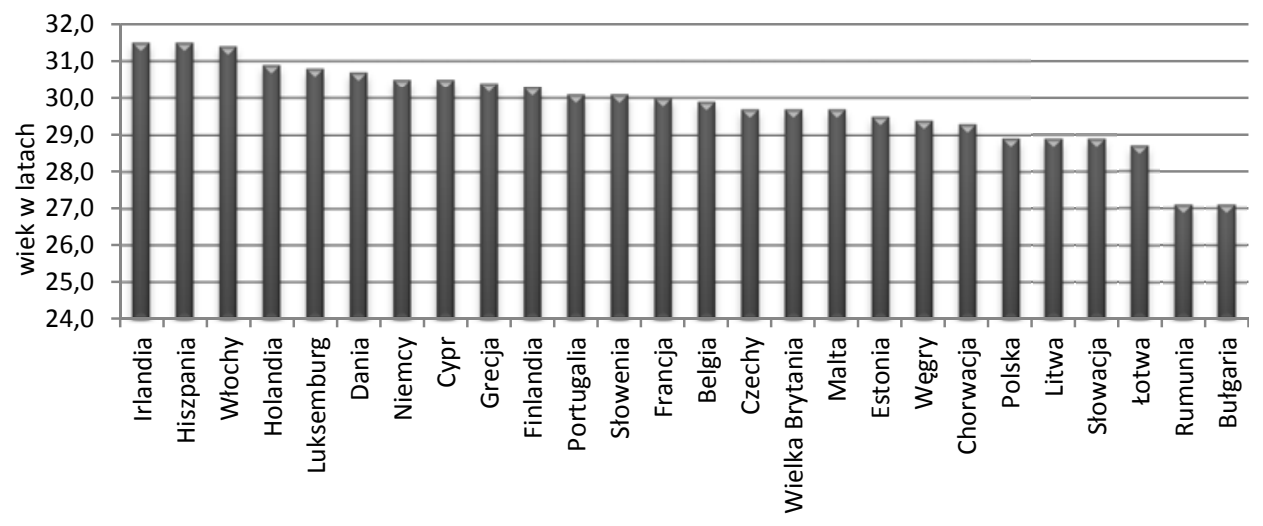

Ryc. 47. Średni wiek kobiet rodzących w wybranych krajach europejskich w $2011 \mathrm{r}$. Źródło: oprac. własne na podstawie: Eurostat, http://epp.eurostat.ec.europa.eu/portal/page/portal/population/data/ database

Wyniki badań wskazują, że intencje dotyczące posiadania (kolejnego) dziecka w perspektywie najbliższych trzech lat lub później są silnie uzależnione od liczby już posiadanych dzieci. Wśród respondentów mających dwoje bądź więcej dzieci, bardzo mało osób deklaruje chęć posiadania kolejnego dziecka. Sugeruje to, że intencje stworzenia dużej rodziny są w społeczeństwie polskim bardzo rzadkie. Jeżeli chodzi o intencje pozostania bezdzietnym, zamiar rezygnacji $\mathrm{z}$ potomstwa $\mathrm{w}$ ogóle (wyrażony z różnym stopniem pewności) zadeklarowało 11,5\% osób bezdzietnych w wieku 18-39 lat. Należy też odnotować, że na tle innych krajów europejskich objętych badaniem w roku 2001, Polskę charakteryzował umiarkowany poziom planowanej bezdzietności. W badanych krajach zamiar rezygnacji z rodzicielstwa deklarowało od 3 do $25 \%$ kobiet oraz od 2 do niemal 30\% mężczyzn (Sobotka, Testa 2008). Bezdzietność i intencje prokreacyjne wydają się bardzo silnie związane ze statusem związku. Wśród bezdzietnych respondentów aż dwie trzecie nie ma partnera ani partnerki, a tylko $12 \%$ mieszka ze współmałżonkiem. Natomiast spośród osób bez-

36 W badaniu uczestniczyło łącznie 19987 respondentów (8409 mężczyzn i 11 578 kobiet). 
dzietnych mieszkających ze współmałżonkiem ponad 80\% zamierza mieć dziecko w ciągu następnych trzech lat. Niemniej, chociaż rodzicielstwo wydaje się silnie związane z małżeństwem, już sam fakt wspólnego zamieszkania z partnerem (partnerką) prowadzi do formułowania intencji zostania rodzicem $\mathrm{w}$ najbliższej przyszłości. Interesujące jest to, że osoby żyjące $w$ kohabitacji oraz osoby pozostające w związku małżeńskim różnią się od siebie przede wszystkim stopniem zdecydowania deklarowanych intencji prokreacyjnych. Osoby w związku nieformalnym „prawdopodobnie" zamierzają mieć dziecko w ciągu kolejnych trzech lat. U osób, które zawarły związek małżeński, „prawdopodobnie” zmienia się w „zdecydowanie". Jest to zgodne z wcześniejszymi wynikami badań, które pokazują, że kohabitacja traktowana jest przez młodych ludzi w Polsce jako etap poprzedzający małżeństwo, a rodzicielstwo ściśle wiąże się ze sformalizowaniem związku. Zależność ta jest szczególnie silna dla kobiet. Jak pokazały wyniki badań, brak ślubu nie stanowi jednak znaczącej przeszkody dla planów posiadania drugiego dziecka. Rodzice jednego dziecka, którzy żyją w kohabitacji (stanowią niewielką grupę), deklarują intencje powiększenia rodziny niemal równie często jak rodzice pozostający w związku małżeńskim.

Osoby bezdzietne w wieku 18-39 lat wiążą wyraźnie swe intencje posiadania potomstwa $\mathrm{z}$ osiągnięciem pewnego etapu w przebiegu życia: z ukończeniem edukacji, wstąpieniem w związek małżeński i z osiągnięciem odpowiedniego wieku. Na tym etapie szczególnie kobiety deklarują zdecydowany zamiar urodzenia dziecka.

Postawy prokreacyjne wydają się silnie związane ze statusem na rynku pracy i sytuacją materialną respondentów. Osoby, które planują mieć pierwsze dziecko to w zdecydowanej większości osoby zatrudnione lub samozatrudnione. To samo odnosi się do mężczyzn myślących o drugim dziecku: brak pracy wydaje się znaczącą przeszkodą dla powiększenia rodziny. U kobiet taka zależność nie występuje przy deklaracji o zamiarach dotyczących drugiego dziecka. Wśród kobiet planujących kolejną ciążę niemal połowa nie pracuje (są bezrobotne, zajmują się domem, są na urlopie wychowawczym). W ich przypadku zapewne to sytuacja zawodowa partnera będzie kluczowa dla planów i zachowań prokreacyjnych. Intencje prokreacyjne wydają się również silnie związane z postrzeganymi konsekwencjami posiadania (kolejnego) dziecka, w szczególności z postrzeganym ograniczeniem swobody działania rodziców oraz z przewidywanym wpływem dziecka na sytuację rodziców na rynku pracy. Osoby, które deklarują zamiar posiadania dziecka (pierwszego lub drugiego), uważają, że decyzja ta nie ograniczy ich swobody działania ani ich perspektyw zawodowych. Sugeruje to, że ważnym determinantem decyzji prokreacyjnych Polaków i Polek jest możliwość godzenia obowiązków zawodowych i rodzicielskich. Ma to znaczenie zarówno dla mężczyzn, jak i dla kobiet, które jednak znacz- 
nie bardziej pesymistycznie oceniają wpływ macierzyństwa na ich sytuację na rynku pracy.

Należy pamiętać, że wszystkie przedstawione tutaj wyniki dotyczą intencji tego, co respondenci planują w ciągu następnych trzech lat. Nie wszystkie osoby, które zamierzają mieć dziecko do roku 2015, rzeczywiście zostaną rodzicami. Jednak przy lepszym zrozumieniu, jakie czynniki wpływają na plany prokreacyjne Polaków i Polek, możliwe jest zaprojektowanie odpowiednich działań, które mogą ułatwić im realizację zamierzeń (Młynarska 2011).

\subsection{Przestrzenne zróżnicowanie rozrodczości w Polsce}

\subsubsection{Zróżnicowanie przestrzenne rozrodczości według podregionów}

Początek XXI w. to okres, w którym poziom rodności w Polsce był niski (pisano o tym w podrozdziale 4.2.1). Rok 2002 był kolejnym rokiem systematycznego spadku współczynnika urodzeń, choć minimum zostało osiągnięte rok później, kiedy to liczba urodzeń żywych na 1000 ludności wyniosła 9,2 (w 2002 r. niewiele więcej bo 9,3\%o). Zróżnicowanie w podregionach w 2002 r. było jednak znaczne, od 6,8\%o we Wrocławiu do 12,1\%o w gdańskim i nowosądeckim (ryc. 48). Natężenie urodzeń według podregionów w 2011 r. wahało się w granicach od 8,3 (opolski) do 13,3\%o (gdański). Połowa podregionów wykazywała mniejszy od średniej krajowej poziom rodności. Bardzo niski poziom urodzeń (oprócz opolskiego) wystąpił w Łodzi, Szczecinie oraz podregionach: sosnowieckim, jeleniogórskim, nyskim i wałbrzyskim (poniżej 9\%o). Wysokie wartości współczynnika urodzeń poza wymienionym już podregionem gdańskim osiągnęły podregiony leżące zarówno w południowej Polsce (np. nowosądecki, tyski), jak i na północy kraju (np. starogardzki czy elbląski). Trzecią grupą podregionów odznaczającą się większymi wartościami współczynnika urodzeń są obszary leżące w bliskim sąsiedztwie dużych aglomeracji - krakowski, warszawski wschodni, poznański. Oddzielny przypadek stanowi Warszawa, gdzie wartość współczynnika sięgnęła 11,1\%o. Obserwuje się dość oczywistą tendencję rodności w układzie miasto-wieś (A III). Jest to sytuacja, w której poziom rodności na trenach wiejskich jest wyższy niż w miastach. Analiza pozwoliła na wyróżnienie tylko jednego podregionu, białostockiego, w którym mieszkańcy miast $(9,415 \%)$ wykazują większą skłonność do posiadania dzieci niż mieszkańcy wsi $(9,373 \%$ ), różnica ta była jednak bardzo niewielka. Pomiędzy rokiem 2002 i 2011 nastąpił spadek rodności w 17 podregionach (w kraju wzrósł z 9,3 do 10,1\%o), a w słupskim i starogardzkim nie zmienił się (ryc. 49). Co prawda tylko w suwalskim spadek był większy o nieco ponad 1\%o. Zdecydowana część podregionów odnotowała wzrost, największy Warszawa (o 3,9\%o), Poznań (2,8\%o), warszawski zachodni i poznański (po 2,2\%o). 


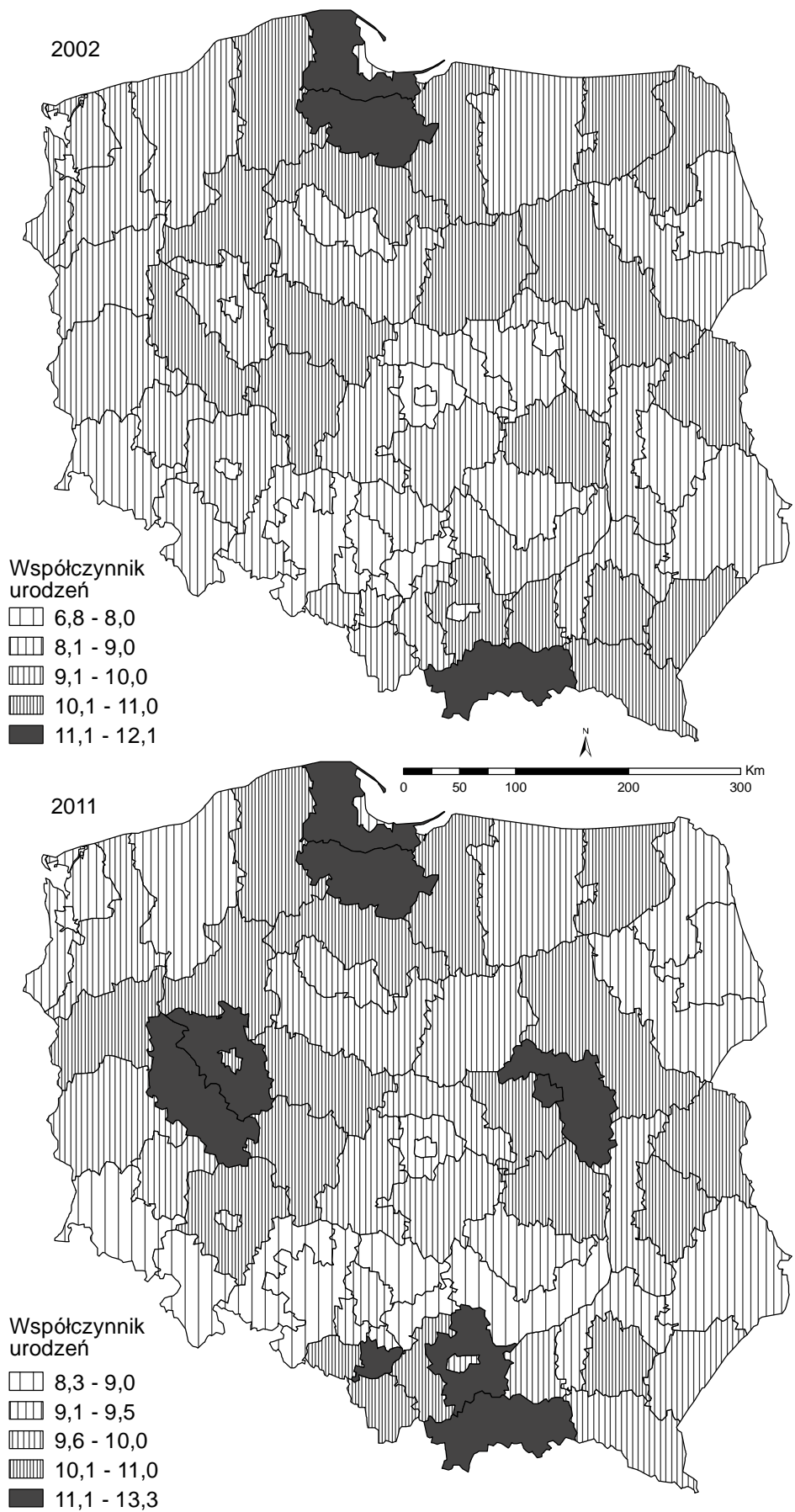

Ryc. 48. Współczynnik urodzeń w 2002 i 2011 r. według podregionów Źródło: oprac. własne na podstawie Bazy Demografia, GUS, Warszawa 
$\mathrm{Na}$ zróżnicowanie przestrzennego rozkładu wartości współczynnika rodności wpływają różne czynniki o charakterze demograficznym, jak choćby obserwowany odpływ ludności młodej na obszary metropolitalne dużych miast, a także postawy i zachowania prokreacyjne uwarunkowane np. poziomem religijności czy sytuacją społeczno-gospodarczą.

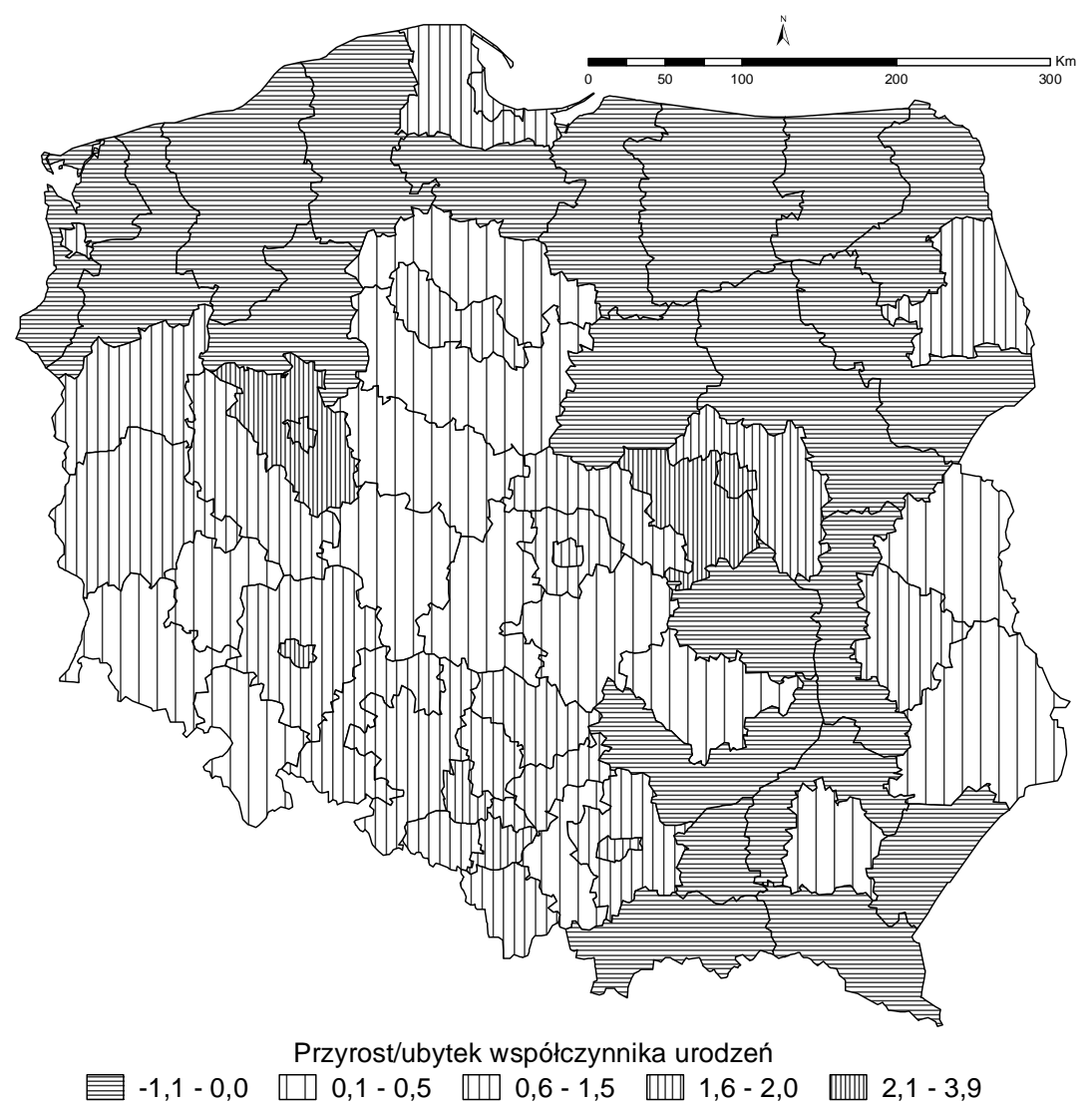

Ryc. 49. Różnice we współczynniku urodzeń pomiędzy 2011 i 2002 r. według podregionów Źródło: oprac. własne na podstawie Bazy Demografia, GUS, Warszawa

W analizach rodności uwzględnia się też kolejność przyjścia na świat poszczególnych dzieci danej matki, co pozwala pośrednio na wnioskowanie o zjawisku wielodzietności. Jak wcześniej pisano, obserwujemy w Polsce ograniczanie liczby dzieci, co jest widoczne chociażby przez malejące odsetki urodzeń trzecich i dalszych. Jeszcze w roku 2002 urodzenia trzecie i dalsze w większości podregionów w kraju stanowiły 1/5 lub 1/4 ogółu urodzeń, a największe udziały notowano w podregionach nowosądeckim, przemyskim, gdańskim oraz północno-wschodniej części kraju z wyjątkiem białostockiego (ryc. 50). 


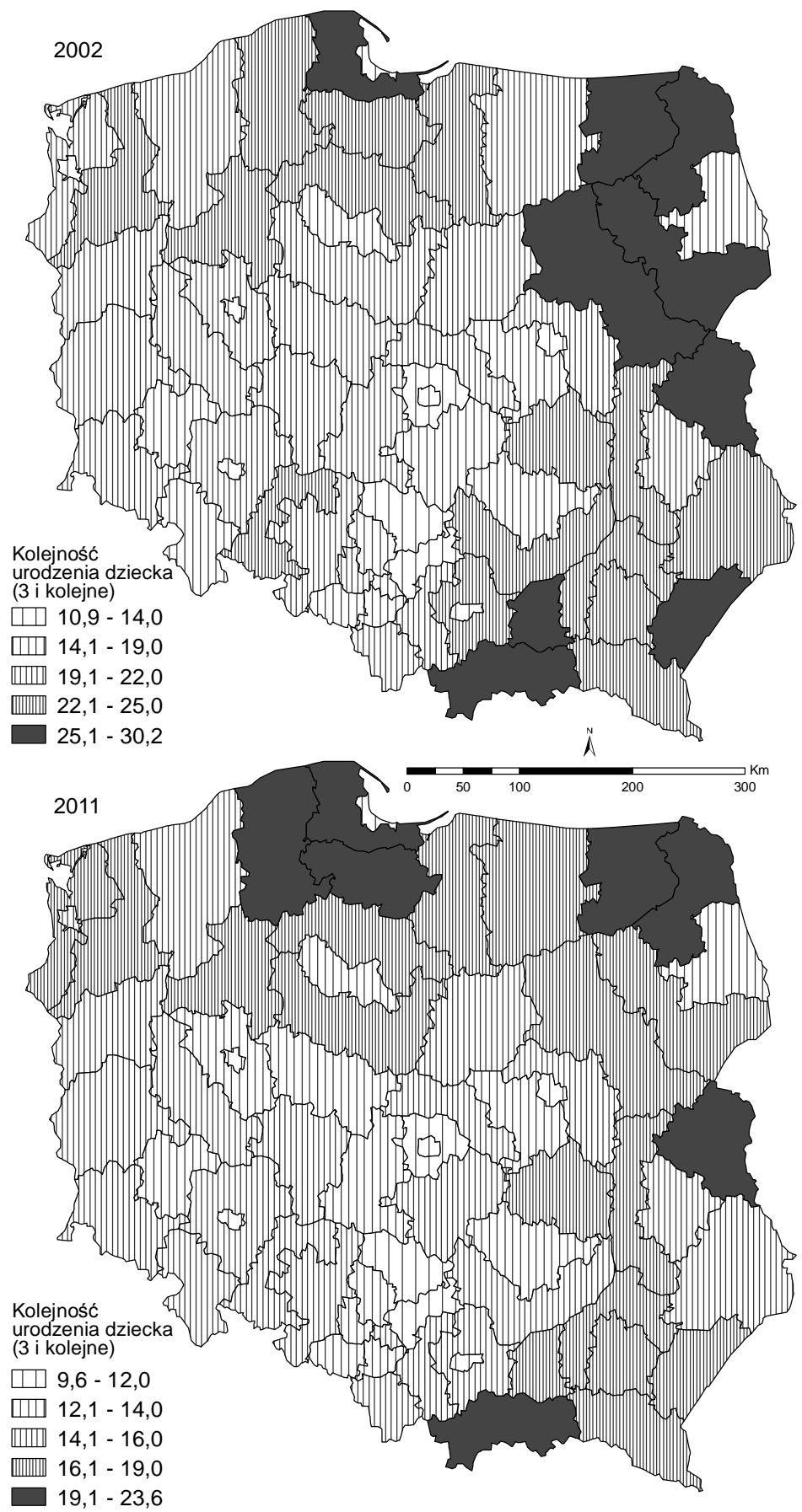

Ryc. 50. Odsetek urodzeń trzecich i dalszych w 2002 i 2011 r. według podregionów Źródło: oprac. własne na podstawie Bazy Demografia, GUS, Warszawa 
Zjawisko to jest w dalszym ciągu dość zróżnicowane przestrzennie zarówno dla ogółu ludności, jak i mieszkańców miast oraz wsi. Największe wartości urodzeń trzecich i dalszych można odnotować dla 2011 r. (od 19,1 do $23,6 \%$ ) w podregionach nowosądeckim, bialskim, suwalskim, ełckim, starogardzkim, gdańskim i słupskim, tendencja do ograniczania liczby dzieci jest zaś wyraźna w dużych miastach i na terenach zurbanizowanych. Jeszcze większe dysproporcje tego zjawiska występują, jeśli porównamy skłonności mieszkanek miast i wsi do posiadania licznego potomstwa. Są one wyraźnie mniejsze w przypadku tych pierwszych (ryc. 51). Mniejsze skłonności do posiadania licznego potomstwa wystąpiły na terenie całego kraju, z wyjątkiem Szczecina, dla którego zaobserwowano niewielki wzrost odsetka urodzeń trzecich i dalszych. Największe skłonności do ograniczania liczby dzieci wystąpiły w podregionach, w których były największe odsetki takich urodzeń, czyli wschodniej i południowo-wschodniej Polsce, w mniejszym stopniu na północy kraju (ryc. 52).

By przeprowadzić właściwą analizę zjawiska wielodzietności należy dysponować informacjami o strukturze rodzin. Ponieważ nie zostały jeszcze opublikowane informacje z NSP 2011 dotyczące struktury gospodarstw domowych, autorka z oczywistych względów nie miała możliwości dokonania takiej analizy. W tym przypadku wykorzystano dane z NSP 2002. Wskazują one na występowanie zjawiska wielodzietności przede wszystkim w Polsce wschodniej i południowo-wschodniej, gdzie odsetek rodzin z trojgiem lub większą liczbą dzieci przewyższa 20\% (ryc. 53). 


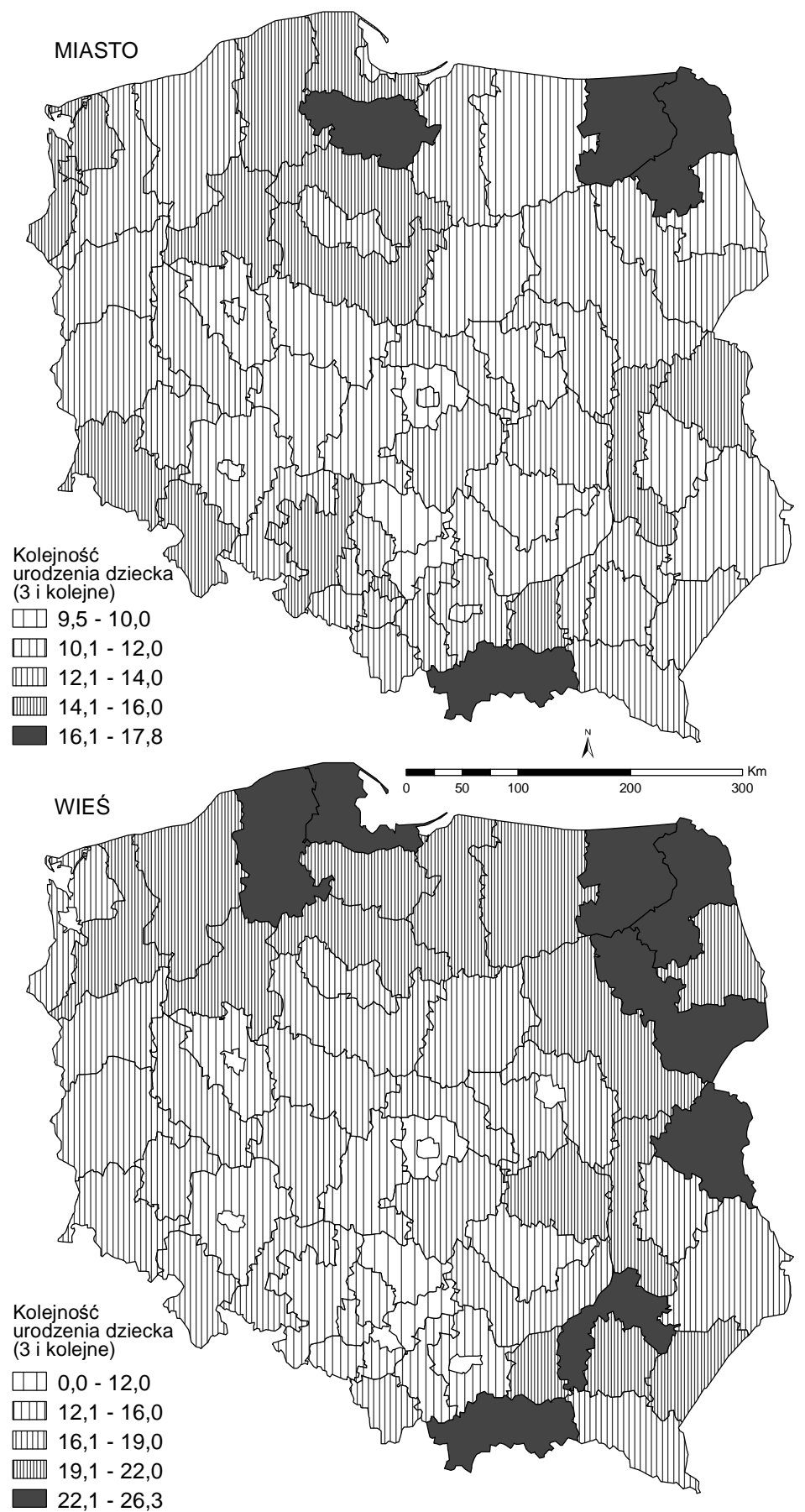

Ryc. 51. Odsetek urodzeń trzecich i dalszych w 2011 r. według podregionów - miasto-wieś Źródło: oprac. własne na podstawie Bazy Demografia, GUS, Warszawa 


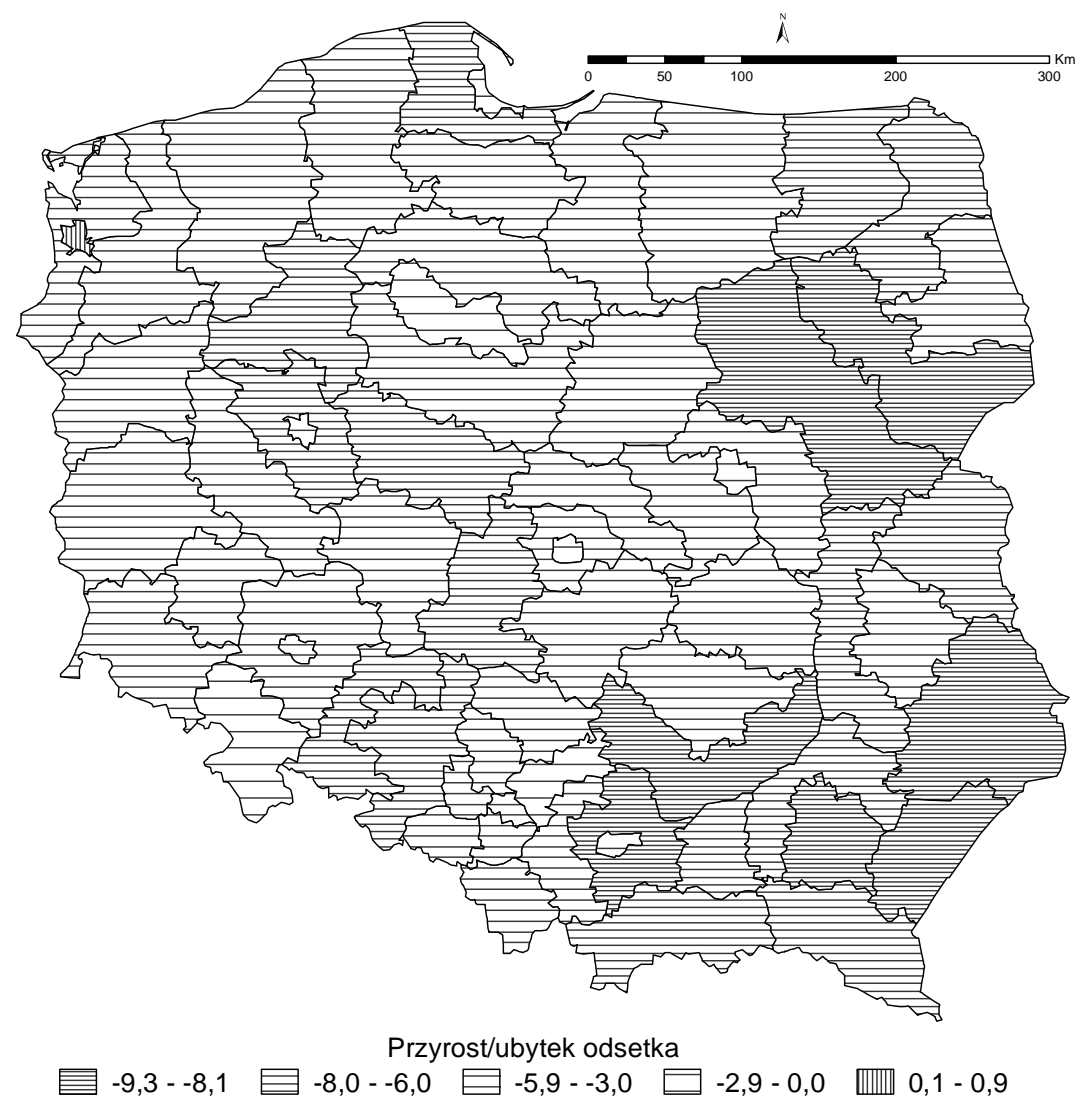

Ryc. 52. Różnica odsetka urodzeń trzecich i dalszych pomiędzy 2011 i $2002 \mathrm{r}$. według podregionów

Źródło: oprac. własne na podstawie Bazy Demografia, GUS, Warszawa

Poziom urodzeń pozamałżeńskich jest w naszym kraju bardzo zróżnicowany przestrzennie. W opinii P. Szukalskiego (2010) zróżnicowanie to jeśli chodzi o uporządkowanie poszczególnych obszarów kraju według porządku hierarchicznego - jest nad wyraz stałe, albowiem obserwuje się je, odkąd tylko w powojennej polskiej statystyce publikować zaczęto odpowiednie dane, $\mathrm{tj}$. od początku lat 60 . W całym powojennym okresie najwyższe udziały urodzeń pozamałżeńskich zaobserwować można było w Polsce północno-zachodniej, najniższe zaś w południowo-wschodniej części kraju (Szukalski 2010). Przyczyn wysokiego odsetka urodzeń pozamałżeńskich upatruje się w następujących czynnikach:

1) odmiennym poziomie kontroli społecznej, wynikającym zarówno z różnic w poziomie zasiedziałości ludności poszczególnych regionów kraju (większa mobilność przestrzenna ludności ziem odzyskanych), jak i ważno- 
ści takiego narzędzia kontroli, jak spadek (własność publiczna ziemi w Polsce północno-zachodniej),

2) dziedziczeniu zachowań demograficznych (obecnie wysoki poziom urodzeń pozamałżeńskich odnotowywany jest w tych samych regionach, co kilka dekad temu, zapewne $\mathrm{w}$ dużym stopniu zachowania te występują w tych samych środowiskach społecznych i rodzinach),

3) różnicach $w$ poziomie religijności - w przypadku jej mierników (udział małżeństw wyznaniowych wśród wszystkich nowo zawieranych oraz udział osób uczęszczających na niedzielne nabożeństwa) występują w Polsce różnice regionalne ściśle powiązane z regionalnym zróżnicowaniem urodzeń pozamałżeńskich,

4) oddziaływaniu przemian społeczno-gospodarczych ostatniego dwudziestolecia (poziomu bezrobocia - w tym zwłaszcza długookresowego i ubóstwa, szczególnie wysokiego na tych ziemiach, gdzie dominowały monokultury przemysłowo-rolne i własność państwowa, a zatem na ziemiach odzyskanych).

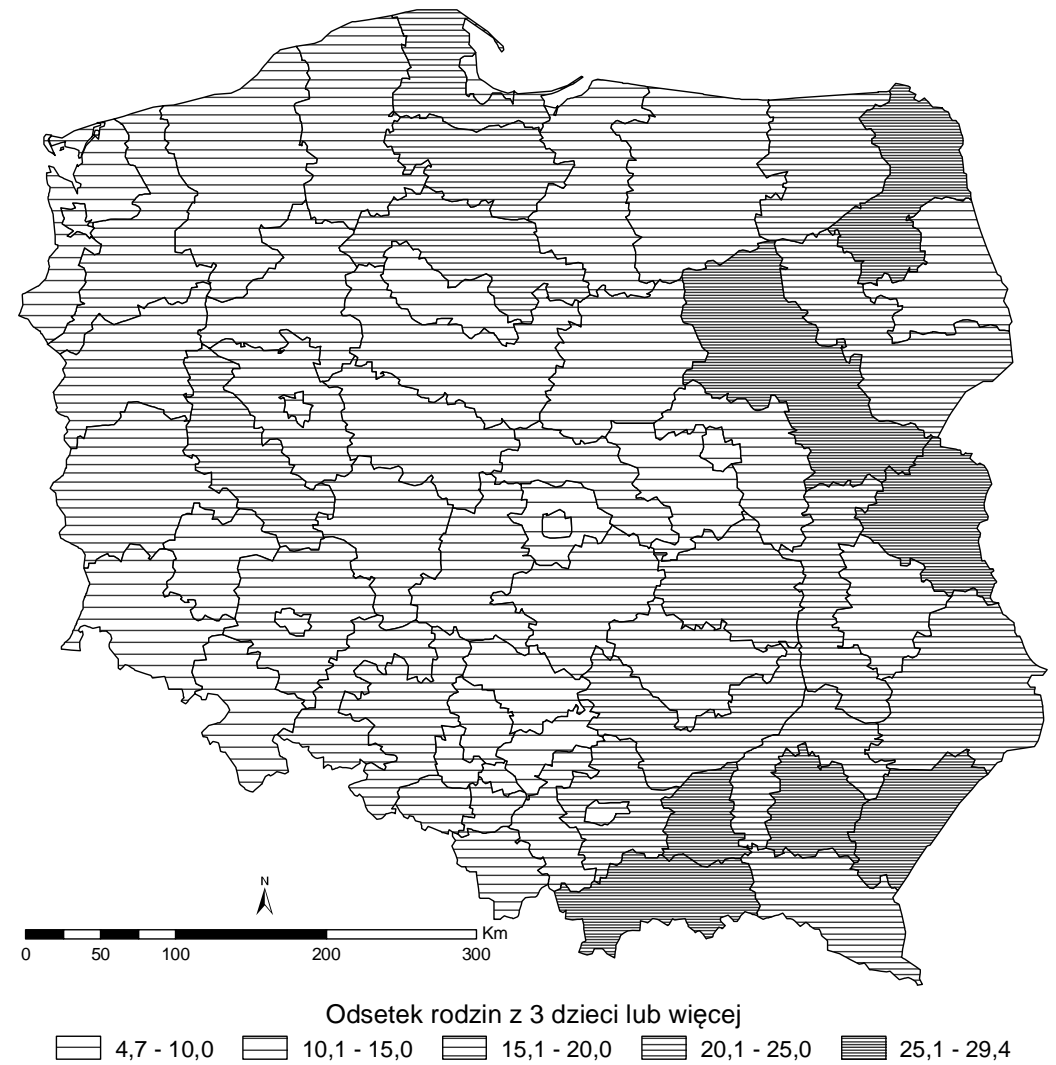

Ryc. 53. Odsetek rodzin z trojgiem dzieci lub więcej w $2002 \mathrm{r}$. według podregionów Źródło: oprac. własne na podstawie Bazy Demografia, GUS, Warszawa 
Bardzo ważna jest z jednej strony swoista zwartość przestrzenna w zakresie występowania nietradycyjnych form życia rodzinnego, z drugiej zaś strony swoista niespójność, gdy przyjrzymy się wpływowi klasy miejscowości zamieszkiwania na częstość urodzeń pozamałżeńskich. W pierwszym przypadku chodzi o zgodność uporządkowania występowania takich nietradycyjnych form życia rodzinno-małżeńskiego, jak częstość urodzeń pozamałżeńskich, kohabitacji (wspólnego zamieszkiwania par nie legalizujących związku), rozwodów, ślubów cywilnych (Slany 2007; Szukalski 2004; 2006). Tym samym regiony odznaczające się wysoką częstością występowania jednej z tych "nowinek" obyczajowych zazwyczaj charakteryzują się wysokim poziomem innych. W przypadku drugim idzie o to, że choć w skali ogólnopolskiej obszary wiejskie są mniej podatne na rozprzestrzenianie się nowinek obyczajowych, znaleźć można na terenie naszego kraju obszary, gdzie różnice między miastem a wsią są niezauważalne, jak i takie województwa, gdzie mieszkańcy wsi są nawet bardziej „innowacyjni” obyczajowo niż „mieszczuchy”. Generalnie zatem mieszkańcy wsi odznaczają się większym zróżnicowaniem skłonności do wydawania pozamałżeńskiego potomstwa niż mieszkańcy miast. Podkreślić wypada, że w trzech województwach - warmińsko-mazurskim, lubuskim i zachodniopomorskim - na wsi frakcja urodzeń nieślubnych jest od wielu już lat wyższa niż wśród ludności miast. Generalnie sformułować można następującą zasadę - im niższy poziom urodzeń pozamałżeńskich, tym większa różnica pomiędzy mieszkańcami miast a wsi, przy czym w takiej sytuacji to osoby zamieszkujące wieś są bardziej konserwatywne. Wraz ze wzrostem ogólnego udziału urodzeń pozamałżeńskich różnice miasto/wieś zmniejszają się (Szukalski 2010).

Zróżnicowanie regionalne urodzeń pozamałżeńskich wykazuje się trwałością zarówno w czasie, jak i przestrzeni. Obraz uzyskany dla urodzeń nieślubnych ${ }^{37} \mathrm{w}$ podregionach $\mathrm{w} 2011 \mathrm{r}$. potwierdza wcześniejsze analizy P. Szukalskiego. Wynika z niego, że największe odsetki takich zdarzeń występują w podregionach Polski zachodniej i północnej (ryc. 54). Podregionami, gdzie rodzi się najwięcej dzieci spoza związków są w kolejności: stargardzki (40,3\%), gorzowski (39,9\%), szczeciński (38,8\%), jeleniogórski (38,4\%), zielonogórski (36,6\%), Szczecin (33,5\%), słupski $(30,8 \%)$ i Łódź (30,8\%). Wysokimi odsetkami (zbliżonymi do 30\% urodzeń nieślubnych) odznaczają się też podregiony Polski północnej (starogardzki, trójmiejski, elbląski, ełcki i olsztyński), jak również największe miasta. Drugie skrajne wartości, tzn. najniższe odsetki urodzeń pozamałżeńskich (nie przekracza-

${ }^{37}$ P. Szukalski stwierdza, że dyskryminująca wymowa terminu „urodzenie nieślubne" straciła wraz z upływem czasu aktualność, w swoich opracowaniach zamiennie używa przymiotników pozamałżeński i nieślubny. 
jące 10\%) dotyczą podregionów południowej i wschodniej Polski - krakowskiego $(8,6 \%)$, rzeszowskiego $(9,5 \%)$, nowosądeckiego $(9,6 \%)$ i tarnowskiego $(9,6 \%)$. W prawie połowie (36) podregionów udział urodzeń nieślubnych jest niższy od średniej krajowej (A IV). Należy dodać, że w stosunku do roku 2002 udział urodzeń pozamałżeńskich w podregionach północnych i zachodnich powiększył się, podregiony te wykazały się bowiem wzrostem odsetka takich urodzeń powyżej 10\% (ryc. 55).

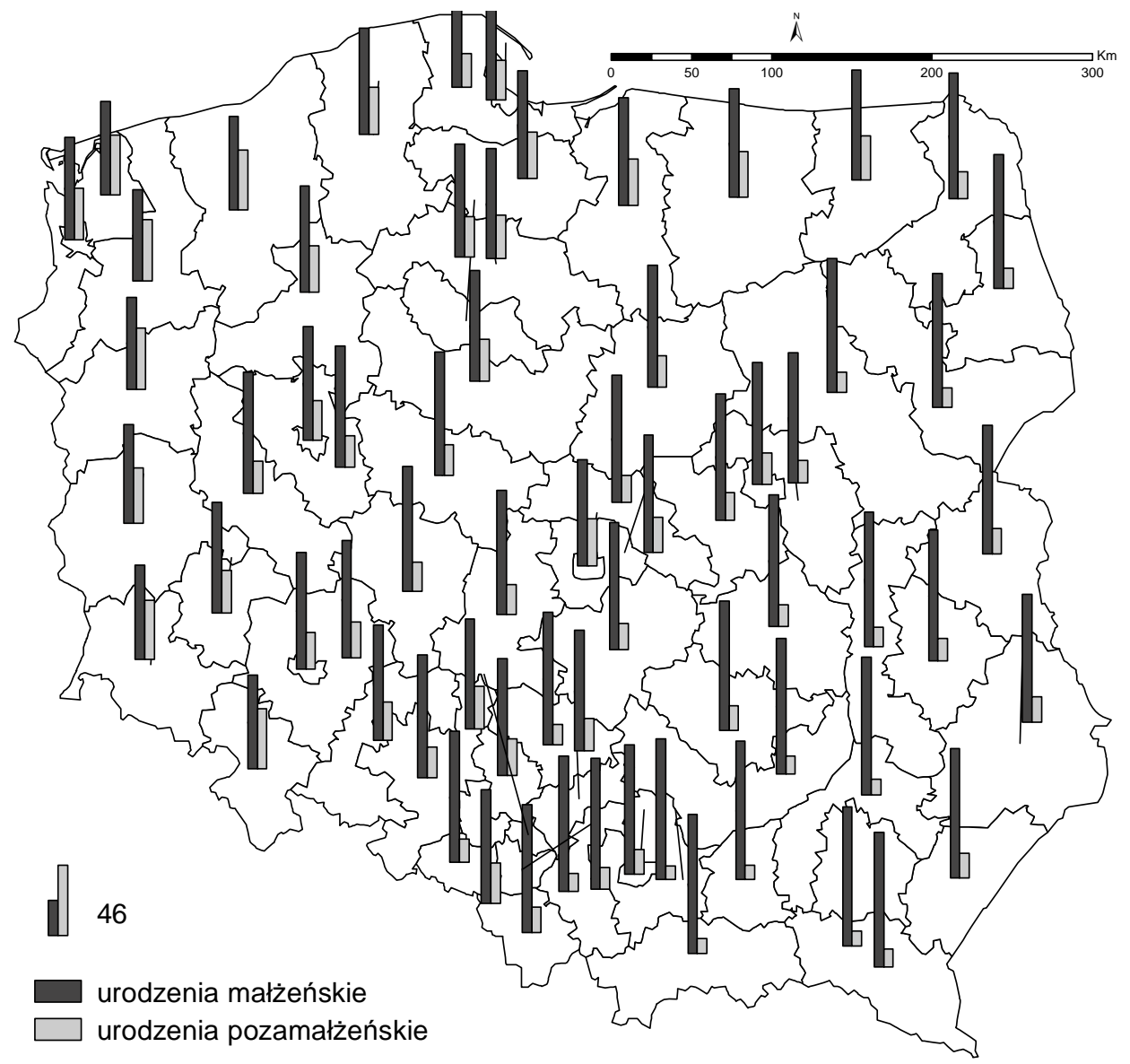

Ryc. 54. Urodzenia małżeńskie i pozamałżeńskie w 2011 r. według podregionów Źródło: oprac. własne na podstawie Banku Danych Lokalnych, GUS, Warszawa 


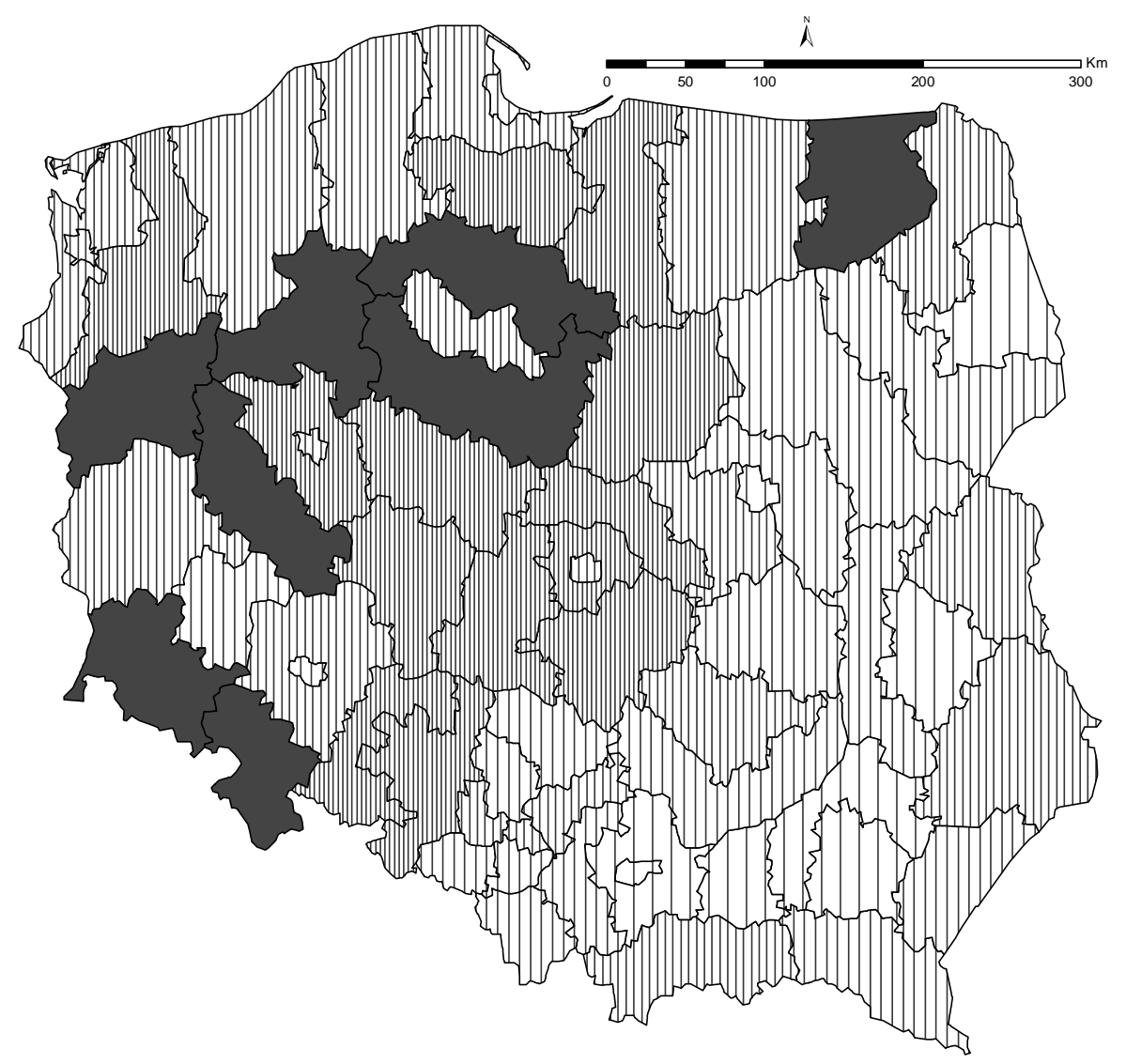

Wzrost odsetka urodzeń pozamałżeńskich

$\square$ 1,0-4,0 Ш

Ryc. 55. Wzrost odsetka urodzeń pozamałżeńskich pomiędzy 2002 i $2011 \mathrm{r}$. według podregionów

Źródło: oprac. własne na podstawie Banku Danych Lokalnych, GUS, Warszawa

\subsubsection{Zróżnicowanie przestrzenne płodności według podregionów}

Małgorzata Podogrodzka (2012a) analizując przestrzenne zróżnicowanie płodności w Polsce według województw w latach 1990-2009 stwierdza, że różne nasilenie zmian współczynnika dzietności teoretycznej według województw nieco zmieniło przestrzenny obraz płodności na obszarach miejskich i wiejskich w badanym okresie. Dodatkowo województwa charakteryzujące się podobnym poziomem dzietności nie tworzyły zwartych przestrzennie terenów. Były to jedno- lub wieloelementowe skupiska rozlokowane w różnych częściach kraju. Według M. Podogrodzkiej sytuacja ta inaczej kształtowała się w przekroju miasto-wieś. Formułując pewne ogólne sądy można jednakże stwierdzić, że w latach 90. im województwa poło- 
żone były dalej od wschodniej granicy Polski, tym charakteryzowały się mniejszą dzietnością. Zjawisko to występowało zarówno na obszarach miejskich, jak i wiejskich. Dekadę później różnicowanie dokonywało się w kierunku północ-południe. Na obszarach wiejskich im dalej od granicy północnej, tym wartości te były niższe. W przypadku terenów miejskich część północna charakteryzowała się najwyższymi wartościami omawianej miary. Na pozostałych obszarach Polski trudno doszukać się wyraźnych prawidłowości w tym zakresie. Sugeruje to, że na terenach miejskich zmiany w płodności w województwach były bardziej zróżnicowane, a na ich natężenie nie wpływały zmiany zachodzące w województwach sąsiednich.

Obraz przestrzennego zróżnicowania zjawiska płodności w Polsce w 2011 r. dla podregionów, jaki uzyskała autorka opracowania, jest zbieżny z wynikami M. Podogrodzkiej, chociaż bardziej szczegółowy, ze względu na dobór jednostki odniesienia. W analizie przestrzennego zróżnicowania płodności i jej zmian wykorzystano wzorce płodności według wieku. Określono je dla podregionów, dla dwóch momentów czasowych - 2002 i 2011 r. (A V).

$\mathrm{Na}$ początku badanego okresu zdecydowana większość podregionów charakteryzowała się płodnością wzorca III, tj. najwyższymi cząstkowymi współczynnikami płodności w grupie wiekowej 25-29 lat. Podregiony: koszaliński, stargardzki, szczeciński, jeleniogórski, grudziądzki, włocławski i ełcki reprezentowały wzorzec II, a w Warszawie, Krakowie, Poznaniu, Wrocławiu oraz podregionach tarnowskim i trójmiejskim najwyższe wartości współczynników płodności odnotowano wśród kobiet 25-29-letnich i jednocześnie dla tych w wieku 20-24 lata były one niższe w porównaniu z tymi w wieku 30-34 lata. W badanym okresie prawie wszystkie podregiony, z wyjątkiem Poznania, zmieniły wzorzec płodności, w zdecydowanej większości z III na V. W dużych miastach i na obszarach silnie zurbanizowanych zaobserwowano pojawienie się nowego wzorca płodności (VI), w którym największa płodność przypada na kobiety w wieku 30-34 lata (tzw. recuperation effect). Zmiany wzorca płodności są obserwowane zarówno dla miast, jak i terenów wiejskich. Przeobrażenia wzorca płodności wskazują, że zmiany na terenach wiejskich odznaczają się dużą dynamiką, w 2002 r. bowiem w 32 podregionach dominował wzorzec III, w pozostałych II (24 podregiony) oraz I (2 podregiony), a dziewięć lat później w większości jednostek zaobserwowano wzorzec $V$ (35 jednostek). Natomiast w miastach występują obecnie dwa wzorce płodności, tj. V i VI.

Rozkład przestrzenny płodności dla wybranych trzech pięcioletnich grup wiekowych kobiet $(20-24 ; 25-29 ; 30-34)^{38}$ o najwyższych wartościach tego zjawiska układa się w obraz kilku skupisk podregionów o podobnych war-

38 Do analizy wybrano trzy pięcioletnie grupy wiekowe kobiet (20-24; 25-29; 3034), ze względu na najwyższe w nich wartości cząstkowych współczynników płodności. 
tościach (ryc. 56-58). Co istotne, część z tych jednostek pojawia się w przypadku każdej z wymienionych grup. Mowa tu o koncentracji podregionów o najwyższych wartościach cząstkowego współczynnika płodności. Podregionami, dla których zaobserwowano najwyższe wartości płodności dla kobiet będących w wieku 20-24; 25-29 oraz 30-34 lata są regiony gdański, leszczyński i nowosądecki. Z tego dość mozaikowego układu przestrzennego wyłania się jeszcze jedna zależność, tym razem dotycząca obszarów najbardziej zurbanizowanych. Dla jednostek tych (Warszawa, Łódź, Szczecin, Kraków, Poznań, Wrocław oraz podregion trójmiejski) odnotowano najniższe wartości cząstkowych współczynników płodności dla kobiet w wieku 20-24 i 25-29 lat i najwyższe z przedziału wiekowego 30-34 lata.

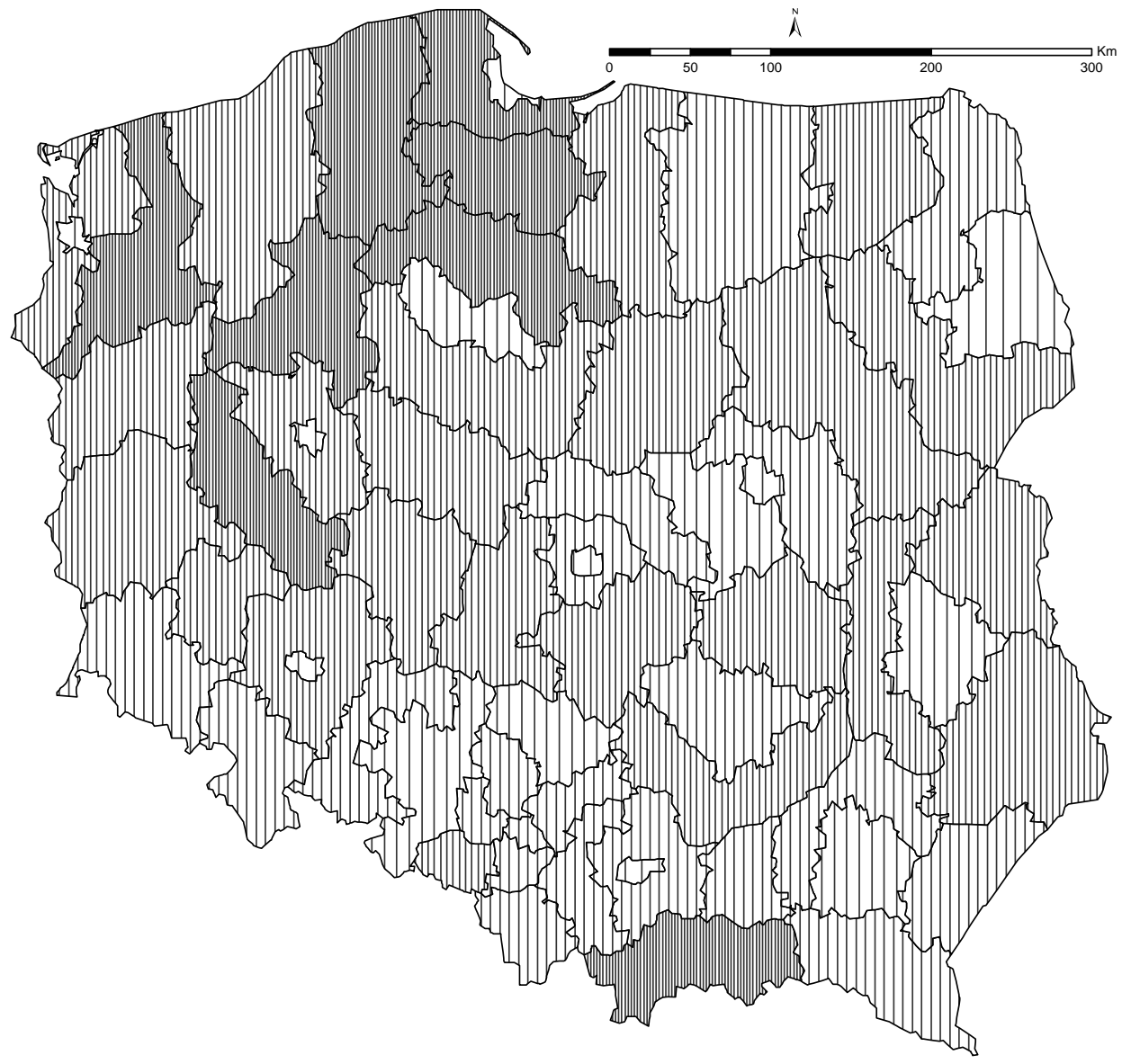

Płodność kobiet w wieku 20-24 lata

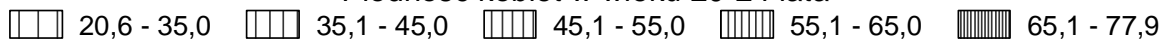

Ryc. 56. Płodność kobiet w wieku 20-24 lata w 2011 r. według podregionów

Źródło: oprac. własne na podstawie Banku Danych Lokalnych, GUS, Warszawa 


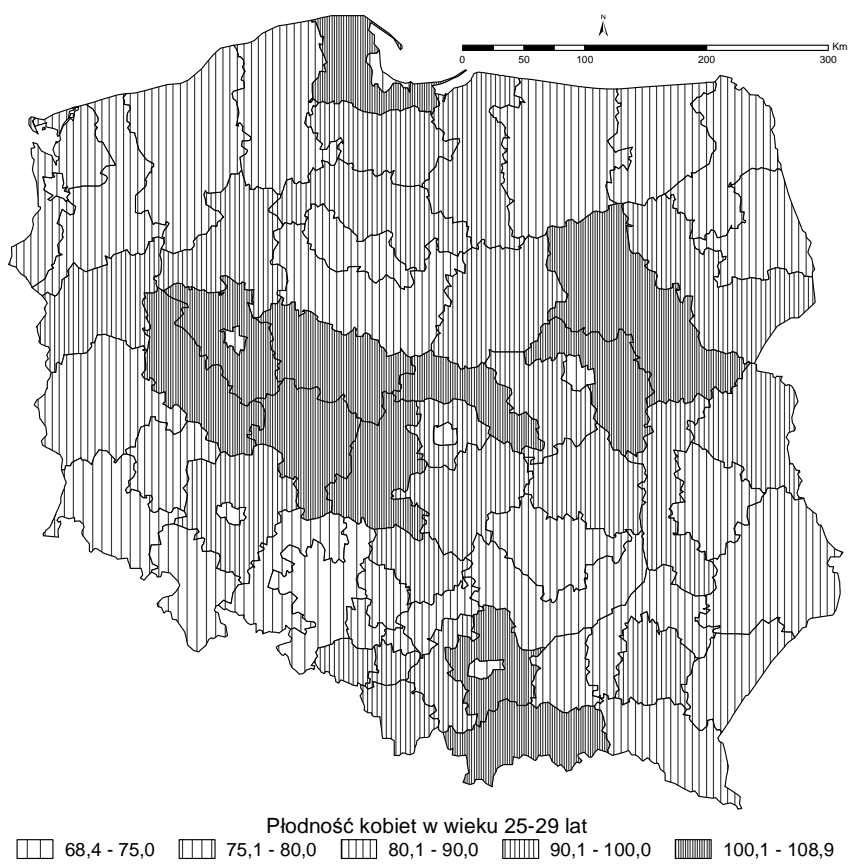

Ryc. 57. Płodność kobiet w wieku 25-29 lat w 2011 r. według podregionów Źródło: oprac. własne na podstawie Banku Danych Lokalnych, GUS, Warszawa

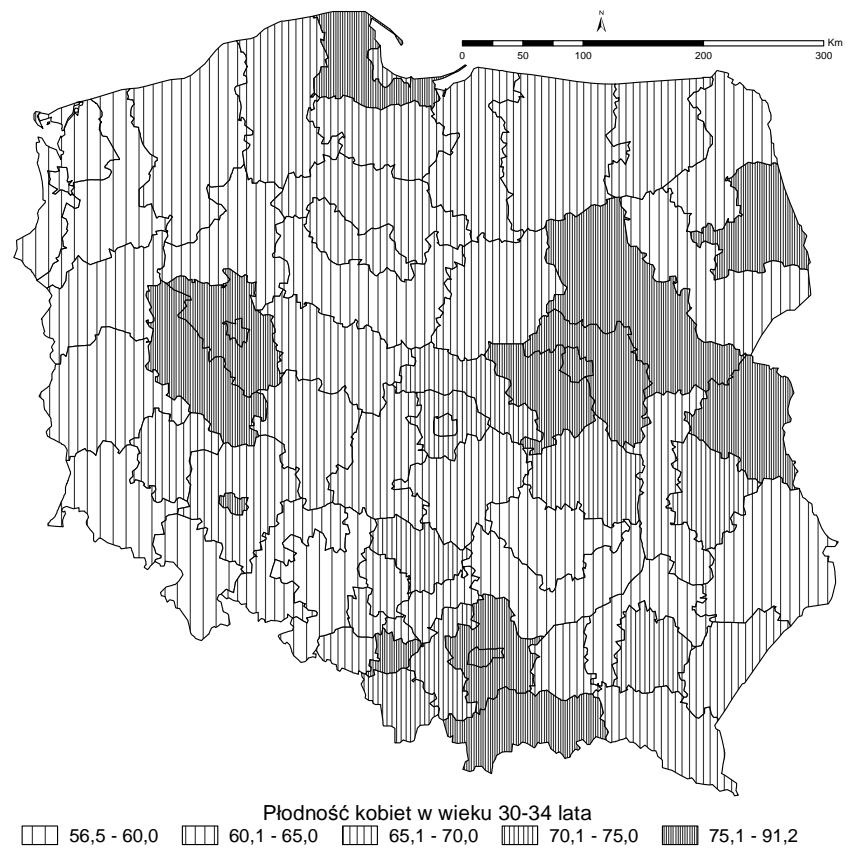

Ryc. 58. Płodność kobiet w wieku 30-34 lata w 2011 r. według podregionów Źródło: oprac. własne na podstawie Banku Danych Lokalnych, GUS, Warszawa 
Przeobrażenia, jakie dokonują się w Polsce w sferze zachowań prokreacyjnych, czego skutkiem są zmiany dzietności, mają swoje odbicie w zróżnicowaniu przestrzennym tego zjawiska. Obserwacja tych zmian w podregionach w latach 2002-2011 pozwala na pewne wnioski. Jak wcześniej pisano, w skali kraju mamy do czynienia ze stałą dynamiką spadkową wartości współczynnika dzietności. W rozkładzie przestrzennym tego miernika wyodrębniają się dwie grupy podregionów, jedna z nich odnotowała przyrost dzietności, a druga to jednostki, gdzie dzietność w tym czasie zmniejszyła się. Mimo że zjawisko wykazywało dynamikę, sytuacja w obszarze dzietności nie uległa wyraźnym zmianom, które doprowadziłyby do pogłębienia różnic wartości współczynnika. Chodzi tu o różnice pomiędzy wartościami maksymalnymi i minimalnymi dla tych dwóch okresów. W $2002 \mathrm{r}$. różnica ta wyniosła 0,639 , a najwyższą wartość odnotowano dla podregionu nowosądeckiego - 1,614, minimum w skali kraju wystąpiło zaś w Łodzi 0,975. W $2011 \mathrm{r}$. wartość maksymalna przypadła podregionowi gdańskiemu $(1,632)$, natomiast minimalną osiągnął Kraków $(1,091)$, różnica więc wyniosła 0,541 (ryc. 59). Według stanu na rok 2011 najwyższą dzietnością, oprócz gdańskiego, odznaczały się następujące podregiony: nowosądecki, ostrołęcko-siedlecki, warszawski wschodni, leszczyński, poznański i starogardzki. Z najniższą dzietnością spotykamy się w największych miastach, z wyłączeniem Warszawy $(1,240)$, a współczynnik dla miast przyjął następujące wartości: Kraków - 1,091; Szczecin - 1,092; Wrocław - 1,102; Łódź 1,110; Poznań - 1,185. Pozostałymi podregionami o bardzo niskiej dzietności, poniżej 1,2 dziecka na kobietę, są opolski, jeleniogórski, białostocki, tarnobrzeski, wałbrzyski, nyski, bydgosko-toruński, trójmiejski i częstochowski (ryc. 60).

0 przemianach demograficznych sfery rozrodczości zgodnie z koncepcją drugiego przejścia demograficznego świadczy także opóźnianie w czasie decyzji prokreacyjnych, czego wyrazem jest wzrost wieku kobiet rodzących dzieci. W okresie 2002-2011 mediana wieku matek w podregionach wzrosła o 2-3 lata (A VI). Największy wzrost środkowego wieku kobiet rodzących odnotował podregion sosnowiecki (o 3,33 roku), a najmniejszy nowosądecki (o 1,34 roku). Zarówno w 2002, jak i 2011 r. większość podregionów o największej medianie stanowiły największe miasta Polski oraz podregiony silnie zurbanizowane. Obecnie został przekroczony próg 30 lat jako środkowej wartości wieku kobiet zostających matkami w Polsce (np. Warszawa - 31,21; Kraków - 30,59; Wrocław - 30,51; Poznań - 30,25; Szczecin $-30,12)$. 


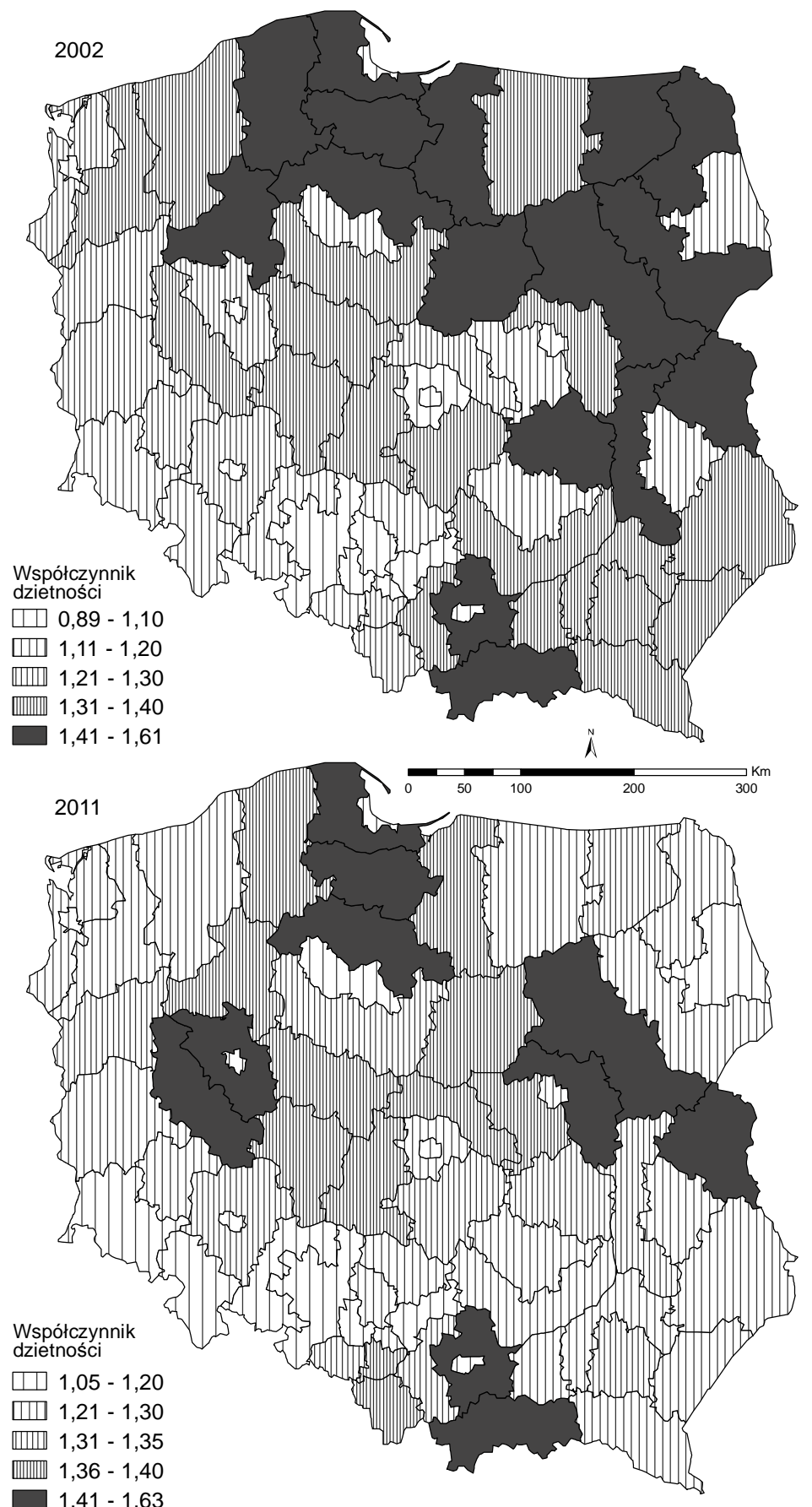

Ryc. 59. Dzietność w 2002 i 2011 r. według podregionów

Źródło: oprac. własne na podstawie Banku Danych Lokalnych, GUS, Warszawa 


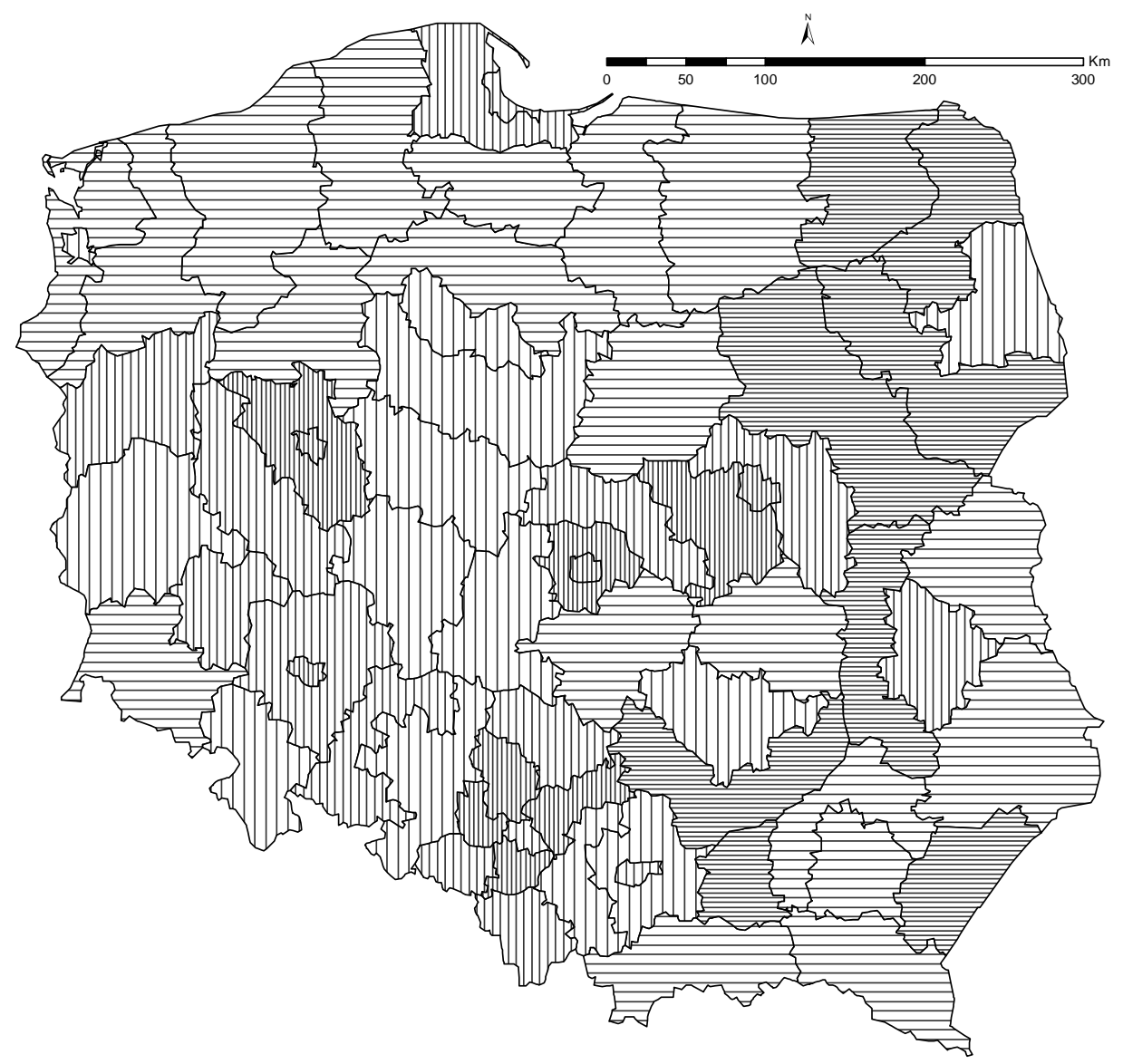

Przyrost/ubytek współczynnika dzietności

\section{$-0,23-0,13 \boxminus-0,12-0,00$ Ш $0,01-0,05$ 血 0,06-0,15 而 0,16-0,30}

Ryc. 60. Różnica we współczynniku dzietności pomiędzy 2011 i 2002 r. według podregionów Źródło: oprac. własne na podstawie Bazy Danych Demografia, GUS, Warszawa 


\section{UWARUNKOWANIA ZACHOWAŃ DEMOGRAFICZNYCH W POLSCE}

\subsection{Uwarunkowania demograficzne rozwoju podregionów}

Na przełomie XX i XXI w. dokonały się w Polsce zmiany demograficzne o zupełnie innym charakterze niż te $\mathrm{z}$ okresu powojennego. Objęły one swym zasięgiem takie procesy, jak rozwój i reprodukcja ludności, w tym formowanie i rozpad małżeństw, rodność, umieralność, a także przyrost naturalny oraz ruchy migracyjne i restrukturyzację demograficzną. Efekty tych przemian dotyczyły m.in. osłabienia dynamiki wzrostu ludnościowego, głębokich przemian rozrodczości i małżeńskości, zmian struktur ludności, a także natężenia i kierunków migracji. Współczesne procesy demograficzne $\mathrm{w}$ Polsce należy rozpatrywać w kontekście przemian społecznych, gospodarczych i politycznych, a szczególnie transformacji społeczno-gospodarczej z końca lat 80., wstąpienia Polski do Unii Europejskiej oraz globalnych procesów przemian społecznych i ekonomicznych.

Przemiany związane z zachowaniami matrymonialnymi i prokreacyjny$\mathrm{mi}$, dokonujące się $\mathrm{w}$ naszym kraju, a rozpoczęte $\mathrm{w}$ krajach europejskich w latach 60. ubiegłego wieku, jak już wcześniej wspomniano, wpisują się w przeobrażenia opisane przez koncepcję drugiego przejścia demograficznego. 0 ile jednak w Europie Północnej i Zachodniej zmiany zachowań rodzinnych były interpretowane jako stanowiące głównie konsekwencje zmian systemu wartości i norm (van de Kaa 1994; 1996; 2001a; Lesthaeghe 1995; Lesthaeghe, Surkyn 2002), o tyle w krajach Europy Środkowowschodniej w pierwszej kolejności podkreślano znaczenie czynników ekonomicznych, przy spadku wpływu demograficznych (Frejka 2008; Kotowska i in. 2008).

Przez kilkadziesiąt lat czynniki demograficzne wywierały istotny wpływ na kształtowanie się modelu rodziny w Polsce. Ich znaczenie obecnie zmalało, niemniej jednak autorka zdecydowała się na określenie rozkładu przestrzennego wybranych zjawisk demograficznych, aby stwierdzić, czy ich zróżnicowanie przestrzenne jest zbieżne z rozkładem w przestrzeni zachowań matrymonialnych i prokreacyjnych. Analiza dotyczyła następujących 
czynników: przyrostu rzeczywistego i jego elementów składowych (przyrost naturalny i saldo migracji), struktury wieku według grup ekonomicznych i przeciętnego dalszego trwania życia dla dwóch momentów czasowych, tj. 2002 i $2011 \mathrm{r}$.

Analiza przyrostu rzeczywistego została przeprowadzona na podstawie procedury J. Webba, jednej z metod typologicznych opierających się na układzie współrzędnych prostokątnych. Jest to jednocześnie jedno z najbardziej znanych narzędzi badawczych, pozwalające określić stan rozwoju ludnościowego w tym przypadku podregionów, z uwzględnieniem współzależności między przyrostem (ubytkiem) naturalnym oraz dodatnim (ujemnym) saldem migracji. W zależności od kształtowania się obu cech można wyodrębnić osiem głównych klas podziału (Runge 2006):

$-\mathrm{A}$ - przewaga przyrostu naturalnego nad ubytkiem migracyjnym (+PN $>-\mathrm{SM})$,

$-\mathrm{B}-$ dominacja przyrostu naturalnego nad dodatnim saldem migracji (+PN > $+\mathrm{SM}$,

$-\mathrm{C}$ - dominacja przyrostu migracyjnego nad dodatnim przyrostem naturalnym $(+\mathrm{PN}<+\mathrm{SM})$,

$-\mathrm{D}$ - przewaga przyrostu migracyjnego nad ubytkiem naturalnym $(-\mathrm{PN}<+\mathrm{SM})$,

$-\mathrm{E}-$ przewaga ubytku naturalnego nad przyrostem migracyjnym (-PN $>+\mathrm{SM})$,

$-\mathrm{F}$ - ubytek migracyjny i jeszcze większy ubytek naturalny $(-\mathrm{PN}>-\mathrm{SM})$,

$-\mathrm{G}$ - ubytek naturalny i jeszcze większy ubytek migracyjny $(-\mathrm{PN}<-\mathrm{SM})$,

$-\mathrm{H}-$ przewaga ubytku migracyjnego nad przyrostem naturalnym $(+\mathrm{PN}<-\mathrm{SM})$.

W wyniku procedury typologicznej uzyskano obraz przestrzennego zróżnicowania przyrostu rzeczywistego w podregionach. Był on w większości jednostek ujemny zarówno w 2002 r. (40 podregionów), jak i w 2011 r. (41 podregionów) - por. ryc. 61. Podregiony (26), w których liczba ludności zwiększyła się w 2002 r., to jednostki położone w różnych częściach kraju. W blisko połowie przypadków (12 podregionów) o wzroście liczby ludności decydował dodatni przyrost naturalny przewyższający straty migracyjne (typ A). Typ B wystąpił w trzech podregionach - gdańskim, szczecińskim i rzeszowskim. W sześciu podregionach dominował przyrost migracyjny nad przyrostem naturalnym - typ C. Wzrost liczby ludności odnotowano także w podregionach białostockim, lubelskim, warszawskim zachodnim oraz Warszawie i Krakowie - typ D. Ujemny przyrost rzeczywisty dotyczył podregionów Górnego Śląska, Dolnego Śląska, Wielkopolski, ale także objął środkową część kraju i niektóre podregiony na zachodzie, północy, wschodzie i południu. Z ubytkiem ludności mieliśmy także do czynienia w dużych miastach z wyjątkiem Warszawy i Krakowa. Wśród podregionów, które odnotowały spadek liczby ludności dominowały dwa typy H (16 jednostek) i G (13 jednostek) W latach 2002-2011 część podregionów zmieniło przynależność do typów (takich jednostek było 22). W czterech podregionach 
nastąpiło przejście od typu A lub D do F, co oznacza ubytek rzeczywisty ludności w stosunku do wcześniejszego przyrostu (oświęcimski, puławski, krośnieński, olsztyński). Podregiony łódzki, kaliski i Wrocław osiągnęły dodatni przyrost rzeczywisty w 2011 r. i ich przynależność adekwatnie zmieniła się z typu E do D; H do A i E do D. W pozostałych podregionach następowało najczęściej przesunięcie $\mathrm{w}$ typach o dodatnim przyroście rzeczywistym (sześć podregionów), w dziewięciu jednostkach w typach o ujemnym przyroście rzeczywistym. Generalnie, obraz zróżnicowania przestrzennego przyrostu rzeczywistego nie uległ diametralnym zmianom w badanym okresie.

Do analizy struktury wieku według grup ekonomicznych wykorzystano jedną z procedur analizy wielozmiennej - trójkąt Ossana. Jest to specyficzne narzędzie, znajdujące zastosowanie w przypadku cech, których wielkości liczbowe dają się zgrupować w trzy klasy. Można się nią posłużyć dla grup ekonomicznych wieku, w ramach którego wyodrębnia się trzy grupy: wiek przedprodukcyjny (0-17 lat), wiek produkcyjny (18-59 lat kobiety, 18-64 lata mężczyźni) ${ }^{39}$, wiek poprodukcyjny (60 lat i więcej kobiety, 65 lat i więcej mężczyźni). W efekcie charakter struktury wieku w danym podregionie wyraża położenie odpowiadającego jej punktu, który znajduje się w miejscu przecięcia się trzech linii równoległych do trzech boków trójkąta. Trójkąt ten podzielono na sześć klas określających różne etapy rozwoju struktury wieku ludności (tab. 16). Jako kryterium podziału zastosowano średnie arytmetyczne z udziału poszczególnych grup wieku w całej populacji.

Wśród 66 podregionów w 2002 r. blisko połowa (29) została zakwalifikowana do stadium młodości demograficznej, natomiast liczebność grupy w fazie starości demograficznej (20) przewyższała grupę podregionów zaliczonych do fazy stabilizacji (17). Podregiony, które zostały zakwalifikowane jako „młode demograficznie”, charakteryzowały się wysokim udziałem osób w wieku przedprodukcyjnym (ponad 22,7\%) oraz niskim udziałem osób w wieku poprodukcyjnym (poniżej 15,1\%). Najwyższy udział osób w wieku 0-17 lat odnotowano w podregionie nowosądeckim - 28,2\%, najniższy w Warszawie - 15,7\%. Sytuacja w 2011 r. wygląda już nieco inaczej i wskazuje na trwające procesy starzenia się ludności, w największym stopniu w Małopolsce, części wschodniej, południowo-zachodniej

${ }^{39}$ Od 1 stycznia 2013 r. wiek emerytalny uległ wydłużeniu. Docelowo ma wynieść 67 lat dla mężczyzn i kobiet (Ustawa z dnia 11 maja 2012 r. o zmianie ustawy o emeryturach i rentach z Funduszu Ubezpieczeń Społecznych oraz niektórych innych ustaw, DzU, 2013, poz. 118). 


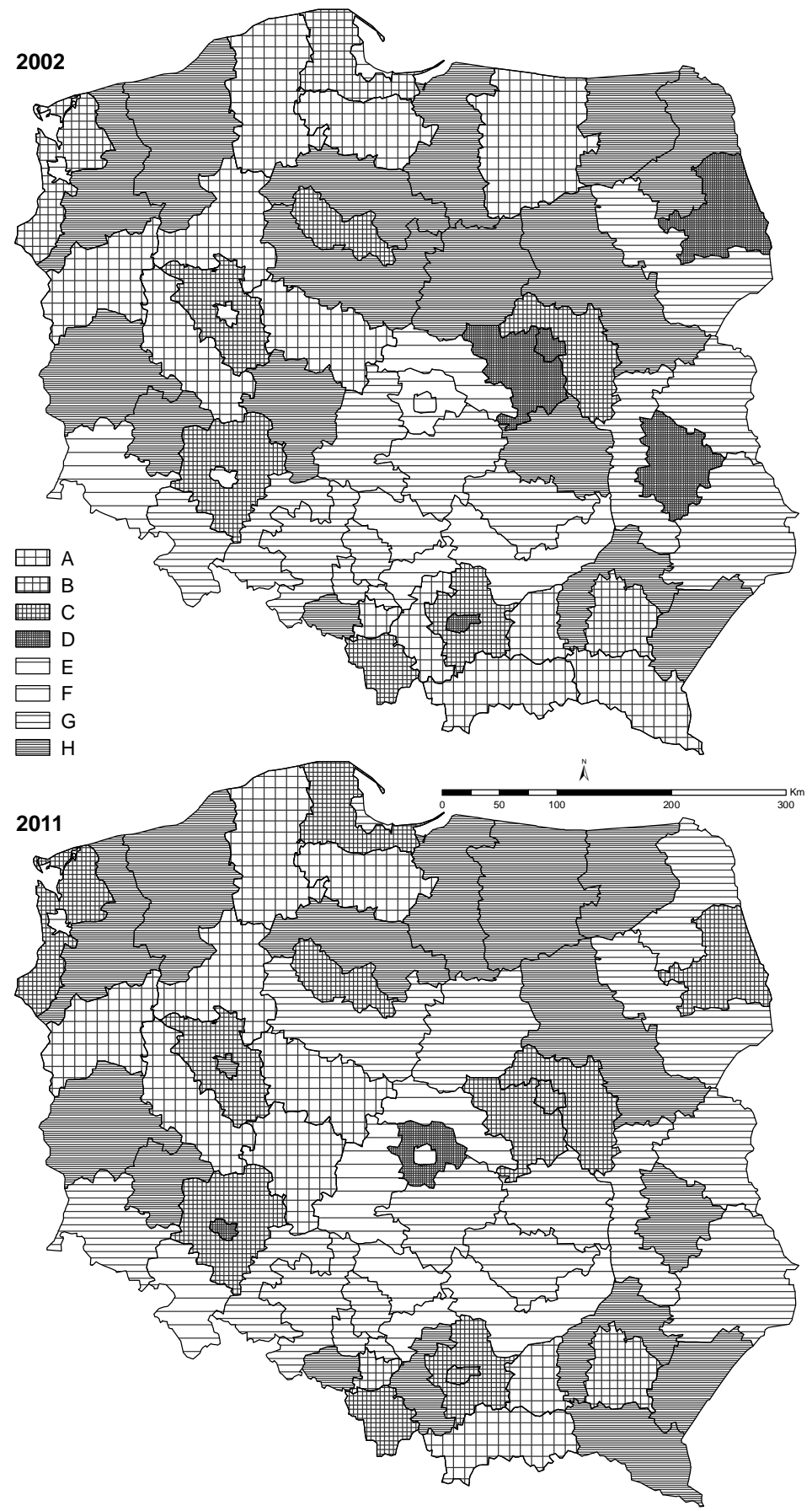

Ryc. 61. Typy przyrostu rzeczywistego w podregionach w 2002 i $2011 \mathrm{r}$. Źródło: oprac. własne na podstawie Banku Danych Lokalnych, GUS, Warszawa 
i środkowej kraju. Tendencje te są również obserwowane w dużych miastach. Stosunkowo młodsze są północne i północno-zachodnie obszary Polski. Zauważa się również zjawisko odmłodzenia ludności w niektórych podregionach (np. warszawski zachodni z ST1 do ML2) - por. ryc. 62. Jest to spowodowane zwyżką urodzeń, jaka wystapiła w latach 2004-2009 (średnio $2 \%$ rocznie) - por. rozdz. 4 . Cykliczny charakter tego zjawiska przyczynił się w tym przypadku do wzrostu odsetka osób w grupie przedprodukcyjnej, nie spowodował natomiast zmian w pozostałych grupach ekonomicznych wieku, tym samym dając obraz społeczeństwa młodszego. Należy jednak mieć na uwadze fakt, że ostatnie lata to obniżka urodzeń i krótkotrwały efekt odmłodzenia zostanie wkrótce zniwelowany (Kurek 2001; 2008).

Tabela 16

Klasy określające etapy rozwoju struktury wieku ekonomicznego ludności (w \%)

\begin{tabular}{|l|c|c|c|c|c|c|l|}
\hline \multirow{2}{*}{ Klasy } & \multicolumn{2}{|c|}{$\begin{array}{c}\text { Wiek przed- } \\
\text { produkcyjny }\end{array}$} & \multicolumn{2}{|c|}{$\begin{array}{c}\text { Wiek produk- } \\
\text { cyjny }\end{array}$} & \multicolumn{2}{c|}{$\begin{array}{c}\text { Wiek popro- } \\
\text { dukcyjny }\end{array}$} & \multirow{2}{*}{ Stadium rozwoju ludności } \\
\cline { 2 - 7 } & 2002 & 2011 & 2002 & 2011 & 2002 & 2011 & \\
\hline ML1 & $>22,7$ & $>18,5$ & $<62,2$ & $<64,2$ & $<15,1$ & $<17,3$ & \multirow{2}{*}{ Młodość demograficzna } \\
\hline ML2 & $>22,7$ & $>18,5$ & $>62,2$ & $>64,2$ & $<15,1$ & $<17,3$ & \\
\hline SB1 & $>22,7$ & $>18,5$ & $<62,2$ & $<64,2$ & $>15,1$ & $>17,3$ & \multirow{2}{*}{ Stabilizacja demograficzna } \\
\hline SB2 & $<22,7$ & $<18,5$ & $>62,2$ & $>64,2$ & $<15,1$ & $<17,3$ & \\
\hline ST1 & $<22,7$ & $<18,5$ & $>62,2$ & $>64,2$ & $>15,1$ & $>17,3$ & \multirow{2}{*}{ Starzenie się demograficzne } \\
\hline ST2 & $<22,7$ & $<18,5$ & $<62,2$ & $<64,2$ & $>15,1$ & $>17,3$ & \\
\hline
\end{tabular}

Źródło: oprac. własne.

Trzecią cechą braną pod uwagę w analizie uwarunkowań demograficznych rozwoju podregionów było trwanie życia. Postęp cywilizacyjny, szczególnie w medycynie, przekłada się w sposób oczywisty na wydłużanie naszego życia. Nawet krótka perspektywa czasowa wzięta pod uwagę w opracowaniu, tj. lata 2002-2011 pokazuje wzrost trwania życia w Polsce z 70,4 do 72,4 lat dla mężczyzn i z 78,8 do 80,9 lat dla kobiet (ryc. 63). Zjawisko to jest dość wyraźnie zróżnicowane w przestrzeni, obszarem gdzie trwanie życia jest najdłuższe zarówno w przypadku kobiet, jak i mężczyzn jest południowa część kraju (podregiony: tarnowski, rzeszowski i tarnobrzeski). Dysproporcje przestrzenne trwania życia są bardziej widoczne wśród kobiet, we wschodniej i południowo-wschodniej części kraju występują wyższe wartości niż w podregionach zachodnich i środkowych (ryc. 64). Dla kraju różnica $w$ trwaniu życia pomiędzy subpopulacjami kobiet i mężczyzn wynosiła w roku 2011 ponad osiem lat. Układ przestrzenny tego zjawiska jest o wiele bardziej zróżnicowany, różnice wynoszą od 6,3 do 10,6 roku. Największe dysproporcje występują w Polsce środkowej (poza War- 
szawą, Łodzią i podregionem warszawskim zachodnim) oraz w podregionie stargardzkim.

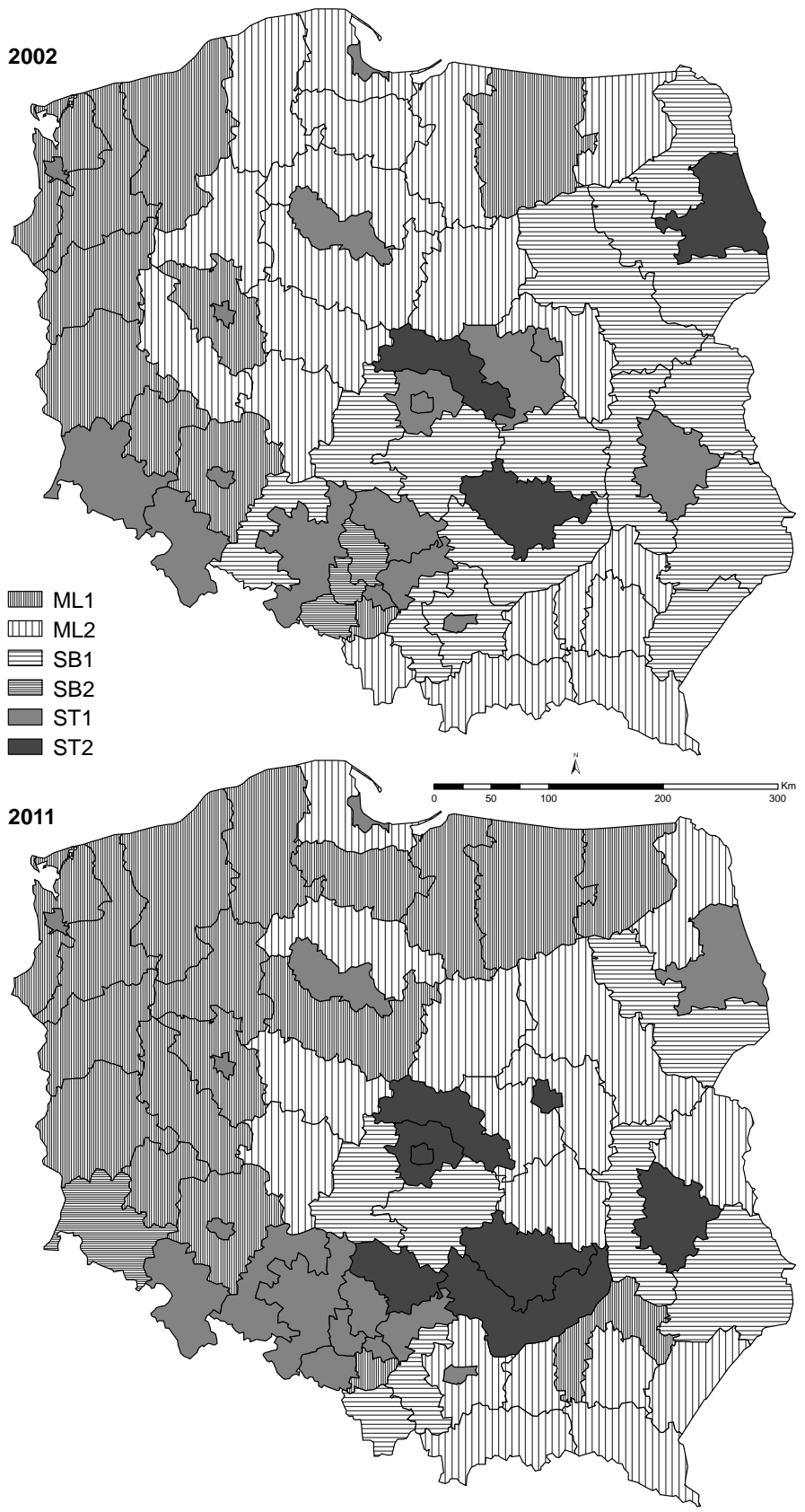

Ryc. 62. Klasy rozwoju struktury wieku w podregionach w 2002 i $2011 \mathrm{r}$. Źródło: oprac. własne na podstawie Banku Danych Lokalnych, GUS, Warszawa 


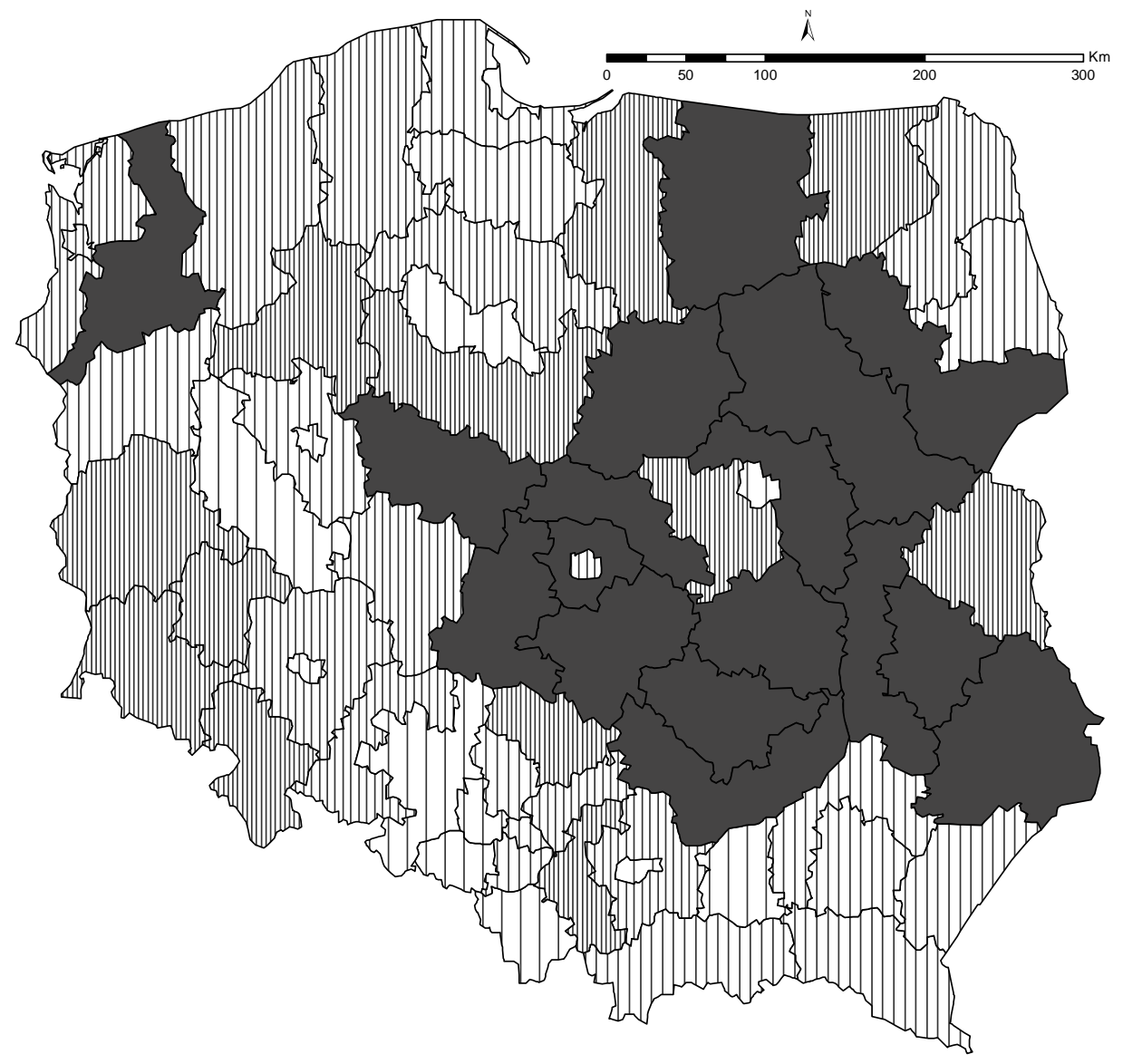

Liczba lat

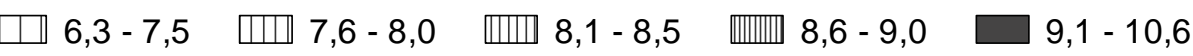

Ryc. 63. Różnice w dalszym trwaniu życia pomiędzy kobietami i mężczyznami w 2011 r. dla podregionów

Źródło: oprac. własne na podstawie Banku Danych Lokalnych, GUS, Warszawa 


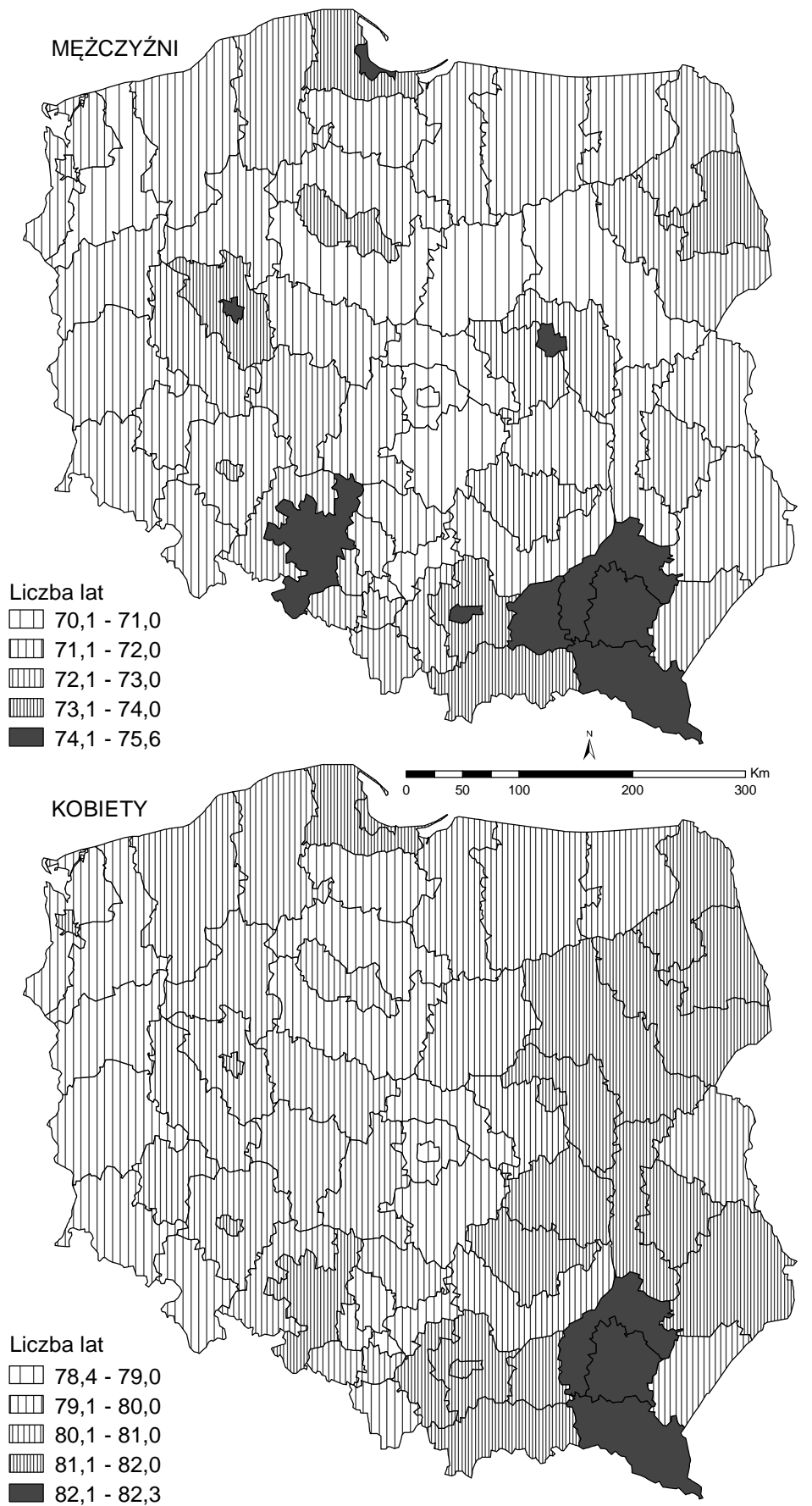

Ryc. 64. Trwanie życia w 2011 r. dla podregionów Źródło: oprac. własne na podstawie Banku Danych Lokalnych, GUS, Warszawa 


\subsection{Uwarunkowania społeczno-ekonomiczne zmian małżeńskości i rozrodczości}

\subsubsection{Uwagi wstępne}

Polska jest krajem terytorialnie zróżnicowanym pod względem poziomu i potencjału rozwojowego zarówno społecznego, jak i gospodarczego. Jak piszą Wójcik i Herbst (2011) skala tego zróżnicowania nie odbiega od zjawisk obserwowanych współcześnie w innych krajach o zbliżonym poziomie dochodu na jednego mieszkańca. Pomimo niedoskonałości tego miernika, jeśli przyjmiemy go jako miarę zróżnicowania na poziomie regionów NTS2 Unii Europejskiej (czyli w przypadku Polski województw), to okaże się, że większe nierówności niż w Polsce występują w Belgii, Rumunii, Wielkiej Brytanii, Irlandii, Czechach, na Węgrzech i Słowacji.

Zróżnicowanie rozwoju $\mathrm{w}$ aspekcie terytorialnym występuje w Polsce w różnych podziałach pomiędzy terenami miejskimi i wiejskimi, metropoliami i regionami peryferyjnymi, historycznie ukształtowanymi dzielnicami czy województwami. Dotychczasowy poziom rozwoju w sposób znaczący determinuje możliwości poprawy sytuacji w perspektywie kolejnych lat i wymaga uruchomienia silniejszych procesów dyfuzji (Gorzelak 2002).

W większości krajów różnice dochodowe między regionami-liderami a biedniejszymi obszarami powiększają się mimo stosowania wielu instrumentów wspomagających rozwój regionów peryferyjnych. W Polsce podejmuje się wiele działań mających na celu złagodzenie różnic rozwojowych, które prowadzą do pogłębiania się niespójności terytorialnej. Zgodnie z nowymi zasadami prowadzenia polityki rozwoju kraju ${ }^{40}$ głównymi dokumentami strategicznymi, na podstawie których prowadzona jest polityka rozwoju, są: długookresowa strategia rozwoju kraju - DSRK (Polska 2030. Trzecia fala nowoczesności), określająca główne trendy, wyzwania oraz koncepcję rozwoju kraju w perspektywie długookresowej, średniookresowa strategia rozwoju kraju - ŚSRK (Strategia Rozwoju Kraju 2020) - najważniejszy dokument w perspektywie średniookresowej, określający cele strategiczne rozwoju kraju do 2020 r., kluczowy dla określenia działań rozwojowych, w tym możliwych do sfinansowania w ramach przyszłej perspektywy finansowej UE na lata 2014-2020 oraz dziewięciu zintegrowanych strategii ${ }^{41}$. Strategie DSRK, ŚSRK oraz dziewięć strategii zintegro-

40 Fundamenty nowego systemu zarządzania rozwojem kraju zostały określone w nowelizowanej Ustawie z dnia 6 grudnia 2006 r. o zasadach prowadzenia polityki rozwoju (DzU, 2009 r., nr 84, poz. 712, z późn. zm.) oraz w przyjętym przez Radę Ministrów 27 kwietnia 2009 r. dokumencie Założenia systemu zarządzania rozwojem Polski.

41 Strategia Innowacyjności i Efektywności Gospodarki, Strategia Rozwoju Kapitału Ludzkiego, Strategia Rozwoju Transportu, Bezpieczeństwo Energetyczne 
wanych łączy spójna hierarchia celów i kierunków interwencji. W strategiach zintegrowanych nastąpiło odejście od wąskiego sektorowego podejścia na rzecz integracji obszarów oraz przenikania się różnych zjawisk i procesów. Szczególną rolę w systemie odgrywa Krajowa Strategia Rozwoju Regionalnego, która wskazuje zakres terytorialnego wpływu interwencji realizowanych $\mathrm{w}$ ramach różnych polityki publicznych, a więc również w ramach pozostałych strategii zintegrowanych. Przedstawia ona kluczowe dla rozwoju regionalnego wyzwania, zarysowuje cele rozwojowe w odniesieniu do różnego rodzaju obszarów uwzględniając funkcje przez nie pełnione, występujące potencjały oraz bariery.

Jednym z trzech głównych obszarów Strategii Rozwoju Kraju jest spójność społeczna i terytorialna. W obszarze tym zapisano, jako jeden z celów, zwiększenie spójności terytorialnej. W dokumencie ustalono jakie działania będą podjęte, by zrealizować to zadanie, czytamy w nim:

W celu poprawy spójności społecznej i terytorialnej tworzone będą warunki do rozprzestrzeniania procesów rozwojowych zarówno w kontekście geograficznym na różne obszary o słabszych potencjałach, jak i włączania w procesy rozwojowe tych, którzy pozostawali dotychczas tylko biernymi odbiorcami zachodzących zmian. Procesom rozwojowym towarzyszy zwykle rozwarstwienie, które jest wynikiem splotu różnych czynników: zapóźnień infrastrukturalnych, przestarzałej struktury społeczno-gospodarczej, niskiej produktywności i innowacyjności, słabości kapitału ludzkiego i społecznego. Podejmowane działania wyrównawcze nie zawsze przynosiły zamierzony efekt. Dlatego też nacisk powinien być położony przede wszystkim na działania wydobywające i wspierające zróżnicowane potencjały, tak poszczególnych jednostek i grup społecznych, jak i poszczególnych terytoriów w oparciu o zasadę solidarności pokoleniowej i terytorialnej (polegającej na wyrównywaniu szans i konkurencyjności). $\mathrm{W}$ tym kontekście istotne jest z jednej strony zmniejszanie „luki rozwojowej” przez działania skierowane na eliminowanie barier ograniczających możliwości rozwojowe, z drugiej zaś wzmacnianie potencjałów rozwojowych. Większa spójność społeczna i przestrzenna umożliwia oddziaływanie czynników prowzrostowych na różne obszary życia społeczno-gospodarczego. $\mathrm{W}$ układzie terytorialnym przejawia się to $\mathrm{z}$ jednej strony $\mathrm{w}$ stymulowaniu rozwoju ośrodków wzrostu konkurencyjności i innowacyjności, jakimi są ośrodki wojewódzkie, a z drugiej - we wzmacnianiu potencjału rozwojowego obszarów o słabszych wskaźnikach makroekonomicznych. Oddziaływanie ośrodków wzrostu na te obszary oraz roz-przestrzenianie procesów rozwojowych, wspierać będzie przemiany w sferze gospodarczej, jak i społecznej. Ważnym elementem spójności terytorialnej jest dbałość o zasoby przyrodnicze, $\mathrm{w}$ tym utrzymanie pełnej funkcjonalności eko-

i Środowisko, Sprawne Państwo, Strategia Rozwoju Kapitału Społecznego, Krajowa Strategia Rozwoju Regionalnego 2010-2020: Regiony, Miasta, Obszary wiejskie, Strategia Rozwoju Systemu Bezpieczeństwa Narodowego RP, Strategia Zrównoważonego Rozwoju Wsi, Rolnictwa i Rybactwa. 
systemów. Dotyczy to zarówno poprawy infrastruktury, jak i uwzględniania potrzeb zrównoważonego zarządzania środowiskiem w procesach rozwojowych (Strategia Rozwoju Kraju 2020, 2012: 30-31).

Dysproporcje terytorialne rozwoju społeczno-gospodarczego - zarówno w Polsce, jak i w UE - są wynikiem tendencji wzrostowej i następstwem szybszego wzrostu gospodarczego generowanego przede wszystkim przez największe obszary miejskie. Stawia to nowe wyzwanie wobec polityki rozwoju i polityki regionalnej, której celem jest zapewnienie spójności wewnętrznej kraju oraz niedopuszczenie do nadmiernych zróżnicowań przestrzennych. Oprócz obszarów, gdzie koncentrują się determinanty rozwoju, istnieją obszary, które w związku z kumulacją barier rozwojowych nie mają możliwości wykorzystania swoich zasobów przestrzennych w celu zwiększenia konkurencyjności i innowacyjności, a tym samym możliwości większej partycypacji $\mathrm{w}$ tworzeniu wzrostu gospodarczego. Obszary te określane są jako obszary problemowe, wymagające restrukturyzacji i rozwoju nowych funkcji przy wsparciu instrumentów właściwych polityce regionalnej. Procesy marginalizacji są w Polsce - inaczej niż w krajach wysoko rozwiniętych - silnie skoncentrowane terytorialnie na peryferyjnych terenach wiejskich oraz na obszarach poprzemysłowych, tracących funkcje gospodarcze, przygranicznych i o niskiej dostępności transportowej, w szczególności na terenie Polski Wschodniej. Jest to największy „obszar problemowy" kraju, który nadal potrzebuje specjalnego traktowania, ponieważ jego spójność z resztą kraju i UE jest niewystarczająca w każdym z jej przekrojów: gospodarczym, społecznym i przestrzennym. Województwa Polski Wschodniej (podkarpackie, świętokrzyskie, lubelskie, podlaskie i warmińsko-mazurskie), mimo znaczącej poprawy sytuacji społecznogospodarczej w ostatnich latach, nadal charakteryzują się niskim w skali kraju i UE poziomem rozwoju, starzejącym się społeczeństwem, gorszym niż reszta kraju poziomem wykształcenia, zapóźnieniami infrastrukturalnymi, niskim poziomem warunków życia (w tym dostępu do dóbr i usług), słabą produktywnością wszystkich sektorów gospodarki oraz niską dostępnością transportową. Potencjał tej części kraju, który wspomagany odpowiednią interwencją publiczną może zostać wykorzystany do zwiększenia udziału województw Polski Wschodniej we wzroście gospodarczym, istnieje m.in. w takich dziedzinach, jak: proekologiczny model rolnictwa i produkcji żywności wysokiej jakości, działalność naukowa w zakresie biotechnologii, rozwój usług specjalistycznych z wykorzystaniem miejscowego zaplecza naukowo-badawczego, logistyka międzynarodowa w kierunku wschód-zachód, produkcja biopaliw (Strategia... 2012). 


\subsubsection{Zróżnicowanie przestrzenne wybranych zjawisk gospodarczych}

Polską przestrzeń tradycyjnie dzieli się na część zachodnią i wschodnią, przy czym podział ten dotyczy wielu aspektów rozwoju i nie jest łatwo przeprowadzić precyzyjną granicę między terenami lepiej i gorzej rozwiniętymi, gdyż zależy to od rozpatrywanej dziedziny życia społecznego lub gospodarczego. Większość dostępnych wskaźników dowodzi, że zachodnia cześć kraju jest zamożniejsza, lepiej wyposażona w infrastrukturę i bardziej przystosowana do współczesnych wyzwań rozwojowych niż regiony wschodnie. Różnice na korzyść zachodu widoczne były na terenie dzisiejszej Polski nawet w epoce średniowiecza, a następujące później wydarzenia historyczne przyczyniły się raczej do ich pogłębienia niż osłabienia ${ }^{42}$ (Gorzelak 2002; Bartkowski 2003).

Zmiany przebiegu polskich granic po II wojnie światowej nie spowodowały zaniku linii demarkacyjnej wschód-zachód dla opisu przestrzennego zróżnicowania rozwoju, a wręcz go jeszcze utrwaliły. Ziemie, które zostały przyłączone do Polski na zachodzie i północy charakteryzowały się, ogólnie rzecz ujmując, wyższym poziomem urbanizacji i nasycenia infrastrukturą rozwojową $\mathrm{w}$ porównaniu $\mathrm{z}$ utraconymi terenami na wschodzie kraju. Jednak z drugiej strony należy pamiętać, że niemal cała ludność zamieszkująca ziemie zachodnie i północne przed wojną została z tych terenów usunięta, dzisiejsi mieszkańcy zostali zaś tam, dobrowolnie bądź przymusowo, przesiedleni. Jak podaje Gawryszewski (2005) między rokiem 1945 a 1950 liczba przesiedlonych na nowo uzyskane terytoria sięgnęła 2,9 miliona, z czego około $55 \%$ stanowiły osoby poprzednio mieszkające na ziemiach utraconych na rzecz Związku Radzieckiego. Socjologowie podkreślają, że brak zakorzenienia mieszkańców ziem zachodnich i północnych oraz związany z tym niski poziom kapitału społecznego może być przyczyną niekorzystnych zjawisk i patologii (Bartkowski 2003).

O utrzymywaniu się podziału Polski na metropolie i peryferia a także wschód i zachód świadczy zróżnicowanie wartości zmiennych opisujących wybrane zjawiska społeczno-gospodarcze według podregionów. W analizie

${ }^{42} \mathrm{~W}$ wieku XVIII, według ówczesnych szacunków, jedna wielkopolska wieś licząca 200 gospodarzy przynosiła dwukrotnie większy dochód niż podobnej wielkości wieś na ziemi rawskiej czy łęczyckiej i trzy razy większy niż wieś na Ukrainie lub Litwie. Przemysł w tym okresie rozwijał się głownie w Wielkopolsce (manufaktury) i Zagłębiu Staropolskim (późniejsza Galicja). W następstwie rozbiorów Polski, między rokiem 1795 a 1918 ziemie należące do zaborów pruskiego i austriackiego znalazły się pod kontrolą krajów postępowych, przechodzących stosunkowo szybką industrializację i urbanizację połączone z odejściem od systemu feudalnego na wsi, część zaś włączona do imperium rosyjskiego rozwijała się wolniej w tym kluczowym dla kształtowania się współczesnych nam państw okresie (Hryniewicz 2008). 
wzięto pod uwagę te mierniki, które wpływają na sytuację ekonomiczną mieszkańców, a przez to pośrednio na ich zachowania demograficzne. Można w takich rozważaniach wykorzystać tradycyjne mierniki obrazujące poziom rozwoju gospodarczego, np. produkt krajowy brutto na 1 mieszkańca, strukturę pracujących według trzech sektorów, ale należy też wziąć pod uwagę mierniki obrazujące np. atrakcyjność inwestycyjną rozumianą jako zdolność skłaniania do inwestycji, poprzez oferowanie kombinacji korzyści lokalizacji możliwych do osiągnięcia $\mathrm{w}$ trakcie prowadzenia działalności gospodarczej.

Produkt krajowy brutto na 1 mieszkańca ${ }^{43}$ w 2002 r. był bardzo zróżnicowany pod względem wartości, najwyższy notowano $\mathrm{w}$ Warszawie (60 862 zł), najniższe zaś jego wartości (poniżej 15 tys. zł) w podregionach Polski Wschodniej i Południowej: bialskim, chełmsko-zamojskim, puławskim, łomżyńskim, nowosądeckim, tarnowskim, krośnieńskim, przemyskim i sandomiersko-jędrzejowskim (A VII). Wartości te były prawie o połowę niższe od średniej krajowej (podczas gdy w stolicy trzykrotnie wyższe). Wyraźnie wyższe od przeciętnych dochody osiągnęły też podregiony: Poznań, Wrocław, Kraków, Szczecin, trójmiejski, katowicki i tyski. Sytuacja nie zmieniła się w ciągu kilku kolejnych lat, poza wzrostem produktu krajowego brutto na 1 mieszkańca w podregionach, dysproporcje przestrzenne tego miernika w 2010 r. były podobne do tych z roku 2002. Odchylenie standardowe PKB podregionów w przeliczeniu na jednego mieszkańca wynosiło w 2002 r. 7761 zł. Między rokiem 2002 a 2010 zwiększyło się ono do 14 680 zł, co oznacza znaczny przyrost zróżnicowania dochodu per capita. Za tę dywergencję odpowiedzialna jest $\mathrm{w}$ dużej mierze szybko rozwijająca się stolica kraju. Pomimo wzrostu wartości PKB per capita, niektóre podregiony południowo-wschodniej części kraju osiągnęły w 2010 r. nieco niższe wartości w stosunku do średniej krajowej niż osiem lat wcześniej (bialski, chełmsko-zamojski, puławski, łomżyński, nowosądecki, tarnowski, krośnieński, przemyski i sandomiersko-jędrzejowski), tym samym podział kraju na „wschód” i „zachód” utrwalił się pod względem wartości tego miernika.

Jak głęboki jest wspomniany podział Polski obrazuje także struktura pracujących w rolnictwie (A VIII). Znaczenie rolnictwa jest wyraźnie największe na wschodzie i południu kraju, przy czym wyraźnie widoczne są tu podziały historyczne - obszary rolnicze leżą w granicach dawnego Królestwa Kongresowego oraz Galicji, podczas gdy pozostałe terytorium kraju charakteryzuje się niższym udziałem rolników wśród pracujących. Najwyższe udziały pracujących $\mathrm{w}$ rolnictwie odnotowano $\mathrm{w}$ podregionach sandomiersko-jędrzejowskim (58,1\%), chełmsko-zamojskim (56,9\%), puławskim $(55,0 \%)$ i łomżyńskim $(50,7 \%)$, natomiast w wielu podregionach zachodniej

${ }^{43}$ Dane dotyczące Produktu Krajowego Brutto podano w cenach bieżących. 
i północnej Polski wartości te nie przekraczały 15\% (np. zielonogórski 13,3\% czy gorzowski - 14,8\%).

Instytut Badań nad Gospodarką Rynkową (IBnGR) od 2005 r. prowadzi badania przestrzennego zróżnicowania atrakcyjności inwestycyjnej Polski dla inwestorów zagranicznych. Ich efektem są raporty pt. Atrakcyjność inwestycyjna województw i podregionów Polski. IBnGR dokonuje syntetycznej oceny atrakcyjności inwestycyjnej województw oraz oceny atrakcyjności podregionów w trzech kategoriach:

- działalności przemysłowej,

- działalności usługowej,

- działalności zaawansowanej technologicznie.

Celem badań jest identyfikacja terytorialnych różnic w poziomie atrakcyjności inwestycyjnej, a także gradacja województw i podregionów ${ }^{44}$ pod tym względem, wskazanie mocnych i słabych stron poszczególnych jednostek w zakresie czynników atrakcyjności inwestycyjnej, analiza zmian tej atrakcyjności w przypadku województw i podregionów. Różnorodność i specyfika działalności gospodarczej kształtują odmienne preferencje lokalizacyjne. Autorzy raportów IBnGR twierdzą, że nie można mówić o absolutnej atrakcyjności inwestycyjnej obszarów. W związku z tym jej ocena przeprowadzona została dwutorowo: w odniesieniu do podregionów w kontekście czynników lokalizacji dla trzech najistotniejszych, z punktu widzenia inwestorów zagranicznych, rodzajów działalności gospodarczej przemysłowej, usługowej i zaawansowanej technologicznie, w odniesieniu do województw zaś w aspekcie uniwersalnych czynników lokalizacji. W tym celu przeanalizowano kilkadziesiąt zmiennych, będących podstawą do oceny przestrzennego zróżnicowania poszczególnych korzyści (czynników) lokalizacji, takich jak dostępność transportowa, koszty pracy, wielkość i jakość zasobów pracy, chłonność rynku zbytu, poziom rozwoju infrastruktury gospodarczej i społecznej, poziom rozwoju gospodarczego, poziom bezpieczeństwa powszechnego. W zależności od rodzaju działalności gospodarczej nadano im różne wagi (Nowicki 2011).

Wśród podregionów o najwyższej atrakcyjności inwestycyjnej dla działalności przemysłowej znalazły się dwa zwarte obszary położone w południowej części Polski. Jeden z nich ukształtowany jest wokół Górnego Śląska i zachodniej Małopolski, drugi zaś wokół Wrocławia, Jeleniej Góry i Wałbrzycha - ośrodków przemysłowych Dolnego Śląska (ryc. 65). Są to obszary wyróżniające się długimi tradycjami przemysłowymi, a co za tym

${ }^{44}$ Na potrzeby raportu podregiony - duże miasta, takie jak Katowice, Kraków, Łódź, Poznań, Szczecin, Trójmiasto, Warszawa, Wrocław połączono z jednostkami otaczającymi, funkcjonalnie powiązanymi z tymi miastami. 


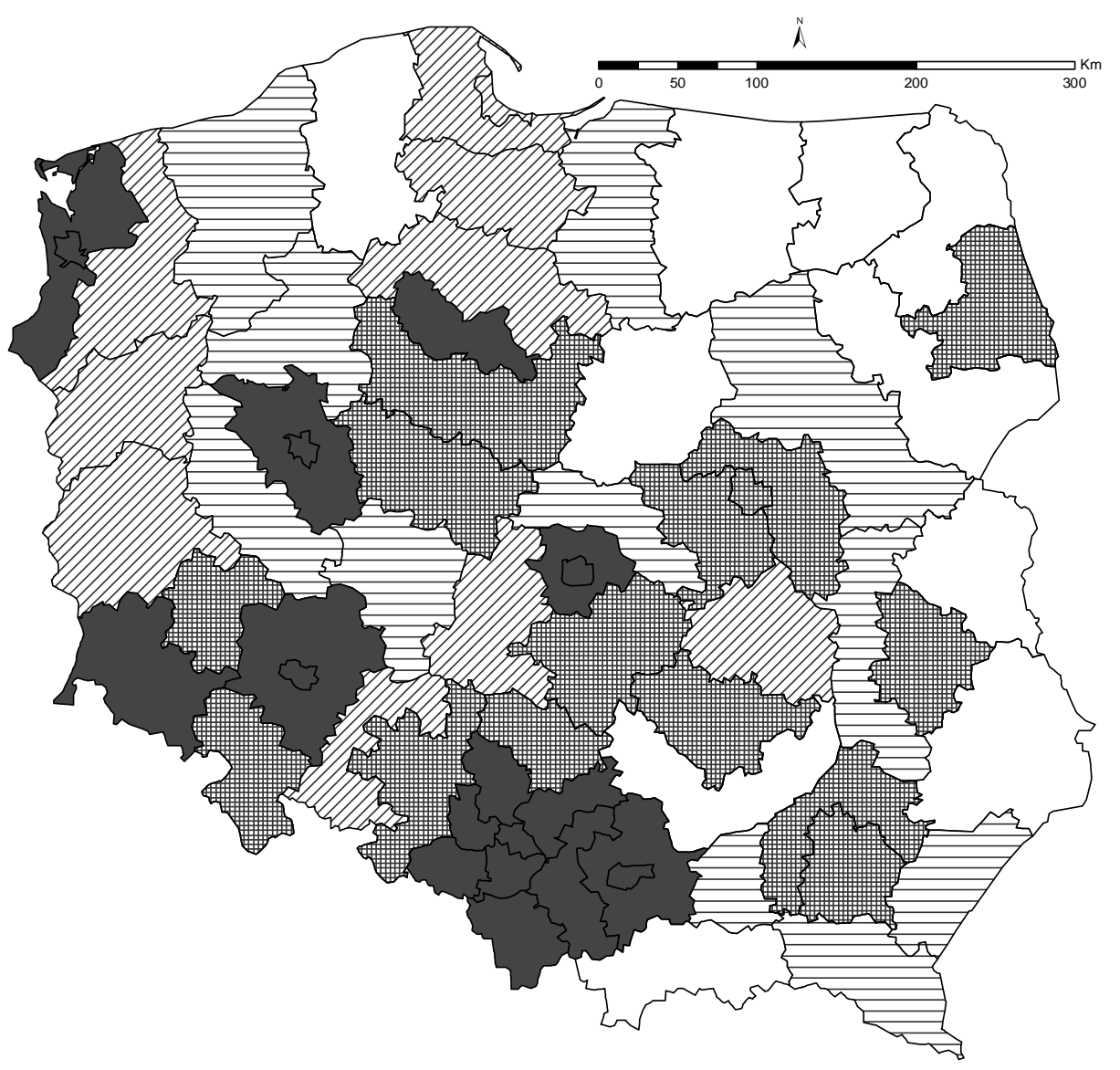

Atrakcyjność

najwyższa mysoka

niska $\square$ najniższa

Ryc. 65. Atrakcyjność inwestycyjna podregionów dla działalności przemysłowej w $2011 \mathrm{r}$. Źródło: Nowicki 2011

idzie dobrze rozwiniętym sektorem przedsiębiorstw produkcyjnych, specjalistycznym rynkiem pracy oraz względnie dobrą, dzięki autostradzie A-4, dostępnością transportową. Do terenów atrakcyjnych inwestycyjnie dla działalności przemysłowej należą jeszcze cztery podregiony: łódzki, poznański, bydgosko-toruński i szczeciński. To także obszary stosunkowo silnie zindustrializowane oraz cechujące się dobrą dostępnością transportową. Najwyższy poziom atrakcyjności inwestycyjnej dla działalności usługowej reprezentują zwłaszcza podregiony o charakterze metropolitalnym (ryc. 66). Ich ośrodkami są największe polskie miasta. Dysponują one przede wszystkim dużymi zasobami pracowników o wysokich, a zarazem zróżnicowanych pod względem profilu kompetencjach, a także dużymi i chłonnymi rynkami zbytu. Poza tym największe miasta oferują bardzo dobrą 
dostępność komunikacyjną i dobrze rozwiniętą infrastrukturę gospodarczą. Grupę podregionów o najwyższym poziomie atrakcyjności inwestycyjnej dla działalności zaawansowanej technologicznie również zdominowały podregiony o charakterze metropolitalnym. To tam koncentruje się infrastruktura oraz kadra badawczo-rozwojowa. Zasoby rynku pracy obejmują specjalistów wykształconych zarówno w lokalnych ośrodkach akademickich, jak i zmotywowanych do migracji przez dobre warunki życia, w tym rozwinięte otoczenie kulturowe. Ośrodki te cechują się zarazem najlepiej rozwiniętą infrastrukturą teleinformatyczną i relatywnie wysoką dostępnością w zakresie transportu pasażerskiego (ryc. 67). W przypadku każdej z trzech rodzajów atrakcyjności inwestycyjnej najniższy jej poziom występuje w znaczącej części w podregionach wschodniej Polski.

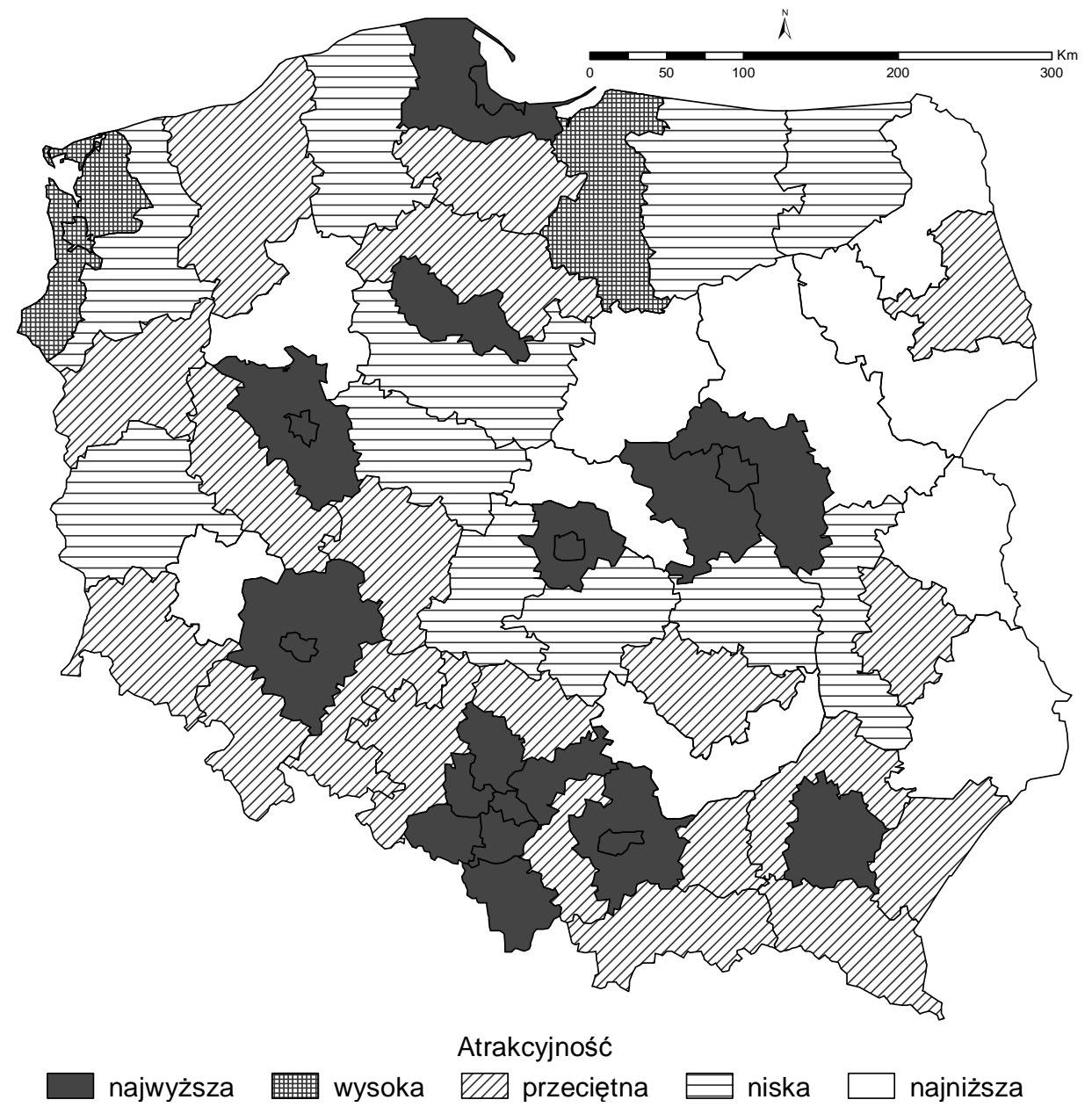

Ryc. 66. Atrakcyjność inwestycyjna podregionów dla działalności usługowej w 2011 r. Źródło: Nowicki 2011 


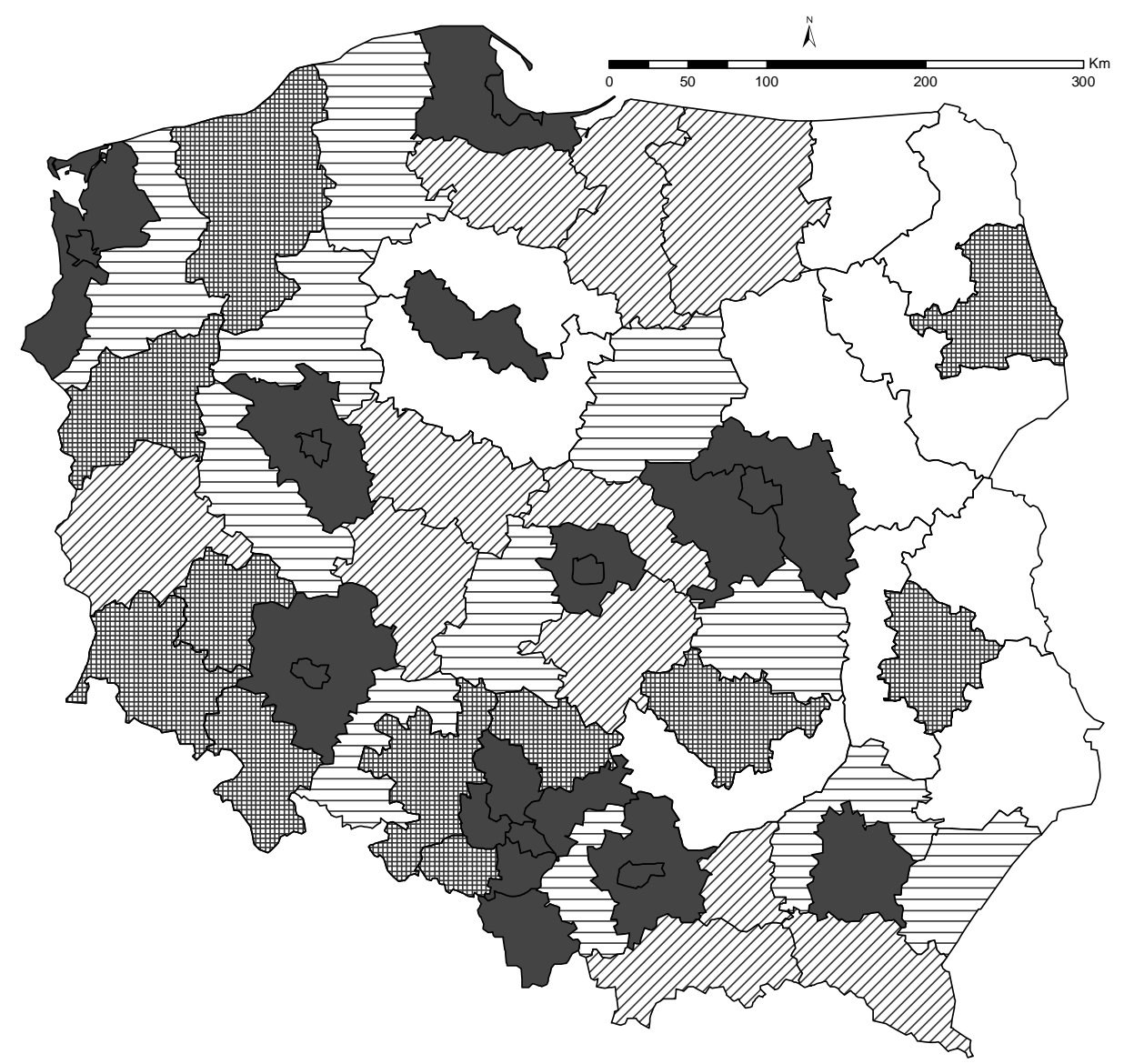

Atrakcyjność

najwyższa wysoka

Ryc. 67. Atrakcyjność inwestycyjna podregionów dla działalności zaawansowanej technologicznie w $2011 \mathrm{r}$.

Źródło: Nowicki 2011

\subsubsection{Zróżnicowanie przestrzenne wybranych zjawisk społecznych}

Społeczne uwarunkowania procesów demograficznych można rozpatrywać z punktu widzenia potencjału, jaki tkwi w kapitale ludzkim i kapitale społecznym. Współcześnie kapitał ludzki odgrywa znaczącą rolę w rozwoju ekonomicznym i społecznym narodów. Przyjmuje się, że kapitał ludzki wpływa na indywidualne zarobki pracowników, efektywność i skuteczność przedsiębiorców, jak i na wielkość wartości dodanej generowanej przez gospodarkę narodową. Definicja OECD mówi, że kapitał ludzki to wiedza, umiejętności, zdolności oraz inne właściwe jednostce atrybuty ułatwiające tworzenie osobistego, społecznego, a także ekonomicznego dobrostanu (The Weell-being... 2001). Spośród wielu miar opisujących kapitał ludzki 
wybrano w niniejszym opracowaniu dwie cechy, tj. wykształcenie i wyniki egzaminów gimnazjalnych, przeanalizowano ich zróżnicowanie przestrzenne według podregionów, aby sprawdzić, czy także w tym przypadku występuje podział kraju na obszary metropolitalne i peryferia oraz wschód i zachód.

W przypadku wykształcenia zwrócono uwagę na najniższy i najwyższy poziom wykształcenia w Polsce, czyli wykształcenie podstawowe i wyższe. Okres 2002-2011 to lata, w których następowało powiększanie kapitału ludzkiego, czego wyrazem jest ubytek w całym kraju osób z wykształceniem podstawowym i jednoczesny przyrost tych $\mathrm{z}$ wykształceniem wyższym. Niewątpliwa poprawa sytuacji w zakresie wykształcenia nie zmieniła jednak w sposób zasadniczy rozkładu przestrzennego osób o najniższym wykształceniu w Polsce. Zarówno w 2002, jak i 2011 r. znaczna część podregionów z najwyższymi odsetkami osób (odpowiednio powyżej 36,1 i $28,1 \%$ ) mających wykształcenie podstawowe leżała we wschodniej części kraju (ryc. 68). Ubytek odsetka osób o najniższym poziomie wykształcenia, jaki nastąpił $\mathrm{w}$ tym czasie $\mathrm{w}$ podregionach wschodnich (z wyjątkiem suwalskiego), też nie należał do największych w kraju (ryc. 69). Nieco inaczej wyglądało zróżnicowanie przestrzenne osób mających wykształcenie wyższe, w obydwu badanych okresach (rok 2002 i 2011), najwyższe wartości odsetka takich osób występowały wśród mieszkańców dużych miast polskich i na większości terenów silnie zurbanizowanych (ryc. 70). Znaczący wzrost odsetka mieszkańców najlepiej wykształconych, jaki odnotowano w tym okresie, także był związany ze środowiskiem wielkomiejskim i z jego otoczeniem. Zauważyć należy także podnoszenie poziomu wykształcenia $\mathrm{w}$ podregionach wschodnich, w wyniku czego dysproporcje pomiędzy wschodnimi i zachodnimi podregionami w 2011 r. są zdecydowanie mniejsze niż w 2002 r. (ryc. 71). 


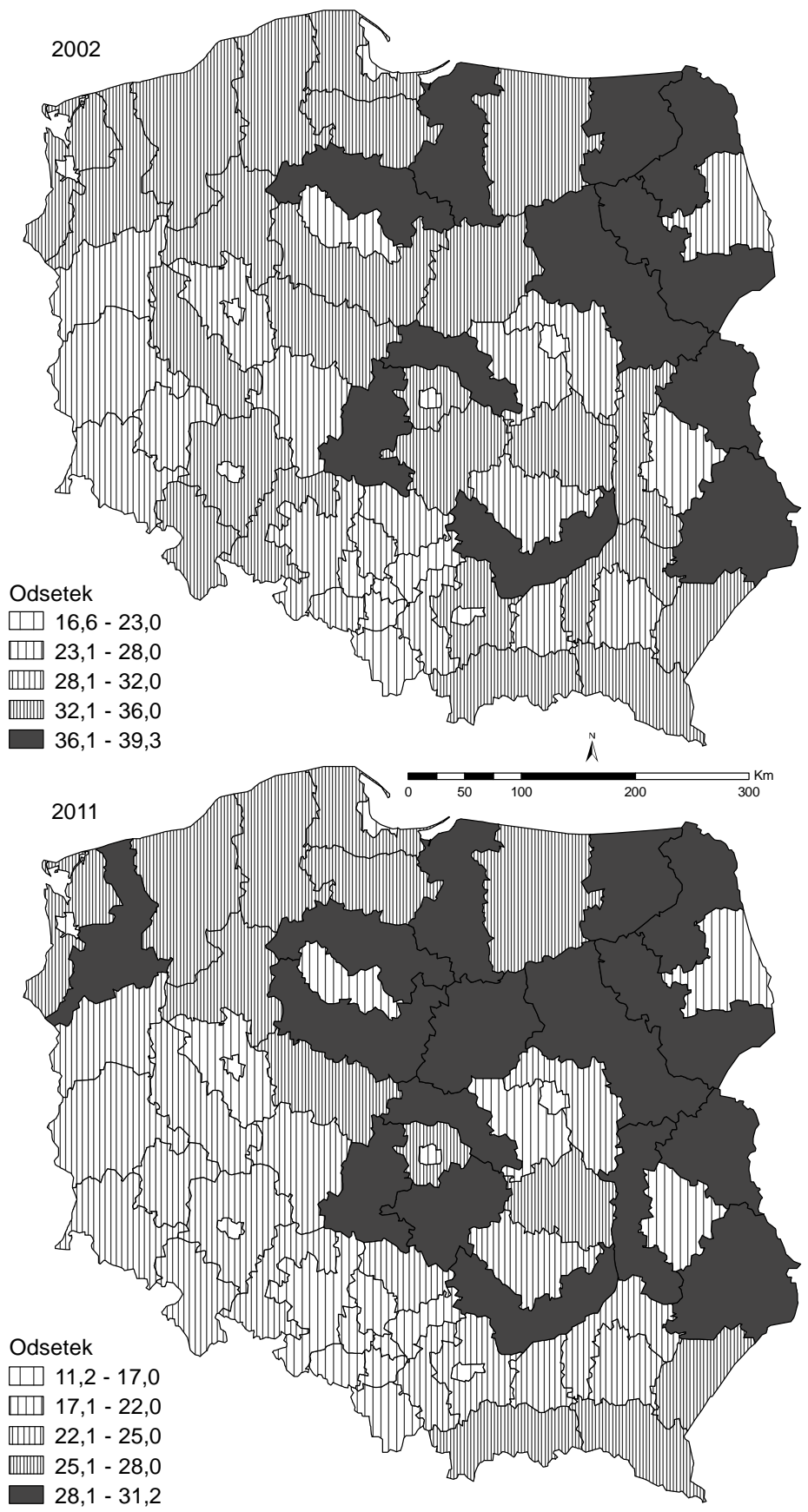

Ryc. 68. Odsetek osób z wykształceniem podstawowym w 2002 i 2011 r. według podregionów

Źródło: oprac. własne na podstawie Banku Danych Lokalnych, GUS, Warszawa 


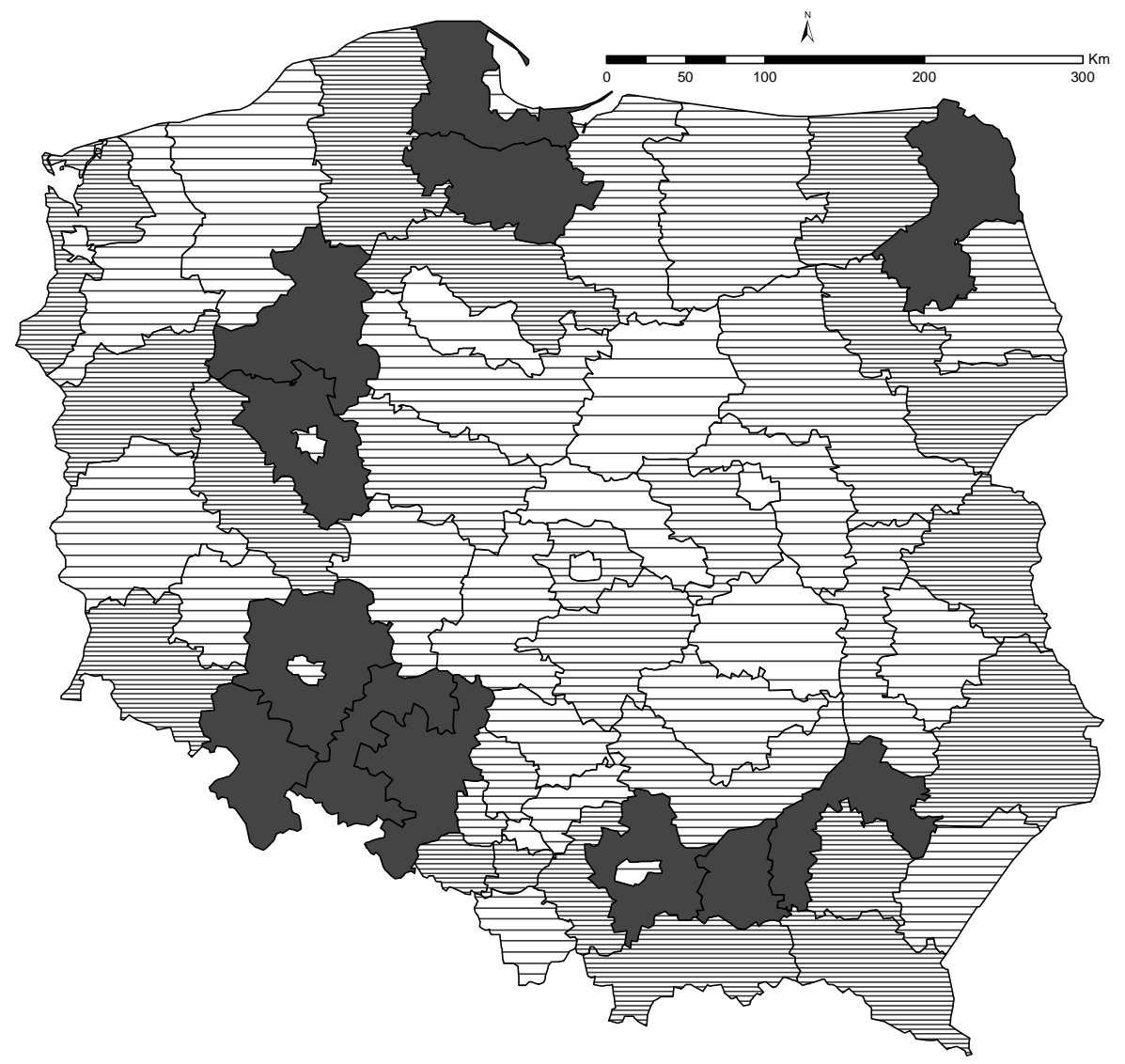

Ubytek

$-9,1--8,0 \rightleftharpoons-7,9--7,5 \rightleftharpoons-7,4--7,0$

$-6,9--6,5$

$-6,4--5,3$

Ryc. 69. Ubytek odsetka osób z wykształceniem podstawowym pomiędzy 2011 i 2002 r. według podregionów

Źródło: oprac. własne na podstawie Banku Danych Lokalnych, GUS, Warszawa

Drugim czynnikiem społecznym branym pod uwagę w analizie zróżnicowania przestrzennego kapitału ludzkiego są wyniki egzaminu gimnazjalnego. Powszechność i obowiązkowość egzaminów zewnętrznych ${ }^{45}$, w tym

45 Egzaminy zewnętrzne zostały wprowadzone wraz z reformą systemu edukacji w 1999 r. Ich celem jest sprawdzanie opanowania przez szóstoklasistów, gimnazjalistów i maturzystów wiadomości oraz umiejętności zawartych w standardach wymagań egzaminacyjnych odpowiednio po szkole podstawowej, gimnazjum i szkole ponadgimnazjalnej. Egzamin gimnazjalny składał się w latach 2002-2008 z dwóch części: humanistycznej - sprawdzającej wiedzę i umiejętności z języka polskiego, historii, wiedzy o społeczeństwie, muzyki i plastyki oraz części matematyczno-przyrodniczej, zawierającej zadania z matematyki, geografii, biologii, fizyki 
dla uczniów kończących gimnazjum, gwarantują porównywalność wyników uzyskiwanych przez uczniów, a także klas, szkół, gmin, powiatów, województw oraz kraju. Od początku przeprowadzania egzaminów badano zróżnicowanie przestrzenne wyników uzyskiwanych przez uczniów ${ }^{46}$. Badania dotyczące zróżnicowania przestrzennego wyników egzaminów gimnazjalnych prowadzone przez CKE, OKE a także IGiPZ PAN potwierdzają, że występuje duże zróżnicowanie regionalne, nawiązujące do historycznie ukształtowanych regionów społeczno-gospodarczych (Śleszyński 2003; 2004; Czapiewski, Śleszyński 2007). Lepsze wyniki uzyskują uczniowie zamieszkali na obszarach dawnego zaboru austriackiego (Galicja) i rosyjskiego (Kongresówka). Natomiast uczniowie zamieszkujący tzw. Ziemie Zachodnie i Północne osiągają wyniki gorsze. Podział regionalny jest lepiej widoczny w zróżnicowaniu przestrzennym wyników części matematycznoprzyrodniczej, postrzeganej jako trudniejsza. Autorzy również potwierdzają, że ludność zasiedziała, mająca lepiej rozwinięte więzi społeczne, przywiązana do własności prywatnej, jest bardziej odpowiedzialna za swój los i wykształcenie swych dzieci. Wpływa to pozytywnie na wyniki egzaminu gimnazjalnego młodego pokolenia (dawna Galicja, Kongresówka). Ponadto badania wskazują na istnienie silnego, negatywnego związku wyników egzaminu gimnazjalnego z poziomem bezrobocia, szczególnie na terenach, gdzie jest ono związane z likwidacją PGR-ów (Ziemie Zachodnie i Północne). Ludność tamtych terenów nie zdążyła wytworzyć silnie rozwiniętych więzi społecznych, a w czasach Polski Ludowej została przyzwyczajona do „opieki” państwa i wręcz „wyręczania” rodziców przez państwo (Śleszyński 2003; 2004; Czapiewski, Śleszyński 2007). Do innych czynników istotnie wpływających na wyniki egzaminu gimnazjalnego zalicza się miejsce zamieszkania ucznia w stosunku do dużych aglomeracji. Uczniowie mieszkający w dużych aglomeracjach lub w ich pobliżu osiągają lepsze wyniki niż ich koledzy mieszkający na obszarach wiejskich, oddalonych od dużych miast. Przykładem są aglomeracje Warszawy, Krakowa, Gdańska czy Poznania (Śleszyński 2003; 2004).

i astronomii oraz chemii. Począwszy od 2009 r. trzecią częścią egzaminu po gimnazjum jest egzamin z języka obcego nowożytnego (Dzięcioł-Kurczoba 2011).

46 W pierwszych latach przeprowadzania egzaminów Centralna Komisja Egzaminacyjna zleciła badania Instytutowi Geografii i Przestrzennego Zagospodarowania Polskiej Akademii Nauk (IGiPZ PAN) w Warszawie. 


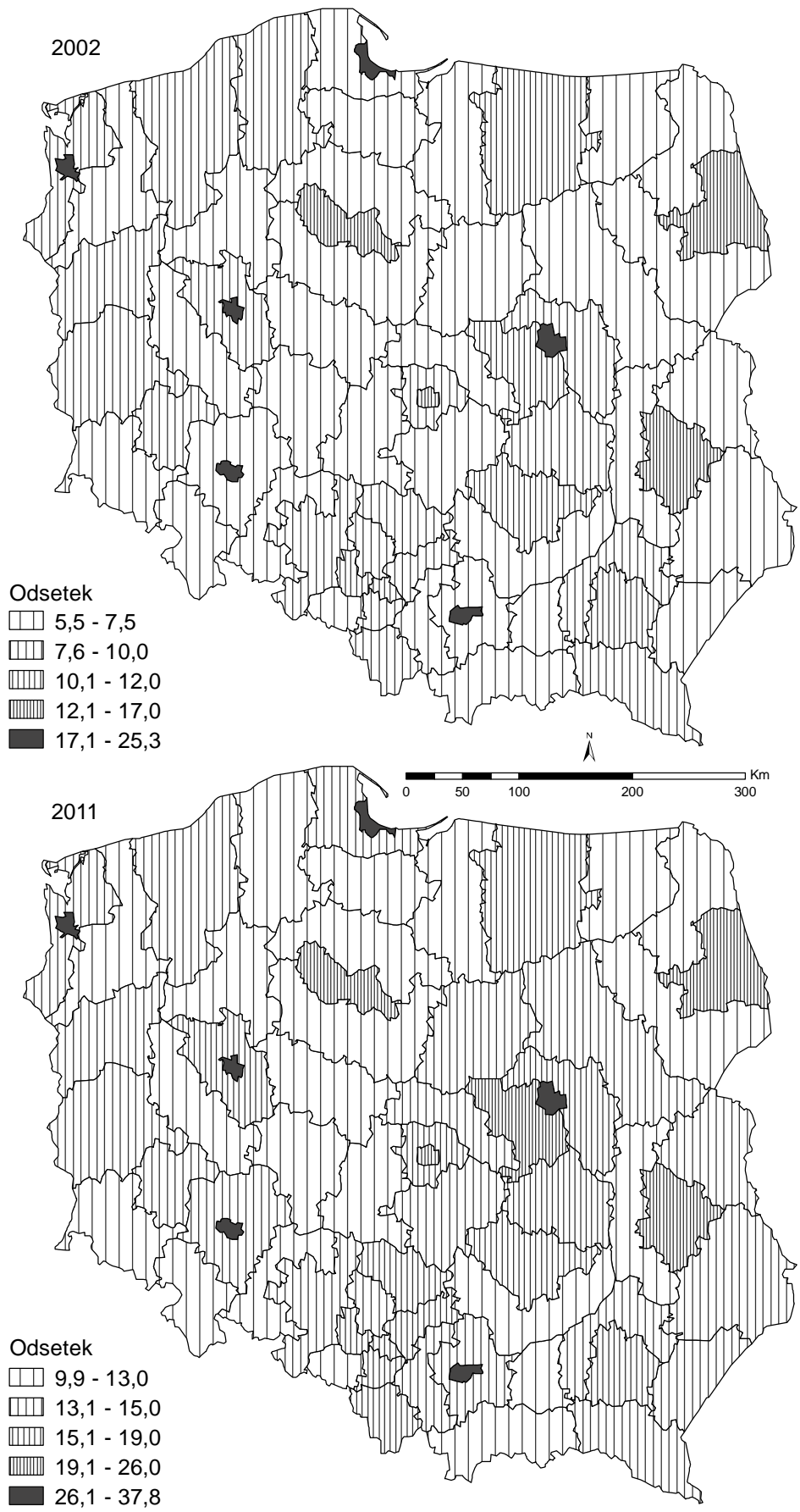

Ryc. 70. Odsetek osób z wykształceniem wyższym w 2002 i 2011 r. według podregionów Źródło: oprac. własne na podstawie Banku Danych Lokalnych, GUS, Warszawa 


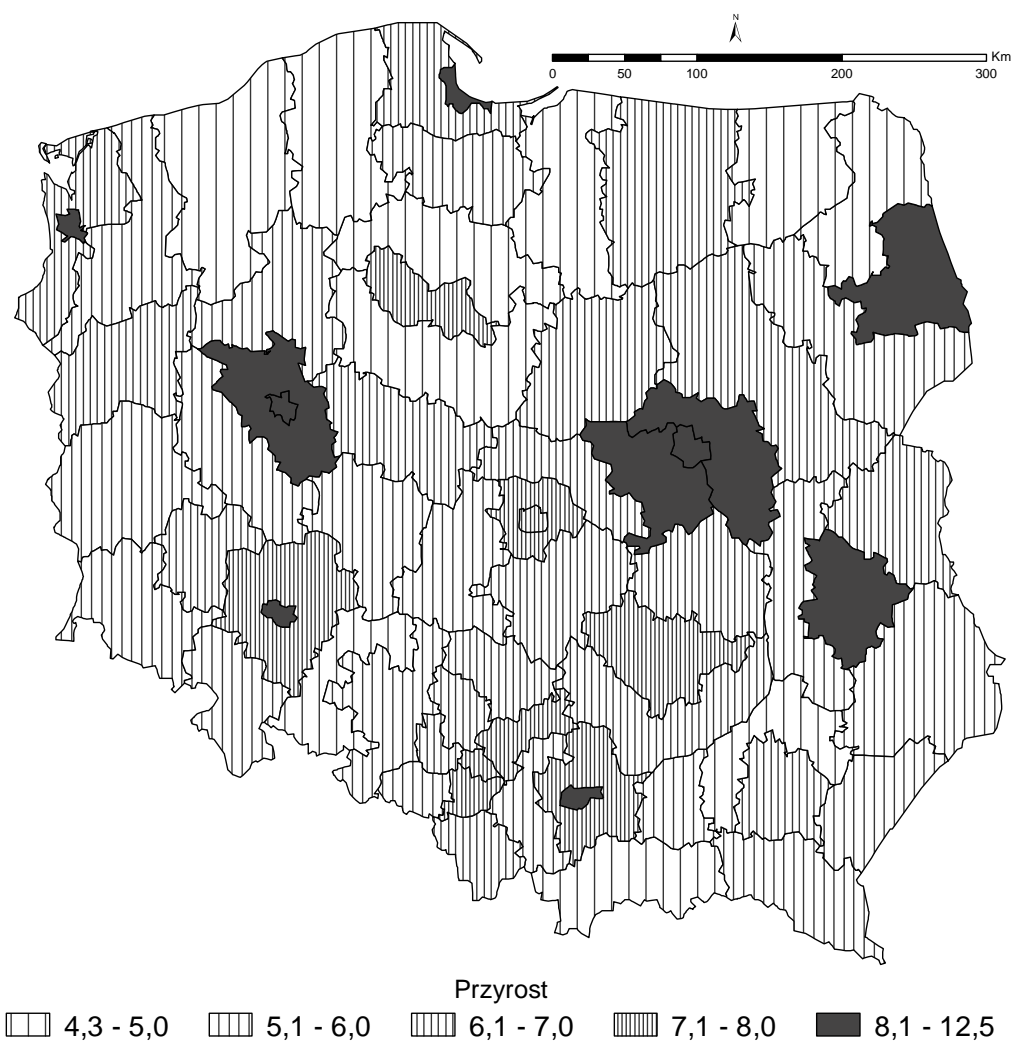

Ryc. 71. Przyrost odsetka osób z wykształceniem podstawowym pomiędzy 2002 i $2011 \mathrm{r}$. według podregionów

Źródło: oprac. własne na podstawie Banku Danych Lokalnych, GUS, Warszawa

Efekty przeprowadzonych badań świadczą o mocnym powiązaniu wyników egzaminacyjnych uczniów z dochodami gospodarstw domowych, poziomem wykształcenia rodziców i ich sytuacją zawodową. Wyższe dochody i wykształcenie rodziców ucznia przekładają się na lepsze warunki materialne kształcenia. Również uwarunkowania regionalne (historyczne, cywilizacyjne i kulturowe) oraz funkcjonalne (oś podziałów miasto-wieś, metropolie-peryferia) wskazują, że najlepszych wyników edukacji należy oczekiwać w tych społecznościach, w których duża odpowiedzialność rodziny jest powiązana z dobrymi warunkami nauczania. Zainteresowanie sukcesem edukacyjnym szkoły musi być poparte działaniami rodziców, ponieważ wpojone w szkole dobre wzorce i rzetelna wiedza mogą zostać zniweczone negatywnymi cechami środowiska rodzinnego na obszarach o złej kondycji społeczno-gospodarczej. I odwrotnie, dobre wzorce wyniesione $\mathrm{z}$ domu rodzinnego mogą być niwelowane w szkole źle zorganizowanej i nieprzygotowanej do roli edukacyjno-wychowawczej (Śleszyński 2007). Badania wskazały, że dzieci z rodzin pełnych uzyskują lepsze wyniki 
w testach. Wykształcenie, zamożność, mieszkanie z obojgiem rodziców lub nie, wpływają na kształtowanie się określonych stylów życia, różniących się wagą przykładaną do nauki i aspiracji związanych z ułożeniem sobie życia w przyszłości. Rodzice dzieci o najlepszych wynikach spędzają z nimi stosunkowo więcej czasu. Nie ma tu jednak prostej zależności. Rodzice wykształceni i pracujący stanowią istotny „zasób” dzieci. Również matki, spędzające więcej czasu z dziećmi niż ojcowie, są w stanie przekazać wiedzę, opinie rzutujące na aspiracje dzieci i postawy wobec nauki i ich przyszłego miejsca w społeczeństwie.

Do wyjaśniania zależności pomiędzy wynikami egzaminów a sytuacją rodzinną może posłużyć teoria kapitału ludzkiego G. S. Beckera. Jego wkład do tej teorii polega na dostarczeniu jej podstaw mikroekonomicznych opartych na przyjęciu prostego założenia, że z punktu widzenia jednostki wykształcenie należy traktować jako inwestycję, której łączny koszt stanowią bezpośrednie wydatki na edukację oraz zarobki utracone w ciągu okresu pobierania nauki, korzyści zaś wyrażają się w strumieniu dochodów. Uważa on, że to rodzina ponosi zawsze główny ciężar takiej inwestycji, wychowując dzieci. Kochająca rodzina jest szczodrym inwestorem, nie tyle $\mathrm{z}$ chęci doczekania się zwrotu z inwestycji, ile przede wszystkim z czystego altruizmu. Naukowo dowodzi, że tylko społeczeństwa, które są liczne, a ich członkowie charakteryzują się wysokim poziomem wytwarzanego w rodzinie „kapitału ludzkiego”, mogą spodziewać się rozwoju gospodarczego i kulturalnego. Becker przedstawia wyliczenia dowodzące, że rodzina i praca w niej wykonywana przynoszą przynajmniej 30\% dochodu narodowego. Dzieje się tak dlatego, że rodzice ucząc na co dzień swoje dzieci, wytwarzają usługi edukacyjne, dbając o ich zdrowie, produkty i usługi medyczne itd. Ponadto doliczyć należy wartość wszelkich czynności, związanych z funkcjonowaniem gospodarstwa domowego, za które rodzinie nikt przecież nie płaci. Świadczenie tych usług poza rynkiem, a w rodzinie, sprzyja oszczędności. Ta z kolei powoduje koncentrację kapitału, która jest alternatywą dla zadłużania się. Zgromadzony w rodzinie kapitał trafia prędzej czy później na rynek, będąc motorem przedsiębiorczości, gospodarczego rozwoju i przynosząc jej dodatkowy dochód lub inne korzyści. Mechanizmy te działać mogą tylko przy założeniu, że nie ma ograniczeń dla wolnego rynku, a ludzie utożsamiają się silnie z wartościami rodzinnymi (Becker 1990).

Na koniec należy także uwzględnić bardzo istotny czynnik, oddziałujący na wyniki egzaminów gimnazjalnych, a mianowicie poziom inteligencji ucznia. Wyniki osób wybitnie inteligentnych na egzaminie są również wyższe niżby to wynikało z ich stopni szkolnych. Odwrotna zależność dotyczy osób mało inteligentnych - ich wyniki egzaminacyjne są gorsze niżby to wynikało z ich ocen szkolnych (Wieczorkowska, Siarkiewicz 2007). 
Opisane wyżej zróżnicowanie przestrzenne wyników egzaminów gimnazjalnych przeprowadzanych w pierwszych kilku latach od ich rozpoczęcia jest $\mathrm{w}$ dalszym ciągu aktualne. W 2011 r. najlepsze wyniki egzaminu gimnazjalnego z części humanistycznej i matematyczno-przyrodniczej osiągnęli uczniowie mieszkający $w$ podregionach Polski południowo-wschodniej i centralnej (ryc. 72 i ryc. 73). Wysokie wartości średniej liczby punktów z egzaminu uzyskała także młodzież pochodząca z dużych miast (Wrocław, Poznań, Szczecin, Trójmiasto). Nieco inaczej wygląda obraz przestrzennego zróżnicowania wyników egzaminu z języka angielskiego, tu również różnice w uzyskanych przez uczniów wynikach są największe - blisko 10 punktów (Warszawa - 35,5 pkt; podregion grudziądzki - 24,9 pkt). Podobnie, jak w przypadku egzaminu z części humanistycznej i matematyczno-przyrodniczej, najlepsze wyniki na egzaminie z języka angielskiego uzyskała młodzież ucząca się w dużych miastach i na terenach zurbanizowanych (ryc. 74). Jest to zapewne efekt lepszej dostępności do dodatkowych, pozalekcyjnych form nauki tego języka. Nie zauważa się jednak w tym zakresie aż tak dużego zróżnicowania pomiędzy podregionami południowo-wschodnimi a zachodnimi kraju.

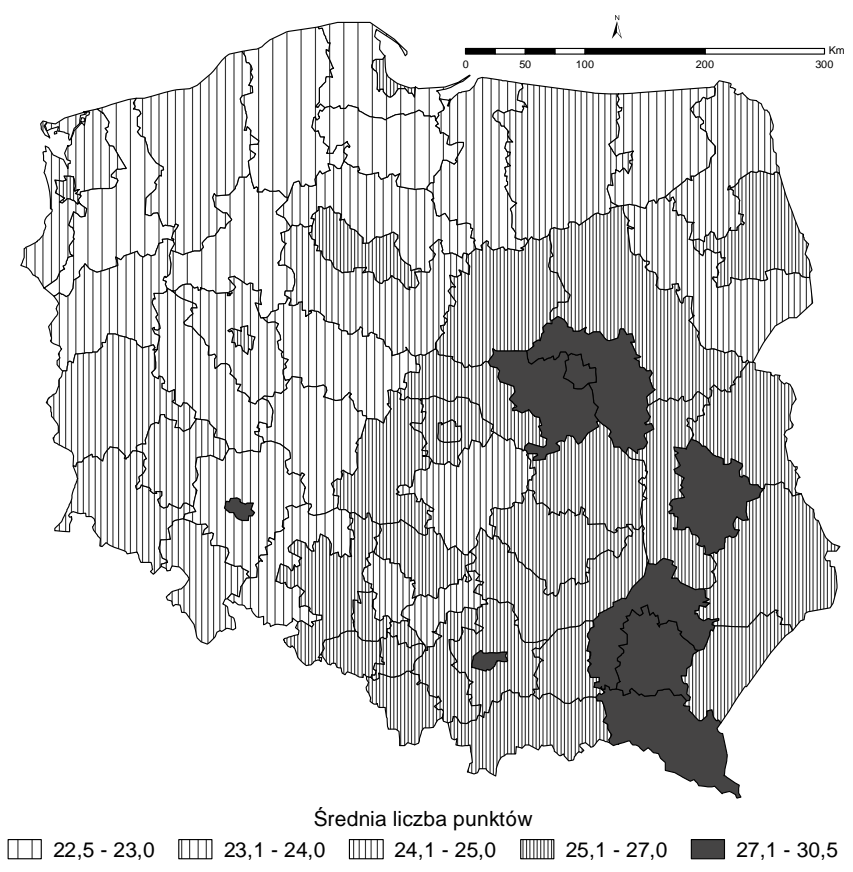

Ryc. 72. Wyniki egzaminu gimnazjalnego w 2011 r. według podregionów

- część humanistyczna

Źródło: oprac. własne na podstawie danych OKE 


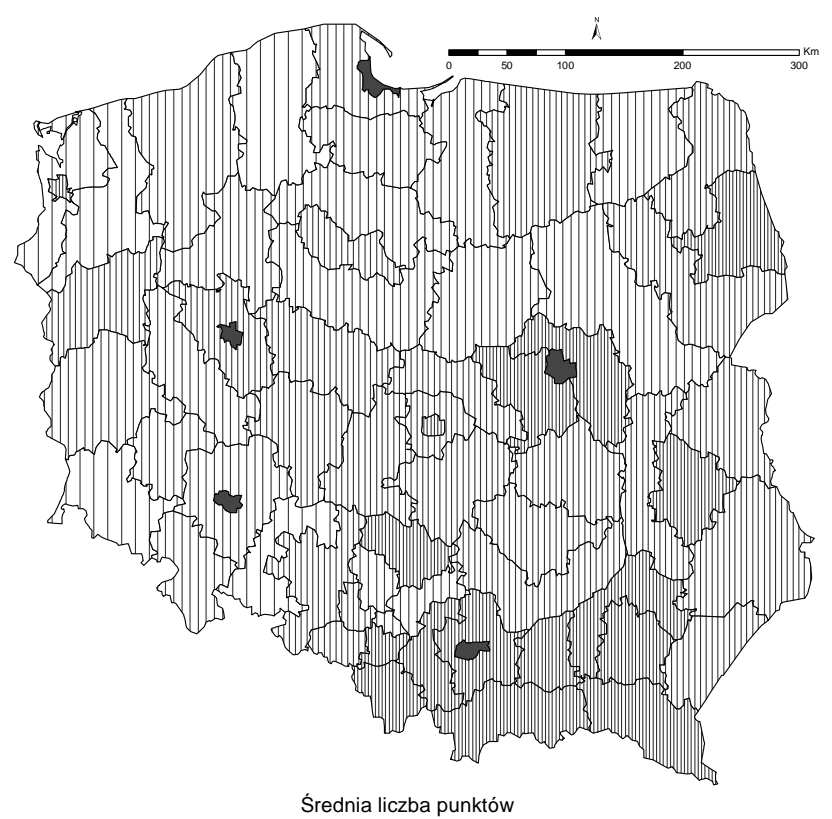

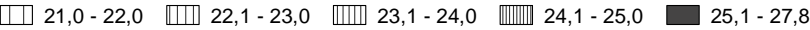

Ryc. 73. Wyniki egzaminu gimnazjalnego w 2011 r. według podregionów

- część matematyczno-przyrodnicza

Źródło: oprac. własne na podstawie danych OKE

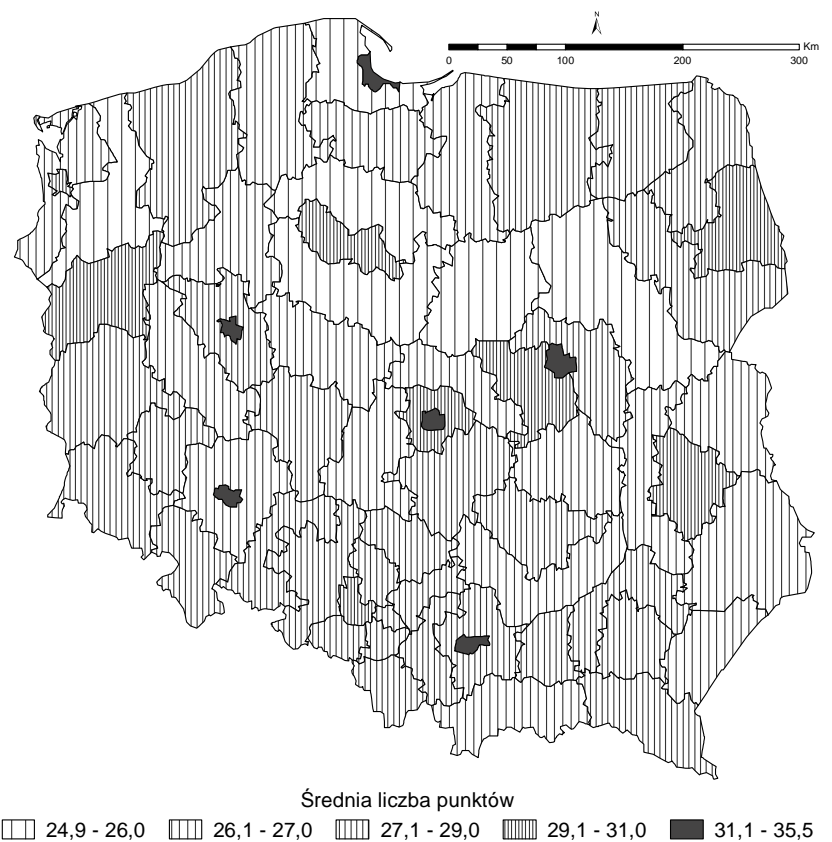

Ryc. 74. Wyniki egzaminu gimnazjalnego w 2011 r. według podregionów - język angielski Źródło: oprac. własne na podstawie danych OKE 
Termin kapitał społeczny związany jest z pojęciem instytucji i ekonomii instytucjonalnej. Na instytucje formalne - zewnętrzne względem człowieka i związane $\mathrm{z}$ istnieniem państwa - składają się przepisy rządowe, prawa, zalecenia formalne dotyczące organizacji życia zarówno z punktu widzenia gospodarki, jak i społeczeństwa. Instytucje nieformalne obejmują systemy wartości, obowiązujące normy i zwyczaje, sposób myślenia, kulturę, poziom zaufania, skłonność do ryzyka i do wykorzystywania okazji. Instytucje takie są zatem nośnikiem wiedzy społecznej oraz zaufania, ograniczają koszty transakcyjne, zwiększają poziom bezpieczeństwa przy podejmowaniu decyzji w warunkach niepewności, porządkują relacje międzyludzkie (North 1990). W literaturze przedmiotu panuje już zgoda co do wielowymiarowości kapitału społecznego, która ma przełożenie na sposób jego pomiaru. Van Oorschot, Arts i Gellisen (2006) przyjęli, że kapitał społeczny ma trzy wymiary: sieć, zaufanie a także społeczeństwo obywatelskie. W ramach sieci wyróżnili członkostwo w organizacjach oraz kontakty z rodziną. W ramach wymiaru „zaufanie” rozważali zaufanie w stosunku do ludzi (zaufanie społeczne) oraz zaufanie do instytucji. Trzeci wymiar kapitału społecznego - społeczeństwo obywatelskie - powiązali z zachowaniami i postawami.

Wskaźnikiem kapitału społecznego, który wybrano do analizy w ramach społeczeństwa obywatelskiego, są frekwencja wyborcza w ostatnich wyborach parlamentarnych z 2011 r. i wyniki głosowania na dwie partie, które uzyskały największe poparcie - Platformę Obywatelską i Prawo i Sprawiedliwość.

Wcześniejsze badania zachowań i postaw wyborczych wskazują, że mieszkańcy ziem zachodnich, w porównaniu z mieszkańcami wschodnich regionów, wykazują daleko mniejszy konserwatyzm odnośnie do wyborów politycznych. Dowodzą tego analizy geografii politycznej Polski przeprowadzone przez T. Zaryckiego (1997) na podstawie danych Państwowej Komisji Wyborczej dotyczących wyników wyborów parlamentarnych i prezydenckich. Podobne wnioski można wyciągnąć analizując terytorialny rozkład wyników ogólnopolskiego referendum z 2003 r., decydującego o przystąpieniu Polski do Unii Europejskiej. Zróżnicowanie przestrzenne wyników referendum wskazuje na wyraźny podział w tej kwestii między mieszkańcami zachodnich terenów kraju, gdzie akcesję poparło ponad $80 \%$ głosujących, a głosującymi na wschodzie, gdzie poparcie dla wstąpienia Polski do UE było wyraźnie niższe (50-60\%).

Zarycki (1997) pisze, że przestrzenny rozkład frekwencji wyborczej w pierwszych wyborach parlamentarnych okresu transformacji, tj. w $1989 \mathrm{r}$. okazał się całkowicie odmienny od układów rejestrowanych w latach poprzednich, a podstawowe prawidłowości tego zróżnicowania wykazały znaczną trwałość, jeśli chodzi o wybory w latach następnych. Zwartym obszarem o wysokiej frekwencji okazał się dawny zabór austriacki, a naj- 
wyższą frekwencję odnotowano w województwie rzeszowskim $(71,5 \%)$. Kolejnym obszarem wysokiej frekwencji była Wielkopolska (pilskie 70,6\%; leszczyńskie 70,2\%) oraz województwo gdańskie. Najniższą frekwencję zanotowano w województwie łódzkim $(53,1 \%)$ oraz ogólnie na terenach byłego zaboru rosyjskiego. Wyniki wyborów z 1989 r. okazały się zaskoczeniem $\mathrm{w}$ perspektywie przestrzennej, odnosiło się ono do ujawnienia się tradycyjnych, historycznych podziałów kraju na mapie wyborczej kraju. To ujawnienie się spuścizny historycznej paradoksalnie okazało się „nowością". Stąd też obraz głosowania w czerwcu 1989 r. nazwano wkrótce „nową geografią polityczną Polski".

Frekwencja wyborcza w ostatnich wyborach parlamentarnych była zróżnicowana - od nieco ponad $40 \% \mathrm{w}$ podregionach sandomierskojędrzejowskim, nyskim, stargardzkim i suwalskim do blisko 68\% w Warszawie (ryc. 75). Obraz zróżnicowania przestrzennego frekwencji wyborczej zmienił się od 1989 r. na kilku obszarach kraju. Dobrym tego przykładem są wyniki frekwencji podczas ostatnich wyborów, jakie odnotowano $\mathrm{w}$ podregionie rzeszowskim (51,3\%), plasujące ów podregion $\mathrm{w}$ grupie o średnich wartościach frekwencji. Gdyby analiza dotyczyła województw, to wynik osiągnięty przez województwo podkarpackie wynosił niespełna $47 \%$ (średnia w kraju 48,7\%), ale trzeba przyznać, że nie były to wartości najniższe w Polsce. W dalszym ciągu dość wysokie wskaźniki odnotowano w niektórych podregionach Mazowsza, Małopolski i Wielkopolski. Zmieniła się frekwencja wyborcza także na ziemi łódzkiej, w samej Łodzi swoje głosy oddało ponad $56 \%$ uprawnionych.

Różnice między wschodnimi i zachodnimi regionami Polski bardzo wyraźnie występują $\mathrm{w}$ przypadku sympatii politycznych i podejmowania decyzji wyborczych ${ }^{47}$. Rozkład przestrzenny wyborców opowiadających się za PO i PIS wyraźnie dzieli kraj na część południowo-wschodnią i wschodnią sympatyzującą z partią Jarosława Kaczyńskiego i część zachodnią i północną, gdzie było zdecydowanie więcej zwolenników partii Donalda Tuska (ryc. 76, 77).

${ }^{47}$ Harrop i Miller (1987) wyróżniają trzy podstawowe podejścia metodologiczne odnośnie do mechanizmów podejmowani decyzji wyborczych. Pierwsze dwa dotyczą ujęcia aktu głosowania w dwojaki sposób. Po pierwsze można go postrzegać jako narzędzie ekspresji tożsamości, z drugiej strony jako działanie świadome, mające na celu instrumentalny wybór optymalnej opcji politycznej z punktu widzenia interesów własnych czy też szerzej rozumianych interesów grupowych. Pierwsza sytuacja to tzw. model identyfikacji partyjnej, druga zaś to model racjonalnego wyboru. Trzeci typ podejść metodologicznych do głosowania można określić jako model socjologiczny, wyjaśnienia oparte są tu na badaniach strukturalnych. 


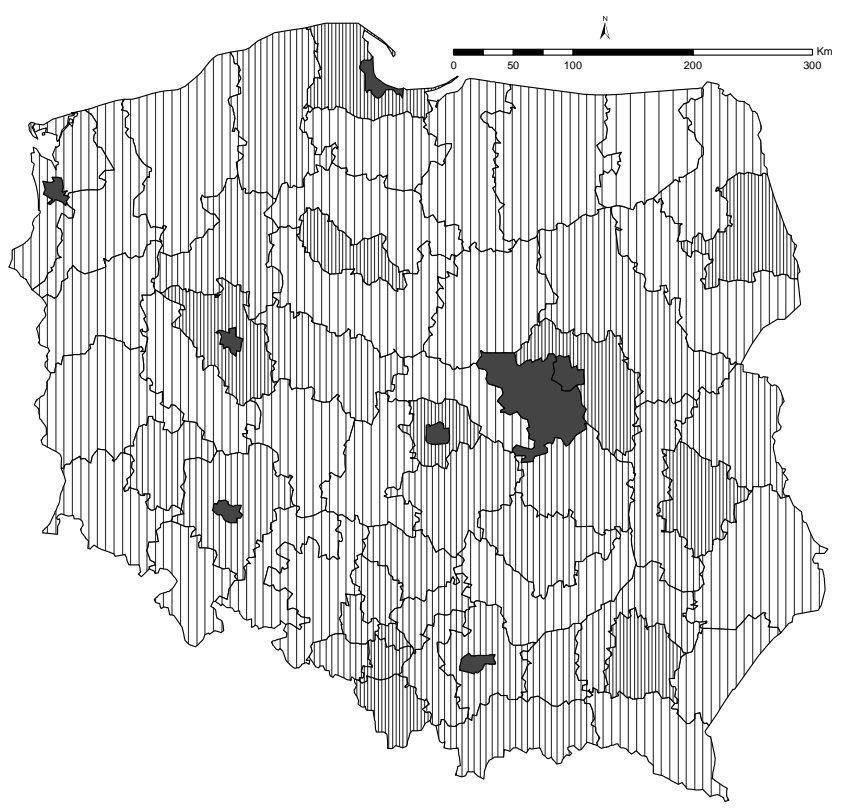

Głosy oddane ważne w \% ogółu uprawnionych

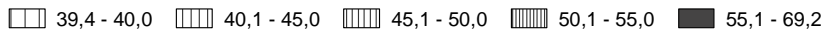

Ryc. 75. Frekwencja wyborcza w wyborach parlamentarnych w $2011 \mathrm{r}$. według podregionów Źródło: oprac. własne na podstawie danych PKW

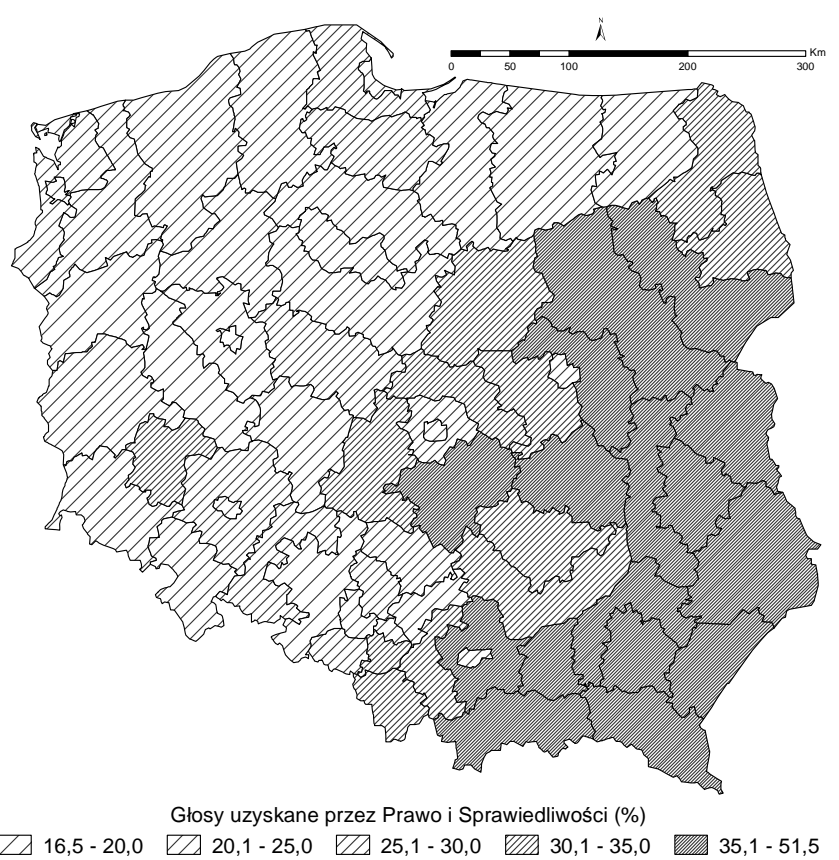

Ryc. 76. Wyniki PIS w wyborach parlamentarnych w $2011 \mathrm{r}$. według podregionów Źródło: oprac. własne na podstawie danych PKW 


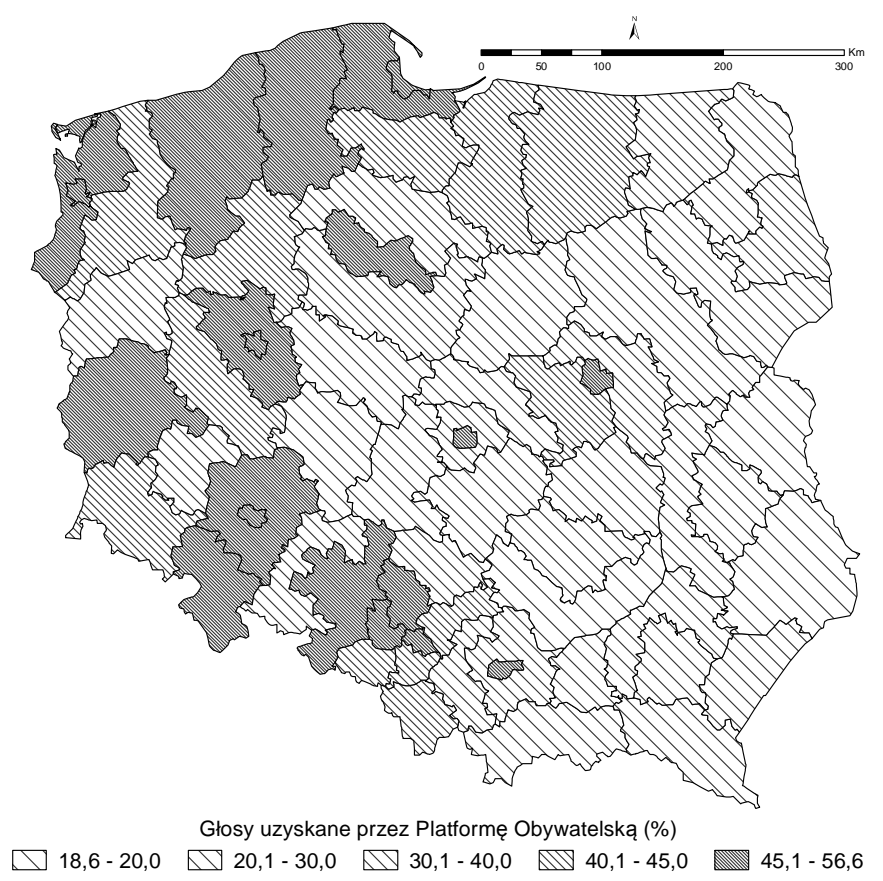

Ryc. 77. Wyniki PO w wyborach parlamentarnych w 2011 r. według podregionów Źródło: oprac. własne na podstawie danych PKW

\subsubsection{Poziom rozwoju społeczno-gospodarczego podregionów}

Do pomiaru rozwoju społeczno-gospodarczego używa się różnych miar, w tym w znacznej części o charakterze ekonomicznym. Bardzo popularnym miernikiem do niedawna był produkt krajowy brutto na 1 mieszkańca. Coraz częściej jest on jednak poddawany krytyce. Zwraca się między innymi uwagę, że pomiar taki nie uwzględnia dóbr wytworzonych w tzw. szarej strefie, pomija wartość czasu wolnego, nie odzwierciedla jakości dóbr i usług, a tylko ich ilość oraz nie bierze się pod uwagę efektów zewnętrznych, czyli niejako społecznej wartości wytworzonych dóbr i usług (Wójcik, Herbst 2012). Dlatego coraz częściej wykorzystuje się mierniki syntetyczne, jak np. HDI (Human Development Index). Wskaźnik Rozwoju Społecznego jest to miara wykorzystywana od 1993 r. przez Agendę ds. Rozwoju ONZ (UNDP). Wskaźnik HDI ocenia kraje na trzech płaszczyznach: „długie i zdrowe życie” (long and healthy life), „wiedza” (knowledge) i "dostatni standard życia" (decent standard of living). 
Do konstrukcji HDI wykorzystuje się cztery mierniki cząstkowe ${ }^{48}$ :

- oczekiwaną długość życia,

- średnią liczbę lat edukacji populacji w wieku od 25 lat,

- oczekiwaną liczbę lat edukacji dzieci rozpoczynających naukę,

- dochód narodowy per capita w USD, liczony według parytetu siły nabywczej.

Polska jako pierwszy kraj na świecie w 2012 r. opracowała Krajowy $R a$ port o Rozwoju Społecznym, w którym prezentuje wyniki „innowacyjnego i unikalnego $\mathrm{w}$ skali świata badania rozwoju społecznego na poziomie lokalnym za pomocą nowatorskiego Wskaźnika Lokalnego Rozwoju Społecznego (Local Human Development Index - LHDI)" - por. Podsumowanie Krajowego Raportu... 2012. Został on skonstruowany na podstawie istniejącej i uznanej międzynarodowo metodologii Wskaźnika Rozwoju Społecznego. LHDI przyjmuje podobną formułę i wykorzystuje następujące dane:

- zdrowie: oczekiwana dalsza długość trwania życia noworodka, zagregowany współczynnik zgonów na nowotwory i choroby serca,

- edukacja: odsetek dzieci w edukacji przedszkolnej (przedział wiekowy 3-4 lata), średnia z wyników egzaminu gimnazjalnego (tylko dla części matematyczno-przyrodniczej),

- zamożność: średni poziom zamożności mieszkańców.

Do innych alternatywnych mierników rozwoju zalicza się Happy Planet Index, publikowany przez New Economic Foundation. Miara ta nawiązuje do „efektywności ekologicznej” rozwoju, czyli budowania dobrobytu przy założeniu oszczędnego wykorzystywania zasobów naturalnych. Krytyka PKB jako miary rozwoju posłużyła autorom tzw. Raportu Stiglitza (napisanego w latach 2008-2009 na zlecenie prezydenta Francji Nicolasa Sarkozy'ego), nie tylko do wskazania ograniczeń w wykorzystaniu PKB jako miary postępu społecznego, ale także do wysunięcia postulatu mierzenia dostępności ważnych usług - na przykład zdrowotnych i edukacyjnych. Według autorów raportu dostępność tych usług jest świadectwem narodowych osiągnięć w dziedzinie uzyskiwania wysokiej jakości życia. Podobne podejście stało się podwaliną dziedziny wiedzy zwanej ekonomią szczęścia. Zajmuje się ona badaniami zadowolenia z życia, traktując przeciętny poziom tego zadowolenia jako lepszy miernik rozwoju kraju niż zagregowany dochód wygenerowany w gospodarce. Ekonomiści szczęścia analizują też wpływ osiągnięć ludzi $w$ rozmaitych dziedzinach ( $w$ tym - w dziedzinie

${ }^{48}$ Do roku 2011 inna była metodologia liczenia HDI, a cząstkowymi miernikami były: średnia długość życia, ogólny wskaźnik skolaryzacji brutto dla wszystkich poziomów nauczania, wskaźnik umiejętności czytania ze zrozumieniem i pisania, PKB per capita w USD, liczony według parytetu nabywczego waluty (PPP \$). 
gromadzenia dóbr materialnych) na poziom życiowej satysfakcji (Wójcik, Herbst 2012).

Procedura określenia poziomu rozwoju społeczno-gospodarczego w niniejszym opracowaniu była dwuetapowa. W pierwszej kolejności dokonano wyboru zmiennych przy wykorzystaniu modelu czterech kapitałów, uwzględniającego różnego rodzaju czynniki rozwojowe. Metodę tę zaproponowali Gorzelak i in. (2006) w kontekście ewaluacji wojewódzkiej strategii rozwoju. Model obejmuje kapitał gospodarczy, kapitał naturalny, kapitał ludzki oraz kapitał społeczny (tab. 17).

Tabela 17

Model czterech kapitałów

\begin{tabular}{|l|l|}
\hline \multicolumn{1}{|c|}{ Rodzaj kapitału } & \multicolumn{1}{c|}{ Opis } \\
\hline Kapitał gospodar- & $\begin{array}{l}\text { Kapitał gospodarczy obejmuje wszystko to, co tradycyjnie rozu- } \\
\text { miane jest jako kapitał (wytworzone zasoby, które są wykorzysty- } \\
\text { wane do produkcji innych dóbr i usług). Do tego kapitału zalicza } \\
\text { się np. maszyny, narzędzia, budynki, infrastrukturę. }\end{array}$ \\
\hline Kapitał naturalny & $\begin{array}{l}\text { Obejmuje wszystkie formy ekosystemu i zasobów naturalnych, } \\
\text { które uczestniczą w tworzeniu społecznego dobrobytu. A zatem, } \\
\text { poza tradycyjnie rozumianymi zasobami naturalnymi (drewno, } \\
\text { woda, energia i zasoby mineralne) do kapitału naturalnego zalicza } \\
\text { się także zasoby naturalne, które nie dają się łatwo wycenić, np. } \\
\text { bioróżnorodność czy też ekosystem, który jest dostarczycielem } \\
\text { ekologicznych usług, takich jak np. filtrowanie wody i powietrza. }\end{array}$ \\
\hline Kapitał ludzki & $\begin{array}{l}\text { Kapitał ludzki to zdrowie, dobrobyt i potencjał produkcyjny } \\
\text { poszczególnych ludzi. Jego elementami są np. zdrowie fizyczne } \\
\text { i psychiczne człowieka, wykształcenie, motywacja i umiejętności. }\end{array}$ \\
$\begin{array}{l}\text { Elementy te nie tylko przyczyniają się do budowy szczęśliwego, } \\
\text { zdrowego społeczeństwa, lecz także - poprzez dostarczenie } \\
\text { produktywnej siły roboczej - stwarzają możliwości dla rozwoju } \\
\text { gospodarczego. }\end{array}$ \\
$\begin{array}{l}\text { Kapitał społeczny jest to system sieci i związków opartych na } \\
\text { zaufaniu oraz na formalnych i nieformalnych zasadach, które } \\
\text { umożliwiają jednostkom lub grupom dostęp do zasobów. Podobnie } \\
\text { jak kapitał ludzki, kapitał społeczny odnosi się do społecznego } \\
\text { dobrobytu, lecz bierze pod uwagę całe społeczności, a nie indywi- } \\
\text { dualnych ludzi. Kapitał społeczny odnosi się do tych zasobów } \\
\text { społecznego zaufania, norm i relacji, z których ludzie mogą korzy- } \\
\text { stać, by rozwiązywać wspólne problemy i tworzyć spójność } \\
\text { społeczną. Przykładowe elementy tego kapitału to stowarzyszenia } \\
\text { sąsiedzkie i obywatelskie oraz spółdzielnie. Polityczne i prawne } \\
\text { struktury, które sprzyjają politycznej stabilności, demokracji, } \\
\text { wydajnemu zarządzaniu, a także sprawiedliwości społecznej, są też } \\
\text { częścią kapitału społecznego. }\end{array}$ \\
\hline sołeczny
\end{tabular}

Źródło: Gorzelak i in. 2006. 
W ramach każdego z tych kapitałów wyznaczono po kilka zmiennych (łącznie 14). Wybór wskaźników uwzględnia rożne aspekty rozwoju, ale jest także wynikiem ograniczenia dostępności danych dotyczących polskich podregionów. Do określenia poziomu rozwoju społeczno-gospodarczego zastosowano metodę miernika rozwoju Z. Hellwiga. Jest to jedna $\mathrm{z}$ powszechnie stosowanych metod taksonomicznych, jej miarę agregatową oblicza się jako syntetyczny wskaźnik odległości danego obiektu od teoretycznego wzorca rozwoju, który stanowi hipotetyczna jednostka o najlepszych zaobserwowanych wartościach zmiennych.

W pierwszym etapie algorytmu postępowania wyeliminowano zmienne quasi-stałe, a następnie zbadano siłę związku między pozostałymi zmiennymi. Ostatecznie do oceny poziomu rozwoju społeczno-gospodarczego podregionów biorących udział w badaniu wykorzystano zbiór 12 zmiennych (tab. 18).

Tabela 18

Miary rozwoju podregionów - operacjonalizacja

\begin{tabular}{|l|l|}
\hline \multicolumn{1}{|c|}{ Kategoria } & \multicolumn{1}{c|}{ Zmienne } \\
\hline Klasyczne & - dochody budżetów gmin i miast na prawach powiatu na 1 \\
& mieszkańca \\
& - miesięczne wynagrodzenie brutto \\
& - odsetek osób pracujących w usługach \\
& - stopa bezrobocia \\
\hline Kapitał fizyczny & - przeciętna powierzchnia użytkowa mieszkania \\
& - odsetek mieszkańców korzystających z sieci kanalizacyjnej \\
\hline Kapitał ludzki & - liczba praktyk lekarskich na 1000 ludności \\
& - zgony niemowląt na 1000 urodzeń żywych \\
& - odsetek osób z wykształceniem wyższym \\
& - udział osób w gospodarstwach domowych korzystających ze \\
& środowiskowej pomocy społecznej w ludności ogółem \\
\hline Kapitał społeczny & - liczba wniosków o dofinansowanie na 10 tys. ludności \\
\hline Ekonomia szczęścia & - migracja netto \\
\hline
\end{tabular}

Źródło: oprac. własne.

Miernik taksonomiczny di przyjmuje wartości z przedziału $(0,1)$. Im bardziej wartości cech danego podregionu zbliżone są do wzorca, tym poziom jego rozwoju jest wyższy. Do klasyfikacji podregionów według poziomu rozwoju wykorzystano dwa parametry miernika taksonomicznego, tj. średnią arytmetyczną i odchylenie standardowe. Na tej podstawie wyodrębniono następujące grupy podregionów:

- grupa 1 - o najwyższym poziomie rozwoju,

- grupa 2 - o bardzo wysokim poziomie rozwoju,

- grupa 3 - o wysokim poziomie rozwoju,

- grupa 4 - o średnim poziomie rozwoju, 
- grupa 5 - o niskim poziomie rozwoju,

- grupa 6 - o bardzo niskim poziomie rozwoju (ryc. 78).

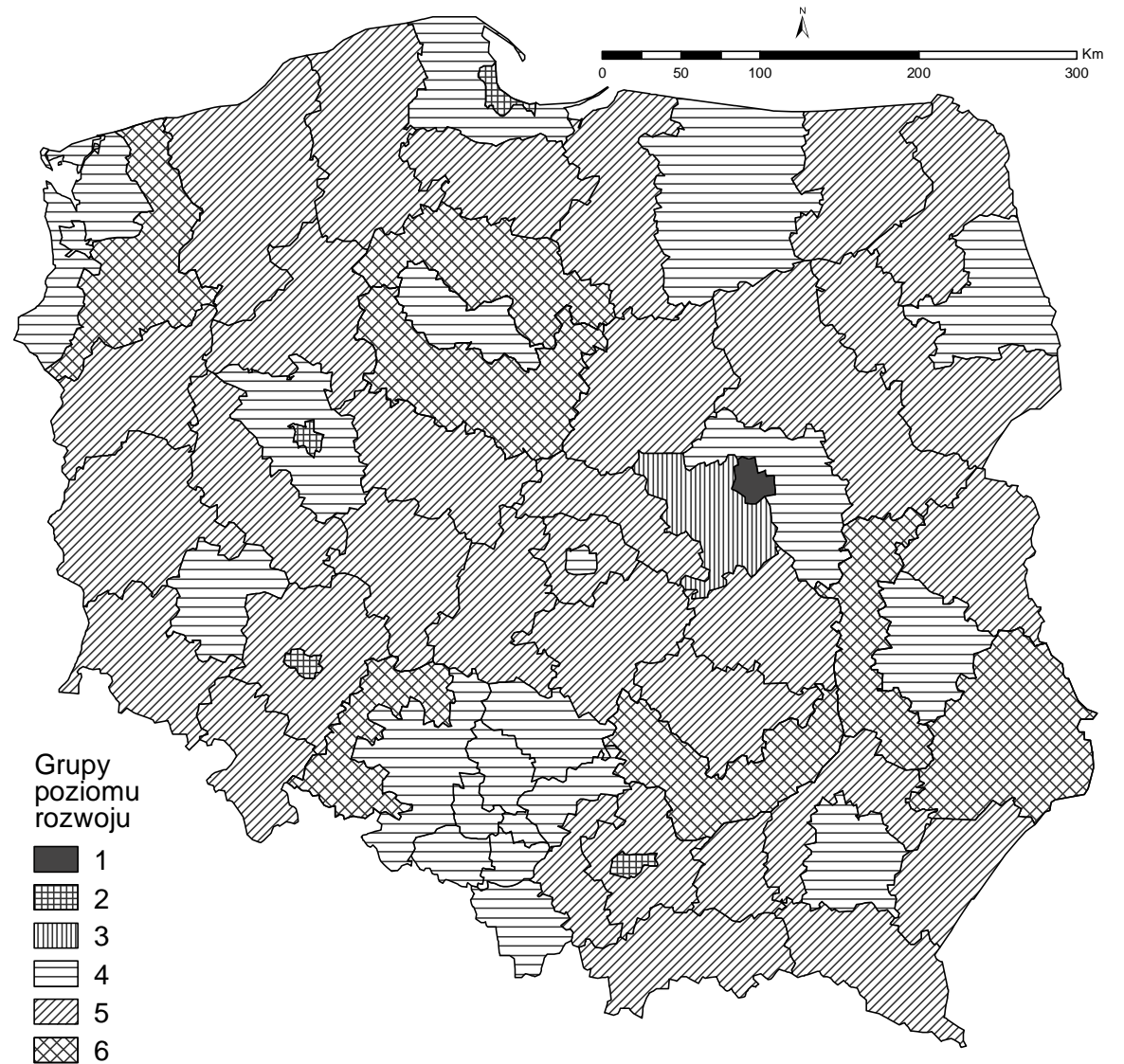

Ryc. 78. Poziom rozwoju społeczno-gospodarczego w 2011 r. według podregionów Źródło: oprac. własne na podstawie Banku Danych Lokalnych, GUS, Warszawa

Do pierwszej grupy zakwalifikowano tylko jeden podregion - Warszawę. Jest wiele czynników, które decydują o wysokiej pozycji tego miasta w rankingu ze względu na poziom rozwoju społeczno-gospodarczego. Jednym z istotniejszych jest funkcja stołeczna pełniona przez miasto, która implikuje rozwój wielu dziedzin życia społecznego i gospodarczego. Miasto osiąga więc „najlepsze” wartości mierników w zakresie cech ekonomicznych (najwyższe dochody budżetowe i zarobki brutto, najniższa stopa bezrobocia) oraz kapitału ludzkiego (np. najwyższy odsetek mieszkańców z wykształceniem wyższym). Drugą (o bardzo wysokim poziomie) i trzecią (o wysokim poziomie) grupę stanowią metropolie, duże miasta i obszary wokół nich (Wrocław, Kraków, Trójmiasto, Poznań i podregion warszawski zachodni). Podregionami, które znajdują się na średnim poziomie rozwoju 
są jednostki położone w różnych częściach kraju, duże ich skupisko występuje na Górnym Śląsku, pozostałe są rozproszone pojedynczo na terenie całego kraju. Dwie ostatnie grupy podregionów o niskim (32 podregiony) i bardzo niskim (7 podregionów) poziomie rozwoju społeczno-gospodarczego koncentrują się w Polsce południowej, wschodniej, ale też centralnej ${ }^{49}$. W zachodniej część kraju tylko jeden podregion, stargardzki, został zaklasyfikowany jako jednostka o bardzo niskim poziomie rozwoju społeczno-gospodarczego.

Przeprowadzone badania rozwoju społeczno-gospodarczego kraju przez Paryska i Mierzejewską (2009) dla dwóch okresów czasowych, tj. 1999 i 2006 r. w układzie województw, potwierdziły pogłębiającą się polaryzację w zakresie rozwoju gospodarczego, w tym także polaryzację przestrzenną. W przypadku cech społecznych, które opisują rozwój społeczny mamy do czynienia z postępującą depolaryzacją czy konwergencją

Różnice poziomu rozwoju społeczno-gospodarczego podregionów są zjawiskiem nieuniknionym, zakorzenionym w procesach długiego trwania. Na podstawie przeprowadzonej analizy poziomu rozwoju podregionów można stwierdzić, że jego obraz przestrzenny jest zróżnicowany. Pomimo korzystania ze środków polityki spójności różnice w tym zakresie utrzymują się, aczkolwiek widać inwestycje czynione w kapitał ludzki (Podsumowanie Krajowego Raportu... 2012). Poczyniona próba syntetycznego określenia poziomu rozwoju społeczno-gospodarczego kraju wskazała na dwie tendencje $w$ ramach tego zjawiska. Jedną $\mathrm{z}$ nich jest przestrzenna polaryzacja rozwoju we współczesnej gospodarce, która następuje przede wszystkim między wielkimi miastami o cechach metropolitalnych a obszarami peryferyjnymi. Potwierdzają to też inne najnowsze badania - np. Wójcik, Herbst (2012) czy Podsumowanie Krajowego Raportu o Rozwoju Społecznym (2012). Według Gorzelaka (2002) koncentracja rozwoju w obszarach metropolitalnych stanowi współczesną wersję tradycyjnego procesu różnicowania się wsi i miasta. Ponieważ następuje zwiększanie się mobilności kapitału (zarówno ludzkiego, jak i fizycznego) i narastanie konkurencji w globalnej gospodarce, to mniejsze miasta nie są w stanie pełnić funkcji centrów rozwojowych dla otaczających je terytoriów. Potencjał gospodarczy metropolii i jego konkurencyjność wpływają w coraz większym stopniu na rozwój gospodarczy całego regionu. Wiąże się to z rozrostem obszarów metropolitalnych, rozumianych jako obszary powiązane funkcjonalnie z miastem centralnym, co wpływa korzystnie na zamożność tych obszarów.

49 Większość obszarów o najniższym LHDI znajduje się na terenie dawnego zaboru rosyjskiego. W południowo-wschodniej Polsce LHDI ma nieco wyższe wartości ze względu na stan zdrowia ludności, który jest tam lepszy niż w centralnej części Polski (Podsumowanie Krajowego Raportu... 2012). 
Jednocześnie jednak tereny położone poza zasięgiem dobroczynnego oddziaływania metropolii doświadczają „wymywania” wartościowych zasobów, co skutkuje powstawaniem i utrwalaniem się „pierścieni biedy” wokół obszarów metropolitalnych (Smętkowski 2001).

Drugi wniosek wypływający z poczynionej próby określenia poziomu rozwoju społeczno-gospodarczego dotyczy podziału przestrzeni kraju na część wschodnią i zachodnią. Autorka uważa, że poglądy te należałoby nieco zweryfikować. Nie ulega wątpliwości, że pod względem uwarunkowań gospodarczych podział ten utrzymuje się nadal, ale w przypadku czynników społecznych dochodzi do przemian. Mowa tu o kapitale ludzkim i o inwestycjach z nim związanych. Nie jest to odosobniony pogląd, na poprawę sytuacji w kwestii potencjału kapitału ludzkiego wskazują też bowiem autorzy Krajowego Raportu o Rozwoju Społecznym (2012).

\subsection{Typy zachowań demograficznych}

Zaobserwowane dysproporcje przestrzenne zachowań matrymonialnych i prokreacyjnych (pisano o tym w rozdziałach 3 i 4) skłoniły autorkę do wyznaczenia grup podregionów o podobnych wartościach badanych zjawisk w 2011 r. Interesujące z poznawczego punktu widzenia będzie także stwierdzenie, czy uzyskany obraz zróżnicowania będzie zbliżony do rozkładu przestrzennego innych zjawisk demograficznych i społeczno-gospodarczych.

$\mathrm{W}$ analizie wykorzystano jedną z metod analizy skupień, a mianowicie metodę aglomeracji Warda 50 . Analiza skupień jest narzędziem do eksploracyjnej analizy danych, której celem jest ułożenie obiektów w grupy w taki sposób, aby stopień powiązania obiektów z obiektami należącymi do tej samej grupy był jak największy, a z obiektami z pozostałych grup jak najmniejszy. Metoda Warda dąży do uzyskania raczej małych skupień i jest uznawana za bardzo efektywną.

W doborze zmiennych do procedury grupowania zastosowano kryteria zarówno merytoryczne, jak i formalno-statystyczne. Kryterium merytoryczne pozwoliło na dobór zmiennych istotnych z punktu widzenia analizowanych zjawisk, wyczerpanie zakresu zjawisk, logiczność wzajemnych powiązań oraz zachowanie proporcjonalności reprezentacji zjawisk cząstkowych. W przypadku kryteriów formalnych istotna okazała się dostępność danych statystycznych dotyczących podregionów. Jak wspomniano we wstępie, napotkano trudności w pozyskaniu informacji o podregionach, niemniej jednak zgromadzone dane prezentują w sposób istotny zjawisko małżeńskości i rozrodczości. W przypadku kryterium statystycznego

50 Przeprowadzono także procedurę grupowania metodą $k$-średnich, uzyskany obraz zróżnicowania przestrzennego zachowań demograficznych okazał się bardzo podobny. 
uwzględniono zdolność dyskryminacyjną zmiennych, czyli ich zmienność względem badanych obiektów, pojemność (potencjał) informacyjną zmiennych, czyli stopień ich skorelowania z innymi zmiennymi oraz stopień trudności w osiąganiu przez zmienne wysokich wartości (Nowak 1977; Grabowski i in. 1982).

Ostatecznie grupując podregiony ze względu na zachowania matrymonialne i prokreacyjne wzięto pod uwagę 11 zmiennych (tab. 19). Cztery z nich mają charakter destymulant - cechy te ujednolicono do postaci stymulant. Wszystkie cechy, poza cechą 4 (wartości tej cechy poddano normalizacji), wykazują rozkład normalny bądź zbliżony do normalnego. Wartości cech zostały zestandaryzowane przed rozpoczęciem procedury typologicznej. W metodzie Warda do wyróżnienia skupień wykorzystywana jest analiza wariancji oszacowanych odległości (stosowana jest odległość euklidesowa). Metoda ta jest bardzo często używana w badaniach, w których wykorzystywane są cechy ilościowe, a skonstruowany dendrogram daje również możliwość analizy kolejności przyłączania poszczególnych elementów do wyróżnionych skupień (Suchecki 2010). Liczbę skupień (4) ustalono na podstawie analizy odległości wiązań - ryc. 79, 80. Efektem przeprowadzonej procedury grupowania są cztery grupy - typy 51.

Tabela 19

Rodzaj zmiennych

\begin{tabular}{|l|l|l|}
\hline $\begin{array}{c}\text { Numer } \\
\text { zmiennej }\end{array}$ & \multicolumn{1}{|c|}{ Zmienne } & $\begin{array}{c}\text { Rodzaj zmien- } \\
\text { nej }\end{array}$ \\
\hline 1 & $\begin{array}{l}\text { Współczynnik małżeństw na 1000 ludności w wieku 15 lat } \\
\text { i więcej }\end{array}$ & stymulanta \\
\hline 2 & Odsetek małżeństw wyznaniowych & stymulanta \\
\hline 3 & $\begin{array}{l}\text { Współczynnik rozwodów na 1000 ludności w wieku 20 lat } \\
\text { i więcej }\end{array}$ & destymulanta \\
\hline 4 & Separacje na 100 tys. ludności w wieku 20 lat i więcej & destymulanta \\
\hline 5 & Współczynnik płodności kobiet w wieku 20-24 lata & stymulanta \\
\hline 6 & Współczynnik płodności kobiet w wieku 25-29 lat & stymulanta \\
\hline 7 & Współczynnik płodności kobiet w wieku 30-34 lata & stymulanta \\
\hline 8 & Kolejność urodzenia dziecka -4 i dalsze & stymulanta \\
\hline 9 & Udział urodzeń pozamałżeńskich & stymulanta \\
\hline 10 & Odsetek mężczyzn kohabitujących & destymulanta \\
\hline 11 & Nowożeńcy o stanie cywilnym rozwiedziona/rozwiedziony & destymulanta \\
\hline
\end{tabular}

Źródło: oprac. własne.

${ }^{51}$ Typ oznacza określoną własność lub zespół własności, jakimi powinny charakteryzować się obiekty, by można je było uznać za odmienne w stosunku do innych (Runge 2006). 


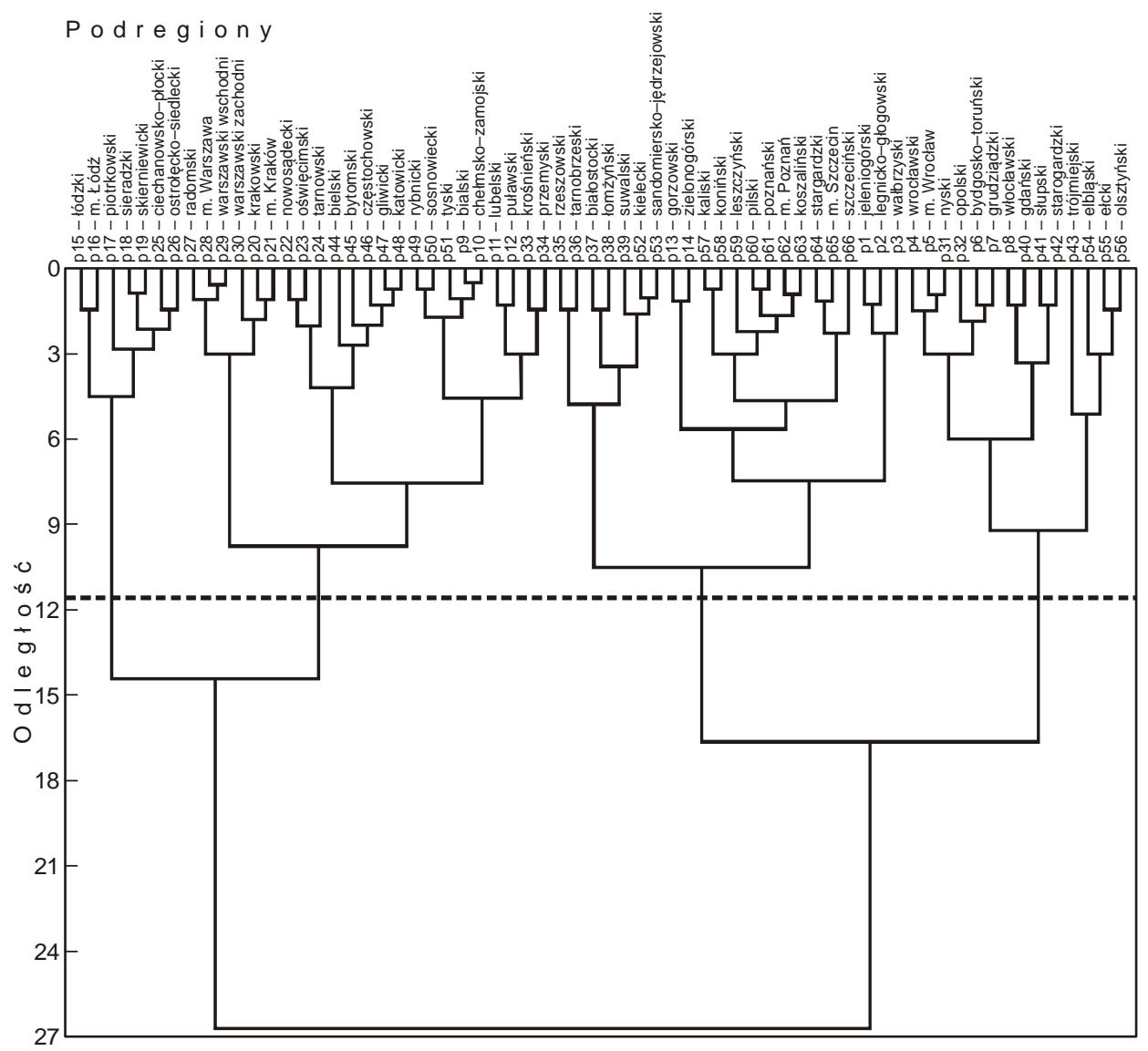

Ryc. 79. Dendrogram grupowania podregionów metodą Warda Źródło: oprac. własne

Typ 1 jest reprezentowany przez siedem podregionów, są to największe miasta Polski: Warszawa, Kraków, Łódź, Poznań, Wrocław, Szczecin i Trójmiasto. Podregiony wchodzące w skład tego typu charakteryzują się kilkoma istotnymi cechami typologicznymi. Przede wszystkim są to wysokie wartości współczynnika rozwodów, wysoki udział osób rozwiedzionych, bardzo niska płodność kobiet w wieku 20-24 lata (nastąpiło przesunięcie największej płodności do grupy 30-34 lata), niski odsetek urodzeń czwartych i dalszych ${ }^{52}$ oraz bardzo wysoki odsetek mężczyzn będących w związ-

${ }^{52} \mathrm{~W}$ rozdz. 4 analiza kolejności urodzenia objęła urodzenia trzecie i dalsze, ponieważ w Polsce za rodziny wielodzietne uważa się rodziny posiadające, co najmniej troje dzieci (art. 3 pkt. 16a Ustawy z dnia 28 listopada 2003 r. o świadczeniach rodzinnych). Przy doborze cech diagnostycznych do wyznaczenia typów zachowań demograficznych autorka celowo wzięła pod uwagę urodzenia czwarte i dalsze. 
kach nieformalnych (ryc. 81). Zachowania demograficzne reprezentowane przez mieszkańców podregionów z typu 1 są najbardziej zbliżone do zachowań obserwowanych w krajach północno- i zachodnioeuropejskich.

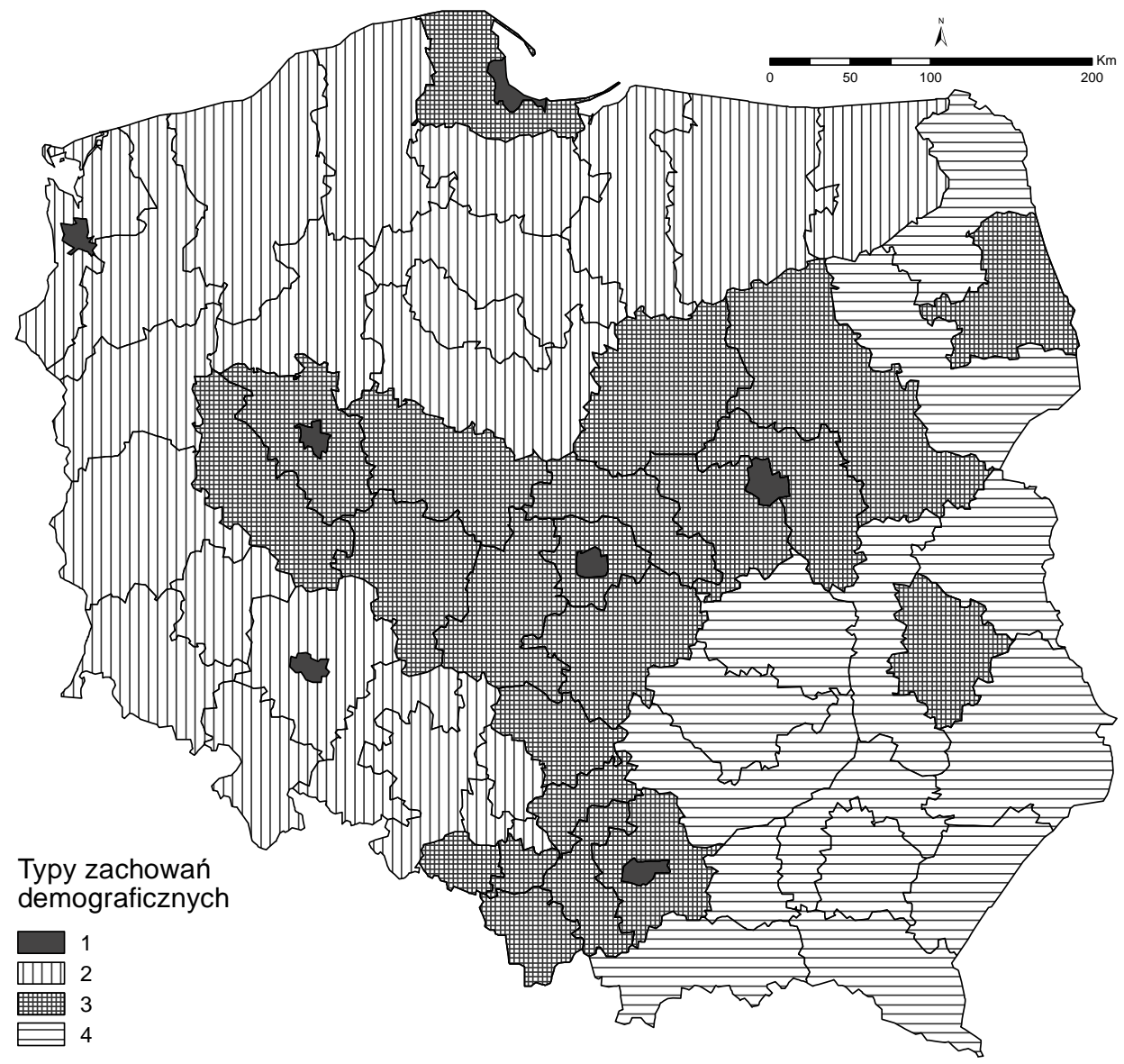

Ryc. 80. Typy zachowań demograficznych dla podregionów Źródło: oprac. na podstawie Banku Danych Lokalnych, GUS, Warszawa

Typ 2 obejmuje podregiony położone w Polsce południowo-zachodniej, zachodniej i północnej, w jego skład wchodzą 23 jednostki. Typ ten charakteryzuje się wysokimi wartościami współczynnika rozwodów, ale przede wszystkim występują tu najniższe wartości współczynnika separacji. W sferze zachowań prokreacyjnych jednostki typu 2 odznaczają się największymi odsetkami urodzeń pozamałżeńskich, występuje tu także stosunkowo wysoka w skali kraju płodność kobiet w wieku 20-24 lata (nie znaczy to, że są to najwyższe wartości współczynnika płodności $\mathrm{w}$ tych podregionach) oraz niska wśród kobiet z przedziału 30-34 lata. 
Typ 3 złożony jest z 22 podregionów przede wszystkim z Polski centralnej (12 jednostek), południowej (7 jednostek) oraz dwóch podregionów położonych we wschodniej części kraju (białostocki i lubelski) i jednego na północy (gdański). Jest to typ przejściowy pomiędzy typami 2 i 4, co oznacza, że w większości zmiennych ich wartości są zbliżone do średnich w kraju. Jedyne cechy je wyróżniające to nieco wyższe wartości współczynnika separacji i płodności kobiet w wieku 25-29 lat.

Typ 4 reprezentują podregiony wschodniej i południowo-wschodniej części kraju i w jego skład wchodzi 14 jednostek. Jest to typ o najbardziej tradycyjnych formach zachowań matrymonialnych i prokreacyjnych. W sferze małżeńskości przejawia się on najwyższymi wartościami współczynnika małżeństw, odsetkami małżeństw wyznaniowych oraz niskimi wartościami współczynnika rozwodów, odsetkami kohabitujących mężczyzn i osób rozwiedzionych. Zachowania prokreacyjne wyznaczają niski odsetek urodzeń pozamałżeńskich i wysoki urodzeń czwartych i dalszych.

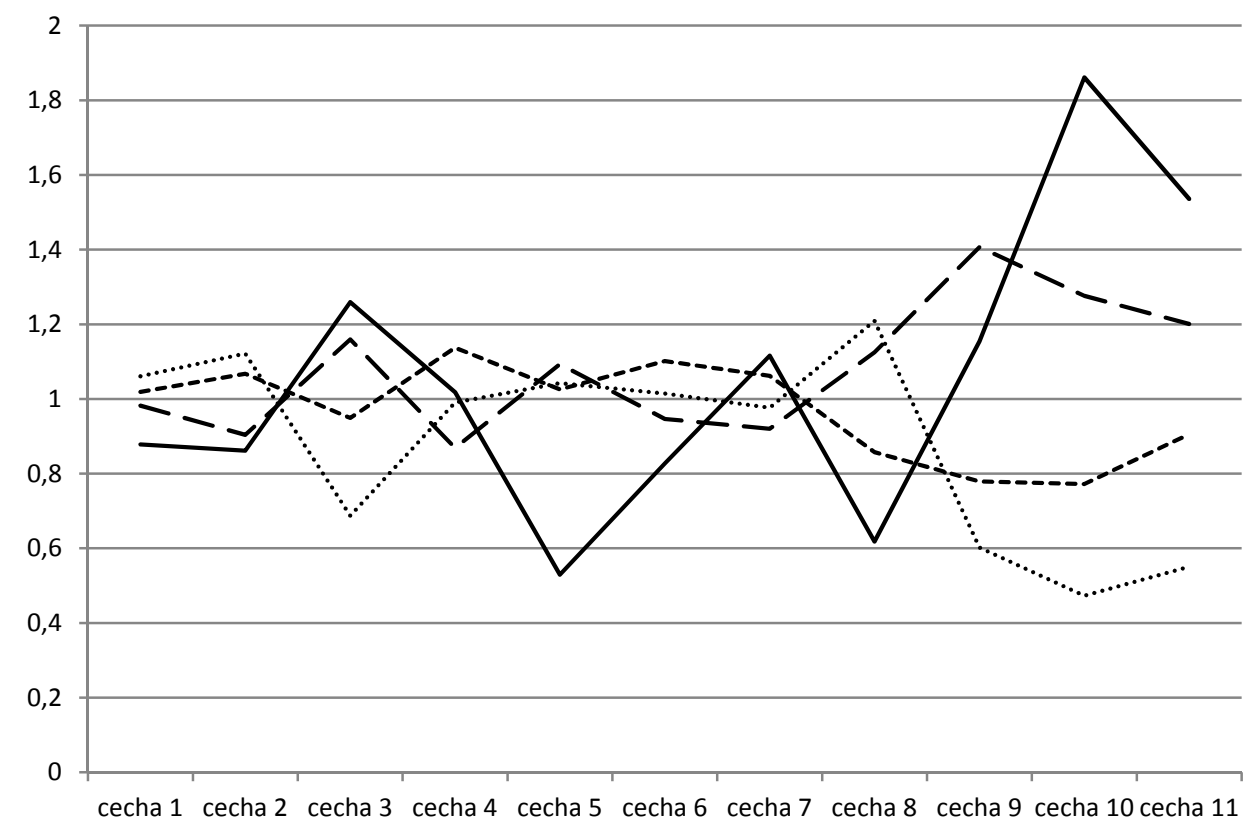

cecha 1 cecha 2 cecha 3 cecha 4 cecha 5 cecha 6 cecha 7 cecha 8 cecha 9 cecha 10 cecha 11

$\longrightarrow \operatorname{typ} 1-\longrightarrow \operatorname{typ} 2 \quad-\cdots \cdot-\operatorname{typ} 3 \quad \cdots \cdots \cdots \cdot \operatorname{typ} 4$

Ryc. 81. Model średnich arytmetycznych dla wyróżnionych typów przestrzennych Źródło: oprac. na podstawie Banku Danych Lokalnych, GUS, Warszawa 
Do oceny wpływu cech demograficznych i społeczno-ekonomicznych na wybrane parametry rodności i małżeńskości ${ }^{33} \mathrm{w}$ podregionach wykorzystano analizę regresji wielorakiej (konstruowano klasyczne modele regresji liniowej wykorzystujące dopasowanie zgodnie $\mathrm{z}$ metodą najmniejszych kwadratów). W pierwszym etapie budowania modelu regresyjnego, za każdym razem badano wpływ dwóch grup cech objaśniających (grupę siedmiu cech demograficznych oraz ośmiu cech społeczno-ekonomicznych).

Do cech objaśniających o charakterze demograficznym zaliczono: przyrost naturalny, saldo migracji, odsetek ludności w wieku przedprodukcyjnym, produkcyjnym, poprodukcyjnym oraz trwanie życia mężczyzn i kobiet. W grupie cech społeczno-ekonomicznych znalazły się następujące uwarunkowania społeczne: średnie wyniki egzaminów gimnazjalnych z części humanistycznej, matematyczno-przyrodniczej, z języka angielskiego, odsetek ludności z wykształceniem wyższym, odsetek ludności z wykształceniem z podstawowym oraz frekwencja wyborcza do Parlamentu z 2011 r. W tej samej grupie cech jako uwarunkowania ekonomiczne uwzględniono PKB per capita oraz odsetek ludności pracującej w rolnictwie.

Siłę związku liniowego zmierzono za pomocą współczynnika determinacji wielorakiej R2 (ze wzglądu na jednakową liczbę cech objaśniających zrezygnowano z jego postaci skorygowanej). Ponadto obliczono wartości F Snedecora, które pozwala na ocenę istotności uzyskanego modelu regresji (tab. 20, 21).

\section{Wnioski:}

- zauważyć można bardzo słaby i nieistotny statystyczne wpływ cech demograficznych i społeczno-ekonomicznych na wskaźnik separacji,

- pozostałe wartości wskaźników determinacji zaliczyć należy do raczej wysokich i bardzo wysokich, co świadczy o dużej sile wyjaśniającej skonstruowanych modeli regresji wielorakiej, a co za tym idzie, o znacznym wpływie przedstawionych w tym rozdziale cech objaśniających na wybrane parametry rodności i małżeńskości w układzie podregionów.

- spotkaną w literaturze tezę o większym znaczeniu zmiennych o charakterze społeczno-ekonomicznym na zachowania demograficzne (rozrodczość i małżeńskość) w Polsce można potwierdzić tylko częściowo. W przypadku czterech cech zanotowano bowiem nieco większą siłę wyjaśniającą modeli demograficznych (nieznacznie wyższe wskaźniki determinacji) w porównaniu z odpowiadającymi im modelami społeczno-ekonomicznymi, są to współczynniki płodności kobiet w wieku 20-24, 25-29, 30-34 oraz kolejność urodzenia dziecka 4 i dalsze.

53 Dobór cech opisujących rozrodczość i małżeńskość, które wykorzystano w procedurze typologicznej zachowań demograficznych, opisano w podrozdziale 5.3. 
Tabela 20

Parametry regresji wielorakiej cech demograficznych na zmienne objaśniane

\begin{tabular}{|l|l|c|c|c|}
\hline \multirow{2}{*}{$\mathrm{Nr}$} & \multicolumn{1}{|c|}{ Zmienne objaśniane } & \multicolumn{2}{|c|}{$\begin{array}{c}\text { Siła } \\
\text { związku } \\
\end{array}$} & \multicolumn{2}{|c|}{$\begin{array}{c}\text { Istotność modelu } \\
\text { Regresji }\end{array}$} \\
\cline { 4 - 5 } & & $\mathrm{F}$ & $\mathrm{p}$ \\
\hline 1 & $\begin{array}{l}\text { Współczynnik małżeństw na 1000 ludności w wieku } \\
\text { 15 lat i więcej }\end{array}$ & 0,712 & 24,3 & 0,000 \\
\hline 2 & Odsetek małżeństw wyznaniowych & 0,573 & 13,2 & 0,000 \\
\hline 3 & $\begin{array}{l}\text { Współczynnik rozwodów na 1000 ludności w wieku } \\
\text { 20 lat i więcej }\end{array}$ & 0,510 & 10,2 & 0,000 \\
\hline 4 & $\begin{array}{l}\text { Separacje na 100 tys. ludności w wieku 20 lat i } \\
\text { więcej }\end{array}$ & 0,094 & 1,0 & 0,418 \\
\hline 5 & Współczynnik płodności kobiet w wieku 20-24 lata & 0,884 & 74,7 & 0,000 \\
\hline 6 & Współczynnik płodności kobiet w wieku 25-29 lat & 0,766 & 32,2 & 0,000 \\
\hline 7 & Współczynnik płodności kobiet w wieku 30-34 lata & 0,820 & 44,8 & 0,000 \\
\hline 8 & Kolejność urodzenia dziecka - czwarte i dalsze & 0,782 & 35,4 & 0,000 \\
\hline 9 & Udział urodzeń pozamałżeńskich & 0,556 & 13,3 & 0,000 \\
\hline 10 & Odsetek mężczyzn kohabitujących & 0,595 & 14,4 & 0,000 \\
\hline 11 & $\begin{array}{l}\text { Nowożeńcy o stanie cywilnym rozwiedzio- } \\
\text { na/rozwiedziony }\end{array}$ & 0,724 & 25,8 & 0,000 \\
\hline
\end{tabular}

Źródło: oprac. własne.

Tabela 21

Parametry regresji wielorakiej cech społeczno-ekonomicznych na zmienne objaśniane

\begin{tabular}{|l|l|c|c|c|}
\hline \multirow{2}{*}{$\mathrm{Nr}$} & \multicolumn{1}{|c|}{ Zmienne objaśniane } & \multicolumn{2}{|c|}{$\begin{array}{c}\text { Siła } \\
\text { związku } \\
\end{array}$} & \multicolumn{2}{|c|}{$\begin{array}{c}\text { Istotność modelu } \\
\text { regresji }\end{array}$} \\
\cline { 4 - 5 } & & $\mathrm{F}$ & $\mathrm{p}$ \\
\hline 1 & $\begin{array}{l}\text { Współczynnik małżeństw na 1000 ludności w wieku } \\
\text { 15 lat i więcej }\end{array}$ & 0,738 & 20,1 & 0,000 \\
\hline 2 & Odsetek małżeństw wyznaniowych & 0,759 & 22,4 & 0,000 \\
\hline 3 & $\begin{array}{l}\text { Współczynnik rozwodów na 1000 ludności w wieku } \\
\text { 20 lat i więcej }\end{array}$ & 0,681 & 15,2 & 0,000 \\
\hline 4 & $\begin{array}{l}\text { Separacje na 100 tys. ludności w wieku 20 lat i } \\
\text { więcej }\end{array}$ & 0,199 & 1,8 & 0,103 \\
\hline 5 & Współczynnik płodności kobiet w wieku 20-24 lata & 0,873 & 49,1 & 0,000 \\
\hline 6 & Współczynnik płodności kobiet w wieku 25-29 lat & 0,692 & 16,0 & 0,000 \\
\hline 7 & Współczynnik płodności kobiet w wieku 30-34 lata & 0,750 & 21,3 & 0,000 \\
\hline 8 & Kolejność urodzenia dziecka - czwarte i dalsze & 0,504 & 7,2 & 0,000 \\
\hline 9 & Udział urodzeń pozamałżeńskich & 0,763 & 23,0 & 0,000 \\
\hline 10 & Odsetek mężczyzn kohabitujących & 0,807 & 29,8 & 0,000 \\
\hline 11 & $\begin{array}{l}\text { Nowożeńcy o stanie cywilnym rozwiedzio- } \\
\text { na/rozwiedziony }\end{array}$ & 0,868 & 46,7 & 0,000 \\
\hline
\end{tabular}

Źródło: oprac. własne. 
W celu wskazania, które cechy w największym stopniu wpływają na zmienne objaśniane zbudowano model na podstawie cech mających statystycznie istotne zależności na przyjętym poziomie ufności $\alpha=0,95$. Procedura ta zakłada usuwanie $\mathrm{z}$ modelu zbudowanego ze wszystkich potencjalnych zmiennych tych spośród nich, które w danym kroku mają najmniej istotny wpływ na zmienną zależną. Postępujemy tak aż do uzyskania „najlepszego” modelu.

Przeprowadzona procedura określiła wpływ cech (skorygowany $R^{2}$ ) na zmienne objaśniane, a także kierunek tego wpływu (tab. 22, 23). Siła związku okazała się niższa, co jest wynikiem mniejszej liczby cech wpływających na zmienne. Potwierdził się bardzo słaby i nieistotny statystyczne wpływ cech demograficznych i społeczno-ekonomicznych na wskaźnik separacji. W przypadku pozostałych zmiennych dla siedmiu z nich zauważono większą moc wyjaśniającą modeli społeczno-ekonomicznych, a w pozostałych przypadkach wpływ ten jest tylko nieco niższy, a co więcej nadal na wysokim poziomie wyjaśniania. Zmiennymi, na które większy wpływ mają cechy demograficzne są płodność kobiet w wieku 25-29 lat, płodność kobiet w wieku 30-34 lata oraz kolejność urodzenia dziecka czwartego i dalszych.

Najwięcej cech demograficznych (po pięć) miało wpływ na dwie zmienne, tj. współczynnik płodności kobiet w wieku 30-34 lata oraz kolejność urodzenia dziecka czwartego i dalszych, a współczynnik zawierania małżeństw na 1000 ludności w wieku 15 lat i więcej był objaśniany tylko przez dwie cechy. W modelu cech społeczno-ekonomicznych sytuacja wyglądała nieco odmiennie, bowiem na współczynnik zawierania małżeństw na 1000 ludności w wieku 15 lat i więcej miało wpływ aż siedem cech, a kolejność urodzenia dziecka czwartego i dalszych była objaśniana tylko przez dwie cechy.

Tabela 22

Parametry regresji wielorakiej cech demograficznych na zmienne objaśniane - modele dopasowane

\begin{tabular}{|c|c|c|c|c|c|c|}
\hline \multirow{2}{*}{$\mathrm{Nr}$} & \multirow{2}{*}{ Zmienne objaśniane } & \multicolumn{2}{|c|}{ Model dopasowany } & \multirow{2}{*}{$\begin{array}{c}\text { Siła } \\
\text { związku } \\
\text { skorygo- } \\
\text { wany } R^{2}\end{array}$} & \multicolumn{2}{|c|}{$\begin{array}{l}\text { Istotność modelu } \\
\text { regresji }\end{array}$} \\
\hline & & $\begin{array}{l}\text { liczba } \\
\text { cech }\end{array}$ & $\begin{array}{l}\text { numery } \\
\text { cech }\end{array}$ & & $F$ & $p$ \\
\hline 1 & 2 & 3 & 4 & 5 & 6 & 7 \\
\hline 1 & $\begin{array}{l}\text { Współczynnik małżeństw na } \\
1000 \text { ludności w wieku } 15 \text { lat i } \\
\text { więcej }\end{array}$ & 2 & $-2 ; 3$ & 0,656 & 62,8 & 0,000 \\
\hline 2 & $\begin{array}{l}\text { Odsetek małżeństw wyznanio- } \\
\text { wych }\end{array}$ & 4 & $-1 ; 3 ; 5 ; 7 ;$ & 0,542 & 20,2 & 0,000 \\
\hline 3 & $\begin{array}{l}\text { Współczynnik rozwodów na } \\
1000 \text { ludności w wieku } 20 \text { lat i } \\
\text { więcej }\end{array}$ & 4 & $1 ; 3 ;-5 ;-7 ;$ & 0,457 & 14,7 & 0,000 \\
\hline
\end{tabular}


Tabela 22 c. d.

\begin{tabular}{|c|c|c|c|c|c|c|}
\hline 1 & 2 & 3 & 4 & 5 & 6 & 7 \\
\hline 4 & $\begin{array}{l}\text { Separacje na } 100 \text { tys. ludności } \\
\text { w wieku } 20 \text { lat i więcej }\end{array}$ & 3 & $1 ;-2 ; 5$ & 0,043 & 1,98 & 0,125 \\
\hline 5 & $\begin{array}{l}\text { Współczynnik płodności kobiet } \\
\text { w wieku 20-24 lata }\end{array}$ & 4 & $\begin{array}{r}-1 ;-4 ;-5 \\
-7 ;\end{array}$ & 0,810 & 70,5 & 0,000 \\
\hline 6 & $\begin{array}{l}\text { Współczynnik płodności kobiet } \\
\text { w wieku 25-29 lat }\end{array}$ & 4 & $1 ; 3 ; 5 ;-6$; & 0,739 & 47,1 & 0,000 \\
\hline 7 & $\begin{array}{l}\text { Współczynnik płodności kobiet } \\
\text { w wieku 30-34 lata }\end{array}$ & 5 & $\begin{array}{r}1 ; 2 ;-4 ; 5 ; \\
-6 ; \\
\end{array}$ & 0,802 & 53,6 & 0,000 \\
\hline 8 & $\begin{array}{l}\text { Kolejność urodzenia dziecka - } \\
4 \text { i dalsze }\end{array}$ & 5 & $\begin{array}{r}-1 ;-2 ; 3 ; 4 ; \\
6 ;\end{array}$ & 0,762 & 42,7 & 0,000 \\
\hline 9 & $\begin{array}{l}\text { Udział urodzeń pozamałżeń- } \\
\text { skich }\end{array}$ & 3 & $4 ; 5 ;-7$ & 0,527 & 25,2 & 0,000 \\
\hline 10 & $\begin{array}{l}\text { Odsetek mężczyzn } \\
\text { kohabitujących }\end{array}$ & 3 & $1 ;-3 ; 7$ & 0,544 & 26,9 & 0,000 \\
\hline 11 & $\begin{array}{l}\text { Nowożeńcy o stanie cywilnym } \\
\text { rozwiedziona/rozwiedziony }\end{array}$ & 4 & $1 ; 2 ;-3 ;-7$ & 0,699 & 38,7 & 0,000 \\
\hline
\end{tabular}

Uwaga: a - numery cech demograficznych: 1 - przyrost naturalny; 2 - saldo migracji; 3 odsetek ludności w wieku przedprodukcyjnym, 4 - odsetek ludności w wieku produkcyjnym; 5 - odsetek ludności w wieku poprodukcyjnym; 6 - trwanie życia mężczyzn; 7 - trwanie życia kobiet; minus wskazuje na ujemny kierunek oddziaływania danej cechy.

Źródło: oprac. własne.

Tabela 23

Parametry regresji wielorakiej cech społeczno-ekonomicznych na zmienne objaśniane - modele dopasowane

\begin{tabular}{|c|c|c|c|c|c|c|}
\hline \multirow{2}{*}{$\mathrm{Nr}$} & \multirow{2}{*}{ Zmienne objaśniane } & \multicolumn{2}{|c|}{ Model dopasowany } & \multirow{2}{*}{$\begin{array}{l}\text { Siła } \\
\text { związku } \\
\text { skorygo- } \\
\text { wany } R^{2}\end{array}$} & \multicolumn{2}{|c|}{$\begin{array}{l}\text { Istotność modelu } \\
\text { regresji }\end{array}$} \\
\hline & & $\begin{array}{l}\text { liczba } \\
\text { cech }\end{array}$ & $\begin{array}{l}\text { numery } \\
\text { cech }\end{array}$ & & $F$ & $P$ \\
\hline 1 & 2 & 3 & 4 & 5 & 6 & 7 \\
\hline 1 & $\begin{array}{l}\text { Współczynnik małżeństw na } \\
1000 \text { ludności w wieku } 15 \text { lat i } \\
\text { więcej }\end{array}$ & 7 & $\begin{array}{r}1 ; 2 ; 4 ;-5 ; \\
-6 ;-7 ; 8 ;\end{array}$ & 0,689 & 21,6 & 0,000 \\
\hline 2 & $\begin{array}{l}\text { Odsetek małżeństw wyznanio- } \\
\text { wych }\end{array}$ & 4 & $2 ; 4 ;-5 ; 8$ & 0,712 & 41,1 & 0,000 \\
\hline 3 & $\begin{array}{l}\text { Współczynnik rozwodów na } \\
1000 \text { ludności w wieku } 20 \text { lat i } \\
\text { więcej }\end{array}$ & 3 & $-2 ; 6 ; 7$ & 0,587 & 31,8 & 0,000 \\
\hline 4 & $\begin{array}{l}\text { Separacje na } 100 \text { tys. ludności } \\
\text { w wieku } 20 \text { lat i więcej }\end{array}$ & 3 & $-2 ; 4 ;-6$ & 0,133 & 4,3 & 0,008 \\
\hline 5 & $\begin{array}{l}\text { Współczynnik płodności kobiet } \\
\text { w wieku 20-24 lata }\end{array}$ & 5 & $\begin{array}{r}1 ;-3 ;-5 ; \\
-6 ; 8 ; \\
\end{array}$ & 0,852 & 75,6 & 0,000 \\
\hline 6 & $\begin{array}{l}\text { Współczynnik płodności kobiet } \\
\text { w wieku 25-29 lat }\end{array}$ & 6 & $\begin{array}{r}1 ; 4 ;-5 ;-6 ; \\
7 ; 8 ; \\
\end{array}$ & 0,648 & 20,9 & 0,000 \\
\hline 7 & $\begin{array}{l}\text { Współczynnik płodności kobiet } \\
\text { w wieku } 30-34 \text { lata }\end{array}$ & 3 & $4 ;-5 ; 8$ & 0,699 & 51,3 & 0,000 \\
\hline
\end{tabular}


Tabela 23 c. d.

\begin{tabular}{|c|l|c|r|c|c|c|}
\hline 1 & \multicolumn{1}{|c|}{2} & 4 & 5 & 6 & 7 \\
\hline 8 & $\begin{array}{l}\text { Kolejność urodzenia dziecka - } \\
4 \text { i dalsze }\end{array}$ & 2 & $2 ;-6 ;$ & 0,460 & 28,7 & 0,000 \\
\hline 9 & $\begin{array}{l}\text { Udział urodzeń pozamałżeń- } \\
\text { skich }\end{array}$ & 4 & $\begin{array}{r}-2 ;-4 ; 6 ; \\
-8 ;\end{array}$ & 0,696 & 38,2 & 0,000 \\
\hline 10 & $\begin{array}{l}\text { Odsetek mężczyzn } \\
\text { kohabitujących }\end{array}$ & 5 & $-2 ;-4 ; 5 ; 6 ;$ & 0,758 & 52,0 & 0,000 \\
\hline 11 & $\begin{array}{l}\text { Nowożeńcy o stanie cywilnym } \\
\text { rozwiedziona/rozwiedziony }\end{array}$ & $5 ; 5 ;$ & 0,868 & 78,0 & 0,000 \\
\hline
\end{tabular}

Uwaga: ${ }^{a}$ - numery cech społeczno-ekonomicznych: 1 - średnie wyniki egzaminów gimnazjalnych z części humanistycznej; 2 - średnie wyniki egzaminów gimnazjalnych z części matematyczno-przyrodniczej; 3 - średnie wyniki egzaminów gimnazjalnych z języka angielskiego; 4 odsetek ludności z wykształceniem wyższym; 5 - odsetek ludności z wykształceniem z podstawowym; 6 - frekwencja wyborcza w wyborach do Parlamentu z 2011 r.; 7 - PKB per capita; 8 odsetek ludności pracującej w rolnictwie; minus wskazuje na ujemny kierunek oddziaływania danej cechy

Źródło: oprac. własne. 



\section{PRZEMIANY ZACHOWAŃ DEMOGRAFICZNYCH W OPINIACH MIESZKAŃCÓW - PRZYKŁAD ŁODZI}

\subsection{Uwagi wstępne}

Na zachowania demograficzne ludności wpływają różnorodne czynniki, o czym pisano w poprzednich rozdziałach pracy. W wielu opracowaniach podkreśla się znaczenie czynników świadomościowych i mentalnościowych, w tym emocji, uczuć i potrzeb jednostek jako indywidualistycznych, a nie jak do tej pory - potrzeb z punktu widzenia rodziny i jej interesu. Szczególną uwagę poświęca się kobietom, które zmieniają porządek w rodzinie i przyczyniają się do przebudowy jej struktury. Nowe podejścia teoretyczne opisują zmianę modelu kobiety na przestrzeni ostatnich stu lat, przechodzącego od modeli "dobrej żony i matki”, który funkcjonował do lat 60., przez model „superwoman” (od lat 70.) aż do modelu „invisible woman” wykreowanego w latach 90 . Ten ostatni model oznacza zacieranie się różnic płciowych i tworzenie nowych modeli socjalizacyjnych (Slany 2002b).

Cechą charakterystyczną zmian, jakie dokonują się w ramach formowania rodziny, jest osłabienie wpływu norm i wartości, które były istotne dla rodziny tradycyjnej, a straciły wyraźnie na ważności w przypadku rodziny nuklearnej. Istotnym elementem dla tych przemian jest fakt oddzielenia życia seksualnego od prokreacji, a nawet od małżeństwa.

Według Tyszki (2002) charakterystyczną cechą epoki postindustrialnej (ponowoczesnej) jest przenoszenie życia publicznego do indywidualnego i rodzinnego, autonomizacja i tendencje wolnościowe (do poszerzenia zakresu swobody). W sensie ogólnym rodzina doświadcza konsekwencji wynikających między innymi ze wzrostu zatrudnienia kobiet, które jest związane nie tylko z potrzebami ekonomicznymi, ale jest również wyznaczane dążeniami kobiet do samorealizacji na gruncie życia zawodowego i społecznego. Kolejne konsekwencje odnoszą się zmian w relacjach małżeńskich w wyniku pogłębiającego się egalitaryzmu życia małżeńskiego i rodzinnego, zmian oceny wartości dziecka, osłabienia spójności rodzin, 
autonomizacji członków rodziny oraz ogólnych zmian systemów wartości i norm obyczajowych.

Polska jest krajem, gdzie tempo przemian demograficznych jest niezwykle szybkie, zmiany te dokonują się w ciągu dekad, a nie stuleci. Mowa tu między innymi o spadku skłonności do zawierania małżeństw, depresji urodzeń, nasilaniu się rozwodów i zmianie ich przyczyn, wzroście kohabitacji, urodzeniach pozamałżeńskich i znaczeniu życia seksualnego.

Indywidualistyczne potrzeby jednostek, jak nigdy do tej pory, zaczęły oddziaływać na zachowania demograficzne, w tym matrymonialne i prokreacyjne. Czy zatem mogą one przyczynić się do kryzysu polskiej rodziny i jej rozpadu? Zdaniem Tyszki (2002) polska rodzina jest specyficznie uwarunkowana przez losy i kulturę naszego społeczeństwa i chociaż istnieją w niej elementy kryzysowe, to nie jest to totalny kryzys.

Podjęte przez autorkę niniejszego opracowania badania nad zachowaniami matrymonialnymi i prokreacyjnymi w Polsce miały na celu określenie tendencji ogólnokrajowych i regionalnych w procesie formowania i rozpadu związków małżeńskich oraz zachowań prokreacyjnych. Zgodnie z założeniami było to podejście ilościowe, które miało pokazać zmiany oraz przestrzenne zróżnicowanie tych zjawisk. Autorka postawiła w pracy jeszcze inny cel, który dotyczył poznania opinii ludzi na temat nowych procesów demograficznych w Polsce. Postanowiła go zrealizować na przykładzie studium przypadku. Jednostką, która została wybrana do badań, była Łódź. Było kilka istotnych powodów, które skłoniły autorkę do wyboru Łodzi. Najważniejsze z nich dotyczyły dużej dynamiki przemian demograficznych, które obserwowane są w tym mieście od lat 90. ubiegłego wieku. Jak pokazały wyniki badań, prezentowane w poprzednich rozdziałach pracy, Łódź jest jednym z podregionów, w których dokonują się głębokie zmiany zachowań matrymonialnych i prokreacyjnych, wraz z innymi największymi miastami są one przykładami pionierskich zachowań demograficznych.

\subsection{Charakterystyka respondentów}

W badaniach, które przeprowadzono w Łodzi w latach 2011-2013 wzięło udział blisko 1900 respondentów, którzy byli mieszkańcami miasta. Badania miały charakter dwuetapowy. W pierwszym etapie kwestionariusz ankiety był skierowany do ogółu mieszkańców Łodzi, a dobór próby miał charakter dostępnościowy i celowy. Ponieważ był to nieprobabilistyczny dobór próby, zastosowano także sposób kwotowy. Celem pierwszego etapu badawczego było poznanie opinii mieszkańców Łodzi o „nowych” zjawiskach i formach życia małżeńsko-rodzinnego w kraju (798 respondentów). Założeniem autorki było także określenie stopnia przyzwolenia społecznego na nowe zjawiska poprzez wyrażanie określonych poglądów przez re- 
spondentów. W kwestionariuszu ankiety zawarto pytania m.in. o poglądy na temat związków kohabitacyjnych, rozwodów, życia samotnego, w pojedynkę, tzw. singli oraz rodzin niepełnych - samotnych matek i samotnych ojców ${ }^{54}$. Drugi etap badań ankietowych był skierowany do młodych łodzian, których poglądy na temat zachowań matrymonialnych i prokreacyjnych mogą w niedługim czasie być zrealizowane i stać się zachowaniami demograficznymi. Z tego właśnie powodu badania skierowano do grupy blisko $1090^{55}$ mieszkańców Lodzi w wieku 18-35 lat. Ten cykl badań składał się z czterech kwestionariuszy, a każdy z nich był poświęcony jednemu zjawisku demograficznemu. Były to, adekwatnie do badań wcześniejszych, zjawiska i procesy demograficzne: małżeństwo vs związek nieformalny, bycie singlem, rozwody i rodziny monoparentalne.

Respondenci biorący udział w pierwszym etapie badań (ogół mieszkańców) to w 55\% kobiety, a mediana wieku ankietowanych wyniosła 48 lat (dla Łodzi 43,8 roku w 2011 r.). Więcej niż połowa ankietowanych była w związkach małżeńskich, ponad $20 \%$ to panny i kawalerowie, a co dziesiąty respondent żył w związku nieformalnym (w Łodzi według spisu powszechnego z 2011 r. odsetek osób kohabitujacych wyniósł 3,6\%). Wśród respondentów prawie $60 \%$ posiadało dzieci. Struktura wykształcenia respondentów przedstawiała się korzystnie, ponad $1 / 4 \mathrm{z}$ nich to osoby z wykształceniem wyższym, a tylko co piąty ma wykształcenie zasadnicze zawodowe lub podstawowe. Głównym źródłem utrzymania ankietowanych mieszkańców jest praca najemna, a blisko $22 \%$ to pracodawcy. Większość respondentów podając swoje miejsce zamieszkania do 14. roku życia określiła je jako miasto powiatowe - blisko 54\%. Ponad połowa mieszkańców biorących udział $\mathrm{w}$ badaniu obecnie mieszka w zabudowie blokowej $(53,4 \%)$, a co piąty jest mieszkańcem kamienic czynszowych. Biorąc pod uwagę ich adres zamieszkania reprezentują prawie wszystkie rejony miasta. Ich sytuacja materialna, według nich samych, jest przeciętna $(50,8 \%)$ lub dobra (35,8\%), a przeciętny miesięczny dochód brutto dla ponad $43 \%$ z nich wynosi od 1000 do 2000 zł. Największa część respondentów bierze udział w praktykach religijnych 1-2 razy w miesiącu, blisko 16\% w ogóle

${ }^{54}$ Autorka, planując badania ankietowe, miała na uwadze informacje, jakie będzie mogła wykorzystać ze spisu powszechnego, przeprowadzonego w $2011 \mathrm{r}$. Dlatego w kwestionariuszu pojawiły się pytania o rodziny monoparentalne i zjawisko singli. Niestety z braku danych (informacje o gospodarstwach domowych i rodzinach mają być opublikowane pod koniec 2013 r.) analiza zachowań demograficznych przeprowadzona w rozdz. 3 i 4 nie uwzględnia tych zjawisk.

${ }^{55} \mathrm{~W}$ grupie respondentów udzielających odpowiedzi było 215 osób, które wyraziły swoją opinię o rodzinach monoparentalnych, 265 osób wypowiedziało się o związkach nieformalnych, 229 osób o rozwodach i 387 osób o zjawisku singli. 
w nich nie uczestniczy. Sympatie polityczne respondentów są prawie równo rozłożone pomiędzy lewicą $(42,5 \%)$ a prawicą $(41,6 \%)$.

Wśród respondentów z drugiej grupy badanych (młodzi łodzianie) przeważały młode kobiety, które stanowiły niewiele ponad $55 \%$ ogółu respondentów. Jak wcześniej zaznaczono, respondenci to ludzie młodzi, w ponad $54 \%$ stanu wolnego, niespełna $22 \%$ z nich było w związkach małżeńskich, a co piąty uczestnik badań zadeklarował, że jest w związku nieformalnym. Blisko $22 \%$ respondentów deklarowało posiadanie dzieci. W ponad $50 \%$ przypadków ankietowani byli aktywni zawodowo, a na utrzymaniu rodziców lub innych członków rodzin pozostawało $40 \%$ z nich. Ich miejsce zamieszkania do 14. roku życia było dość zróżnicowane, największe odsetki dotyczyły miasta wojewódzkiego $(38,4 \%)$, wsi $(31,8 \%)$ i miasta powiatowego $(19,1 \%)$.

Ankietowani młodzi łodzianie mieszkają we wszystkich rejonach miasta, tylko 6 jednostek osiedlowych nie zostało wskazanych jako miejsce zamieszkania respondentów. Najwięcej respondentów pochodziło z Radogoszcza, Śródmieścia Wschodu, Starego Polesia i Zarzewia. Miejsca zamieszkania respondentów wykazują ścisły związek z terenami miasta o najwyższym odsetku terenów mieszkaniowych. Świadczy to o tym, że respondenci biorący udział $\mathrm{w}$ badaniu reprezentują całe miasto. Najliczniej reprezentowana była zabudowa blokowa (wielorodzinna), bo ponad $46 \%$ badanych wybrało $\mathrm{w}$ opisie ten jej rodzaj, na drugim miejscu znalazła się zabudowa jednorodzinna - blisko 33\% (z czego jednorodzinna wolnostojąca dominowała - ponad 23\%). Prawie 9\% ankietowanych mieszkało w akademikach, które zostały wyodrębnione jako oddzielny rodzaj zabudowy, najmniejszy udział dotyczył zabudowy czynszowej (śródmiejskiej) i wiejskiej (zagrodowej).

Młodzi łodzianie swoją sytuację materialną ocenili w ponad $43 \%$ jako przeciętną, blisko 37\% jako dobrą, niewielu ankietowanych uznało ją za złą lub bardzo złą. Mając możliwość wyboru miesięcznego dochodu brutto na osobę, ponad 30\% ankietowanych wskazało na dochód poniżej $1000 \mathrm{zł}$, a blisko 37\% na przedział dochodów w granicach 1000-2000 zł. Respondenci, którzy brali udział $\mathrm{w}$ badaniach, nie określili jednoznacznie swoich sympatii politycznych - blisko $65 \%$ na to pytanie odpowiedziało "trudno powiedzieć", nieco ponad $16 \%$ wskazało na prawicę, centrum - 8,3\%, a lewica uzyskała zaledwie niewiele ponad 6\% wskazań. Swój udział w praktykach religijnych niewiele ponad 38\% określiło jako „raz w tygodniu i częściej", a blisko 20\% stwierdziło, że w ogóle w nich nie uczestniczy. 


\subsection{Cele życiowe respondentów oraz ocena zachowań moralnych dotyczących wartości małżeńskich i rodzinnych}

Wśród najważniejszych celów, którymi - według własnych deklaracji łodzianie kierują się w swoim codziennym życiu, jest zdrowie $(64,4 \%$ wskazań jako celu życiowego ocenionego na maksymalną liczbę punktów, w skali 0-6), które zajmuje pierwsze miejsce, prawie ex aequo z własną rodziną $(63,7 \%)$. Następnym na liście celów dla łodzian okazały się dobre relacje z rodziną - ponad $55,1 \%$ wskazań. Za stosunkowo najmniej ważne w swoim życiu badani uznali bezinteresowność, tolerancję i pracowitość. Ankietowani zasadniczo nie różnili się w ocenie hierarchii celów biorąc pod uwagę ich płeć. Łodzianki nieco wyżej oceniały religię czy bezinteresowność. Dla mężczyzn zaś w hierarchii celów wyżej stoją wolność bądź kariera (ryc. 82). Hierarchia celów młodych łodzian jest nieco inna, najważniejsza jest miłość (54,4\% wskazań), następnie własna rodzina (53,6\%), a na trzecim miejscu zdrowie - ponad $41 \%$ wskazań. W przypadku tej grupy respondentów ważność celów różnicowała się w zależności od płci. Młode kobiety najwyżej sobie cenią miłość, zdrowie, własną rodzinę oraz dobre relacje z rodziną. Dla mężczyzn zaś najważniejszymi wartościami są wolność, zdrowie, samoakceptacja oraz honor i godność, miłość znalazła się zaś dopiero na 7. miejscu wśród 23 wymienionych celów życiowych.

Wyniki badań wskazały na nieznaczny wpływ cech demograficznych i społecznych w wyborze najważniejszych celów życiowych mieszkańców Łodzi. Świadczą o tym niewielkie wartości współczynnika v-Kramera, pokazujące siłę związku pomiędzy celami życiowymi i ich hierarchią a cechami respondentów. W przypadku ogółu mieszkańców najistotniejszą cechą wpływającą na wybór celów życiowych był wiek łodzian (dla większości celów współczynnik osiągnął wartości powyżej 0,3, najwyższa jego wartość to 0,422 - pracowitość; 0,363 - honor i godność oraz 0,353 - praca). W grupie młodych łodzian, gdzie wiek był w niewielkim stopniu zróżnicowany (wybór celowy respondentów), istotniejszą zmienną decydująca o wyborze celu życiowego okazała się płeć ankietowanych, ale także i w tym przypadku współczynnik v-Kramera był niski (od 0,23 do 0,32). Z pozostałych cech ankietowanych najwyższą korelację odnotowano dla wykonywanego zawodu. 

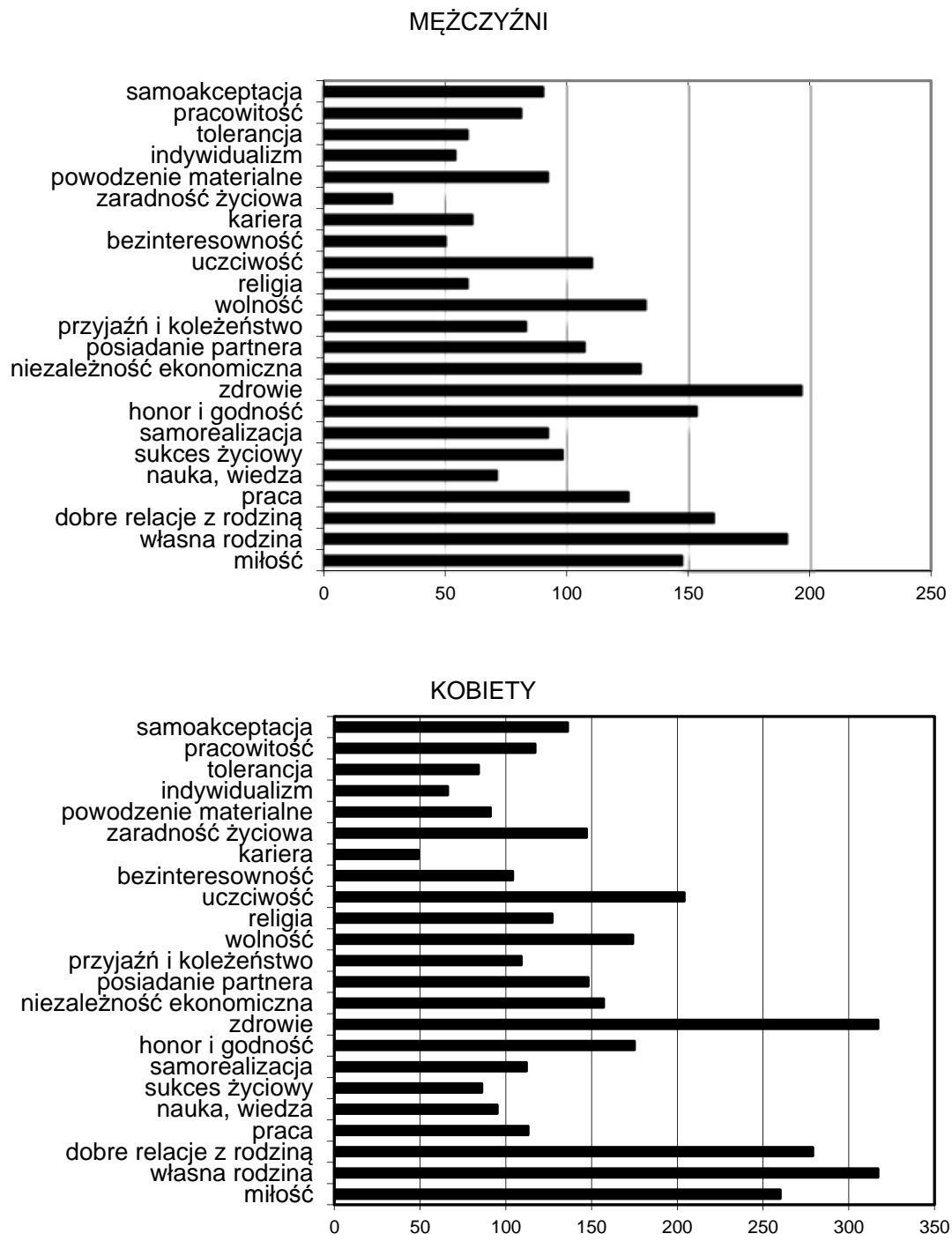

Ryc. 82. Hierarchia celów życiowych łodzian (wskazania dotyczą najwyższej oceny, które respondenci mogli przypisać w skali 0-6 poszczególnym celom)

Źródło: oprac. własne na podstawie badań ankietowych

Istnieją różnego rodzaju zachowania, powiązane w jakiś sposób z życiem małżeńskim i rodzinnym, które z punktu widzenia moralności (zwłaszcza katolickiej) często są oceniane jako naganne, a mimo to charakteryzują się mniej lub bardziej powszechnym występowaniem w społeczeństwie, nierzadko budząc przy tym liczne kontrowersje. Ankietowani łodzianie podczas badań mieli możliwość oceny tego typu zachowań. Posługując się skalą od 1 do 10, na której 1 oznaczało, iż dane postępowanie jest zawsze złe 
i w związku z tym nigdy nie może być usprawiedliwione, a 10 - że nie ma w tym nic złego i zawsze można je usprawiedliwić - wyrażali oni swój stosunek do poszczególnych zachowań.

Spośród zachowań przedstawionych respondentom bezwzględnemu potępieniu podlegają przede wszystkim bicie dzieci oraz romans z mężatką lub żonatym (średnie wartości bardzo zbliżone) - por. ryc. 83. Młodzi łodzianie podobnie potępiają bicie dzieci, za niedopuszczalne uznaje je blisko $82 \%$ badanych, z tego ponad połowa (54\%) uważa, że nigdy nie może być ono usprawiedliwione. Jednak młodsi respondenci nie są już tak krytyczni wobec takiego zachowania, jak romans z mężatką lub żonatym. Z dezaprobatą łodzian, choć już nie z tak silnym potępieniem, spotykają się zdrada $\mathrm{w}$ małżeństwie, homoseksualizm oraz flirtowanie $\mathrm{z}$ osobą trzecią, gdy jest się w małżeństwie lub w stałym związku.

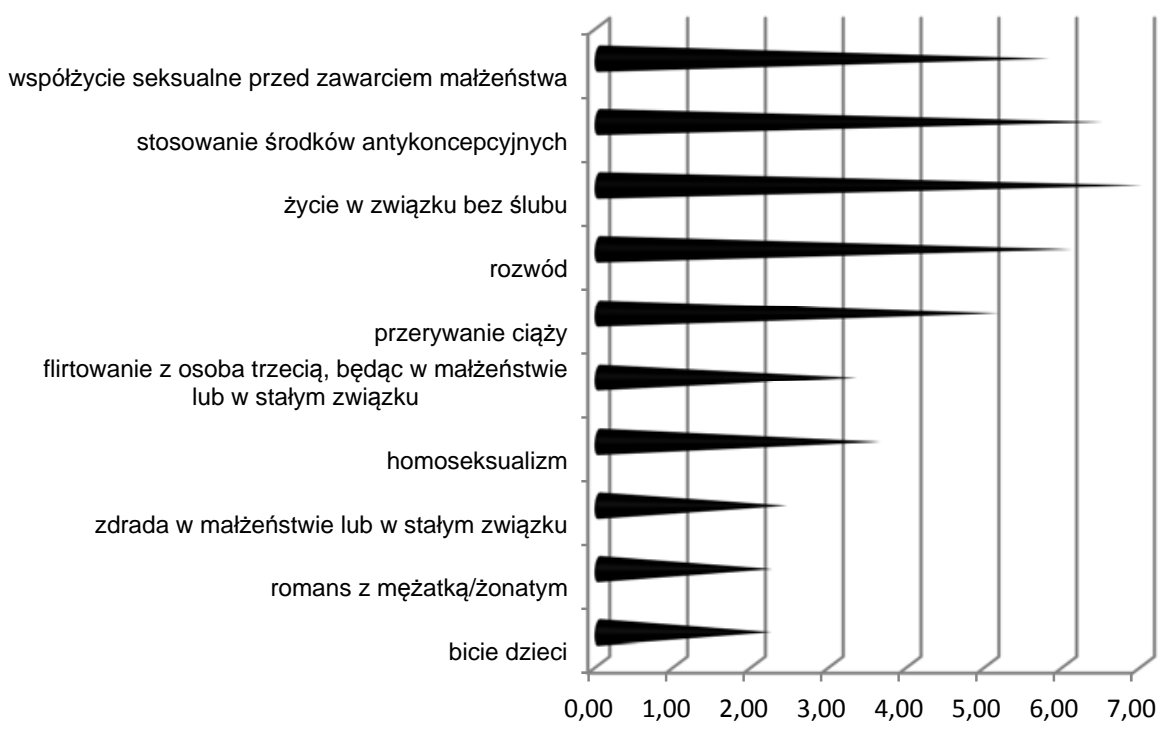

Ryc. 83. Ocena zachowań moralnych - średnie z udzielonych odpowiedzi respondentów w skali od 1 do 10

Źródło: oprac. własne na podstawie badań ankietowych

Oceny zachowań powiązane w jakiś sposób z życiem małżeńskim i rodzinnym, które wybrali łodzianie, nie odbiegają od ocen Polaków ${ }^{56}$. Mieszkańcy Łodzi są w swoich ocenach zbliżeni do opinii innych obywateli, szczególnie dotyczy to zachowań związanych z nowymi postawami demograficznymi, takich jak życie w związku bez ślubu (średnia 6,98), współżycie sek-

56 Kontrowersje wokół różnych zjawisk dotyczących życia małżeńskiego i rodzinnego. Komunikat z badań, 2008, CBOS, Warszawa. 
sualne przed ślubem $(5,79)$ czy stosowanie środków antykoncepcyjnych $(6,48)$. Młodzi łodzianie są bardziej liberalni w swych ocenach dotyczących wyżej wymienionych trzech zachowań.

Na ocenę wybranych zachowań związanych z życiem małżeńskim i rodzinnym, szczególnie ogółu mieszkańców miasta, wpływ miały udział respondentów w praktykach religijnych oraz ich wiek. Najwyższą korelację odnotowano pomiędzy praktykowaniem religijnym, a oceną takiego zachowania jak „współżycie seksualne przed zawarciem małżeństwa” (współczynnik v-Kramera wyniósł 0,519), wiek zaś miał największe znaczenie przy ocenie życia w związku bez ślubu i stosowania środków antykoncepcyjnych (adekwatnie v-Kramer osiągnął wartości 0,324 i 0,343).

Z badań ogólnopolskich CBOS-u wynika, że stopień liberalizacji w podejściu do takich zjawisk, jak: homoseksualizm, kohabitacja, rozwód, antykoncepcja, współżycie przed ślubem oraz flirt pozamałżeński, znacząco rośnie wraz z wykształceniem respondentów. Jednocześnie osoby lepiej wykształcone bardziej stanowczo niż te, które osiągnęły niższy pułap edukacji, sprzeciwiają się biciu dzieci. Łódzkie badania tylko w części są zgodne z wyżej wspomnianymi wynikami, uzyskane wartości wskazują bowiem na dość niskie zależności (v-Kramer od 0,161 do 0,211).

Młodzi łódzcy respondenci w subiektywnym odczuciu lepiej sytuowani w porównaniu z tymi, którzy swoją sytuację w tym względzie określają jako złą, deklarują większe zrozumienie i poparcie dla takich zjawisk, jak: homoseksualizm, współżycie przedmałżeńskie, rozwód, rzadziej zaś aprobują bicie dzieci.

\subsection{Opinie mieszkańców dotyczące zachowań matrymonialnych i prokreacyjnych}

\subsubsection{Najlepsza forma życia malżeńsko-rodzinnego wedlug respondentów}

W społeczeństwach ponowoczesnych pojawiło się wiele alternatywnych form życia małżeńsko-rodzinnego. Coraz częściej traktuje się je jako rzeczywiste odmiany życia, z których wiele jest aprobowanych społecznie i po pewnym czasie zwykle legalizowanych, ex post facto przez prawo.

Podejścia definicyjne do małżeństwa i rodziny zmieniają się w zależności od czasu, kultury, typu społeczeństwa. Sposoby definiowania małżeństwa wynikają z istoty oraz charakteru tego zjawiska społecznego i uwzględniają wielopostaciowość i wielowymiarowość samego związku. Definiowanie istoty małżeństwa poprzez eksponowanie cech związku jest najczęstszym sposobem ujmowania jego charakteru. W większości definicji klasycznych (tradycyjnych) małżeństwa proponowanych przez socjologów i psychologów pojawia się określenie jego istoty przez cechy związku. Również w ujęciach słownikowych małżeństwo na ogół traktowane jest jako związek 
kobiety i mężczyzny uznawany przez prawo, religię lub obyczaj (Janiszewska 2007). W takim klasycznym ujęciu za rodzinę należałoby traktować małżeństwo z dziećmi. W związku z tym pomijane są inne formy, w których żyją ludzie. Dlatego też bardziej zasadne byłoby wyróżnienie czterech sposobów definiowania rodziny: strukturalnego, funkcjonalnego, inkluzyjnego i uniwersalnego (Larson, Goltz, Hobart 1994). Podejście strukturalne zwraca uwagę na skład i członkostwo w grupie, rodzinę tworzy przynajmniej jeden rodzic i jedno dziecko. W podejściu funkcjonalnym podkreśla się zadania i funkcje, które rodzina winna wypełniać zarówno względem poszczególnych członków, jak i całego społeczeństwa. Rodzina może być definiowana jako grupa przynajmniej $z$ jednym rodzicem i jednym lub więcej dzieckiem/dziećmi, realizująca podstawową funkcję socjalizacyjną. Na znaczenie relacji pomiędzy członkami grupy rodzinnej kładzie nacisk podejście inkluzyjne. W definiowaniu rodziny nie zwraca się uwagi na jej instytucjonalny charakter, ale określa się ją jako prywatną, dobrowolną grupę społeczną o szczególnych związkach. W ostatnim podejściu uniwersalnym zakłada się, że rodzina jest grupą normatywnie określoną, mającą na celu realizację zadań prokreacyjnych i socjalizacyjnych. Pojęcie „grupa pokrewieństwa" znaczy tutaj, że jej członkowie połączeni są więzami pokrewieństwa określonymi przez małżeństwo; pokrewieństwo nie wyznacza liczby rodziców ani liczby dzieci.

Ankietowani młodzi mieszkańcy Łodzi, mając do wyboru osiem form życia małżeńsko-rodzinnego, najczęściej wskazywali, że rodzina to małżeństwo z dziećmi (96,7\%), matka/ojciec samotnie wychowująca dziecko/dzieci $(89,7 \%)$, osoby pozostające w związku nieformalnym wychowujące dzieci z tego związku $(80,8 \%)$, małżeństwo bez dzieci $(77,7 \%)$ oraz matka/ojciec z dziećmi i konkubent/konkubina $(67,9 \%)$ - por. ryc. 84 . Pozostałe wyróżnione związki między ludźmi, tj. osoby pozostające w związku nieformalnym nieposiadające dzieci, związki osób tej samej płci wychowujące wspólnie dziecko (dzieci) jednej z nich oraz związki osób tej samej płci niewychowujących dzieci nie zostały uznane za rodziny, zdecydowana większość respondentów dała tu odpowiedź przeczącą (od 71 do 87\%). Wskaźnik „pojemności” pojęcia rodzina (powstał ze zliczenia twierdzących odpowiedzi na pytanie o ocenę różnych form związków jako rodziny i może przyjmować wartości od 0 do 8) przyjął wartość 4,82 i był tylko nieco wyższy od wartości wskaźnika uzyskanego z ogólnopolskiej grupy badanych $^{57}(4,76)$. Opierając się na wartości sumarycznego wskaźnika utworzonego na podstawie twierdzących odpowiedzi na pytanie o definicję rodziny, można powiedzieć, że szerszemu rozumieniu tego pojęcia przez

57 Rodzina - jej współczesne znaczenie i rozumienie, marzec 2013, CBOS, Warszawa. 
respondentów sprzyja tworzenie związku nieformalnego $(5,84)$, wyższe wykształcenie $(5,26)$, przynależność do kadry kierowniczej i specjalistów wyższego szczebla $(4,97)$, praca na stanowisku administracyjno-biurowym $(5,01)$ lub prowadzenie własnej działalności gospodarczej $(4,99)$, a ponadto uzyskiwanie najwyższych dochodów w przeliczeniu na osobę w gospodarstwie domowym $(5,15)$, nieuczestniczenie $w$ praktykach religijnych lub jedynie sporadyczny w nich udział $(5,12)$.

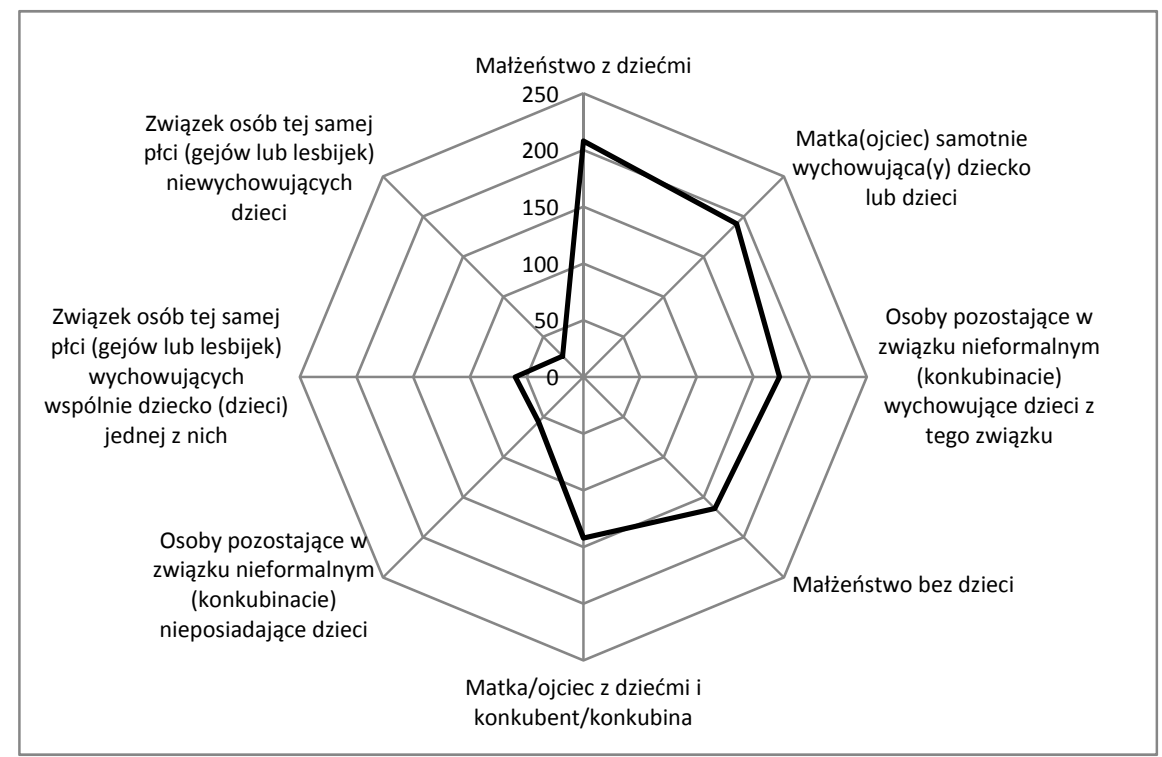

Ryc. 84. Związki między ludźmi, które są rodziną według respondentów (młodzi łodzianie)

(na osi liczba wskazań „na tak”)

Źródło: oprac. własne na podstawie badań ankietowych

Biorąc pod uwagę zmiany, jakie dokonują się w ramach rodziny, jej zmieniające się formy, respondenci mieli możliwość określenia, w jakiej rodzinie chcieliby żyć niezależnie od tego w jakiej funkcjonują teraz. Odpowiedzi były dość wyraźnie zróżnicowane w zależności od wieku odpowiadających (współczynnik v-Kramera wyniósł 0,372). Najmłodsi respondenci z pierwszej grupy badanych (18-34 lata) zdecydowanie preferowali rodzinę nuklearną, składająca się z rodziców i dzieci, a także najliczniej reprezentowali stanowisko preferujące związki nieformalne. Bardziej dojrzali mieszkańcy Łodzi (35-49 lat) także wskazywali małą rodzinę, jako preferowaną formę życia małżeńsko-rodzinnego, ale pojawiającą się także najlepszą formą w przyszłości jest tu rodzina wielopokoleniowa. Następne dwie grupy respondentów (50-64 i 65>) w coraz większym stopniu wyrażają chęć życia w dużej wielopokoleniowej rodzinie (ryc. 85). Niezależnie od 
wieku ankietowanych najbardziej „popularną” formą życia małżeńskorodzinnego jest rodzina z dziećmi, chociaż widać, że młodsza część mieszkańców Łodzi wybrałaby też inne formy, które nie znajdują zwolenników wśród starszej części społeczeństwa.
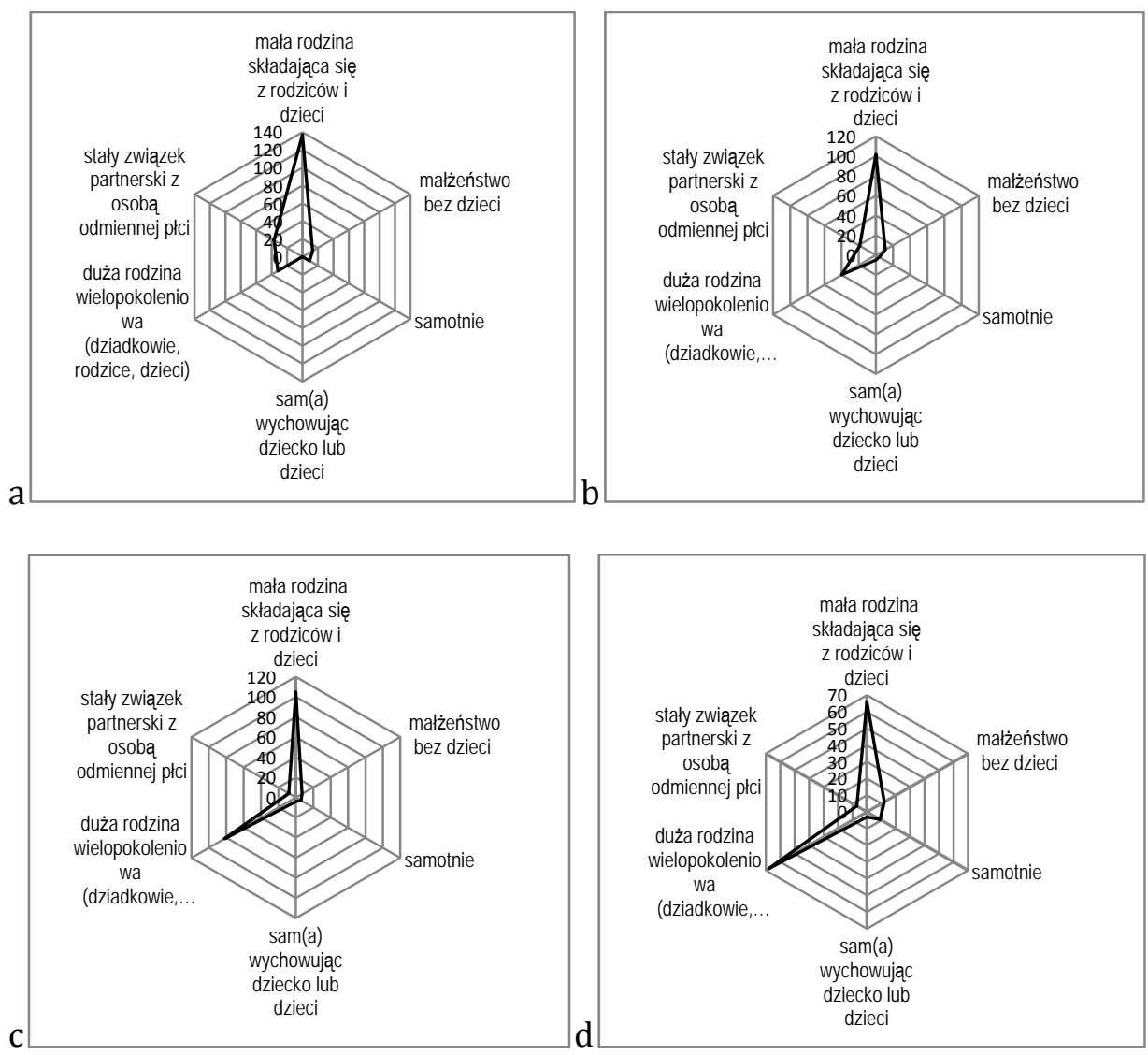

Ryc. 85. Najlepsza forma życia małżeńsko-rodzinnego w przyszłości według wieku respondentów w latach; a:18-34; b: 35-49; c: 50-64; d: 65> (na osi liczba wskazań) Źródło: oprac. własne na podstawie badań ankietowych

W drugiej grupie badanych (młodych łodzian) preferencje dotyczące wielkości i składu rodziny były wyraźnie ukierunkowane na jej małą formę, tj. rodzinę składającą się z rodziców i dzieci (ponad 64\% wskazań). Mniejszym zainteresowaniem cieszyły się wśród ankietowanych młodych mieszkańców Łodzi duże rodziny wielopokoleniowe (blisko17\% odpowiedzi). Dla ponad 13\% respondentów preferowaną przyszłą formą życia małżeńskorodzinnego jest związek nieformalny (10\%) lub życie singla (ponad 3\%) por. ryc. 86. W tym przypadku zaobserwowano zależność pomiędzy stanem cywilnym respondentów oraz ich wykształceniem a preferowaną w przy- 
szłości formą życia małżeńsko-rodzinnego, współczynnik v-Kramera osiągnął adekwatne wartości 0,302 i 0,278. Rozkład udzielonych odpowiedzi odnoszących się do tego, jak ma wyglądać przyszłe życie małżeńskorodzinne wyraźnie wskazuje na dokonujące się współcześnie zmiany w sferze preferencji matrymonialnych młodych osób.

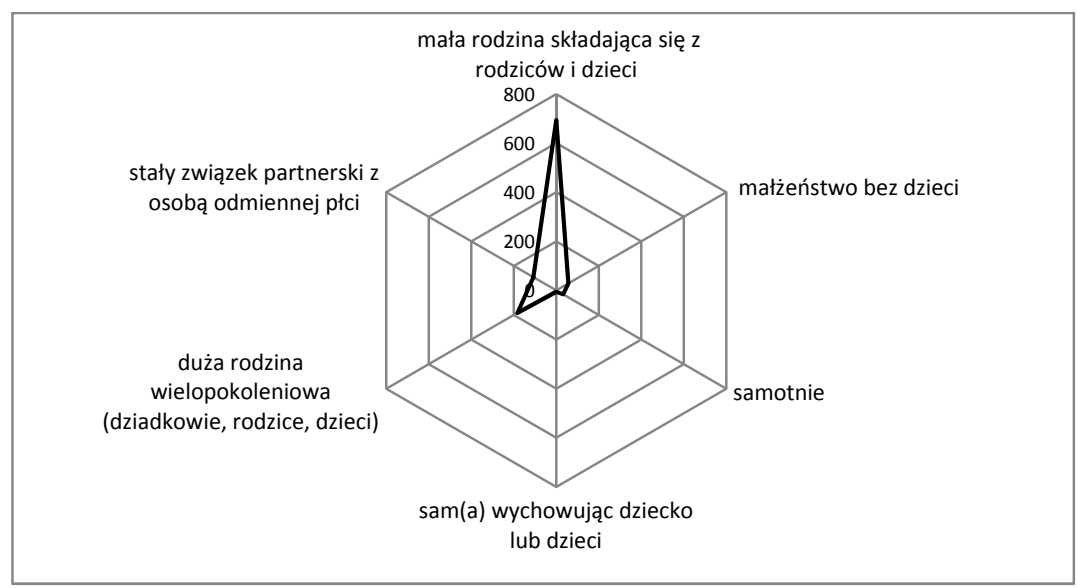

Ryc. 86. Najlepsza forma życia małżeńsko-rodzinnego w przyszłości według młodych łodzian (na osi liczba wskazań)

Źródło: oprac. własne na podstawie badań ankietowych

\subsubsection{Kohabitacja wedhug respondentów}

Jednym ze zjawisk związanych $\mathrm{z}$ nowym etapem życia małżeńskorodzinnego $\mathrm{w}$ ponowoczesnym świecie jest zjawisko kohabitacji. Jest to forma, która staje się stopniowo uniwersalną formą życia rodzinnego oraz instytucją, ponieważ rodzą się w niej i wychowują dzieci. Kohabitacja nie jest nowym zjawiskiem, które pojawiło się wraz z innymi przemianami drugiego przejścia demograficznego. W niektórych krajach tradycja związków kohabitacyjnych jest długa, w innych pojawiła się na szerszą skalę w latach 60. XX w. Jest to zjawisko, które w Polsce nie jest rozpowszechnione, według informacji pozyskanych w ostatnim spisie ludności, odsetek osób kohabitujących w naszym kraju wyniósł w 2011 r. zaledwie $2 \%$.

Kohabitacja może przybierać różne formy, Kirnan (2002) wyróżnia następujące stadia jej rozwoju:

- niemałżeńska kohabitacja jest rzadka i ograniczona do marginesowych grup społecznych, jest traktowana jako dewiacja albo awangardowe zachowanie;

- liczba kohabitujących par powiększa się, kohabitacja zaczyna pojawiać się wśród innych grup społecznych, w tym stadium kohabitacja jest postrzegana jako forma poprzedzająca małżeństwo; 
- pary pozostają w niemałżeńskich związkach w coraz dłuższych okresach, kohabitacja staje się możliwą do przyjęcia alternatywą małżeństwa;

- kohabitacja i małżeństwo stają się równorzędne (równoważne).

Respondenci wyrażają zróżnicowane poglądy na temat kohabitacji, zależy to od wieku (współczynnik v-Kramera 0,356) i udziału w praktykach religijnych $(\mathrm{v}=0,269)$. Młodsi łodzianie są zdecydowanie bardziej tolerancyjni w stosunku do związków nieformalnych niż starsi. W przypadku pierwszej grupy ewidentnie pozytywny i pozytywny odbiór związków nieformalnych występuje w 46\% wypowiedzi, u starszych ankietowanych w 40\%. U młodych łodzian obserwuje się mniej ocen negatywnych takich związków - 12\% przy 25\% wskazań w drugiej grupie badanych (ryc. 87). $\mathrm{Na}$ opinie młodych mieszkańców Łodzi ma wpływ ich stan cywilny (v=0,278) oraz wykształcenie $(\mathrm{v}=0,233)$.

Poziom akceptacji związków nieformalnych w Polsce powoli zwiększa się, takiego zdania są obydwie grupy respondentów. W tym przypadku bardziej optymistycznie wypowiadali się młodzi łodzianie, według ich opinii (80\% odpowiedzi) społeczeństwo polskie zmienia się i wykazuje coraz większe przyzwolenie dla związków nieformalnych (ryc. 88). Są także zdania, że w większym stopniu to ludzie młodzi i mieszkańcy miast są bardziej tolerancyjni niż ludzie starsi i mieszkający na wsi. Pomimo takich opinii młodzi łodzianie akceptują potencjalne życie w związku nieformalnym swoich bliskich, jeśli związek ten przybiera formę poprzedzającą małżeństwo (87,6\%) lub stanowi przygotowanie do małżeństwa (85,3\%). Nie wyrażają już tak zdecydowanej aprobaty, jeśli miałby on stanowić alternatywę dla związku małżeńskiego, w tym przypadku mniej niż połowa ankietowanych udzieliła pozytywnych odpowiedzi.

Młodzi łodzianie są też zdania, że jeśli ludzie się kochają i ufają sobie, to nie ma znaczenia, czy żyją ze sobą w małżeństwie, czy też bez ślubu (blisko $60 \%$ odpowiedzi), niespełna $1 / 3$ twierdziła, że dobrze by było, gdyby osoby żyjące ze sobą bez ślubu zdecydowały się na małżeństwo, a tylko co dwudziesty respondent uważał, że osoby żyjące razem bez ślubu bezwzględnie powinny zawrzeć małżeństwo. Starsi respondenci także i w tym przypadku wykazali nieco bardziej konserwatywne poglądy, prawie równo rozłożyły się odpowiedzi dotyczące konieczności wstępowania w związek małżeński lub pozostania w związku nieformalnym. Młodzi mieszkańcy Łodzi w związkach nieformalnych upatrują pełnienia różnych funkcji. Dla zdecydowanej większości z nich (82,8\%) związek kohabitacyjny może być związkiem „na próbę”, nie wymaga długotrwałych osobistych zobowiązań $(40,8 \%)$, ale też nie jest gwarantem trwałości, stałości i odpowiedzialności $(46,4 \%)$ - por. tab. 24. Dla starszych łodzian związki nieformalne, w większym stopniu niż dla młodych, są zbliżone do małżeństw pod względem pełnionych przez nie funkcji, świadczą o tym ich opinie dotyczące zaanga- 
żowania w związek. W drugiej grupie respondentów (ogół łodzian) pojawiło się więcej odpowiedzi wskazujących, że związki nieformalne mogą gwarantować trwałość, stabilność i odpowiedzialność.

Młodzi łodzianie deklarują, że w przyszłości zamierzają zawrzeć związek małżeński (prawie 85\% odpowiedzi), tylko, a może aż, 14\% ankietowanych chce żyć w związku nieformalnym. Życie singla/singielki wybierze ok. $2 \%$ badanych. Wybór małżeństwa jest podyktowany chęcią założenia rodziny, względami religijnymi! (pomimo że tylko 38\% deklarowało częste praktykowanie) i stabilizacją. Motywacja wejścia w związek nieformalny była najczęściej czysto racjonalna i instrumentalna (wygoda, brak zobowiązań, możliwość szybkiego zakończenia związku).

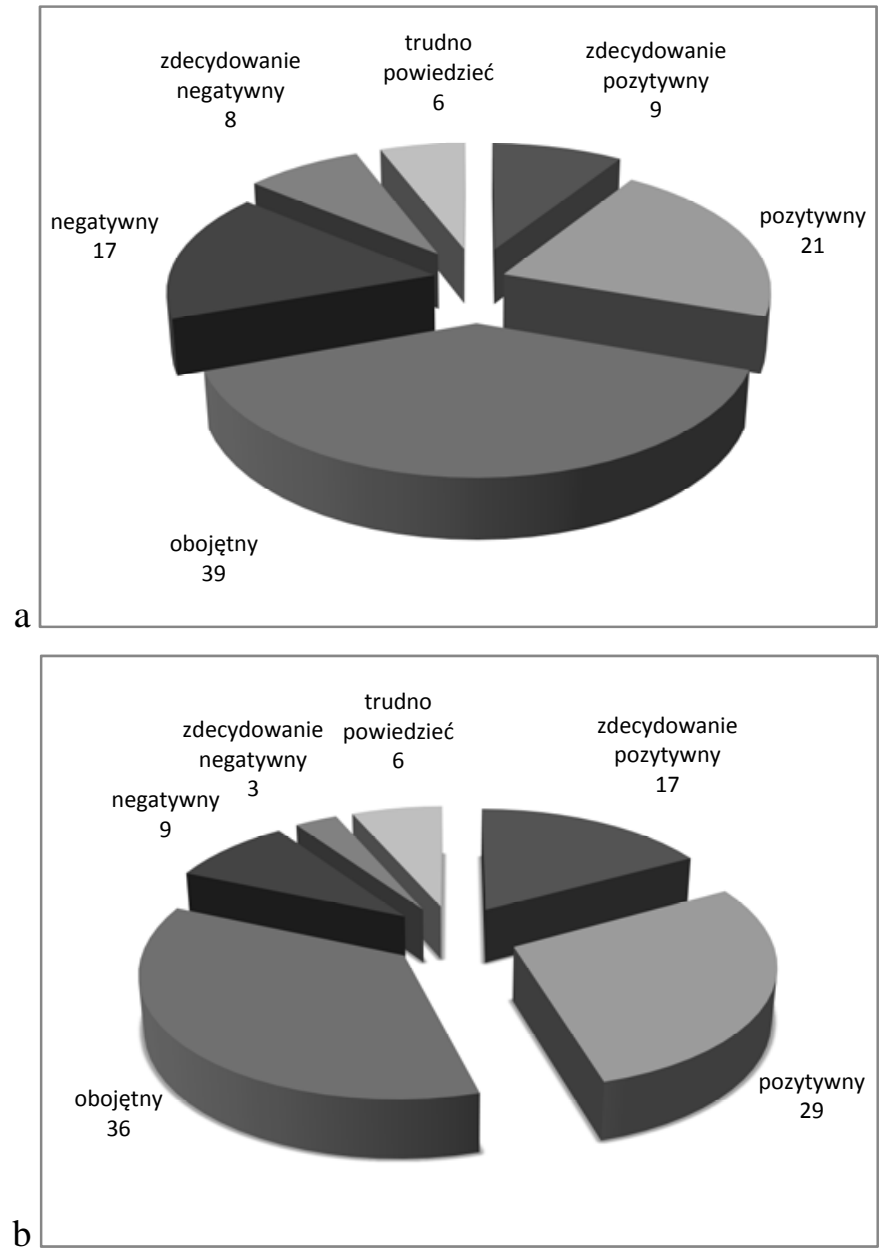

Ryc. 87. Stosunek respondentów do kohabitacji; a: łodzianie ogółem; b: młodzi łodzianie (w \%)

Źródło: oprac. własne na podstawie badań ankietowych 


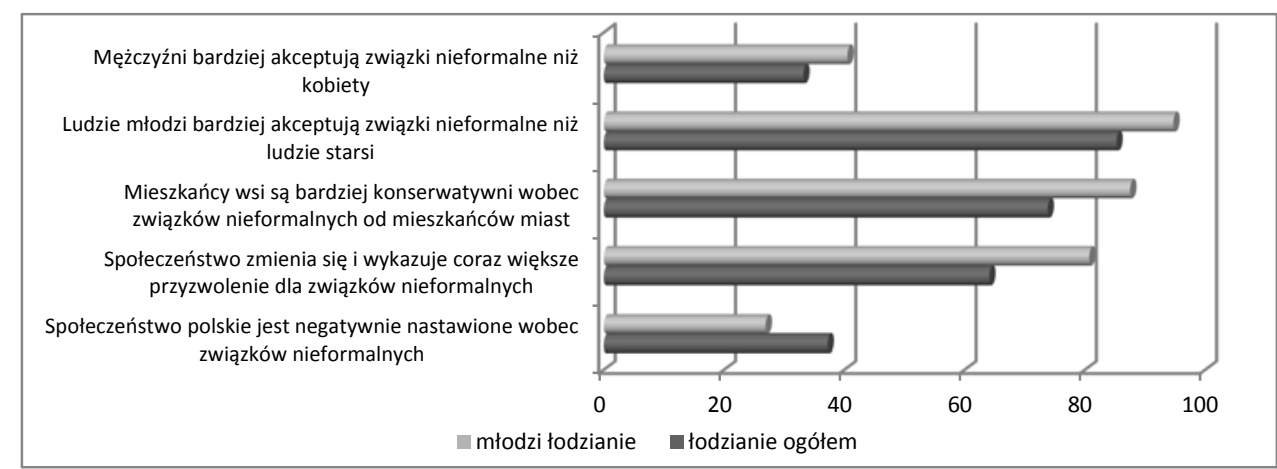

Ryc. 88. Akceptacja związków nieformalnych przez polskie społeczeństwo według respondentów (odsetki odpowiedzi „tak”)

Źródło: oprac. własne na podstawie badań ankietowych

Tabela 24

Funkcje związku nieformalnego według respondentów

\begin{tabular}{|c|c|c|c|c|c|c|}
\hline Funkcje związku nieformalnego & 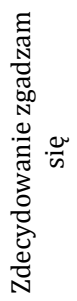 & 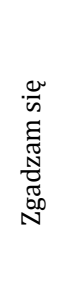 & 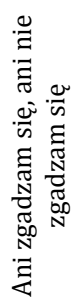 & 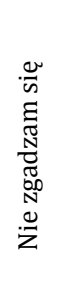 & 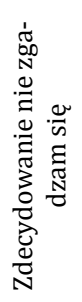 & 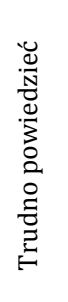 \\
\hline \multirow{2}{*}{$\begin{array}{l}\text { Może być związkiem „na próbę”, co pozwala } \\
\text { uniknąć pomyłek życiowych }\end{array}$} & 41,4 & 41,4 & 7,2 & 4,6 & 3,0 & 2,3 \\
\hline & 22,1 & 41,7 & 14,4 & 13,0 & 4,0 & 4,8 \\
\hline \multirow[t]{2}{*}{ Pozwala opóźnić zawarcie małżeństwa } & 6,5 & 30,5 & 33,6 & 17,9 & 4,6 & 0,4 \\
\hline & 8,0 & 33,3 & 26,3 & 18,9 & 3,9 & 9,6 \\
\hline \multirow[t]{2}{*}{ Wzmacnia wzajemną atrakcyjność partnerów } & 8,8 & 23,3 & 30,9 & 20,2 & 6,5 & 10,3 \\
\hline & 8,0 & 21,3 & 27,3 & 24,9 & 6,1 & 12,5 \\
\hline \multirow[t]{2}{*}{ Pozwala na swobodne życie seksualne } & 13,5 & 29,7 & 22,4 & 18,5 & 12,7 & 3,1 \\
\hline & 13,3 & 30,0 & 17,2 & 22,5 & 8,1 & 8,9 \\
\hline \multirow[t]{2}{*}{ Pozwala na opóźnienie prokreacji } & 5,9 & 18,8 & 33,7 & 22,0 & 6,7 & 12,9 \\
\hline & 5,1 & 18,1 & 30,5 & 25,0 & 6,6 & 14,8 \\
\hline \multirow{2}{*}{$\begin{array}{l}\text { Nie gwarantuje trwałości, stabilności i odpowie- } \\
\text { dzialności }\end{array}$} & 17,1 & 29,3 & 20,2 & 24,3 & 6,5 & 2,7 \\
\hline & 5,6 & 15,7 & 21,7 & 33,5 & 10,5 & 13,0 \\
\hline \multirow[t]{2}{*}{ Wymusza zawarcie małżeństwa w przypadku ciąży } & 2,7 & 16,2 & 23,1 & 36,5 & 13,5 & 8,1 \\
\hline & 7,1 & 24,4 & 17,0 & 30,2 & 8,5 & 12,9 \\
\hline \multirow[t]{2}{*}{ Nie wymaga długotrwałych osobistych zobowiązań } & 4,6 & 34,2 & 20,8 & 28,5 & 5,4 & 6,6 \\
\hline & 3,9 & 19,1 & 22,7 & 31,8 & 8,4 & 14,2 \\
\hline \multirow[t]{2}{*}{ Nie ogranicza wolności człowieka } & 13,8 & 28,4 & 26,1 & 21,5 & 3,4 & 6,9 \\
\hline & 3,1 & 11,8 & 21,7 & 38,4 & 13,3 & 11,8 \\
\hline
\end{tabular}

Uwaga: wartości w wierszu górnym dotyczą wypowiedzi młodych łodzian, w dolnym ogółu łodzian.

Źródło: oprac. własne na podstawie badań ankietowych. 


\subsubsection{Rozwody i separacje wedlug respondentów}

Obecnie w Polsce sądy orzekają rozpad niemal co trzeciego małżeństwa (stosunek małżeństw zawartych do rozwiązanych wskutek rozwodu w 2011 r. wyniósł 3,2). To sprawia, że problem rozwodu dotyczy - bezpośrednio lub pośrednio - coraz większej liczby osób. W konsekwencji zmienia się podejście Polaków do rozwodów, gdyż, jak się wydaje, opinie na ich temat coraz rzadziej wyrażane są z punktu widzenia pewnych ogólnych norm, a częściej przez pryzmat konkretnych sytuacji życiowych.

Łodzianie wyrażają w kwestii rozwodów opinie bardzo zbieżne z poglądami ogółu Polaków ${ }^{58}$, ponad $1 / 4$ respondentów jest zwolennikami tej instytucji i uważa, że jeżeli oboje małżonkowie zdecydują się na rozwód w drodze postępowania sądowego, nie powinni mieć ku temu żadnych przeszkód. Zarówno wśród badanych w starszej grupie, jak i młodszej (ryc. 89) dominował pogląd, że nie popierają oni rozwodów, ale dopuszczają je w pewnych sytuacjach (odpowiednio 49,9 i 56\%). Wystarczającym powodem, aby nastąpił rozwód, dla ankietowanych jest: brutalne traktowanie członków rodziny przez jednego z małżonków (76\%) oraz zdrada jednego z nich (40,2\%). Młodzi łodzianie wyrażają też opinię, że społeczeństwo polskie zmienia się i istniejący kiedyś negatywny stosunek do rozwodów jest zastępowany pozytywnym, takiego zdania jest 83\% ankietowanych. Nieco mniej optymistyczne opinie o postrzeganiu przez społeczeństwo rozwodów wyraża ogół łodzian, uzyskano bowiem niespełna 55\% odpowiedzi na "tak”. Opinie ankietowanych łodzian (ogół mieszkańców), w kwestii rozwodów, kształtują się w zależności od ich wieku $(v=0,409)$, wykonywanego zawodu $(\mathrm{v}=0,291)$ oraz udziału $\mathrm{w}$ praktykach religijnych $(\mathrm{v}=0,157)$. Na zdanie młodszej części społeczeństwa Łodzi w większym stopniu oddziałuje ich sytuacja materialna $(v=0,205)$.

W Kościele rzymskokatolickim jest możliwość przeprowadzenia procesu o stwierdzenie nieważności zawarcia małżeństwa kościelnego. Małżeństwo można uznać za nieważnie zawarte z powodu jakieś przeszkody zrywającej (kan. 1083-1094 KPK) czy na skutek braków dotyczących zgody małżeńskiej (kan. 1095-1107 KPK). Przyczyną nieważności małżeństwa mogą być braki dotyczące formy kanonicznej, a więc sposobu zawierania małżeństwa. Dotyczy to w szczególności kapłana asystującego przy zawieraniu małżeństwa (posiadanie przez niego odpowiedniego upoważnienia).

Ankietowani mieszkańcy Łodzi nie popierają unieważnienia zawarcia związku małżeńskiego przez Sąd Biskupi - ponad 45\% jest zdania, że dopuszczalne jest ono tylko w pewnych sytuacjach. Zdecydowanych zwolenników rozwiązania małżeństwa przez unieważnienie było ponad $22 \%$, uważali oni, że jeśli oboje małżonkowie zdecydują się na unieważnienie, nie

${ }^{58}$ Polacy o rozwodach, 2013, CBOS, Warszawa. 
powinni mieć ku temu żadnych przeszkód. Tylko co ósmy badany był zdecydowanym przeciwnikiem takiego rozwiązania, bez względu na sytuację. Wydaje się dość oczywiste, że bardziej konserwatywne poglądy w tej sprawie były wyrażane przez osoby, których udział w praktykach religijnych był częsty (współczynnik v-Kramera dla tej zmiennej wyniósł 0,478).
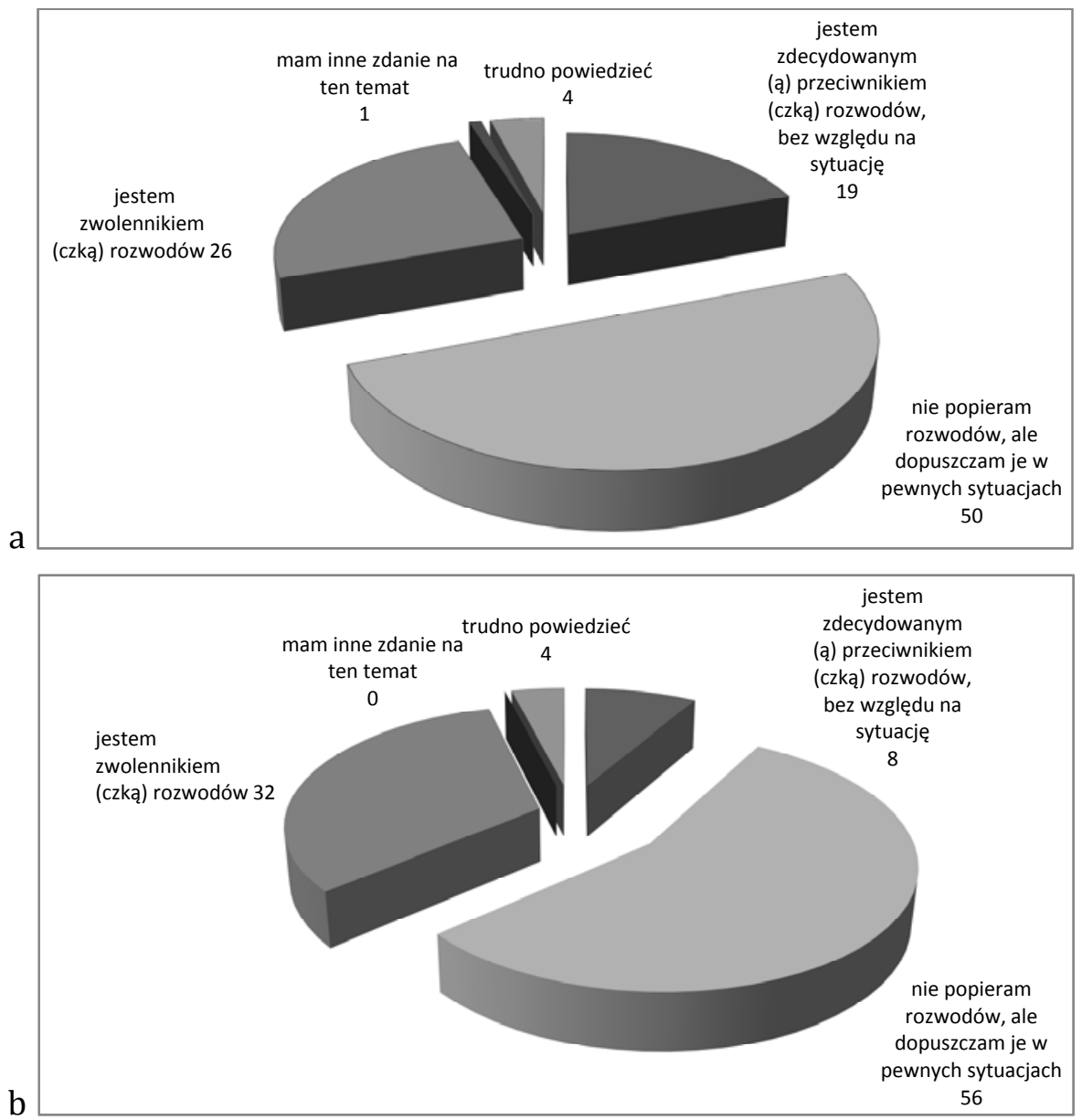

Ryc. 89. Stosunek respondentów do rozwodów, a: łodzianie ogółem; b: młodzi łodzianie (w \%)

Źródło: oprac. własne na podstawie badań ankietowych

W naszym kraju od kilkunastu lat, zgodnie ze zmianami w Kodeksie rodzinnym i opiekuńczym, orzekane są przez sąd separacje małżeńskie. Separacja prawna polega na uchyleniu wspólnoty małżeńskiej, jednak bez prawa wstępowania przez małżonków w nowy związek małżeński. Jak wynika z danych statystycznych z tej możliwości „korzysta” corocznie od kilku do 
kilkunastu tysięcy Polek i Polaków. Według prawa polskiego przesłanką separacji jest zupełny rozkład pożycia małżonków (lecz niejednocześnie trwały, albowiem jest to przesłanką orzeczenia rozwodu) rozumiany jako całkowity zanik więzi psychicznej, fizycznej oraz gospodarczej pomiędzy małżonkami.

Dla większości ankietowanych młodych mieszkańców Łodzi instytucja separacji jest potrzebna $\mathrm{w}$ polskim prawie, takiego zdania jest ponad $51 \%$ respondentów, przeciwne stanowisko reprezentowało niespełna 16\% badanych (ryc. 90). Uważają oni także, że przeprowadzenie w sądzie separacji zamiast rozwodu jest korzystne dla rodzin, w których nastąpił rozkład pożycia. Takie opinie wydało blisko $47 \%$ ankietowanych, przeciwnego zdania był co piąty młody łodzianin. Młode łodzianki nieco częściej niż młodzi mężczyźni wyrażały opinie o możliwości skorzystania z separacji, była to jedyna zmienna, która różnicowała odpowiedzi respondentów $(\mathrm{v}=0,265)$.

Separację, zgodnie z §2 art. 61 Kodeksu rodzinnego i opiekuńczego, orzeka się na podstawie zgodnego żądania małżonków, sąd nie decyduje o winie za rozkład o winie rozkładu pożycia. W tym wypadku następują skutki takie, jak gdyby żaden z małżonków nie ponosił winy. Ponad połowa ankietowanych uważa, że separacja powinna być orzeczona jedynie za zgodą obojga małżonków, blisko $1 / 4$, że także wtedy, gdy chce tego tylko ten z małżonków, który nie jest winien rozkładu pożycia. Według respondentów najlepszym sposobem naprawy sytuacji w związku, w którym nastąpił rozkład pożycia, jest podjęcie samemu takiej inicjatywy (blisko 40\%) lub rozpoczęcie terapii małżeńskiej w poradni świeckiej lub kościelnej (ponad $37 \%$ ). Co dziesiąty pytany wskazuje na pomoc/mediację ze strony rodziny, przyjaciół.

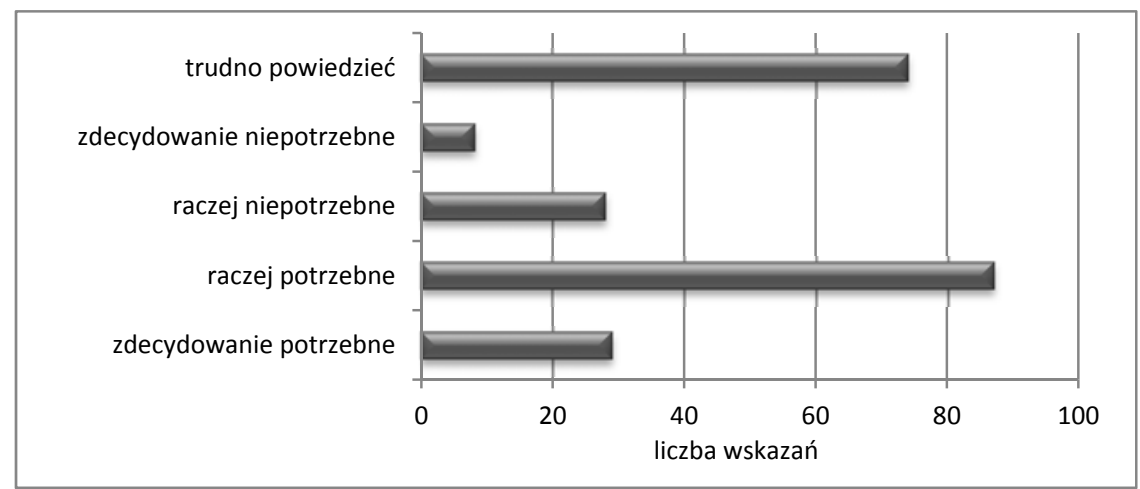

Ryc. 90. Ocena respondentów odnośnie do wprowadzenia do polskiego prawa instytucji separacji - młodzi łodzianie

Źródło: oprac. własne na podstawie badań ankietowych 


\subsubsection{Single wedhug respondentów}

Jedną z alternatywnych form życia małżeńsko-rodzinnego, obok związków kohabitacyjnych, jest życie w samotności, w pojedynkę. Według niektórych badaczy zajmujących się tym zagadnieniem zjawisko fenomenu samotności staje się nawet konkurencyjną formą życia wobec związków nieformalnych czy małżeństwa (Davis 1984; Giddens 1990; Hoorn 1999). W zależności od tego, jaką definicję singla wybierzemy, zmienia się zarówno charakterystyka osób żyjących w pojedynkę, jak i kontekst społeczny ich funkcjonowania, co wynika $\mathrm{z}$ niejednorodności tej grupy pod względem cech społeczno-demograficznych (Żurek 2005; 2008). Wśród żyjących samotnie są zarówno osoby o wysokim poziomie wykształcenia i pokaźnych dochodach, jak i osoby biedne, bezrobotne, chore i niepełnosprawne (Slany 2002a). Krystyna Slany przyjmuje, że życie w samotności obejmuje nie tylko panny i kawalerów, ale także osoby rozwiedzione i owdowiałe. Z kolei Julita Czarnecka (2011) stwierdza, że singiel to „osoba młoda, żyjąca w pojedynkę w dużych miastach, nie pozostająca w stałym związku, bezdzietna". Gromadząc używane do tej pory definicje singla, można powiedzieć, że „żyjący w pojedynkę jest osobą stanu wolnego", nie pozostającą w stałym związku, a także nie zamieszkującą i nie prowadzącą gospodarstwa domowego z inną osobą (Żurek 2008).

Osoby samotne tradycyjnie były postrzegane jako zgorzkniałe i osamotnione, natomiast $\mathrm{w}$ społeczeństwach ponowoczesnych są traktowane jako „proaktywny” typ singla. Zapewne jest to efekt modernizacji społeczeństwa, przejawiającej się industrializacją i urbanizacją, w wyniku których powstały wielkomiejskie skupiska ludności. W dużych ośrodkach miejskich mamy do czynienia ze specyficznymi dla nich zjawiskami, takim jak rozpad rodziny wielopokoleniowej i pojawienie się rodziny nuklearnej, styl życia, anonimowość życia, bezosobowe stosunki społeczne, samotność jednostki oraz rozwój instytucjonalnych form życia społecznego (Slany 2002a). Wśród osób żyjących w pojedynkę istnieją zwolennicy permanentnej samotności oraz samotności czasowej i jest to efekt ich preferencji życiowych, przebytych doświadczeń rodzinnych czy nawet oddziaływania „mody na samotność". Nawet jeśli ludzie mieszkają samotnie, nie znaczy to, że są samotni i nie mają nikogo bliskiego. Świadczą o tym np. związki kohabitacyjne typu Living Apart Together (LAT).

W przypadku zjawiska singli59 mieszkańcy Łodzi wyrażają opinie dość podzielone, tyle samo $\mathrm{z}$ nich popiera taką formę życia co jest przeciwnego zdania (ryc. 91). Jednak poglądy ankietowanych łodzian na temat stosunku polskiego społeczeństwa do osób żyjących samotnie są jeszcze wyraźniej zróżnicowane. Bardziej krytycznie oceniają opinie Polaków i Polek dotyczą-

${ }^{59}$ Zgodnie z definicją, że są to osoby młode, żyjące w pojedynkę. 
ce singli młodzi łodzianie, dla blisko $2 / 3$ z nich społeczeństwo polskie jest negatywnie nastawione do singli, podczas gdy takiego samego zdania jest tylko $24 \%$ z grupy badanych łodzian ogółem. Jednocześnie młodzi ludzie są bardziej pozytywnie nastawieni do zmian i ponad 70\% z nich twierdzi, że społeczeństwo polskie zmienia się stopniowo a istniejący kiedyś negatywny stosunek zastępowany jest pozytywnym. W przypadku ogółu łodzian odsetek ten był mniejszy o 15 punktów procentowych. Jeszcze większe rozbieżności występują w ocenie poziomu akceptacji fenomenu singli przez młodszą i starszą generację naszego społeczeństwa. Młodzi łodzianie są zdania, że bardziej tolerancyjni w sprawie singli są ludzi młodzi, odpowiedzi na "tak" padło blisko 65\%, podczas gdy w drugiej grupie respondentów takich opinii było zaledwie nieco powyżej $24 \%$.
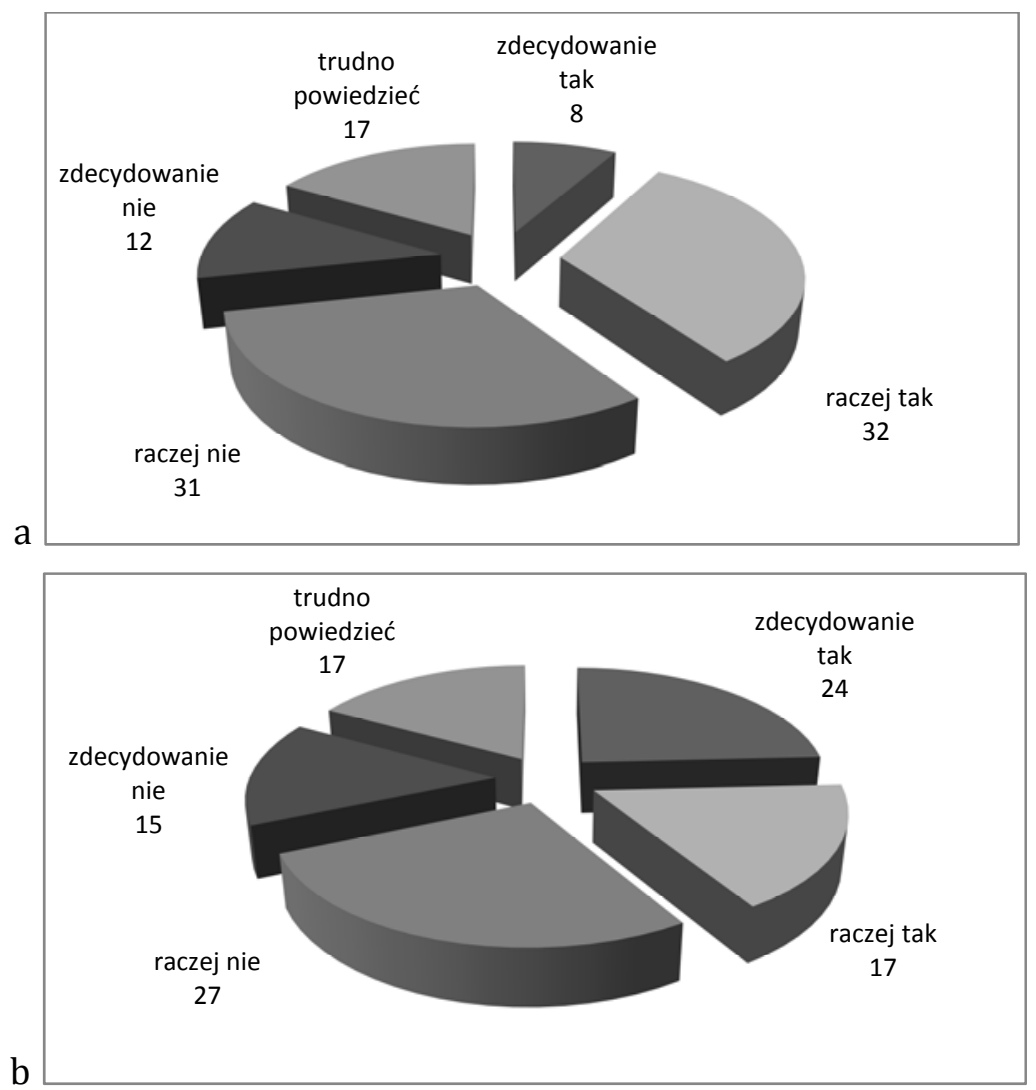

Ryc. 91. Stosunek poparcia respondentów formy życia w pojedynkę; a: łodzianie ogółem; b: młodzi łodzianie ( $w \%$ )

Źródło: oprac. własne na podstawie badań ankietowych 
Jak pisze Slany (2002b) motywy wpływające na wybór życia w pojedynkę wyraźnie różnicują się w zależności od wieku i przebytych doświadczeń. Ludzie młodzi głównie pragną wolności, samodzielności i życia na własny rachunek. Stanowiska reprezentowane przez obydwie grupy badanych mieszkańców Łodzi w kwestii motywacji bycia singlem są stosunkowo zbieżne. Blisko $75 \%$ respondentów z pierwszej grupy uważa, że osoby zostają singlami ponieważ wybierają wolność, a więc życie bez zobowiązań, w opinii $61 \%$ ankietowanych żyją sami, ponieważ nie mogą znaleźć odpowiedniego kandydata, a ponad połowa stwierdziła, że powodem bycia singlem jest obawa przed nieudanym małżeństwem. Dla młodych mieszkańców Łodzi najistotniejszymi powodami, dla których ludzie żyją w pojedynkę jest obawa przed obowiązkami rodzicielskimi $(68,7 \%)$, życie bez zobowiązań $(66,1 \%)$, są też zdania, że założenie rodziny może przeszkodzić w karierze zawodowej (63\%) - por. ryc. 92.

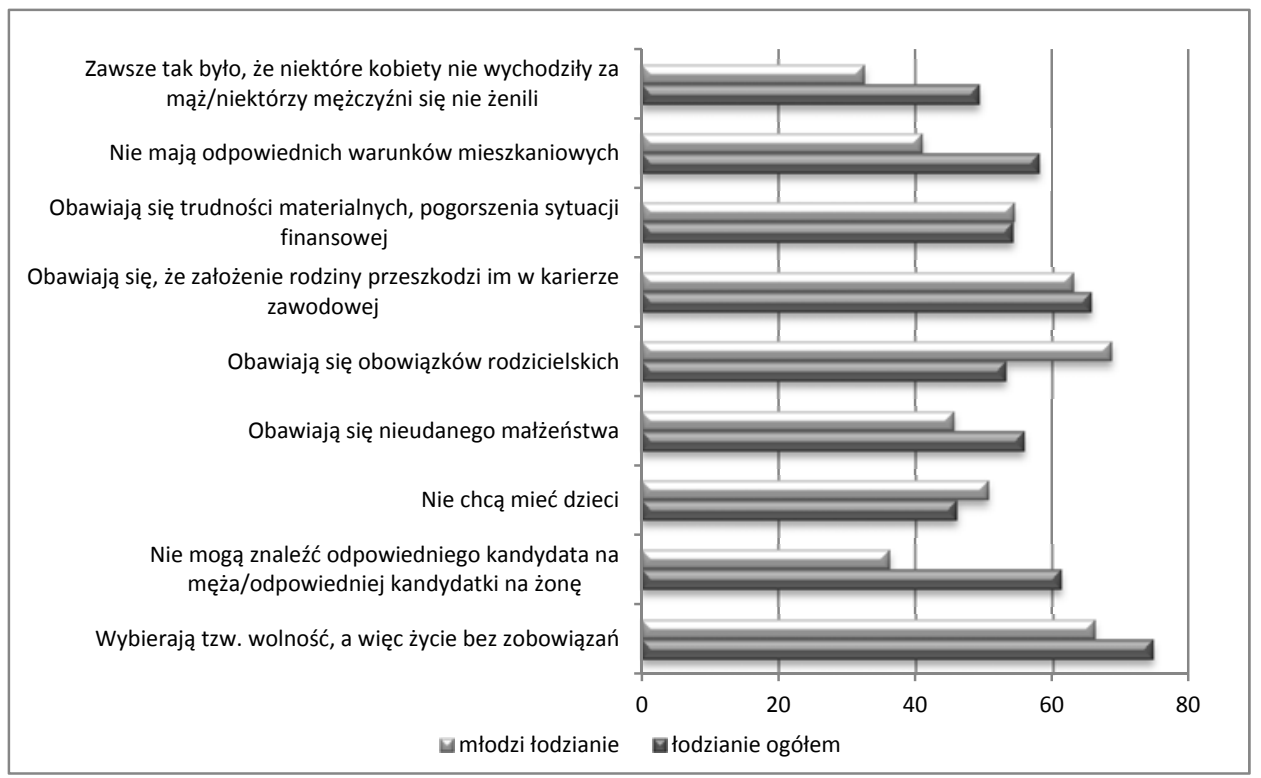

Ryc. 92. Powody, dla których ludzie żyją w pojedynkę (odsetek odpowiedzi na „tak”); Źródło: oprac. własne na podstawie badań ankietowych

Motywacja wpływająca na taki sposób życia według ankietowanych może określać jednocześnie wady i zalety bycia singlem. Jako najważniejsze korzyści życia $\mathrm{w}$ pojedynkę młodzi łodzianie wymieniają czas na pracę i rozwój kariery (w życiu zawodowym), brak zobowiązań i swobodę seksualną (na gruncie towarzyskim) oraz niezależność i swobodę działań (w życiu osobistym). Wśród wad „singlowania” podawano najczęściej brak wsparcia w rozwoju kariery (w życiu zawodowym), „wykluczenie towarzyskie” 
i bycie samotnym (na gruncie towarzyskim) oraz samotność i brak poczucia bezpieczeństwa emocjonalnego (w życiu osobistym). Wymieniane wady $\mathrm{w}$ wielu punktach pokrywają się $\mathrm{z}$ negatywnymi konsekwencjami upowszechniania się tej formy życia. Wskazują na nie przedstawiciele takich dyscyplin jak socjologia, psychologia, filozofia czy teologia (Gajda 1987; Szczepański 1980; Szyszkowska 1988). Do negatywnych stron życia w pojedynkę zalicza się samotność fizyczną, psychiczną i moralną. W wyniku braku więzi fizycznej z innymi, braku rodziny może dojść do samotności psychicznej czyli osamotnienia, które wyraża się brakiem więzi psychicznej z drugim człowiekiem. Natomiast samotność moralna to głęboki kryzys wartości, ideałów, wzorów zachowań.

Zadaniem respondentów było także opisanie życia singla. Wykorzystano dyferencjał semantyczny proponując sześć antonimicznych par określeń i ich ocenę w skali od 0 do 5 . Uzyskane średnie wartości zawierają się od 2,3 do 4,1 . Najwyższe średnie oceny dotyczące życia singla zostały przypisanie możliwościom swobody, jakie niesie taki styl życia $(4,1)$, a najniżej oceniono poczucie bezpieczeństwa $(2,3)$. Nie zaobserwowano znaczącego wpływu płci respondentów na oceny dotyczące życia singli, różnice były bardzo niewielkie, największa $(0,2)$ dotyczyła sytuacji materialnej osób żyjących w pojedynkę, którą wyżej ocenili mężczyźni (ryc. 93).

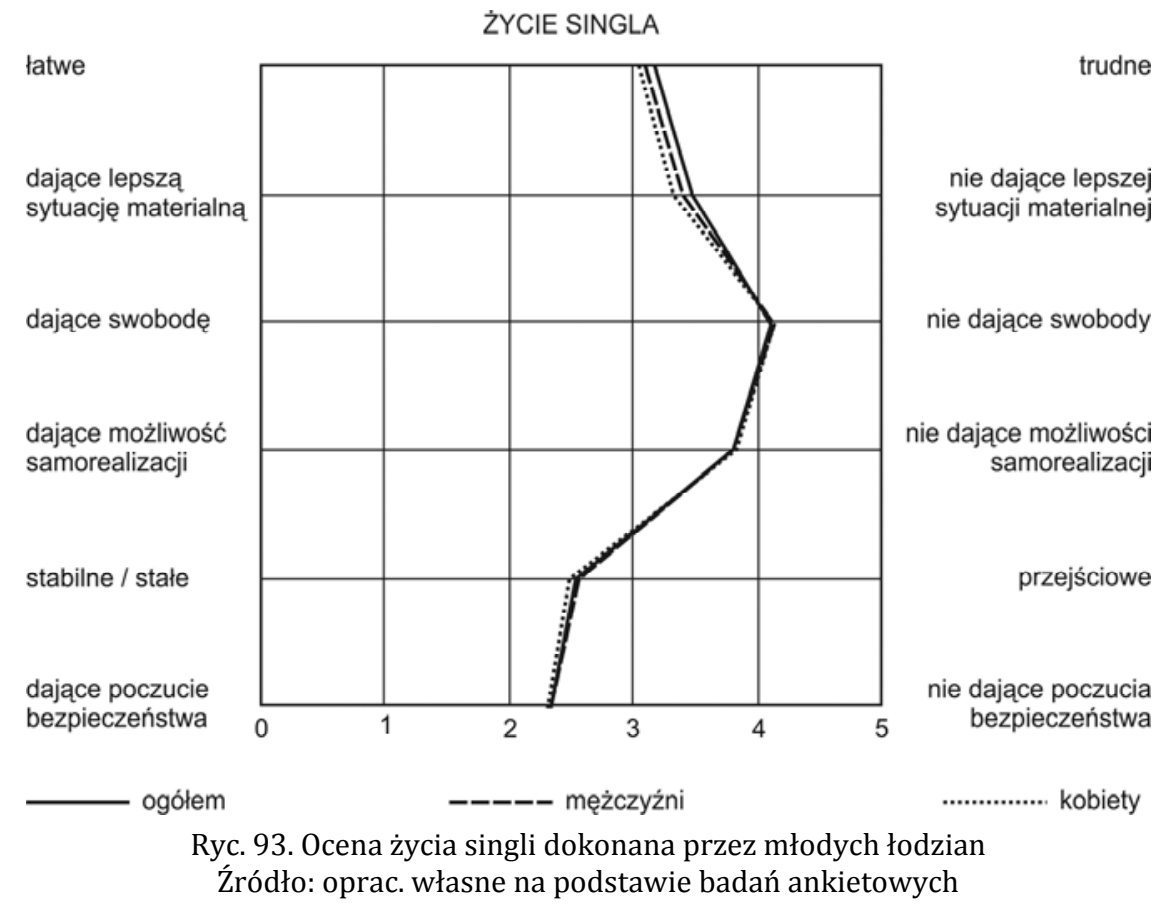




\subsubsection{Rodziny monoparentalne wedhug respondentów}

Monoparentalność obok związków kohabitacyjnych i życia w pojedynkę jest alternatywną formą życia w społeczeństwie. Rodziny monoparentalne to niejednorodne zjawisko, które różnicuje się w zależności od przyczyny jego powstania i od głowy rodziny. Rodziny tego rodzaju mogą być tworzone przez samotne matki lub samotnych ojców, przyczynami zaś ich powstania są śmierć rodzica, rozwód lub separacja oraz urodzenie dziecka przez samotną kobietę poza małżeństwem. Potocznie pojęcie „samotny rodzic” jest przypisywane najczęściej kobietom odpowiedzialnym za wychowanie dzieci. Należy zwrócić także uwagę, że w ponowoczesnym świecie znaczna część społeczeństwa jest zdania, iż samotna kobieta (jeśli jest emocjonalnie gotowa) może zostać matką, o ile sama tego pragnie. W poprzednich typach społeczeństw prokreacja pozamałżeńska była stygmatyzowana i kobiety nie miały swobody w podejmowaniu decyzji prokreacyjnych.

W większości ankietowani mają do rodzin monoparentalnych stosunek pozytywny lub obojętny (ryc. 94). Bardziej akceptowane są takie rodziny przez młodsze pokolenie niż przez osoby starsze, zdecydowanie pozytywny i pozytywny stosunek do nich wyraziło ponad 50\% młodych łodzian i blisko $42 \%$ ogółu mieszkańców Łodzi. Negatywny i zdecydowanie negatywny stosunek miało adekwatnie ponad 7 i 10\% respondentów. Młodzi respondenci wyrażając swoje opinie na temat matek/ojców samotnie wychowujących dzieci unikali skrajnych osądów zarówno zdecydowanego popierania, jak i skrajnego braku akceptacji. Dotyczyło to w równiej mierze świadomego samotnego rodzicielstwa, jak bycia samotnym rodzicem $\mathrm{z}$ powodów losowych. Zdecydowanie akceptowali samotne rodzicielstwo w sytuacji śmierci jednego z rodziców $(72,1 \%)$, powodów losowych $(43,3 \%)$ i opuszczenia rodziny przez jednego z rodziców $(40,0 \%)$. Świadome samotne rodzicielstwo spotkało się ze znacznie mniejszą wyrozumiałością ze strony ankietowanych (tylko 7,9\% odpowiedzi „zdecydowanie tak”).

Wśród cech respondentów wyznaczających ich opinie o rodzinach monoparentalnych, jak już wyżej pisano, jest wiek $(\mathrm{v}=0,279)$ oraz wykształcenie $(\mathrm{v}=0,218)$, a w młodszej części społeczeństwa $\mathrm{w}$ niewielki stopniu stan cywilny $(\mathrm{v}=0,158)$ i status materialny $(\mathrm{v}=0,144)$. 


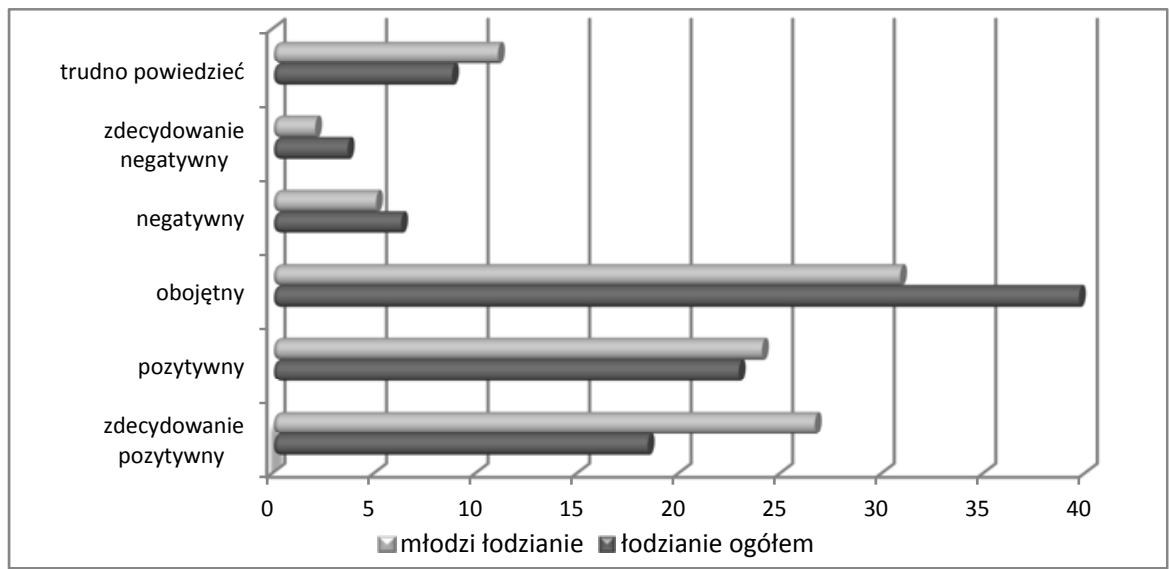

Ryc. 94. Stosunek respondentów do rodzin monoparentalnych (odsetki)

Źródło: oprac. własne na podstawie badań ankietowych

Rodziny monoparentalne są silnie sfeminizowane, w 2002 r. w Łodzi wśród takich rodzin samotne matki stanowiły blisko 90\% ogółu rodzin. Samotny ojciec to dość nietypowa sytuacja w polskim społeczeństwie, ponieważ $\mathrm{w}$ przypadku rozwodu to $\mathrm{z}$ reguły kobietom przyznawane są prawa do opieki nad dziećmi. Łodzianie wyrażali opinie, że samotne tacierzyństwo może się sprawdzić w przypadku pełnienia codziennych funkcji opiekuńczych nad dziećmi i łączeniu ich z pracą zawodową. Gorzej według nich, sprawdzają się samotni ojcowie, jeśli chodzi o kontakty emocjonalne z dziećmi i budowanie więzi rodzinnych (ryc. 95).

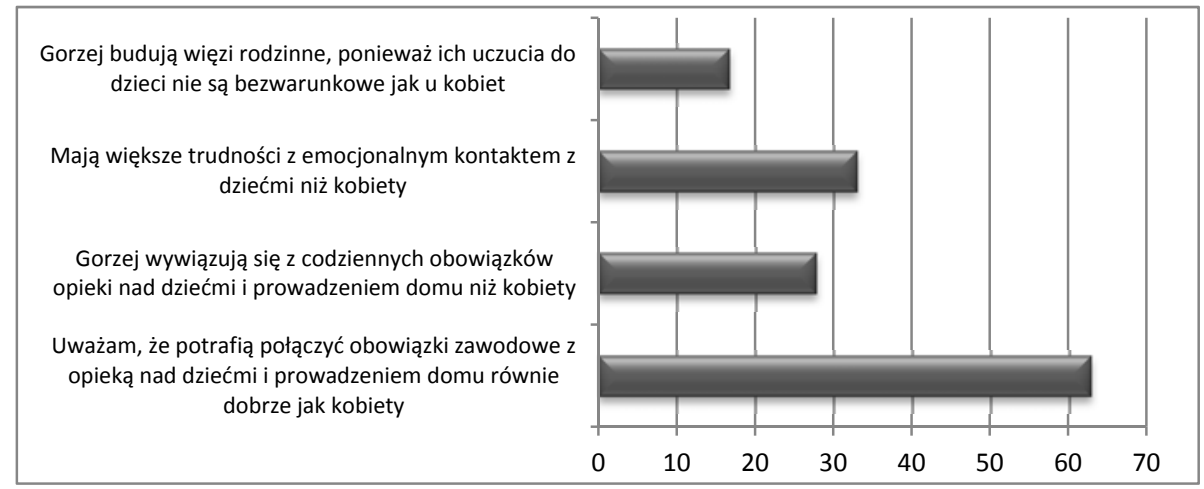

Ryc. 95. Stosunek respondentów do samotnych ojców (odsetki odpowiedzi na „tak”) Źródło: oprac. własne na podstawie badań ankietowych

Tak jak w przypadku innych form życia małżeńsko-rodzinnego respondenci są zdania, że dokonujące się przemiany w kraju obejmują także zwiększony poziom akceptacji dla rodzin niepełnych. Takiego zdania jest 54,2\% ogółu i 49,8\% młodych łodzian. Rozbieżne są natomiast opinie respondentów, która część społeczeństwa jest bardziej tolerancyjna w sto- 
sunku do matek/ojców samotnie wychowujących dzieci. Młodzi respondenci uważają, że młodsze generacje bardziej akceptują takie rodziny niż ludzie starsi (blisko 80\% odpowiedzi na „tak”), natomiast respondenci z drugiej grupy podzielali tę opinię w jedynie blisko w 53\% przypadków.

\subsubsection{Postawy prokreacyjne wedlug respondentów}

Badacze zaobserwowali, że w krajach rozwiniętych, gdzie liczba urodzeń znacząco się obniżyła, mamy do czynienia z tak zwaną fertility gap, czyli różnicą pomiędzy pożądaną, chcianą czy też idealną a faktycznie posiadaną liczbą dzieci (np. Bongaarts 2001; Chesnais 1998; Goldstein i in. 2003; Testa i Grilli 2006). Innymi słowy, istnieją przesłanki, aby przypuszczać, że część zamierzeń prokreacyjnych nie jest realizowana. Chesnais (1998) nazywa to „ukrytym popytem na wsparcie polityki społecznej dla rodzin” (latent demand for family support). Zrozumienie powodów, dla których ludzie mają mniej dzieci niż chcą, czyli powodów dla których nie realizują swoich intencji w tym zakresie, pozwoli na określenie działań, które mogą prowadzić do zwiększenia liczby urodzeń. Zauważono ponadto, że również same pragnienia i zamierzenia prokreacyjne ulegają zmianie. Chociaż nadal istnieje rozbieżność pomiędzy tym, jaka jest pożądana lub idealna liczba dzieci w rodzinie, a tym ile dzieci się faktycznie rodzi - to kolejne pokolenia chcą mieć coraz mniejsze rodziny (Goldstein i in. 2003; Lutz i in. 2005).

Postawy prokreacyjne ankietowanych respondentów w największym stopniu dotyczyły posiadania dwójki dzieci (39\%). Taki sam odsetek respondentów (po 17\%) deklarował chęć zostania rodzicami jednego dziecka i trójki dzieci - por. ryc. 96. Trzeba mieć jednak na uwadze, że bardzo często preferencje nie przekładają się na zachowania demograficzne. Jednocześnie ankietowani w ponad $60 \%$ akceptują odkładanie decyzji prokreacyjnych na później oraz rezygnację z posiadania potomstwa, a tylko nieco więcej niż $1 / 4$ nie pochwala takich postaw (ryc. 97). Na preferencje prokreacyjne młodych osób z Łodzi wpływają ich cechy społeczno-ekonomiczne, chociaż uzyskane wartości współczynnika v-Kramera nie są duże. Zaobserwowano oddziaływanie wykształcenia $(\mathrm{v}=0,201)$, statusu materialnego $(\mathrm{v}=0,187)$ oraz stanu cywilnego $(v=0,157)$. 


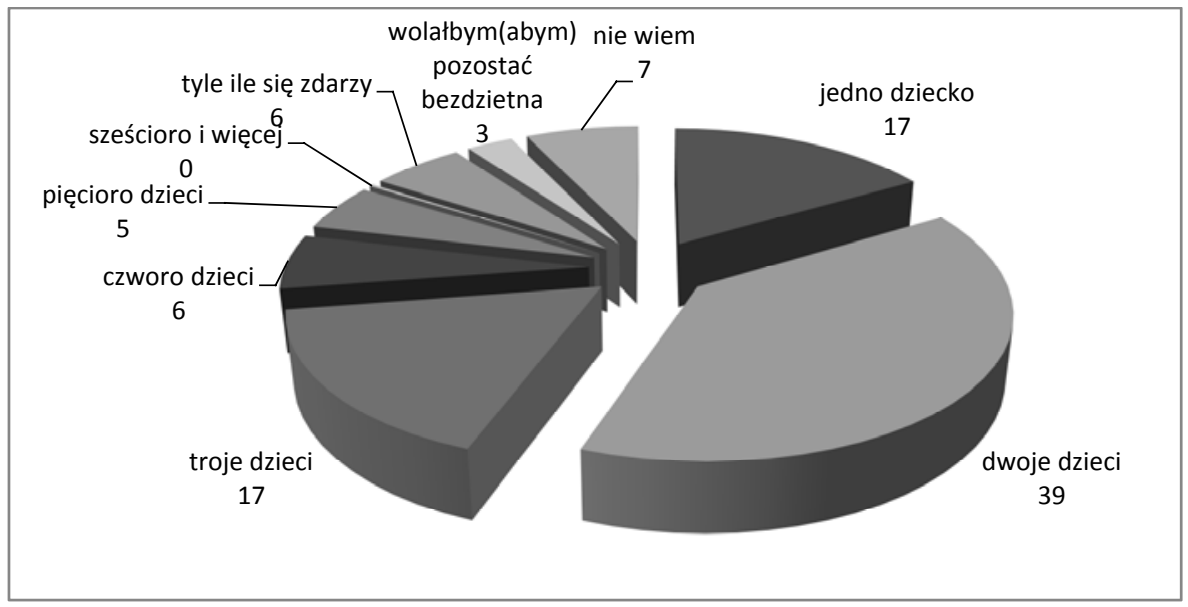

Ryc. 96. Preferencje dotyczące liczby dzieci (w \%)

Źródło: oprac. własne na podstawie badań ankietowych

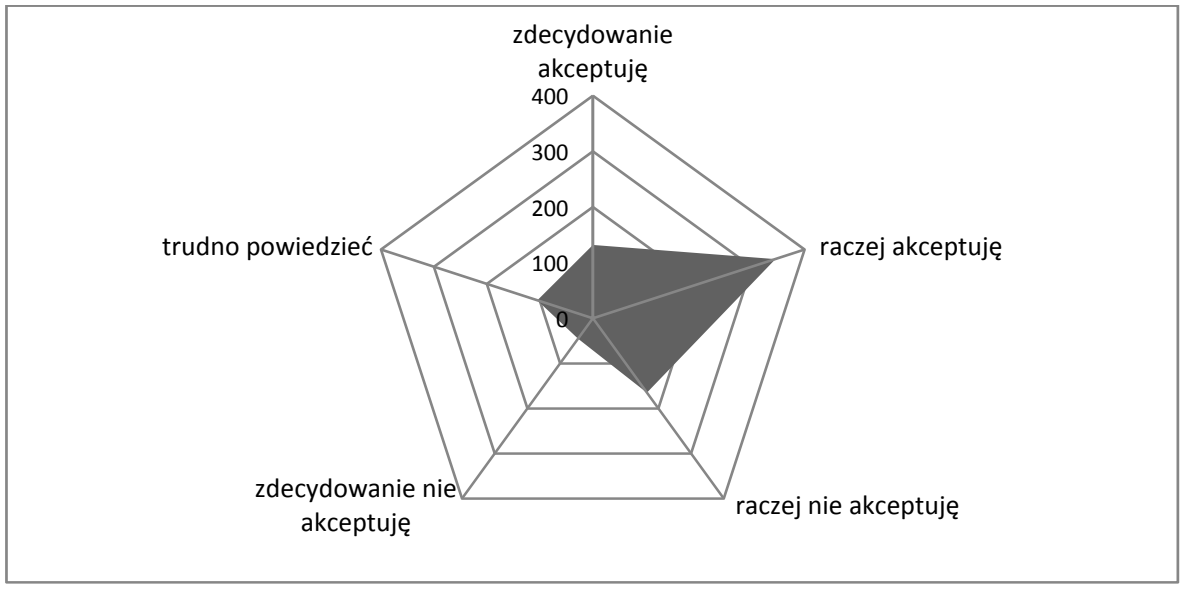

Ryc. 97. Stosunek respondentów do odraczania lub zaniechania zachowań reprodukcyjnych ludzi

Źródło: oprac. własne na podstawie badań ankietowych 


\section{WNIOSKI KOŃCOWE}

W Polsce od blisko ćwierćwiecza dokonują się zmiany zachowań i procesów demograficznych związanych z małżeńskością i rozrodczością. Są to przeobrażenia życia małżeńsko-rodzinnego, które opisuje i wyjaśnia teoria drugiego przejścia demograficznego. Jako najważniejsze uwarunkowania przemian zachowań demograficznych ludności podawane są najczęściej zmiany strukturalne, kulturowe oraz technologiczne. Siłą napędową tych zmian jest szeroko rozumiana modernizacja społeczeństwa. Wśród istotnych czynników odgrywających znaczącą rolę w zmianach zachowań demograficznych jest zmiana systemu norm i wartości wynikająca z indywidualizacji i autonomizacji jednostki. Nie oznacza to zaniku wszelakiego rodzaju form małżeńsko-rodzinnych istniejących dotychczas, tylko pojawienie się nowych, alternatywnych form przy współistnieniu wcześniejszych.

Dyfuzja nowych procesów zachowań matrymonialnych i prokreacyjnych jest zróżnicowana w czasie i przestrzeni. Zapoczątkowane ponad pół wieku temu w Europie Północnej i Zachodniej zmiany objęły pozostałe kraje europejskie oraz kraje wysoko rozwinięte na świecie. Trudno jednoznacznie rozstrzygnąć, jaki był udział procesów transformacyjnych $\mathrm{w}$ przebiegu zmian demograficznych w byłych krajach demokracji ludowej w Europie, a jaki ma wpływ rozprzestrzenianie się nowych wzorców zachowań demograficznych. Nie bez znaczenia pozostają także uwarunkowania wynikające ze specyfiki rozwoju społeczno-gospodarczego kraju. Co prawda Jonathan I. Israel (2001) pisząc o przemianach demograficznych opisywanych przez drugie przejście demograficzne, twierdzi, że „badanie zjawiska w kontekście historii kraju[...] to zdecydowanie niewłaściwe ramy dla tak międzynarodowego i paneuropejskiego zjawiska", niemniej jednak niewłaściwe wydaje się pomijanie tych uwarunkowań w procesach demograficznych. Nie znaczy to, że ze względu na swoją historię pewne kraje są „odporne” na przemiany życia małżeńsko-rodzinnego. Ale może to znaczyć, że przebieg tych procesów jest nieco odmienny w wybranych aspektach zachowań matrymonialnych oraz prokreacyjnych i zależny od tych specyficznych warunków krajowych. Nie wynika z tego, że nasz kraj odznacza się wyjątkowością w tym 
zakresie, niemniej jednak wydaje się, że pewna specyfika w ramach zachowań występuje. Jeśli nawet kierunek zmian i tendencji jest podobny, to są pewne sfery życia małżeńsko-rodzinnego, które wydają się mieć mocne korzenie $\mathrm{w}$ tradycji, religii i nie ulegają całkowitej transformacji. Nie bez znaczenia dla tych zmian jest, zdaniem autorki, to, że Polska znajduje się obecnie na pograniczu dwóch systemów normatywnych (indywidualistycznego i tradycyjnego) i trzech kultur (przednowoczesnej, nowoczesnej i ponowoczesnej), tym samym mając niejednolity system wartości.

Przeprowadzone przez autorkę badania zachowań matrymonialnych i prokreacyjnych $\mathrm{w}$ Polsce potwierdziły wnioski $\mathrm{z}$ innych badań, ale też dostarczyły nowych spostrzeżeń na zmiany w zachowaniach demograficznych. Autorka jako cel główny analizy określiła wyznaczenie tendencji zmian w zachowaniach matrymonialnych i prokreacyjnych w Polsce, uwarunkowań tych przemian oraz wyjaśnienie ich przestrzennego zróżnicowania. Badaniu podano wiele zachowań demograficznych $w$ ramach małżeńskości i rozrodczości. Nie wszystkie zmiany dokonujące się w ramach tych procesów mają ten sam kierunek i tempo zmian. Dlatego też trudno jest z powodu mnogości poruszanych problemów ograniczyć się do wysunięcia jednego czy dwóch ogólnych wniosków. W związku z tym podsumowanie przeprowadzonej analizy autorka sprowadza do następujących wniosków, które jednocześnie dają odpowiedzi na postawione przez autorkę we wstępie pytania badawcze i weryfikują wysunięte hipotezy:

1) Postępujące zmiany w sferze małżeńskości sytuują Polskę wśród krajów Europy Środkowowschodniej o umiarkowanym tempie przemian (blisko wartości średnich dla krajów europejskich). W ramach przemian zachowań matrymonialnych w Polsce zaobserwowano:

- spadek tendencji wchodzenia w związki małżeńskie, szczególnie przy uwzględnieniu dłuższej perspektywy czasowej. W ramach tych zachowań nastąpiła także zmiana rozkładu przestrzennego częstości zawierania małżeństw; tereny północno-zachodnie, które przez kilkadziesiąt lat po wojnie miały najwyższe wartości współczynnika obecnie mają jedne z najniższych wartości w kraju, natomiast podregiony południowo-wschodnie, o niskich do niedawna skłonnościach zawierania związków małżeńskich aktualnie wykazują najwyższe wartości częstości zawierania małżeństw,

- zmianę tendencji częstości legalizowania związków w układzie miastowieś, przez kilkadziesiąt lat po wojnie wyższe wartości wskaźników zawierania małżeństw występowały $\mathrm{w}$ miastach, obecnie są one wyższe na wsi (od 1989 r.), choć różnice wartości wskaźnika są niewielkie,

- wyraźne przemiany w strukturze wieku nowożeńców - w Polsce związki małżeńskie zawierane są w coraz późniejszym wieku, a efektem 
tych zmian jest wzrost mediany wieku i jego zróżnicowanie w układzie miasto-wieś,

- dominację związków wyznaniowych nad cywilnymi, chociaż w rozpatrywanym okresie występowały tendencje zmienne w strukturze związków, od 2002 r. wystąpił spadek „popularności” związków kościelnych, wyraźne są dysproporcje w układzie miasto-wieś, związki wyznaniowe częściej bowiem zawierają mieszkańcy wsi,

- tendencję wzrostową liczby udzielanych rozwodów, szczególnie widoczną w dynamice relacji udzielonych rozwodów do nowo zawartych małżeństw; wystąpił także wzrost rozwodów na wsi,

- zmienny kierunek zmian liczby orzekanych separacji (rekordowy rok 2005), zauważa się większe rozmiary tego zjawiska w miastach,

- wzrostową (acz powolną) tendencję zjawiska kohabitacji w Polsce, niewątpliwie jednak kohabitacja jest fenomenem w dalszym ciągu miejskim i osób o wolnym stanie cywilnym prawnym.

Zjawiska zaliczane do zachowań matrymonialnych wykazują w naszym kraju wyraźne zróżnicowanie przestrzenne. Można zaobserwować trzy układy przestrzenne tych zachowań. Po pierwsze jest to układ wschódzachód, którego cechą charakterystyczną są skrajne wartości analizowanych zjawisk na terenach wschodniej i zachodniej Polski. Przykładami takiego zróżnicowania przestrzennego są rozwody, małżeństwa wyznaniowe, kohabitacja. Jako drugi układ przestrzenny można wyróżnić odmienność zachowań ludności podregionów północnej i zachodniej Polski od wschodniej i południowej, przy czym należy zaznaczyć odwrócenie kierunku zmian wartości analizowanych zjawisk. Przykładem takich zmian jest malejąca skłonność wstępowania w związki małżeńskie w Polsce północnej i zachodniej przy utrzymywaniu się wyższych częstości legalizowania związków w południowych i wschodnich rejonach kraju. Ostatnie zaobserwowane dysproporcje przestrzenne zachowań matrymonialnych wskazują na różnice pomiędzy metropoliami i terenami peryferyjnymi.

2) Dynamika zmian w sferze zachowań prokreacyjnych jest umiarkowana w stosunku do innych krajów Europy Środkowej i Wschodniej, a obserwowane zmiany dotyczą:

- cyklicznego charakteru zjawiska rodności i prawdopodobnego wejścia ludności Polski w kolejną fazę wzrostu rodności, w przypadku przestrzennego zróżnicowania nastąpiło odwrócenie tendencji natężenia rodności w przestrzeni „ziemie dawne - ziemie północne i zachodnie” (od 2000 r.) w stosunku do sytuacji powojennej, przez pół wieku współczynniki urodzeń były wyższe na terenach Polski północnej i zachodniej, obecnie najwyższa rodność jest obserwowana na kilku obszarach kraju leżących w jego różnych częściach, 
- powiększania się zwyżkowej tendencji urodzeń 1. i 2. dziecka i zmniejszanie się udziału urodzeń trzecich i kolejnych - w wyniku tego następują zmiany w strukturze rodziny, dotyczące zmniejszenia rozmiarów zjawiska wielodzietności,

- znaczącego wzrostu urodzeń pozamałżeńskich, pogłębia się różnica w poziomie częstości urodzeń pozamałżeńskich pomiędzy obszarami miejskimi i wiejskimi, w miastach bowiem udział urodzeń pozamałżeńskich jest stale o blisko połowę wyższy niż wśród ludności wiejskiej,

- zmiany wzorca płodności zarówno na terenach miejskich, jak i wiejskich, w miastach pojawił się nowy wzorzec płodności,

- systematycznego spadku dzietność kobiet, przy czym obserwowane zmiany są większe na wsi niż w miastach.

Podobnie jak w przypadku zachowań matrymonialnych, także w sferze zjawisk prokreacyjnych występują dysproporcje przestrzenne. Mamy tu do czynienia ze zróżnicowaniem przestrzennym według podziału wschódzachód (np. urodzenia pozamałżeńskie,) oraz wyraźnymi różnicami w zachowaniach pomiędzy ludnością mieszkającą na terenach miejskich i wiejskich a także mieszkańców metropolii i regionów peryferyjnych.

3) Uwzględniając zróżnicowanie przestrzenne zachowań matrymonialnych i prokreacyjnych można wyróżnić cztery typy zachowań demograficznych w przestrzeni Polski jako efekt dysproporcji przestrzennych sfery małżeńskości i rozrodczości. Przeprowadzona analiza wskazała na utrwalenie się podziału kraju na wschód oraz zachód i północ, które są wyraźnie odmienne pod względem zachowań demograficznych. Ponadto można mówić o pojawieniu się „pionierów nowych zachowań demograficznych”, są nimi aglomeracje miejskie i północno-zachodnia Polska.

4) Przeprowadzone badania potwierdziły wpływ czynników społecznoekonomicznych i demograficznych na zachowania matrymonialne i prokreacyjne. Siła wpływu ich jest zróżnicowana i zależy od rodzaju zachowania.

5) Opinie mieszkańców na temat zachowań demograficznych są zróżnicowane i zależą od ich cech społeczno-demograficznych (wiek, wykształcenie, udział w praktykach religijnych, status materialny). Bardziej tolerancyjni są młodsi respondenci, badani jednak zgodnie twierdzą, zarówno młodsi jak i starsi, że społeczeństwo polskie zmienia się i jest bardziej tolerancyjne niż było kiedyś w stosunku do wybranych zjawisk demograficznych.

Zaobserwowane trendy przemian zachowań matrymonialnych i prokreacyjnych będą się nadal utrzymywać, choć tempo ich może być zróżnicowane. Podobna sytuacja wystąpi w rozkładzie przestrzennym badanych zjawisk. Dalsze badania geograficzne powinny koncentrować się na analizie uwarunkowań zachowań matrymonialnych i prokreacyjnych. Wśród czyn- 
ników wpływających na te zachowania lepiej rozpoznane są czynniki demograficzne i społeczno-ekonomiczne. Inaczej sytuacja przedstawia się, jeśli chodzi o czynniki psychologiczno-świadomościowe. Określenie znaczenia i wpływu czynników $\mathrm{z}$ tych trzech grup na zachowania matrymonialne i prokreacyjne powinno stanowić przyszłe problemy badawcze dla różnych dyscyplin naukowych, $w$ tym geografii ludności. 



\section{LITERATURA}

Abramowicz B., 2008, Teoria imperium jako teoria (anty)globalizacji, „Acta Universitatis Lodziensis Folia Sociologica", nr 33.

Adamczewski W., 1999, Małżeństwo we współczesnych konkordatach, Kontrast, Warszawa.

Ahrons C. R., 1980, Divorce: A crisis of family transition and change, „Family Relations", No 4.

Albrow M., 2005, Globalizacja: teoretyczne aspekty zmian, [w:] P. Sztompka, M. Kucia (red.), Socjologia. Lektury, Znak, Kraków.

Anspach D., 1976, Kinship and divorce, "Journal of Marriage and the Family", vol. 38, No 2.

Aries P., 1980, Two Succesive Motivation for Declining Birth Rate in the West, „Population and Development Review”, No 4.

Arystoteles, 2006, Polityka, PWN, Warszawa.

Babbie E., 2004, Badania społeczne w praktyce, Wyd. Nauk. PWN, Warszawa.

Baizán P., Aassve A., Billari F. C., 2003, Cohabitation, marriage, and fi rst birth: The interrelationship of family formation events in Spain, "European Journal of Population" vol. 19, No 2.

Baker R., 2000, Wojny plemników. Niewierność, konflikt płci oraz inne batalie łóżkowe, Dom Wydawniczy Rebis, Poznań.

Balicki J., Frątczak E., Nam Ch. B., 2007, Przemiany ludnościowe. Fakty - Interpretacje - Opinie, Wyd. Kardynała Stefana Wyszyńskiego, Warszawa.

Barański T., Kaczmarek S., 2007, Changing marriage and divorce rate in Poland compared to other EU Countries, „Bulletin of Geography”, No 7.

Bartkowski J., 2003, Tradycja i polityka, Wyd. Akademickie Żak. Warszawa.

Beck U., 2002, Społeczeństwo ryzyka. W drodze do innej nowoczesności, Wyd. Nauk. Scholar, Warszawa. 
Beck U., Beck-Gernsheim E., 2002, Individualization. Institutionalized individualism and its social and political consequences, Sage Publications, LondonThousand Oaks-New Delhi.

Becker G. S., 1981, A Treatise on the Family, Cambridge, Mass, London.

Becker G. S., 1990, Ekonomiczne teorie zachowań ludzkich, PWN, Warszawa.

Becker G. S., Landes E. M., Michael R. T., 1977, An economic analysis of marital instability, "Journal of Political Economy”, vol. 42.

de Beer J., Deerenberg I., 2007, An Explanatory Model for Projecting Regional Fertility Differences in the Netherlands, „Population Research and Policy Review”, vol. 26, No 5/6.

Beisert M., 1994, Rozwód jako wydarzenie krytyczne w cyklu rozwoju rodziny, „Problemy Rodziny”, nr 2.

Billari F. C., Kohler H.-P., 2004, Patterns of lowest-low fertility in Europe, „Population Studies", vol. 58, No 2.

Billy J. O. G., Landale N. S., McLaughlin S. D., 1986, The effect of marital status at first birth on marital dissolution among adolescent mothers, „Demography”, No 3.

Bloom B. L., Niles R. L, Tatcher A. M., 1985, Sources of marital dissatisfaction among newly separated persons, „Journal od Family Issues”, No 3.

Bogacka H., 1968, Przyczyny rozwodów. Wyniki badania ankietowego przyczyn rozkładu małżeństwa, Warszawa.

Bogacka H., Sobieszak A., 1976, Rozwody w Polsce w latach 1950-1974, [w:] M. Jarosz (red.), Wybrane zagadnienia patologii rodziny, Warszawa.

Bongaarts J., 2001, Fertility and reproductive preferences in post-transitional societies, „Population and Development Review”, No 27, Supplement: Global Fertility Transition.

Bongaarts J., Watkins S. C., 1996, Social interactions and contemporary fertility transitions, „Population and Development Review”, vol. 22.

Booth A., Edwards J., 1985, Age at marriage and marital instability, "Journal of Marriage and the Family, vol. 47, No 1.

Brow S. L., Booth A., 1996, Cohabitation versus Marriage: a Comparison of Relationship Quality, „Journal of Marriage and The Family”, vol. 58.

Bryant J., 2007, Theories of Fertility Decline and the Evidence from Development Indicators, „Population and Development Review”, vol. 33.

Brzezińska A., Ćwiek W., Pietkiewicz B., 2003, Kociołapy, „Polityka”, nr 24.

Brzozowska Z., 2011, Przestrzenne zróżnicowanie urodzeń pozamałżeńskich $w$ Polsce w latach 2002-2010, „Studia Demograficzne”, nr 2(160).

Budnik A., Mrowicka B., Baran S., 2007, The fertility of women Poland in the period of transformation of the political and economics system (the 80's and 90's), „Human Evolution", vol. 18, No 3-4. 
Bumpass L. L, Sweet J. A, 1989, National Estimates of Cohabitation, „Demography”, vol. 26.

Bumpass L.L., Sweet J.A., 1972, Differentials in marital stability, „American Sociological Review", No 37.

Castells M., 2003, Galaktyka Internetu. Refleksje nad Internetem, biznesem i społeczeństwem, Dom Wydawniczy Rebis, Poznań.

Castells M., 2009, Siła tożsamości, Wyd. Nauk. PWN, Warszawa.

Chechliński W., 1978, Kohabitacja - nowa forma współżycia pary, „Problemy rodziny", nr 1.

Chechliński W., 1982, Kohabitacja - nowe zjawisko życia rodzinnego, [w:] M. Ziemska, A. Kwak (red.), Funkcjonowanie rodziny a problemy profilaktyki społecznej i resocjalizacji, Wyd. UW, Warszawa.

Cherlin A., 1977, The effect of children on marital dissolution, „Demography”, No 3.

Chesnais J. C., 1986, La transition demograpique. Etapes, forms. Impilcations economiques, Presses Universitaires, Paris.

Chesnais J. C., 1998, Below-Replacement Fertility in the European Union (EU-15): Facts and Policies, 1960-1997, „Review of Population and Social Policy”, No 7.

Chester R., 1977, Divorce and the family life cycle in Great Britain, [w:] J. Cuisenier (ed.), The family life cycle in European societies, Haga-Paryż.

Chester R., 1981, Divorce and consequences for society, XIXth CFR International Seminar on Divorce and Remarriage, Leuven, Belgium, August-September.

Cieślak M., 1992, Demografia. Metody, analizy i prognozowania, PWN, Warszawa.

Cleek-Guminski M., Pearson T. A., 1985, Perceived causes of divorce: an analysis of interrelationships, „Journal of Marriage and the Family”, vol. 47, No 1.

Cleland J., 2001, The effects of improved survival on fertility: A reassessment, „Population and Development Review”, vol. 27.

Coleman D., 2001, Why Europe does not need a European immigration policy, Evidence submitted to the House of Lords Select Committee on the European Union, in House of Lords, Session 2000-01, 13th Report, „A Community Immigration Policy", The Stationery Office.

Coleman D., 2003, Mass migration and population change, Zeitschrift für Bevölkerungswissenschaft 28 Special issue In Memoriam. Dr. H.-J. Hoffmann-Nowotny, No 2-4.

Coleman D., 2006, Immigration and Ethnic Change in Low-Fertility Countries: A Third Demographic Transition, "Population and Development Review”, vol. 32, Issue 3, September 2006, [dostęp: 13 marca 2013]. Dostępny w internecie: <whttp://onlinelibrary.wiley.com/doi/10.1111/j.1728457.2006.00131.x/ abstrakt>. 
Coleman D., 2007, Tetrii Demograficheskii Perechod (The Third Demographic Transition), 'Demoskop Weekly', No. 299-300, 3-16 September 2007. Translated by Anatoly Vishnevsky, [dostęp: 20 marca 2013]. Dostępny w internecie: <http://demoscope.ru/weekly/2007/0299/tema01.php ISSN 1726-2887>.

Czapiewski K. Ł., Śleszyński P., 2007, Geografia zróżnicowania wyników egzaminów zewnętrznych, „Biuletyn Badawczy. Egzamin”, nr 11, CKE, [dostęp: 16 marca 2013]. Dostępny w internecie: <http://www.cke.edu.pl/index. php? option=content\&task=view\&id=365\&Itemid=179>.

Czaputowicz J., 2004, Społeczność międzynarodowa, [w:] B. Szlachta (red.), Słownik społeczny, Wyd. WAM, Kraków.

Czarnecka J., 2009, Cechy idealnego partnera i idealnego zwiq̨zku w opinii polskich singli i singielek, „Acta Universitatis Lodziensis Folia Sociologica”, 34.

Czarnecka J., 2011, Wielkomiejscy single, Wyd. Poltext, Warszawa.

Davis K., 1945, The World Demographic Transition, „Annals of the American Academy of Political and Social Science", No 237.

Davis K., 1955, Malthus and the Theory of Population, [w:] F. P. Lazarsfeld, M. Rosenberd (eds), The Languageof social Research, Free Press, Glencoe.

Davis K., 1984, Wives and Work: The Sex Role Revolution and its Concequences, „Population and Development Review”, No 10(3).

Demography Report 2010. Older, More Numerous and Diverse Europeans, Eurostat, European Commission, 2011, Luxemburg.

Duchêne j., Gabadinho A., Willems M., Wanner P.,2004., Study of low fertility in the regions of the European Union: Places, periods and causes, [w:] Eurostat: Population and social conditions, 3/2004/F/No 4.

Dzieciuchowicz J., 1992, Zmiany demograficzne w aglomeracji łódzkiej, „Kronika Miasta Łodzi", z. 1.

Dzieciuchowicz J., 1998, Ludność Polski Środkowej: procesy i struktury przestrzenne [w:] A. Werwicki (red.), Transformacja społeczno-ekonomiczna Polski Środkowej, Wyd. UŁ, Łódź.

Dzieciuchowicz J., 2001, Rozwój, ruch naturalny i migracje ludności, [w:] S. Liszewski (red.), Zarys monografii województwa łódzkiego, ŁTN, Łódź.

Dzieciuchowicz J., 2002, Zróżnicowanie demograficzne regionu łódzkiego, [w:] A. Jewtuchowicz, A. Suliborski (red.), Struktury i procesy kształtujące łódzki region społeczno-gospodarczy, Łódź.

Dzieciuchowicz J., 2009 (2010)a, Obraz demograficzny świata u progu XXI wieku, „Acta Universitatis Lodziensis. Folia Geographica Socio-Oeconomica”, No 10, Wyd. UŁ, Łódź.

Dzieciuchowicz J., 2009 (2010)b, Population changes in Łódź at the turn of the 20th and 21st century. The demographic forecast for Łódź, [w:] S. Liszewski (red.), Łódź a monograph of the city, Łódź Scientific Society, Łódź. 
Dzięcioł-Kurczoba B., 2011, Uwarunkowania zróżnicowania przestrzennego wyników matury $w$ Polsce $w$ latach 2005-2008 ze szczególnym uwzględnieniem matury z geografii, UŁ, Łódź [maszynopis pracy doktorskiej].

Easterlin E. A, 1976, An Economic Framework for Fertility Analysis, „Studies and Family Planning", vol. 6, No.2.

Eberhardt P., 2002, Nowe tendencje $w$ ruchu naturalnym ludności Europy $w$ ujęciu geograficznym, „Przegląd Geograficzny”, nr 74(2).

Eberhardt P., 2007, Problematyka demograficzna Polski, „Roczniki Nauk Społecznych", vol. 32.

Eberhardt P., 2011, Phases to the demographic development of Poland, „Czasopismo Geograficzne,, t. 83, z 1-2.

Eberhardt P., 2012, Stopień trafności polskich prognoz demograficznych, „Czasopismo Geograficzne", t. 82, z 1-2.

Eurostat, 2005, Population Projections of the Member States of the EU 2004-Based. Luxembourg:, [dostęp: 15 marca 2012]. Dostępny w internecie: <http://epp. euroat.ec.europa.eu/portal/page/portal/product_details/publication?p_product_c ode=KS-CD-05-001>.

Evans J., 1995, Feminist Theory Today. An Introduction to Second-Wave Feminism, Sage, London.

Flaga M., 2000, Procesy demograficzne na Ukrainie $w$ okresie transformacji ustrojowej, „Czasopismo Geograficzne”, t. 71, z. 3-4.

Florczak W., 2008, Makroekonomiczne uwarunkowania płodności w Polsce: próba kwantyfikacji, „Studia Demograficzne” nr 1-2/153-154.

Frątczak E., 2000, Changes in Fertility Pattern in Poland during the Transformation Period - Measurement and Interpretation, „Polish Population Review”, nr 16.

Frątczak E., 2004, Family and fertility in Poland - changes during the transition period, Paper presented at The PIE International Workshop on Demographic Changes and Labor Markets in Transition Economies, Institute of Economic Research, Hitotsubashi University Tokyo, [dostęp: 15 marca 2012]. Dostępny w internecie: <http://www. ier.hitu.ac.jp/pie/Japanase/seminar/workshop040220/ Fratczak.pdf>.

Frątczak E., 2012, Trwałość pierwszych zwiq̨zków w kohortach urodzeniowych 19511960 oraz 1961-1970, „Studia Demograficzne”, nr 1(161).

Frejka T., 2008, Determinants of family formation and childbearing during the societal transition in Central and Eastern Europe, „Demographic Research”, No 19(7).

Frejka T., Sobotka T., 2008, Fertility in Europe: Diverse, delayed and below replacement, „Demographic Research”, vol. 19, [dostęp: 13 marca 2013]. Dostępny w internecie: <http://www.demographic-research.org/Volumes/ Vol19/3/>. 
Friedan B., 1963, The Femine Mystique, W. W. Norton, New York.

Fukuyama F., 2000, Wielki wstrzas, Politeja, Warszawa.

Gajda J., 1987, Samotność i kultura, IWZZ, Warszawa.

Gałka J., 2009, Dynamika i struktura małżeństw w województwie lubelskim jako wskaźnik przemian społeczno-gospodarczych, Prace Geograficzne, 121, Instytut Geografii i Gospodarki Przestrzennej UJ, Kraków.

Gawryszewski A., 2005, Ludność Polski w XX wieku, PAN IGiPZK, Monografie, 5, Warszawa.

Gawryszewski A., 2008, Historia geografii ludności, [w:] A. Jackowski, S. Liszewski, A. Richling (red.), Historia geografii polskiej, Wyd. Nauk. PWN, Warszawa.

Gawryszewski A., 2009, Ludność Warszawy w XX wieku, Monografie IGIKPZK PAN nr 10, Warszawa.

Gerstel N., 1987, Divorce and stigma, „Social Problems”, No 2.

Giddens A., 1990, The Concequences of Modernity, Polity Press, Cambridge.

Giddens A., 1998, Socjologia. Zwięzłe lecz krytyczne wprowadzenie, Wyd. Zysk i S-ka, Poznań.

Giddens A., 1999, Runway World, BBCnReith Lectures 1999, BBC World Service, London.

Giddens A., 2001, Nowoczesność i tożsamość, Wyd. Nauk. PWN, Warszawa.

Giddens A., 2006, Socjologia, Wyd. Nauk. PWN, Warszawa.

Goldstein J., Lutz W., Testa M. R., 2003, The emergence of Sub-Replacement Family Size Ideals in Europe, „Population Research and Policy Review”, 22(5).

Golinowska S., 1995, Społeczno-demograficzne uwarunkowania przemian rodziny, [w:] S. Golinowska, B. Balcerzak-Paradowska (red.), Rodziny w Polsce. Ewolucja. Zróżnicowanie. Okres transformacji, IPiSS, Warszawa.

Gołata E., 1990, Studia nad terytorialnym zróżnicowaniem płodności kobiet w Polsce, „Monografie i Opracowania SGPiS” nr 13/322.

Gołata E., 1995, Płodność i małżeńskość w Polsce w okresie transformacji społecznogospodarczej, „Studia Demograficzne”, nr 3(121).

Goode W. J., 1963, World revolutions and family patterns, New York.

Gorzelak G., 2002, Polskie regiony w procesie integracji europejskiej, „Studia Regionalne i Lokalne", nr 9(2-3).

Gorzelak G., Płoszaj A., Smętkowski M., 2006, Ocena strategii rozwoju regionu wykorzystanie modelu czterech kapitałów, „Studia Regionalne i Lokalne”, nr 3(25).

Góralski W., 1994, Zawieranie małżeństwa w świetle konkordatu, [w:] W. Góralski (red.), Prawda o konkordacie, Częstochowa.

Grabiński T., Wydymus S., Zeliaś A., 1982, Metody doboru zmiennych w modelach ekonometrycznych, PWN, Warszawa. 
Gręźlikowski J., 2000, Zawarcie małżeństwa konkordatowego, „Ateneum Kapłańskie", z. 3 (547), t. 134.

Gruszczyński L. A., 1991, Kwestionariusze w socjologii. Budowa narzędzi badań surveyowych, Skrypty UŚ, Katowice.

Guraj-Kaczmarek K., 1995, Wiek nowożeńców w różnych typach małżeństw powtórnych, [w:] J. Paradysz (red.), Badania koniunktury demograficznej. Materiały z konferencji Baranowo 7-9.12.1999, Poznań.

Harrop M., Miller W. M., 1987, Elections and Voters. A Comparative Introductions, Macmilian Education Ltd., London.

Haskey J., 2001, Demographic aspects of cohabitation in Great Britain, „International Journal of Law, Policy and Family", vol. 15, No 1.

Héran, F., 2004, Cinq idées reçues sur l'immigration, „Population et Sociétés”, No 397.

Hlond A., 1931, Zarządzenie $w$ sprawie projektu ustawy o małżeństwie. Komentarz do listu pasterskiego biskupów polskich z dnia 10 listopada 1931. Poznań, dnia 13 listopada 1931, „Miesięcznik Kościelny Archidiecezyj Gnieźnieńskiej i Poznańskiej”, t 46, nr 11.

Hoem B., 2000, Entry into motherhood in Sweden: The influence of economic factors on the rise and fall in fertility, 1986-1997, „Demographic Research”, vol. 2.

Hoem J. M., Kostova D., 2008, Early traces of the second Demographic Transition in Bulgaria: A joint analysis of marital and non-marital union formation, 1960-2004, „Population Studies”, vol. 62, No 3.

Holzer J. Z., 1999, Demografia, PWE, Warszawa.

Holzer J. Z., 2003, Demografia, PWE, Warszawa.

Hoorn W. D., 1999, Glad to Live Alone or Happier Together, European Population Conference, The Hague.

Hryniewicz J., 2008, Regiony ideologiczne w Polsce i Niemczech. Zarys procesów długiego trwania, „Studia Regionalne i Lokalne”, nr 33(3).

Ignatczyk W., 1990, Postawy małżeńskie i prokreacje młodzieży polskiej stanu wolnego. Studium statystyczno-demograficzne, „Monografie i Opracowania” nr 305, SGPiS, Warszawa.

Ignatczyk W., 1993, System wartości małżeńskich preferowany przez młodzież polska, „Problemy Rodziny”, nr 3.

Ignatczyk W., 2000, Małżeństwo jako wartość $w$ okresie przemian społeczno-gospodarczych kraju $w$ świetle postaw młodzieży $w$ wieku matrymonialnym w województwie poznańskim, „Ruch Prawniczy, Ekonomiczny i Socjologiczny”, R. 62, nr 2 [Wydawnictwo Naukowe WAM, Poznań].

Inglehart R., 2006, Pojawienie się wartości postmaterialistycznych, [w:] P. Sztompka, M. Kucia (red.), Socjologia, Znak, Kraków. 
Instrukcja dla duszpasterzy, dotycząca małżeństwa konkordatowego, 1998, „Akta Konferencji Episkopatu Polski", t. 1, nr 2.

Israel J. I., 2001, Radical Enlightenment, Philosophy and the Making of Modernity 1650-1750, University Press, Oxford.

Iwanicka-Lyrowa E., 1991, Transformacja poziomu płodności w okresie przejścia demograficznego na świecie, [w:] P. Korcelli, E. Iwanicka-Lyrowa (red.), Geograficzne badania nad płodnościq, Institute of Geography and Spatial Organisation Polish Academy of Science, Materiały konferencyjne 11, Warszawa.

Iwanicka-Lyrowa E., Witkowski J., 1991, Uwarunkowania, determinanty i przestrzenne zróżnicowanie płodności kobiet w latach 1975, 1980, 1983 i 1987, [w:] P. Korcelli, E. Iwanicka-Lyrowa (red.), Geograficzne badania nad płodnościq, Institute of Geography and Spatial Organisation Polish Academy of Science, Materiały konferencyjne 11, Warszawa.

Jabłoński D., Ostasz L., 2001, Zarys wiedzy o rodzinie małżeństwie, kohabitacji i konkubinacie. Perspektywa antropologii kulturowej i ogólnej, Adiaphora, Olsztyn.

Jagielski A., 1978, Geografia ludności, PWN, Warszawa.

Janicka I., 2006, Kohabitacja a małżeństwo w perspektywie psychologicznej, Wyd. UŁ, Łodź.

Janiszewska A., 2007, Dobór przestrzenny i demograficzno-społeczny małżeństw zawieranych $w$ Łodzi, Wyd. UŁ, Łódź.

Jedlicki J., 1988, Jakiej cywilizacji Polacy potrzebuja. Studia z dziejów idei i wyobraźni XIX wieku, Warszawa.

Jędrzejczyk D., 2001, Podstawy geografii ludności, Wyd. Dialog, Warszawa.

Johnson A., 2000, The Blackwell Dictionary of Sociology, A User's Guide to Sociological Language, Blackwell, Oxford, Cambridge.

Kaa van de D. J., 1978, Recent Trends in Fertility in Western Europe. NIDI-Working Paper, No 11, Voorburg, NIDI (published under the same title, [w:] R. W. Hiorns (ed), 1980, Demographic Patterns, [w:] Developed Societies, London, Taylor and Francis Ltd., 1980).

Kaa van de D. J., 1987, Europe's Second Demographic Transition, Washington, DC.

Kaa van de D. J., 1994, The second demographic transition revisited: Theories and expectations, [w:] G. Beets i in. (eds), Population and family in the Low Countries 1993: Late fertility and other current issues, NIDI/CBGS Publication, No. 30, Swets and Zeitlinger, Berwyn, Pennsylvania/Amsterdam.

Kaa van de D. J., 1996, Anchored narratives: The story and findings of half a century of research into the determinants of fertility, „Population Studies”, vol. 50, No 3.

Kaa van de D. J., 1997, Options and sequences: Europe's demographic patterns, „Journal of the Australian Population Association", vol. 14, No 1. 
Kaa van de D. J., 1999, Europe and its population: the long view, [w:] D. J. van de Kaa, H. Leridon, G. Gesano, M. Okolski, European Populations: Unity in Diversity, Dordrecht etc., Kluwer Academic Publishers.

Kaa van de D. J., 2001a, Demographic Transition, Second, „International Encyclopedia of the Social \& Behavioral Sciences", vol. 5.

Kaa van de D. J, 2001b, Postmodern fertility preferences: from changing value orientation to new behavior, [w:] R. A. Bulatao, J. B. Casterline (eds), Global Fertility Transition, Supplement to PDR, vol. 27, New York, Population Council.

Kaa van de D. J., 2001c, Second Demographic Transition:concepts, dimensions, new evidence, [dostęp: 17 lipca 2013]. Dostępny: www.google.pl/\#q=Van+de +Kaa\%C+D.+J.\%2C2001\%2C+Second+Demographic+Transition\%3Aconcepts $\% 2 \mathrm{C}+$ dimensions $\% 2 \mathrm{C}+$ new+evidence $\% 2 \mathrm{C}$.

Kaa van de D. J., 2008, Demographic Transitions, NIDI Working Paper No 1. The Hague: NIDI. 49 p.

Kałuża D., 2008, Małżeństwa „naprawcze" w powojennej Polsce, [w:] E. Ozorowski, R. Cz. Horodeński (red.), Dziecko - Etyka - Ekonomia, Wyd. WSE, Białystok.

Kiernan K., 2000, European perspectives on union formation, [w:] L. Waite, C. Bachrach, M. Mindin, E. Thomson, A. Thornton (eds), Ties that Bind: perspectives on marriage and cohabitation, Aldine de Gruyter, New York.

Kiernan, K., 2002, Cohabitation in Western Europe: trends, issues and implications, [w:] Booth, A. Crouter (eds), Just Living Together: implications of cohabitation on families, children and social policy, Lawrence Erlbaum Associates, New York.

Kitson G. C., Sussman M. B., 1982, Marital complaints, demographic characteristics, and symptoms of mental distress in divorce, „Journal of Marriage and the Family", vol. 42, No 1.

Klima E., 2011, Przestrzeń religijna miasta, Wyd. UŁ, Łódź.

Kluzowa K., Slany K., 1990, Małżeństwa powtórne w Polsce, „Studia Demograficzne”, nr 2 (100).

Kluzowa K., Slany K., 1993, Powtórne małżeństwa osób w starszym wieku w aspekcie demograficznym, „Problemy Rodziny”, nr 3.

Kodeks Prawa Kanonicznego, [dostęp: 12 stycznia 2013]. Dostępny w internecie: <http://episkopat.pl/kosciol/nasza_wiara/kodeks_prawa_kanonicznego/453 8.1,Kodeks_Prawa_Kanonicznego.html>.

Kolevzon M. S., Gottlieb S. J, 1984, The impact of divorce: A multivariate study, „Journal of Divorce”, No 2.

Kontrowersje wokół różnych zjawisk dotyczących życia małżeńskiego i rodzinnego. Komunikat z badań, 2008, CBOS, Warszawa.

Koo H. P., Janovitz B. K., 1983, Interrelationships between fertility and marital dissolution: Results of a simultaneous logit model, 'Demography', $\mathrm{nr}, 2$. 
Kopaliński W., 1989, Słownik wyrazów obcych i zwrotów obcojęzycznych, Wiedza Powszechna, Warszawa.

Korcelli P., 1991, Międzyregionalne zmiany ludnościowe w Polsce: schematy płodności, [w:] P. Korcelli, E. Iwanicka-Lyrowa (red.), Geograficzne badania nad płodnościq, Institute of Geography and Spatial Organisation Polish Academy of Science, Materiały konferencyjne 11, Warszawa.

Kosiński L., 1967, Geografia ludności, PWN, Warszawa.

Kotowska I. E., 1998, Teoria drugiego przejścia demograficznego a przemiany demograficzne w Polsce w latach 1990, „Studia Demograficzne”, nr 4 (134).

Kotowska I. E. (red.), 1999, Przemiany demograficzne w Polsce w latach 90. w świetle koncepcji drugiego przejścia demograficznego, Szkoła Główna Handlowa, Warszawa.

Kotowska I. E., 2005, Europejskie modele rodziny $w$ dobie transformacji, [w:] D. Kalwa, A. Walaszek, A. Żarnowska (red.), Rodzina, prywatność, intymność. Dzieje rodziny polskiej w kontekście europejskim, Wyd. DiG, Warszawa.

Kotowska I. E. (red.), 2009a, Strukturalne i kulturowe uwarunkowania aktywności zawodowej kobiet w Polsce, Wyd. Nauk. SCHOLAR, Warszawa.

Kotowska I. E., 2009b, Zmiany aktywności zawodowej kobiet a modele rodziny w Europie, [w:] M. Sikorska (red.), Być rodzicem we współczesnej Polsce. Nowe wzory w konfrontacji z rzeczywistościq, Wyd. UW, Warszawa

Kotowska I. E., 2010, Uwagi o polityce łączenia pracy zawodowej i rodziny w kontekście nowej demografii Europy i zmian na rynku pracy, [w:] J. Szambelańczyk, M. Żukowski (red.), Człowiek w pracy i polityce społecznej, Wyd. UE w Poznaniu.

Kotowska I. E., Giza-Poleszczuk A., 2010, Zmiany demograficzno-społeczne i ich wpływ na rekonceptualizację polityki rodzinnej w kierunku równowagi $w$ zakresie ochrony praw rodziny i poszczególnych jej członków. Polska na tle Europy, [w:] E. Leś, S. Bernini (red.), Przemiany rodziny w Polsce i we Włoszech i ich implikacje dla polityki rodzinnej, Wyd. UW, Warszawa.

Kotowska I., Jóźwiak J., 2012, Nowa demografia Europy a rodzina, „Roczniki Kolegium Analiz Ekonomicznych", z 28

Kotowska I.E, Jóźwiak J., Matysiak A., Baranowska A., 2008, Poland: fertility decline as a response to profound societal and labour market changes?, „Demographic Research", vol. 19.

Kotowska I., Jóźwiak J., (red.), 2003, Population of Central and Eastern Europe. Challenges and Opportunities, Zakład Wydawnictw Statystycznych, Warszawa.

Kotowska I. E., Jóźwiak J., 2011, Panelowe badanie przemian relacji między pokoleniami, $w$ rodzinie oraz między kobietami i mężczyznami: generacje, rodziny i płeć kulturowa - GGS-PL, „Studia Demograficzne”, nr 1(159).

Kotowska I. E., Sztanderska U., Wóycicka I. (red.), 2007, Aktywność zawodowa i edukacyjna a obowiq̨zki rodzinne w Polsce w świetle badań empirycznych, Wyd. Nauk. SCHOLAR, Warszawa. 
Kowalska I., 1999, Zmiany procesu tworzenia małżeństw, [w:] I. E. Kotowskiej (red.), Przemiany demograficzne w Polsce w świetle drugiego przejścia demograficznego, SGH, Warszawa.

Kressel K., 1985, The process of divorce. How professionals and couples negotiate settlements, New York.

Kulczycka B., 1990, Mieszkaniowe czynniki rozkładu rodzin, [w:] M. Jarosz (red.), Patologia życia rodzinnego, Warszawa.

Kunzel R., 1977, The connections between the family life cycle and divorce rates. An analysis based on European data, [w:] J. Cuisenier (ed.), The family life cycle in European societies, Haga-Paryż.

Kupiszewski M., 1991, Obserwowane i istotne współczynniki rodności w Polsce: 1977-1988, [w:] P. Korcelli, E. Iwanicka-Lyrowa (red.), Geograficzne badania nad płodnością, Institute of Geography and Spatial Organisation Polish Academy of Science, Materiały konferencyjne 11, Warszawa.

Kurczewska U., 2011, Czy Unia Europejska może przezwyciężyć pogłębiający się deficyt demograficzny?, [w:] J. Osiński (red.), Współczesne problemy demograficzne. Rzeczywistość i mity. Ujęcie krajowe, regionalne i globalne, Oficyna Wydawnicza SGH, Warszawa.

Kurek S., 2001, Obszary zagrożone starością w Polsce południowo-wschodniej, „Czasopismo Geograficzne", t. 72, z 1.

Kurek S., 2008, Typologia starzenia się ludności Polski w ujęciu przestrzennym, „Prace Monograficzne AP”, nr 497, Wyd. Nauk. Akademii Pedagogicznej, Kraków.

Kurek S., Lange M., 2012, Zmiany zachowań prokreacyjnych w ujęciu przestrzennym, Wyd. Uniwersytet Pedagogiczny im. Komisji Edukacji, Kraków.

Kurkiewicz J., 1998, Podobieństwa i różnice przemian demograficznych krajów Europy Zachodniej i Środkowo-wschodniej, „Studia Demograficzne”, nr 4 (134).

Kurkiewicz J. (red.), 2010, Procesy demograficzne i metody ich analizy, Wyd. Uniwersytetu Ekonomicznego, Kraków.

Kwak A., 1995a, Konkubinat - kohabitacja w świadomości społecznej, „Problemy Rodziny", t. 35, nr 5.

Kwak A., 1995b, Niezamężna kohabitacja jako zjawisko społeczne, „Studia Socjologiczne", nr 3-4.

Kwak A., 2005, Rodzina w dobie przemian. Małżeństwo i kohabitacja, Wyd. Akademickie „Żak”, Warszawa.

Landry A., 1909 (1982), Les trios theories principates de la population [The three main theories of population], (Originally published in Scientia. Reprinted in 1982 in Adolphe Landry, La revolution demographique, Paris: INED).

Landry A., 1934, La Revolution demographique: Etudes et essays sur les problems de la population, Sirey, Paris.

Landry A., 1945, Traité de Démographie, Payot. 
Larson L., Goltz J. W., Hobart Ch. W., 1994, Families in Canada, Prentices Hall.

Leibenstein H., 1963, Rozwój i zacofanie gospodarcze. Studia z teorii rozwoju gospodarczego, Warszawa.

Lesthaeghe R., 1983, A Century of Demographic and Cultural Change in Wester Europe: An Exploration of Underlying Dimensions, 'Population and Development Review', No 9(3).

Lesthaeghe R., 1991, The Second Demographic Transition in Western Countries: An Interpretations, IPD Working Paper 1991-2, Brussels.

Lesthaeghe R., 1995, The second demographic transition in Western countries: An interpretation, [w:] K. O. Mason, A.-M. Jensen (eds), Gender and family change in industrialized countries, Oxford, Clarendon Press.

Lesthaeghe R., Kaa D. J. van de, 1986, Twee Demografishe Transities, [w:] D. J. van de Kaa, R. Lesthaeghe (eds.), Bevolking: Groei en Krimp, Deventer: Van Loghem Slaterus.

Lesthaeghe R., Surkyn J., 2002, New forms of household formation in Central and Eastern Europe: are they related to the newly emerging value orientations?, „Economic Survey of Europe”, No 1.

Lestheaghe R., Neidert L., Surkyn J., 2006, Household formation and the 'Second demographic transition' in Europe and the U.S. Insinghts from midlle range models, [dostęp: 2 lutego 2011]. Dostępny w internecie: <http://sdt.psc.isr. umich.edu/>.

Leszczycki S., 1962, Rozwój myśli geograficznej, [w:] Geografia powszechna, t. 1, PWN, Warszawa.

Levinger G., 1965, Marital cohesiveness and dissolution: An integrative review, „Journal of Marriage and the Family”, vol. 27, No 1.

Levinger G., 1976, A social psychological perspective on marital dissolution, „Journal of Social Issues", vol. 32.

Lewis R. A., Spanier, G. B, 1979, Theorizing about the quality and stability of marriage, [w:] W. R. Burr, R. Hill, F. I. Nye, I. L. Reiss (eds), Contemporary theories about the family, vol. 1, New York-London.

Lloyd C. B., Ivanov S., 1988, The Effects of Improved Child Survival on Family Planning Practice and Fertility, „Studies in Family Planning”, No 19.

Ludność. Stan i struktura demograficzno-społeczna, 2003, GUS, Warszawa.

Ludność. Stan i struktura demograficzno-społeczna, 2013, GUS, Warszawa.

Lutyńska K., 1984, Wywiad kwestionariuszowy. Przygotowanie i sprawdzenie narzędzia badawczego, Wrocław.

Lutyński J., 1977, Ankieta i jej rodzaje, Materiały do nauczania empirycznych metod badawczych, Warszawa.

Lutyński J., 2000, Metody badań społecznych. Wybrane zagadnienia, ŁTN, Łódź. 
Lutz W., Skirbekk V., Testa M. R., 2005, The Low Fertility Trap Hypothesis: Forces that may lead to further postponemaent and fewer births in Europe, European Demographic Research Papers 4, Vienna Institute of Demography of the Austrian Academy of Sciences, Vienna.

Łobodzińska B., 1974, Rodzina w Polsce, Warszawa.

Mansbridge J., 1995, What is the feminist movement?, [w:] M. M. Ferree, P. Y. Martin (ed.), Feminist Organizations: Harvest of the Women's Movement, Temple University Press, Philadelphia.

Manting D., 1996, The changing meaning of cohabitation and marriage, „European Sociological Review", vol. 12, No 1.

Marti C., Thery I., 2001, The Pacs and marriage and cohabitation in France, „International Journal of Law, Policy and Family", No 15(1).

Matlin N., 1996, The Psychology of Women, Harcourt Brace College Publishers, New York.

Matuszek K., 2004, Zmiana społeczna, [w:] B. Szlachta (red.), Słownik społeczny, Wyd. WAM, Kraków.

Matysiak A., 2009, Is Poland really „immune” to the spread of cohabitation?, „Demographic Research", vol. 21, article 8.

Megasłownik [b.d.], [dostęp: 15 kwietnia 2012]. Dostępny w internecie: <http://megaslownik.pl/slownik/angielsko_polski/62159,common-law+marriage>.

Michalczyk T., 1991, Specyfika systemu wartości młodego pokolenia Ziem Zachodnich, [w:] B. Kozera, T. Michalczyk (red.), Wzory społeczno-kulturowe młodego pokolenia Ziem, Opole.

Miller A. A., 1970, Reactions of friends to divorce, [ w:] P. Bohannan (ed.), Divorce and after, Garden City.

Miszewska B., 1994, Badania nad ruchem naturalnym w Polsce w Latach 1918-1993, [w:] Geografia osadnictwa i ludności w niepodległej Polsce lata 1918-1993, Kierunki badań naukowych, t. 2, Łódź.

Młynarska M., 2009, Individual fertility choices in Poland, Universität Rostock, Rostock

Mynarska M., 2011, Kto planuje mieć dzieci w Polsce do 2015 roku?, „Studia Demograficzne", nr 1(159).

Mynarska M., Bernardi L., 2007, Meanings and attitudes attached to cohabitation in Poland: Qualitative analyses of the slow diffusion of cohabitation among the young generations, „Demographic Research”, vol. 16, article 17.

Mynarska M., Matysiak A., 2010, Diffusion of cohabitation in Poland, „Studia Demograficzne", nr 1-2(157-158).

Mott F. L., More S. F., 1979, The causes of marital disruption among young American women: An interdisciplinary perspective, „Journal of Marriage and the Family”, vol. 41. 
Murphy M., 2000, Editorial: Cohabitation in Britain, „Journal of the Royal Statistical Society", vol. 163.

Nam Ch. B., Philliber S. G., 1984, Population: A Basic Orientation, Prentice Hall, Englewoods Clifs, New York.

Nazio T., Blossfeld H-P., 2003, The diffusion of cohabitation among young women in West Germany, East Germany and Italy, „European Journal of Population”, vol. 19.

North D. C., 1990, Institutions, Institutional Change, and Economic Performance, Cambridge University Press, New York.

Notestein F. M., 1945, Population - the Long View, [w:] T. Schultz (ed.), Food for the World, Chicago.

Nowak E., 1977, Metody taksonomiczne w klasyfikacji obiektów społecznogospodarczych, PWE, Warszawa.

Nowicki M. (red.), 2011, Atrakcyjność inwestycyjna województw i podregionów Polski 2011, IBnGR, Gdańsk.

OECD, 2004, Trends in International Migration: SOPEMI 2003, Paris, OECD.

Ogden P. E., 1998, Population geography, „Progress in Human Geography”, vol. 22, No 1.

Okólski M., 2004, Demografia zmiany społecznej, Wyd. Nauk. SCHOLAR, Warszawa

Okólski M., 2005, Demografia. Podstawowe pojęcia, procesy i teorie w encyklopedycznym zarysie, Wyd. Nauk. SCHOLAR, Warszawa.

Okólski M., Fihel A., 2008, Bilans demograficzny Polski w roku 2033, [w:] Ekspertyzy do Koncepcji i Przestrzennego Zagospodarowania Kraju 2008-2033, vol. IV, Warszawa.

Okólski M. (red.), 1990, Teoria przejścia demograficznego, PWE, Warszawa.

Olshansky S. J., Carnes B. A., Rogers R. G., Smith L., 1998, Emerging infection diseases: The Fifth Stage of the Epidemiologic Transition?, „The World Health Statistics Quarterly", vol. 51, No 4.

Olshansky S. J., Ault B., 1986, The Fourth Stage of the Epidemiologic Transition: the Age of delayed Degenerative Diseases, „The Milbank Quarterly”, vol. 64, No 3.

ONZ, 2004, World Population to 2300, [dostęp 10 stycznia 2011]. Dostępny w internecie: <www.un.org/esa/population/publications/.../WorldPop2300final>

Oorschot van W., Arts W., Gelissen J., 2006, Social Capital in Europe. Measurement and Social and Regional Distribution of a Multifaceted Phenomenon, „Acta Sociologica", vol. 49, No 2.

Paprzycka E., 2009, „Kobiecość” współczesnych kobiet żyjących w pojedynkę, „Acta Universitatis Lodziensis Folia Sociologica", nr 34.

Parysek J. J., Mierzejewska L., 2009, Zmiany społeczno-ekonomicznej struktury Polski w układzie regionalnym (w latach 1999-2006), „Czasopismo Geograficzne”, t. 80, z 1-2. 
Pielka H., 1996, Młodzież szkolna o małżeństwie i przyszłej dobrej rodzinie, „Roczniki Socjologii Rodziny", t. 8.

Pielka H., 1997, Małżeństwo i rodzicielstwo $w$ ocenie rodziców dzieci $w$ młodszym wieku szkolnym, „Roczniki Socjologii Rodziny”, t. 9.

Pielka H., 1998, Nowożeńcy o własnym małżeństwie i rodzinie, „Roczniki Socjologii Rodziny", t. 10.

Piwowarski W., 1977, Religijność miejska w regionie uprzemysłowionym. Studium socjologiczne, Biblioteka „Więzi”, Warszawa.

Platon, 1997, Państwo, Prawa, Antyk, Kęty.

Podogrodzka M., 2011, Rynek pracy determinanta przestrzennego zróżnicowania procesu zawierania małżeństw w Polsce w latach 1990-2009, [w:] M. Balcerowicz-Szkutnik (red.), Współczesne problemy demograficzne $w$ dobie globalizacji aspekty pozytywne i negatywne, Studia Ekonomiczne, nr 95, Uniwersytet Ekonomiczny w Katowicach.

Podogrodzka M., 2012a, Przestrzenne zróżnicowanie płodności w Polsce, „Studia Demograficzne", nr 159.

Podogrodzka M., 2012b, Zmiany zachowań matrymonialnych na obszarach miejskich i wiejskich w Polsce w latach 1990-2009, „Wieś i Rolnictwo”, nr 3, Instytut Rozwoju Wsi i Rolnictwa PAN, Warszawa.

Podogrodzka M., 2013, Przestrzenne zróżnicowanie poziomu oraz dynamiki zawierania małżeństw w Polsce w latach 1999-2011, „Przegląd Geograficzny”, t. 85, z. 2.

Podsumowanie Krajowego Raportu o Rozwoju Społecznym Polska 2012. Rozwój regionalny i lokalny, 2012, Biuro Projektowe UNDP w Polsce, Warszawa.

Polacy o rozwodach, marzec 2013, CBOS, Warszawa, [dostęp: 2 maja 2013]. Dostępny w internecie: < www.cbos.pl/SPISKOM.POL/2013/K_036_13.PDF>.

Poselski projekt ustawy o związkach partnerskich, druk nr 552, [dostęp: 15 listopada 2012]. Dostępny w internecie: <http://www.sejm.gov.pl/Sejm7.nsf/ druki.xsp\#7>.

Potrykowska A., 1991, Zmiany i przestrzenne zróżnicowanie płodności $w$ regionie miejskim Warszawy, [w:] P. Korcelli, E. Iwanicka-Lyrowa (red.), Geograficzne badania nad płodnością, Institute of Geography and Spatial Organisation Polish Academy of Science, Materiały konferencyjne 11, Warszawa.

Poursin J. M., 1976, Ludność świata, PWN, Warszawa.

Prawa o aktach stanu cywilnego z dnia 24 lipca 1998, DzU, 1998, nr 117, poz. 757.

Prinz C., 1995, Cohabiting, Married or Singlei: Portraying, Analyzing and Modeling New Living Arrangements in the Changing Societies of Europe, Avebury, Aldershot, UK.

Raley R. K., 2000, Recent Trends in Marriage and Cohabitation [w:] L. Waite, C. Bachrach, M. Hindin, E. Thompson, A. Thornton (eds), Ties than Bind: Perspectives on Marriage and Cohabitation, Aldine de Gruyter, New York. 
Raport Ewolucja rodziny w Europie 2009, [dostęp: 10 września 2012]. Dostępny w internecie: <http://pl.scribd.com/doc/22418149/Report-Evolution-on-theFamily-in-Europe-2009>.

Raschke H., 1987, Divorce, [w:] M. B. Sussman, S. K. Steinmetz (eds.), Handbook of marriage and the family, New York-London.

Reher D., 2007, Towards long-term population decline: a discussion of relevant issues, „European Journal of Population”, No 23.

Rocznik Demograficzny z różnych lat, GUS, Warszawa.

Rodzina - jej współczesne znaczenie i rozumienie, marzec 2013, CBOS, Warszawa, [dostęp: 5 maja 2013]. Dostępny w internecie: <www.cbos.pl/SPISKOM. POL/2013/K_033_13.PDF>.

Rogers R., Hackenberg R., 1987, Extending Epidemiologic Transition Theory: A New Stage, „Social Biology”, vol. 34, No 3-4.

Romaniuk K., 1967, Skutki ekonomiczne wyżu demograficznego, „Problemy demograficzne Polski Ludowej", Biblioteka Wiadomości Statystycznych, 4, GUS, Warszawa.

Rosset E., 1963, Małżeństwo a reprodukcja ludności, „Studia Demograficzne”, nr 1.

Rosset E., 1975, Demografia Polski. t. 1, Stan, rozmieszczenie i struktura ludności; t. 2, Reprodukcja ludności, PWN, Warszawa.

Rosset E., 1986, Rozwody, PWE, Warszawa.

Rosset E., 1987, Studia nad teoriami ludnościowymi, SGPiS, Instytut Statystyki i Demografii, Warszawa.

Roussel L., 1994, Fertility and Family, [w:] European Population Conference, 1993, Proocedings, Vol. 1, United Nations, Counsil of Europe.

Równość praw kobiet i mężczyzn. Ustawodawstwo Unii Europejskiej i Rady Europy. Orzecznictwo Europejskiego Trybunału Sprawiedliwości oraz Europejskiego Trybunału Praw Człowieka. Teksty i komentarze, 2000, Centrum Praw Kobiet, Warszawa.

Runge J., 1992, Wybrane zagadnienia analizy przestrzennej $w$ badaniach geograficznych, Uniwersytet Śląski, Katowice.

Runge J., 2007, Metody badań w geografii społeczno-ekonomicznej - elementy metodologii, wybrane narzędzia badawcze, Wyd. UŚ, Katowice.

Rychtarikova J., 2000, Demographic Transition or Demographic Shock in Recent Population Development in the Czech Republic?, „Acta Universitas Carolinae Geographica", No 1.

Rydzewski P, 1990, Rozwód w perspektywie teorii wymiany społecznej, „Ruch Prawniczy, Ekonomiczny i Socjologiczny", nr 2.

Rydzewski P., 1991a, Modele i typologie procesu rozwodowego, „Ruch Prawniczy, Ekonomiczny i Socjologiczny", nr 1. 
Rydzewski P., 1991b, Przyczyny rozwodów, „Ruch Prawniczy, Ekonomiczny i Socjologiczny", nr 4.

Rydzewski P., 1992, Rozwód w cyklu życia rodziny, „Studia Demograficzne”, nr 3.

Rydzewski P. 1993, Małżeństwa powtórne osób rozwiedzionych, „Studia Demograficzne", nr 3 (113).

Rydzewski P., 1994, Rozwód - zjawisko wielowymiarowe, „Studia Demograficzne”, nr 3.

Salt J., 2005, Current Trends in International Migration in Europe, Strasbourg: Council of Europe.

Sanchez L., Manning W., Smock P., 1998, Sex-Specialized or Collaborative Mate Selection? Union Transition among Cohabitors, „Social Science Research”, vol. 27.

Sánchez-Berricarde J. J., Fernández-Carro R., 2007, Patterns in the delay and recovery of fertility in Europe, „European Journal of Population”, vol. 23.

Simon J. L., 1981, The Ultimate Resource, Pharos Books, New York.

Simons J., 1995, Fertility and values in 15 Western countries during the 1980's, [w:] R. de Moor (ed.), Values in Western Societies, Tilburg University Press.

Sitek B., 2002, Trwałość i nierozerwalność małżeństwa. Ze studiów nad małżeństwem $w$ prawie rzymskim, kanonicznym Kościoła katolickiego i polskim prawie cywilnym, Wyd. Uniwersytetu Warmińsko-Mazurskiego, Olsztyn.

Slany K., 2000, Przemiany demograficzne w Polsce końca XX wieku, „Problemy Rodziny", nr 4.

Slany K., 2001, Marital and family orientations among students in Poland (in Polish), „Problemy Rodziny”, nr 3.

Slany K., 2002a, Alternatywne formy życia małżeńsko-rodzinnego w ponowoczesnym świecie, Nomos, Kraków.

Slany K., 2002b, Definicje pojęć „małżeństwo i rodzina” w obliczu pojawienia się alternatywnych form życia małżeńsko-rodzinnego, „Małżeństwo i Rodzina”, nr 4.

Slany K., 2003, Dylematy i kontrowersje wokół małżeństwa i rodziny we współczesnym świecie, [w:] J. Balicki i in. (red.), Wybrane problemy współczesnej demografii, Zakład Demografii UŁ, Łódź.

Slany K., 2007, Alternatywne formy życia małżeńsko-rodzinnego, [w:] A. Kojder (red.), Jedna Polska? Dawne i nowe zróżnicowania społeczne, Wyd. WAM, Komitet Socjologii PAN, Kraków.

Slany K., Baszarkiewicz K., 2004, Socjodemograficzny obraz związków partnerskich w Polsce, „Małżeństwo i Rodzina”, nr 4.

Smętkowski M., 2001, Nowe relacje miedzy metropoliq a regionem $w$ gospodarce informacyjnej, „Studia Regionalne i Lokalne”, 7(4).

Sobotka T., 2002, Ten years of Rapid Fertility Changes in European Post-Communist Countries - Evidence and Interpretation, „Groningen Population Research Center Working Papers", No 1. [Groningen NL: University of Groningen]. 
Sobotka T., 2004, Is lowest-low fertility in Europe explained by the postponement of childbearing?, „Population and Development Review”, vol. 30, No 2.

Sobotka T., Testa M. R., 2008, Attitudes and intentions towards childlessness in Europe, [w:] C. Höhn, D. Avramov, I. E. Kotowska (eds), People, Population Change and Policies. Lessons from the Population Policy Acceptance Study, Springer.

Sobotka T., Touleman L., 2008, Changing family and partnership behavior: Common trends and persistent diversity across Europe, „Demographic Research", vol. 19, [dostęp: 10 marca 2013]. Dostępny w internecine: <www. demographic-research.org/Volumes/Vol19/6/>.

Sobotka T., Zeman K., Kantorova V., 2003, Demographic Shifts in the Czech Republic after 1989: A Second Demographic Transition View, „European Journal of Population", No 19(1).

South S.J., 1985, Economic conditions and divorce rate: A time-series analysis of the postwar United States, „Journal of Marriage and the Family”, vol. 47, No 1.

Spéder Z., 2005, The rise of cohabitation as fi rst union and some neglected factors of recent demographic developments in Hungary, „Demografia, English Edition”, vol. 48.

Spengler O., 2001, Zmierzch Zachodu. Zarys morfologii historii uniwersalnej, Wyd. KR, Warszawa.

Stacey J., 1990, Brave New Families: Stories of Domestic Upheaval in Late Twentieth Century America, New York, Basic Books.

Stangeland Ch. E., 1966, Pre-Maltusian doctrinies of Population. A Study in the History of Economic Theory, Augustus M. Kelley, New York.

Starosta P., 2000, Globalizacja i nowy komunitaryzm, „Kultura i Społeczeństwo”, nr 3.

Strzelecki Z., 2001, Polska a Europa. Procesy demograficzne u progu XXI wieku, [w:] Z. Strzelecki, A. Ochocki (red.), Polska a Europa. Procesy demograficzne u progu XXI wieku, RRL, RCSS, Warszawa.

Styrc M., 2011, Ryzyko rozpadu pierwszych małżeństw w Polsce - znaczenie cech indywidualnych, małżeństwa i otoczenia, nr 12, Institute of Statistics and Demography.

Suchecki B. (red.), 2010, Ekonometria przestrzenna. Metody i modele analizy danych przestrzennych, Wyd. C. H. Beck, Warszawa.

Sytuacja Demograficzna Polski. Raport 2010-2011, 2011, Rządowa Rada Ludnościowa, Warszawa.

Sytuacja Demograficzna Polski. Raport 2011-2012, Rządowa Rada Ludnościowa, 2013, Warszawa.

Szacka B., 2003, Wprowadzenie do socjologii, Oficyna Naukowa, Warszawa.

Szacki J., 2010, Historia myśli socjologicznej, Wyd. Nauk. PWN, Warszawa.

Szczepański J., 1980, Sprawy ludzkie, Czytelnik, Warszawa. 
Sztompka P., 1993, Socjologia zmian społecznych, Znak, Kraków.

Sztompka P., 2005, Socjologia zmian społecznych, Znak, Kraków.

Szukalski P., 2001, Płodność i urodzenia pozamałżeńskie w Polsce, „Prace Instytutu Ekonometrii i Statystyki UŁ", seria A, nr 132.

Szukalski P., 2004a, Kohabitacja w Polsce, [w:]: W. Warzywoda-Kruszyńska, P. Szukalski (red.), Rodzina w zmieniającym się społeczeństwie polskim, Wyd. UŁ, Łódź.

Szukalski P., 2004b, Urodzenia pozamałżeńskie w Polsce, [w:] W. WarzywodaKruszyńska, P. Szukalski (red.), Rodzina $w$ zmieniającym się społeczeństwie polskim, Wyd. UŁ, Łodź.

Szukalski P., 2006, Przestrzenne zróżnicowanie związków kohabitacyjnych $w$ Polsce, [w:] P. Szukalski (red.), Szansa na sukces. Recepty współczesnych Polaków, Wyd. UŁ, Łodź.

Szukalski P, 2010, Status społeczny matek dzieci pozamałżeńskich w Polsce przełomu XX i XXI wieku, „Roczniki Socjologii Rodziny”, 2008-2009, t. 19.

Szukalski P., 2012, Wpływ kryzysów na zachowania demograficzne, „Wiadomości Statystyczne", nr 4.

Szukalski P., Oliwińska I., Bojanowska E., Szweda-Lewandowska Z., 2008, To idzie starość - polityka społeczna a przygotowanie do starzenia się ludności Polski, Instytut Spraw Publicznych, Warszawa.

Szyszkowska M., 1988, Samotność i osamotnienie, IWZZ, Warszawa.

Śleszyński P., 2003, Uwarunkowania zróżnicowań przestrzennych wyników egzaminu gimnazjalnego w 2002 r., IGiPZ PAN, Warszawa. Opracowanie wykonano dla Centralnej Komisji Egzaminacyjnej w Warszawie, [dostęp: 16 marca 2013]. Dostępny w internecie: <http://www.igipz.pan.pl/miasto/zbiory/egz_gimn_ 2002_igipz_pan.pdf>.

Śleszyński P., 2004, Ekonomiczne uwarunkowania wyników sprawdzianu szóstoklasistów i egzaminu gimnazjalnego przeprowadzonych w latach 2002-2004. Opracowanie wykonane na zlecenie Ministerstwa Edukacji Narodowej i Sportu, IGiPZ PAN, Warszawa, [dostęp: 16 marca 2013]. Dostępny w internecie: <http://www2. men.gov.pl/images/stories/analizy_ i_badania/ekspertyza.pdf ostatnio dostępne 15.02.2010 r.>.

Śleszyński P., 2007, Środowisko społeczne ucznia a wyniki oceny zewnętrznej w szkołach podstawowych i gimnazjach (2002-2004), [w:] A. Hibszer, T. Michalski (red.), Geografia na egzaminach zewnętrznych 2002-2006 (wybrane zagadnienia), Wydaw. Bernardinum, Pelplin.

Testa M.R., Grilli L., 2006, The influence of childbearing regional contexts on ideal family size in Europe: A multilevel analysis, Forthcoming in Population, vol. 61.

Thibout J. W., Kelley H. H., 1959, The psychology of groups, New York-London.

Thompson W. S., 1929, Population, „American Journal of Sociology”, vol. 34, No 6. 
Thompson W. S., 1946, Population and Peace in the Pacific, Chicago: University of Chicago Press.

Thornton A., 1977, Children and marital stability, „Journal of Marriage and the Family", vol. 39.

Thurnher M., Fenn C. B., Melichar J., Chiriboga D., 1983, Sociodemographic perspectives on reasons for divorce, „Journal of Divorce”, No 4.

Toński P., 1999, Przestrzenne zróżnicowanie płodności w Polsce w latach 1989-1997, „Studia Demograficzne” nr 1/135.

Trent K., South S., 1989, Structural determinants of the divorce rate: A crosssocietal analysis, „Journal of Marriage and the Family”, vol. 51, No 2.

Trost J., 1979, Unmarried Cohabitation, International Library, Vaster.

Tymicki K., 2001, Starokawalerstwo i staropanieństwo. Analiza zjawiska, „Studia Socjologiczne" nr 4.

Tyszka Z., 2003, Rodzina we współczesnym świecie, Wyd. UAM, Poznań.

Vallin J., Meslé F., 2004, Convergences and divergences in mortality. A new approach to health transition, „Demographic Research”, Special Collection 2, art. 2, Published 16 April 2004, [dostęp: 10 marca 2013]. Dostępny w internecie: <www.demographicresearch.org.>.

Walle van de E., 1983, Malthus Today, [w:] J. Dupquier, A. Fauve-Chamoux, E. Grebenik (eds), Maltus Pastand Present, AcademicPress, London.

Warzywoda-Kruszyńska W. (red.), 2004, Rodzina w zmieniającym się społeczeństwie polskim, Wyd. UŁ, Łódź.

Weeks J. R., 2008, Population. An Introduction to Concepts and Issues, Thomson Wadsworth.

The Well-being of Nations. The Role of Human and Social Capital, 2001,0ECD, [dostęp: 12 lipca 2013]. Dostępny w internecie: <http://www.oecd.org/ dataoecd/36/40/33703702.pdf>.

Whelehan I., 1995, Modern Feminist Thought. From the Second Wave to 'PostFeminism', Edinburgh University Press, Edinburgh.

Wieczorkowska G., Siarkiewicz M., 2007, Inteligencja ucznia a wynik egzaminu zewnętrznego, „Biuletyn Badawczy. Egzamin”, nr 13, CKE, Warszawa, [dostęp: 16 marca 2013]. Dostępny w internecie: <www.cke.edu.pl/Badania>.

Wilson B., Smallwood S., 2008, Age differences at marriage and divorce, „Population Trends", No 132.

Wilson C., Airey P., 1999, How can a homeostatic perspective enhance demographic transition theory?, „Population Studies”, vol. 53.

Witt D. D., Davidson B., Sollie D. L., Lowe G. D., Peek C. W., 1987, The consequences of early marriage on marital dissolution, „Sociological Spectrum”, No 7.

Włostowska K., 1996, Małżeństwo i życie rodzinne w świadomości studentów uczelni wychowania fizycznego, „Roczniki Naukowe AWF”, Warszawa, t. 2. 
Wnuk-Lipiński E., 2004, Oblicza globalizacji - konceptualizacja pojęcia, [w:] S. Amsterdamski (red.), Globalizacja i co dalej?, Wyd. IFiS PAN, Warszawa.

World Population Prospect. The 2010 Revision, New York, 2011, [dostęp: 26 października 2012]. Dostępny w internecie: <http://esa.un.org/wpp/ Documentation/publications.htm>.

Wójcik P., Herbst M., 2011, Obszary polaryzacji i dyfuzji rozwoju społeczno-gospodarczego w Polsce. Próba delimitacji, Ministerstwo Rozwoju Regionalnego, Warszawa, [dostęp: 17 marca 2012]. Dostępny w internecie: <http:// www.mrr.gov.pl/szukaj/strony/Results.aspx?k=obszary\%20polaryzacji\%20i2 0dyfuzji\&s=www.mrr.gov.pl>.

Wrigley E. A., 1983, Malthus' Model of Pre-Industrial Economy, [w:] J. Dupquier, A. Fauve-Chamoux, E. Grebenik (eds), Maltus Pastand Present, AcademicPress, London.

Wróblewska W., 2009, Teoria przejścia epidemiologicznego oraz fakty na przełomie wieków w Polsce, „Studia Demograficzne”, nr 1(155).

Wu Z., Pollard M. S., 2000, Economic circumstances and the stability of nonmarital cohabitation, „Journal of Family Issues”, vol. 21.

Yearbook Demographic 2011, 2012, United Nations, New York, [dostęp: 15 listopada 2012]. Dostępny w internecie: <http://unstats.un.org/unsd/demographic /products/dyb/dyb2.htm>.

Zagórny S., 1991, Przemiany więzi społecznej młodzieży Ziem Zachodnich, [w:] B. Kozera, T. Michalczyk (red.), Wzory społeczno-kulturowe młodego pokolenia Ziem Zachodnich, Opole.

Zakharov S., 1997, Fertility Trends in Russia and the European New Independent States: Crisis or Turning Point?, „Expert Group Meeting on Below-replacement Fertility”, ESA/P/WP.140, Nov. 4-6. New York: United Nations Population Division.

Zakharov S., 2008, Russian Federation: From the first to second demographic transition, „Demographic Research”, vol. 19.

Zakharov S., Ivanova E., 1996, Fertility Decline and Recent Changes in Russia - On the Threshold of the Second Demographic Transition, [w:] DaVanzo J. (ed.), Russia's Demographic Crisis, Santa Monica CA: Rand Corporation.

Zaręba S. H., 2006, Religijność dorosłych Polaków na początku XXI wieku, Instytut Statystyki Kościoła Katolickiego SAC, Licheń.

Zarycki T., 1997, Nowa przestrzeń społeczno-polityczna Polski, EUROREG, Uniwersytet Warszawski, Warszawa.

Zawadzki K., 1995, Małżeństwa osób niepełnoletnich, „Acta Universitatis Lodziensis", Folia Paedagogica et Psychologica, nr 35.

Żurek A., 2005, Przejście od kolektywizmu do indywidualizmu. O popularności instytucji małżeństwa, [w:] A. Sakson (red.), Porządek społeczny a wyzwania współczesności, Wyd. Nauk. UAM, Poznań.

Żurek A., 2008, Single. Żyjąc w pojedynkę, Wyd. Nauk. UAM, Poznań. 


\section{Materiały źródłowe}

Bank Danych Lokalnych, GUS, Warszawa, www.stat.gov.pl.

Baza Danych Demografia, GUS, Warszawa, www.stat.gov.pl.

Dekret z dnia 25 września 1945 r. Prawo małżeńskie, DzU, 1945, nr 48, poz. 270.

Dekret z dnia 25 września 1945 r. Prawo o aktach stanu cywilnego, DzU, 1945, nr 48, poz. 272.

Dekret z dnia 25 września 1945 r. Przepisy wprowadzające prawo o aktach stanu cywilnego, DzU, 1945, $\mathrm{nr} 48$, poz. 273.

Dekret z dnia 8 czerwca 1955 r. Prawo o aktach stanu cywilnego, DzU, 1955, nr 25, poz. 151.

Kodeks Prawa Kanonicznego, [dostęp: 13 listopada 2012]. Dostępny w internecie: $<$ http://archidiecezja.lodz.pl/prawo.html>.

Obwieszczenie Ministra Spraw Wewnętrznych i Administracji z dnia 4 listopada 1998 $r$ r. $w$ sprawie ogłoszenia wykazu stanowisk, których zajmowanie upoważnia do sporządzenia zaświadczenia stanowiq̨cego podstawę sporządzenia aktu małżeństwa zawartego w sposób określony w art. 1 \& 2 i 3 Kodeksu rodzinnego i opiekuńczego, „Monitor Polski”, 1998, nr 40, poz. 554.

Obwieszczenie Prezesa Trybunału Konstytucyjnego z dnia 18 grudnia 1997 r. o utracie mocy obowiqzującej art. 1 pkt 2, art. 1 pkt 5, art. 2 pkt 2, art. 3 pkt 1 i art. 3 pkt 4 ustawy o zmianie ustawy o planowaniu rodziny, ochronie płodu ludzkiego i warunkach dopuszczalności przerywania ciqży oraz o zmianie niektórych innych ustaw, DzU, $1997 \mathrm{nr}, 157$, poz. 1040.

Rozporzqdzenie Ministra Zdrowia z dnia 19 grudnia 1959 r. w sprawie przerywania ciąży, DzU, 1960, nr 2, poz. 15.

Rozporządzenie Ministra Zdrowia i Opieki Społecznej z dnia 13 stycznia 1962 r. zmieniajace rozporzq̨dzenie $z$ dnia 19 grudnia 1959 r. w sprawie przerywania ciq$\dot{z} y$, DzU, 1962, nr 7, poz. 35.

Rozporzqdzenie Ministra Zdrowia i Opieki Społecznej z dnia 7 listopada 1980 r. zmieniające rozporządzenie w sprawie przerywania ciąży, DzU, 1980, nr 26, poz. 110.

Rozporzqdzenie Ministra Zdrowia i Opieki Społecznej z dnia 30 kwietnia 1990 r. $w$ sprawie kwalifikacji zawodowych, jakie powinni posiadać lekarze dokonujący zabiegu przerywania ciąży, oraz trybu wydawania orzeczeń lekarskich o dopuszczalności dokonania takiego zabiegu, DzU, 1990, nr 29, poz. 178.

Rozporzq̨dzenie Rady Ministrów z dnia 17 lipca 1981 r. w sprawie urlopów wychowawczych, DzU, 1981, nr 19, poz. 97.

Rozporzadzenie Rady Ministra z dnia 13 lipca w sprawie wprowadzenia Nomenklatury Jednostek Terytorialnych do Celów Statystycznych, DzU, 2000, nr 58, poz. 685. 
Rozporzq̨dzenie Rady Ministrów z dnia 14 listopada 2007 r. w sprawie wprowadzenia Nomenklatury Jednostek Terytorialnych do Celów Statystycznych, DzU, 2007, nr 214, poz. 1572 i 1573.

Ustawa z dnia 27 czerwca 1950 r. Kodeks rodzinny, DzU, 1950, nr 34, poz. 308.

Ustawa z dnia 27 kwietnia 1956 r. o warunkach dopuszczalności przerywania ciąży, DzU, 1956, nr 12, poz. 61.

Ustawa z dnia 2 grudnia 1958 r. o zmianie przepisów prawa o aktach stanu cywilnego, DzU, 1958, nr 72, poz. 358.

Ustawa z dnia 25 lutego 1964 r. - Kodeks rodzinny i opiekuńczy, DzU, 1964, nr 9, poz. 59 z późniejszymi zmianami.

Ustawa z dnia 26 czerwca 1974 r. Kodeks pracy, DzU, 1974, nr 24, poz. 141.

Ustawa z dnia 29 września 1986 r. - Prawo o aktach stanu cywilnego, DzU, 1986, nr 36, poz. 180.

Ustawa z dnia 7 stycznia 1993 r. o planowaniu rodziny, ochronie płodu ludzkiego i warunkach dopuszczalności przerywania ciąży, DzU, 1993, nr 17, poz. 78.

Ustawa z dnia 30 sierpnia 1996 r. o zmianie ustawy o planowaniu rodziny, ochronie płodu ludzkiego i warunkach dopuszczalności przerywania ciąży oraz o zmianie niektórych innych ustaw, DzU, 1996, nr 139, poz. 646.

Ustawa z dnia 21 maja 1999 r. o zmianie ustaw Kodeks rodzinny i opiekuńczy, Kodeks cywilny, Kodeks postępowania cywilnego oraz niektórych innych ustaw, Dz.U., 1999, nr 52, poz. 532.

Ustawa z dnia 28 listopada 2003 r. o świadczeniach rodzinnych, DzU, 2003, nr 228, poz. 2255.

Ustawa z dnia 11 maja 2012 r. o zmianie ustawy o emeryturach i rentach z Funduszu Ubezpieczeń Społecznych oraz niektórych innych ustaw, DzU, nr 0, poz. 118.

Ustawa z dnia 12 lipca 2013 r. o zmianie ustawy - Kodeks pracy oraz ustawy o zwiąkach zawodowych, [dostęp: 28 lipca 2013]. Dostępny w internecie: http://orka.sejm. gov.pl/proc7.nsf/ustawy/1105_u.htm 


\section{SPIS TABEL}

Tabela 1. Cechy rodzin tradycyjnych i ich alternatyw ....................................................11

Tabela 2. Cechy rodzin tradycyjnych i ich alternatyw ....................................................14

Tabela 3. Opracowania naukowe podejmujące problematykę współczesnych zachowań matrymonialnych i prokreacyjnych ............................................18

Tabela 4. Rodzaje zjawisk i zdarzeń demograficznych...............................................25

Tabela 5. Koncepcja wyjaśniania przemian drugiego przejścia demograficznego ....59

Tabela 6. Periodyzacja historii według Sorokina.

Tabela 7. Udział kawalerów i panien w wybranych grupach wieku w 1900 r...... 105

Tabela 8. Rodzaje pierwszych związków wśród kobiet według wieku w czasie badania

Tabela 9. Ludność w wieku 15 lat i więcej według stanu cywilnego prawnego i faktycznego oraz płci w $2002 \mathrm{r}$.

Tabela 10. Ludność $w$ wieku 15 lat i więcej według stanu cywilnego prawnego i faktycznego oraz płci w $2011 \mathrm{r}$.

Tabela 11. Urodzenia żywe na ziemiach dawnych oraz zachodnich i północnych w latach 1948-2011

Tabela 12. Urodzenia żywe według kolejności urodzenia w Polsce w latach 1950-2011.

Tabela 13. Urodzenia pozamałżeńskie w Polsce w latach 1960-2011 ................... 160

Tabela 14. Płodność kobiet w latach 1950-2011........................................................ 163

Tabela 15. Wzorce płodności w Polsce w latach 1950-2011 ……………………..... 165

Tabela 16. Klasy określające etapy rozwoju struktury wieku ekonomicznego

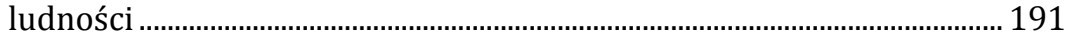

Tabela 17. Model czterech kapitałów............................................................................. 218

Tabela 18. Miary rozwoju podregionów - operacjonalizacja ..................................... 219

Tabela 19. Rodzaj zmiennych.....................................................................................223

Tabela 20. Parametry regresji wielorakiej cech demograficznych na zmienne objaśniane.

Tabela 21. Parametry regresji wielorakiej cech społeczno-ekonomicznych na zmienne objaśniane

Tabela 22. Parametry regresji wielorakiej cech demograficznych na zmienne objaśniane - modele dopasowane.

Tabela 23. Parametry regresji wielorakiej cech społeczno-ekonomicznych na zmienne objaśniane - modele dopasowane

Tabela 24. Funkcje związku nieformalnego według respondentów 


\section{SPIS RYCIN}

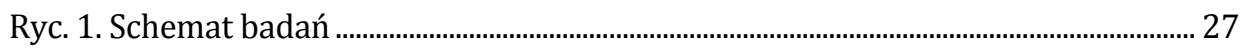

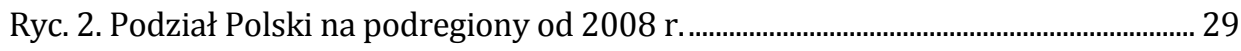

Ryc. 3. Wzrost liczby ludności i produkcja żywności ........................................................... 40

Ryc. 4. Klasyczny model przejścia demograficznego............................................................ 45

Ryc. 5. Trójfazowy model przejścia demograficznego......................................................... 46

Ryc. 6. Trójfazowy model przejścia demograficznego a struktura wieku ...................... 48

Ryc. 7. Czterofazowy model przejścia demograficznego...................................................... 49

Ryc. 8. Powiązanie przemian modernizacyjnych i postmodernizacyjnych z przekształceniami ludnościowymi w poszczególnych fazach przejścia demograficznego.................................................................................. 50

Ryc. 9. Przemiany w ramach przejścia demograficznego ................................................... 51

Ryc. 10. Podstawowe typy przejścia demograficznego (według J. C. Chesnaisa) ........ 54

Ryc. 11. Społeczne zmiany relacji międzyludzkich na poziomie makro i mikro........... 61

Ryc. 12. Czynnik wpływające na przemiany w sferze płodności ........................................ 62

Ryc. 13. Powiązanie przemian modernizacyjnych i postmodernizacyjnych z przekształceniami ludnościowymi w poszczególnych fazach przejścia demograficznego.

Ryc. 14. Roczna imigracja legalna, EU-15 (netto), 12 zachodnioeuropejskich krajów (brutto), i Stany Zjednoczone (brutto)

Ryc. 15. Wskaźnik dzietności ludności krajowej i obcokrajowców: wybrane

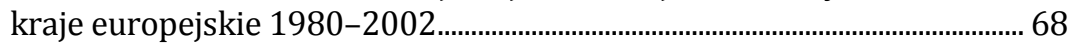

Ryc. 16. Obcokrajowcy i ich struktura, Holandia 1956-2003 (w mln) ............................ 70

Ryc. 17. Interakcje między liczbą i jakością dzieci w rodzinie: krzywe obojętności wyboru dzieci oraz krzywe ograniczeń budżetowych gospodarstwa domowego .

Ryc. 18. Małżeństwa na 1000 mieszkańców w Polsce w latach 1946-2011 ...............104

Ryc. 19. Współczynnik zawierania małżeństw w krajach europejskich w 2011 r...107

Ryc. 20. Mediana wieku nowożeńców w Polsce w latach 1950-2011 ...........................108

Ryc. 21. Rozwody na 1000 ludności w Polsce w latach 1946-2011 ...............................110

Ryc. 22. Rozwody na 1000 zawartych małżeństw w Polsce w latach 1946-2011 ....111

Ryc. 23. Rozwody w krajach europejskich w 2011 r..........................................................112

Ryc. 24. Współczynnik zawierania małżeństw na 1000 ludności w wieku 15 lat i więcej w 2011 r. według podregionów - miasto-wieś..............................125

Ryc. 25. Współczynnik zawierania małżeństw na 1000 ludności w wieku 15 lat i więcej w 2002 i 2011 r. według podregionów 
Ryc. 26. Zmiany wartości współczynnika zawierania małżeństw na 1000 ludności w wieku 15 lat i więcej pomiędzy 2011 i 2002 r. według podregionów

Ryc. 27. Związek z religią według województw w latach 1992 i 2008

Ryc. 28. Odsetek małżeństw wyznaniowych w 2002 i 2011 r. według podregionów

Ryc. 29. Spadek odsetka małżeństw wyznaniowych pomiędzy 2011 i 2002 r. według podregionów.

Ryc. 30. Udział osób w stanie małżeńskim w ogólnej liczbie osób w wieku 15 lat i więcej - różnice pomiędzy 2011 i 2002 r.

Ryc. 31. Struktura wieku nowożeńców - mężczyzn w 2002 i 2011 r. według podregionów

Ryc. 32. Struktura wieku nowożeńców - kobiet w 2002 i 2011 r. według podregionów

Ryc. 33. Struktura stanu cywilnego nowożeńców - mężczyzn w 2002 i 2011 r. według podregionów.

Ryc. 34. Struktura stanu cywilnego nowożeńców - kobiet w 2002 i 2011 r. według podregionów.

Ryc. 35. Współczynnik rozwodów na 1000 ludności w wieku 20 lat i więcej w 2002 i 2011 r. według podregionów.

Ryc. 36. Różnice wartości współczynnika rozwodów na 1000 ludności w wieku 20 lat i więcej pomiędzy 2011 i 2002 r. według podregionów

Ryc. 37. Udział osób rozwiedzionych w ogólnej liczbie osób w wieku 15 lat i więcej - różnice pomiędzy 2011 i 2002 r.

Ryc. 38. Separacje ogółem na 100000 ludności w 2002 i 2011 r. według podregionów

Ryc. 39. Różnice wartości współczynnika separacji na 100 tys. ludności w wieku 20 lat i więcej pomiędzy 2011 i 2002 r. według podregionów

Ryc. 40. Odsetek osób kohabitujących w 2002 r. według podregionów. 148

Ryc. 41. Odsetek osób w stanie małżeńskim nie pozostających w małżeństwie w 2002 r. według podregionów

Ryc. 42. Odsetek osób kohabitujących w 2011 r. według podregionów. 150

Ryc. 43. Urodzenia w Polsce w latach 1946-2011 156

Ryc. 44. Urodzenia pozamałżeńskie w wybranych krajach europejskich w 2011 r.....161

Ryc. 45. Współczynnik dzietności w latach 1950-2011 165

Ryc. 46. Współczynnik dzietności w krajach europejskich w 2011 r. 167

Ryc. 47. Średni wiek kobiet rodzących w wybranych krajach europejskich w $2011 \mathrm{r}$. 
Ryc. 48. Współczynnik urodzeń w 2002 i 2011 r. według podregionów . 171

Ryc. 49. Różnice we współczynniku urodzeń pomiędzy 2011 i 2002 r. według podregionów

Ryc. 50. Odsetek urodzeń trzecich i dalszych w 2002 i 2011 r. według podregionów

Ryc. 51. Odsetek urodzeń trzecich i dalszych w 2011 r. według podregionów miasto-wieś

Ryc. 52. Różnica odsetka urodzeń trzecich i dalszych pomiędzy 2011 i 2002 r. według podregionów.

Ryc. 53. Odsetek rodzin z trojgiem dzieci lub więcej w 2002 r. według podregionów

Ryc. 54. Urodzenia małżeńskie i pozamałżeńskie w 2011 r. według podregionów 179

Ryc. 55. Wzrost odsetka urodzeń pozamałżeńskich pomiędzy 2002 i 2011 r. według podregionów 180

Ryc. 56. Płodność kobiet w wieku 20-24 lata w 2011 r. według podregionów.. 182

Ryc. 57. Płodność kobiet w wieku 25-29 lat w 2011 r. według podregionów . 183

Ryc. 58. Płodność kobiet w wieku 30-34 lata w 2011 r. według podregionów 183

Ryc. 59. Dzietność w 2002 i 2011 r. według podregionów 185

Ryc. 60. Różnica we współczynniku dzietności pomiędzy 2011 i 2002 r. według podregionów

Ryc. 61. Typy przyrostu rzeczywistego w podregionach w 2002 i $2011 \mathrm{r}$. 190

Ryc. 62. Klasy rozwoju struktury wieku w podregionach w 2002 i 2011 r .192

Ryc. 63. Różnice w dalszym trwaniu życia pomiędzy kobietami i mężczyznami w 2011 r. dla podregionów.

Ryc. 64. Trwanie życia w 2011 r. dla podregionów

Ryc. 65. Atrakcyjność inwestycyjna podregionów dla działalności przemysłowej w $2011 \mathrm{r}$

Ryc. 66. Atrakcyjność inwestycyjna podregionów dla działalności usługowej w $2011 \mathrm{r}$.

Ryc. 67. Atrakcyjność inwestycyjna podregionów dla działalności zaawansowanej technologicznie w $2011 \mathrm{r}$.

Ryc. 68. Odsetek osób z wykształceniem podstawowym w 2002 i 2011 r. według podregionów

Ryc. 69. Ubytek odsetka osób z wykształceniem podstawowym pomiędzy 2011 i 2002 r. według podregionów

Ryc. 70. Odsetek osób z wykształceniem wyższym w 2002 i 2011 r. według podregionów

Ryc. 71. Przyrost odsetka osób z wykształceniem podstawowym pomiędzy 2002 i 2011 r. według podregionów 
Ryc. 72. Wyniki egzaminu gimnazjalnego w 2011 r. według podregionów - część humanistyczna.

Ryc. 73. Wyniki egzaminu gimnazjalnego w 2011 r. według podregionów część matematyczno-przyrodnicza

Ryc. 74. Wyniki egzaminu gimnazjalnego w 2011 r. według podregionów - język angielski

Ryc. 75. Frekwencja wyborcza w wyborach parlamentarnych w 2011 r. według podregionów

Ryc. 76. Wyniki PIS w wyborach parlamentarnych w 2011 r. według podregionów

Ryc. 77. Wyniki PO w wyborach parlamentarnych w 2011 r. według podregionów

Ryc. 78. Poziom rozwoju społeczno-gospodarczego w 2011 r. według podregionów

Ryc. 79. Dendrogram grupowania podregionów metodą Warda. .224

Ryc. 80. Typy zachowań demograficznych dla podregionów 225

Ryc. 81. Model średnich arytmetycznych dla wyróżnionych typów przestrzennych .226

Ryc. 82. Hierarchia celów życiowych łodzian ...................................................................238

Ryc. 83. Ocena zachowań moralnych................................................................................239

Ryc. 84. Związki między ludźmi, które są rodziną według respondentów ...................242

Ryc. 85. Najlepsza forma życia małżeńsko-rodzinnego w przyszłości według wieku respondentów .

Ryc. 86. Najlepsza forma życia małżeńsko-rodzinnego w przyszłości według młodych łodzian

Ryc. 87. Stosunek respondentów do kohabitacji.

Ryc. 88. Akceptacja związków nieformalnych przez polskie społeczeństwo według respondentów..

Ryc. 89. Stosunek respondentów do rozwodów. 249

Ryc. 90. Ocena respondentów odnośnie do wprowadzenia do polskiego prawa instytucji separacji - młodzi łodzianie.

Ryc. 91. Stosunek poparcia respondentów formy życia w pojedynkę 252

Ryc. 92. Powody, dla których ludzie żyją w pojedynkę .253

Ryc. 93. Ocena życia singli dokonana przez młodych łodzian 254

Ryc. 94. Stosunek respondentów do rodzin monoparentalnych 256

Ryc. 95. Stosunek respondentów do samotnych ojców..... .256

Ryc. 96. Preferencje dotyczące liczby dzieci .258

Ryc. 97. Stosunek respondentów do odraczania lub zaniechania zachowań reprodukcyjnych ludzi 
ANEKS 

A I. Liczba ludności faktycznie zamieszkałej w 2011 r.

\begin{tabular}{|c|c|c|c|}
\hline Jednostka & Ogółem & Miasto & Wieś \\
\hline 1 & 2 & 3 & 4 \\
\hline POLSKA & 38538447 & 23385828 & 15152619 \\
\hline ŁÓDZKIE & 2533681 & 1615408 & 918273 \\
\hline Podregion 15 - łódzki & 384235 & 241918 & 142317 \\
\hline Podregion 16 - m. Łódź & 725055 & 725055 & - \\
\hline Podregion 17 - piotrkowski & 597681 & 300541 & 297140 \\
\hline Podregion 18 - sieradzki & 454940 & 173874 & 281066 \\
\hline Podregion 19 - skierniewicki & 371770 & 174020 & 197750 \\
\hline MAZOWIECKIE & 5285604 & 3393043 & 1892561 \\
\hline Podregion 25 - ciechanowsko-płocki & 631010 & 289833 & 341177 \\
\hline Podregion 26 - ostrołęcko-siedlecki & 758056 & 287438 & 470618 \\
\hline Podregion 27 - radomski & 624600 & 309043 & 315557 \\
\hline Podregion 28 - m. Warszawa & 1708491 & 1708491 & - \\
\hline Podregion 29 - warszawski wschodni & 786750 & 418333 & 368417 \\
\hline Podregion 30 - warszawski zachodni & 776697 & 379905 & 396792 \\
\hline MAŁOPOLSKIE & 3346796 & 1641853 & 1704943 \\
\hline Podregion 20 - krakowski & 698003 & 160245 & 537758 \\
\hline Podregion 21 - m. Kraków & 759137 & 759137 & - \\
\hline Podregion 22 - nowosądecki & 785894 & 262253 & 523641 \\
\hline Podregion 23 - oświęcimski & 639991 & 286856 & 353135 \\
\hline Podregion 24 - tarnowski & 463771 & 173362 & 290409 \\
\hline ŚLĄSKIE & 4626357 & 3594242 & 1032115 \\
\hline Podregion 44 - bielski & 662442 & 333145 & 329297 \\
\hline Podregion 45 - bytomski & 449553 & 356959 & 92594 \\
\hline Podregion 46 - częstochowski & 529314 & 309634 & 219680 \\
\hline Podregion 47 - gliwicki & 482429 & 431058 & 51371 \\
\hline Podregion 48 - katowicki & 762097 & 762097 & - \\
\hline Podregion 49 - rybnicki & 640032 & 491621 & 148411 \\
\hline Podregion 50 - sosnowiecki & 710208 & 627888 & 82320 \\
\hline Podregion 51 - tyski & 390282 & 281840 & 108442 \\
\hline LUBELSKIE & 2171857 & 1009175 & 1162682 \\
\hline Podregion 9 - bialski & 309560 & 122056 & 187504 \\
\hline Podregion 10 - chełmsko-zamojski & 649203 & 246433 & 402770 \\
\hline Podregion 11 - lubelski & 717488 & 453012 & 264476 \\
\hline Podregion 12 - puławski & 495606 & 187674 & 307932 \\
\hline PODKARPACKIE * & 2128687 & 880736 & 1247951 \\
\hline Podregion 33 - krośnieński & 487033 & 166665 & 320368 \\
\hline Podregion 34 - przemyski & 398173 & 154814 & 243359 \\
\hline Podregion 35 - rzeszowski & 621843 & 267237 & 354606 \\
\hline Podregion 36 - tarnobrzeski & 621638 & 292020 & 329618 \\
\hline PODLASKIE & 1200982 & 724027 & 476955 \\
\hline Podregion 37 - białostocki & 509677 & 379526 & 130151 \\
\hline Podregion 38 - łomżyński & 412678 & 193406 & 219272 \\
\hline
\end{tabular}


A I. Liczba ludności faktycznie zamieszkałej w 2011 r. - c. d.

\begin{tabular}{|c|c|c|c|}
\hline 1 & 2 & 3 & 4 \\
\hline Podregion 39 - suwalski & 278627 & 151095 & 127532 \\
\hline ŚWIĘTOKRZYSKIE & 1278116 & 575507 & 702609 \\
\hline Podregion 52 - kielecki & 781468 & 434211 & 347257 \\
\hline Podregion 53 - sandomiersko-jędrzejowski & 496648 & 141296 & 355352 \\
\hline LUBUSKIE & 1023158 & 648692 & 374466 \\
\hline Podregion 13 - gorzowski & 386904 & 250068 & 136836 \\
\hline Podregion 14 - zielonogórski & 636254 & 398624 & 237630 \\
\hline WIELKOPOLSKIE & 3455477 & 1924014 & 1531463 \\
\hline Podregion 57 - kaliski & 673001 & 318308 & 354693 \\
\hline Podregion 58 - koniński & 660778 & 312431 & 348347 \\
\hline Podregion 59 - leszczyński & 551327 & 252439 & 298888 \\
\hline Podregion 60 - pilski & 414463 & 225877 & 188586 \\
\hline Podregion 61 - poznański & 602344 & 261395 & 340949 \\
\hline Podregion 62 - m. Poznań & 553564 & 553564 & - \\
\hline ZACHODNIOPOMORSKIE & 1722739 & 1185967 & 536772 \\
\hline Podregion 63 - koszaliński & 604433 & 380571 & 223862 \\
\hline Podregion 64 - stargardzki & 380260 & 211959 & 168301 \\
\hline Podregion 65 - m. Szczecin & 409596 & 409596 & - \\
\hline Podregion 66 - szczeciński & 328450 & 183841 & 144609 \\
\hline DOLNOŚLĄSKIE & 2916577 & 2034656 & 881921 \\
\hline Podregion 1 - jeleniogórski & 581993 & 362554 & 219439 \\
\hline Podregion 2 - legnicko-głogowski & 454789 & 324175 & 130614 \\
\hline Podregion 3 - wałbrzyski & 682333 & 496340 & 185993 \\
\hline Podregion 4 - wrocławski & 566227 & 220352 & 345875 \\
\hline Podregion 5 - m. Wrocław & 631235 & 631235 & - \\
\hline OPOLSKIE & 1013950 & 530395 & 483555 \\
\hline Podregion 31 - nyski & 403151 & 208391 & 194760 \\
\hline Podregion 32 - opolski & 610799 & 322004 & 288795 \\
\hline KUJAWSKO-POMORSKIE & 2098370 & 1267284 & 831086 \\
\hline Podregion 6 - bydgosko-toruński & 774317 & 610144 & 164173 \\
\hline Podregion 7 - grudziądzki & 539652 & 254342 & 285310 \\
\hline Podregion 8 - włocławski & 784401 & 402798 & 381603 \\
\hline POMORSKIE & 2283500 & 1498435 & 785065 \\
\hline Podregion 40 - gdański & 540477 & 214988 & 325489 \\
\hline Podregion 41 - słupski & 490363 & 264910 & 225453 \\
\hline Podregion 42 - starogardzki & 504620 & 270497 & 234123 \\
\hline Podregion 43 - trójmiejski & 748040 & 748040 & - \\
\hline WARMIŃSKO-MAZURSKIE & 1452596 & 862394 & 590202 \\
\hline Podregion 54 - elbląski & 537452 & 312555 & 224897 \\
\hline Podregion 55 - ełcki & 291261 & 168767 & 122494 \\
\hline Podregion 56 - olsztyński & 623883 & 381072 & 242811 \\
\hline
\end{tabular}

Źródło: Bank Danych Lokalnych, GUS, Warszawa. 


\section{A II. Mediana wieku nowożeńców w 2002 i 2011 r.}

\begin{tabular}{|c|c|c|c|c|}
\hline \multirow{2}{*}{ Nazwa i numer podregionu } & \multicolumn{2}{|c|}{2002} & \multicolumn{2}{|c|}{2011} \\
\hline & kobiety & mężczyźni & kobiety & mężczyźni \\
\hline 1 & 2 & 3 & 4 & 5 \\
\hline Podregion 15 - łódzki & 23,47 & 26,20 & 26,71 & 28,09 \\
\hline Podregion 16 - m. Łódź & 25,96 & 27,37 & 27,79 & 28,97 \\
\hline Podregion 17 - piotrkowski & 22,95 & 25,80 & 26,01 & 27,39 \\
\hline Podregion 18 - sieradzki & 22,84 & 25,64 & 25,88 & 27,43 \\
\hline Podregion 19 - skierniewicki & 23,11 & 26,02 & 26,04 & 27,53 \\
\hline Podregion 25 - ciechanowsko-płocki & 22,74 & 25,86 & 25,72 & 27,38 \\
\hline Podregion 26 - ostrołęcko-siedlecki & 22,69 & 25,79 & 25,33 & 27,06 \\
\hline Podregion 27 - radomski & 22,90 & 25,88 & 25,79 & 27,30 \\
\hline Podregion $28-$ m. Warszawa & 26,41 & 27,88 & 28,05 & 29,30 \\
\hline Podregion 29 - warszawski wschodni & 23,12 & 26,05 & 26,04 & 27,47 \\
\hline Podregion 30 - warszawski zachodni & 23,40 & 26,49 & 26,80 & 28,11 \\
\hline Podregion 20 - krakowski & 22,82 & 25,89 & 25,41 & 27,18 \\
\hline Podregion 21 - m. Kraków & 25,66 & 27,11 & 27,44 & 28,54 \\
\hline Podregion 22 - nowosądecki & 22,85 & 26,01 & 24,87 & 26,87 \\
\hline Podregion 23 - oświęcimski & 22,80 & 25,93 & 25,71 & 27,39 \\
\hline Podregion 24 - tarnowski & 23,11 & 26,21 & 25,57 & 27,44 \\
\hline Podregion 44 - bielski & 23,14 & 25,97 & 25,94 & 27,45 \\
\hline Podregion 45 - bytomski & 23,27 & 26,39 & 26,49 & 27,92 \\
\hline Podregion 46 - częstochowski & 23,08 & 26,11 & 26,28 & 27,59 \\
\hline Podregion 47 - gliwicki & 23,52 & 26,66 & 26,79 & 28,07 \\
\hline Podregion 48 - katowicki & 23,82 & 26,71 & 27,13 & 28,22 \\
\hline Podregion 49 - rybnicki & 23,03 & 25,95 & 25,76 & 27,40 \\
\hline Podregion 50 - sosnowiecki & 23,35 & 26,36 & 26,84 & 28,19 \\
\hline Podregion 51 - tyski & 23,12 & 26,17 & 26,09 & 27,44 \\
\hline Podregion 9 - bialski & 22,94 & 26,11 & 25,71 & 27,33 \\
\hline Podregion 10 - chełmsko-zamojski & 22,84 & 25,86 & 25,55 & 27,25 \\
\hline Podregion 11 - lubelski & 23,28 & 26,24 & 26,26 & 27,52 \\
\hline Podregion 12 - puławski & 22,78 & 25,91 & 25,51 & 27,10 \\
\hline Podregion 33 - krośnieński & 22,96 & 25,93 & 25,35 & 27,23 \\
\hline Podregion 34 - przemyski & 22,90 & 25,99 & 25,53 & 27,10 \\
\hline Podregion 35 - rzeszowski & 23,15 & 26,01 & 25,50 & 27,23 \\
\hline Podregion 36 - tarnobrzeski & 22,73 & 25,80 & 25,41 & 27,21 \\
\hline Podregion 37 - białostocki & 23,77 & 26,67 & 26,45 & 27,78 \\
\hline Podregion 38 - łomżyński & 22,90 & 26,17 & 25,58 & 27,26 \\
\hline Podregion 39 - suwalski & 23,19 & 26,47 & 25,79 & 27,33 \\
\hline Podregion 52 - kielecki & 22,92 & 26,03 & 26,06 & 27,48 \\
\hline $\begin{array}{l}\text { Podregion } 53 \text { - sandomiersko- } \\
\text { jędrzejowski }\end{array}$ & 22,62 & 25,72 & 25,54 & 27,37 \\
\hline Podregion 13 - gorzowski & 23,60 & 26,70 & 26,96 & 28,37 \\
\hline Podregion 14 - zielonogórski & 23,53 & 26,55 & 26,93 & 28,28 \\
\hline Podregion 57 - kaliski & 22,92 & 25,87 & 25,75 & 27,37 \\
\hline
\end{tabular}


A II. Mediana wieku nowożeńców w 2002 i 2011 r. - c. d.

\begin{tabular}{|l|r|r|r|r|}
\hline \multicolumn{1}{|c|}{1} & \multicolumn{1}{l|}{2} & \multicolumn{1}{l|}{3} & \multicolumn{1}{l|}{5} \\
\hline Podregion 58 - koniński & 22,80 & 25,94 & 25,88 & 27,44 \\
\hline Podregion 59 - leszczyński & 22,92 & 25,86 & 25,93 & 27,35 \\
\hline Podregion 60 - pilski & 23,02 & 25,89 & 26,08 & 27,67 \\
\hline Podregion 61 - poznański & 23,13 & 26,22 & 26,48 & 27,66 \\
\hline Podregion 62 - m. Poznań & 26,00 & 27,23 & 27,80 & 28,86 \\
\hline Podregion 63 - koszaliński & 23,54 & 26,64 & 26,92 & 28,46 \\
\hline Podregion 64 - stargardzki & 23,14 & 26,41 & 26,65 & 28,28 \\
\hline Podregion 65 - m. Szczecin & 26,18 & 27,76 & 28,08 & 29,41 \\
\hline Podregion 66 - szczeciński & 23,53 & 26,76 & 27,21 & 28,90 \\
\hline Podregion 1 - jeleniogórski & 23,43 & 26,69 & 27,05 & 28,52 \\
\hline Podregion 2 - legnicko-głogowski & 23,32 & 26,24 & 26,61 & 28,03 \\
\hline Podregion 3 - wałbrzyski & 23,55 & 26,73 & 27,04 & 28,49 \\
\hline Podregion 4 - wrocławski & 22,86 & 25,85 & 26,17 & 27,88 \\
\hline Podregion 5 - m. Wrocław & 25,90 & 27,57 & 27,84 & 29,04 \\
\hline Podregion 31 - nyski & 22,93 & 26,07 & 26,24 & 27,66 \\
\hline Podregion 32 - opolski & 23,25 & 26,41 & 26,05 & 27,62 \\
\hline Podregion 6 - bydgosko-toruński & 23,67 & 26,54 & 27,07 & 28,30 \\
\hline Podregion 7 - grudziądzki & 22,84 & 25,83 & 25,73 & 27,30 \\
\hline Podregion 8 - włocławski & 22,98 & 26,02 & 26,02 & 27,64 \\
\hline Podregion 40 - gdański & 22,78 & 25,92 & 25,32 & 27,27 \\
\hline Podregion 41 - słupski & 23,08 & 26,22 & 26,26 & 27,76 \\
\hline Podregion 42 - starogardzki & 22,96 & 26,06 & 25,79 & 27,53 \\
\hline Podregion 43 - trójmiejski & 25,87 & 27,33 & 27,67 & 28,86 \\
\hline Podregion 54 - elbląski & 22,99 & 26,03 & 26,13 & 27,73 \\
\hline Podregion 55 - ełcki & 22,83 & 25,83 & 25,75 & 27,48 \\
\hline Podregion 56 - olsztyński & 23,15 & 26,30 & 26,64 & 27,97 \\
\hline
\end{tabular}

Źródło: oprac. własne na podstawie Banku Danych Lokalnych, GUS, Warszawa. 


\section{A III. Urodzenia na 1000 ludności w 2011 r.}

\begin{tabular}{|c|c|c|c|}
\hline \multirow{2}{*}{ Nazwa i numer podregionu } & \multicolumn{3}{|c|}{ Współczynnik rodności } \\
\hline & ogółem & miasto & wieś \\
\hline 1 & 2 & 3 & 4 \\
\hline Podregion 15 - łódzki & 9,438 & 9,141 & 9,948 \\
\hline Podregion 16 - m. Łódź & 8,598 & 8,598 & - \\
\hline Podregion 17 - piotrkowski & 9,923 & 9,282 & 10,573 \\
\hline Podregion 18 - sieradzki & 9,824 & 9,524 & 10,010 \\
\hline Podregion 19 - skierniewicki & 9,836 & 10,107 & 9,598 \\
\hline Podregion 25 - ciechanowsko-płocki & 10,018 & 9,913 & 10,108 \\
\hline Podregion 26 - ostrołęcko-siedlecki & 10,852 & 10,539 & 11,044 \\
\hline Podregion 27 - radomski & 10,109 & 9,636 & 10,573 \\
\hline Podregion $28-\mathrm{m}$. Warszawa & 11,075 & 11,075 & - \\
\hline Podregion 29 - warszawski wschodni & 11,726 & 11,945 & 11,478 \\
\hline Podregion 30 - warszawski zachodni & 10,785 & 11,230 & 10,358 \\
\hline Podregion 20 - krakowski & 11,123 & 10,819 & 11,214 \\
\hline Podregion 21 - m. Kraków & 9,782 & 9,782 & - \\
\hline Podregion 22 - nowosądecki & 11,940 & 10,118 & 12,857 \\
\hline Podregion 23 - oświęcimski & 10,098 & 9,374 & 10,689 \\
\hline Podregion 24 - tarnowski & 9,819 & 9,290 & 10,135 \\
\hline Podregion 44 - bielski & 10,597 & 10,050 & 11,153 \\
\hline Podregion 45 - bytomski & 9,378 & 9,291 & 9,715 \\
\hline Podregion 46 - częstochowski & 8,932 & 8,913 & 8,959 \\
\hline Podregion 47 - gliwicki & 9,296 & 9,233 & 9,826 \\
\hline Podregion 48 - katowicki & 9,363 & 9,363 & - \\
\hline Podregion 49 - rybnicki & 10,285 & 10,146 & 10,748 \\
\hline Podregion 50 - sosnowiecki & 8,796 & 8,694 & 9,577 \\
\hline Podregion 51 - tyski & 11,168 & 10,762 & 12,228 \\
\hline Podregion 9 - bialski & 10,502 & 9,812 & 10,950 \\
\hline Podregion 10 - chełmsko-zamojski & 9,118 & 8,577 & 9,450 \\
\hline Podregion 11 - lubelski & 10,199 & 10,025 & 10,498 \\
\hline Podregion 12 - puławski & 9,779 & 8,806 & 10,373 \\
\hline Podregion 33 - krośnieński & 9,812 & 8,683 & 10,401 \\
\hline Podregion 34 - przemyski & 9,751 & 8,691 & 10,426 \\
\hline Podregion 35 - rzeszowski & 10,567 & 10,673 & 10,486 \\
\hline Podregion 36 - tarnobrzeski & 9,503 & 8,840 & 10,093 \\
\hline Podregion 37 - białostocki & 9,404 & 9,415 & 9,373 \\
\hline Podregion 38 - łomżyński & 9,170 & 8,895 & 9,414 \\
\hline Podregion 39 - suwalski & 9,218 & 8,686 & 9,847 \\
\hline Podregion 52 - kielecki & 9,091 & 8,402 & 9,955 \\
\hline Podregion 53 - sandomiersko-jędrzejowski & 9,016 & 8,789 & 9,106 \\
\hline Podregion 13 - gorzowski & 10,444 & 10,267 & 10,769 \\
\hline Podregion 14 - zielonogórski & 10,029 & 9,593 & 10,762 \\
\hline Podregion 57 - kaliski & 10,543 & 9,638 & 11,357 \\
\hline Podregion 58 - koniński & 10,692 & 9,755 & 11,535 \\
\hline Podregion 59 - leszczyński & 11,552 & 10,542 & 12,407 \\
\hline
\end{tabular}


A III. Urodzenia na 1000 ludności w 2011 r. - c. d.

\begin{tabular}{|c|c|c|c|}
\hline 1 & 2 & 3 & 4 \\
\hline Podregion 60 - pilski & 10,664 & 10,045 & 11,407 \\
\hline Podregion 61 - poznański & 12,227 & 11,495 & 12,794 \\
\hline Podregion 62 - m. Poznań & 10,534 & 10,534 & - \\
\hline Podregion 63 - koszaliński & 9,468 & 8,952 & 10,347 \\
\hline Podregion 64 - stargardzki & 9,711 & 8,830 & 10,823 \\
\hline Podregion 65 - m. Szczecin & 8,429 & 8,429 & - \\
\hline Podregion 66 - szczeciński & 9,534 & 8,825 & 10,440 \\
\hline Podregion 1 - jeleniogórski & 8,731 & 8,189 & 9,632 \\
\hline Podregion 2 - legnicko-głogowski & 10,028 & 9,749 & 10,726 \\
\hline Podregion 3 - wałbrzyski & 8,623 & 8,301 & 9,487 \\
\hline Podregion 4 - wrocławski & 10,401 & 10,082 & 10,604 \\
\hline Podregion 5 - m. Wrocław & 9,911 & 9,911 & - \\
\hline Podregion 31 - nyski & 8,940 & 8,387 & 9,533 \\
\hline Podregion 32 - opolski & 8,297 & 8,332 & 8,258 \\
\hline Podregion 6 - bydgosko-toruński & 9,613 & 9,218 & 11,096 \\
\hline Podregion 7 - grudziądzki & 10,704 & 9,667 & 11,632 \\
\hline Podregion 8 - włocławski & 9,884 & 9,087 & 10,729 \\
\hline Podregion 40 - gdański & 13,271 & 12,177 & 14,000 \\
\hline Podregion 41 - słupski & 10,722 & 9,351 & 12,342 \\
\hline Podregion 42 - starogardzki & 11,380 & 10,582 & 12,306 \\
\hline Podregion 43 - trójmiejski & 9,281 & 9,281 & - \\
\hline Podregion 54 - elbląski & 10,374 & 9,321 & 11,842 \\
\hline Podregion 55 - ełcki & 10,091 & 9,439 & 10,989 \\
\hline Podregion 56 - olsztyński & 9,987 & 9,298 & 11,071 \\
\hline
\end{tabular}

Źródło: Bank Danych Lokalnych, GUS, Warszawa. 


\section{A IV. Urodzenia małżeńskie i pozamałżeńskie w 2011 r.}

\begin{tabular}{|c|c|c|c|c|}
\hline \multirow[b]{2}{*}{ Nazwa i numer podregionu } & \multicolumn{3}{|c|}{ Liczba urodzeń } & \multirow{2}{*}{$\begin{array}{l}\text { Udział urodzeń } \\
\text { pozamałżeń- } \\
\text { skich }\end{array}$} \\
\hline & ogółem & małżeńskie & $\begin{array}{l}\text { pozamałżeń- } \\
\text { skie }\end{array}$ & \\
\hline 1 & 2 & 3 & 4 & 5 \\
\hline Podregion 15 - łódzki & 3637 & 2790 & 847 & 23,29 \\
\hline Podregion 16 - m. Łódź & 6278 & 4343 & 1935 & 30,82 \\
\hline Podregion 17 - piotrkowski & 5977 & 4955 & 1022 & 17,10 \\
\hline Podregion 18 - sieradzki & 4501 & 3631 & 870 & 19,33 \\
\hline Podregion 19 - skierniewicki & 3678 & 3036 & 642 & 17,46 \\
\hline $\begin{array}{l}\text { Podregion } 25 \text { - ciechanowsko- } \\
\text { płocki }\end{array}$ & 6361 & 5053 & 1308 & 20,56 \\
\hline $\begin{array}{l}\text { Podregion } 26 \text { - ostrołęcko- } \\
\text { siedlecki }\end{array}$ & 8272 & 7215 & 1057 & 12,78 \\
\hline Podregion 27 - radomski & 6367 & 5468 & 899 & 14,12 \\
\hline Podregion $28-\mathrm{m}$. Warszawa & 18911 & 15035 & 3876 & 20,50 \\
\hline $\begin{array}{l}\text { Podregion } 29 \text { - warszawski } \\
\text { wschodni }\end{array}$ & 9214 & 7834 & 1380 & 14,98 \\
\hline $\begin{array}{l}\text { Podregion } 30 \text { - warszawski } \\
\text { zachodni }\end{array}$ & 8373 & 6876 & 1497 & 17,88 \\
\hline Podregion 20 - krakowski & 7757 & 7089 & 668 & 8,61 \\
\hline Podregion 21 - m. Kraków & 7445 & 6251 & 1194 & 16,04 \\
\hline Podregion 22 - nowosądecki & 9400 & 8500 & 900 & 9,57 \\
\hline Podregion 23 - oświęcimski & 6487 & 5729 & 758 & 11,68 \\
\hline Podregion 24 - tarnowski & 4568 & 4129 & 439 & 9,61 \\
\hline Podregion 44 - bielski & 7039 & 5860 & 1179 & 16,75 \\
\hline Podregion 45 - bytomski & 4234 & 3225 & 1009 & 23,83 \\
\hline Podregion 46 - częstochowski & 4750 & 4109 & 641 & 13,49 \\
\hline Podregion 47 - gliwicki & 4518 & 3331 & 1187 & 26,27 \\
\hline Podregion 48 - katowicki & 7182 & 5161 & 2021 & 28,14 \\
\hline Podregion 49 - rybnicki & 6610 & 5619 & 991 & 14,99 \\
\hline Podregion 50 - sosnowiecki & 6290 & 4949 & 1341 & 21,32 \\
\hline Podregion 51 - tyski & 4365 & 3734 & 631 & 14,46 \\
\hline Podregion 9 - bialski & 3265 & 2735 & 530 & 16,23 \\
\hline $\begin{array}{l}\text { Podregion } 10 \text { - chełmsko- } \\
\text { zamojski }\end{array}$ & 5956 & 4972 & 984 & 16,52 \\
\hline Podregion 11 - lubelski & 7342 & 6269 & 1073 & 14,61 \\
\hline Podregion 12 - puławski & 4885 & 4283 & 602 & 12,32 \\
\hline Podregion 33 - krośnieński & 4802 & 4227 & 575 & 11,97 \\
\hline Podregion 34 - przemyski & 3900 & 3287 & 613 & 15,72 \\
\hline Podregion 35 - rzeszowski & 6591 & 5966 & 625 & 9,48 \\
\hline Podregion 36 - tarnobrzeski & 5931 & 5316 & 615 & 10,37 \\
\hline Podregion 37 - białostocki & 4801 & 4180 & 621 & 12,93 \\
\hline Podregion 38 - łomżyński & 3811 & 3322 & 489 & 12,83 \\
\hline
\end{tabular}


A IV. Urodzenia małżeńskie i pozamałżeńskie w 2011 r. - c. d.

\begin{tabular}{|c|c|c|c|c|}
\hline 1 & 2 & 3 & 4 & 5 \\
\hline Podregion 39 - suwalski & 2587 & 2130 & 457 & 17,67 \\
\hline Podregion 52 - kielecki & 7158 & 6029 & 1129 & 15,77 \\
\hline $\begin{array}{l}\text { Podregion } 53 \text { - sandomier- } \\
\text { sko-jędrzejowski }\end{array}$ & 4506 & 3967 & 539 & 11,96 \\
\hline Podregion 13 - gorzowski & 4055 & 2437 & 1618 & 39,90 \\
\hline Podregion 14 - zielonogórski & 6405 & 4102 & 2303 & 35,96 \\
\hline Podregion 57 - kaliski & 7116 & 5770 & 1346 & 18,92 \\
\hline Podregion 58 - koniński & 7089 & 5679 & 1410 & 19,89 \\
\hline Podregion 59 - leszczyński & 6402 & 5051 & 1351 & 21,10 \\
\hline Podregion 60 - pilski & 4441 & 3091 & 1350 & 30,40 \\
\hline Podregion 61 - poznański & 7342 & 5814 & 1528 & 20,81 \\
\hline Podregion 62 - m. Poznań & 5856 & 4343 & 1513 & 25,84 \\
\hline Podregion 63 - koszaliński & 5757 & 3512 & 2245 & 39,00 \\
\hline Podregion 64 - stargardzki & 3713 & 2218 & 1495 & 40,26 \\
\hline Podregion 65 - m. Szczecin & 3464 & 2304 & 1160 & 33,49 \\
\hline Podregion 66 - szczeciński & 3141 & 1920 & 1221 & 38,87 \\
\hline Podregion 1 - jeleniogórski & 5114 & 3148 & 1966 & 38,44 \\
\hline $\begin{array}{l}\text { Podregion } 2 \text { - legnicko- } \\
\text { głogowski }\end{array}$ & 4576 & 3313 & 1263 & 27,60 \\
\hline Podregion 3 - wałbrzyski & 5923 & 3609 & 2314 & 39,07 \\
\hline Podregion 4 - wrocławski & 5888 & 4509 & 1379 & 23,42 \\
\hline Podregion 5 - m. Wrocław & 6271 & 4763 & 1508 & 24,05 \\
\hline Podregion 31 - nyski & 3623 & 2718 & 905 & 24,98 \\
\hline Podregion 32 - opolski & 5099 & 4071 & 1028 & 20,16 \\
\hline $\begin{array}{l}\text { Podregion } 6 \text { - bydgosko- } \\
\text { toruński }\end{array}$ & 7459 & 5489 & 1970 & 26,41 \\
\hline Podregion 7 - grudziądzki & 5797 & 4151 & 1646 & 28,39 \\
\hline Podregion 8 - włocławski & 7794 & 5645 & 2149 & 27,57 \\
\hline Podregion 40 - gdański & 7151 & 5607 & 1544 & 21,59 \\
\hline Podregion 41 - słupski & 5282 & 3656 & 1626 & 30,78 \\
\hline Podregion 42 - starogardzki & 5773 & 4043 & 1730 & 29,97 \\
\hline Podregion 43 - trójmiejski & 6969 & 5163 & 1806 & 25,91 \\
\hline Podregion 54 - elbląski & 5598 & 3929 & 1669 & 29,81 \\
\hline Podregion 55 - ełcki & 2960 & 2112 & 848 & 28,65 \\
\hline Podregion 56 - olsztyński & 6256 & 4406 & 1850 & 29,57 \\
\hline
\end{tabular}

Źródłó: oprac. własne na podstawie Banku Danych Lokalnych, GUS, Warszawa. 
A V. Wzorce płodności w 2002 i 2011 r.

\begin{tabular}{|c|c|c|c|c|c|c|}
\hline \multirow{2}{*}{ Nazwa i numer } & \multicolumn{3}{|c|}{2002} & \multicolumn{3}{|c|}{2011} \\
\hline & ogółem & miasto & wieś & ogółem & miasto & wieś \\
\hline 1 & 2 & 3 & 4 & 5 & 6 & 7 \\
\hline Podregion 15 - łódzki & III & III & III & $\mathrm{V}$ & $\mathrm{V}$ & $\mathrm{V}$ \\
\hline Podregion 16 - m. Łódź & III & III & - & V & V & - \\
\hline Podregion 17 - piotrkowski & III & III & III & $\mathrm{V}$ & $\mathrm{V}$ & $\mathrm{V}$ \\
\hline Podregion 18 - sieradzki & III & III & II & $\mathrm{V}$ & $\mathrm{V}$ & $\mathrm{V}$ \\
\hline Podregion 19 - skierniewicki & III & III & III & $\mathrm{V}$ & $\mathrm{V}$ & $\mathrm{V}$ \\
\hline $\begin{array}{l}\text { Podregion } 25 \text { - ciechanow- } \\
\text { sko-płocki }\end{array}$ & III & III & II & $\mathrm{V}$ & $\mathrm{V}$ & III \\
\hline $\begin{array}{l}\text { Podregion } 26 \text { - ostrołęcko- } \\
\text { siedlecki }\end{array}$ & III & III & III & $\mathrm{V}$ & $\mathrm{V}$ & $\mathrm{V}$ \\
\hline Podregion 27 - radomski & III & III & III & $\mathrm{V}$ & V & $\mathrm{V}$ \\
\hline Podregion 28 - m. Warszawa & $\mathrm{V}$ & $\mathrm{V}$ & - & VI & VI & - \\
\hline $\begin{array}{l}\text { Podregion } 29 \text { - warszawski } \\
\text { wschodni }\end{array}$ & III & III & III & $\mathrm{V}$ & $\mathrm{V}$ & $\mathrm{V}$ \\
\hline $\begin{array}{l}\text { Podregion } 30 \text { - warszawski } \\
\text { zachodni }\end{array}$ & III & $\mathrm{V}$ & III & V & V & V \\
\hline Podregion 20 - krakowski & III & III & III & $\mathrm{V}$ & $\mathrm{V}$ & $\mathrm{V}$ \\
\hline Podregion 21 - m. Kraków & $\mathrm{V}$ & $\mathrm{V}$ & - & VI & VI & - \\
\hline Podregion 22 - nowosądecki & III & III & III & $\mathrm{V}$ & $\mathrm{V}$ & $\mathrm{V}$ \\
\hline Podregion 23 - oświęcimski & III & III & III & V & V & V \\
\hline Podregion 24 - tarnowski & $\mathrm{V}$ & $\mathrm{V}$ & III & $\mathrm{V}$ & $\mathrm{V}$ & $\mathrm{V}$ \\
\hline Podregion 44 - bielski & III & III & III & V & V & V \\
\hline Podregion 45 - bytomski & III & III & III & V & V & V \\
\hline Podregion 46 - częstochowski & III & III & III & $\mathrm{V}$ & $\mathrm{V}$ & $\mathrm{V}$ \\
\hline Podregion 47 - gliwicki & III & III & III & $\mathrm{V}$ & $\mathrm{V}$ & $\mathrm{V}$ \\
\hline Podregion 48 - katowicki & III & III & - & V & V & - \\
\hline Podregion 49 - rybnicki & III & III & III & $\mathrm{V}$ & $\mathrm{V}$ & $\mathrm{V}$ \\
\hline Podregion 50 - sosnowiecki & III & III & III & $\mathrm{V}$ & $\mathrm{V}$ & $\mathrm{V}$ \\
\hline Podregion 51 - tyski & III & III & III & V & V & $\mathrm{V}$ \\
\hline Podregion 9 - bialski & III & III & III & $\mathrm{V}$ & $\mathrm{V}$ & $\mathrm{V}$ \\
\hline $\begin{array}{l}\text { Podregion } 10 \text { - chełmsko- } \\
\text { zamojski }\end{array}$ & III & III & III & V & V & $\mathrm{V}$ \\
\hline Podregion 11 - lubelski & III & $\mathrm{V}$ & III & $\mathrm{V}$ & $\mathrm{V}$ & $\mathrm{V}$ \\
\hline Podregion 12 - puławski & III & III & III & $\mathrm{V}$ & $\mathrm{V}$ & $\mathrm{V}$ \\
\hline Podregion 33 - krośnieński & III & III & III & $\mathrm{V}$ & $\mathrm{V}$ & $\mathrm{V}$ \\
\hline Podregion 34 - przemyski & III & III & III & $\mathrm{V}$ & $\mathrm{V}$ & $\mathrm{V}$ \\
\hline Podregion 35 - rzeszowski & III & $\mathrm{V}$ & III & $\mathrm{V}$ & $\mathrm{V}$ & $\mathrm{V}$ \\
\hline Podregion 36 - tarnobrzeski & III & III & III & $\mathrm{V}$ & $\mathrm{V}$ & III \\
\hline Podregion 37 - białostocki & III & $\mathrm{V}$ & III & $\mathrm{V}$ & VI & $\mathrm{V}$ \\
\hline Podregion 38 - łomżyński & III & III & III & $\mathrm{V}$ & $\mathrm{V}$ & III \\
\hline Podregion 39 - suwalski & III & III & II & V & V & $\mathrm{V}$ \\
\hline Podregion 52 - kielecki & III & III & II & $\mathrm{V}$ & $\mathrm{V}$ & $\mathrm{V}$ \\
\hline
\end{tabular}


A V. Wzorce płodności w 2002 i 2011 r. - c. d.

\begin{tabular}{|c|c|c|c|c|c|c|}
\hline 1 & 2 & 3 & 4 & 5 & 6 & 7 \\
\hline $\begin{array}{l}\text { Podregion } 53 \text { - sandomier- } \\
\text { sko-jędrzejowski }\end{array}$ & III & III & II & V & $\mathrm{V}$ & III \\
\hline Podregion 13 - gorzowski & III & III & II & $\mathrm{V}$ & $\mathrm{V}$ & III \\
\hline Podregion 14 - zielonogórski & III & III & II & $\mathrm{V}$ & $\mathrm{V}$ & III \\
\hline Podregion 57 - kaliski & III & III & II & V & V & $\mathrm{V}$ \\
\hline Podregion 58 - koniński & III & III & II & $\mathrm{V}$ & $\mathrm{V}$ & III \\
\hline Podregion 59 - leszczyński & III & III & III & $\mathrm{V}$ & $\mathrm{V}$ & III \\
\hline Podregion 60 - pilski & III & III & II & III & V & III \\
\hline Podregion 61 - poznański & III & III & III & $\mathrm{V}$ & $\mathrm{V}$ & $\mathrm{V}$ \\
\hline Podregion 62 - m. Poznań & $\mathrm{V}$ & $\mathrm{V}$ & - & $\mathrm{V}$ & $\mathrm{V}$ & - \\
\hline Podregion 63 - koszaliński & II & III & $\mathrm{I}$ & $\mathrm{V}$ & $\mathrm{V}$ & III \\
\hline Podregion 64 - stargardzki & II & III & I & III & $\mathrm{V}$ & III/IV \\
\hline Podregion 65 - m. Szczecin & III & III & - & $\mathrm{V}$ & V & - \\
\hline Podregion 66 - szczeciński & II & II & II & III & $\mathrm{V}$ & III \\
\hline Podregion 1 - jeleniogórski & II & III & II & $\mathrm{V}$ & $\mathrm{V}$ & III \\
\hline $\begin{array}{l}\text { Podregion } 2 \text { - legnicko- } \\
\text { głogowski }\end{array}$ & III & III & II & V & $\mathrm{V}$ & III \\
\hline Podregion 3 - wałbrzyski & III & III & II & $\mathrm{V}$ & $\mathrm{V}$ & $\mathrm{V}$ \\
\hline Podregion 4 - wrocławski & III & III & II & $\mathrm{V}$ & $\mathrm{V}$ & $\mathrm{V}$ \\
\hline Podregion 5 - m. Wrocław & V & V & - & VI & VI & - \\
\hline Podregion 31 - nyski & III & III & III & $\mathrm{V}$ & $\mathrm{V}$ & $\mathrm{V}$ \\
\hline Podregion 32 - opolski & III & III & III & $\mathrm{V}$ & $\mathrm{V}$ & $\mathrm{V}$ \\
\hline $\begin{array}{l}\text { Podregion } 6 \text { - bydgosko- } \\
\text { toruński }\end{array}$ & III & III & II & V & V & III \\
\hline Podregion 7 - grudziądzki & II & III & II & III & $\mathrm{V}$ & III \\
\hline Podregion 8 - włocławski & II & III & II & $\mathrm{V}$ & V & III \\
\hline Podregion 40 - gdański & III & III & II & III & $\mathrm{V}$ & III \\
\hline Podregion 41 - słupski & III & III & II & III & V & III \\
\hline Podregion 42 - starogardzki & III & III & II & III & $\mathrm{V}$ & III \\
\hline Podregion 43 - trójmiejski & $\mathrm{V}$ & $\mathrm{V}$ & - & VI & VI & - \\
\hline Podregion 54 - elbląski & III & III & II & $\mathrm{V}$ & $\mathrm{V}$ & III \\
\hline Podregion 55 - ełcki & II & III & II & $\mathrm{V}$ & $\mathrm{V}$ & III \\
\hline Podregion 56 - olsztyński & III & III & II & $\mathrm{V}$ & $\mathrm{V}$ & III \\
\hline
\end{tabular}

Źródło: oprac. własne na podstawie Banku Danych Lokalnych, GUS, Warszawa. 


\section{A VI. Mediana wieku kobiet rodzących (w latach) w 2002 i 2011 według podregionów}

\begin{tabular}{|c|c|c|}
\hline Nazwa i numer podregionu & 2002 & 2011 \\
\hline 1 & 2 & 3 \\
\hline Podregion 15 - łódzki & 26,62 & 29,26 \\
\hline Podregion 16 - m. Łódź & 27,13 & 29,93 \\
\hline Podregion 17 - piotrkowski & 26,16 & 28,63 \\
\hline Podregion 18 - sieradzki & 26,41 & 28,54 \\
\hline Podregion 19 - skierniewicki & 26,36 & 28,43 \\
\hline Podregion 25 - ciechanowsko-płocki & 26,21 & 28,22 \\
\hline Podregion 26 - ostrołęcko-siedlecki & 26,43 & 28,35 \\
\hline Podregion 27 - radomski & 26,42 & 28,56 \\
\hline Podregion 28 - m. Warszawa & 28,45 & 31,21 \\
\hline Podregion 29 - warszawski wschodni & 26,88 & 29,48 \\
\hline Podregion 30 - warszawski zachodni & 27,13 & 29,95 \\
\hline Podregion 20 - krakowski & 26,85 & 29,13 \\
\hline Podregion 21 - m. Kraków & 28,18 & 30,59 \\
\hline Podregion 22 - nowosądecki & 27,12 & 28,47 \\
\hline Podregion 23 - oświęcimski & 26,66 & 28,78 \\
\hline Podregion 24 - tarnowski & 27,41 & 28,76 \\
\hline Podregion 44 - bielski & 26,89 & 29,14 \\
\hline Podregion 45 - bytomski & 26,34 & 28,85 \\
\hline Podregion 46 - częstochowski & 26,33 & 29,02 \\
\hline Podregion 47 - gliwicki & 26,85 & 29,07 \\
\hline Podregion 48 - katowicki & 26,56 & 28,84 \\
\hline Podregion 49 - rybnicki & 26,47 & 28,54 \\
\hline Podregion 50 - sosnowiecki & 26,05 & 29,38 \\
\hline Podregion 51 - tyski & 26,77 & 28,97 \\
\hline Podregion 9 - bialski & 26,94 & 28,66 \\
\hline Podregion 10 - chełmsko-zamojski & 26,66 & 28,46 \\
\hline Podregion 11 - lubelski & 27,13 & 29,61 \\
\hline Podregion 12 - puławski & 26,53 & 28,62 \\
\hline Podregion 33 - krośnieński & 26,80 & 28,68 \\
\hline Podregion 34 - przemyski & 26,70 & 28,54 \\
\hline Podregion 35 - rzeszowski & 27,37 & 29,17 \\
\hline Podregion 36 - tarnobrzeski & 26,82 & 28,72 \\
\hline Podregion 37 - białostocki & 27,69 & 29,48 \\
\hline Podregion 38 - łomżyński & 26,70 & 28,27 \\
\hline Podregion 39 - suwalski & 26,92 & 28,22 \\
\hline Podregion 52 - kielecki & 26,14 & 28,68 \\
\hline Podregion 53 - sandomiersko-jędrzejowski & 26,07 & 28,42 \\
\hline Podregion 13 - gorzowski & 26,03 & 28,26 \\
\hline Podregion 14 - zielonogórski & 25,90 & 28,69 \\
\hline
\end{tabular}


A VI. Mediana wieku kobiet rodzących (w latach) w 2002 i 2011 według podregionów - c. d.

\begin{tabular}{|l|r|r|}
\hline \multicolumn{1}{|c|}{1} & 2 & 3 \\
\hline Podregion 57 - kaliski & 26,27 & 28,35 \\
\hline Podregion 58 - konínski & 26,21 & 28,29 \\
\hline Podregion 59 - leszczyński & 26,16 & 28,16 \\
\hline Podregion 60 - pilski & 26,18 & 28,06 \\
\hline Podregion 61 - poznański & 26,60 & 29,23 \\
\hline Podregion 62 - m. Poznań & 27,67 & 30,25 \\
\hline Podregion 63 - koszaliński & 25,69 & 28,23 \\
\hline Podregion 64 - stargardzki & 25,58 & 27,67 \\
\hline Podregion 65 - m. Szczecin & 27,24 & 30,12 \\
\hline Podregion 66 - szczeciński & 25,79 & 28,52 \\
\hline Podregion 1 - jeleniogórski & 25,93 & 28,63 \\
\hline Podregion 2 - legnicko-głogowski & 25,97 & 28,78 \\
\hline Podregion 3 - wałbrzyski & 26,02 & 28,56 \\
\hline Podregion 4 - wrocławski & 25,98 & 28,86 \\
\hline Podregion 5 - m. Wrocław & 27,84 & 30,51 \\
\hline Podregion 31 - nyski & 26,36 & 28,22 \\
\hline Podregion 32 - opolski & 26,96 & 28,76 \\
\hline Podregion 6 - bydgosko-toruński & 26,69 & 29,45 \\
\hline Podregion 7 - grudziądzki & 25,92 & 27,78 \\
\hline Podregion 8 - włocławski & 25,97 & 28,00 \\
\hline Podregion 40 - gdański & 26,50 & 28,16 \\
\hline Podregion 41 - słupski & 26,16 & 27,85 \\
\hline Podregion 42 - starogardzki & 26,02 & 27,75 \\
\hline Podregion 43 - trójmiejski & 27,54 & 30,13 \\
\hline Podregion 54 - elbląski & 26,17 & 28,09 \\
\hline Podregion 55 - ełcki & 26,07 & 27,91 \\
\hline Podregion 56 - olsztyński & 26,51 & 28,89 \\
\hline
\end{tabular}

Źródło: oprac. własne na podstawie Banku Danych Lokalnych, GUS, Warszawa. 


\section{A VII. Produkt krajowy brutto na 1 mieszkańca (ceny bieżące - PKD 2007)} w 2002 i 2010 r.

\begin{tabular}{|c|c|c|c|c|c|}
\hline \multirow{2}{*}{ Nazwa i numer } & \multicolumn{2}{|c|}{2002} & \multicolumn{2}{|c|}{2010} & \multirow{2}{*}{$2002=100$} \\
\hline & w zł & Polska $=100$ & w zł & Polska $=100$ & \\
\hline 1 & 2 & 3 & 4 & 5 & 6 \\
\hline Podregion 15 - łódzki & 17318 & 81,9 & 30706 & 82,8 & 177,3068 \\
\hline Podregion 16 - m. Łódź & 25156 & 118,9 & 45838 & 123,6 & 182,215 \\
\hline Podregion 17 - piotrkowski & 17890 & 84,6 & 34706 & 93,6 & 193,9966 \\
\hline Podregion 18 - sieradzki & 15556 & 73,6 & 23984 & 64,7 & 154,1785 \\
\hline Podregion 19 - skierniewicki & 15722 & 74,3 & 26061 & 70,3 & 165,7614 \\
\hline $\begin{array}{l}\text { Podregion } 25 \text { - ciechanowsko- } \\
\text { płocki }\end{array}$ & 19234 & 90,9 & 43433 & 117,1 & 225,8137 \\
\hline $\begin{array}{l}\text { Podregion } 26 \text { - ostrołęcko- } \\
\text { siedlecki }\end{array}$ & 15273 & 72,2 & 28213 & 76,1 & 184,7247 \\
\hline Podregion 27 - radomski & 15625 & 73,9 & 27699 & 74,7 & 177,2736 \\
\hline Podregion $28-\mathrm{m}$. Warszawa & 60862 & 287,8 & 111696 & 301,1 & 183,5234 \\
\hline $\begin{array}{l}\text { Podregion } 29 \text { - warszawski } \\
\text { wschodni }\end{array}$ & 17101 & 80,9 & 31242 & 84,2 & 182,6911 \\
\hline $\begin{array}{l}\text { Podregion } 30 \text { - warszawski } \\
\text { zachodni }\end{array}$ & 26204 & 123,9 & 45919 & 123,8 & 175,2366 \\
\hline Podregion 20 - krakowski & 13037 & 61,6 & 24309 & 65,5 & 186,4616 \\
\hline Podregion 21 - m. Kraków & 31421 & 148,6 & 55970 & 150,9 & 178,1293 \\
\hline Podregion 22 - nowosądecki & 12341 & 58,4 & 21467 & 57,9 & 173,9486 \\
\hline Podregion 23 - oświęcimski & 17199 & 81,3 & 27990 & 75,5 & 162,742 \\
\hline Podregion 24 - tarnowski & 13785 & 65,2 & 23655 & 63,8 & 171,5996 \\
\hline Podregion 44 - bielski & 21869 & 103,4 & 36320 & 97,9 & 166,0798 \\
\hline Podregion 45 - bytomski & 17737 & 83,9 & 28574 & 77,0 & 161,0983 \\
\hline Podregion 46 - częstochowski & 18681 & 88,3 & 30446 & 82,1 & 162,9784 \\
\hline Podregion 47 - gliwicki & 22256 & 105,2 & 42726 & 115,2 & 191,9752 \\
\hline Podregion 48 - katowicki & 33026 & 156,2 & 52046 & 140,3 & 157,591 \\
\hline Podregion 49 - rybnicki & 18679 & 88,3 & 36295 & 97,8 & 194,3091 \\
\hline Podregion 50 - sosnowiecki & 21034 & 99,5 & 35780 & 96,5 & 170,1055 \\
\hline Podregion 51 - tyski & 29059 & 137,4 & 55543 & 149,7 & 191,1387 \\
\hline Podregion 9 - bialski & 12967 & 61,3 & 21829 & 58,8 & 168,3427 \\
\hline $\begin{array}{l}\text { Podregion } 10 \text { - chełmsko- } \\
\text { zamojski }\end{array}$ & 12777 & 60,4 & 21291 & 57,4 & 166,6354 \\
\hline Podregion 11 - lubelski & 19601 & 92,7 & 32521 & 87,7 & 165,915 \\
\hline Podregion 12 - puławski & 12893 & 61,0 & 21262 & 57,3 & 164,9112 \\
\hline Podregion 33 - krośnieński & 13146 & 62,2 & 21602 & 58,2 & 164,3237 \\
\hline Podregion 34 - przemyski & 13366 & 63,2 & 19718 & 53,2 & 147,5236 \\
\hline Podregion 35 - rzeszowski & 16750 & 79,2 & 29668 & 80,0 & 177,1224 \\
\hline Podregion 36 - tarnobrzeski & 15718 & 74,3 & 26316 & 70,9 & 167,4259 \\
\hline Podregion 37 - białostocki & 19186 & 90,7 & 31332 & 84,5 & 163,3066 \\
\hline Podregion 38 - łomżyński & 13429 & 63,5 & 23714 & 63,9 & 176,588 \\
\hline Podregion 39 - suwalski & 15167 & 71,7 & 23859 & 64,3 & 157,3086 \\
\hline Podregion 52 - kielecki & 17635 & 83,4 & 30227 & 81,5 & 171,4035 \\
\hline
\end{tabular}


A VII. Produkt krajowy brutto na 1 mieszkańca (ceny bieżące - PKD 2007) w 2002 i 2010 r. - c. d.

\begin{tabular}{|c|c|c|c|c|c|}
\hline 1 & 2 & 3 & 4 & 5 & 6 \\
\hline $\begin{array}{l}\text { Podregion } 53 \text { - sandomier- } \\
\text { sko-jędrzejowski }\end{array}$ & 14450 & 68,3 & 24843 & 67,0 & 171,9239 \\
\hline Podregion 13 - gorzowski & 19689 & 93,1 & 32215 & 86,8 & 163,6193 \\
\hline Podregion 14 - zielonogórski & 17839 & 84,3 & 30819 & 83,1 & 172,7619 \\
\hline Podregion 57 - kaliski & 16215 & 76,7 & 29340 & 79,1 & 180,9436 \\
\hline Podregion 58 - koniński & 16935 & 80,1 & 28355 & 76,4 & 167,4343 \\
\hline Podregion 59 - leszczyński & 16949 & 80,1 & 31474 & 84,8 & 185,6983 \\
\hline Podregion 60 - pilski & 17268 & 81,6 & 28152 & 75,9 & 163,0299 \\
\hline Podregion 61 - poznański & 22636 & 107,0 & 42597 & 114,8 & 188,1825 \\
\hline Podregion 62 - m. Poznań & 41387 & 195,7 & 72664 & 195,9 & 175,572 \\
\hline Podregion 63 - koszaliński & 17425 & 82,4 & 29180 & 78,7 & 167,4605 \\
\hline Podregion 64 - stargardzki & 14480 & 68,5 & 23679 & 63,8 & 163,529 \\
\hline Podregion 65 - m. Szczecin & 30959 & 146,4 & 45466 & 122,6 & 146,8587 \\
\hline Podregion 66 - szczeciński & 19595 & 92,7 & 31294 & 84,4 & 159,704 \\
\hline Podregion 1 - jeleniogórski & 17328 & 81,9 & 29805 & 80,3 & 172,0048 \\
\hline $\begin{array}{l}\text { Podregion } 2 \text { - legnicko- } \\
\text { głogowski }\end{array}$ & 26366 & 124,7 & 66937 & 180,4 & 253,8762 \\
\hline Podregion 3 - wałbrzyski & 16569 & 78,3 & 27932 & 75,3 & 168,5799 \\
\hline Podregion 4 - wrocławski & 17213 & 81,4 & 33665 & 90,8 & 195,5789 \\
\hline Podregion 5 - m. Wrocław & 31700 & 149,9 & 56461 & 152,2 & 178,1104 \\
\hline Podregion 31 - nyski & 13975 & 66,1 & 23306 & 62,8 & 166,7692 \\
\hline Podregion 32 - opolski & 18860 & 89,2 & 33541 & 90,4 & 177,842 \\
\hline $\begin{array}{l}\text { Podregion } 6 \text { - bydgosko- } \\
\text { toruński }\end{array}$ & 25168 & 119,0 & 39989 & 107,8 & 158,8883 \\
\hline Podregion 7 - grudziądzki & 15205 & 71,9 & 24870 & 67,0 & 163,5646 \\
\hline Podregion 8 - włocławski & 16171 & 76,5 & 26655 & 71,9 & 164,8321 \\
\hline Podregion 40 - gdański & 14548 & 68,8 & 25896 & 69,8 & 178,0038 \\
\hline Podregion 41 - słupski & 16244 & 76,8 & 27895 & 75,2 & 171,7249 \\
\hline Podregion 42 - starogardzki & 17304 & 81,8 & 28362 & 76,5 & 163,9043 \\
\hline Podregion 43 - trójmiejski & 31175 & 147,4 & 52164 & 140,6 & 167,3264 \\
\hline Podregion 54 - elbląski & 15148 & 71,6 & 25876 & 69,8 & 170,8212 \\
\hline Podregion 55 - ełcki & 12970 & 61,3 & 23161 & 62,4 & 178,5736 \\
\hline Podregion 56 - olsztyński & 18228 & 86,2 & 30278 & 81,6 & 166,1071 \\
\hline
\end{tabular}

Źródło: oprac. własne na podstawie Banku Danych Lokalnych, GUS, Warszawa. 


\section{A VIII. Struktura pracujących według trzech sektorów w \% w 2011 r.}

\begin{tabular}{|c|c|c|c|}
\hline Nazwa i numer & Rolnictwo & $\begin{array}{l}\text { Przemysł } \\
\text { i budownic- } \\
\text { two }\end{array}$ & Usługi \\
\hline 1 & 2 & 3 & 4 \\
\hline Podregion 15 - łódzki & 20,53 & 36,60 & 42,87 \\
\hline Podregion 16 - m. Łódź & 0,96 & 26,13 & 72,91 \\
\hline Podregion 17 - piotrkowski & 29,31 & 32,41 & 38,28 \\
\hline Podregion 18 - sieradzki & 43,08 & 26,72 & 30,20 \\
\hline Podregion 19 - skierniewicki & 43,79 & 22,63 & 33,58 \\
\hline Podregion 25 - ciechanowsko-płocki & 33,05 & 26,35 & 40,60 \\
\hline Podregion 26 - ostrołęcko-siedlecki & 45,58 & 19,24 & 35,18 \\
\hline Podregion 27 - radomski & 39,45 & 21,30 & 39,26 \\
\hline Podregion 28 - m. Warszawa & 0,60 & 13,79 & 85,61 \\
\hline Podregion 29 - warszawski wschodni & 21,95 & 31,07 & 46,98 \\
\hline Podregion 30 - warszawski zachodni & 19,54 & 25,38 & 55,08 \\
\hline Podregion 20 - krakowski & 41,81 & 23,48 & 34,71 \\
\hline Podregion 21 - m. Kraków & 1,50 & 22,57 & 75,94 \\
\hline Podregion 22 - nowosądecki & 45,55 & 18,59 & 35,87 \\
\hline Podregion 23 - oświęcimski & 24,66 & 37,10 & 38,24 \\
\hline Podregion 24 - tarnowski & 41,74 & 22,15 & 36,10 \\
\hline Podregion 44 - bielski & 14,33 & 39,34 & 46,32 \\
\hline Podregion 45 - bytomski & 6,80 & 36,45 & 56,75 \\
\hline Podregion 46 - częstochowski & 19,00 & 35,84 & 45,16 \\
\hline Podregion 47 - gliwicki & 4,07 & 40,87 & 55,06 \\
\hline Podregion 48 - katowicki & 0,62 & 32,72 & 66,66 \\
\hline Podregion 49 - rybnicki & 8,52 & 46,42 & 45,06 \\
\hline Podregion 50 - sosnowiecki & 7,57 & 40,34 & 52,09 \\
\hline Podregion 51 - tyski & 6,10 & 56,63 & 37,27 \\
\hline Podregion 9 - bialski & 49,74 & 14,50 & 35,76 \\
\hline Podregion 10 - chełmsko-zamojski & 56,89 & 13,00 & 30,11 \\
\hline Podregion 11 - lubelski & 27,21 & 20,56 & 52,24 \\
\hline Podregion 12 - puławski & 55,01 & 17,70 & 27,29 \\
\hline Podregion 33 - krośnieński & 41,03 & 24,31 & 34,66 \\
\hline Podregion 34 - przemyski & 47,68 & 16,97 & 35,35 \\
\hline Podregion 35 - rzeszowski & 32,83 & 23,12 & 44,04 \\
\hline Podregion 36 - tarnobrzeski & 35,51 & 31,37 & 33,12 \\
\hline Podregion 37 - białostocki & 21,80 & 21,29 & 56,92 \\
\hline Podregion 38 - łomżyński & 50,65 & 18,53 & 30,82 \\
\hline Podregion 39 - suwalski & 45,27 & 19,47 & 35,25 \\
\hline Podregion 52 - kielecki & 24,20 & 29,05 & 46,75 \\
\hline Podregion 53 - sandomiersko-jędrzejowski & 58,13 & 15,57 & 26,30 \\
\hline Podregion 13 - gorzowski & 14,78 & 34,55 & 50,66 \\
\hline
\end{tabular}


A VIII. Struktura pracujących według trzech sektorów w \% w 2011 r. - c. d.

\begin{tabular}{|c|c|c|c|}
\hline 1 & 2 & 3 & 4 \\
\hline Podregion 14 - zielonogórski & 13,29 & 34,36 & 52,35 \\
\hline Podregion 57 - kaliski & 30,04 & 35,48 & 34,48 \\
\hline Podregion 58 - koniński & 30,70 & 31,97 & 37,33 \\
\hline Podregion 59 - leszczyński & 27,96 & 35,90 & 36,14 \\
\hline Podregion 60 - pilski & 24,64 & 34,57 & 40,79 \\
\hline Podregion 61 - poznański & 14,66 & 43,11 & 42,23 \\
\hline Podregion 62 - m. Poznań & 0,74 & 22,36 & 76,89 \\
\hline Podregion 63 - koszaliński & 15,92 & 30,47 & 53,60 \\
\hline Podregion 64 - stargardzki & 22,48 & 31,29 & 46,23 \\
\hline Podregion 65 - m. Szczecin & 1,31 & 19,26 & 79,43 \\
\hline Podregion 66 - szczeciński & 16,39 & 36,83 & 46,77 \\
\hline Podregion 1 - jeleniogórski & 16,46 & 35,22 & 48,32 \\
\hline Podregion 2 - legnicko-głogowski & 11,09 & 41,00 & 47,91 \\
\hline Podregion 3 - wałbrzyski & 13,33 & 36,99 & 49,68 \\
\hline Podregion 4 - wrocławski & 20,48 & 44,00 & 35,52 \\
\hline Podregion 5 - m. Wrocław & 0,83 & 21,06 & 78,12 \\
\hline Podregion 31 - nyski & 25,66 & 30,54 & 43,80 \\
\hline Podregion 32 - opolski & 17,48 & 33,82 & 48,71 \\
\hline Podregion 6 - bydgosko-toruński & 5,67 & 33,53 & 60,80 \\
\hline Podregion 7 - grudziądzki & 29,06 & 33,38 & 37,56 \\
\hline Podregion 8 - włocławski & 30,59 & 27,62 & 41,79 \\
\hline Podregion 40 - gdański & 20,51 & 32,80 & 46,69 \\
\hline Podregion 41 - słupski & 17,70 & 33,92 & 48,38 \\
\hline Podregion 42 - starogardzki & 19,30 & 37,49 & 43,21 \\
\hline Podregion 43 - trójmiejski & 0,88 & 23,08 & 76,04 \\
\hline Podregion 54 - elbląski & 21,23 & 35,40 & 43,37 \\
\hline Podregion 55 - ełcki & 26,73 & 28,38 & 44,89 \\
\hline Podregion 56 - olsztyński & 17,17 & 28,54 & 54,29 \\
\hline
\end{tabular}

Źródło: oprac. własne na podstawie Banku Danych Lokalnych, GUS, Warszawa. 